Mona Lisa Lobo de Souza Choas

Sobre as Características do Espaço Arquitetônico Facilitadoras do Ensino-Aprendizagem na Universidade

Brasília

Outubro 2016 

Mona Lisa Lobo de Souza Choas

\title{
Sobre as Características do Espaço Arquitetônico Facilitadoras do Ensino-Aprendizagem na Universidade
}

Tese apresentada à Faculdade de Arquitetura e Urbanismo (FAU) da Universidade de Brasília como requisito parcial para a obtenção do título de Doutor em Arquitetura e Urbanismo.

\author{
Universidade de Brasília - UnB \\ Faculdade de Arquitetura e Urbanismo (FAU) \\ Programa de Pós-Graduação em Arquitetura e Urbanismo (PPGFAU)
}

Orientador: Prof ${ }^{\mathrm{a}}$. Dr ${ }^{\mathrm{a}}$. Maria do Carmo de Lima Bezerra Coorientador: Prof. Dr. Mamede Lima-Marques

Brasília

Outubro 2016 

Choas, Mona Lisa Lobo de Souza

Sobre as Características do Espaço Arquitetónico

CM735s Facilitadoras do Ensino-Aprendizagem na Universidade / Mona Lisa Lobo de Souza Choas; orientador Maria do Carmo de Lima Bezerra; co-orientador Mamede Lima Marques. -- Brasilia, 2016. 409 p.

Tese (Doutorado - Doutorado em Arquitetura e Urbanismo) -- Universidade de Brasilia, 2016.

1. Ensino-aprendizagem . 2. Programa de necessidades.. 3. Projeto arquitetônico. . 4. MCDA C.. 5. Arquitetura da Informação.. I. Bezerra, Maria do Carmo de Lima, orient. II. Lima-Marques, Mamede , co-orient. III. Título. 


\title{
Referência bibliográfica
}

Choas, Mona Lisa Lobo de Souza. Sobre as Características do Espaço Arquitetônico Facilitadoras do Ensino-Aprendizagem na Universidade. Universidade de Brasília, 2016. 409 fl. Tese de Doutorado.

\section{Cessão de direitos}

NOME DO AUTOR: Mona Lisa Lobo de Souza Choas

TÍTULO DA TESE: Sobre as Características do Espaço Arquitetônico Facilitadoras do Ensino-Aprendizagem na Universidade.

GRAU/ANO: Doutor/2016

É concedida à Universidade de Brasília pvermissão para reproduzir cópias desta Tese de Doutorado e emprestar ou vender tais cópias somente para propósitos acadêmicos e científicos. Do mesmo modo, a Universidade de Brasília tem permissão para divulgar este documento em biblioteca virtual, em formato que permita o acesso via redes de comunicação e a reprodução de cópias, desde que protegida a integridade do conteúdo dessas cópias e proibido o acesso a partes isoladas desse conteúdo. O autor reserva outros direitos de publicação e nenhuma parte deste documento pode ser reproduzida sem a autorização por escrito do autor.

\author{
Mome lise Loba de Jover Choes \\ Mona Lisa Lobo de Souza Choas \\ arqmona05@gmail.com
}





\section{Mona Lisa Lobo de Souza Choas}

\section{Sobre as Características do Espaço Arquitetôníco Facilitadoras do Ensino-Aprendizagem na Universidade}

Tese apresentada à Faculdade de Arquitetura e Urbanismo (FAU) da Universidade de Brasília como requisito parcial para a obtenção do título de Doutor em Arquitetura e Urbanismo.

Trabalho aprovado. Brasília, Outubro 2016:
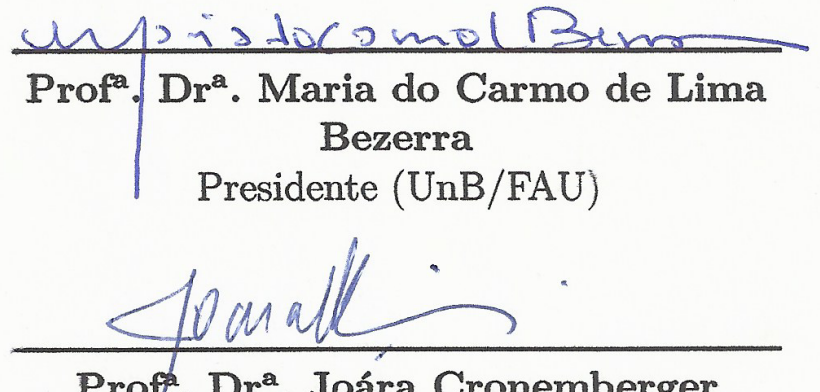

Proff. Dr ${ }^{\mathfrak{a}}$. Joára Cronemberger

Membro Externo (Escuela Técnica Superior de Arquitectura de Madrid /UPM)

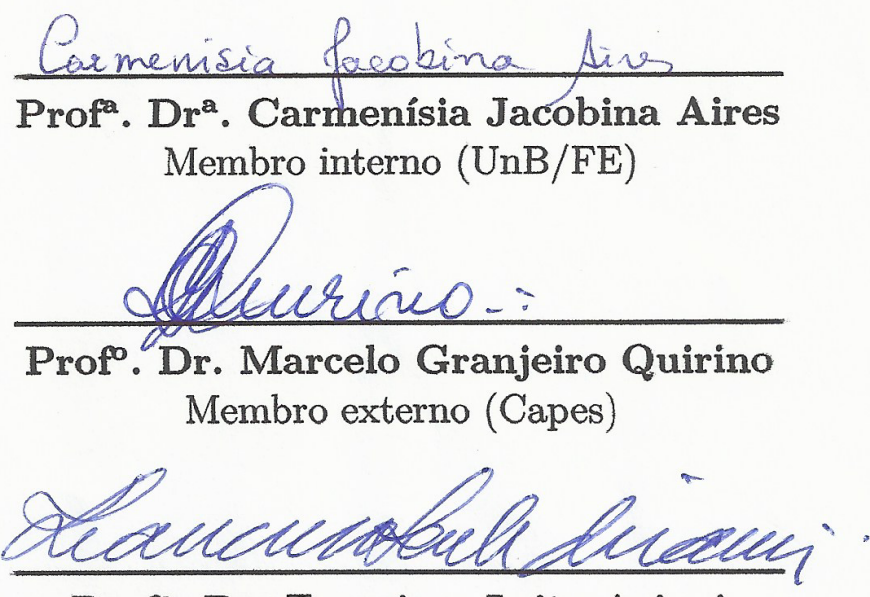

Prof ${ }^{\circ}$. Dr. Francisco Leite Aviani Membro Interno (UnB/Desenho Industrial)

Prof ${ }^{\circ}$. Dr. Marcos Thadeu Queiroz Magalhães Suplente (UnB/FAU) 
A Deus, o Grande Arquiteto do Universo, por me dar forças para seguir em frente em mais uma conquista, e por ter colocado em minha vida pessoas tão especiais, que contribuíram para a concretização deste sonho.

A Amador Teodoro, meu querido pai, e a Maria Dulce, minha querida mãe "in memorian", pela oportunidade e exemplo de vida, pela educação, pelo amor e incentivo de sempre.

Ao Ivan, meu companheiro e amigo, que, com muita paciência, amor e compreensão, recebeu-me de braços abertos a cada volta ao lar.

À família abençoada que Deus me deu, sempre presente e compartilhando momentos alegres e difíceis: meus filhos Daniel, Ivone e Moisés, meus netos Matheus e Isaac, meu genro Ramon, e minha nora Esther. 



\section{Agradecimentos}

À amiga e orientadora, professora Maria do Carmo Bezerra, com admiração, pelo seu espírito crítico e paciência, com bravura no acompanhamento desta tese, pela dedicação e por seus valiosos ensinamentos que foram essenciais para o desenvolvimento do trabalho.

Ao amigo e coorientador, professor Mamede Lima-Marques, pelos conhecimentos transmitidos, pelo apoio e pela valiosa orientação, pela parceria em trabalhos conjuntos, pela disponibilidade e presença constante na minha vida profissional. Grande mestre nos ensinamentos sobre Architecture of Information.

Aos dois amigos agradeço imensamente por todo o carinho que me foi concedido e por terem me dado a honra de compartilhar o conhecimento.

Especial agradecimento aos professores Otto Ribas, Gunther Harmut, Francisco Aviani e Jaime Almeida pela valiosa contribuição da pesquisa como especialistas em suas respectivas áreas e pela disponibilidade.

Ao prof. Marcelo Quirino pela disponibilidade constante, pelos valiosos ensinamentos sobre a MCDA-C e por ter acreditado na proposta da pesquisa.

Ao corpo docente do curso de Arquitetura e Urbanismo da Faculdade de Arquitetura e Urbanismo da Universidade de Brasília, que apoiaram essa pesquisa, avaliando as questões do questionário repassado e contribuindo com sua validação.

Aos professores da banca avaliadora de qualificação, que enriqueceram o trabalho com as observações durante o processo de elaboração da pesquisa.

Aos membros da banca de defesa da tese pela disponibilidade e pelas valiosas contribuições para melhoria da pesquisa.

À Faculdade de Arquitetura e Urbanismo da Universidade de Brasília, pela oportunidade de realização de um sonho e pelo acolhimento, apoio e excelente ambiente.

Aos amigos da secretaria de Graduação e de Pós-Graduação da FAU, em especial ao Josué, ao Diego e ao Júnior, pelo imenso apoio nas horas em que precisei tanto.

À equipe do DGP/Codac/CAC, servidores Adamilson, Edivonete e Patricia, pelo apoio administrativo nos trâmites necessários.

À equipe do Centro de Pesquisa da Arquitetura da Informação (CPAI) e da Faculdade de Ciência da Informação(FCI), em especial à Jucilene, à Dora, ao Bruno, à Fabiana, à Sebastiana e à Cilene, pela atenção e apoio.

Aos alunos do PPGT da Faculdade de Tecnologia da UnB, Paulo e Aldery, pelo apoio e disponibilidade. 
Aos amigos do Ceplan, arqt. ${ }^{o}$ Eduardo Soares e arqt. ${ }^{a}$ Claudia Guidalle, pelo apoio e disponibilidade.

Ao prof. Mamede, ao Bruno e, ao Lauro pelo auxilio inestimável no processador de texto $\mathrm{IT}_{\mathrm{E} X}$.

Em especial a meu filho Moisés, pela determinação e desafio na execução enfadonha, mas preciosa no formatador de texto $\mathrm{HT}_{\mathrm{E} X}$.

Ao meu filho Daniel, pelas orientações quanto à formatação da tese e suas representações.

Ao amigo, prof. Gustavo pelo apoio na execução de gráficos e desenhos da estrutura arborescente do modelo (MCDA-C).

A todas as pessoas que direta ou indiretamente contribuíram para a realização deste trabalho.

Obrigada a todos! 
“...bons edifícios não acontecem simplesmente. Eles são planejados para ter uma boa aparência e funcionar adequadamente, e surgem quando bons arquitetos e bons clientes juntam-se em um esforço pensado e cooperativo. Programar os requisitos do projeto de um edifício é a primeira tarefa do arquiteto, senão a mais importante (PEÑA; PARSHALL, 2001). 



\section{Resumo}

Esta tese discute a relevância do espaço arquitetônico como facilitador do processo de ensino-aprendizagem. Utiliza metodologia analítica fundamentada na pesquisa bibliográfica para conhecer a visão das áreas da Arquitetura e da Pedagogia sobre o tema e identificar atributos espaciais relevantes para facilitação do ensino. A pesquisa demonstrou que existem recorrências apontando os campos disciplinares do Conforto Ambiental, Ergonomia e Psicologia Ambiental, o que permitiu a identificação de quadro de referência de atributos e parâmetros, suas possibilidades de espacialização e a relevância para o ensino e a aprendizagem a ser utilizado como apoio à formulação de programas de necessidades arquitetônicas, ou seja: na primeira etapa do processo de elaboração de um projeto de arquitetura. Utilizando a análise multicritério de apoio à decisão, esse conjunto de características do espaço arquitetônico facilitadoras do ensino-aprendizagem foi validado com pesquisa empírica com professores da Faculdade de Arquitetura e Urbanismo da Universidade de Brasília. A escolha da Metodologia Multicritério de Apoio à Decisão (MCDA-C) para construção do modelo de avaliação mostrou-se adequada para contemplar a validação de um tema complexo que envolveu múltiplos critérios e subcritérios (atributos e parâmetros) do espaço arquitetônico. Com os resultados obtidos foi definido um modelo de arquitetura da informação para ser utilizado como insumo a elaboração do programa de necessidades de espaços de ensino-aprendizagem. Apesar do fato de que a subjetividade é parte inerente ao processo de projeto, um procedimento metodológico é importante para aumentar as bases científicas do projeto. Nessa direção, a pesquisa vem mostrar a necessidade de se utilizar uma metodologia para a elaboração de programa de necessidade, que contemple informação de parâmetros facilitadores do ensino-aprendizagem como norteadora para arquitetos e profissionais da área de arquitetura.

Palavras-chave: Aprendizagem. Arquitetura. Escola. Espaço. Projeto. Espaço arquitetônico. Projeto arquitetônico. Programa de necessidades. Ensino-aprendizagem. Arquitetura da Informação. MCDA-C. 



\section{Abstract}

This thesis discusses the relevance of architectural space as a facilitator of teaching and learning process. Uses analytical methodology based on bibliographic research to know the view of the areas of architecture and pedagogy on the subject and identify relevant spatial attributes for facilitating teaching. Research has shown that there are recurrences pointing disciplinary fields of environmental comfort, ergonomics and environmental psychology which allowed attributes framework ID and parameters, their spatial possibilities and relevance to the teaching and learning to be used as support the formulation of architectural needs programs, ie: in the first stage of the process of developing an architectural project. Using the multi-criteria analysis to support the decision that set of characteristics of architectural space facilitative teaching / learning has been validated with empirical research with the Faculty of Architecture and Urbanism at the University of Brasilia. The choice of Multicriteria Methodology Decision Support (MCDA-C) Construction of the evaluation model was appropriate to consider the validation of a complex issue involving multiple criteria and sub-criteria (attributes and parameters) the architectural space. With the results defined an information architecture model to be used as input to the preparation of the program of teaching spaces / learning needs. Despite the fact that subjectivity is an inherent part of the design process, a methodological procedure is important to increase the scientific bases of the project. In this direction, the study shows the need to use a methodology for the preparation of need program, covering facilitators parameters information of teaching / learning as guiding for architects and architecture professionals.

Keywords: Learning. Architecture. School. Space. Project. Architectural space. Architectural project. Needs program. Teaching and learning. Information Architecture. MCDA-C. 



\section{Lista de ilustrações}

Figura 1 - Percurso Metodológico . . . . . . . . . . . . . . . . 43

Figura 2 - DQI: Esquema dos princípios de qualidade . . . . . . . . . 62

Figura 3 - Esquema dos grupos de critérios dos três princípios de qualidade a partir da ferramenta DQI. . . . . . . . . . . . . . . . . . 62

Figura 4 - Fatores componentes de uma Análise Ergonômica do Projeto de Ambiente 98

Figura 5 - Esquema do processamento de informação. . . . . . . . . . . . . . 103

Figura 6 - Os parâmetros do ambiente físico criam qualidades ambientais e dão lugar a uma percepção e avaliação integradas do homem. . . . . . . . . 104

Figura 7 - Processo subjetivo de apreensão do ambiente iluminado . . . . . . . . 118

Figura 8 - Posto de trabalho para uma pessoa sentada . . . . . . . . . . . 130

Figura 9 - Pessoa utilizando equipamento em posto de trabalho . . . . . . . . 134

Figura 10 - Reflexo das ondas sonoras . . . . . . . . . . . . . . . . . 137

Figura 11 - Intensidade do Som . . . . . . . . . . . . . . . . . . . . 138

Figura 12 - Círculo Cromático. . . . . . . . . . . . . . . . . . . . . . . 139

Figura 13 - Relações pessoa-meio no espaço de aprendizado . . . . . . . . . . . . 145

Figura 14 - Alojamento de estudantes em prédios altos, Universidade da Califórnia

- Davis . . . . . . . . . . . . . . . . . . . . . . . . 147

Figura 15 - Alojamento em prédio básico agrupado em clusters, Universidade da Califórnia - Davis . . . . . . . . . . . . . . . . 147

Figura 16 - Ligação entre o Mundo Real e do Modelo . . . . . . . . . . . . . . . . 175

Figura 17 - Construção da Árvore da Família de Pontos de Vista Fundamentais (PVFs) . . . . . . . . . . . . . . . . . . . 180

Figura 18 - Elementos que compõem a arborescência da família do PVF 1 - Conforto Ambiental (Estrutura Inicial) _ . . . . . . . . . . . . . . 181

Figura 19 - Elementos que compõem a arborescência da família do PVF 2 - Ergonomia (Estrutura Inicial) . . . . . . . . . . . . . . . . . 182

Figura 20 - Elementos que compõem a arborescência da família do PVF 3 - Psicologia Ambiental (Estrutura Inicial) . . . . . . . . . . . . . 184

Figura 21 - Estrutura genérica da árvore de valor do estudo de caso validado pelos decisores . . . . . . . . . . . . . . . . 186

Figura 22 - Elementos que compõem a arborescência da família do PVF 1 - Conforto Ambiental . . . . . . . . . . . . . . . . . . . 187

Figura 23 - Elementos que compõem a arborescência da família do PVF 2 - Ergonomia189

Figura 24 - Elementos que compõem a arborescência da família do PVF 3 - Psicologia Ambiental . . . . . . . . . . . . . . . . 190 
Figura 25 - Níveis que compõem a arborescência da família de Pontos de Vista Fundamentais (PVFs) . . . . . . . . . . . . . . . . . . 191

Figura 26 - Eixos de avaliação que compõem a arborescência da família de Pontos de Vista Fundamentais (PVFs) . . . . . . . . . . . . . . . . . 192

Figura 27 - Critérios de avaliação que compõem a arborescência da família de Pontos de Vista Fundamentais (PVFs) . . . . . . . . . . . . . . . . . . 192

Figura 28 - Fluxograma para gerar um descritor construído . . . . . . . . . . . . . 195

Figura 29 - Estados possíveis de um descritor . . . . . . . . . . . . . . . . . 196

Figura 30 - Descritor com os níveis de impacto Bom e Neutro . . . . . . . . . . . . 196

Figura 31 - Função de valor do SubPVE 1.1.1 - Ventilação . . . . . . . . . . . . . 205

Figura 32 - Função de valor do SubPVE 2.1.1 - Frequência . . . . . . . . . . . . . 205

Figura 33 - Função de valor do SubPVE 3.1 .1 - Distância Interpessoal . . . . . . . 206

Figura 34 - Demonstração esquemática dos níveis de impacto Bom e Neutro . . . . 207

Figura 35 - Estrutura arborescente do Modelo Multicritério de avaliação com a indicação das taxas de substituição . . . . . . . . . . . . . . . . . 218

Figura 36 - Turnos das disciplinas ministradas pelos professores da FAU/UnB . . . 231

Figura 37 - Tipos de disciplina ministradas pelos professores da FAU/UnB . . . . . 231

Figura 38 - Perfil de impacto do avaliador professor P1 . . . . . . . . . . . . 237

Figura 39 - Perfil de impacto do avaliador professor P2 . . . . . . . . . . . . . 239

Figura 40 - Perfil de impacto do avaliador professor P3 . . . . . . . . . . . . . . . 240

Figura 41 - Perfil de impacto do avaliador professor P4 . . . . . . . . . . . . . . 242

Figura 42 - Perfil de impacto dos avaliadores professores P1, P2, P3 e P4 . . . . 243

Figura 43 - Valor global da avaliação dada pelo professor P1 . . . . . . . . . . . . 246

Figura 44 - Pontuações ponderadas das avaliações dos professores da FAU/UnB no PVF $1 \ldots \ldots \ldots \ldots \ldots \ldots$

Figura 45 - Contribuição de cada PVE do PVF 1 na pontuação dos professores da FAU/UnB . . . . . . . . . . . . . . . . . . . . . 259

Figura 46 - Pontuações ponderadas dos professores da FAU/UnB no PVE 1.1 . . . 260

Figura 47 - Contribuição de cada SubPVE do PVE 1.1 na pontuação dos professores da FAU/UnB . . . . . . . . . . . . . . . . . . . . . . 261

Figura 48 - Pontuações ponderadas dos professores da FAU/UnB no PVE 1.2 . . . 262

Figura 49 - Contribuição de cada SubPVE do PVE 1.2 na pontuação dos professores

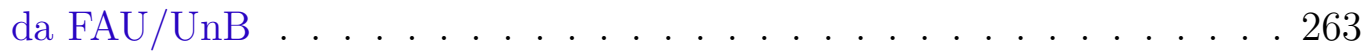

Figura 50 - Pontuações ponderadas dos professores da FAU/UnB no PVE 1.3 . . . 264

Figura 51 - Contribuição de cada SubPVE do PVE 1.3 na pontuação dos professores

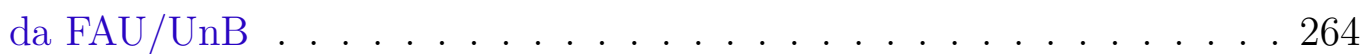

Figura 52 - Pontuações ponderadas dos professores da FAU/UnB no PVF 2 . . . . 265

Figura 53 - Contribuição de cada PVE do PVF 2 na pontuação dos professores da FAU/UnB . . . . . . . . . . . . . . . . . . . . 266 
Figura 54 - Pontuações ponderadas dos professores da FAU/UnB no PVE 2.1 . . . 267

Figura 55 - Contribuição de cada SubPVE do PVE 2.1 na pontuação dos professores da FAU/UnB . . . . . . . . . . . . . . . . . . . . . . 267

Figura 56 - Pontuações ponderadas dos professores da FAU/UnB no PVE 2.2 . . . 268

Figura 57 - Contribuição de cada SubPVE do PVE 2.2 na pontuação dos professores

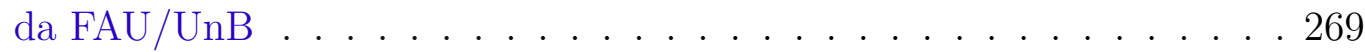

Figura 58 - Pontuações ponderadas dos professores da FAU/UnB no PVE 2.3 . . . 270

Figura 59 - Contribuição de cada SubPVE do PVE 2.3 na pontuação dos professores da FAU/UnB . . . . . . . . . . . . . . . . . . . . . . . 270

Figura 60 - Pontuações ponderadas dos professores da FAU/UnB no PVF 3 . . . . 271

Figura 61 - Contribuição de cada PVE do PVF 3 na pontuação dos professores da FAU/UnB . . . . . . . . . . . . . . . . . . . . . 272

Figura 62 - Pontuações ponderadas dos professores da FAU/UnB no PVE 3.1 . . . 273

Figura 63 - Contribuição de cada SubPVE do PVE 3.1 na pontuação dos professores da FAU/UnB . . . . . . . . . . . . . . . . . . . . . . 273

Figura 64 - Pontuações ponderadas dos professores da FAU/UnB no PVE 3.2 . . . 274

Figura 65 - Contribuição de cada SubPVE do PVE 3.2 na pontuação dos professores

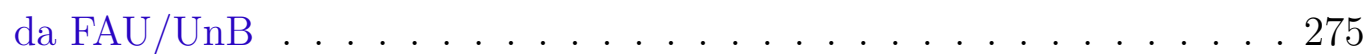

Figura 66 - Pontuação global dos professores da FAU/UnB . . . . . . . . . . . . 276

Figura 67 - Contribuição de cada PVF na pontuação dos professores da FAU/UnB 277

Figura 68 - Análise de sensibilidade do modelo no PVF 1 - Conforto Ambiental . . 280

Figura 69 - Análise de sensibilidade do modelo no PVF 2 - Ergonomia . . . . . . . 281

Figura 70 - Análise de sensibilidade do modelo no PVF 3 - Psicologia Ambiental . 282

Figura 71 - Perspectiva pedagógica . . . . . . . . . . . . . . . . . . . 407

Figura 72 - Perspectiva arquitetônica . . . . . . . . . . . . . . . 407

Figura 73 - Perspectiva ambiental . . . . . . . . . . . . . . . . . . 407

Figura 74 - Perspectiva ergonômica . . . . . . . . . . . . . . . . . . . . 407

Figura 75 - Perspectiva psciológica . . . . . . . . . . . . . . . . 407 



\section{Lista de tabelas}

Tabela 1 - Funções de projeto de um espaço escolar . . . . . . . . . . . . . . . 50

Tabela 2 - Valores arquitetônicos contemporâneos . . . . . . . . . . . . . 61

Tabela 3 - Objetivos positivos do projeto escolar . . . . . . . . . . . . 63

Tabela 4 - Princípios para arquitetura escolar segundo Cabe (2005) . . . . . . . . 63

Tabela 5 - Atributos desejáveis à atividade escolar . . . . . . . . . . . 65

Tabela 6 - Pattters - parâmetros de projeto para o projeto escolar . . . . . . . 66

Tabela 7 - Lista de valores que podem funcionar como questões de projeto elaborada por Hershberger (1999) . . . . . . . . . . . . . . . . . . . 84

Tabela 8 - Estrutura da informação em projeto, segundo o Método Problem Seeking 88

Tabela 9 - Estrutura geral para o Programa Arquitetônico segundo a norma ISO 9699 (INTERNATIONAL ORGANIZATION FOR STANDARDIZATION, 1994) . . . . . . . . . . . . . . . . . . 91

Tabela 10 - Elementos das avaliações térmicas de ambientes escolares . . . . . . . . 117

Tabela 11 - Níveis de iluminação para ambientes escolares . . . . . . . . . . . . . . 120

Tabela 12 - Relação entre as cores e seus graus de reflexão e superfícies . . . . . . . 122

Tabela 13 - Relação da cor às influências sobre o ânimo . . . . . . . . . . . . . . . 123

Tabela 14 - Características do conforto ambiental segundo a visão dos autores . . . 127

Tabela 15 - Fatores físicos de risco não organizacionais . . . . . . . . . . . . 136

Tabela 16 - Efeitos psicológicos das cores . . . . . . . . . . . . . . . . . . . 138

Tabela 17 - As cores e alguns de seus efeitos terapêuticos . . . . . . . . . . . 139

Tabela 18 - Uma visão geral das reações emocionais e mentais e algumas cores . . . 140

Tabela 19 - Principais características da ergonomia segundo a visão dos autores . . 142

Tabela 20 - Principais características da psicologia ambiental segundo a visão dos

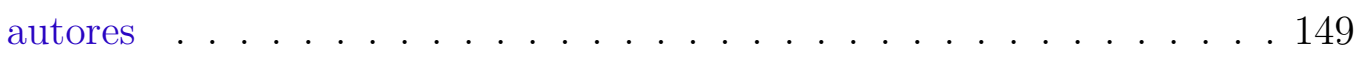

Tabela 21 - Processo de projetos por DQI (Design Quality Indicator) - Cabe (2005)

- Comparação com atributos e parâmetros propostos pela pesquisa . 151

Tabela 22 - Relação entre o método Patterns (Parâmetros de Projeto Escolar) de Nair e Fielding (2005) e os atributos e parâmetros propostos na pesquisa156

Tabela 23 - Atributos dos espaços arquitetônicos facilitadores do ensino-aprendizagem163

Tabela 24 - Campo disciplinar, atributos e parâmetros do espaço arquitetônicos necessários ao programa de necessidades para elaboração de projeto de Arquitetura . . . . . . . . . . . . . . . . . 165

Tabela 25 - Propriedades dos Pontos de Vista Fundamentais (PVFs) . . . . . . . . 179

Tabela 26 - Estrutura inicial dos PVEs e SubPVEs do PVF 1 - Conforto Ambiental 182 Tabela 27 - Estrutura inicial dos PVEs e SubPVEs do PVF 2 - Ergonomia . . . . 183 Tabela 28 - Estrutura inicial dos PVEs e SubPVEs do PVF 3 - Psicologia Ambiental184 
Tabela 29 - PVEs e SubPVEs do PVF 1 - Conforto Ambiental . . . . . . . . . . . 188

Tabela 30 - PVEs e SubPVEs do PVF 2 - Ergonomia . . . . . . . . . . . . . . . 189

Tabela 31 - PVEs e SubPVEs do PVF 3 - Psicologia Ambiental . . . . . . . . . . . 190

Tabela 32 - Tipos dos descritores utilizados na presente pesquisa . . . . . . . . . . 194

Tabela 33 - Propriedades dos descritores . . . . . . . . . . . . . . . . . . 194

Tabela 34 - Descritor com os níveis Bom e Neutro do SubPVE 1.1.1 - Ventilação . 197

Tabela 35 - Descritor com os níveis Bom e Neutro do SubPVE 1.1.2 - Resfriamento evaporativo . . . . . . . . . . . . . . . . . 197

Tabela 36 - Descritores com níveis de impacto e de referência do PVF 1 - Conforto Ambiental . . . . . . . . . . . . . . . . . . . . . . 198

Tabela 37 - Descritores com níveis de impacto e de referência do PVF 2 - Ergonomia200

Tabela 38 - Descritores com níveis de impacto e de referência do PVF 3 - Psicologia Ambiental . . . . . . . . . . . . . . . . . . . . . 201

Tabela 39 - Escala ordinal semântica utilizada pelo Macbeth . . . . . . . . . . . . . 203

Tabela 40 - Função de valor do SubPVE 1.1 .1 - Ventilação . . . . . . . . . . . . . . . 204

Tabela 41 - Ordenamento dos PVFs, PVEs e SubPVEs dos decisores em suas respectivas áreas de ensino . . . . . . . . . . . . . . . . . . 209

Tabela 42 - Cálculo das taxas de substituição dos critérios (PVFs) . . . . . . . . . 211

Tabela 43 - Pontuação dos PVFs . . . . . . . . . . . . . . . . . . . . . . 211

Tabela 44 - Cálculo das taxas de substituição dos subcritérios (PVEs) . . . . . . . 211

Tabela 45 - Pontuação dos subcritérios (SubPVEs) . . . . . . . . . . . . . . . 212

Tabela 46 - Cálculo das taxas de substituição dos SubPVEs . . . . . . . . . . . . . 212

Tabela 47 - Pontuação dos subcritérios (SubPVEs) . . . . . . . . . . . . . 213

Tabela 48 - Taxas de substituição dos critérios (PVFs) e subcritérios (PVEs e SubPVEs) . . . . . . . . . . . . . . . . . . . 215

Tabela 49 - Atividades/funções do espaço da FAU/UnB . . . . . . . . . . . . . . 230

Tabela 50 - Avaliação local dos critérios e subcritérios avaliados pelos professores da FAU/UnB . . . . . . . . . . . . . . . . . . . . . . . . . . . 234

Tabela 51 - Avaliação dos professores da FAU/UnB para o PVF 1 - Conforto Ambiental . . . . . . . . . . . . . . . . . . . 250

Tabela 52 - Avaliação dos professores da FAU/UnB para o PVF 2 - Ergonomia . . 254

Tabela 53 - Avaliação dos professores da FAU/UnB para o PVF 3 - Psicologia Ambiental . . . . . . . . . . . . . . . . . 256

Tabela 54 - Pontuação global das avaliações dos critérios e subcritérios . . . . . . . 278

Tabela 55 - Taxas de substituição para análise de sensibilidade . . . . . . . . . . . 279

Tabela 56 - Pontuação da avaliação dos professores da FAU por categoria de disciplina do curso da FAU/UnB . . . . . . . . . . . . . . . . . . . . 285

Tabela 57 - Perspectiva Pedagógica: premissas, abordagens, referenciais e resultados do modelo de AI . . . . . . . . . . . . . . . . . . . . . . . . 293 
Tabela 58 - Perspectiva Arquitetônica: premissas, abordagens, hipótese e resultados do modelo de AI . . . . . . . . . . . . . . . . . . . . . 296

Tabela 59 - Perspectiva Ambiental: Abordagens, Descrições e Aplicações do Modelo de AI . . . . . . . . . . . . . . . . . . . . 297

Tabela 60 - Perspectiva Ergonômica: abordagens, descrição e aplicações do modelo de arquitetura da informação . . . . . . . . . . . . . . . . . . . 306

Tabela 61 - Perspectiva Psicológica: abordagens, descrição e aplicações do modelo de arquitetura da informação . . . . . . . . . . . . . . . . . . . . . . . 312

Tabela 62 - Distribuição dos espaços da FAU/UnB e suas características . . . . . . 370

Tabela 63 - Diretrizes gerais para elaboração de alteração do espaço físico da FAU. 372

Tabela 64 - Diretrizes programáticas para elaboração do projeto arquitetônico da FAU. . . . . . . . . . . . . . . . . . . . . 372

Tabela 65 - Diretrizes para Programa de Necessidades da FAU/UnB . . . . . . . . 372

Tabela 66 - Diretrizes de Zoneamento da FAU/UnB . . . . . . . . . . . . . . . . 376 



\section{Lista de abreviaturas e siglas}

ABNT Associação Brasileira de Normas Técnicas

AFNOR Association Française de Normalisation

AET Análise Ergonômica da Trabalho

AEPA Análise Ergonômica do Projeto do Ambiente

AI Arquitetura da Informação

AIA American Institute of Architects

CABE Commission for Architecture and the built Environment

CTISM Colégio Técnico Industrial da Universidade Federal de Santa Maria

DORT Doenças Osteoarticulares Relacionadas ao Trabalho

DQI Design Quality Indicator

EAD Educação a Distância

FV Função de valor

EFL Educational Facilities Laboratories

EPA Elementos Primários de Avaliação

FAU Faculdade de Arquitetura e Urbanismo

FIS Fundamentos da Ciência da Informação

INEP Instituto Nacional de Estudos e Pesquisas Anísio Teixeira

ISO International Organization for Standardization

LER Lesões por Esforços Repetitivos

MACBETH Measuring attractiveness by a categorical based evaluation technique

MAUT Multiatribute utility theory

MARAD United States Maritime Administration

MCDA-C Multicriteria decision aid 
MCDM Multicriteria decision making

MEC Ministério da Educação

MT Ministério dos Transportes

NCEF National Cleoring-House for Educational Facilities

NI Nível de impacto

NR 17 Norma Regulamentadora

NBR 5.413 Norma Brasileira Registrada

PRO Departamento de Projeto, Expressão e Representação da FAU/UnB

PVE Ponto de vista elementar

PVF Ponto de vista fundamental

PMV Índice do voto médio estimado

PPD Porcentagem de pessoas satisfeitas

SISI Instituto de Ciência da Informação Social

SAEB Sistema Nacional de Avaliação da Educação Básica

SSS Short sea shipping

SubPVE Sub Ponto de Vista Elementar

TEC Departamento de Tecnologia da FAU/UnB

THA Departamento de Teoria e História da FAU/UnB

UFRJ Universidade Federal do Rio de Janeiro

UFSC Universidade Federal de Santa Catarina

UNESCO Organização das Nações Unidas para a Educação, Ciência e Cultura

UR Umidade relativa do ar

UnB Universidade de Brasília 


\section{Sumário}

Introdução $\ldots \ldots \ldots \ldots \ldots \ldots \ldots \ldots \ldots \ldots \ldots \ldots$

ELEMENTOS DE PESQUISA . . . . . . . . . . . 35

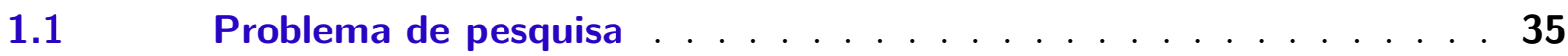

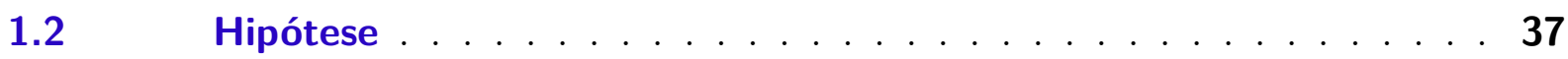

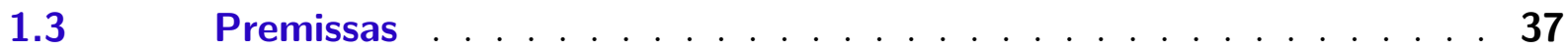

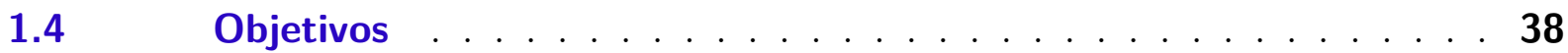

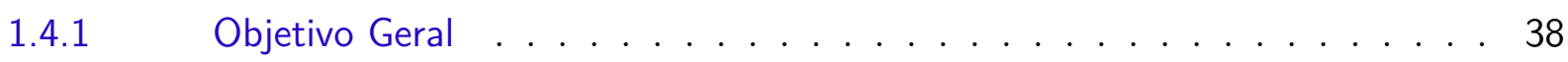

1.4 .2 Objetivos Específicos . . . . . . . . . . . . . . . . 38

1.5 Relevância e contribuição da pesquisa . . . . . . . . . . . . . 39

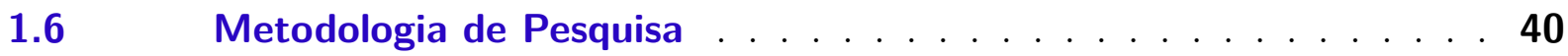

1.6 .1 Classificação da Pesquisa . . . . . . . . . . . . . . . . . . 40

1.6.2 Procedimentos técnicos utilizados . . . . . . . . . . . . . . 40

1.6.3 Percurso Metodológico . . . . . . . . . . . . . . . . . . . . 43

$1.7 \quad$ Estrutura da tese . . . . . . . . . . . . . . . 44

II REFERENCIAIS TEÓRICOS

2 REVISÃO DA LITERATURA E FUNDAMENTOS . . . . . . . . . 49

$2.1 \quad$ Práticas pedagógicas e o papel do espaço . . . . . . . . . 49

2.1.1 Conceito de percepção e cognição . . . . . . . . . . . . . . . . 51

2.1.2 Qualidade dos espaços que favorecem o aprendizado: a visão dos pedagogos 52

2.1.3 O papel do espaço no aprendizado . . . . . . . . . . . . . 54

$2.2 \quad$ Espaço arquitetônico e percepção espacial . . . . . . . . . . 56

2.3 Projeto Arquitetônico: a visão do campo disciplinar da arquitetura sobre as relações entre espaço e ensino . . . . . . . . . . . . 59

2.3.1 O processo de elaboração do projeto do espaço escolar . . . . . . . . . 80

2.3.2 Iniciando o projeto de um espaço de ensino: definição do Programa de Necessidades . . . . . . . . . . . . . . . . . . . . . 82

2.4 Campos disciplinares relativos ao desempenho do espaço na aprendizagem . . . . . . . . . . . . . . . . . 93

2.4.1 Contribuição da ergonomia a arquitetura . . . . . . . . . . . . . . 94

2.4.1.1 Ergonomia aplicada à atividade de ensino . . . . . . . . . . . . . . . 95 
2.4.2 Contribuição da psicologia ambiental a arquitetura . . . . . . . . . . . 100

2.4.3 Contribuição do conforto ambiental a arquitetura . . . . . . . . . . . . . 103

$\begin{array}{ll}\text { III RESULTADOS } & 109\end{array}$

3 CARACTERÍSTICAS ESPACIAIS FACILITADORAS DA APREN-

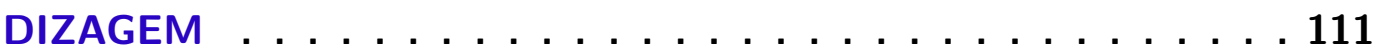

3.1 Elementos e parâmetros técnicos que estruturam a relação entre espaço arquitetônico e ensino-aprendizagem . . . . . . . . . . . . 111

3.1.1 O papel do conforto ambiental na concepção de espaços de ensino-aprendizagem 112

3.1.1.1 Conforto térmico . . . . . . . . . . . . . . . . . . . . . . . . 114

3.1.1.2 Conforto lumínico . . . . . . . . . . . . . . . . . . . 117

3.1.1.3 Conforto sonoro . . . . . . . . . . . . . . . . . . . 124

3.1.2 O papel da ergonomia na concepção de espaços de ensino-aprendizagem . . 129

3.1.2.1 Antropometria . . . . . . . . . . . . . . . . . . . 129

3.1.2.2 Adequabilidade do mobiliário ao desempenho das atividades . . . . . . . . . . 131

3.1.2.3 Ambiências na ergonomia . . . . . . . . . . . . . . . . . . 136

3.1.3 O papel da psicologia ambiental na concepção de espaços de ensinoaprendizagem . . . . . . . . . . . . . . . . . . . . . . . . 144

3.1.3.1 Espaço pessoal . . . . . . . . . . . . . . . . . . . . . . . 144

3.1.3.2 Territorialidade e privacidade . . . . . . . . . . . . . . 146

3.1.3.3 Humanização . . . . . . . . . . . . . . . . . . . . . . . . . . 148

3.2 Recorrência dos aspectos abordados por diferentes técnicas para programa de necessidades . . . . . . . . . . . . . . . . . . . . 150

3.3 Identificação das características espaciais facilitadoras do ensinoaprendizado . . . . . . . . . . . . . . . . . . . . . 163

4 MÉTODO DE AVALIAÇÃO DOS ATRIBUTOS/PARÂMETROS FACILITADORES DO ENSINO-APRENDIZAGEM E BASES PARA 0 MODELO DE ARQUITETURA DA INFORMAÇÃO . . . . . . . . 169

$4.1 \quad$ Escolha do método adequado ao tema da pesquisa . . . . . . . . 169

4.1.1 Fundamentos teóricos da análise Multicritério . . . . . . . . . . . . . . 170

4.1.2 Processo decisório e a MCDA . . . . . . . . . . . . . . 171

4.2 Estruturação do Modelo MCDA-C . . . . . . . . . . . . . 175

4.2.1 Operacionalização da análise multicritério ao estudo de caso . . . . . . . 176

$4.2 .2 \quad$ Definição do rótulo . . . . . . . . . . . . . . . . 176

$4.2 .3 \quad$ Contexto decisório . . . . . . . . . . . . . . . . . . 176

4.2.4 Identificação dos atores . . . . . . . . . . . . . . . 176

4.2.5 Identificação dos elementos de avaliação . . . . . . . . . . . . . . 177 
4.2.6 Estrutura da árvore de valor . . . . . . . . . . . . . . . . . . 179

4.2.7 Construção dos descritores . . . . . . . . . . . . . . . . . . . . . 193

4.2.8 Funções de Valor . . . . . . . . . . . . . . . . . . . . . 202

4.2 .9 Taxa de substituição (peso) . . . . . . . . . . . . . . 207

4.2.9.1 Construção das taxas de substituição ou compensação (pesos) . . . . . . . . . 207

4.2.9.2 Determinação das taxas de substituição dos critérios e subcritérios . . . . . . . 207

$4.3 \quad 0$ contexto da Ciência da Informação . . . . . . . . . . . . . . . . 219

4.3.1 Arquitetura da Informação - aspectos conceituais . . . . . . . . . . . . 220

5 CARACTERIZAÇÃO DO UNIVERSO DE ESTUDO, DESENVOLVIMENTO DA PESQUISA DE CAMPO E ANÁLISE DOS RESULTADOS . . . . . . . . . . . . . . . . . 223

5.1 Características do universo de análise: ensino de arquitetura e urbanismo . . . . . . . . . . . . . . . . . . . . 223

5.1.1 A natureza do ensino de Arquitetura e Urbanismo e a FAU/UnB . . . . . . 223

5.1.2 Histórico sobre a estrutura do curso da FAU/UnB . . . . . . . . . . . 225

5.1.3 Discussão sobre a requalificação do espaço físico da FAU/UnB . . . . . . . 228

5.2 Características do universo de análise: perfil dos professores . . . . 230

5.3 Aplicação do modelo Análise Multicritério de Apoio à Decisão (MCDA-

C) . . . . . . . . . . . . . . . . . . . . . 232

5.3.1 Avaliação das ações potenciais . . . . . . . . . . . . . . . . 232

5.3.1.1 Perfil de impacto das ações potenciais . . . . . . . . . . . . . . . . 237

5.3.2 Fórmula de Agregação Aditiva Global . . . . . . . . . . . . . . . . . . . 244

$5.3 .3 \quad$ Análise de Sensibilidade . . . . . . . . . . . . . . . 246

5.3.4 Robustez do modelo à variação das taxas de substituição . . . . . . . . . . . 247

$5.4 \quad$ Analise dos resultados . . . . . . . . . . . . . . . . . 248

5.4.1 Análises dos dados . . . . . . . . . . . . . . . 258

5.4.1.1 Conforto Ambiental - PVF 1 . . . . . . . . . . . . . . 258

5.4.1.2 Ergonomia - PVF 2 . . . . . . . . . . . . . 265

5.4.1.3 Psicologia Ambiental - PVF $3 \ldots \ldots$. . . . . . . . . . . . . . . 271

$5.5 \quad$ Avaliação Global . . . . . . . . . . . . . . . 276

5.6 Aplicação da Análise de Sensibilidade . . . . . . . . . . 279

5.7 Análise do resultado final da MCDA-C . . . . . . . . . . . 283

5.8 Modelo de Arquitetura da Informação para edificações escolares . . 288

5.8.1 Construção do Modelo de Al em apoio à elaboração de programa de necessidades arquitetônicas de espaços escolares . . . . . . . . . . . . . . 289

6 CONCLUSÕES E RECOMENDAÇÕES . . . . . . . . . . . 319

$6.1 \quad$ Alcance dos objetivos . . . . . . . . . . . . . . 320

6.2 Análise do programa de necessidades da FAU/UnB . . . . . . . 322 


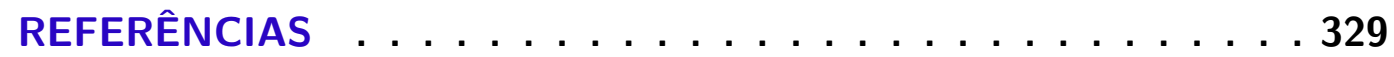

Glossário . . . . . . . . . . . . . . . . . . . . . . . . . . 349

APÊNDICES

APÊNDICE A - DISTRIBUIÇÃO DOS ESPAÇOS ARQUITETÔNICOS DA FAU/UNB E SUAS CARACTERÍSTICAS . . . . . . . . . . . . 369

APÊNDICE B - QUESTIONÁRIO UTILIZADO NA PESQUISA . . 379

APÊNDICE C - TELAS DO SOFTWARE MACBETH COM AS MATRIZES SEMÂNTICAS . . . . . . . . 383

APÊNDICE D - TELAS DO SOFTWARE HIVIEW3 COM AS PONTUAÇÕES NÃO PONDERADAS $\ldots \ldots \ldots . \ldots 391$

APÊNDICE E - TELAS DO SOFTWARE MACBETH COM OS PERFIS DE IMPACTO DAS AÇÕES POTENCIAIS395

APÊNDICE F - ÍCONES DAS PERSPECTIVAS DO MODELO DE ARQUITETURA DA INFORMAÇÃO - AI . . . . 407

Índice . . . . . . . . . . . . . . . . . . . . 409 


\section{Introdução}

A discussão acerca do papel do espaço arquitetônico no desempenho das funções do ensino e da aprendizagem de nível superior tem sido objeto de poucas reflexões em oposição ao ensino infantil, em que está concentrada a maioria dos estudos sobre o tema. Associar e extrapolar as relações válidas dessa relação para os diferentes níveis de ensino constitui o desafio do estudo que se relata nesta pesquisa.

Uma constante entre os autores pesquisados é a referência à enorme distância entre arquitetos e pedagogos no momento de definição do programa de necessidades para construção de uma escola. Apesar de não ficar claro se, em algum momento na história, a relação entre a forma de projetar escolas considerou as metodologias de ensino os estudos pesquisados destacam o que ocorre hoje quando predomina a padronização das escolas como resposta a um ideário arquitetônico do movimento modernista.

A observação corrente é a de que os edifícios escolares modernos deixam sua marca na paisagem urbana, porém nem sempre respondem às funções a que se destinam. O que predomina na prática de concepção de espaços arquitetônicos escolares é a busca pela padronização. Buffa e Pinto (2002) destacam que, a partir dos anos de 1960, o diálogo entre educadores e arquitetos na definição do projeto do edifício escolar tornou-se praticamente inexistente e o distanciamento dos profissionais ligados às áreas pedagógicas permitiu o surgimento de certas idiossincrasias na articulação dos espaços escolares.

Assim, se por um lado o exterior dos edifícios tornaram-se imponentes em suas formas geométricas simples esculpidas no concreto aparente transparecendo toda plenitude modernista, por outro lado, o espaço interior passou a não obedecer a nenhuma política pedagógica definida que poderia orientar o projeto de edifícios.

Mais do que os materiais e a forma externa, o que está em jogo nessa relação é a busca de espaços que atendam às atividades que se desenvolverão, sem ter em mente modelo predefinido, mas que vise, sobretudo, investigar as demandas para encontrar a forma que represente as necessidades da escola, do hospital ou da fábrica, que longe estão de serem semelhantes.

O programa de necessidades é a primeira etapa na elaboração de um projeto de arquitetura e resulta no denominado Estudo Preliminar. Entende-se que, nessa etapa, devem interagir todas as informações sobre as características referentes às atividades que ocorrerão no edifício, tendo em conta que, para cada atividade, deve existir um conjunto de atributos espaciais,que podem facilitar ou não seu desempenho.

Os arquitetos tendem a cumprir essa etapa de forma muito intuitiva com entrevistas 
com usuários do futuro edifício, e possuem dificuldades em traduzir os atributos espaciais necessários ao desempenho de suas atividades, e de estabelecer as superfícies necessárias para acomodar as atividades para as quais o edifício está sendo projetado.

Entretanto, o currículo (listagem das disciplinas) e o método de ensino de uma escola devem influenciar o projeto dos ambientes, que podem potencializar e facilitar o processo educacional (MCDONALD, 1996). Segundo Pauly (1992) cada currículo e cada metodologia demandam espaços específicos, influenciando cada ambiente em suas características arquitetônicas, que incluem o tamanho dos espaços, a disposição do mobiliário, a infraestrutura e os equipamentos necessários e o próprio estilo arquitetônico da edificação escolar.

É importante o entendimento das atividades educacionais, suas condições de localização no espaço e na sociedade para evitar um desencontro de propostas, em que os edifícios não atendem aos aspectos pedagógicos da política educacional e de inserção urbana das escolas. Essa interface é extremamente complexa, porém, fundamental na diretriz dos programas construtivos das novas escolas.

Assim, os estudos que ofereçamos elementos espaciais que possam facilitar o ensino e a aprendizagem durante a etapa de elaboração do programa de necessidades pode ser uma ferramenta de objetividade e assertividade na elaboração do espaço escolar. 


\section{Parte I}

\section{Preparação da Pesquisa}





\section{Elementos de pesquisa}

Este capítulo aborda a problemática a ser investigada e sua relevância, define os objetivos da pesquisa e os procedimentos metodológicos a serem seguidos e, por fim, apresenta a estrutura da tese com os resultados sobre a identificação de parâmetros para elaboração de programa de necessidades de projetos arquitetônicos de espaços de ensino-aprendizagem .

\subsection{Problema de pesquisa}

O que predomina na prática de concepção de espaços arquitetônicos escolares , na atualidade, é a busca pela estandização dos espaços . Essa visão foi assumida na forma de uma linha conceitual a ser seguida sobre o tema, especialmente, no período que se segue à corrente arquitetônica do modernismo. Buffa e Pinto (2002) destacam que, a partir dos anos de 1960, o diálogo entre educadores e arquitetos na definição do projeto do edifício escolar tornou-se praticamente inexistente. Para os arquitetos, preexistia uma forma a ser seguida, o partido arquitetônico a ser tomado era claro: uma ação moderna com materiais contemporâneos e que atendesse ao dimensionamento das atividades a serem desenvolvidas no edifício.

O distanciamento dos profissionais ligados às áreas pedagógicas permitiu o surgimento de certas idiossincrasias na articulação dos espaços escolares . Assim, se por um lado, os edifícios exteriormente fossem imponentes e se apresentassem em toda a plenitude moderna estampada nas formas geométricas simples e no concreto aparente, por outro lado, interiormente, certos detalhes importantes teriam sido negligenciados, por essa distância entre arquitetos e pedagogos no momento da definição do programa das escolas.

Assim, o problema é colocado como uma necessidade de identificação de atributos espaciais que podem favorecer a atividade de ensino-aprendizagem e que, portanto, deveriam ser o objetivo do projeto arquitetônico. São características espaciais que diferenciam um projeto de escola de outro como um hospital ou fábrica em que pese existirem aspectos da concepção arquitetônica de natureza construtiva e técnica que podem ser comuns a diferentes programas arquitetônicos.

Ainda tomando os estudos de Buffa e Pinto (2002), verifica-se uma fase explosiva, inovadora da arquitetura moderna que se expressou nos projetos dos edifícios escolares, projetos que puderam ser desenvolvidos com total liberdade criativa dos arquitetos modernos do período. Como resultado, foram construídos alguns belíssimos e marcantes edifícios, frutos de uma arquitetura ousada e eficiente e com materiais adequados à época. Por 
outro lado, as propostas pedagógicas do período permaneceram as mesmas dos períodos anteriores.

A ação moderna e criativa dos arquitetos foram exercidas a partir de aspectos relativos à arquitetura e a sua construção obedecendo a um programa pré-determinado, porém não obedecendo a nenhuma política pedagógica definida que poderia orientar o projeto de edifícios. O arquiteto tende a definir o programa de necessidades (determina a realização de um espaço arquitetônico para abrigar e favorecer o exercício de certas atividades humanas), de forma intuitiva, partindo de questionamentos aos possíveis usuários do espaço (que possuem dificuldades de traduzir os atributos espaciais necessários ao desempenho de suas atividades) e/ou por estabelecimento das metragens quadradas que acomodarão as atividades para as quais o edifício está sendo construído.

Para Buffa e Pinto (2002) é clara a cisão entre os produtores de espaço, os arquitetos, e os produtores do ensino, os pedagogos, que pouco ou quase nenhum contato tiveram entre si na época marcada pelo modernismo na arquitetura. A ação dos pedagogos restringia-se quase que unicamente à definição de programas escolares e os arquitetos, com toda a liberdade, os articulavam segundo suas premissas e ação criativa.

Assim, é importante o entendimento das atividades educacionais, suas condições de localização no espaço e na sociedade para evitar um desencontro de propostas em que os edifícios não atendem aos aspectos pedagógicos/políticos e de inserção urbana das escolas. Essa interface é extremamente complexa, porém, fundamental na diretriz dos programas construtivos das novas escolas.

A alocação espacial e a sua projetação arquitetônica na universidade, também, devem ocorrer como função do campo disciplinar e das metodologias de ensino e suas tecnologias (os avanços tecnológicos em hardware e software no campo da educação, permitem a introdução de novas técnicas que enriquecem o processo de ensino-aprendizagem), sendo possível a partir da identificação dos parâmetros dos espaços arquitetônicos, que melhor propiciam a aprendizagem, estabelecer um sistema de gerenciamento fundamentado na educação.

Assim, tanto pelas características do campo disciplinar quanto de uma proposta pedagógica, existe carência de estudos que correlacionem atributos do espaço arquitetônico para orientar na tomada de decisão e na elaboração de projetos e requalificação dos espaços arquitetônicos voltados à atividade educacional. Há também uma real necessidade de gerenciamento das informações sobre os parâmetros dos espaços arquitetônicos relevantes para a elaboração do programa de necessidades de modo a retroalimentar a elaboração e requalificação dos projetos arquitetônicos com fins educacionais.

Portanto, o problema abordado nesta pesquisa refere-se à carência de procedimento de análise dos parâmetros a serem considerados na definição de programa de necessidade 
para a elaboração de projetos de arquitetura com fins educacionais.

Como encaminhamento de pesquisa, o problema é colocado como a necessidade de que o espaço arquitetônico para a educação (espaço físico destinado ao desempenho da aprendizagem em seus diferentes níveis) considere a relevância das implicações da inexistência de parâmetros (ferramentas de apoio ao processo de projeto arquitetônico, que é um conjunto de premissas que define o programa de necessidades, local onde será implantado o edifício e um modo de construir adequado, elaborado graficamente em um desenho que opera como mediador entre a ideia do projeto e sua realização concreta), que possam apoiar a projetação (que define a produção do projeto de arquitetura como um processo) de novos espaços ou sua requalificação (tornar a qualificar; qualificar de novo o espaço arquitetônico) para que a adequação real dos atributos do espaço não fiquem a cargo da "sensibilidade do arquiteto", e sim de um sistema que informe quais os atributos que ele deve utilizar para cada tipo de ensino, que serão desempenhados no espaço objeto do projeto arquitetônico.

A partir dessa consideração, levantam-se algumas indagações de pesquisa:

- Quais aspectos do espaço mais influenciam no aprendizado, se é que existem?

- O espaço arquitetônico possui relevância no aprendizado de nível superior como o estabelecido nas pesquisas para o ensino infantil ?

- A Arquitetura da Informação é uma ferramenta que possibilita a organização e o gerenciamento das informações do espaço arquitetônico para apoio a elaboração de projetos arquitetônicos escolares?

\subsection{Hipótese}

A pesquisa parte da hipótese de que o espaço arquitetônico pode colaborar para um melhor desempenho das funções de ensino-aprendizagem, existindo atributos espaciais identificáveis e capazes de parametrização, que possibilitem a definição do programa de necessidades para atender à elaboração de projetos arquitetônicos.

\subsection{Premissas}

a) O ensino não é aespacial ${ }^{1}$. O conhecimento do ensino-aprendizagem na área infantil demonstra a relevância do espaço no aprendizado, sendo essa relação

1 Nem aespacial nem a-espacial se encontram nos dicionários de língua portuguesa, apesar de ambas as formas estarem presentes em artigos científicos: neste estudo o termo é utilizado com o significado de que o ensino ocorre em um espaço físico e esse possui influencia sobre seu desempenho, ou seja o ensino não independe do espaço físico onde ele ocorre. 
pertinente aos diferentes níveis de ensino.

b) A alocação espacial e a projetação arquitetônica dos espaços para o ensino universitário devem ocorrer como função do campo disciplinar e das metodologias de ensino e suas tecnologias, existindo atributos dos espaços arquitetônicos, que melhor propiciam a aprendizagem.

c) A Arquitetura da Informação possibilita o ordenamento, a organização e a gestão do conjunto de informações das necessidades da função ensino-aprendizagem para dar insumos à elaboração de projetos de arquitetura.

\subsection{Objetivos}

\subsubsection{Objetivo Geral}

Identificar atributos do espaço arquitetônico que favoreçam o aprendizado para áreas de ensino universitário, proceder a sua parametrização e forma de gerenciamento com vistas a apoiar a definição do programa de necessidades para a elaboração de projetos de arquitetura.

\subsubsection{Objetivos Específicos}

- Proceder à revisão bibliográfica no campo da Pedagogia, Arquitetura e áreas disciplinares nas quais se mostrem relevantes suas relações para identificar atributos do espaço arquitetônico que favoreçam o aprendizado (capítulos 2 e 3);

- Propor um modelo para avaliar as características/parâmetros identificados na referência bibliográfica com base na Metodologia Multicritério de Apoio à Decisão, de acordo com o juízo de valorticas dos especialistas em Conforto Ambiental, Ergonomia e Psicologia Ambiental (decisores) (capítulo 4 e 5);

- Aplicar o Modelo MCDA-C com os professores do curso de Arquitetura e Urbanismo para ajustar parâmetros identificados na referência bibliográfica e validar sua relevância no ensino de arquitetura (Capítulos 5); e

- Propor um Modelo de Arquitetura da Informação aplicável a ambientes informacionais de natureza educacional, que seja capaz de ordenar, organizar e gerenciar os parâmetros a serem considerados na definição de programa de necessidade para a elaboração de projetos de arquitetura com fins educacionais (Capítulos 4 e 5). 


\subsection{Relevância e contribuição da pesquisa}

O objetivo desta seção é apresentar por que é cientificamente relevante resolver os problemas apresentados na seção 1.1 a partir dos objetivos propostos na seção 1.4.

A motivação para realizar esta pesquisa se baseia na percepção de que há uma carência de procedimento de análise dos parâmetros a serem considerados na definição de programa de necessidade para a elaboração de projetos de arquitetura com fins educacionais. O desafio a ser enfrentado consiste na possibilidade de criar tais procedimentos de análise e identificação para a área de ensino de arquitetura, com vistas a contribuir com a falta de informação para o projeto arquitetônico na área educacional.

Loureiro (1999, p. 9) afirma que estudar a relação entre organização social e padrão espacial significa admitir que arquitetura e organizações sociais interagem tanto no plano simbólico, sendo arquitetura construção, mas construção concebida com o propósito primordial de ordenar e organizar o espaço para determinada finalidade e visando a determinada intenção, quanto no plano mais pragmático, do programa e da organização espacial. Significaria, portanto, admitir, em relação às edificações institucionais, que o prédio, ele mesmo, não só exerceria o papel simbólico de representar aquela instituição, mas também agiria como um coadjuvante nos procedimentos para a realização da função social que é seu o objetivo.

A articulação arquitetura e educação apresenta múltiplas dimensões que podem ser tecidas em conjunto, uma vez que ambas são, também isoladamente, pluridimensionais. Para Beltrame e Moura (2009), o espaço escolar é fundamental para a formação do ser humano devendo ser elemento de atenção na relação dinâmica entre usuário e o ambiente, portanto as questões pertinentes à interação entre espaço físico, atividades pedagógicas e comportamento humano devem ser consideradas prioritárias no processo de elaboração do projeto arquitetônico.

Na área da Pedagogia os estudos existentes sobre a importância do espaço na aprendizagem tem se restringido somente aos primeiros anos de vida dos alunos, como se o ambiente não exercesse qualquer influência sobre aqueles quando ficam mais velhos. Essa tônica é apresentada por Frago

[...]até aqui, tudo se referiu aos ensinos pré-escolar e elementar. No ensino secundário e no universitário, continua vigorando o modelo de aula/sala, com seu estrado, como um púlpito, de onde o professor ministra a doutrina, com seus bancos ou carteiras alinhadas e enfileiradas numa disposição fixa, muitas vezes até mesmo fixos no chão[...] (FRAGO, 1998, p. 133).

Como seriam as disposições espaciais em disciplinas específicas, laboratórios, salas práticas ou seminários em pequenos grupos, este tema continua sem estudos que o fundamentem. 
Existem, no entanto, muitas pesquisas que avaliam a qualidade do espaço arquitetônico com foco no conforto, segurança e salubridade das pessoas, mas que pouco relacionam estes aspectos ao aprendizado, menos ainda ao aprendizado de núcleos diferentes de conhecimento.

A experiência em elaboração de projetos e execução de obras da pesquisadora motivou a presente pesquisa. Os problemas identificados no acompanhamento de obras na execução de edificações escolares na Universidade de Brasília apontam para a relevância da existência das relações aqui expressa como premissas e para a possível existência de parâmetros que irão auxiliar o arquiteto na fase de elaboração de projetos, reduzindo o eterno retrabalho que implica adaptar edifícios novos a funções de ensino que já deveriam ter sido consideradas de forma antecipada.

Assim, a contribuição pretendida se relaciona aos estudos acadêmicos e à prática profissional da arquitetura por proporcionar aos arquitetos e especialistas na área de arquitetura o conhecimento das informações referentes aos parâmetros necessários à elaboração do programa de necessidades para a formulação do projeto arquitetônico com fins educacionais.

\subsection{Metodologia de Pesquisa}

\subsubsection{Classificação da Pesquisa}

A pesquisa se enquadra em duas classificações metodológicas: na primeira parte, referente à investigação sobre os atributos espaciais que favorecem o ensino, quando serão estudados o campo da Pedagogia e da Arquitetura. A pesquisa se caracteriza como descritiva, isto é, visa descrever as características de determinada população ou fenômeno ou o estabelecimento de relações entre variáveis (MELO, 2010). Envolve o uso de técnicas padronizadas de coleta de dados: questionário e observação sistemática. Portanto, essa pesquisa busca a identificação de atributos/parâmetros do espaço arquitetônico para levantamento de programa de necessidades para elaboração de projeto de arquitetura com fins educacionais.

\subsubsection{Procedimentos técnicos utilizados}

1. Definição dos atributos e parâmetros

a) Os atributos e parâmetros considerados na pesquisa foram identificados, avaliados e analisados a partir do universo de mais de 80 autores contemplados no capítulo 3, nos campos disciplinares do Conforto Ambiental (Tabela 14 ), Ergonomia (Tabela 19) e Psicologia Ambiental (Tabela 20). 
b) Os especialistas (decisores) contribuíram com adequações de atributos, parâmetros e terminológica (seção 4.2 , capítulo 4).

A revisão bibliográfica teve como objetivo identificar subsídios teóricos e conceitos para definição de características do espaço que favorecem o aprendizado, suas categorias e atributos em temos do espaço arquitetônico. Estudos técnicos para definir os parâmetros que orientem a definição dos programas de necessidades arquitetônicos. O que envolve o campo da Arquitetura, Psicologia Ambiental e Ergonomia. Outra vertente será a pesquisa sobre arquitetura da informação para escolha das bases para proposição do modelo de gerenciamento dos atributos/parâmetros alcançados pela pesquisa.

2. Análise Multicritério de Apoio à decisão - (MCDA-C) (capítulos 4 e 5).

No segundo momento, confere-se relevância aos atributos encontrados pelos usuários dos espaços de ensino-aprendizagem em escolas de arquitetura quando se adota como método de pesquisa é de Análise Multicritério de Apoio a Decisão - (MCDA-C), que consiste em uma técnica de avaliação que auxilia na interação entre atores para a construção de uma estrutura e uma linguagem de comunicação partilhada por todos. A principal característica da análise multicritério é a estruturação dos problemas em termos de um número de critérios individualizados, cada um representando um eixo de avaliação, conduzindo a uma processo de tomada de decisão mais robusto. A MCDA-C vem sendo frequentemente abordada em trabalhos de pesquisa por autores como Bana e Costa (2001), Ostanello (1990), Roy (1993), Malczewski (1999), Bouyssou (1989), Silva et al. (2004), Ensslin, Neto e Noronha (2001) e Saboya et al. (2005).

3. Estudo de caso - realizado na Faculdade de Arquitetura e Urbanisno da Universidade de Brasília (capítulo 5).

O estudo de caso se constituiu de aplicação questionário e entrevistas para validação e ajuste dos atributos e parâmetros a um campo específico de aprendizagem, no caso o campo disciplinar da arquitetura. Será definido um curso de Arquitetura e Urbanismo de caráter público.

4. Procedimentos especiais (capítulo 5).

a) Ícones - meras representações estéticas (ilustrações), não influenciando os resultados da pesquisa (Tabelas 57, 58, 59, 60 e 61 e Apêndice F).

b) Normas Técnicas - utilizadas como referências orientadoras no estabelecimento de regras, diretrizes e características dos parâmetros elencados pelos autores literários e pelos decisores nos campos disciplinares: Conforto Ambiental, Ergonomia e Psicologia Ambiental. 
Por fim, serão empregados procedimentos metodológicos fundamentados na Arquitetura da Informação para estruturar o conjunto de atributos a serem utilizados em apoio a elaboração do programa de necessidades do projeto arquitetônico. 


\subsubsection{Percurso Metodológico}

O percurso metodológico do trabalho está representado de forma esquemática na Figura 1, contendo as fases básicas do estudo realizado.

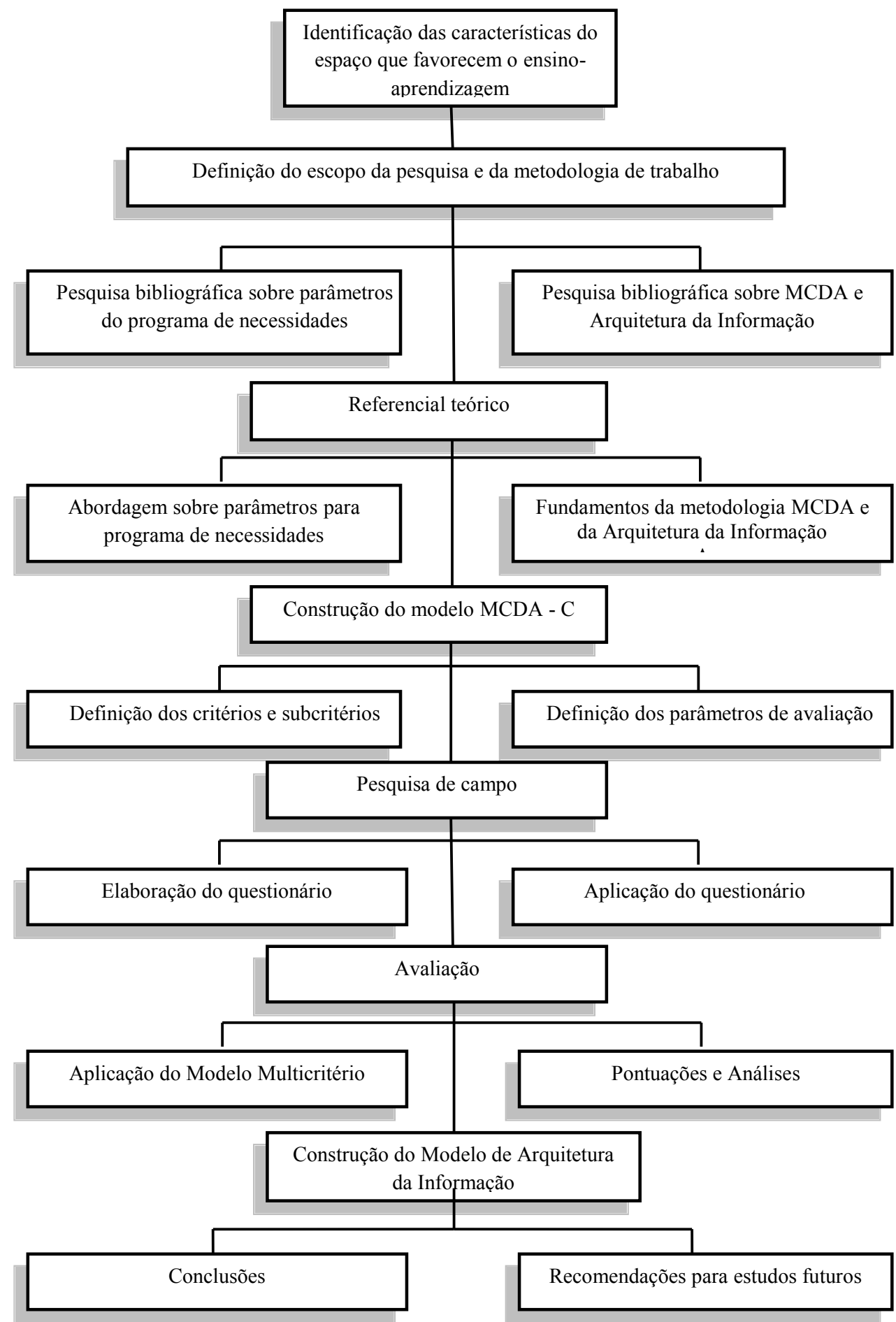

Figura 1 - Percurso Metodológico

Elaboração própria (2016) 


\subsection{Estrutura da tese}

O trabalho a seguir apresentado se organiza em duas partes: uma, de natureza teórica, estruturada a partir da definição das bases da pesquisa e da investigação sobre as referências conceituais da relação ensino e espaço arquitetônico - correspondente aos três primeiros capítulos, e a segunda parte de cunho empírico, onde constam as bases metodológicas, aplicação da pesquisa de campo e análise de resultados e, por fim, estabelece a validação das hipóteses levantadas e resposta às questões de pesquisa.

\section{a) Parte I: Preparação da pesquisa}

\section{Capítulo 1 - OBJETIVO E MÉTODO DE PESQUISA}

O capítulo aborda a problemática a ser investigada e sua relevância, define os objetivos da pesquisa e os procedimentos metodológicos a serem seguidos e apresenta a estrutura da tese com os resultados sobre a identificação de parâmetros para elaboração de programa de necessidades de projetos arquitetônicos de espaços de ensino-aprendizagem .

\section{b) Parte II: Referenciais Teóricos}

\section{Capítulo 2 - REVISÃO DA LITERATURA E FUNDAMENTOS}

Contempla discussão sobre os conceitos que ancoram a pesquisa, no intuito de identificar as características da forma arquitetônica que se correlacionam com ensino-aprendizagem bem como os parâmetros relevantes para elaboração do programa de necessidades para projetos arquitetônicos. Revisa também a definição de conceitos das diferentes disciplinas que ancoram a pesquisa: Pedagogia, Arquitetura, Conforto Ambiental, Ergonomia, Psicologia Ambiental e Arquitetura da Informação.

c) Parte III - Resultados

Capítulo 3 - CARACTERÍSTICAS ESPACIAIS FACILITADORAS DA APRENDIZAGEM

O capítulo aprofunda as relações entre espaço arquitetônico e sua influência na aprendizagem podendo facilitar ou dificultar o ensino e identifica uma primeira aproximação do conjunto de aspectos afetos aos três campos disciplinares identificados como intervenientes nessa relação por meio de um conjunto de atributos espaciais a serem posteriormente validados no âmbito do ensino superior com ferramental de pesquisa de campo.

Capítulo 4 - MÉTODO DE AVALIAÇÃO DOS ATRIBUTOS/PARÂMETROS FACILITADORES DO ENSINO-APRENDIZAGEM E BASES PARA O MODELO DE ARQUITETURA DA INFORMAÇÃO 
Discussão conceitual da Metodologia de Análise Multicritério e sua aplicabilidade ao tema de estudo. Estruturação do Modelo Multicritério de Apoio à Decisão (MCDA - Construtivista) com enfoque para a identificação do contexto decisório, construção do modelo de avaliação e análise de sensibilidade. Bases conceituais da Arquitetura da Informação e discussão de sua relevância para apoio à elaboração de programas de necessidades de projetos de Arquitetura.

\section{Capítulo 5 - CARACTERIZAÇÃO DO UNIVERSO DE ESTUDO, DESENVOLVIMENTO DA PESQUISA DE CAMPO E ANÁLISE DOS RESULTADOS}

Caracterização do universo de estudo e apresentação das diferentes fases de aplicação da pesquisa de campo, os dados levantados e análise dos resultados da pesquisa com base no modelo de avaliação desenvolvido. Estruturação do Modelo de Arquitetura da Informação (AI) utilizado para o gerenciamento das informações geradas pela pesquisa.

\section{Capítulo 6 - CONCLUSÃO E RESULTADOS ALCANÇADOS}

Apresentação dos principais resultados alcançados ao longo da trajetória da pesquisa, discute a pertinência da hipótese levantada e responde às questões de pesquisa. Elaboração de análise crítica do processo, com apresentação de limitações e recomendações para outras pesquisas. 

Parte II

Referenciais Teóricos 



\section{Revisão da Literatura e Fundamentos}

O capítulo contempla discussão sobre os conceitos que ancoram a pesquisa, no intuito de identificar as características da forma arquitetônica que se correlacionam com ensino-aprendizagem, bem como os parâmetros relevantes para elaboração do programa de necessidades para projetos arquitetônicos. Assim, como base conceitual se utiliza do conhecimento sobre o espaço arquitetônico e sua capacidade de transmitir sensações e a natureza do processo de aprendizagem destacando o papel do espaço arquitetônico para seu desempenho. Revisa também a definição de conceitos das diferentes disciplinas que ancoram a pesquisa: projeto arquitetônico, programa de necessidades, ensino e aprendizagem e demais conceitos correlatos necessários à clareza da pesquisa.

\subsection{Práticas pedagógicas e o papel do espaço}

O ensino considera conteúdos de diferentes áreas de conhecimento para o exercício de sua atividade primordial que consiste em que o aluno se aproprie dos conhecimentos de um campo de conhecimento específico que a disciplina em pauta preconiza. Assim, ensinar e aprender são uma atividade complexa que exige do ser humano procedimentos diferenciados segundo a natureza do conhecimento que se quer transmitir.

Além da observação do registro, da organização, do relato e da comunicação das informações de conteúdo, o espaço escolar deve considerar algumas funções centrais do desenvolvimento humano que levam à aprendizagem; são conteúdos diversos como a função simbólica, a percepção e a qualidade do espaço manifestam de diferentes formas.

Segundo Nair e Fielding (2005), as metodologias de ensino demonstram que os ambientes devem possibilitar maior variedade de configurações para desenvolver as 18 modalidades de atividades de aprendizagem, consideradas funções de projeto de um espaço escolar (Tabela 1).Para os autores, trabalhar com as modalidades de ensino quebra o paradigma de desenvolver o projeto arquitetônico de escolas como um jogo de quebracabeças de organização de espaços consagrados, como salas de aula ou quadra de esportes, e passa-se à compreensão das necessidades pedagógicas e de ensino, com espaços diferenciados e mais adequados à aprendizagem (KOWALTOWSKI, 2011).

A concepção de escola como a entendemos hoje vem do modelo humanista concebido no século XVI, como afirmam Buffa e Pinto (2002, p. 159): "foi nesse momento histórico preciso que a escola deixou de ser apenas um agrupamento de mestres e discípulos e tornou-se um prédio específico, um lugar". A arquitetura dos edifícios escolares começou, então, a ter uma identidade na paisagem urbana e um reconhecimento da sociedade como 
Tabela 1 - Funções de projeto de um espaço escolar

\begin{aligned} & \hline Ítem Modalidades de atividades de aprendizagem \\ & \hline 1 Estudo independente \\ & \hline 2 Grupos de trabalhos supervisionados ( "peer tutoring") \\ & \hline 3 Trabalho colaborativo em grupos pequenos de 2 - 6 alunos \\ & \hline 4 Instrução individual (aluno - professor) \\ & \hline 5 Palestra, professor ou especialista convidado ocupando o palco principal \\ & \hline 6 Ensino baseado em projetos temáticos previamente estabelecidos ( Project-based learning") \\ & \hline 7 Aprendizado com base em tecnologia móvel (laptops) \\ & \hline 8 Ensino a distância \\ & \hline 10 Pesquisa via internet por meio de conexões sem fio \\ & \hline 11 Apresentações dos alunos \\ & \hline 12 Ensino por meio da instrução por seminários \\ & \hline 13 Aprendizado por meio de serviço comunitário \\ & \hline 14 Aprendizado por meio da natureza \\ & \hline 15 Aprendizado social e emocional \\ & \hline 16 Ensino baseado em artes \\ & \hline 18 Ensino por meio de ato de conto de histórias \\ & \hline\end{aligned}

Fonte: Nair e Fielding (2005).

símbolo para a educação.

Os recursos físicos das instalações escolares passam mensagens às vezes mais fortes e poderosas do que os conteúdos apresentados por professores ou materiais didáticos. O pertencimento ao espaço escolar e seu entorno são fundamentais na constituição do ser humano. A articulação arquitetura e educação apresentam múltiplas dimensões que podem ser tecidas em conjunto, uma vez que ambas são, também isoladamente, pluridimensionais.

Para Freire:

\begin{abstract}
"O espaço é retrato da relação pedagógica. Nele é que o nosso conviver vai sendo registrado, marcando nossas descobertas, nosso crescimento, nossas dúvidas. O espaço é retrato da relação pedagógica porque registra, concretamente, através de sua arrumação (dos móveis...) e organização (dos materiais...) a nossa maneira de viver esta relação". (FREIRE, 1994, p.96)
\end{abstract}

Para Almeida e Rocha (2009), a articulação arquitetura e educação guarda proximidade com o pensamento complexo na medida em que ambos os termos dessa relação apresentam múltiplas dimensões que podem ser tecidas em conjunto. Tanto a arquitetura como a educação são pluridimensionais. A sala de aula, onde se dá o processo de aprendizagem e a relação professor-aluno, está inserida no edifício escolar com suas especificidades de conforto ambiental, constituídas pela luminosidade natural ou artificial, pela acústica, pela sensação térmica, pela ergonomia do mobiliário, pelo esquema de cores e pelo dimensionamento espacial. Há uma complexidade na qual interior, entorno e contextos se entrelaçam. 
O pedagogo Teixeira (1960) expõe sua visão sobre o espaço escolar quando diz que "nenhum outro elemento é tão fundamental, no complexo da situação educacional, depois do professor, como o prédio e suas instalações". Vai ao encontro dessa ideia o arquiteto Sophie (2007, p.45) quando, em entrevista ao Dossiê Arquitetura da Revista Educação, define que fazer arquitetura é entender um problema, refletir, planejar, muito mais que desenhar. É preciso compreensão do programa de atividades, entender o projeto pedagógico; conhecer o território em que a escola vai ser implantada, a legislação que versa sobre o território e sobre a escola. E conseguir externar e traduzir em linguagem espacial.

Conforme afirma Morin (2002, p. 132), o aporte do pensamento complexo pode trazer contribuições na articulação entre arquitetura e educação, pois o olhar da complexidade sendo dinâmico e polissêmico é capaz de superar a fragmentação da realidade e respeitar as diversas riquezas e conexões com o urbano propostas pelos contextos dos edifícios escolares. Partindo do ponto de vista da complexidade, é importante trazer a ideia de estado estético para pensar a questão em estudo e entender como o cotidiano vivido na precariedade de uma escola de lata ou em uma escola planejada afeta o sentir de professores, funcionários e alunos.

A arquitetura pode ser estudada como veículo de mensagens mais ou menos codificadas, uma vez que sua intervenção no espaço ocorre por meio da organização deste por meio da criação de elementos. Sendo assim, a arquitetura pode ser considerada um fenômeno de comunicação, ou seja, uma linguagem não verbal. Como linguagem, a arquitetura está presente nos limites e distâncias, aproximações ou recusas impostas pelos usuários (MELLO, 2007).

Diante do fenômeno citado, torna-se relevante identificar os elementos de destaque nessa relação para que não ocorra a utilização de projeto arquitetônico padrão que recebe destaque na literatura já referida como favorável/prejudicial ao processo de aprendizagem.

\subsubsection{Conceito de percepção e cognição}

O conceito de percepção tem sido compreendido e definido, fundamentalmente, de duas maneiras: uma relacionada à interação entre o espaço e o usuário, exclusivamente, por meio dos sentidos básicos (visão, olfato, audição, tato e paladar); outra, relacionada à interação entre o espaço e o usuário, por meio dos sentidos básicos e de outros fatores, tais como memória, personalidade, cultura e tipo de transmissão (RAPOPORT, 2013).

A percepção passa a ser uma palavra-chave para a realização de trabalhos que envolvam a avaliação do edifício durante o processo de sua utilização, sendo identificada por Monzéglio (1990) como

[...] fator de relevância para análise do ambiente em fruição, indicando e dimensionando seus aspectos qualitativos, de categorias tipológicas, 
incidência e relações, alertando sobre as demandas e anseios de melhoria, tendo em vista a evolução, atualização e as projeções futuras [...], avaliação que procede segundo seu alcance de conhecimento para uso também de seu alcance no saber e na cultura própria (MONZÉGLIO, 1990, p. 33).

De acordo com Piaget (1973), cognição é o processo de construção de sentido na mente, cumulativo, que se forma por meio da experiência cotidiana, sendo complementar à percepção, quando esta é tratada como exclusivamente sensorial, relacionada à experiência direta com o ambiente. É pela cognição que as sensações adquirem valores, significados, e formam uma imagem no universo de conhecimento do indivíduo, envolvendo necessariamente reconhecimento, memória e pensamento, e gerando expectativas sobre o ambiente, que se traduzem em atitudes e comportamentos dos usuários (REIS; LAY, 2006). Para estes autores, a cognição ambiental está relacionada com o aprendizado e a memória, mediante o armazenamento, organização, reconstrução e chamamento de imagens dos atributos ambientais que não estão disponíveis no ambiente físico num primeiro momento.

É importante destacar que nas interações pessoa-ambiente, percepção e cognição compõem um sistema e que o conhecimento é um processo de aprendizagem adquirido pelo reforço e associação de estímulos específicos e sugestões. A cognição permite o exercício da discriminação de percepções para identificar e selecionar estímulos que respondam às suas necessidades ou desejos. As sensações visuais agem no indivíduo e, a partir daí, desenvolve-se tanto nas questões fisiológicas quanto nos aspectos socioeconômico-culturais da vivência, influindo em comportamentos individuais e de grupo, portanto, nas redes de relacionamentos desenvolvidas 'com' ou 'nos' ambientes iluminados (VARGAS, 2009).

A partir do levantamento bibliográfico sobre a importância das sensações produzidas, destacam-se os conceitos de percepção e cognição como fundamentais na relação espaço/aprendizagem. A abordagem perceptiva e cognitiva é adotada na área de estudos Ambiente-Comportamento, que tem por objetivo investigar as relações entre as características físico-espaciais do ambiente construído e o comportamento dos indivíduos, focando, principalmente, na aplicação de métodos das ciências sociais para analisar e avaliar a qualidade do ambiente construído (REIS; LAY, 2006).

\subsubsection{Qualidade dos espaços que favorecem o aprendizado: a visão dos peda- gogos}

Maria Montessori, Basil Bernstein e Paulo Freire são alguns educadores que, em suas reflexões e práticas educativas, consideraram o meio ambiente e, sobretudo, o espaço construído - o edifício, as áreas verdes, os equipamentos e o mobiliário escolar - como espaços educativos (CARPINTERO; ALMEIDA, 2008).

Para Carpintero e Almeida (2008), Montessori foi uma das primeiras educadoras a se preocupar com a qualidade do espaço da escola para a educação. Olhou com especial 
carinho as condições físicas da sala de aula. Chegou a afirmar que o educador atua mais sobre o ambiente do que sobre a criança. Afirmava que o ambiente escolar deveria ser aberto às intervenções das crianças, isto é, deveria ser um território em que as crianças pudessem elas mesmas organizar e utilizar, sem constrangimento e interferências dos mestres.

O sociólogo da educação Bernstein (1996) aponta o ambiente escolar como um facilitador e, sobretudo, um meio pelo qual os educadores incutiam nos educandos comportamentos sociais. O espaço da escola, especialmente a disposição de suas instalações físicas e prediais, tem relação direta com a maneira como as práticas pedagógicas são nela desenvolvidas e, principalmente, controladas. Para esse autor, os mecanismos de controle das atividades e das práticas pedagógicas da escola são a classificação, a maneira como são reguladas as relações entre os agentes que atuam na escola, assim como as atividades por eles exercidas, e enquadramento refere-se ao modo e ao lugar de ocorrência das atividades pedagógicas.

Avançando na definição dos elementos que interferem no aprendizado, Nogueira (2011) diz que os espaços da sala de aula devem ser um recurso polivalente, que podem ser utilizados de muitas maneiras e do qual se podem extrair grandes possibilidades para a formação. Segundo a autora, as crianças pequenas veem o espaço como aquilo que nós chamamos de espaço equipado, ou seja, com tudo o que efetivamente o compõe: móveis, objetos, odores, cores, coisas duras e moles, coisas longas e curtas, coisas frias e coisas quentes.

A autora cita ainda a diferença entre espaço e ambiente, sendo que espaço refere-se ao espaço físico, caracterizado pelos objetos, pelos materiais didáticos, pelo mobiliário e pela decoração, e ambiente refere-se ao conjunto do espaço físico e às relações que nele se estabelecem (os afetos, as relações interpessoais entre as crianças e os adultos e entre as próprias crianças), concluindo que o espaço escolar funciona como ambiente de aprendizagem.

Oliveira (2002, p. 192-194) afirma que deve haver grande preocupação com a funcionalidade e a estética dos ambientes, já que todos os espaços servem para a educação visual, expressiva, cognitiva, ética e estética. Na mesma linha, considera que a educação escolar desenvolve-se no espaço físico, o qual, a depender da sua infraestrutura e dos recursos disponibilizados, contribui (ou não) para que os objetivos enunciados (e os ocultos) sejam alcançados.

Da mesma opinião compartilha Rocha (2000): a disposição espacial - seja aquela da localização da escola no tecido urbano, da distribuição do(s) edifícios(s) no terreno, da organização interna (salas de aula, espaços cheios e vazios, abertos e fechados, corredores, fluxos de entrada e saída, salas de professores, espaço reservado à administração e direção entre outros), e mesmo aquela da distribuição interna entre os vários elementos (móveis, portas, janelas etc.) que compõem os diversos ambientes/espaços escolares - é sempre 
um elemento de demarcação não somente arquitetural, mas também consideravelmente pedagógico.

Assim, percebe-se que a atratividade ambiental, que facilita o acolhimento, e a disposição da infraestrutura física da escola concorrem para o sucesso do trabalho pedagógico ( organização do espaço, dos meios físicos - equipamentos, móveis etc. - nos recintos escolares e das áreas abertas - jardins, pomares etc. - como também à disposição dos prédios no terreno). Essas condições concorrem para prolongar a permanência das pessoas na escola e, sobretudo, fazem dela um ponto de atração, isto é, um lugar apropriado para a educação (CARPINTERO; ALMEIDA, 2008).

O ambiente, com ou sem o conhecimento do educador, envia mensagens, e os que aprendem respondem a elas. A influência do meio por meio da interação possibilitada por seus elementos é contínua e penetrante. As crianças e/ou os usuários dos espaços são os verdadeiros protagonistas da sua aprendizagem, na vivência ativa com outras pessoas e objetos, que possibilita descobertas pessoais num espaço onde será realizado um trabalho individualmente ou em pequenos grupos (HANK, 2006).

\subsubsection{O papel do espaço no aprendizado}

A ideia de que a arquitetura e os espaços escolares, sua disposição e equipamentos possuem uma ligação com a pedagogia é uma convicção antiga, de pedagogos e arquitetos. Froebel já projetava materiais didáticos e localizava o espaço da sua escola em um jardim, Dewey experimentou configurações espaciais na sua Escola Laboratório da universidade de Chicago. Na área da arquitetura, Le Corbusier, em Paris, e Hélio Duarte, em São Paulo e Salvador, possuíam um discurso de que o projeto educativo deveria fazer parte do planejamento do espaço, mesmo que advogassem a arquitetura moderna a que os pedagogos atribuem o descolamento entre essas relações.

Diante das reflexões dos diversos pedagogos, verifica-se que, além de relevantes os aspectos físicos do ambiente escolar, são considerados pouco estudados nas discussões pedagógicas ou em estilos de aprendizagem. Como pelo menos $20 \%$ da população passam grande parte do dia dentro de prédios escolares, é pertinente indagar acerca do impacto de elementos arquitetônicos sobre os níveis de aprendizagem dos alunos e de produtividade dos professores ao transmitir conhecimento. Para a comunidade escolar deve existir a certeza de que o ambiente físico contribui positivamente para criar o contexto adequado, confortável e estimulante para uma produção acadêmica expressiva.

Por mais que muitos autores como Foucault, Bourdieu e Certeau, nos mostrem a existência de um "currículo oculto" nos prédios escolares, estes ainda possuem a condição de " objeto pouco estudado"(BARGUIL, 2006, p. 151). Moussatché (1998, p. 13-14) destaca que nas sociedades complexas contemporâneas, planejavam-se os ambientes físicos sem dar 
a devida atenção a suas características educativas (positivas e negativas) como se estes não tivessem nenhuma relação com as representações neles e sobre eles elaboradas.

Segundo Nogueira (2011), o espaço funciona como elemento curricular, considerando que jamais é neutro, que o educador não pode conformar-se com o meio tal como lhe é oferecido e que este deve ser uma estrutura de oportunidades e contexto de aprendizagem e de significados. Informa que os professores de educação infantil sabem bem que, quando fazem seu plano de trabalho, uma parte importante do seu esforço e das suas decisões irá referir-se aos espaços: como organizá-lo, como equipá-lo e enriquecê-lo para que se transforme em fator estimulante da atividade.

A educação, na Lei de Diretrizes e Bases (LDB), é também dever do Estado, conforme preconiza o art. 40 "O dever do Estado com educação escolar pública será efetivado mediante a garantia de: [...] IX - padrões mínimos de qualidade de ensino, definidos como a variedade e quantidade mínimas, por aluno, de insumos indispensáveis ao desenvolvimento do processo de ensino-aprendizagem".

A Organização das Nações Unidas para a Educação, Ciência e Cultura (UNESCO, 2008) ressalta a mudança dos paradigmas da educação, que, além das novas práticas pedagógicas, exige um espaço físico apropriado, que abrigue as didáticas, estimule a atuação de discentes e docentes, e atenda tanto o aprender a conhecer e a fazer quanto o aprender a conviver e a ser.

Reforçando essa visão, Sanoff (2001) diz que a qualidade da aprendizagem é alcançada por meio de elementos físicos e não físicos do ambiente. Sendo assim, torna-se relevante associar os aspectos físicos do ambiente ao processo de aprendizagem. O espaço de sala de aula deve ser parte integrante do currículo escolar, já que sua finalidade é responder às necessidades dos professores e dos alunos . Para o autor, o ambiente físico é como o segundo professor dentro da sala de aula, uma vez que, quando bem planejado, tem a capacidade de organizar e promover uma interação harmoniosa entre pessoas de diferentes idades, favorecer mudanças, possibilitar escolhas e atividades, além de estimular o aprendizado social, cognitivo e afetivo.

Segundo Vieira (2000), a arquitetura escolar vai mais adiante do que apenas mostrar, materializar e visibilizar funções culturais e pedagógicas. A arquitetura escolar está presente também nas metodologias utilizadas na escola. Também os trabalhos de Piaget (1973) tratam da concepção do espaço na criança, uma construção internalizada a partir das ações ou manipulações sobre o ambiente físico, entre eles a escola.

O projeto político-pedagógico tem sido objeto de estudos para professores, pesquisadores e instituições educacionais em nível nacional, estadual e municipal, em busca da melhoria da qualidade do ensino. Ele é entendido, neste estudo, como a própria organização do trabalho pedagógico da escola. A construção do projeto político-pedagógico 
parte dos princípios de igualdade, qualidade, liberdade, gestão democrática e valorização do magistério. A escola é concebida como espaço social marcado pela manifestação de práticas contraditórias que apontam para a luta e/ou acomodação de todos os envolvidos na organização do trabalho (VEIGA, 2002).

Segundo Carpintero e Almeida (2008), para o espaço escolar, o essencial é que os componentes de um prédio se articulem com o projeto político-pedagógico, que contribuam para se alcançar os objetivos educacionais. Para os autores, o projeto político pedagógico (PPP) da escola é parte essencial para conhecer as necessidades e as condições técnicas e sociais da instituição atuais e futuras, satisfazendo a alguns requisitos de ordem prática, funcional e pedagógica. Para contemplar a funcionalidade, é necessário ter o conforto ambiental, a área de circulação, o espaço para as cadeiras e as mesas quanto às exigências pedagógicas, a disposição e mobilidade do mobiliário, a posição de quadros, mapas e outros equipamentos, bem como as condições propícias ao desenvolvimento do trabalho educativo previsto no PPP.

A decodificação espacial do projeto pedagógico, entretanto, não é tão evidente. Isso provavelmente deve-se tanto à rápida mudança dos métodos psicopedagógicos, quanto à maior liberalidade em sua adoção, até mesmo com a possibilidade de variação metodológica em uma mesma instituição e turma, permitindo aos professores elegerem a melhor abordagem para cada tema em pauta (ELALI, 2003).

Além disso, Oliveira (1998) ressalta a necessidade de enfrentar- se a própria diferença temporal entre pedagogia e arquitetura, o que se reflete no tipo de expectativas e até na durabilidade das ações empreendidas nessas áreas. O projeto de escola, seja ela qual for, é elaborado prevendo espaços para trabalhos com determinados métodos. E os métodos não duram para sempre. Ficam obsoletos e exigem reciclagem, o que nem sempre acontece, com a mesma velocidade, com o espaço construído. Daí a importância de pensar edifícios que levem em conta a mutabilidade, tão natural nas coisas humanas.

Diante dessas considerações pode-se dizer que a configuração do espaço sempre foi importante para caracterizar a instituição escolar e a própria sociedade num determinado período, porque materializa as aspirações, conflitos e incertezas vividas. Entretanto, sua evolução parece ter se estagnado, já que, praticamente, o mesmo tipo de escola vem sendo construído e mobiliado, de modo bastante desatualizado, fazendo-nos inferir qual a razão desse hiato criado e quais as intenções existentes atrás da descontextualização do espaço escolar (FRANÇA, 1994, p. 57).

\subsection{Espaço arquitetônico e percepção espacial}

A discussão da importância do espaço como o próprio fundamento da arquitetura é encontrado em Bruno Zevi 
" $a$ arquitetura bela será a arquitetura que tenha um espaço interno que nos atraia, nos eleve, nos subjugue espiritualmente; a arquitetura feia será aquela que tenha um espaço interno que nos enfastie e nos repila. Mas o importante é estabelecer que tudo o que não tem espaço interno não é arquitetura". Depreende-se que este espaço interno deve assim possuir características que propicie a atividade que nele se pretende desenvolver. Zevi (1996, p.22)

Em arquitetura, o fenômeno da quarta dimensão (deslocamento sucessivo do ângulo visual) é totalmente diferente e concreto: aqui é o homem que, movendo-se no edifício, estudando-o de pontos de vista sucessivos, cria, por assim dizer, a quarta dimensão, dá ao espaço a sua realidade integral. Ela propiciou uma sustentação científica à exigência crítica de distinguir entre arquitetura construída e arquitetura desenhada, entre arquitetura e cenografia que durante muito tempo permaneceu em estado confuso (ZEVI, 1996, p. 22).

Sobre a importância do espaço não construído, Zevi opina:

se pensarmos um pouco a respeito, o fato de o espaço, o vazio, ser o protagonista da arquitetura é, no fundo, natural, porque a arquitetura não é apenas arte nem só imagem de vida histórica ou de vida vivida por nós e pelos outros; é também, e sobretudo, o ambiente, a cena onde vivemos a nossa vida. Zevi (1996, p. 28)

Para Laki e Lipai (2007), espaço, tempo e matéria constituem os elementos básicos com que o arquiteto-urbanista pensa e concebe um espaço. Segundo os autores, a forma, definida pela geometria, constrói ambientes extraídos da matéria (substância, textura e cor), e esta se traduz em elementos que, em conjunto, vão oferecer condições (adequadas ou não) para que um espaço possa ser percebido pelo ser humano, estimulando respostas positivas ou negativas diante de si.

Nos dizeres de Costa (1995, p. 382), a arquitetura é a construção que,

enquanto satisfaz apenas às exigências técnicas e funcionais - não é ainda arquitetura; quando se perde em intenções meramente decorativas - tudo não passa de cenografia; mas quando - popular ou erudita - aquele que a ideou para e hesita ante a simples escolha de um espaçamento de pilar ou de relação entre altura e a largura de um vão e se detém na procura obstinada da justa medida entre cheios e vazios, na fixação dos volumes e subordinação deles a uma lei e se demora atento ao jogo de materiais e seu valor expressivo - quando tudo isso se vai pouco a pouco somando, obedecendo aos mais severos preceitos técnicos e funcionais, mas também àquela intenção superior que seleciona, coordena e orienta em determinado sentido toda essa massa confusa e contraditória de detalhes, transmitindo assim ao conjunto ritmo, expressão, unidade e clareza - o que confere à obra o seu caráter de permanência, isto sim é arquitetura.(COSTA, 1995, p. 382)

Segundo Rocha (2001), a arquitetura pode ser definida por corpos tridimensionais que ocupam um lugar no espaço real ou virtual, quando em fase de projeto. A atividade 
projetual e construtiva do arquiteto se desenvolve no espaço tridimensional, porém esse espaço não é igual ao espaço euclidiano manipulado pelos matemáticos; cada um desses campos de atuação possui uma noção diferente do significado, da aplicação e das dimensões do espaço. Associa-se, assim, às ciências humanas e sociais aplicadas, em que outras dimensões (além das físicas: comprimento, altura e largura) integram-se na reflexão e produção de projetos de arquitetura. Surge, então, a importância de outras dimensões como: a quarta dimensão, que é o tempo; a quinta, a proxêmia, também denominada dimensão cultural; e a sexta, que é a percepção individual.

Lefebvre (1991) afirma que apesar de se fundamentar em grande parte no conhecimento do espaço "abstrato" (geométrico, matemático), principalmente no que concerne à sua representação no projeto arquitetônico, o objetivo da arquitetura é a transformação do espaço "real", o espaço apreendido pelos nossos sentidos: o espaço "vivido". Falar sobre espaço "vivido" é, antes, falar sobre vivência do espaço. É procurar entender de que maneira se dá a interação do homem com o ambiente; compreender de que forma o espaço, coisa do "mundo externo", é internalizado - percebido.

Para Limonad (2012), o espaço produzido também é visto como expressão de manifestações do inconsciente, gestalt, sistema de símbolos e signos a ser interpretado, iniciado com os trabalhos de Lynch (1997), que, preocupado com a legibilidade, estrutura, identidade, significado e imageabilidade do desenho urbano, abriu uma nova linha de interpretação. No entanto, ainda assim o espaço configura-se enquanto ambiente ou meio ou, ainda, como cenário.

A discussão sobre o papel do espaço na arquitetura nos remete à revisão dos conceitos de espaço e espacialidades. Segundo o autor, em pesquisa fundamentada nos historiadores da Einfühlung, a medida e o valor da espacialidade são naturalmente dados pelo corpo; pelo usuário do espaço, pelo modo como ocorre sua apropriação do espaço, a acomodação do(s) corpo(s) ao espaço. Portanto, o conceito de espacialidade se refere ao grau de encadeamento de dois elementos da arquitetura: o espaço e o usuário na função que nele prevalece (AGUIAR, 2009).

O conceito de espacialidade, portanto, abrange os conceitos de espaço (geometria) e movimento (topologia). Quanto à materialidade - o espaço como matéria espacial - a pesquisa da espacialidade se ocupa das características e propriedades do vazio, o espaço deixado livre entre os objetos, a forma desse vazio, seu modo de arranjo tanto na escala do interior dos edifícios quanto na escala dos interiores urbanos. O reconhecimento da arquitetura a partir da espacialidade, ao posicionar-se na mão contrária da tendência dominante das arquiteturas espetaculares, repropõe os valores essenciais de uma arquitetura como arte social.

Harrison e Dourish (1996, p. 2-3) entendem o espaço como um "ambiente tridimensional no qual objetos e eventos acontecem, e no qual eles têm posição relativa e direção". 
2.3. Projeto Arquitetônico: a visão do campo disciplinar da arquitetura sobre as relações entre espaço e ensino

O lugar, por sua vez, do ponto de vista físico é encarado como um espaço investido de concepções de apropriação comportamental, expectativas culturais, e assim por diante. Nesse sentido, segundo estes autores "estamos situados no 'espaço', mas agimos no lugar".

Segundo Carpintero e Almeida (2008), os conjuntos de unidades escolares são submetidos ao crivo de uma operação mental, chamada de "espacialização do projeto de arquitetura". O edifício toma corpo e "cara", isto é, volume e massa. Nessa fase, o projeto de arquitetura é desenhado na sua plenitude. Esse desenho mostra não somente a aparência externa, mas, também, como serão os ambientes internos da edificação proposta pelo profissional. No desenho comparece ainda a extensão do prédio - comprimento, largura e altura -, isto é, o volume a ser construído.

Em arquitetura, o programa de uma edificação é o conjunto de necessidades que um projeto deve contemplar e o roteiro de como os requisitos funcionais devem estar dispostos em um novo prédio. No caso específico da tipologia escolar, o programa define o número de salas de aula e quais serão os outros ambientes de ensino, como biblioteca, quadras, laboratórios etc. além de estabelecer as características desejadas a tais ambientes e as respectivas disposições na edificação. A disposição espacial de todos os itens de um programa configura uma visão educacional (BRITO CRUZ; CARVALHO, 2004). O programa de necessidades também inclui valores que o projeto representará e os indicadores qualitativos que se pretendem atingir. O programa não é apenas uma lista de ambientes, mas um documento que interage com as pedagogias e o modo de abrigar as atividades essenciais para o tipo de ensino almejado.

É a partir do desenvolvimento do projeto de arquitetura que se constitui o espaço físico escolar. O estudo pode partir do programa mencionado e das carências apresentadas pelos espaços educacionais com o objetivo de atender às necessidades de ocupação de cada comunidade escolar. A concepção arquitetônica dos prédios escolares, principalmente em países em desenvolvimento, depende da situação socioeconômica e política, mas deve se preocupar com os conceitos educacionais e de conforto, necessários para atingir a qualidade do sistema ensino-aprendizagem (KOWALTOWSKI, 2011).

\subsection{Projeto Arquitetônico: a visão do campo disciplinar da arqui- tetura sobre as relações entre espaço e ensino}

A revisão acerca da visão dos arquitetos sobre o espaço escolar remete a estudos que propõem configurações inovadoras para o espaço de ensino, como : DesignShare, EFL (Education al Facilities Laboratories), NCEF (National Cleoring-House for Educational Facilities), dos Estados Unidos, e Cabe (Commission for Architecture and the built Environment), da Inglaterra. No Brasil, a sala de aula do futuro é amplamente discutida, mas ainda dentro de um formato bastante tradicional e algumas variações na disposição dos 
móveis, com a inclusão de equipamentos, principalmente para projeção de imagens, ou alterações para trabalhos em grupo.

Na literatura nacional, os estudos se debruçam muito sobre a avaliação das escolas existentes e demonstram que a maioria das edificações escolares apresenta condições ambientais aquém das desejadas. As principais falhas dizem respeito às condições de conforto térmico e de funcionalidade. Um levantamento feito pelo Inep, o Relatório do Sistema Nacional de Avaliação da Educação Básica de 2003 (INEP/MEC, 2006b) mostrou uma alta porcentagem de alunos em prédios escolares com defeitos construtivos em telhados, paredes, pisos, portas e janelas, banheiros, cozinhas, instalação hidráulica e elétrica, em mobiliário (carteiras, mesas e armários) ou de manutenção de áreas externas.

Instituto de Estudos e Pesquisas Educacionais (INEP/MEC, 2006a) revela que $13 \%$ da população apontam como ruim o estado dos prédios escolares, e um problema grave da educação pública brasileira é a falta de material didático. Um número crescente de estudos demonstra a relação direta existente entre a qualidade do espaço físico e o desempenho acadêmico dos alunos. Sanoff (2001) destaca o poder que o espaço físico tem de organizar e promover relações entre pessoas de diversas idades, promover mudanças, escolhas e atividade e [...] potencial de despertar diferentes tipos de aprendizado social, cognitivo e afetivo (KOWALTOWSKI, 2011).

Sanoff (2001) destaca que a imagem da escola como um todo e a configuração das salas de aula são aspectos prioritários. Defende, ainda, a ideia de que espaços escolares contribuem para o processo de aprendizagem e que existem princípios que devem ser seguidos em todos os projetos escolares. Esses princípios são: criação de ambientes estimulantes, presença de lugares para ensino em grupo, conexão entre espaços do interior com o exterior, áreas públicas incorporadas ao espaço escolar, segurança, variedade espacial, interação com o ambiente externo, flexibilidade, riqueza de recursos, ambientes ativos e passivos, espaços personalizados e espaços comunitários.

O currículo de uma escola deve influenciar o projeto dos ambientes (MCDONALD, 1996). No entanto, enquanto as escolas têm seu foco nos melhores currículos e método de ensino, o espaço das salas de aula e as condições ambientais têm sido ignorados (PAULY, 1992), mas cada currículo e cada metodologia demandam espaços específicos, influenciando cada ambiente em suas características arquitetônicas, que incluem o tamanho dos espaços, a disposição do mobiliário , a infraestrutura e os equipamentos necessários e o próprio estilo arquitetônico da edificação escolar (KOWALTOWSKI, 2011).

É necessário que os projetos de escolas pensem edificações que possam ser modificadas ao longo dos anos, além de considerar o conforto ambiental: as condições térmicas, luminosas e acústicas que resultam em variações climáticas, comprometendo o bem-estar e o aproveitamento didático dos alunos que estejam nesses ambientes. Os fatores externos podem contribuir ou retardar o processo de ensino-aprendizagem dependendo da natureza 
2.3. Projeto Arquitetônico: a visão do campo disciplinar da arquitetura sobre as relações entre espaço e ensino

de cada elemento. Percebe-se que as escolas falham no que diz respeito a essas normas arquitetônicas.

Estudo de Hershberger (1999) estabeleceu uma lista de valores que devem servir de base ao desenvolvimento do programa de necessidades com as informações necessárias à fase de preparação que antecede o projeto, e também como ferramenta de avaliação ao final do processo verificando se os itens estabelecidos foram adequadamente considerados. (Tabela 2).

Tabela 2 - Valores arquitetônicos contemporâneos

\begin{tabular}{ll}
\hline Valores & Informações \\
\hline Humanos & adequação funcional, social, física, fisiológica e psicológica \\
\hline Ambiental & local, clima, contexto, fontes e gastos \\
\hline Tecnológico & materiais, sistemas, e processos \\
\hline Econômicos & financeiro, construção, operações, manutenção e energia \\
\hline Segurança & estrutural, fogo, químico, pessoal e vandalismo \\
\hline Temporal & crescimento, mudanças, e permanências \\
\hline Estético & forma, espaço, cor e significado \\
\hline Cultural & histórico, institucional, político e legal \\
\hline & Fonte: Hershberger $(1999)$.
\end{tabular}

As ferramentas de apoio ao processo de projetos com base no DQI - (Design Quality Indicator) têm seus princípios apresentados nas figuras 2 e 3. Segundo Cabe (2005), como a arquitetura é definida como forma, função e tecnologia, sujeitas a condições específicas como tempo, dinheiro e regulamentações, os princípios do DQI representam os fatores essenciais para uma arquitetura de qualidade e estão fundamentados na visão tripartida com mais de 2000 anos, proposta por Vitruvius (1960).

Os princípios do DQI em consonância com as categorias de Vitruvius, trata dos componentes básicos da arquitetura : Utilitas - funcionalidade ou valor de utilização, ou seja, a dimensão social; Firmitas - solidez ou durabilidade, ou seja a dimensão tecnológica e de segurança; e Venustas - a beleza, ou seja, a dimensão estética ou artística, que fundamenta a importância da qualidade estética do projeto de arquitetura. Assim, os princípios para arquitetura escolar recomendadas deveriam partir de três conceitos (CABE, 2005), conforme Figuras 2 e 3):

a) Funcionalidade: o arranjo, a quantidade e a inter-relação de espaços e como o edifício é projetado para ser utilizado.

b) Qualidade do edifício: determina as características construtivas e de execução do edifício, ou seja, quão bem ele foi construído na estrutura, nos acabamentos, nos sistemas de engenharia e na coordenação desses elementos, garantindo seu bom funcionamento.

c) Impacto do edifício: possibilidade de o edifício agradar, intrigar e criar um senso de localização e pertencimento, inspirando a comunidade local e seu 
ambiente. Inclui a contribuição do projeto para a arte e para a ciência da construção e da arquitetura.

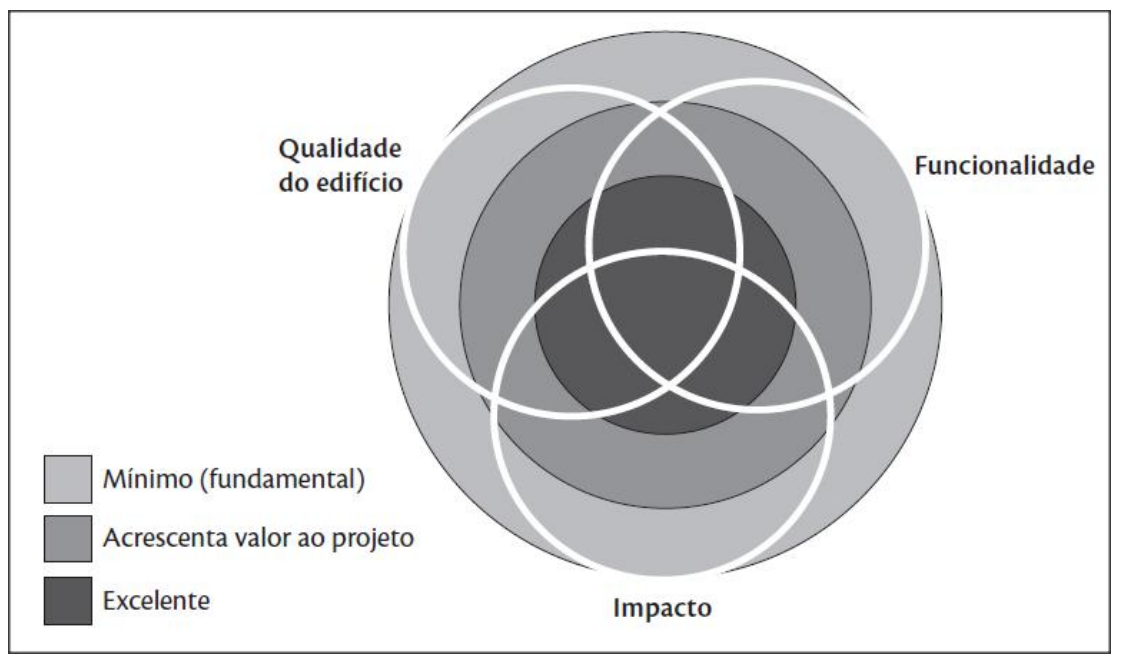

Figura 2 - DQI: Esquema dos princípios de qualidade

Fonte - Cabe (2005).

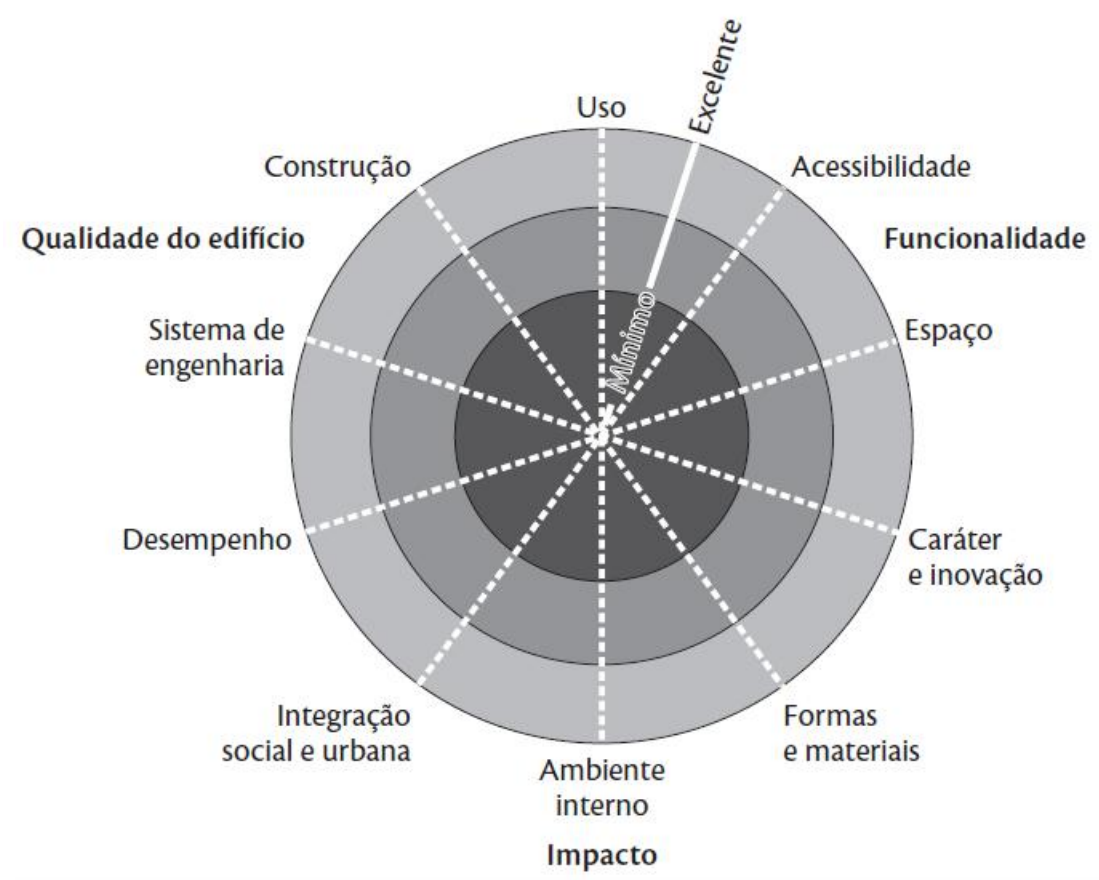

Figura 3 - Esquema dos grupos de critérios dos três princípios de qualidade a partir da ferramenta DQI.

Fonte: Cabe (2005).

Segundo Kowaltowski (2011) é difícil traduzir para a prática de projeto os conceitos que se deseja do espaço para o ensino, talvez pela dificuldade que os profissionais arquitetos possuem de descrever conceitualmente o que significa sua arquitetura, possivelmente em função do hábito de trabalho desses profissionais com a linguagem visual. A concretização 
dos princípios expostos deve ser pensada à luz dos objetivos definidos para o projeto escola, que estão relacionados na Tabela 3 , com os respectivos meios para seu atendimento.

Tabela 3 - Objetivos positivos do projeto escolar

\begin{tabular}{|c|c|}
\hline Objetivo & Meio de obtenção \\
\hline $\begin{array}{l}\text { Projetar edifícios com ambi- } \\
\text { entes "convidativos" }\end{array}$ & $\begin{array}{l}\text { - espaços com estética diferenciada, detalhamento e aca- } \\
\text { bamento cuidadoso, esquema de cores detalhados, níveis } \\
\text { de iluminação natural alto sem ofuscamento; } \\
\text { - espaços projetados para acomodar as atividades escola- } \\
\text { res, sociais e administrativas; } \\
\text { - espaços que evitem conotações de escolas tradicionais } \\
\text { ou institucionais: características físicas que os associem a } \\
\text { instituições de cerceamento da liberdade, como as prisões } \\
\text { e hospitais Foucault (1987). }\end{array}$ \\
\hline $\begin{array}{l}\text { Edifício com alto índice de } \\
\text { desempenho }\end{array}$ & $\begin{array}{l}\text { - criação de edifícios saudáveis do ponto de vista de con- } \\
\text { forto dos usuários e de segurança ambiental; } \\
\text { - qualidade do ar interno, conforto térmico, visual e acús- } \\
\text { tico,, segurança, eficiência no uso da água, eficiência ener- } \\
\text { gética, especificação de materiais, escolha do terreno, im- } \\
\text { plantação e tratamento das áreas externas. }\end{array}$ \\
\hline $\begin{array}{l}\text { Edifício com uso de materi- } \\
\text { ais e mobiliários de alto ín- } \\
\text { dice de qualidade }\end{array}$ & $\begin{array}{l}\text { - foco na qualidade dos materiais, considerando o ciclo } \\
\text { de vida e o custo de manutenção, e não somente o custo } \\
\text { de implantação. }\end{array}$ \\
\hline
\end{tabular}

Fonte: Nair e Fielding (2005).

A seguir apresentam-se na Tabela 4 os princípios para arquitetura escolar segundo Cabe (2005).

Tabela 4 - Princípios para arquitetura escolar segundo Cabe (2005)

\begin{tabular}{|c|c|c|}
\hline Princípios & Critérios & Definição \\
\hline Funcionalidade & Acessibilidade & $\begin{array}{l}\text { Descrição sobre o quão fácil é para todas as pessoas che- } \\
\text { garem e se movimentarem no espaço escolar. Transpondo } \\
\text { para a arquitetura escolar, pode-se dizer que esse aspecto } \\
\text { considera o conceito de arquitetura inclusiva, ou seja, o } \\
\text { atendimento das diferentes necessidades dos usuários em } \\
\text { seus mais diversos aspectos: físicos, psicológicos, fisiológi- } \\
\text { cos etc. Para isso, é essencial considerar os aspectos do } \\
\text { wayfinding, ou seja, da clara organização espacial (indi- } \\
\text { cação de usos e funções, caminhos, acessos etc.) e dos } \\
\text { aspectos de desenho universal (DU). }\end{array}$ \\
\hline
\end{tabular}




\begin{tabular}{|c|c|c|}
\hline Princípios & Critérios & Definição \\
\hline & Espaço & $\begin{array}{l}\text { Descrição das características dos diversos ambientes, ta- } \\
\text { manho e relação dos espaços com outras áreas etc. Com } \\
\text { relação ao espaço escolar, esse critério deve observar que: } \\
\text { - Os espaços de ensino devem estar relacionados ao currí- } \\
\text { culo e à própria organização da escola; } \\
\text { - As áreas de circulação devem ser de dimensões adequa- } \\
\text { das e projetadas de acordo com seu propósito (incorpo- } \\
\text { ração de usos para esse espaço, além da circulação em } \\
\text { si); } \\
\text { - As áreas de funcionários e administrativas devem ser } \\
\text { adequadas às necessidades das equipes; } \\
\text { - Deve haver espaços apropriados à guarda de materiais; } \\
\text { - As áreas sociais e de alimentação devem extrapolar } \\
\text { suas necessidades, promovendo atividades de saúde, re- } \\
\text { laxamento, recreação e socialização; } \\
\text { - Os sanitários devem estar bem localizados. }\end{array}$ \\
\hline & Uso & $\begin{array}{l}\text { Análise da capacidade do espaço escolar atender às fun- } \\
\text { ções que pretendem acomodar e, como isso, coloca-se } \\
\text { para as demandas futuras. Devem ser planejados os as- } \\
\text { pectos de flexibilidade que devem considerar: possibilida- } \\
\text { des de expansão, mudanças de layout, generosidade no } \\
\text { dimensionamento, modulação inteligente, distribuição de } \\
\text { redes de infraestrutura etc. }\end{array}$ \\
\hline \multirow[t]{3}{*}{ Qualidade do edifício } & Desempenho & $\begin{array}{l}\text { Sistemas de segurança, ambientais e mecânicos do edifí- } \\
\text { cio, de modo a garantirem seu perfeito e adequado fun- } \\
\text { cionamento. No ambiente escolar, indica-se a utilização } \\
\text { de materiais duráveis, principalmente dos acabamentos, } \\
\text { pensando na variável custo de operação e manutenção. }\end{array}$ \\
\hline & $\begin{array}{l}\text { Sistemas de } \\
\text { Engenharia }\end{array}$ & $\begin{array}{l}\text { Aspectos que garantam a qualidade dos componentes do } \\
\text { edifício. O projeto escolar deve minimizar as necessidades } \\
\text { de condicionamento ambiental mecânicos. }\end{array}$ \\
\hline & Construção & $\begin{array}{l}\text { Aspectos que garantam o funcionamento do edifício no } \\
\text { todo. Deve-se pensar em projetos integrado de layout, es- } \\
\text { trutura e equipamentos e também nos aspectos de sus- } \\
\text { tentabilidade e sistemas renováveis. }\end{array}$ \\
\hline \multirow[t]{4}{*}{ Impactos do edifício } & $\begin{array}{l}\text { Escola e a co- } \\
\text { munidade }\end{array}$ & $\begin{array}{l}\text { Relação da escola com seu entorno e contexto social. Para } \\
\text { o processo de projeto escolar, podem-se considerar proces- } \\
\text { sos participativos e as relações do edifício com o entorno: } \\
\text { volumetria, materiais, acessos, paisagismo etc. }\end{array}$ \\
\hline & $\begin{array}{l}\text { Espaços } \\
\text { Interno }\end{array}$ & $\begin{array}{l}\text { Qualidade da composição espacial interna. Deve-se pla- } \\
\text { nejar relação entre espaços com áreas funcionais de circu- } \\
\text { lação agradáveis e com iluminação natural adequada. }\end{array}$ \\
\hline & $\begin{array}{l}\text { Formas e Ma- } \\
\text { teriais }\end{array}$ & $\begin{array}{l}\text { Formas e materiais adequados e bem detalhados. No pro- } \\
\text { jeto escolar, é essencial a análise da relação custo inicial } \\
\text { x custo de operação x custo de manutenção. }\end{array}$ \\
\hline & $\begin{array}{l}\text { Caráter + Ino- } \\
\text { vações }\end{array}$ & $\begin{array}{l}\text { O que a comunidade e as demais pessoas acham da com- } \\
\text { posição geral do edifício. Essas questões são estabelecidas } \\
\text { a partir da relação da forma, função e materiais com o } \\
\text { contexto etc. }\end{array}$ \\
\hline
\end{tabular}

Fonte: Cabe (2005).

Ainda de acordo com a autora, nos últimos 40 anos alguns pesquisadores como Chistopher Alexander, procuraram qualificar a arquitetura com métodos de projetos 
2.3. Projeto Arquitetônico: a visão do campo disciplinar da arquitetura sobre as relações entre espaço e ensino

menos subjetivos. Em sua busca metodológica de projeto, expressa em suas obras mais importantes (ALEXANDER, 1979; ALEXANDER; ISHIKAWA; SILVERSTEIN, 1977) ele define o que denominou patterns, peças-chave a serem incorporadas e repetidas em projetos para qualificar o espaço e alcançar um determinado resultado esperado.

Numa referência aos patterns, Kowaltowski (2011) diz que estes expressam a percepção das necessidades humanas no ambiente construído por meio da descrição da relação "se...então", auxiliada por croquis e fotografias. Já nas palavras de Nair e Fielding (2005), os patterns devem servir como ponto de partida para estabelecer parâmetros adequados a cada projeto específico, para obtenção de uma arquitetura de qualidade. Os autores lembram que a aplicação do método dos patterns abarca quatro campos da experiência humana: espacial, psicológico, fisiológico e comportamental (Tabela 5).

Tabela 5 - Atributos desejáveis à atividade escolar

\begin{tabular}{ll}
\hline $\begin{array}{l}\text { Campos da experiência hu- } \\
\text { mana cuja influência estende- } \\
\text { se ao planejamento e ao pro- } \\
\text { jeto de escolas }\end{array}$ & $\begin{array}{l}\text { Atributos desejáveis à atividade escolar, conforme o tipo de } \\
\text { uspaço }\end{array}$ \\
\hline Espacial & $\begin{array}{l}\text { Íntimo, aberto, iluminado, fechado, ativo, quieto, conectado à natureza, } \\
\text { monumental e tecnológico. }\end{array}$ \\
\hline Psicológico & $\begin{array}{l}\text { Tranquilo, seguro, assustador, alegre, divertido, estimulante, criativo, } \\
\text { encorajador da reflexão, espiritualmente moralizante, criador de senso } \\
\text { comunitário. }\end{array}$ \\
\hline Fisiológico & $\begin{array}{l}\text { Quente, frio, acochegante, vivo, saudável, aromático, texturizado, visu- } \\
\text { almente prazeroso. }\end{array}$ \\
\hline Comportamental & $\begin{array}{l}\text { Estudo independente, trabalho colaborativo, trabalho em equipe, ativi- } \\
\text { dades físicas, pesquisa, atividades de leitura e escrita, trabalhos com o } \\
\text { computador, atividades de canto, dança, atuar, apresentar, trabalho } \\
\text { em grandes grupos, comunicação com a natureza, projetar , construir, } \\
\text { ensinar, relaxar, refletir, brincar. }\end{array}$ \\
\hline
\end{tabular}

Fonte: Nair e Fielding (2005).

A tese fundamental que embasou o trabalho de Alexander e, posteriormente, o desenvolvimento dos parâmetros escolares é que os "patterns" definem a qualidade do edifício, nos níveis micro e macro e que, embora sejam aparentemente independentes, devem funcionar no todo. As permutações e combinações entre esses vários atributos positivos apresentados são infinitas, e é por isso que se torna importante identificar os "parâmetros saudáveis" adequados a cada atividade educacional (NAIR; FIELDING, 2005). Os "patterns" desenvolvidos pelos autores serão apresentados a seguir e podem funcionar como princípios da arquitetura escolar de qualidade (Tabela 6). 


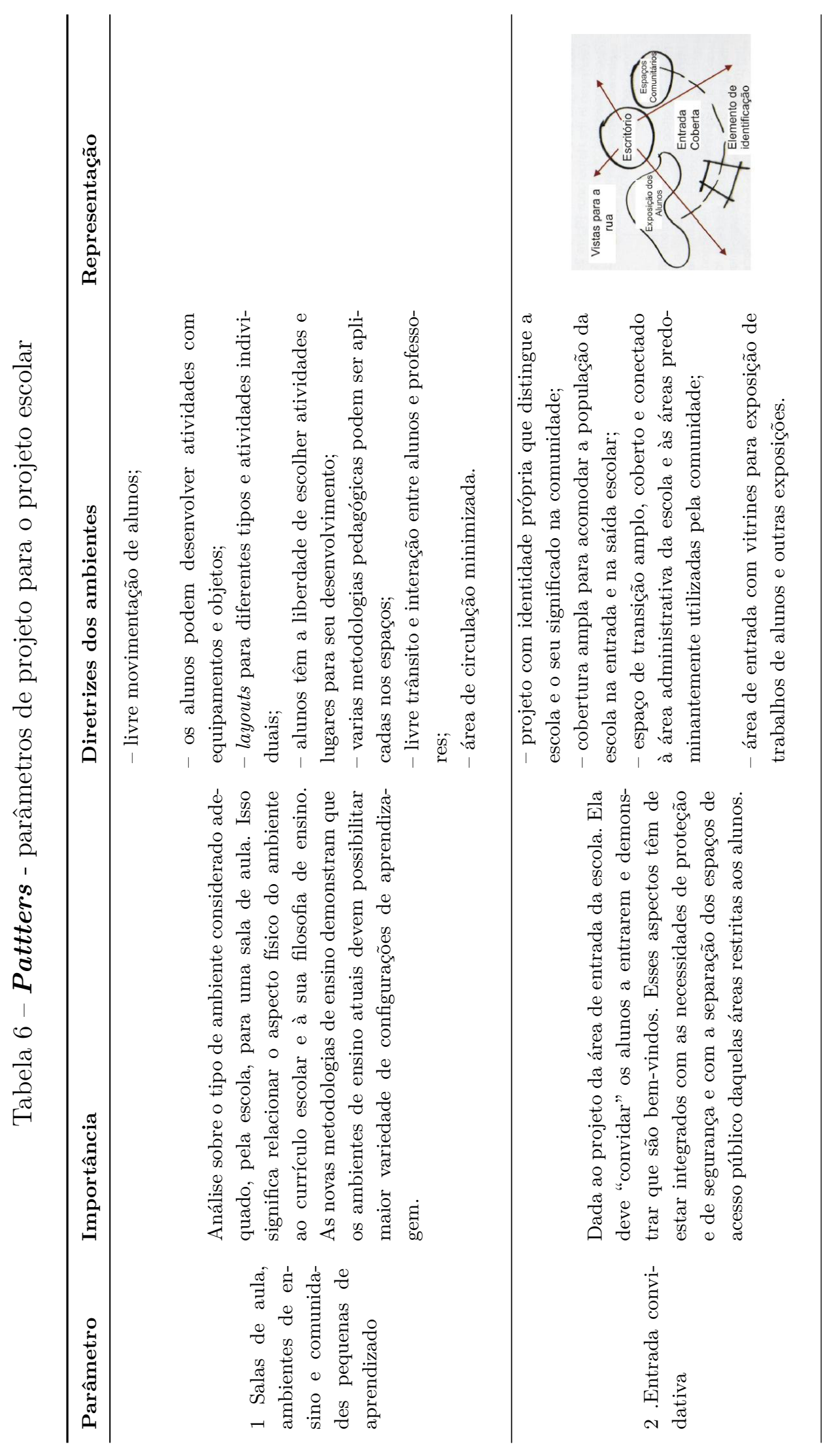




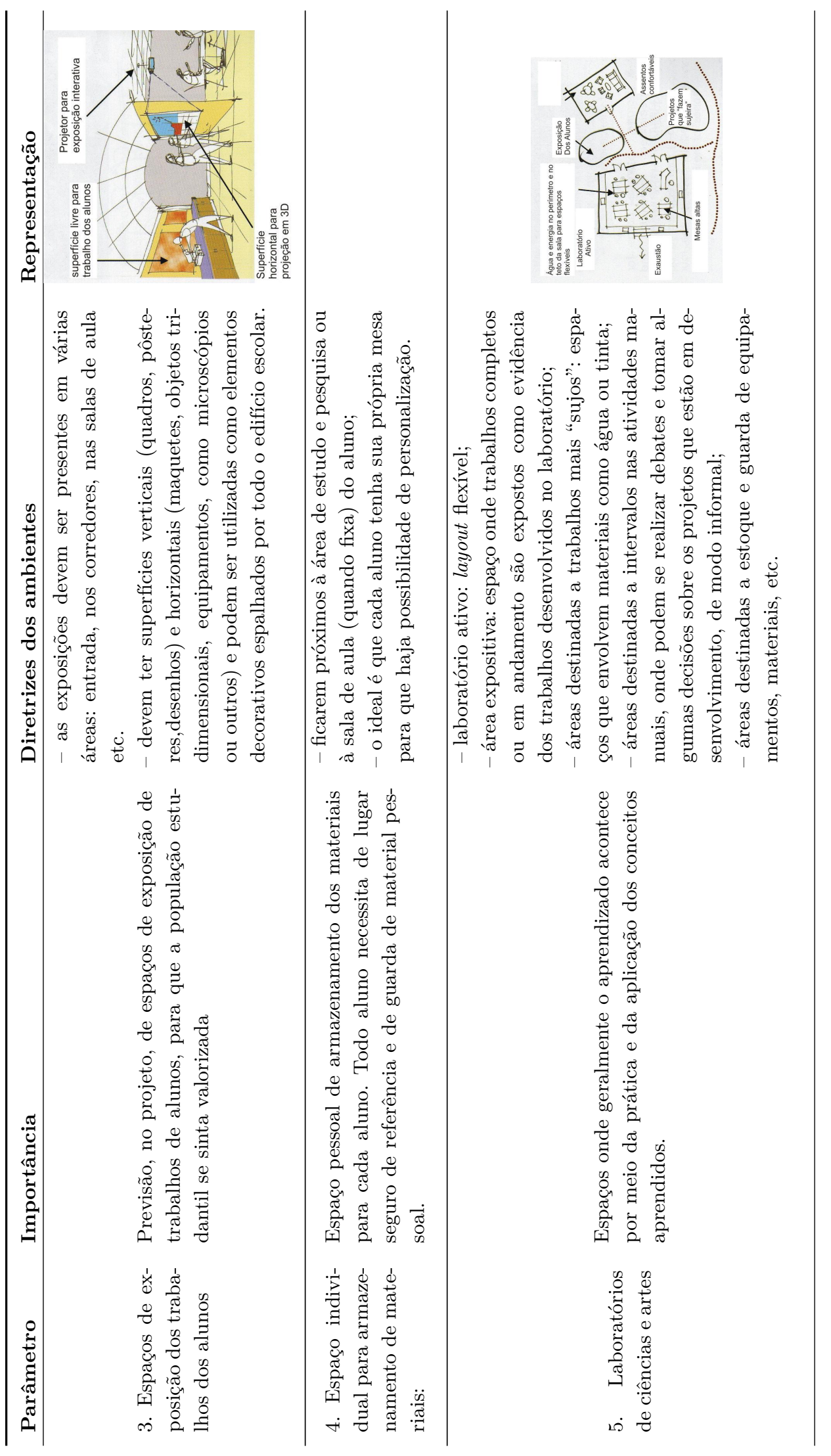




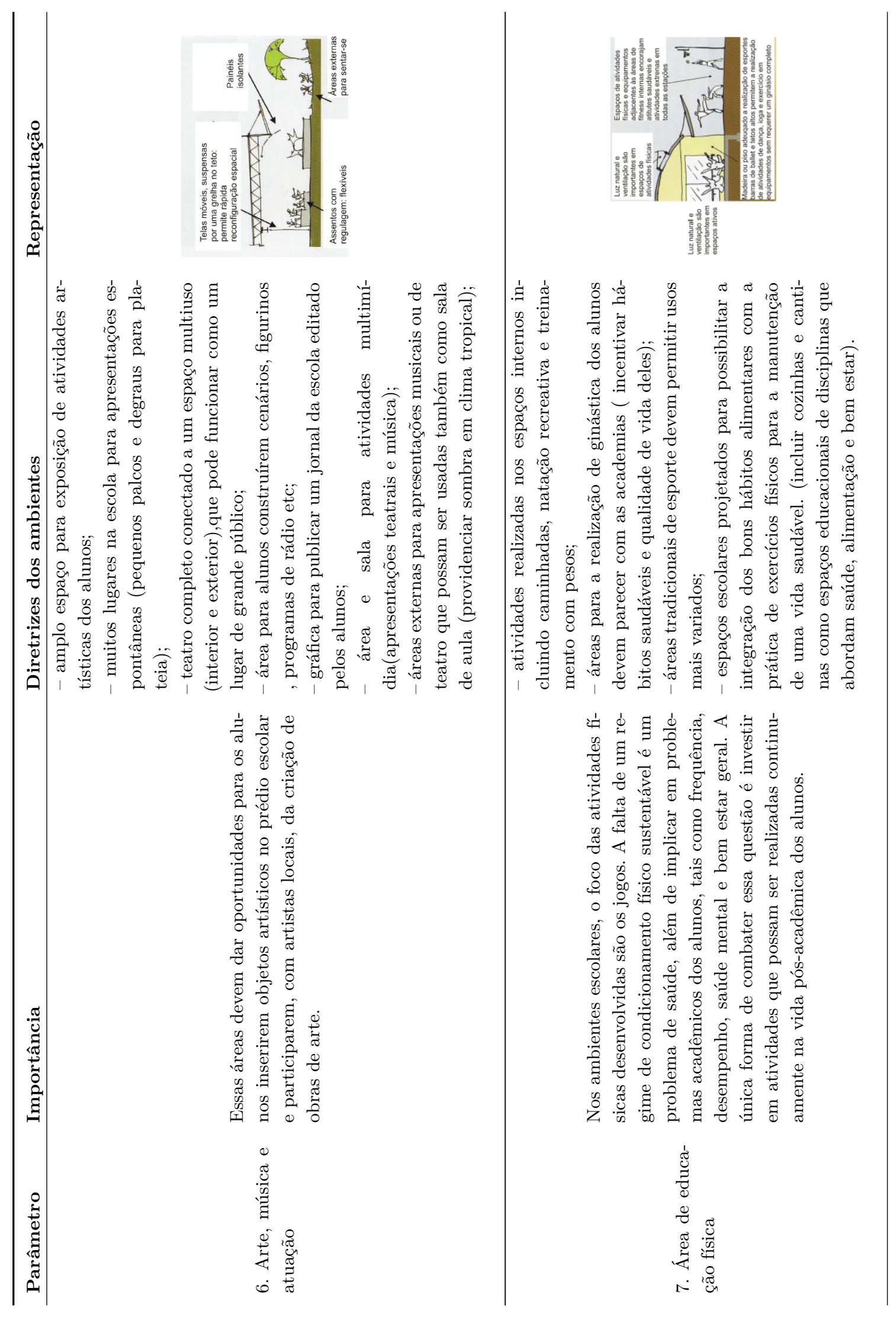




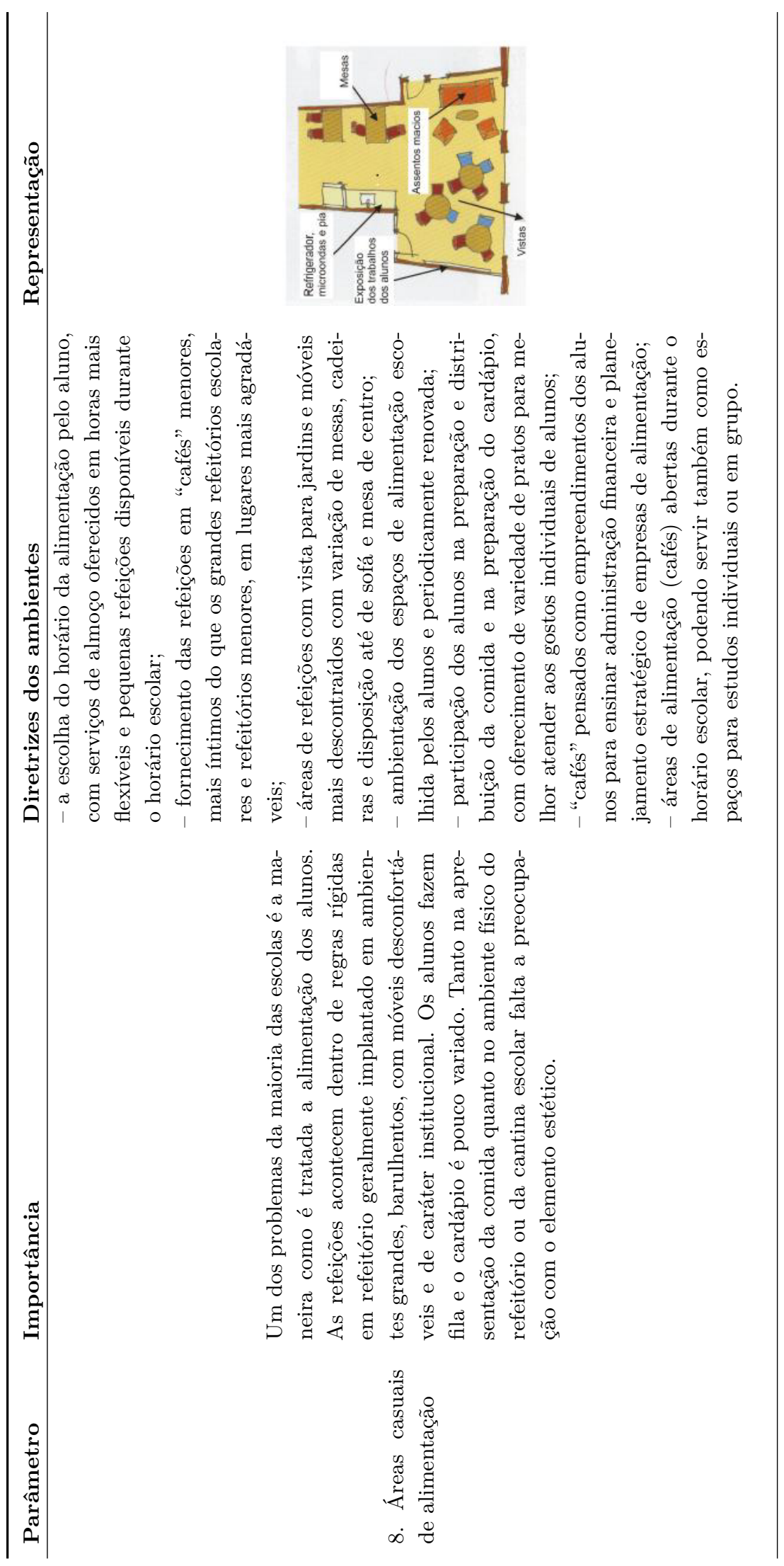



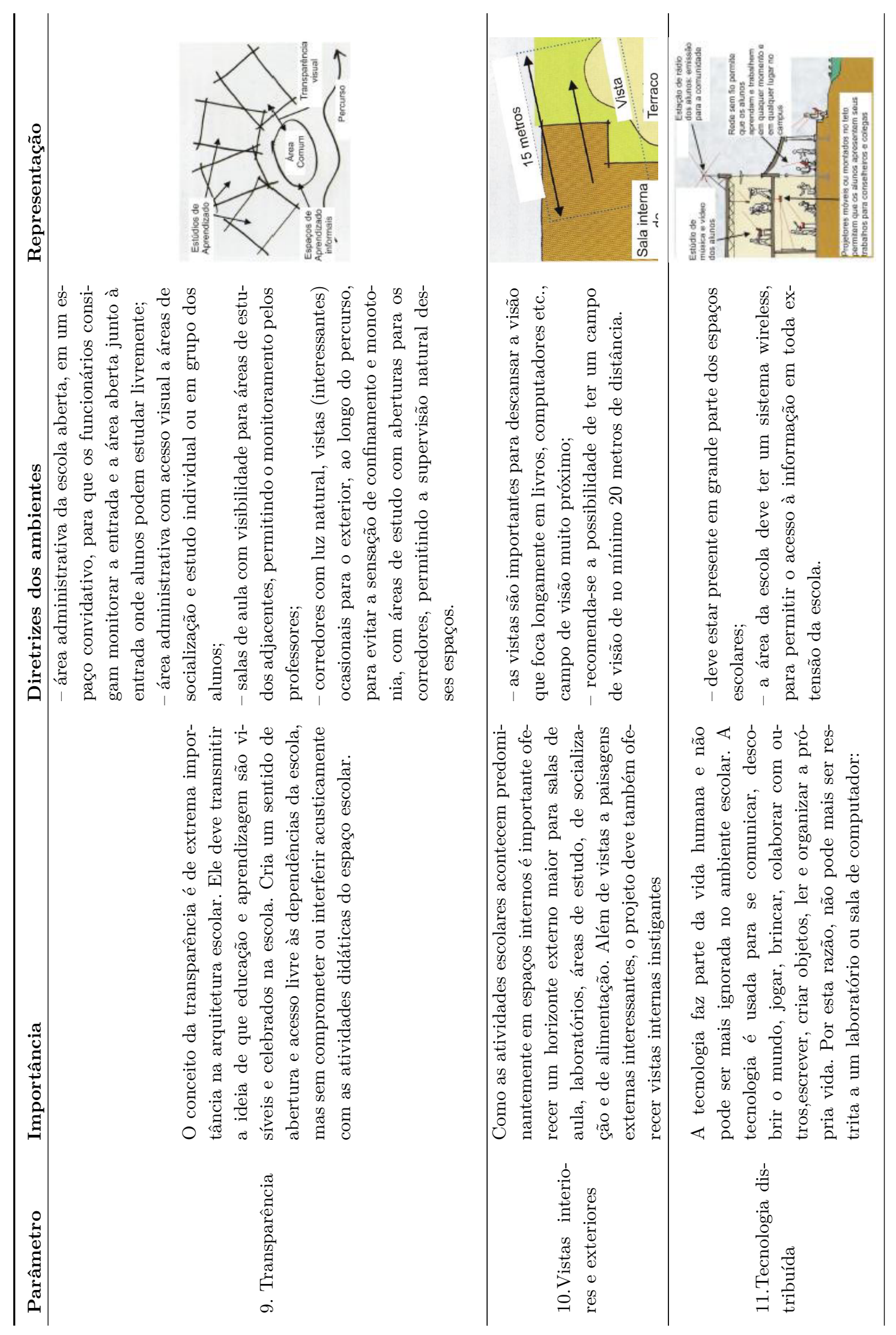

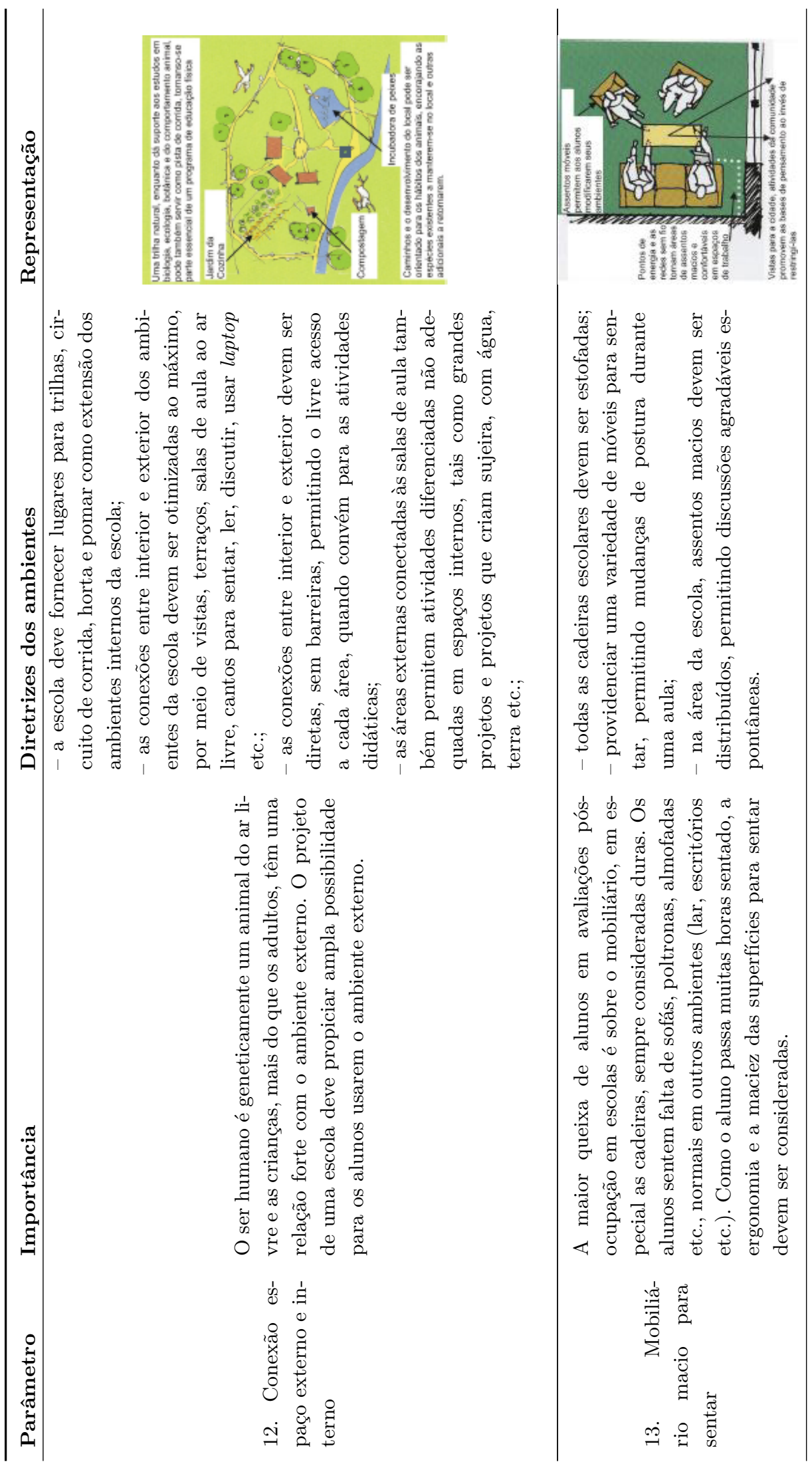


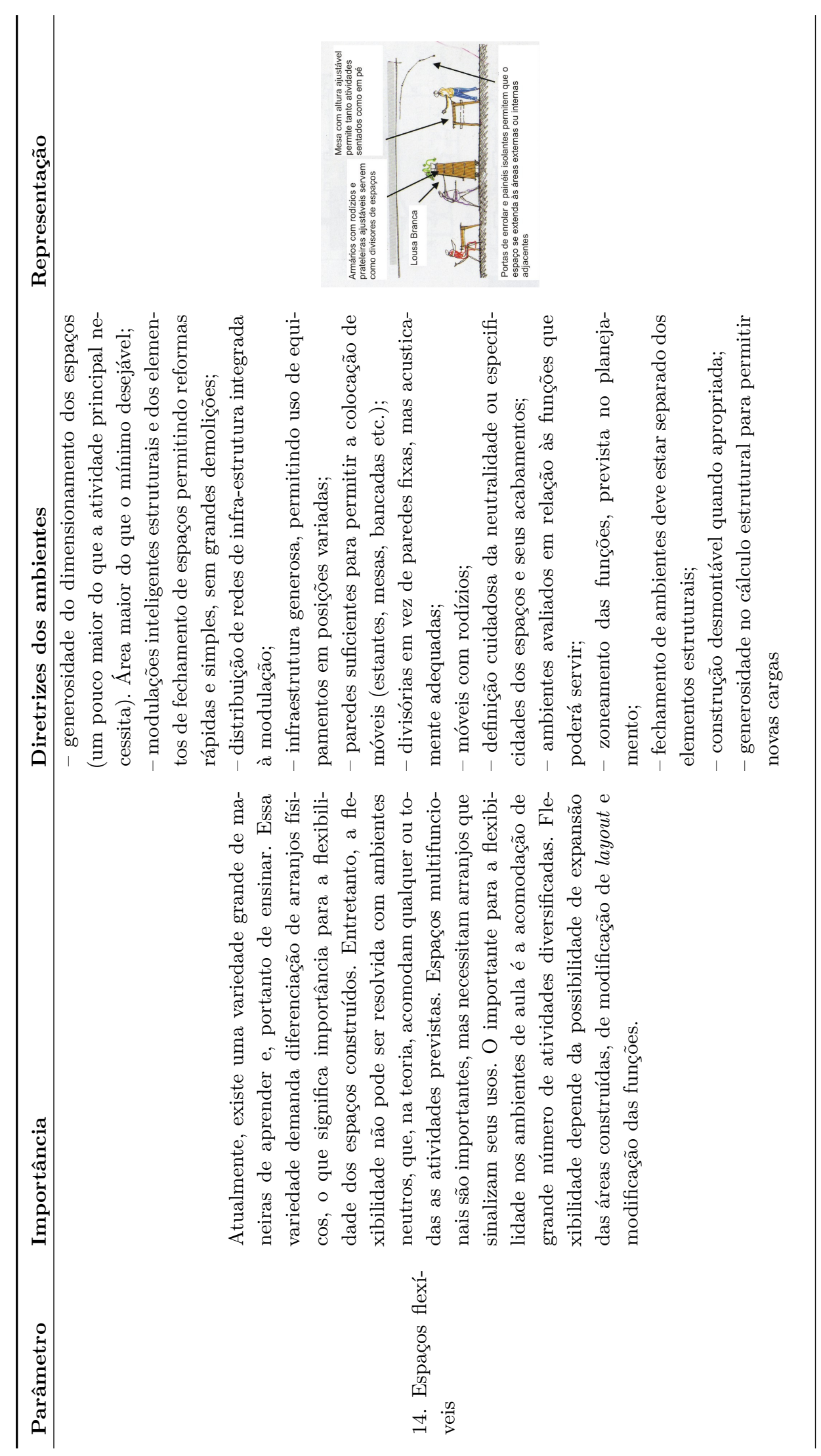




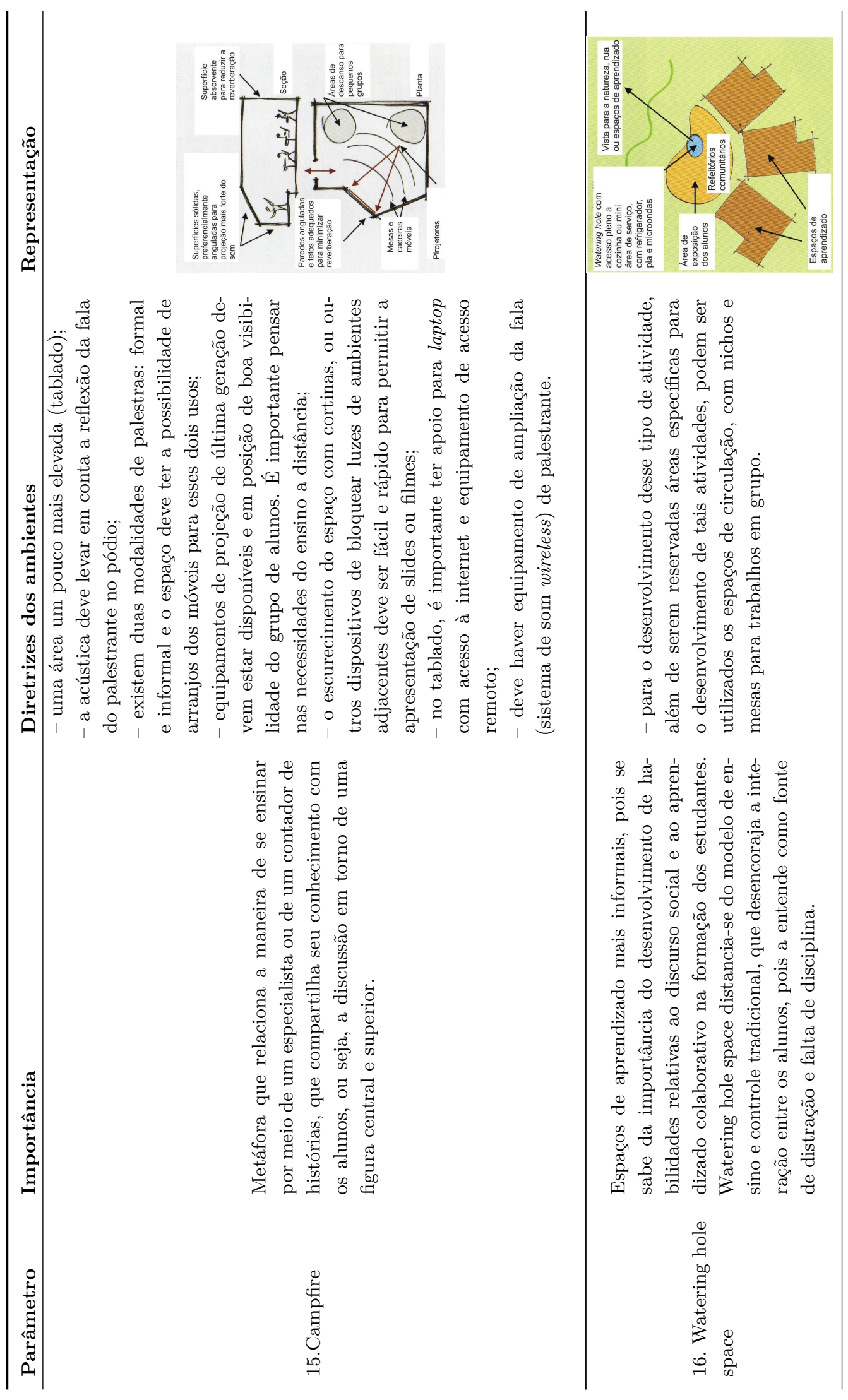




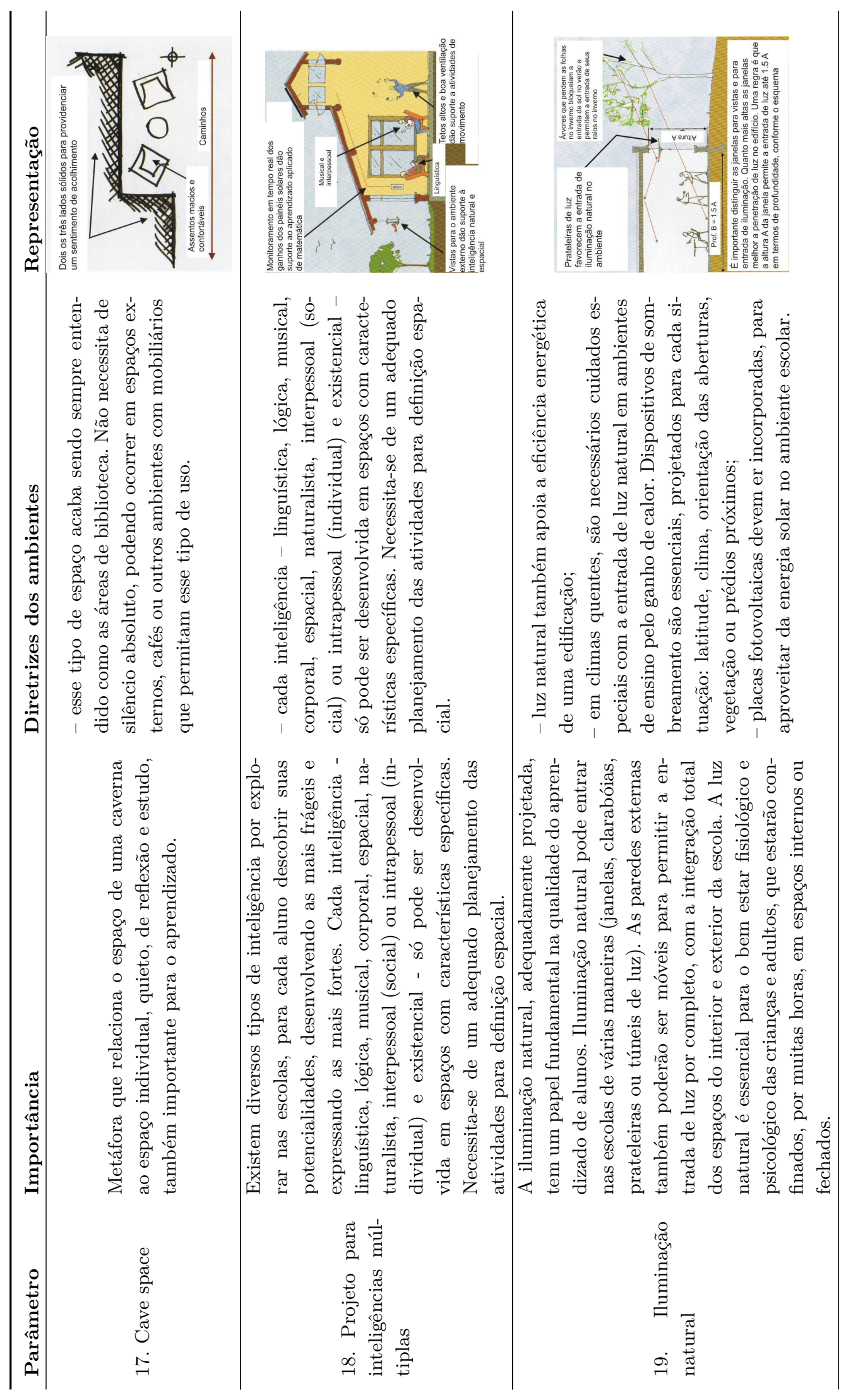




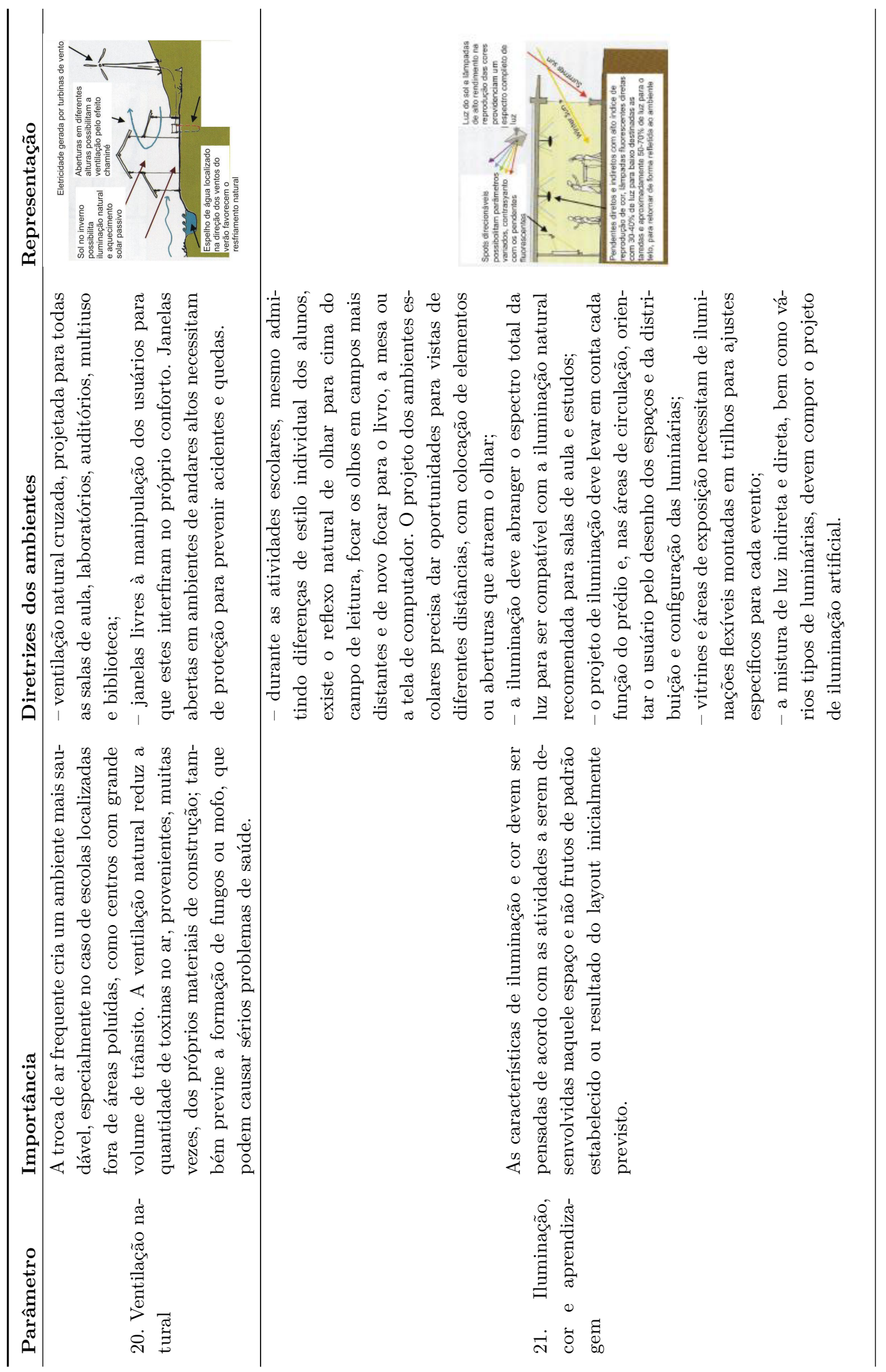




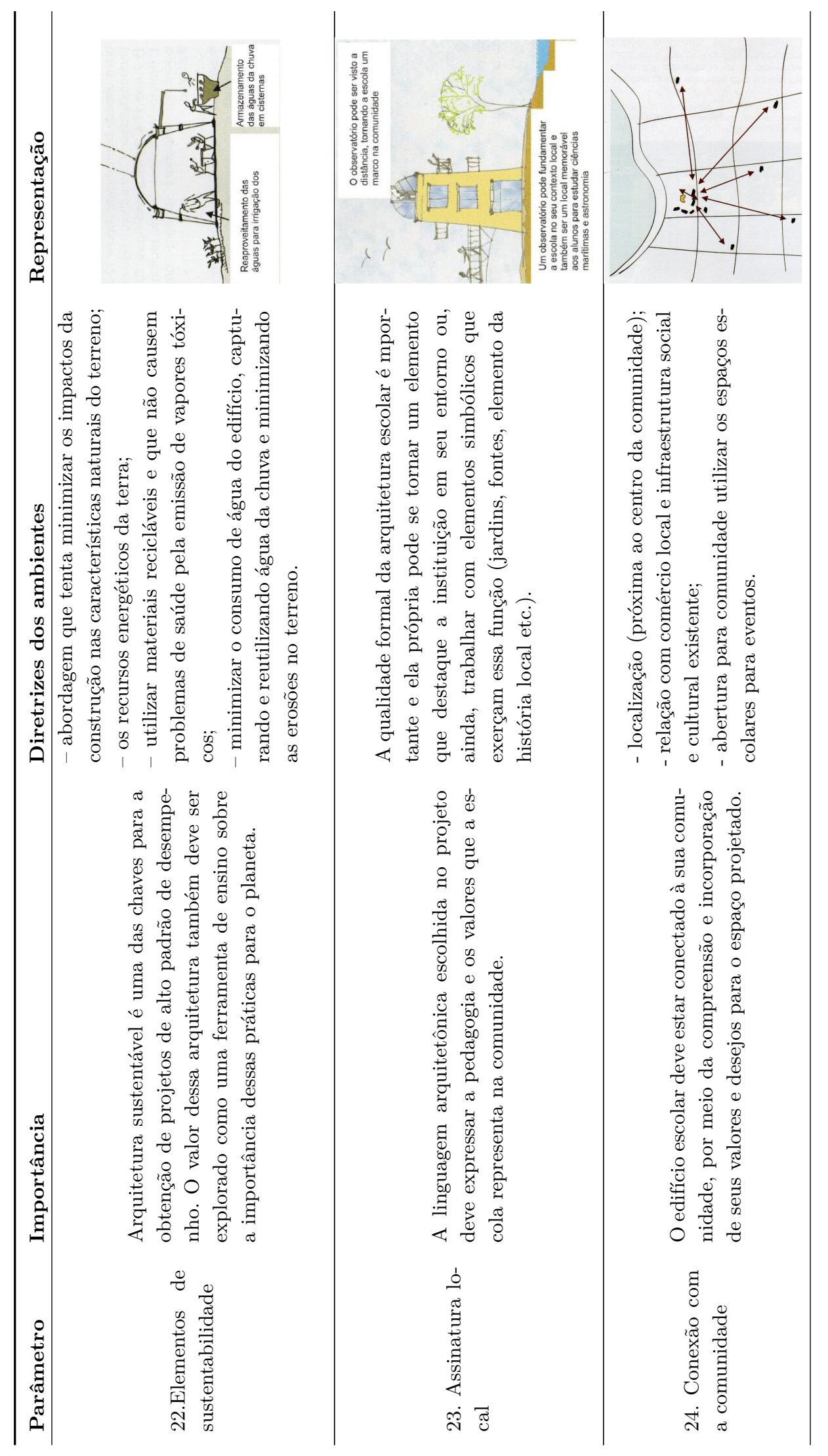




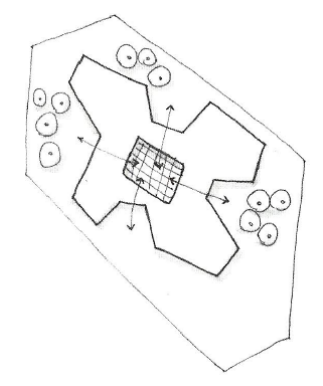

$\exists \cong$

乎

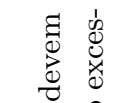

夏

焉

क

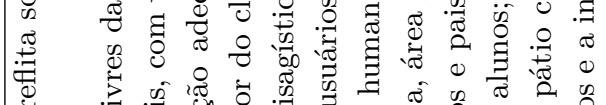

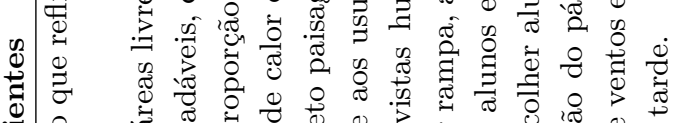

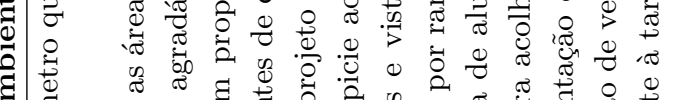

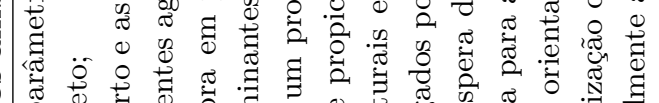

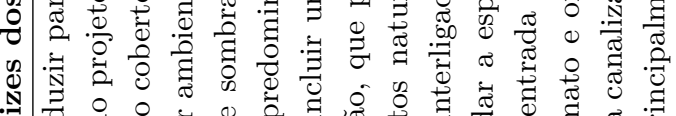

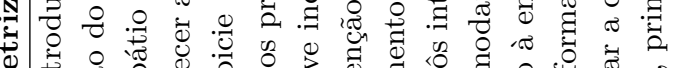

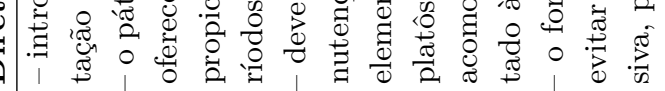

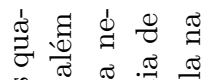

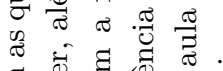

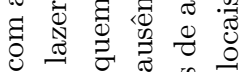

द्व 0

สై

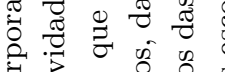

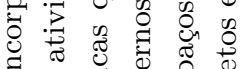

$\exists$ की

获

đ

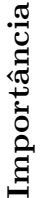

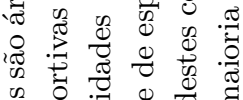

की 0 .

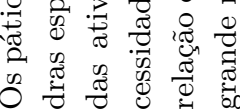

当 के के

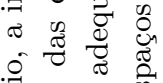

$\mid$

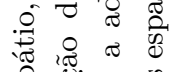

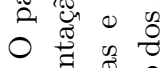

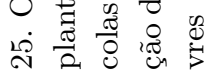

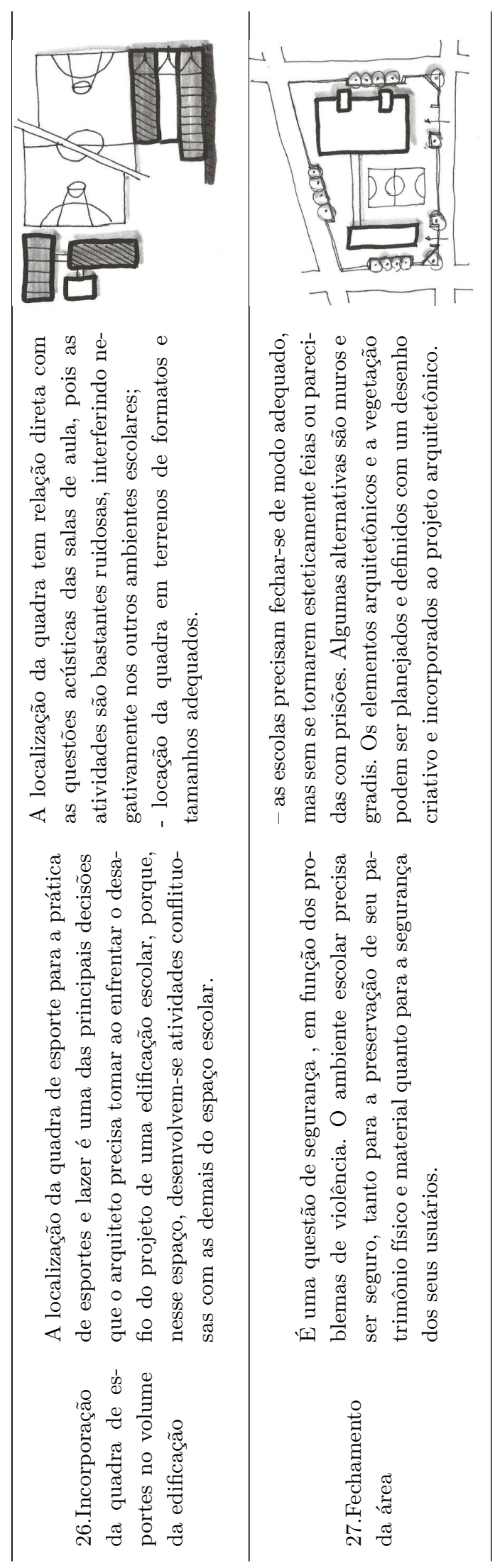




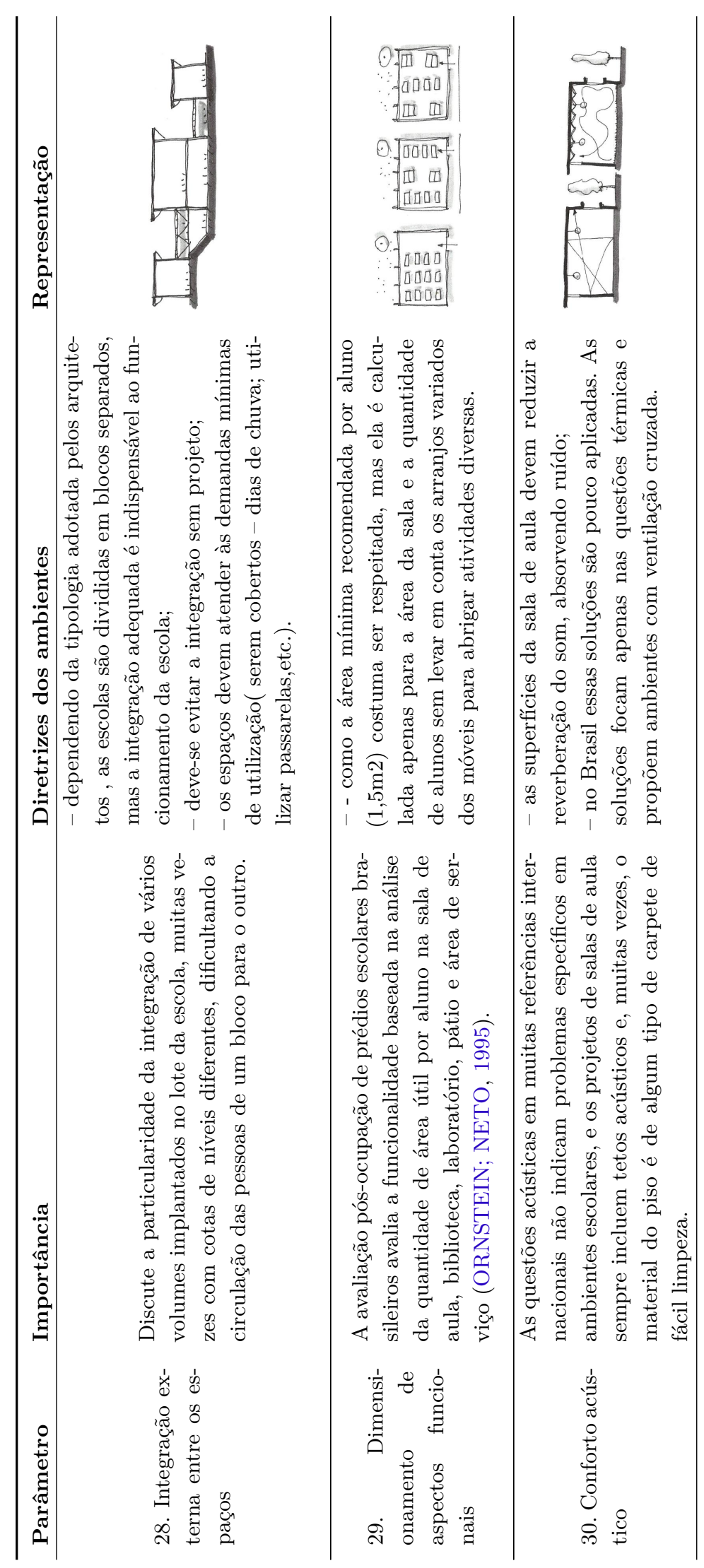




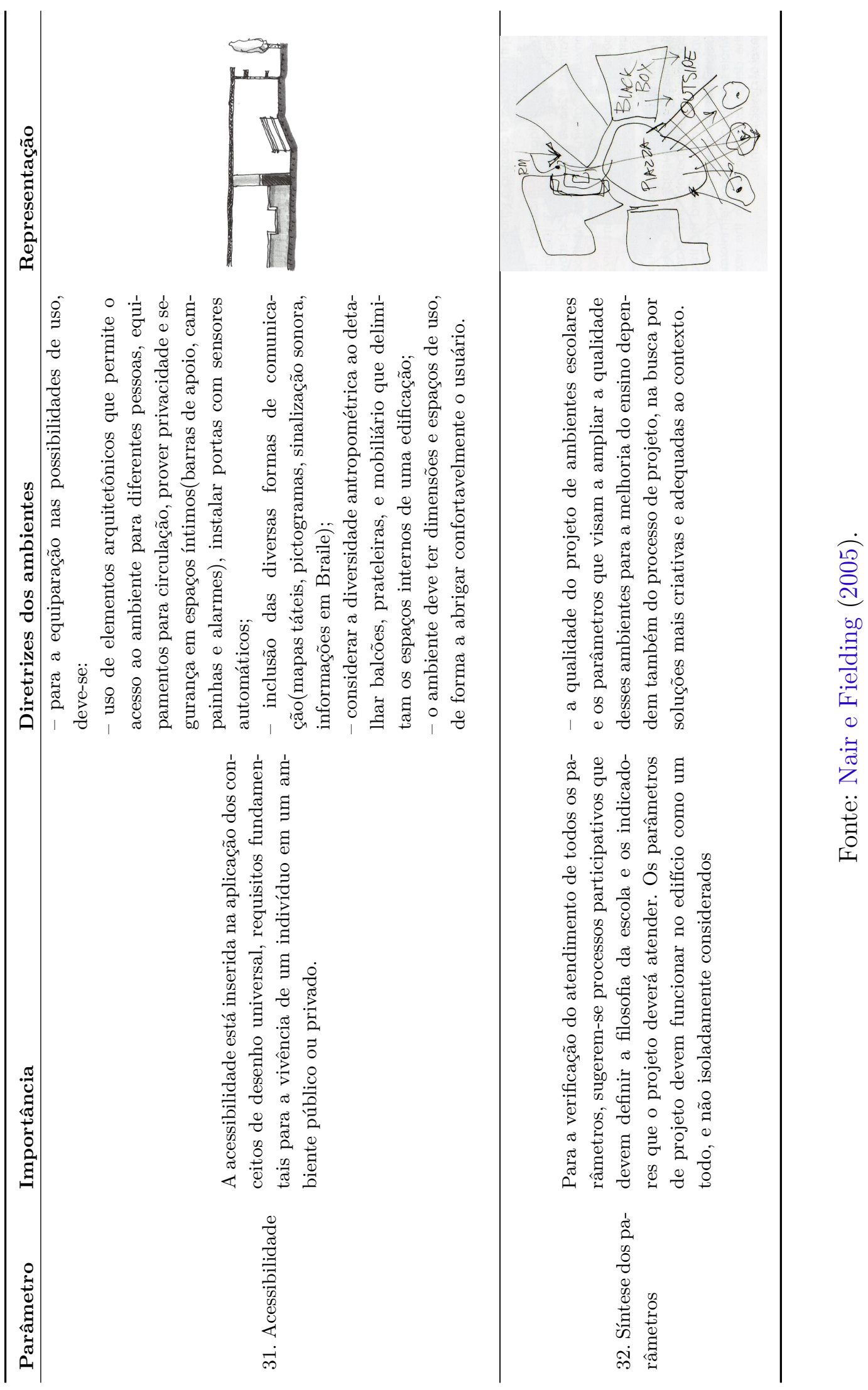


A qualidade do projeto de ambientes escolares e os parâmetros que visam ampliar a qualidade desses ambientes para a melhoria do ensino dependem também do processo de projeto, na busca por soluções mais criativas e adequadas no contexto. O processo tradicional de projeto necessita ser enriquecido com os parâmetros adequados, obtidos com a participação ativa da comunidade escolar e amparados por ferramentas de gerenciamento da informação e métodos de avaliação.

\subsubsection{O processo de elaboração do projeto do espaço escolar}

Conforme apontam estudos de Chvatal, Kowaltowski e Labaki (1998) e de Kowaltowski e Labaki (1993), a qualidade do ambiente construído é resultado de um adequado processo de projeto, de obra e de manutenção, assim como de um uso condizente com as suas funções. A qualidade do projeto em arquitetura depende da equipe e de sua experiência, bem como das informações disponíveis para o desenvolvimento do projeto.

Diversos autores relatam a complexidade do campo projetivo arquitetônico (BARROSOKRAUSE, 1998; DULGEROGLU-VUKSEL, 1999; FERNANDEZ, 1998; JUTLA, 1996), que: a) se situa entre a ciência e a arte, e tem de responder a questões não bem definidas, que permitem múltiplas abordagens; b) há subáreas - representação da forma, história e teoria, tecnologia das construções, estudo das estruturas - que se desenvolvem de maneira independente, cada uma com um tipo de dialeto, sendo necessário integrá-las na concepção de projeto; c) possui o conhecimento universal para ditar normas e padronizar e o conhecimento específico para cada caso, ou seja, cada problema é único e cada solução baseia-se em um conjunto diferente de critérios.

Uma das críticas do processo tradicional de projeto escolar é a rigidez dos programas de necessidades, estabelecidos pelas secretarias de educação de cada local e a falta de detalhamento do ponto de vista de metas, objetivos, desejos e desempenhos, nos momentos iniciais do processo criativo (KOWALTOWSKI, 2011). Isso faz com que as escolas sejam projetadas com um mesmo padrão, o que mostra pouca preocupação com as necessidades específicas de cada comunidade. Quando muitas escolas são inauguradas, já apresentam deficiências espaciais que acabam supridas com adaptações no espaço, originando problemas funcionais e de conforto ambiental.

Essa complexidade agrega grande dificuldade para enquadrar as características do processo projetivo em metodologias, porque o processo de criação de formas em arquitetura é informal, individual ou pertence a ideologias ou escolas de linguagem estética diferentes.

Lang (1987) e Papalambros e Wilde (2000) consideram o processo de projeto um número de atividades intelectuais organizadas em fases, com características e resultados distintos que são: análise, previsão, avaliação e decisão. Segundo Lang (1987), na prática, algumas podem ser realizadas pela intuição, outras, de forma consciente ou segundo 
2.3. Projeto Arquitetônico: a visão do campo disciplinar da arquitetura sobre as relações entre espaço e ensino

um padrão. O projeto arquitetônico faz parte da família de processos de decisão, e as principais fases da prática profissional dos projetistas, são: programa de necessidades, projeto, avaliação e decisão, construção e avaliação pós-ocupacão. Em cada fase, pode ser realizada uma série de atividades (LANG, 1974). Na rotina dos escritórios de arquitetura, observa-se ainda a divisão da fase de projeto em croquis, anteprojeto e projeto. Essas fases são conhecidas como o ciclo de vida de projeto.

Para kowaltowski et al. (2006) pode-se considerar o processo de projeto como um conjunto de atividades intelectuais básicas, organizadas em fases de características e resultados distintos. Essas atividades são análise, síntese, previsão, avaliação e decisão. Na prática, algumas atividades podem ser realizadas por meio da intuição, algumas de forma consciente e outras a partir de padrões ou normas (LANG, 1974). O processo de decisão em um projeto pode utilizar a descrição verbal, gráfica ou simbólica, isto é, vários mecanismos de informação, para antecipar analiticamente um modelo e seu comportamento (ROSSO, 1980).

O projeto lida com vários parâmetros conflitantes, o que significa que, a despeito de outros fatores, a metodologia adotada deve possibilitar a visualização dos conflitos, o gerenciamento de informações e tomada de decisões, a avaliação de aspectos de conforto térmico, acústico e visual e, ao ser constatada uma avaliação ruim, prever medidas que melhorem o desempenho desses aspectos (GRAÇA et al., 2008, p. 107). É sabido que em arquitetura existem muitos aspectos conflitantes que necessitam de resolução. A maneira criativa de solucionar requisitos conflitantes é aquela que encontra nestes impulso para gerar inovações e descobertas (KIATAKE, 2004, p. 5). Métodos que auxiliam esse processo buscam restringir o espaço ou escopo do problema para reduzir o tempo no desenvolvimento do projeto e aumentar a sua qualidade.

O grande desafio nas pesquisas em arquitetura tem sido, nos últimos anos, a introdução sistemática de conhecimento de fatores comportamentais no processo criativo. Estabelecer regras com profundo conteúdo humanista e científico dentro de uma metodologia de projeto demonstra importante contribuição no enriquecimento conceitual do processo criativo.

Existem tentativas na busca de métodos para o processo projetual e a garantia da qualidade dos seus produtos. Uma vertente é a especialização da profissão para projetos de tipologias específicas, tais como hospitais, escolares ou indústrias. As metodologias participativas de projeto, cujo objetivo é amenizar o autoritarismo do projetista no processo, são também contribuições positivas. Há ainda a criação de profissões novas, como os programadores de necessidades que atuam na preparação de material para o ato de projetar e na avaliação dos produtos com o intuito de criar um corpo de conhecimento apropriado para direcionar e alimentar o processo criativo.

O processo de projeto arquitetônico apresenta fases cíclicas de análise, desenvolvi- 
mento de soluções, ou síntese da forma e avaliação. A melhoria dos processos de projeto, por meio de métodos e ferramentas que sirvam de suporte ao processo de tomada de decisão dos arquitetos pode contribuir para a qualidade das edificações pela produção de uma arquitetura consideradas de alto desempenho. Os arquitetos devem se preparar para atender a essas demandas da arquitetura do presente e do futuro, pois o processo de projeto deve fundamentar-se, cada vez mais, em informações e metodologias seguras, e não realizar de modo puramente intuitivo.

Nair e Fielding (2005) afirmam que na literatura encontra-se um rico material com parâmetros de projeto para ambientes escolares considerados de alto desempenho funcional e ambiental. A primeira recomendação é que os ambientes de aprendizagem sejam associados às metodologias de ensino, que pressupõem flexibilidade de uso dos espaços e maior variedade de configurações. Dessa forma, a escola não é composta apenas de salas de aula, mas de espaços para estudos individuais e em grupo, laboratórios de ciências e artes, salas de música e teatro, sala de ginástica e espaços para convívio e alimentação humanizados. A arquitetura escolar deve incorporar valores que conferem significado às pessoas e criam impactos positivos na vizinhança. Assim, a linguagem arquitetônica necessita de caráter expressivo que pode ser obtido pelas formas, materiais, pela integração social e urbana ou pela inovação.

\subsubsection{Iniciando o projeto de um espaço de ensino: definição do Programa de Necessidades}

A discussão sobre o processo de projeto para a construção de escolas de qualidade enfatiza a importância do programa arquitetônico (MOREIRA; KOWALTOWSKI, 2009).

Segundo Kumlin (1995), o programa arquitetônico se estabeleceu como uma etapa distinta no processo de projetação em 1966, quando o American Institute of Architects (AIA) publicou um pequeno manual chamado "Emerging Techniques of Architectural Practice". Até o final da década de 1960, algumas outras publicações haviam tratado do programa arquitetônico, como o "Problem Seeking: An Architectural Programming Primer", que ainda hoje é reeditado em novas atualizações (PEÑA; PARSHALL, 2001). Alguns arquitetos também são conhecidos por serem os precursores da prática de desenvolver programa arquitetônico como parte do processo de projeto, como os arquitetos Louis Kahn (DOGAN; ZIMRING, 2002; HERSHBERGER, 1999; ALEXANDER, 1964) e Richard Neutra (FRAMPTON, 2007; LAMPRECHT, 2009).

A etapa do programa de necessidades consiste na reunião do material de referência necessário ao desenvolvimento do projeto, à organização e apresentação clara de dados, para obter as informações diferenciais das etapas do projeto. Entre as informações importantes no caso escolar está o conhecimento da linha pedagógica, pois o arquiteto, ao definir os 
2.3. Projeto Arquitetônico: a visão do campo disciplinar da arquitetura sobre as relações entre espaço e ensino

espaços e usos da instituição escolar, pode influenciar a definição da concepção de ensino da escola.

Por essa razão, o primeiro aspecto do processo de projeto considerado referência sugere a necessidade de incorporação dos aspectos pedagógicos no projeto de arquitetura, uma vez que refletem o tipo de atividade que as escolas vão desenvolver e são, consequentemente, elementos essenciais na definição das necessidades espaciais de cada edificação escolar. Há, sem dúvidas, uma evolução dos paradigmas educacionais que necessita ser traduzida em termos de espaço, cultura, pedagogia e tempo, deixando explícitas as mudanças para o futuro, o que demanda adaptação nos processos de projeto (DELIBERADOR, 2010)

O espaço físico de uma escola deve ser projetado em função do desenvolvimento do programa de necessidades de modo a garantir que a forma seja obtida a partir das prioridades e metas estabelecidas pela comunidade e pelos profissionais envolvidos no planejamento de projetos escolares. Muitas das escolas com arquiteturas consideradas recomendadas surgiram a partir de inovação no conceito que a comunidade possuía de educação. A discussão deve ter seu foco não apenas no edifício propriamente dito, mas sim na visão de educação que a comunidade pretende implantar na escola.

O usuário do edifício é o elemento ativo, e as atenções devem estar focadas nele, para estabelecer as necessidades que a forma projetada deverá cumprir. As necessidades funcionais são expressas por requisitos de conforto ambiental, bem como as características físicas, psicológicas e culturais dos usuários, as atividades desempenhadas no espaço a ser projetado e seus valores.

Como destacam Peña e Parshall (2001),

[...]bons edifícios não acontecem simplesmente. Eles são planejados para ter uma boa aparência e funcionar adequadamente, e surgem quando bons arquitetos e bons clientes juntam-se em um esforço pensado e cooperativo. Programar os requisitos do projeto de um edifício é a primeira tarefa do arquiteto, senão a mais importante [...] (PEÑA; PARSHALL, 2001, p. 12)

A responsabilidade primordial dessa etapa do programa é a articulação dos valores aos quais o arquiteto deveria responder no projeto (crenças, filosofias, ideologias, entendimento, propósitos ou ideias) e que são a razão do edifício e deveriam influenciar o modo como ele será projetado (HERSHBERGER, 1999).

Nem todos os valores têm a mesma importância para todos os tipos de projeto: cabe ao arquiteto descobrir, na fase do programa, quais deles são o foco de cada projeto ou de cada parte dele. Hershberger (1999) propôs uma série de valores considerados contemporâneos que poderiam funcionar como questões do projeto. Essa lista de valores pode servir como referência, devendo ser checada e alimentada com informações no 
programa. Outros valores também podem ser descobertos, principalmente em processos participativos. A estrutura elaborada por Hershberger (1999) é bastante completa e, se bem aplicada, conduz a um programa de necessidades responsável (Tabela 7).

Tabela 7 - Lista de valores que podem funcionar como questões de projeto elaborada por Hershberger (1999)

\begin{tabular}{ll}
\hline & Conceito \\
\hline Questões & Considera que a arquitetura \\
Humanas & é uma arte social, não ha- \\
& vendo razão para o trabalho \\
& se a base não for constituída \\
& pelos propósitos e atividades \\
& do ser humano.
\end{tabular}

Aspectos abordados

- Atividades funcionais: (um dos valores primordiais do projeto escolar). Significa a solução de uma série de aspectos relativos ao desempenho adequado das tarefas dos usuários. Essa questão vai além da articulação do espaço mínimo ou ótimo, em termos de layout: incluiu a disponibilização de informações com relação a hierarquia das atividades, relações desejáveis ou não entre os ambientes ou entre atividades, tamanhos dos ambientes, equipamentos necessários, mobiliários etc. É um aspecto em torno de que muitas informações devem ser recolhidas e tratadas;

- Aspectos sociais: poucas atividades sociais realizam-se solitariamente, o que significa que o programa deve abordar questões que expliquem o funcionamento dos grupos, a hierarquia e a comunicação entre as pessoas (nas escolas, relação professor/aluno) e se possível, identificar quais relações sociais que contribuem para que os usuários atinjam mais rapidamente seus objetivos.

- Aspectos físicos: o conhecimento das características físicas dos usuários é indispensável, pois podem influenciar profundamente a forma e os dimensionamentos do edifício. Crianças, idosos ou pessoas com necessidades especiais podem ter necessidades específicas que precisam ser identificadas nessa etapa.

- Aspectos psicológicos: o programa de necessidades tem a responsabilidade de conduzir a pesquisa nessa área de modo a destacar quais são os importantes aspectos psicológicos manifestos no grupo de futuros usuários

\begin{tabular}{ll}
\hline Questões & Considera as informações re- \\
ambientais & lativas ao ambiente, indis- \\
& pensáveis a uma boa solução \\
& projetual.
\end{tabular}

- Terreno: topografia, vistas internas e externas mais significativas ou negativas, aspectos de geologia ou hidrologia.

- Clima.

- Contexto: entorno (formas naturais aliadas ao ambiente construído do entorno imediato).

- Recursos: recursos ambientais disponíveis. Em função das crises energéticas, os valores da energia e de sua conservação tornaramse de impacto significativo, influenciando a escolha de materiais, a implantação e outros fatores do edifício.

- Lixo: o descarte de produtos do edifício e, principalmente, a destinação final de seus elementos quando o fim sua vida são questões raramente consideradas no projeto de arquitetura. Outro fator importante em edifícios de grande porte, como é o caso das escolas, é pensar como serão descartados os resíduos, uma vez que isso demanda grandes containeres que, se não adequadamente locados, podem causar problemas de circulação de pessoas e veículos. 


\begin{tabular}{ll}
\hline & Conceito \\
\hline Questões & Considera as informações re- \\
culturais & lativas à maneira como as \\
& pessoas percebem e usam o \\
& espaço, o significado que elas \\
& atribuem para as variadas \\
& formas e o que elas espe- \\
& ram em termos de arte do \\
& novo empreendimento. Es- \\
& sas questões muitas vezes \\
& são confundidas com as ques- \\
& tões humanas. A grande \\
& diferença está no fato de \\
& as questões culturais esta- \\
& rem vinculadas às expecta- \\
& tivas da sociedade (comuni- \\
& dade), enquanto as humanas \\
& vinculam-se imediatamente \\
& aos clientes e usuários.
\end{tabular}

Aspectos abordados

- Aspectos históricos: identificação da tradição de linguagem e de arte que condiciona o pensamento e a utilização humanos dos espaços, além da maneira como as formas arquitetônicas são interpretadas.

- Aspectos institucionais: se o cliente está envolvido com uma atividade que tem continuidade ou um desenvolvimento histórico na sociedade, o arquiteto está projetando para uma instituição humana, como é o caso das escolas. Esse valor é extremamente importante pois deve responder quais os valores da instituição que deverão estar expressos no projeto.

- Aspectos políticos: determinam o tipo de lugar que a sociedade quer, por meio de atitudes de cunho político. As regulamentações de zoneamento também devem ser conhecidas e levantadas no programa pois trazem impacto para o que pode ou não ser projetado,

- Aspectos legais: parte das regulamentações se transforma em leis, que devem constar do programa, de modo a agilizar o trabalho dos projetistas.

\section{Questões} tecnológicas
As novas tecnologias disponíveis têm sido uma das maiores influências na arquitetura. Atualmente, diante da grande variedade de materiais, sistemas e processos que podem ser aplicados ao projeto, decide-se em função das preferências dos profissionais e da disponibilidade, dos fatores econômicos e do potencial estético da especificação.

\section{- Materiais.}

- Sistemas: o programa deve mencionar se há alguma preferência da comunidade por determinado material ou sistema, para que o projetista verifique a viabilidade de aplicá-lo.

- Processos: quando o projetista vai projetar e o programa de necessidades não foi bem desenvolvido ele terá que programar o edifício durante o projeto, podendo tornar o processo ineficiente. Os métodos de projeto, as técnicas e as ferramentas empregadas no processo de projeto tem uma influência profunda na arquitetura produzida. Um projetista que entende na plenitude os valores dos usuários e clientes está muito mais apto a produzir uma arquitetura criativa, instigante e de qualidade do que aquele que se restringe ao atendimento aos espaços requeridos. Os processos construtivos também devem ser conhecidos, pois impactam sua forma.

\section{Questões temporais}

Devem ser conhecidas e consideradas, pois o tempo "impacta" a arquitetura de várias maneiras.
- Crescimento: é essencial o conhecimento do potencial de crescimento do empreendimento para que sejam consideradas provisões adequadas para futuras adições. No caso do ambiente escolar, essa é uma das mais presentes omissões nos programas, possivelmente também função do limitado tamanho da maior parte dos terrenos, que geralmente não atendem nem mesmo às condições desejáveis para acomodação do programa no tempo presente.

- Mudança: edifícios bem projetados devem acomodar certo grau de mudança de seus usuários e de suas necessidades. Geralmente sugere-se super dimensionamento das instalações, pois isso favorece alterações em função do desenvolvimento tecnológico.

- Permanência: a maior parte dos edifícios são projetados para ter longa vida, mesmo que necessite de remodelações ou adições para acomodar as mudanças necessárias. No caso escolar, a imagem de permanência pode ser um dos importantes valores a que a arquitetura deve responder. 


\begin{tabular}{lll}
\hline & Conceito & Aspectos abordados \\
\hline Questões & Devem ser conhecidas e con- & - Finanças: estudos de viabilidade econômica são, geralmente, \\
econômicas & sideradas, pois influenciam & realizados antes do programa de necessidades. \\
& as decisões projetuais. & - Construção: é necessário conhecer o orçamento disponível, fa- \\
& tor importante a ser considerado nas definições de projeto e na \\
& escolha de sistemas e materiais. O custo de ajustes na etapa de \\
& programa é bem menor do que em outras etapas do processo \\
& de projeto ou da construção. No ambiente escolar do Estado de \\
& São Paulo, essa avaliação é feita pela FDE (Fundação para o \\
& Desenvolvimento Escolar), logo nas primeiras entregas. \\
& - Operação: como será o funcionamento do empreendimento: im- \\
& pacto direto no projeto, nas definições de implantação, acesso, \\
& localização etc. \\
& - Manutenção: é geralmente desconsiderada nos programas de \\
& necessidades, em função do desejo do cliente em diminuir gastos \\
& na etapa de construção. Entretanto, muitos materiais e sistemas \\
& possuem custos inversamente proporcionais aos custos de sua \\
& manutenção. Esse item é muito importante nos edifícios públicos, \\
& não sendo diferente para o edifício escolar. Isso porque se sabe \\
& da dificuldade em disponibilizar verbas de manutenção, o que \\
& implica problemas, caso sejam realizadas escolhas erradas na \\
& fase de programa e projeto. \\
& - Energia: aspecto muito importante que, associado à manuten- \\
& ção e à operação do edifício, influencia os gastos gerados pelo \\
& edifício, quando em funcionamento.
\end{tabular}

\begin{tabular}{lll}
\hline Questões esté- & Aspecto importante para a & - Forma: restrições devem ser pesquisadas, assim como desejos \\
ticas & busca de uma arquitetura de & e preferências de usuários e clientes. \\
& qualidade, envolvendo o ne- & - Espaço: preferências espaciais podem ser essenciais a deter- \\
cessário conhecimento sobre & minados projetos. No ambiente escolar, as salas de aula devem \\
as preferências dos clientes e & permitir acomodação das frequentes mudanças educacionais, evi- \\
& tando grandes alterações em curto tempo, após construídos. \\
& - Significado: alguns clientes desejam comunicar alguma imagem \\
& específica para a comunidade ou para seus usuários. É impor- \\
& tante o programa identifique os valores de maior importância \\
& para que possa ser comunicado pelo edifício.
\end{tabular}




\begin{tabular}{lll}
\hline & Conceito & Aspectos abordados \\
\hline \multirow{2}{*}{ Questões de } & Maior preocupação dos & - Estrutura: a estrutura proposta deve ser adequada à função do \\
& governantes, direcionada à & edifício, sendo que o programa deve identificar cargas incomuns \\
& segurança e ao bem-estar & que estarão presentes para que essas sejam consideradas. Tais \\
dos cidadãos, principal- & cargas podem ser relativas a fenômenos naturais (ventos, chuvas, \\
mente nos espaços públicos. & terremotos etc.) ou por mobiliários ou usos específicos do edifício \\
& (como as estantes das bibliotecas). \\
& - Fogo: o programa deve identificar na legislação (rotas de fuga, \\
& saídas de emergência) e em outras referências os fatores neces- \\
& sários à proteção do edifício contra incêndio; \\
& - Química: devem ser identificados fatores externos ao edifício \\
& (contexto) ou mesmo produzidos pela própria atividade interna \\
& do edifício que possam trazer insegurança aos usuários por fato- \\
& res químicos. \\
& - Pessoal: mais uma vez devem ser identificados fatores internos \\
& ou externos que possam causar danos aos usuários para que os \\
& projetistas estejam atentos a tais fatores no momento do projeto. \\
& Como exemplos dessa situação podem-se mencionar os cantos \\
& vivos, as esquadrias que se abrem em áreas de circulação em \\
& níveis elevados etc. \\
& - Criminal: muitos aspectos podem favorecer a segurança dos \\
& edifícios públicos e estes devem ser identificados no programa. \\
& Iluminaçáo e transformação de áreas particulares em áreas semi- \\
& públicas podem ser elementos favorecedores, pois fazem que \\
& os próprios moradores do entorno contribuam para a segurança \\
& do edifício.
\end{tabular}

Fonte: Adaptado de Hershberger (1999).

Muitas são as possibilidades de organização dos dados, assim como as técnicas para o desenvolvimento de um programa de necessidades completo. Como destacam Moreira e Kowaltowski (2009), as técnicas de programa de necessidades são tão variadas como são as estruturas que descrevem um contexto. Mas, fundamentalmente, os resultados de diferentes programas sobre um mesmo contexto deveriam ser, pelo menos, semelhantes. $\mathrm{O}$ método do Problem Seeking, por exemplo, estrutura as informações de projeto que um programa de necessidades deve abranger e serve como um checklist para a programação (PEÑA; PARSHALL, 2001). A Tabela 8 apresenta a relação dos tópicos ressaltados pelo Problem Seeking: 


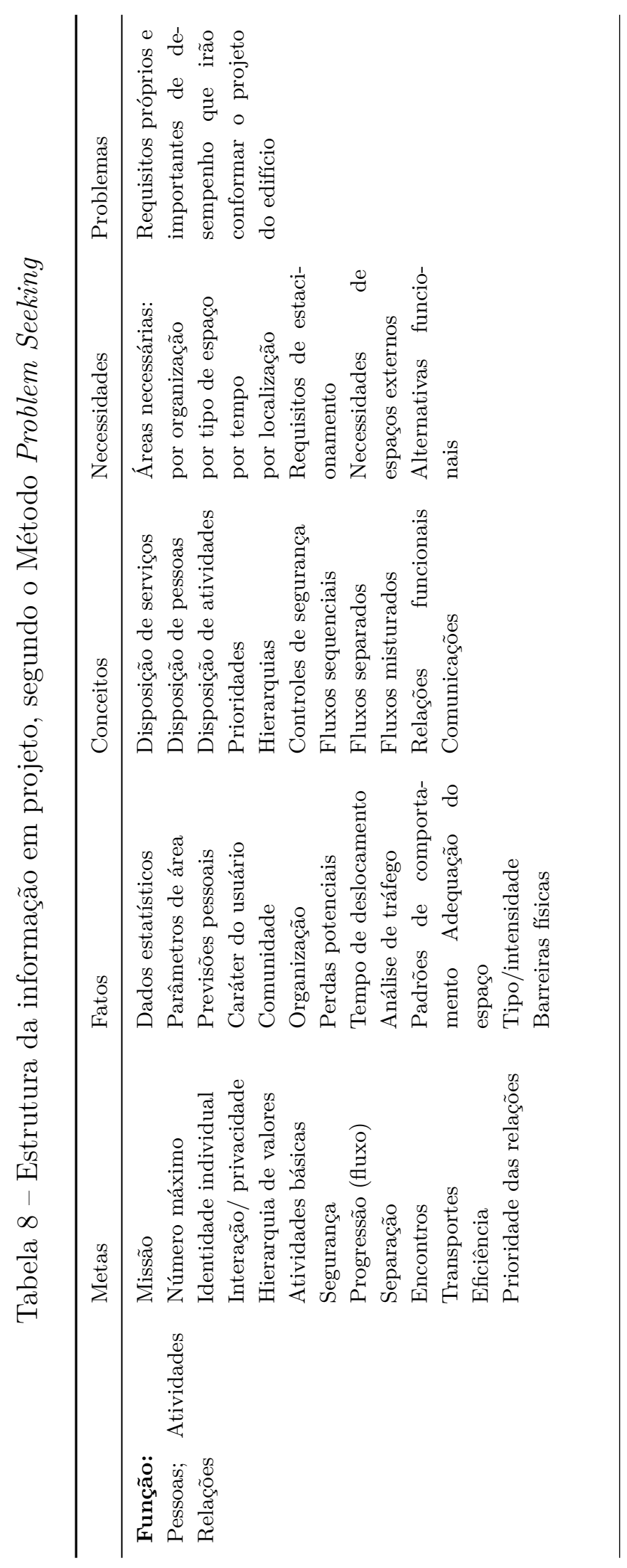



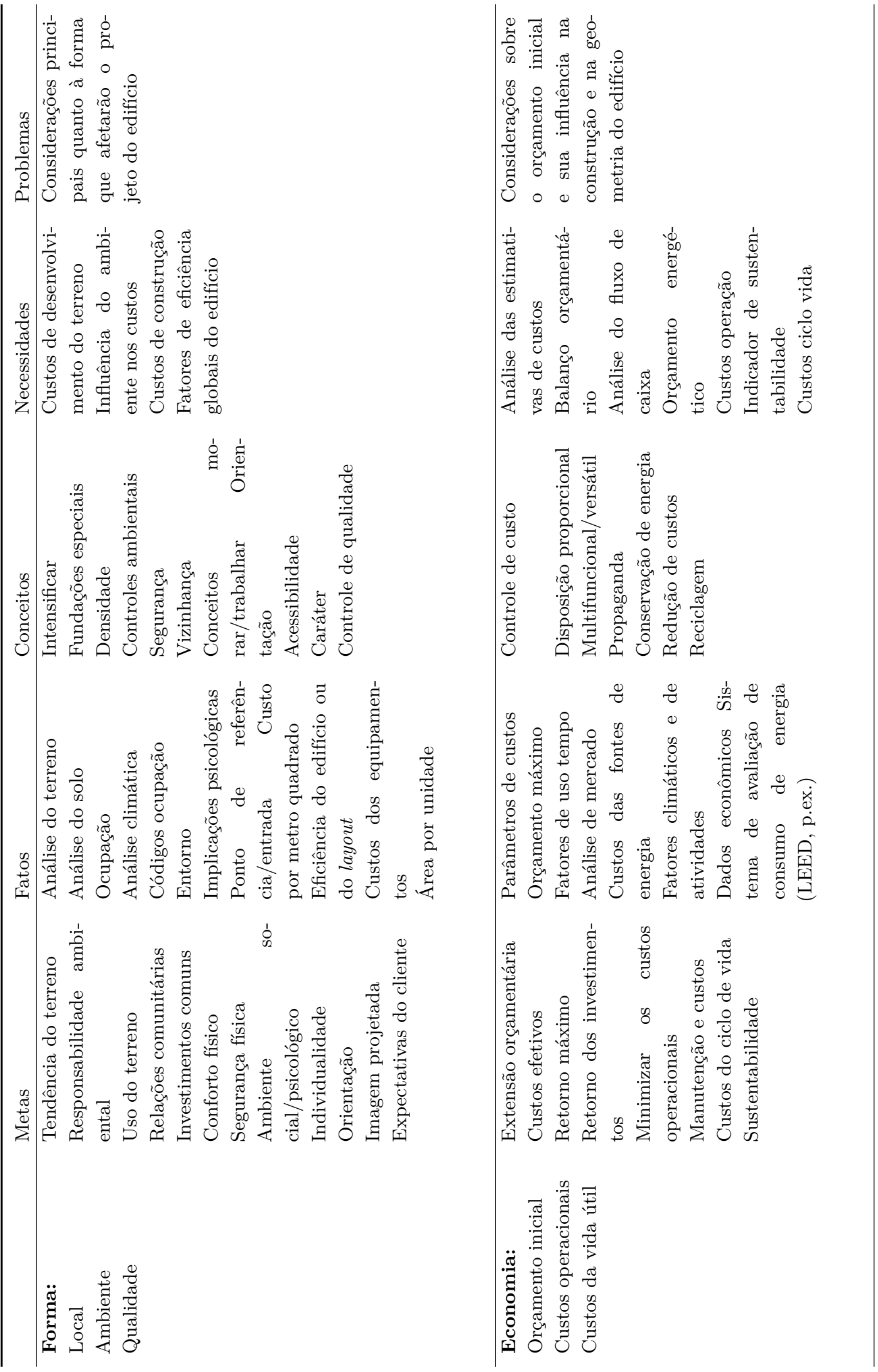


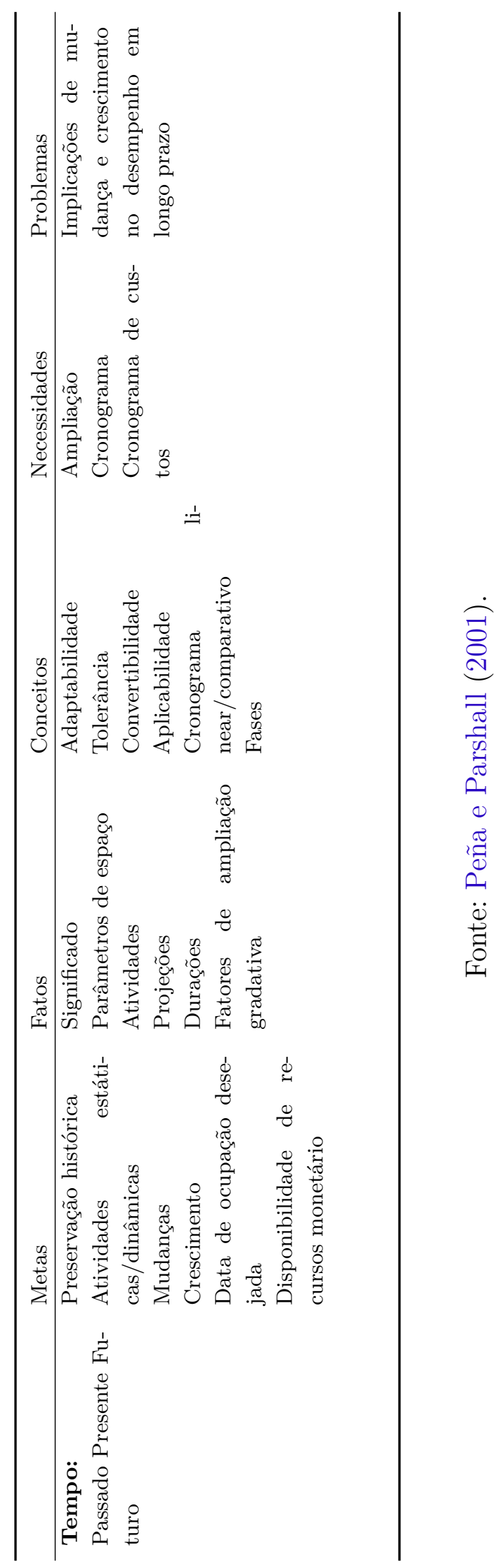


2.3. Projeto Arquitetônico: a visão do campo disciplinar da arquitetura sobre as relações entre espaço e ensino

Outro método difundido para organizar as informações do Programa Arquitetônico pode ser obtido na ISO (International Organization for Standardization), a norma ISO 9599 (1994) Performance Standards in Building - Checklist for Briefing - Contents of Brief for Building Design, descreve o conteúdo das instruções (brief) para o projeto do edifício.

Nessa estrutura as informações são organizadas de acordo com três grupos principais. Uma estrutura conceitual para o programa arquitetônico orienta o raciocínio e estabelece uma conduta de trabalho no levantamento das informações sobre o contexto. Tabela 9, a seguir:

Tabela 9 - Estrutura geral para o Programa Arquitetônico segundo a norma ISO 9699 (INTERNATIONAL ORGANIZATION FOR STANDARDIZATION, 1994)

\begin{tabular}{|c|c|c|c|}
\hline \multicolumn{4}{|c|}{ (A) Identificação } \\
\hline A.1. & Identidade & $\begin{array}{l}\text { A.1.1 Projeto, nome/título/número } \\
\text { A.1.2 Localização/endereço }\end{array}$ & A.1.3 Categoria do edifício/tipo de uso \\
\hline A. 2 & Proposta & $\begin{array}{l}\text { A.2.1 Razão principal do projeto } \\
\text { A.2.2 Objetivos principais do projeto }\end{array}$ & A.2.3 Propósitos (tarefas) do programa \\
\hline A. 3 & Escopo & $\begin{array}{l}\text { A.3.1 Dimensões } \\
\text { A.3.2 Qualidade } \\
\text { A.3.3 Quadro financeiro }\end{array}$ & $\begin{array}{l}\text { A.3.4 Cronograma } \\
\text { A.3.5 Planejamento do projeto } \\
\text { A.3.6 Modificações futuras }\end{array}$ \\
\hline A. 4 & $\begin{array}{l}\text { Identificação } \\
\text { dos } \\
\text { participantes }\end{array}$ & $\begin{array}{l}\text { A.4.1 Cliente } \\
\text { A.4.2 Ocupantes/Usuários } \\
\text { A.4.3 Gerente geral/Administrador } \\
\text { A.4.4 Consultor do programa }\end{array}$ & $\begin{array}{l}\text { A.4.5 Projetista } \\
\text { A.4.6 Outros consultores } \\
\text { A.4.7 Construtores }\end{array}$ \\
\hline A.5. & $\begin{array}{l}\text { Identificação } \\
\text { de outros } \\
\text { grupos }\end{array}$ & $\begin{array}{l}\text { A.5.1 Governo Central } \\
\text { A.5.2 Agências Nacionais/Internac. } \\
\text { A.5.3 Governo Local } \\
\text { A.5.4 Planej./Construção Municipais } \\
\text { A.5.5 Financiadores }\end{array}$ & $\begin{array}{l}\text { A.5.6 Grupos/Pessoas especiais } \\
\text { A.5.7 Proprietário/Locatário } \\
\text { A.5.8 Vizinhança e seus representantes } \\
\text { A.5.9 Meios de comunicação } \\
\text { A.5.10 Seguradoras }\end{array}$ \\
\hline
\end{tabular}

(B) Contexto, objetivos e recursos

\begin{tabular}{|c|c|c|c|}
\hline B. 1 & Gerenciamento & $\begin{array}{l}\text { B.1.1 Participantes } \\
\text { B.1.2 Organização de grupos afins }\end{array}$ & $\begin{array}{l}\text { B.1.3 Avaliação de projeto } \\
\text { B.1.4 Controle de qualidade }\end{array}$ \\
\hline B. 2 & $\begin{array}{l}\text { Legislação, } \\
\text { normas e } \\
\text { códigos }\end{array}$ & $\begin{array}{l}\text { B.2.1 Planejamento urbano } \\
\text { B.2.2 Restrições legais } \mathrm{p} / \text { o terreno } \\
\text { B.2.3 Leis ocupacionais } \\
\text { B.2.4 Finanças }\end{array}$ & $\begin{array}{l}\text { B.2.5 Códigos de construção/projeto } \\
\text { B.2.6 Leis ambientais/poluição } \\
\text { B.2.7 Político/Administrativo } \\
\text { B.2.8 Social/Cultural }\end{array}$ \\
\hline B. 3 & $\begin{array}{l}\text { Restrições } \\
\text { financeiras e } \\
\text { prazos }\end{array}$ & $\begin{array}{l}\text { B.3.1 Financiamento do projeto } \\
\text { B.3.2 Orçamentos } \\
\text { B.3.3 Custos de uso }\end{array}$ & $\begin{array}{l}\text { B.3.4 Prazos } \\
\text { B.3.5 Expectativa de vida } \\
\text { B.3.6 Riscos financeiros e de prazos }\end{array}$ \\
\hline B. 4 & $\begin{array}{l}\text { Panorama e } \\
\text { Influências } \\
\text { históricas }\end{array}$ & $\begin{array}{l}\text { B.4.1 Histórico do projeto } \\
\text { B.4.2 Situação atual }\end{array}$ & $\begin{array}{l}\text { B.4.3 Razões para a iniciativa } \\
\text { B.4.4 Compromissos }\end{array}$ \\
\hline B. 5 & $\begin{array}{l}\text { Influência do } \\
\text { local e } \\
\text { entorno }\end{array}$ & $\begin{array}{l}\text { B.5.1 Disponibilidade do terreno } \\
\text { B.5.2 Comercial e social } \\
\text { B.5.3 Dados ambientais } \\
\text { B.5.4 Infraestrutura }\end{array}$ & $\begin{array}{l}\text { B.5.5 Dados geofísicos } \\
\text { B.5.6 Características do solo } \\
\text { B.5.7 Edifícios existentes }\end{array}$ \\
\hline
\end{tabular}




\begin{tabular}{|c|c|c|c|}
\hline B. 6 & $\begin{array}{l}\text { Futuro do } \\
\text { empreendimento }\end{array}$ & $\begin{array}{l}\text { B.6.1 Propósitos } \\
\text { B.6.2 Dimensões }\end{array}$ & $\begin{array}{l}\text { B.6.3 Contexto } \\
\text { B.6.4 Mudanças futuras }\end{array}$ \\
\hline B.7 & $\begin{array}{l}\text { Detalhes da } \\
\text { ocupação } \\
\text { pretendida }\end{array}$ & $\begin{array}{l}\text { B.7.1 Relação de ativida- } \\
\text { des/processos } \\
\text { B.7.2 Usuários } \\
\text { B.7.3 Relações } \\
\text { B.7.4 Relação de bens acomodados }\end{array}$ & $\begin{array}{l}\text { B.7.5 Consumos especiais } \\
\text { B.7.6 Subprodutos } \\
\text { B.7.7 Riscos à proteção e à saúde }\end{array}$ \\
\hline B. 8 & Efeitos esperados & $\begin{array}{l}\text { B.8.1 Sobre o empreendimento } \\
\text { B.8.2 Sobre usuário/público } \\
\text { B.8.3 Sobre o ambiente }\end{array}$ & $\begin{array}{l}\text { B.8.4 Controle dos efeitos indesejáveis } \\
\text { B.8.5 Prioridades }\end{array}$ \\
\hline
\end{tabular}

(C) Requisitos e desempenho

\begin{tabular}{|c|c|c|c|}
\hline C. 1 & Local e entorno & $\begin{array}{l}\text { C.1.1 Relações especiais } \\
\text { C.1.2 Proteção } \\
\text { C.1.3 Acessos } \\
\text { C.1.4 Segurança } \\
\text { C.1.5 Zoneamento }\end{array}$ & $\begin{array}{l}\text { C.1.6 Controle ambiental } \\
\text { C.1.7 Utilidades públicas } \\
\text { C.1.8 Descarte de resíduos } \\
\text { C.1.9 Manutenção }\end{array}$ \\
\hline C. 2 & O edifício & $\begin{array}{l}\text { C.2.1 Características físicas } \\
\text { C.2.2 Circulação/acesso } \\
\text { C.2.3 Proteção } \\
\text { C.2.4 Ambiente } \\
\text { C.2.5 Comunicações }\end{array}$ & $\begin{array}{l}\text { C.2.6 Segurança } \\
\text { C.2.7 Aspectos } \\
\text { C.2.8 Obras de arte } \\
\text { C.2.9 Operação }\end{array}$ \\
\hline C. 3 & $\begin{array}{l}\text { Desempenho } \\
\text { do edifício }\end{array}$ & $\begin{array}{l}\text { C.3.1 Estrutura } \\
\text { C.3.2 Invólucro externo } \\
\text { C.3.3 Divisores espaciais externos }\end{array}$ & $\begin{array}{l}\text { C.3.4 Divisores espaciais internos } \\
\text { C.3.5 Serviços }\end{array}$ \\
\hline C. 4 & $\begin{array}{l}\text { Agrupamento } \\
\text { dos espaços }\end{array}$ & $\begin{array}{l}\text { C.4.1 Zoneamento } \\
\text { C.4.2 Relações espaciais }\end{array}$ & C.4.3 Características físicas \\
\hline C.5 & $\begin{array}{l}\text { Espaços com } \\
\text { detalhes }\end{array}$ & $\begin{array}{l}\text { C.5.1 Características físicas } \\
\text { C.5.2 Atividades relacionadas }\end{array}$ & $\begin{array}{l}\text { C.5.3 Relações com outros espaços } \\
\text { C.5.4 Serviços do edifício }\end{array}$ \\
\hline C. 6 & $\begin{array}{l}\text { Instalação, } \\
\text { equipamentos } \\
\text { e mobiliário }\end{array}$ & $\begin{array}{l}\text { C.6.1 Itens por categoria } \\
\text { C.6.2 Localização/área de uso } \\
\text { C.6.3 Instalação }\end{array}$ & $\begin{array}{l}\text { C.6.4 Aspecto } \\
\text { C.6.5 Manutenção }\end{array}$ \\
\hline
\end{tabular}

Fonte: Norma International Organization For Standardization (1994).

As avaliações de desempenho ambiental dos edifícios destacam-se em todas as metodologias de projeto de arquitetura escolar, outro aspecto de destaque é a relação saudável entre o ambiente e os usuários.

Sanoff (2001) oferece um método participativo para projetos escolares que começa com uma fase de avaliação, quando se examina "cultura específica da escola", para enfatizar que nenhuma escola é igual a outra e, assim, ressaltar as individualidades da comunidade e sua vizinhança. A análise do ambiente escolar da comunidade é realizada por um walking tour ou walkthrough, com um checklist de seis fatores: contexto, volumes, interface, orientação (wayfinding), espaços de socialização e conforto.

O autor recomenda vários métodos de levantamento de dados, com observações diretas, entrevistas e simulações. São avaliados os aspectos gerais do prédio, das áreas 
externas, dos ambientes de ensino, das áreas sociais, o acesso à tecnologia (infraestrutura); os espaços de transição e circulação, a aparência visual e estética dos ambientes e dos prédios, os níveis de segurança e as impressões gerais e pessoais. Sanoff prioriza a aplicação de ferramentas visuais (desenho, fotografias e esquemas) para saber a opinião dos usuários sobre a linguagem arquitetônica mais apreciadas e apropriadas, o tipo de projeto para as áreas de circulação, de socialização e as áreas de ensino.

Nas Normas Técnicas Brasileiras não existe referência direta ao Programa de Necessidades de Edificações Escolares. Entretanto a ABNT (1995b), referente à Elaboração de Projetos de Edificações - Arquitetura, apresenta diretrizes gerais para um programa de necessidades de edificações. Nela destacam-se as condições exigíveis para a elaboração de projetos de arquitetura para a construção de edificações, aplicável a todas as classes (ou categorias) tipológicas funcionais e formais das edificações (ou de quaisquer ambientes construídos ou artificiais), bem como aos serviços técnicos de obras.

Devido à complexidade do processo de concepção em arquitetura, não existem fórmulas precisas ou fixas que unam forma, função e tecnologias disponíveis no contexto de implantação. O profissional aplica o conhecimento, a experiência e a compreensão de um problema de maneira heurística, na busca da melhor solução de projeto, que nem sempre é alcançada. Por essa razão, é fundamental a introdução consciente de dados de pesquisa, as ferramentas de análise de projeto.

Assim considerando a discussão anterior sobre espaço arquitetônico e ensino, destacam-se os assuntos relativos a: conforto e percepção ambiental, relações antropométricas, arranjos de mobiliário e tecnologias de organização espacial. Esses temas serão explorados para estabelecer as relações prioritárias a serem consideradas num projeto de arquitetura de espaço de ensino.

\subsection{Campos disciplinares relativos ao desempenho do espaço na aprendizagem}

A consideração de áreas do conhecimento como psicologia ambiental, ergonomia e conforto ambiental reúnem as principais preocupações pertinentes aos aspectos relacionados por pedagogos e arquitetos em suas pesquisas sobre a relação espaço e aprendizagem.

A discussão das abordagens e de como podem contribuir para a elaboração de um projeto arquitetônico que considere um melhor desempenho da aprendizagem na fase de organização e dimensionamento dos espaços constitui a primeira aproximação teórica da pesquisa com esses campos disciplinares para depois investigar os parâmetros a serem considerados na definição de um programa de necessidades.

Villarouco e Andreto (2008) afirmam que a Psicologia Ambiental revela a impor- 
tância dos fatores físicos e simbólicos dos espaços de trabalho e a relação destes com os indivíduos. A Ergonomia preocupa-se com os objetos que compõem o ambiente de trabalho e sua relação com a funcionalidade, o significado e o componente social, além de estudar a maneira como os espaços são utilizados, buscando uma adequação do processo produtivo, por meio de uma configuração espacial que reflita as exigências do trabalho, favoreça a saúde, a segurança e a produtividade. O Conforto Ambiental garante a qualidade necessária ao exercício das atividades.

Segundo Vasconcelos et al. (2009), a arquitetura foca o ambiente físico e seu relacionamento com a vida humana, adaptando o mesmo ao modo de vida dos usuários (onde pode se incluir o conforto ambiental). A psicologia ambiental busca a importância dos valores simbólicos do espaço físico e a ergonomia coloca o humano como elemento norteador, estudando a forma como o espaço é utilizado, de maneira a adequá-lo às tarefas e atividades que nele serão desenvolvidas.

A ergonomia ambiental, ainda de acordo com Vasconcelos et al. (2009), tem o seu posicionamento focado na adaptabilidade e conformidade do espaço às tarefas e atividades que nele são desenvolvidas. Para tal, convoca elementos da antropometria, da psicologia ambiental, da ergonomia cognitiva e da metodologia ergonômica. Acreditam que também alguns conceitos do conforto térmico, acústico e lumínico devem compor o leque de preocupações contempladas na concepção de ambientes ergonomicamente adequados, que agrega ainda características de sustentabilidade, em consonância com as recentes necessidades que apontam naquela direção

Para Elali (1997), essas abordagens oportunizam o início dos estudos comportamentais do homem por meio de suas relações com o espaço - base dos pressupostos da Psicologia Ambiental, ou seja, o estudo de aspectos construtivos e funcionais do espaço construído acrescido da análise comportamental e social, essencial à sua compreensão.

Por essas definições, verifica-se que existe uma linha da ergonomia que entende que tanto aspectos de conforto ambiental, normalmente tratados como estudos técnicos no campo da arquitetura, e também, aspectos de psicologia ambiental são parte da ergonomia que agregaria, assim, todos os campos até aqui investigados. Diante de visões diferenciadas entre os estudiosos dos três campos disciplinares, optou-se por uma breve conceituação do que trata cada aspecto de forma predominante e de como podem contribuir para a pesquisa sem entrar na discussão se integram um grande campo disciplinar ou não.

\subsubsection{Contribuição da ergonomia a arquitetura}

A definição pioneira do engenheiro inglês Murrel (1969), um dos fundadores da ergonomia na Europa pode ser apresentada da seguinte forma: 
Nesse sentido, o termo ambiente não se refere apenas ao contorno ambiental, no qual o homem trabalha, mas também a suas ferramentas, seus métodos de trabalho e à organização deste, considerando-se este homem, tanto como indivíduo quanto como participante de um grupo de trabalho [...]. Na periferia da ergonomia [...] estão as relações do homem com seus companheiros de trabalho, seus supervisores, gerente e com sua família (MURREL, 1969, p. 13)

Lourenço e Menezes (2008) descrevem a ergonomia como um "conjunto de conhecimentos a respeito do desempenho do homem em atividade, a fim de aplicá-los à concepção de tarefa, instrumentos, das máquinas e dos sistemas de produção". Este autor distingue a ergonomia de correção de ergonomia de concepção. A primeira procura adequar às condições de trabalho já existentes, é de eficácia limitada, além de ter alto custo. Já a ergonomia de concepção tende a introduzir os conhecimentos sobre o homem desde o projeto do posto de trabalho, da máquina ou dos sistemas de produção.

Para Bins Ely et al. (2002), Mont'Alvão (2011), Villarouco (2008), a relação entre a arquitetura e a ergonomia é um requisito primordial para a harmonia entre o homem, as atividades e o ambiente, pois ao integrar a ideia do ambiente arquitetônico com o ambiente do desenvolvimento das tarefas, de acordo com as capacidades, habilidades e limitações humanas (que inclui características como percepção, compreensão e interação com o espaço) parece clara a necessidade dos conhecimentos da ergonomia nos projetos de design e arquitetura que contemplam o ambiente construído.

A Ergonomia é uma ciência multidisciplinar onde se unem diversos aspectos do conhecimento científico do homem no trabalho: o fisiológico, o psicológico, o técnico (engenharia), o sociológico, o médico, entre outros, tendo como principal objetivo a adaptação do trabalho ao homem, respeitando suas limitações como ser humano individual, ou interagindo em um contexto (VELÁZQUEZ, 1997).

\subsubsection{Ergonomia aplicada à atividade de ensino}

Segundo Luz et al. (2005) a ergonomia de ensino é a interação física e psíquica dos alunos em relação à estrutura escolar, equipamentos, materiais, ambiente, metodologia e avaliação. Este trabalho enfatiza a importância da estrutura e do ambiente escolar, mostrando os benefícios e os malefícios para que se obtenha um bom desempenho educacional, constatando-se, por meio de relatos de pesquisas, consultas literárias e observações, que a falta de infraestrutura escolar afeta a eficácia do aluno na aquisição de conhecimento em sala de aula.

Iida (2005, p. 569-575) relata alguns resultados de pesquisa em ergonomia de ensino nas áreas de:

- Processo de ensino - embora sejam disponíveis diversas tecnologias educacionais, 
ainda predominam aulas do tipo verbal-expositivo, que é um método comprovadamente de pouca eficiência. A postura imobilizada dos alunos por longo período em carteiras provoca solicitações estáticas de sua musculatura, que dificultam a circulação e provocam fadiga. Por ser o ensino-aprendizagem um processo gradual de transmissão do conhecimento em que cada indivíduo se comporta de diferentes maneiras, torna-se, também, necessário o desenvolvimento de métodos que se adaptem às suas características.

- Compatibilidade do processo educacional - o processo educacional deve ser compatível com o objetivo instrucional. Para cada tipo de objetivo existem procedimentos, materiais e métodos mais adequados.

Alguns aspectos são destacados como relevantes para o desempenho da atividade pelo autor:

- Postura - para garantir o conforto dos alunos, que geralmente permanecem sentados durante longos período, é necessário fazer estudo da postura e das dimensões antropométricas, para se projetar adequadamente o "posto" de trabalho escolar.

- Dimensões antropométricas - cada pessoa apresenta uma velocidade própria de crescimento, em cada faixa etária, bem como os segmentos corporais (cabeça, pés, mãos). Autores sugerem que, a partir de uma única medida (estatura) das crianças, podem-se determinar os principais parâmetros para o projeto de carteiras escolares, com um erro não superior a $5 \%$.

- Carteira escolar - é considerada como um posto de trabalho para a criança. Os móveis escolares devem facilitar a realização das tarefas escolares, de modo confortável, pois as crianças passam de $25 \%$ a $30 \%$ do tempo em que estão acordadas na escola. Segundo Soares (1998) um dos requisitos mais importantes no projeto da carteira escolar é a constante mobilidade exigida do corpo humano.

- Equipamentos e material didático - diversas tecnologias novas têm sido introduzidas na educação, como uso de materiais audiovisuais, vídeos, máquinas de ensinar e aparelhos de autoinstrução. Toda essa área recebe um grande impulso com a informática e a telecomunicação. O livro didático continua sendo o material mais difundido. A eficiência do livro didático pode ser aumentada melhorando-se o nível de compreensão e retenção dos conhecimentos, se estes forem apresentados em uma sequencia lógica e com uma gradação progressiva das dificuldades.

- Infraestrutura - o projeto correto das máquinas, postos de trabalho e do ambiente influem no desempenho do trabalhador. Da mesma forma, o projeto adequado dos mobiliários, salas de aula, bibliotecas, laboratórios, e outros meios de apoio didático 
podem influir no desempenho dos professores e alunos. Na sala de aula deve-se cuidar do posicionamento correto do quadro negro, janelas que não provoquem brilho ou ofuscamentos.

- Condições do Ambiente - o ambiente físico, como a iluminação, ruídos, temperatura, ventilação e uso de cores, influi no conforto físico e psicológico e, portanto, no rendimento do ensino.

De acordo com Vasconcelos et al. (2009), a ergonomia do ambiente construído, também conhecida como ergonomia ambiental, corresponde a mais uma vertente que se insere nas pesquisas da relação do homem com o ambiente, a partir dos aspectos sociais, psicológicos, culturais e organizacionais.

Assim, fica evidente a necessidade de uma abordagem interdisciplinar, integrando as áreas da ergonomia, arquitetura e psicologia ambiental, na investigação e consecução de projetos de ambientes. Os autores consideram que, dessa forma, a ergonomia ambiental tem o seu posicionamento focado na adaptabilidade e conformidade do espaço às tarefas e atividades que nele são desenvolvidas. Para tal, convoca elementos da antropometria, da psicologia ambiental, da ergonomia cognitiva e da metodologia ergonômica.

Fonseca (2004) define a ergonomia ambiental ou ergonomia do ambiente construído como a vertente da ergonomia que se dedica ao estudo do ambiente físico da tarefa, visto que ele pode contribuir positiva ou negativamente no desempenho dos usuários que dele se utilizam, na consecução de suas tarefas e atividades. Assim, conceitos do conforto térmico, acústico e lumínico devem compor o leque de preocupações contempladas na concepção de ambientes ergonomicamente adequados, que agrega ainda características de sustentabilidade, em consonância com as recentes necessidades que apontam naquela direção.

De acordo com Villarouco (2002), a ergonomia do ambiente se dedica às questões de adaptabilidade e conformidade do espaço às tarefas e atividades nele desenvolvidas. Para o alcance desse objetivo, ela utiliza elementos da antropometria, da psicologia ambiental, da ergonomia cognitiva e da Análise Ergonômica da Trabalho (AET). Alguns conceitos de conforto térmico, acústico e lumínico e cromático também compõe o leque de preocupações contempladas na concepção de ambientes ergonomicamente adequados (Figura 4).

Em outras palavras, Ribeiro (2004) afirma que a ergonomia surge, então, na arquitetura como o meio de conhecer o usuário. A abrangência dos estudos ergonômicos e seu enfoque no usuário fazem deles um dos mais completos para abordar as consequências do espaço sobre o homem, quais constrangimentos os usuários sofrem e quais os custos humanos resultantes desses constrangimentos.

Para Fonseca (2004), o estudo da ergonomia aplicada a um determinado espaço 


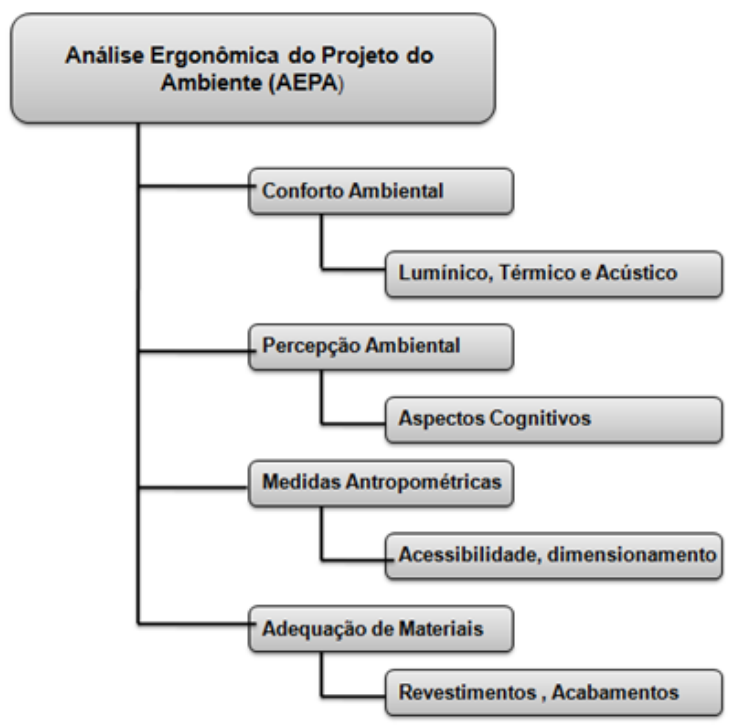

Figura 4 - Fatores componentes de uma Análise Ergonômica do Projeto de Ambiente Fonte - Villarouco et al. (2005).

deve privilegiar a apreensão de dados relevantes sobre as necessidades físicas, cognitivas e psíquicas dos usuários do local de trabalho e as exigências das atividades desenvolvidas.

A incorporação desses dados ao projeto de locais de trabalho contemplará todos os aspectos de adequabilidade ergonômica, assim definidos por Villarouco (2002):

- aspectos referentes à percepção ambiental, daqueles que irão utilizar efetivamente o espaço projetado;

- aspectos de adequabilidade dos revestimentos propostos, bem como da adequabilidade da cor desses revestimentos, em função de tarefas a serem desenvolvidas nos ambientes, e da interferência desses materiais no desempenho físico e cognitivo dos usuários;

- aspectos cognitivos dos futuros usuários, na medida em que estes representam papel determinante na relação homem-ambiente e na realização da tarefa envolvida pelo ambiente;

- aspectos concernentes à realização do trabalho a ser desenvolvido no ambiente, a fim de permitir dimensionamento adequado, incluindo as características dos postos de trabalho e as variáveis antropométricas interferentes nesse segmento; e

- aspectos concernentes ao conforto ambiental, tais como, iluminação, cores, ventilação e ruídos.

Um conjunto de informações deve ser elencado, para cada um desses elementos, a fim de conduzir o processo de avaliação do projeto, sendo esses mesmos procedimentos 
sugeridos na análise de ambientes em utilização, nos quais se formule uma demanda, a partir de problemas identificados (FONSECA, 2004).

Segundo a autora, constituindo agrupamentos de funções, pode-se estruturar em tópicos alguns dos problemas geralmente relacionados com a inadequabilidade do ambiente:

- Percepção ambiental - elemento de avaliação ambiental e projetual, que, em associação com os aspectos cognitivos dos usuários, no que concerne às questões ambientais, representam o fator de mais difícil identificação. Os aspectos envolvidos nessa adequação devem advir do sentimento que o usuário experimenta, na interação cotidiana com o ambiente construído. Sua avaliação independe de índices pré-estabelecidos, ou legislações, trazendo ao nível decisório o sentimento do homem, interfaceando os limites entre a razão e a emoção, tendo ainda como elemento mediador a bagagem cognitiva adquirida na trajetória vivencial do indivíduo.

- Materiais de revestimento, cores e acabamentos - para adequação nesses itens, pode-se adotar posturas distintas, em função do uso do ambiente e da atividade desenvolvida. Alguns setores produtivos apresentam normatizações quanto ao emprego desses materiais e suas cores, competindo ao ergonomista, o devido zelo na identificação das fontes de informações mais adequadas.

- Postos de trabalho e medidas antropométricas - na falta de um maior cuidado com a configuração e identificação de necessidades dos postos, residem muitos dos problemas da inadequação de ambientes, ao desenvolvimento do trabalho aos quais se destinam. A pouca interação entre arquitetos que concebem os espaços e especialistas nos métodos de execução do trabalho, fatalmente, pode conduzir a falhas de altas proporções nesse segmento. Também as questões antropométricas envolvidas no dimensionamento dos postos de trabalho carregam forte parcela de responsabilidade no estabelecimento de condições adversas. A projetação do mobiliário e postos deve estar em perfeita consonância com os padrões do usuário, não sendo suficiente a adoção de valores referentes ao homem médio.

- Conforto ambiental (iluminação, cores, ventilação, ruídos e vibrações) - as normas ISO, ABNT e AFNOR estabelecem como níveis permissíveis à saúde os padrões máximos para exposição sonora cotidiana e de pressão acústica, os valores de $85 \mathrm{~dB}$ (A) e 200 pascal. No que se refere à vibração, tem-se as normas ISO e ABNT. Para níveis de iluminação as normas ISO e ABNT (1991) estabelecem níveis de conforto visual e padrões ajustados para conferir segurança ao trabalho. Entretanto, as recomendações das normas vigentes devem servir apenas como elementos norteadores e de padrões mínimos a serem obtidos. A definição real deverá advir de um cuidadoso confronto entre aqueles padrões e as necessidades captadas dos usuários, para os quais alguns padrões mínimos podem parecer inadequados. 


\subsubsection{Contribuição da psicologia ambiental a arquitetura}

Psicologia ambiental é "o estudo da transação entre indivíduos e o cenário físico. Nessas transações, indivíduos modificam o ambiente e seu comportamento e experiências são modificados pelo ambiente" (GIFFORD, 1997, p. 1). Segundo Günther (2003), esta definição leva em conta os três elementos básicos da psicologia ambiental:

- Comportamento e experiência humanos - podem ser considerados tanto em nível individual quanto de grupo e compreendidos não como univariados, mas constituindo um conjunto de eventos acontecendo paralelamente e de forma inter-relacionada. Enquanto se trata somente da questão do impacto unidirecional do espaço físico sobre o comportamento e experiência das pessoas, várias áreas das ciências sociais estudam essas manifestações, em escalas que vão desde o indivíduo até grupos do tamanho de uma nação.

- Espaço (ou cenário) físico - o espaço físico igualmente é multifacetado. A percepção dos cenários físicos não somente passa por múltiplos sentidos (visão, audição etc.), mas registra múltiplos estímulos ao mesmo tempo. Entretanto, dificilmente, respondese ou se é atingido por apenas um aspecto deste ambiente físico, mas por sua gestalt, composta por múltiplos estímulos.

- A ligação recíproca entre (a) e (b) - o elemento da ligação recíproca. O objeto de estudo não (somente) consiste das relações unidirecionais, o impacto das pessoas sobre o espaço e o do espaço sobre as pessoas, mas do processo de retroalimentação entre comportamento e experiência das pessoas e o espaço físico. Embora várias definições da área tratem da relação entre pessoas e espaço físico, enfatizamos que a psicologia ambiental se distingue de outras áreas da psicologia no sentido de estudar explicitamente essa relação recíproca e circular entre estes dois elementos.

Fisher, Bell e Baum (1984) definem psicologia ambiental como o estudo do interrelacionamento entre comportamento e ambiente físico, tanto o construído quanto o natural. Surgida a partir desse tipo de entendimento, a psicologia ambiental é um campo de estudo relativamente recente, gerada pelos ideais ecológicos das décadas de 1950/1960, e começou a consolidar-se a partir da Conferência de Estocolmo, em 1972 (GÜNTHER; ROZESTRATEN, 2005).

Para Elali (2006), a literatura pesquisada admite duas grandes vertentes para o setor: a psicologia ambiental arquitetural e a psicologia ambiental verde (POL, 1993). A primeira concentra seu interesse no ambiente construído, e a segunda se envolve com as grandes questões ecológicas da atualidade. Saliente-se que esses dois momentos não são estanques e convivem a partir da atuação dos diferentes pesquisadores. 
Segundo Carvalho, Calvalcante e Nóbrega (2011), a psicologia ambiental estuda as inter-relações entre pessoas e ambiente desde o nível microambiente, abarcando espaços privados como moradia até ambiente global. Define ambiente como um conceito multidimensional sendo constituído pelo espaço físico concreto em que se vive - construído ou natural - e pelas pessoas, acompanhadas das condições sociais, econômicas, políticas, culturais e psicológicas. Devido à relação intrínseca e dinâmica entre pessoa e ambiente, as alterações sofridas em qualquer de seus componentes acarretam modificações nos demais, conferindo ao ambiente uma nova configuração espacial, dinâmica e unitária.

A constituição de um ambiente é dividida em três aspectos segundo Carvalho, Calvalcante e Nóbrega (2011),

- componentes físicos compostos de: arquitetura, decoração, acústica, iluminação, temperatura, equipamentos, mobiliários, objetos, características topográficas, climáticas etc.;

- componentes não físicos: aspectos psicológicos ou pessoais dos usuários do espaço estudado - as expectativas e experiências anteriores, desejos, motivações, padrões comportamentais, crenças, autoestima etc.;

- aspectos sociais: papéis, atividades e valores dos participantes do contexto do ambiente, bem como aspectos culturais, econômicos e políticos.

Em psicologia e arquitetura, duas das áreas mais proximamente ligadas ao estudo da relação pessoa-ambiente, este quadro não é diferente. Gradualmente, a psicologia ampliou sua área de atuação do indivíduo para o social e o ambiental, "redefinindo" e complementando seu objeto de estudo de modo a abarcar as interações ambiente/comportamento, e contribuindo para um conhecimento mais amplo da realidade por meio de um enfoque ecologica e humanamente consistente. Em arquitetura, por sua vez, aos poucos observa-se o deslocamento da ênfase na análise de aspectos estéticos/construtivos/ funcionais do edifício para a preocupação com a percepção/satisfação dos usuários e com as implicações das intervenções em termos de paisagem, propiciando a elaboração de propostas mais centradas no indivíduo e/ou no social e nas implicações ecológicas das interferências realizadas (ELALI, 1997).

Sob esta ótica, o edifício deixa de ser encarado apenas a partir das suas características físicas (construtivas) e passa a ser avaliado/discutido enquanto espaço "vivencial", sujeito à ocupação, leitura, reinterpretação e/ou modificação pelos usuários, ou seja, ao estudo de aspectos construtivos e funcionais do espaço construído acrescenta-se a análise comportamental e social essencial à sua compreensão. Esse processo implica, necessariamente, a análise do uso - enquanto fator que possibilita a transformação de espaços 
em lugares - e a valorização do ponto de vista do usuário, destinatário final do espaço construído, e portanto imprescindível à compreensão da realidade.

A relação do comportamento humano com o ambiente construído é estudada na teoria da arquitetura e na psicologia ambiental. A primeira trata da relação entre ambiente físico e comportamento humano e a segunda trata essencialmente da percepção humana do ambiente que envolve o indivíduo e os sentimentos resultantes em relação a esse mesmo ambiente (GIFFORD, 1997).

Para Kowaltowski (2011), a percepção do espaço passa por um processo de regulação de distâncias, que podem ser pessoais e sociais, e consideram-se as influências e regras culturais, a sem sensação de medo e segurança que o ambiente oferece pela disposição dos ambientes arquitetônicos. Essas influências levam o indíviduo a criar um "entorno próximo", no qual ele sente que tem domínio sobre o que o envolve e segurança para interagir com o meio. Quatro conceitos são aplicáveis para caracterizar a qualidade do ambiente e a interação do homem com o espaço físico: privacidade, espaço pessoal, espaço territorial e densidade territorial.

- O conceito de privacidade - cada indivíduo percebe, sente e atua em um ambiente conforme o seu ponto de vista, que vai originar um espaço ao seu redor, no qual ele está apto a agir com naturalidade e confiança.

- O espaço pessoal em torno do indivíduo é imaginário, e este impõe limites para evitar uma aproximação indesejável de outras pessoas. Como o homem está envolvido pelo meio, é natural que ele delimite a sua zona pessoal, ou seja, o seu entorno, mais próximo, no qual ele tem completo domínio (SOMMER, 1969). Hall (1981) mostra como esse espaço é utilizado nas diferentes culturas, pois a percepção do espaço é dinâmica e relaciona-se à ação num dado espaço, em vez de relacionar-se apenas com a visão da observação passiva.

- O conceito de espaço territorial, onde o indivíduo necessita de uma demarcação, para sentir que pertence ao meio ou que esse pertence a ele. É uma relação de posse.

- O conceito de densidade territorial - os índices populacionais estão relacionados com as questões da proximidade e com as experiências coletivas, e influenciam o bem-estar do homem.

Com esses conceitos estuda-se como a arquitetura influencia e satisfaz, ou não, a vivência de cada usuário, fornecendo subsídios a futuros projetos ou introduzindo melhorias nas edificações existentes. A percepção de um ambiente está relacionada com a experiência vivida pelo indivíduo em um espaço com todos os seus aspectos: físicos, sociais, culturais e históricos. Os ambientes estão cheios de estímulos, e esses estímulos bombardeiam os indivíduos a todo instante. 
O comportamento é o resultado destas informações (ver Figura 5). Pinheiro (2003, p. 283) descreve a percepção ambiental como o "[. . .] elo fundamental na cadeia de processos psicológicos que compõe as interações humanas com os ambientes", no qual não há distinção entre sujeito e objeto, pois o sujeito está imerso no tempo e no espaço do ambiente.

Bins Ely (2003, p. 2-3) descreve, a seguir, o processamento da informação até resultar no comportamento:

Recebemos informações do meio ambiente ou das demais pessoas através de nossos sistemas de percepção [. . .]. Estas informações são tratadas através das atividades mentais [. . .]. Representações são construídas a partir de conhecimento adquirido, atribuindo significado aos elementos resultantes da análise perceptiva. Como resultado das atividades mentais tem-se decisão de ação, traduzidas no comportamento.(BINS ELY, 2003, p. 2-3)

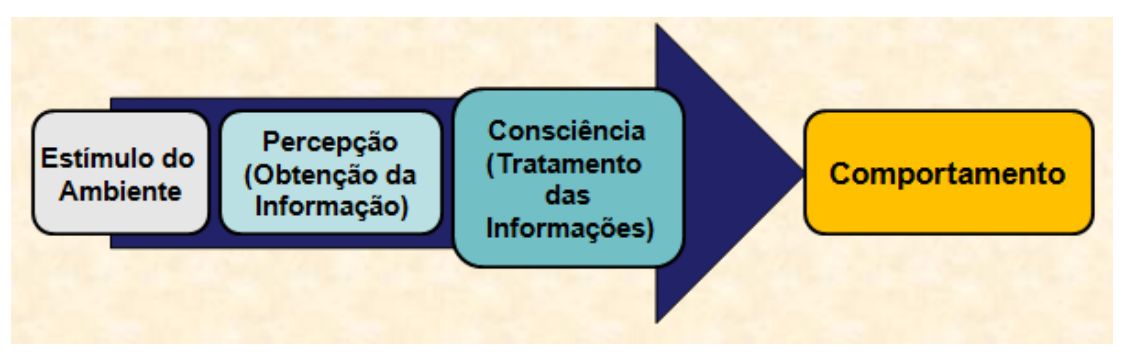

Figura 5 - Esquema do processamento de informação.

Fonte: adaptada de Bins Ely (2003).

As sensações de conforto dos usuários no ambiente construído são mais do que reações fisiológicas, visto que desempenham também papel cultural, simbólico e sensorial. Heschong (2002) enfatiza como as sensações térmicas afetam a experiência do ambiente pelas pessoas, reforçando o significado deste como abrigo ou proteção na vida de seus usuários. As sensações de conforto luminoso e acústico. As sensações de conforto também ficam retidas na memória como qualidade avaliada a partir de um repertório de experiências espaciais acumuladas, associando-se à experiência completa do ambiente e contribuindo para sua identificação.

Os conceitos de espaço pessoal, territorialidade, apinhamento (crowding ) e privacidade estruturam grande parte dos estudos sobre o comportamento humano no ambiente construído pela psicologia ambiental.

\subsubsection{Contribuição do conforto ambiental a arquitetura}

Para Santos et al. (1998) o conforto ambiental é constituído por um conjunto de condições térmica, acústica e visual, propicia sensação de bem-estar aos usuários 
de um ambiente e sua inobservância constitui a principal causa de sintomas diversos e desagradáveis, como: a fadiga, desconcentração, desanimo, etc. (Figura 6). Por conta disso, a área de conforto ambiental começa a ganhar força nos setores responsáveis por pensar, projetar e construir espaços escolares.

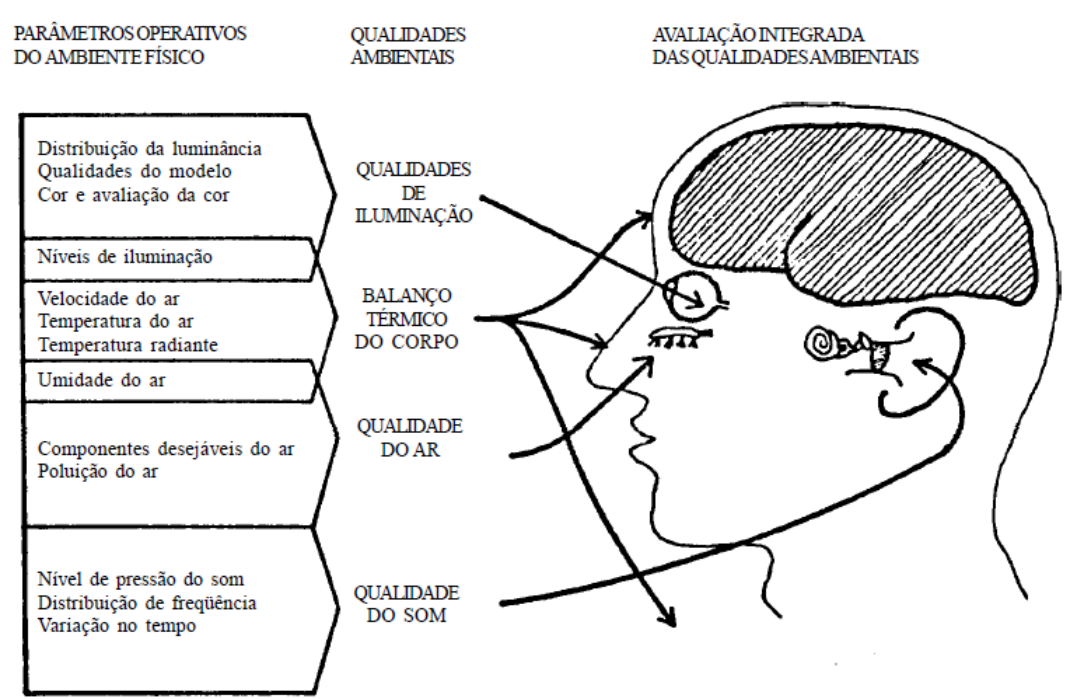

Figura 6 - Os parâmetros do ambiente físico criam qualidades ambientais e dão lugar a uma percepção e avaliação integradas do homem.

$$
\text { Fonte - Ryd (1967). }
$$

Segundo Mueller (2007), com base nos manuais e guias publicados por órgãos norte-americanos e na revisão bibliográfica sobre espaços de ensino-aprendizagem com qualidade ambiental e alto desempenho energético, formulou-se uma lista de características apresentadas por espaços de ensino-aprendizagem com qualidade ambiental e alto desempenho energético. Pôde-se também concluir sobre alguns benefícios resultantes para as construções que apresentam tais características:

- Possuir uma planejada e eficiente inserção no sítio

Entendendo que o sítio é o elemento essencial para o bom desempenho do edifício, os projetistas devem buscar soluções que conservem os locais ecossistemas existentes, restaurem áreas danificadas, minimizem alagamentos, controlem a erosão e incorporem tecnologias que não poluam e tampouco degradem o meio ambiente. Assim, a ocupação no terreno é planejada e o projeto de implantação permite ao edifício o melhor acesso solar, utiliza acidentes e elementos naturais para prover sombra e barrar ruídos, considera as variações sazonais de direção e velocidade do vento, e integra a escola à vizinhança. Para isso, os projetistas devem realizar estudos preliminares das condições do solo, vegetação, 
áreas de preservação, áreas alagáveis, vias de acesso, orientação solar e direção dos ventos do local, para, posteriormente, prosseguir com os estudos de implantação.

- Ser saudável e confortável

Para os espaços físicos escolares serem saudáveis e confortáveis, os responsáveis pelas soluções arquitetônicas devem se preocupar com todos os fatores internos e externos que podem influenciar na saúde e no conforto dos usuários (como a temperatura e umidade, o nível de iluminação e de ruído e a qualidade do ar e poluentes).

- Ser termicamente agradável

A escola termicamente agradável deve possuir um bom projeto de envoltórias, respondendo às condições climáticas locais, como materiais de isolamento e de coeficiente de absorção apropriados, inércia térmica apropriada, insolação das superfícies quando desejável, barreiras radiantes etc. Ainda, deve incluir o desenho de esquadrias eficientes, com a correta escolha dos materiais, cores, películas protetoras, elementos sombreadores, sistema de aberturas e possibilidades de manuseio.

Deve-se apurar a qualidade do ar interno e considerar as diferentes estratégias de ventilação e renovação do ar interno, separando a ventilação de áreas com demandas diferentes e criando zonas de vegetação entre o tráfego e as áreas com aberturas para a ventilação natural. Ainda, devem utilizar a ventilação noturna para melhor desempenho energético.

- Ser visualmente agradável

A escola visualmente agradável deve apresentar boa qualidade luminosa nos ambientes, além de qualidades espaciais que enriquecem a vivência nesses espaços, como a interação visual com o ambiente externo por meio da geometria do edifício, layout e janelas. O projeto dos espaços deve utilizar corretamente as luzes (natural e artificial) e cores, contribuindo para aumentar a satisfação do usuário, melhorar a produtividade ou desempenho escolar, reduzir a fadiga e os acidentes, além de reduzir a carga de resfriamento e a carga elétrica. O edifício deve apresentar estratégias de iluminação natural de modo a utilizá-la em pelo menos $\frac{2}{3}$ do dia e a eliminar a entrada de luz diretamente sobre o plano de trabalho. Para isso, o projeto de estrutura do edifício deve ser desenvolvido integrando as estratégias de luz natural e minimizando os elementos estruturais redundantes. Por fim, devem ser utilizados materiais de acabamento e cores das superfícies internas adequadas para refletir melhor a luz natural, sem descuidar do brilho e áreas de grande contraste de luminância. 
- Ser acusticamente agradável

A escola acusticamente agradável deve apresentar condições ideais para que os professores e estudantes possam falar e ouvir melhor, melhorando tanto o desempenho escolar quanto o rendimento e a produtividade dos funcionários e professores. Portanto, os ruídos do sistema de ventilação e de ar-condicionado, os ruídos externos (rua, comércio e indústria) e os ruídos internos da própria escola (pátio interno, ginásio, sala de música) devem ser minimizados. Utiliza-se, para isso, a própria arquitetura como elemento formal que reduz a reverberação e melhora a compreensão da palavra falada. Devem ser utilizadas também as barreiras acústicas e os materiais de acabamento que reduzam a reverberação e que absorvam o som.

- Ser energeticamente eficiente

Para a escola ser energicamente eficiente, esta deve possuir um baixo custo de operação e reduzir a emissão de poluentes ao meio ambiente. Para tanto, deve apresentar sistemas de energia renovável, como a luz natural, tecnologias de energia solar e eólica, coletores fotovoltaicos, aquecimento solar passivo, entre outros. Nos edifícios em que, por algum motivo, for necessário o uso de ar-condicionado, os projetistas e proprietários devem considerar o custo inicial do sistema de condicionamento artificial e prever os gastos com manutenção e operação deste. Ainda, um eficiente projeto de instalações elétricas deve ser adotado, selecionando lâmpadas que ofereçam mais lúmens por watt, que tenham uma vida útil maior, que necessitem de menos manutenção, e que sejam compatíveis com a oferta de luz natural dentro do ambiente.

De acordo com Kowaltowski (2011), as questões do conforto abordam diversos fatores, tais como a qualidade do ar, as condições de ventilação, de comunicação verbal, os níveis de iluminação, a disponibilidade de espaço, os materiais de acabamento. Os elementos construtivos podem ser avaliados em relação às patologias e às questões de manutenção e higiene. Ambientes escolares são ricos em informações e podem ter avaliações em relação à satisfação dos usuários e à aprendizagem dos alunos, medindo-se a produtividade do ambiente.

Ainda segundo Kowaltowski (2011), observa-se que nos países onde há normas e rigorosos códigos de obras, as condições de conforto atingem níveis mínimos na maioria das suas construções, e as pesquisas do ambiente escolar concentram-se em detalhes que contribuem para a aprendizagem. Existem estudos que definem com precisão os níveis de parâmetros de conforto ambiental, como a temperatura do ar interno, que pode propiciar melhor desempenho escolar, ou a economia e o gerenciamento de prédios escolares, que implicam gastos com manutenção, eficiência energética da edificação e sustentabilidade dos projetos escolares (GIFFORD, 1997; YANNAS, 1995). 
Afirma-se que o conforto ambiental é uma parceria entre ambiente físico (características do local, arquitetura da edificação e uso dos ambientes) e usuários do espaço. Kowaltowski (2011) afirma que são essenciais as pesquisas das condições do conforto ambiental e a possibilidade de introduzir melhorias para propiciar um ambiente adequado ao ensino. Segundo a autora, a importância do conforto ambiental em relação à produtividade no trabalho ou na aprendizagem depende do projeto do edifício e de seus ajustes às atividades dos usuários.

$\mathrm{Na}$ fase do projeto, independe de índices preestabelecidos ou legislações, que devem ser tomados apenas como norteadores e identificadores de descumprimento de normas, não servindo como meta a ser perseguida em termos absolutos. Os índices que regulam esta avaliação apoiam-se na conjunção dessas metas com a necessidade identificada na percepção de conforto do usuário, suas necessidades psicológicas e de necessidades específicas do bom desempenho de suas atividades.

A partir do entendimento de que esses três campos disciplinares possuem relevância na qualificação dos espaços arquitetônicos facilitadores do aprendizado, resta aprofundar a investigação sobre os atributos e seus parâmetros de modo constituir um conjunto a ser considerado na elaboração de programas de necessidades de edifícios escolares. 

Parte III

Resultados 



\section{Características Espaciais Facilitadoras da Aprendizagem}

No capítulo anterior, por meio da revisão de literatura, foi possível confirmar que características do espaço arquitetônico exercem influência na aprendizagem, podendo facilitar ou dificultar o ensino. Neste capítulo, será possível aprofundar essas relações para estabelecer um conjunto de aspectos afetos aos três campos disciplinares, bem como um conjunto de atributos espaciais a serem posteriormente validados no âmbito do ensino superior com ferramental de pesquisa de campo.

\subsection{Elementos e parâmetros técnicos que estruturam a relação en- tre espaço arquitetônico e ensino-aprendizagem}

Os três grandes eixos/categorias que seguem serão utilizados para ordenar as informações:

- pesquisas que tratam do conforto ambiental, que se refere aos estabelecimentos escolares identificando agentes ambientais (calor, ruído, vibrações, iluminação), que, por sua ausência, podem causar desconforto e falta de concentração, interferindo no ensino-aprendizagem;

- pesquisas que tratam da ergonomia, que se refere às interações entre seres humanos e outros elementos, como mobiliário, cores equipamentos, comunicação visual e tecnologia, a fim de otimizar desempenho das atividades, podendo interferir na relação ensino-aprendizagem;

- pesquisas que tratam da psicologia ambiental, que se refere ao conhecimento sobre a qualidade do espaço arquitetônico e sua capacidade de transmitir sensações a seus usuários, também interferindo no ensino-aprendizagem;

A seguir, foi realizada pesquisa sobre elementos e parâmetros técnicos sobre a relevância de cada campo disciplinar para, em seguida, verificar quais são as características desses espaços que devem ser priorizadas nos estudos prévios à elaboração de um projeto arquitetônico de uma edificação de ensino. 


\subsubsection{O papel do conforto ambiental na concepção de espaços de ensino- aprendizagem}

Conforto ambiental é definido pelo Ministério da Educação do Brasil quando estabelece a obrigatoriedade de seu estudo na formação mínima do arquiteto e integra a disciplina no currículo dos cursos de arquitetura e urbanismo, como uma área técnica que compreende o estudo das condições térmicas, acústicas, luminosas e energéticas e os fenômenos físicos a elas associados como um dos condicionantes da forma e da organização do espaço (MEC, 1994).

Por outro lado, a organização EFL (1963) relaciona a área a aprendizagem de fatores como: qualidade do ar, temperatura e umidade, ventilação e iluminação e acústica. Como já referido, pesquisas de diferentes autores em contextos e tempos diferenciados demonstram as relações entre os diversos aspectos do conforto ambiental e sua influência no ensino-aprendizagem.

Para Beltrame e Moura (2009), condições desfavoráveis de conforto ambiental são causa de mau desempenho dos alunos. De acordo com as autoras, é necessário que os projetos de escolas pensem edificações que possam ser modificadas ao longo dos anos, além de considerar o conforto ambiental: as condições térmicas, luminosas e acústicas que resultam em variações climáticas, comprometendo o bem-estar e o aproveitamento didático dos alunos que estejam nesses ambientes.

Shalaway (1998) afirma que, dentre as características ambientais destacam-se a temperatura, a iluminação e o nível de ruído. Esses fatores afetam estudantes de diferentes maneiras e estão diretamente relacionadas aos estilos individuais de aprendizagem. A mesma constatação se encontra em Sommer (1973), quando afirma que o conforto ambiental é fator de interferência no desenvolvimento didático dos alunos, destacando: acústica, temperatura, insolação, ventilação e luminosidade.

Para Mueller (2007), é certo que estudantes em uma sala de aula silenciosa, bem iluminada e apropriadamente ventilada (com uma boa qualidade do ar) aprenderão mais rápido, porque eles se encontram mais confortáveis, podem ver e ouvir melhor e se distraem menos. Ao mesmo tempo, professores ensinarão melhor em uma sala de aula com as mesmas características. Ambientes com iluminação, acústica e qualidade do ar deficientes são barreiras para a educação. Ambientes com alto desempenho removem essas barreiras, permitindo que professores e estudantes trabalhem sob melhores condições.

Como explicado por CHPS (2002), uma ventilação inadequada favorece a concentração de dióxido de carbono e outros poluentes dentro do edifício, agentes esses responsáveis pelo desconforto e pela incapacidade de concentração. A exposição a esses poluentes, assim como aos compostos orgânicos voláteis, pode causar sintomas agudos relacionados à baixa concentração e à dificuldade na assimilação das informações: olhos vermelhos, 
3.1. Elementos e parâmetros técnicos que estruturam a relação entre espaço arquitetônico e ensino-aprendizagem

dificuldade na respiração, crises asmáticas, dor de cabeça, distúrbio mental, problemas de comportamento e fadiga.

Conforme afirma Mueller (2007), os estudos de Heschong Mahone Group (1999), que foram amplamente divulgados também nas publicações de Heschong (2002), CHPS (2002) e Plympton, Conway e Epstein (2000) comprovaram que há uma forte correlação entre o aumento da luz natural e a melhora do desempenho do estudante. Esses estudos constataram que na Califórnia, por exemplo, estudantes em salas de aula com iluminação natural adequada progrediram 20\% mais rápido em exames de matemática e $26 \%$ mais rápido em exames de leitura do que os estudantes em salas de aula com menor quantidade de luz natural. Também, estudantes em salas de aula com mais área de janelas, progrediram, respectivamente, $15 \%$ e $23 \%$ mais rápido do que em salas com menos janelas. Estudantes em salas de aula com um bom dispositivo de luz zenital progrediram $20 \%$ mais rápido do que os estudantes sem esse dispositivo. Já em Washington e Colorado, o desempenho dos estudantes foi de $7 \%$ a $18 \%$ mais elevado quando expostos a um maior nível de iluminação natural.

Mueller (2007) relata que esses estudos também comprovaram que estudantes em salas de aula com luz zenital proveniente de vidro transparente (portanto, luz direta) e suscetíveis a ofuscamentos e desequilíbrios na distribuição da luz tiveram um progresso em seu desempenho escolar 21\% mais lento. Depois dos estudos de Küller e Lindsten (1992) relatados por CHPS (2002) e Plympton, Conway e Epstein (2000), baseados na observação do comportamento, dos níveis de hormônios e da saúde de crianças suecas de oito anos, concluiu-se que o trabalho em salas de aula sem iluminação natural pode interferir nos hormônios básicos das crianças, influenciando, assim, na capacidade de concentração e no crescimento corporal anual destas.

Os resultados das pesquisas relacionando a acústica e o aprendizado são consistentes e convincentes: a boa acústica é fundamental ao bom desempenho escolar. Algumas pesquisas explicam essa relação: Earthman e Lemasters (1998), em que se constatou que os estudantes que obtêm mais sucesso nos seus resultados vêm de escolas que têm menos ruído externo; Crandell, Smaldino e Flexer (1995) e Nabelek e Nabelek (1994) relacionaram os níveis de ruído e reverberação em sala de aula às habilidades de leitura e ortografia, ao comportamento, à atenção, à concentração e ao rendimento escolar; Evans e Maxwell (1997) examinaram 100 alunos de duas escolas em Nova Iorque que estão na rota dos aviões que vão ao aeroporto e estes apresentaram um rendimento $20 \%$ mais baixo na atividade de leitura do que alunos de outra escola (SCHNEIDER, 2002).

Segundo Mellati (2004), não se deve deixar de lado o conforto acústico dentro das salas de aula, principalmente na visão do professor, pois $99 \%$ das falas são dele e, como se viu anteriormente, a maioria dos alunos sofre por não entender o que os professores falam. Quando a sala tem ar-condicionado convencional, por exemplo, fica impossível escutar o 
professor. É preferível que os cantos das salas passem a ser arredondados, e que a parede oposta ao professor tenha uma inclinação de oito graus, ou seja revestida com algum tecido ou fibra de vidro, o que ajuda a retirar o efeito de eco. Por último, não utilizar pé-direito muito alto (mais de $3 \mathrm{~m}$ de altura) igualmente favorece a boa acústica, e não esquecendo do teto inclinado sugerido por Neufert (1976).

Quanto às cores nas salas de aula, Mellati (2004) recomenda evitar pigmentações vibrantes. Estas só são admitidas em salas de recreação ou de outra atividade que envolva movimento, como a educação física. Deve-se usar cores em tons pastéis e não saturadas, como verde claro ou azul claro. No caso de lugares com altas temperaturas, seria mais aconselhável o azul claro. Esse tipo de cor nas paredes faz com que os alunos fiquem menos agitados. É importante lembrar que o azul faz com que o cérebro ative o poder de concentração, aumentando, assim, a capacidade de raciocínio.

Ainda segundo a autora, o teto deve sempre ser branco para que se tenha uma leitura melhor e mais clara. Um teto escuro, além de escurecer a sala, pode transmitir ao aluno sensações desagradáveis depois de certo tempo, como a de estar sendo esmagado, pois a cor escura tem o efeito de "baixar" o pé-direito. Quanto ao piso, depende das cores que estão sendo usadas no conjunto, mas não pode ser brilhante para que não reflita luz, o que provocaria um rápido cansaço. Deve ser antiderrapante, para evitar acidentes, e sem os degraus do patamar do professor, pois ficou claro que, quando todos estão no mesmo nível, há mais interação. Ainda com relação às cores, é importante lembrar que para prevenir acidentes seria melhor utilizar cores diferentes dos pisos nos degraus, rampas, corrimãos e em áreas de perigo potencial.

Essas relações serão abordadas pelos diferentes tipos de conforto necessários ao bom desempenho do espaço.

\subsubsection{Conforto térmico}

Dentre os diversos estudos que vêm sendo desenvolvidos sobre a análise da relação homem/conforto térmico, existem alguns que fazem abordagens voltadas para o ensinoaprendizagem nas escolas da rede pública, onde as reações fisiológicas desses alunos são afetadas vindo a prejudicar a qualidade do ensino, quando expostos aos ambientes não adequados ao clima local com elevadas temperaturas (NOGUEIRA; DURANTE; NOGUEIRA, 2005).

Segundo Silva et al. (1996), a temperatura e a UR (umidade relativa do ar) são variáveis climáticas que influenciam diretamente no desempenho do trabalho humano. Um ambiente termicamente bem projetado pode contribuir para a diminuição da carga de estresse mental, aumento do nível de concentração, redução da hiperemia e, por conseguinte, aumento de eficiência na elaboração das tarefas. 
Para Filho et al. (2007)

[...] o excesso de calor dificulta a concentração, causa inquietação e afeta o desempenho dos mesmos. A umidade pode provocar sonolência e aumento de suor. Tais fatores, nem sempre diagnosticados, podem causar estresse e, depois de maior permanência, causar doenças mais complexas. Se as trocas de calor entre o organismo humano e o meio ambiente forem prejudicadas pode-se chegar ao ponto de ocorrer um estresse térmico. (FILHO et al., 2007, p. 5-6)

Frota e Schiffer (1995) relatam que os primeiros trabalhos desenvolvidos em 1916, pela Comissão Americana de Ventilação, confirmaram que, para trabalhos físicos, o aumento da temperatura de $20^{\circ} \mathrm{C}$ para $24^{\circ} \mathrm{C}$ diminui o rendimento em $15 \%$, e a $30^{\circ} \mathrm{C}$ de temperatura ambiente, com umidade de $80 \%$, o rendimento cai $28 \%$. Apesar de não serem dados produzidos no Brasil, pode-se levá-los em consideração.

Lamberts e Xavier (2008) afirmam que, quando os parâmetros físicos de um ambiente, temperatura do ar, temperatura radiante média, velocidade do ar e umidade do ar, bem como os parâmetros pessoais como atividade desempenhada e vestimenta utilizada pelas pessoas são conhecidos ou medidos, a sensação térmica para o corpo como um todo pode ser estimada pelo cálculo do índice do voto médio estimado, PMV, descrito na (INTERNATIONAL ORGANIZATION FOR STANDARDIZATION, 2005).

O desconforto térmico também pode ser causado por aquecimento ou resfriamento localizado do corpo (LAMBERTS; XAVIER, 2008). Os fatores de desconforto localizado mais comuns são assimetria radiante de temperatura (superfícies frias ou quentes), correntes de ar, diferença vertical de temperatura e pisos frios ou quentes. A versão anterior da norma fornecia um método para o cálculo da percentagem de pessoas insatisfeitas somente devido às correntes de ar. Na versão atual, a norma especifica como predizer o PPD para os demais parâmetros de desconforto localizado.

Deve-se levar em consideração, para análise do conforto térmico, as variáveis ambientais, que incluem temperatura radiante média, temperatura do ar, velocidade do ar, umidade do ar, e as variáveis pessoais, que compreendem o isolamento térmico por roupas e a atividade desempenhada. Os autores destacam alguns métodos para avaliar o conforto térmico, dentre eles a International Organization For Standardization (2005), que oferece os índices de PMV (voto médio estimado) e PPD (porcentagem de pessoas satisfeitas) e a International Organization For Standardization (1998), que especifica as características e formas de medição dos instrumentos das variáveis físicas. Para tanto, consideram-se os materiais construtivos, cuja característica determinará a sua capacidade de reflexão, absorção e transmissão de calor (LAMBERTS; XAVIER, 2008)

Uma das dificuldades encontradas no campo de iluminação e ventilação é a falta de padronização. Como cada município tem o seu código de posturas (norma construtiva), 
existem vários dispositivos legais para a construção de escolas, muitos deles contraditórios entre si. Uns determinam, por exemplo, que $\frac{1}{4}$ do total da sala deve ter ventilação e iluminação diretas, enquanto outros estabelecem $\frac{1}{6}$ e alguns não definem qualquer medida. Esta pesquisa conclui que $\frac{1}{6}$ é a medida mais indicada, apesar de aumentar a dificuldade de execução e, consequentemente, o custo. O ambiente fica mais acolhedor para o aluno: a sala se torna mais clara e ventilada, trazendo um conforto térmico maior (MELLATI, 2004).

Para Kowaltowski (2011), situações de desconforto causadas por temperaturas extremas, falta de ventilação adequada, umidade excessiva combinada com temperaturas elevadas ou por radiação térmica de superfícies muito aquecidas podem ser prejudiciais e causar sonolência, alteração nos batimentos cardíacos, aumento da sudação. Psicologicamente provoca apatia e desinteresse pelo trabalho. Segundo a autora, os fatores que influenciam o conforto térmico são classificados em ambientais e individuais. Os ambientais dependem das condições climáticas e são: temperatura do ar, temperatura radiante média, umidade relativa e velocidade do ar (RUAS, 1999).

Os parâmetros para a avaliação térmica de um ambiente são:

- temperatura do ar;

- temperatura radiante;

- ventilação e troca de ar;

- exposição a radiação solar;

- umidade relativa;

- presença de superfície muito aquecidas;

- paredes expostas a radiação solar direta ou coberturas sem a resistência térmica adequadas;

- mofo e deterioração de materiais construtivos.

Para as avaliações térmicas de ambientes escolares, observam-se os seguintes elementos (Tabela 10): 
3.1. Elementos e parâmetros técnicos que estruturam a relação entre espaço arquitetônico e ensino-aprendizagem

Tabela 10 - Elementos das avaliações térmicas de ambientes escolares

\begin{tabular}{ll}
\hline Tipo & Elementos \\
\hline De sombra & $\begin{array}{l}\text { cortinas, persianas, brises externos, edificações no en- } \\
\text { torno, vegetação }\end{array}$ \\
\hline De ventilação & $\begin{array}{l}\text { janelas abertas e em que proporção, portas abertas, ele- } \\
\text { mentos vazados, ventilação cruzada }\end{array}$ \\
\hline Tipo de ventilador & de teto ou de parede, móvel ou fixo, ligado ou desligado \\
\hline Existência de mofo & em que local \\
\hline $\begin{array}{l}\text { Reflexão de raios solares nas super- } \\
\text { fícies vizinhas }\end{array}$ & grama, piso de cimento, paredes, brises etc. \\
\hline $\begin{array}{l}\text { Medições dos parâmetros ambien- } \\
\text { tais }\end{array}$ & $\begin{array}{l}\text { temperatura de bulbo a seco (TBS), temperatura do } \\
\text { bulbo úmido (TBU), temperatura de Globo (TG), ve- } \\
\text { locidade do ar(Var) }\end{array}$ \\
\hline
\end{tabular}

Fonte: Kowaltowski (2011).

\subsubsection{Conforto lumínico}

Gonçalves e Vianna (2001) afirmam que o conceito de conforto luminoso é o mesmo que pode ser usado de um modo geral para definir o conforto ambiental, ou seja, a sensação de conforto luminoso de um indivíduo será maior quanto maiores forem as suas exigências de adaptação ao meio. Rio e Pires (2001) consideram que as condições básicas para uma boa situação de iluminação são as seguintes: intensidade de iluminação adequada à atividade, de acordo com a ABNT (1992a), que proporciona contrastes pouco intensos e ausência de ofuscamento (ABNT, 1991).

Dudek (2007) afirma que estudos científicos comprovaram o impacto da iluminação natural no bem-estar dos alunos e sua influência na capacidade de aprendizagem. Um deles, desenvolvido por Heschong Mahone Group (1999), demonstrou que os estudantes em sala de aula com mais iluminação natural adequadamente filtrada) trabalhavam de maneira 20\% mais eficiente nos testes de matemática e 26\% nos testes de leitura. Também se observou que as salas de aula com maior área de abertura, claraboias, e janelas que poderiam ser operadas pelo usuário resultavam em níveis melhores de desempenho dos alunos do que em ambientes desprovidos dessas características.

CHPS (2002) e Plympton, Conway e Epstein (2000) relatam que depois dos estudos de Küller e Lindsten (1992), baseados na observação do comportamento dos níveis de hormônios e da saúde de crianças suecas de oito anos, concluiu-se que o trabalho em salas de aula sem iluminação natural pode interferir nos hormônios básicos das crianças, influenciando, assim, na sua capacidade de concentração e no crescimento corporal anual.

Segundo Vargas (2009), o aspecto subjetivo da percepção da luz provoca alterações comportamentais e de humor que determinarão avaliações sobre o espaço físico e a qualidade dos ambientes construídos (Figura 7). 


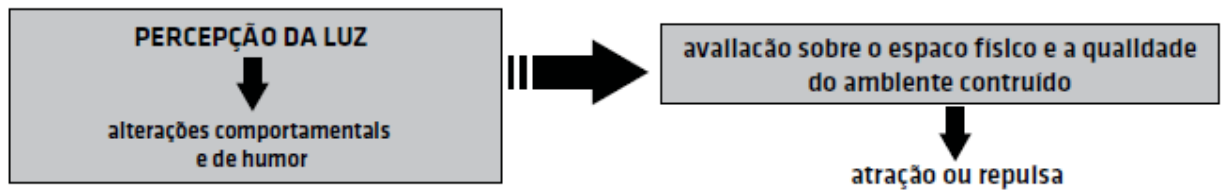

Figura 7 - Processo subjetivo de apreensão do ambiente iluminado

Fonte: Vargas (2009).

Filho (1997, p. 101) afirma que a iluminação contribui de forma significativa para uma melhor aprendizagem, pois um ambiente iluminado de forma correta proporciona aos discentes e docentes um bem-estar visual. "As lâmpadas devem permitir ao observador que os objetos sejam vistos com todo o espectro de cor que os caracteriza [...]", evitando um esforço físico do olho, a fadiga ocular e a irritabilidade de professores e alunos.

Randon (2007, p.3), afirma que:

"A iluminação insuficiente pode causar fadiga, dor de cabeça e irritabilidade [...]" o que se observa nos professores, na grande maioria, é a presença de irritabilidade assim como estresse, em decorrência da correria do dia a dia, sendo agravados pela má iluminação. Portanto, deve-se adequar o ambiente escolar às atividades ali desenvolvidas.

Segundo Oliveira e Ribas (1995), os efeitos nocivos da iluminação não se relacionam apenas aos aspectos quantitativos (nível mínimo de lux por atividade), mas também aos aspectos qualitativos. Os efeitos qualitativos negativos que interferem no conforto visual são:

a) Velamento: criado por luz intensa difusa no ambiente e reduz o contraste de luz e sombra na imagem - efeito muito empregado em filmes onde aparecem "fantasmas do além": gera a sensação de insegurança, especialmente em pacientes;

b) Ofuscamento: causado por intensa luz direta que incide sobre os olhos do usuário;

c) Deslumbramento: causado pela luz que penetra diretamente na pupila, formando focos de escuridão como quando se olha para a luz intensa;

d) Iluminamento uniforme prolongado: o orgulho dos engenheiros luminotécnicos em manter um ambiente constantemente e homogeneamente iluminado traz prejuízos ao mecanismo fisiológico do ser humano. Esses efeitos são observados tanto nos funcionários de ES, que tiram plantão em áreas fechadas, quanto em espeleólogos, que passam dias nas cavernas e têm seu ciclo biorrítmico completamente alterado.

O nível de iluminamento interfere diretamente no mecanismo fisiológico da visão e também na musculatura que comanda o movimento dos olhos (IIDA, 2005). Portanto, a ilu- 
3.1. Elementos e parâmetros técnicos que estruturam a relação entre espaço arquitetônico e ensino-aprendizagem

minação é condição fundamental no desenvolvimento da tarefa, influenciando decisivamente no comportamento do usuário e na sua eficiência (ALBUQUERQUE, 1998).

No que tange às necessidades lumínicas, Karuse et al. (2005) afirmam que a luz natural é psicologicamente mais atraente, uma vez que suas mudanças ocorrem de forma sutil ao longo do dia, todavia seu uso pode ser insatisfatório em períodos e locais onde os raios solares são pouco ou demasiadamente intensos. Assim a incidência solar direta nas aberturas pode causar ofuscamento e aumento da temperatura do ambiente, sendo necessária, portanto a utilização de proteções solares.

De forma geral, quanto maior a área iluminante, maior a iluminância do ambiente, que pode causar problemas ocasionados por zonas de contraste elevado e de ofuscamento, que ocorrem geralmente quando há incidência solar direta, superfícies excessivamente refletoras ou visão do céu. A questão térmica associada à penetração de radiação solar direta também deve ser ponderada.

Para Ribeiro (2004), a iluminação deve ter intensidade e direcionamento adequados, propiciar boa definição das cores e ausência de ofuscamento para que o aluno possa desenvolver suas tarefas visuais de leitura e escrita, com o máximo de acuidade e o mínimo de esforço e de riscos à sua vista. No Brasil, apesar de a Associação Brasileira de Normas Técnicas (ABNT - NB 57) ABNT (1991) fixar as iluminâncias mínimas para cada tipo de tarefa visual, no ambiente escolar isso não tem sido observado, propiciando cansaço, dor de cabeça e irritabilidade em seus usuários.

Por sua vez, o conforto visual decorrente das condições de iluminação é importante para a saúde e produtividade das pessoas, principalmente em edifícios educativos, por seu uso diurno e pelo tipo de função realizada. A maioria das atividades desenvolvidas em sala de aula demanda percepção visual adequada, o que depende, necessariamente, de luz em quantidade suficiente e com qualidade (ÁLVARES, 1995). Uma adequada estratégia de iluminação natural nas escolas deve proporcionar uma quantidade de luz insuficiente onde necessário, para assegurar que não haja desconforto visual (DUDEK, 2007). Uma das grandes queixas dos alunos quanto à iluminação em sala de aula é a reflexão veladora, um tipo de ofuscamento que dá a sensação de que a imagem está apagada em alguns trechos do quadro-negro e que provém da radiação direta no objeto.

Labaki e Bueno-Bartholomei (2001) apontam a necessidade de adoção de parâmetros construtivos para os seguintes aspectos:

- Níveis de iluminação recomendados para uma tarefa visual: quantidade mínima de luz no plano de trabalho para a realização das atividades com um esforço visual que não comprometa a saúde;

- Uniformidade entre níveis de contraste: distribuição uniforme dos níveis mínimos 
de iluminância pelo ambiente que depende da forma das dimensões e posições das aberturas;

- Distância entre os usuários e os objetos;

- Uso de cores nas superfícies;

- Elementos externos e internos de proteção da insolação direta: Evitar ofuscamento. Em relação à luz natural, implica evitar a incidência de luz solar direta nos planos de trabalho, como lousas, carteiras, brinquedos e monitores de computador.

- Iluminação artificial suplementar.

Bertolotti (2007) cita os manuais da Iesna (2000), MEC (2002), ABNT (1992), ABNT (2005) CHPS (2002) e FDE (2003), além das normas NBR 5413 Iluminância de Interiores - Especificação da ABNT (1992) e NB -57 ABNT (1991) ( Tabela 11).

Tabela 11 - Níveis de iluminação para ambientes escolares

\begin{tabular}{lc}
\hline Tipo de Ambiente & Níveis de Iluminância recomendado (Lux) \\
\hline Salas de aula & $300-500$ \\
\hline Perto da lousa & $500-750$ \\
\hline Sala de trabalhos manuais & $300-500$ \\
\hline Laboratórios & $200-300$ \\
\hline Sala de desenho & $500-700$ \\
\hline Biblioteca & \\
\hline Área de leitura & $500-750$ \\
\hline Área de estantes do acervo & $300-500$ \\
\hline Fichário & $300-500$ \\
\hline Área para esportes & $300-500$ \\
\hline Local de jogos & $150-200$ \\
\hline Locais recreativos & $200-300$ \\
\hline Sala de ginástica & $200-300$ \\
\hline Quadra coberta & 500 \\
\hline Secretarias (área administrativa) & $200-300$ \\
\hline Auditório & $500-750$ \\
\hline Plateia & $1992)$. \\
\hline Palco ou tribuna & \\
\hline \hline
\end{tabular}

Fonte: NB - 52 (ABNT, 1992).

O Manual Iesna (2000) recomenda a iluminação natural em escolas, mas não especifica os níveis mínimos de iluminação para tarefas visuais ou aplicações específicas. As principais recomendações são:

- Iluminância - como os ambientes educacionais apresentam tarefas visuais variadas, cada uma é avaliada em termos de variação de tamanho, contraste e tempo para determinar um nível de iluminância ótimo. Deve-se eleger como nível de iluminância para o ambiente a tarefa que exige o maior nível de iluminância. No caso de ambientes de aprendizagem, geralmente é o nível necessário para a leitura de um texto escrito 
a lápis. Deve-se eleger um nível mais alto para ambientes onde a tarefa exige o maior nível de iluminância . É o caso de lousas e mesas de desenho.

- Refletância - devem-se evitar diferenças entre os níveis de refletância da superfície da tarefa visual e os das superfícies mais significativas da sala de aula. As paredes, cortinas e venezianas devem ter cores claras e mesma refletância. Paredes próximas às janelas devem ter alto nível de refletância para evitar contraste com as janelas, o que pode causar ofuscamento. Os tetos devem ter superfícies altamente refletivas, de preferência brancas, e o piso deve ser de material opaco, com refletância em torno de $30 \%$.

- Luminância - a diferença entre o brilho das diversas superfícies de uma sala de aula é fundamental para a visualização de uma tarefa e deve ser mantida em determinados limites, porque, quando o olho muda de uma tarefa visual para outra, tem que se adaptar à luminância da nova tarefa.

- Ofuscamento - para evitar o ofuscamento em salas de aula, impede-se a incidência direta de radiação solar sobre as superfícies das tarefas a serem desenvolvidas, com brises, cortinas, venezianas e prateleiras de luz. As luminárias também devem ter dispositivos que atenuem o ofuscamento. Utilizam-se, de preferência, materiais opacos para superfícies móveis e equipamentos da sala de aula. Evitam-se altos contrastes de sombra sobre a superfície da tarefa visual, exceto em ambiente sem que seja importantes para a definição de rostos e objetos, como em ginásios de esportes e sala de artes (IESNA, 2000).

As pesquisas em iluminação natural em escolas, nos últimos anos, não se detiveram apenas na necessidade de encontrar um nível quantitativo ao desempenho das tarefas visuais, mas buscaram entender os aspectos qualitativos da iluminação. Para a avaliação das condições do conforto visual, é preciso verificar (KOWALTOWSKI, 2011):

- a existência de ofuscamento: horário, local e origem;

- as condições atmosféricas: para cada horário, se o céu está claro, parcialmente encoberto ou encoberto;

- as características da janela: se há visão externa, tipo de vidro (liso, texturizado, pintado);

- o tipo de iluminação natural: se lateral ou zenital, com os dados referentes a cada caso;

- o tipo de iluminação artificial: se é lâmpada fluorescente ou incandescente, ligada ou desligada, posição do controle na sala ou fora dela; 
- as medições dos níveis de iluminância, realizadas com luxímetro cujo sensor é colocado sobre as carteiras, sobre as mesas do professor e junto à lousa: nota-se na folha de observação a localização das janelas, portas e lousa;

- as medições das condições devem ser comparadas com as recomendações da NB-57, norma brasileira referente aos níveis adequados de iluminação de interiores.

Castro, Rheingantz e Gonçalves (2006) citam vários critérios relativos à percepção visual, como contrastes, ângulos de visão, ofuscamentos e níveis de iluminamento, que podem interferir nas atividades produtivas e provocar desajustes à saúde, influenciando na avaliação e, consequentemente, nas relações afetivas travadas com o lugar, sejam elas positivas ou negativas.

A relação entre contraste e cor é designada por Grandjean (1998), o contraste é definido pela relação entre as diferenças entre claridades, ou densidades luminosas, de duas superfícies ou áreas. Quando o contraste se dá entre superfícies ou áreas, relaciona-se diretamente com o seu grau de reflexão, como paredes, móveis e objetos. Porém, o contraste pode se dar entre fontes luminosas relacionando-se com as intensidades das fontes de luz.

O uso de cores como instrumento de conforto ambiental tem sido amplamente estudado. Gropius (1945, p. 64) já mencionara, em seu livro sobre a Nova Arquitetura, que a "cor e textura de superfície têm, por assim dizer, uma existência própria e emitem energias físicas, que são até mensuráveis. O efeito pode ser quente ou frio, aproximativo ou retrocessivo em relação a nós, de tensão ou de repouso, ou mesmo repulsivo ou atraente."

Grandjean (1998) sugere que as cores, quando usadas em ambientes distintos, podem ordenar o conjunto e dar melhor visão geral. Para a dinâmica desses ambientes de convivência, que apresentam superfícies com cores, devem se considerar os graus de reflexão, como apresentados na Tabela 12.

Tabela 12 - Relação entre as cores e seus graus de reflexão e superfícies

\begin{tabular}{lc}
\hline Cor e materiais coloridos & Reflecção em $\backslash \%$ \\
\hline Branco & 100 \\
\hline Alumínio, papel branco & 80 a 85 \\
\hline $\begin{array}{l}\text { Amarelo forte, ocre-claro, verde-claro, azul-pastel, } \\
\text { "tons"creme }\end{array}$ & 60 a 65 \\
\hline Verde-limão, cinza-claro, rosa, laranja forte, cinza-azulado & 50 a 55 \\
\hline Madeira clara, azul celeste & 40 a 45 \\
\hline Madeira de carvalho clara, concreto seco & 30 a 35 \\
\hline Vermelho forte, verde-grama, madeira, verde-oliva, marrom & 20 a 25 \\
\hline Azul-escuro, vermelho-púrpura, castanho, cinza-ardósia & 10 a 15 \\
\hline Preto & 0 \\
\hline
\end{tabular}

Fonte: Grandjean (1998). 
3.1. Elementos e parâmetros técnicos que estruturam a relação entre espaço arquitetônico e ensino-aprendizagem

Oliveira e Ribas (1995) afirmam que, além de funcionar como instrumento de melhora da condição visual (pela reflexão), a cor tem funções terapêuticas. A cromoterapia propõe a restauração do equilíbrio a partir da utilização das cores. Pimentel (1992) apresenta quadro que relaciona a cor às influências sobre o ânimo (Tabela 13):

Tabela 13 - Relação da cor às influências sobre o ânimo

\begin{tabular}{ll}
\hline Cor & Influências \\
\hline Amarelo & Estimulação mental, concentração. Incentiva a conversação; \\
\hline Azul & Tem efeito tranquilizante e refrescante. Evita a insônia; \\
\hline Branco & O excesso de claridade pode levar a um cansaço mental; \\
\hline Laranja & Estimulante, dá um ar social ao ambiente; \\
\hline Lilás & Sedante, pode causar sensação de frustação; \\
\hline Rosa & Aconchega, traz calor sem excitação; \\
\hline Verde & Recompões, equilibra. Efeito regenerador; \\
\hline Vermelho & Excitante, pode deixar as pessoas agitadas e irritadiças. \\
\hline
\end{tabular}

Fonte: Pimentel (1992).

Segundo Heidi e Maki (2009), pesquisas realizadas em salas de aula com paredes coloridas e paredes brancas mostraram que a cor pode reduzir o comportamento fora do contexto e a ansiedade, bem como afetar positivamente a percepção de aprendizagem, a sensação de bem-estar e o aumento da atenção dos alunos. Após a pintura das paredes das salas de aula, mesmo sem a alteração da iluminação, houve a sensação de diminuição das sombras e brilho, o que provavelmente, ajudou na concentração dos alunos.

De acordo com Willard et al. (2008), a cor é um grande elemento de design que desempenha um papel importante no ambiente de sala de aula, podendo afetar tanto o desempenho do aluno quanto a eficácia do professor.

Em suas pesquisas sobre como a cor pode ser usada para criar um "ambiente de aprendizagem enriquecida", observaram que as crianças pequenas preferem cores quentes e brilhantes e que as preferências de cor mudam à medida que as crianças amadurecem. $\mathrm{O}$ uso de uma variedade de cores reduz o tédio, mas a utilização de mais do que seis cores em uma sala de aula pode levar a um excesso de estimulação e distração.

Os autores sugerem uma extensa lista de cores para locais e atividades específicas: as cores quentes reduzem a escala e tamanho de espaços mais amplos e emprestam uma intimidade com espaços imponentes contrários. As cores frias expandem espaços menores, dando-lhes uma sensação de aberto e arejado. O uso da cor dentro da sala de aula é útil na diferenciação de espaços para fins específicos, criando uma sensação única de espaço.

Para Willard et al. (2008), a cor tem o potencial de mudar o "sentimento" de um espaço. Consideram que as cores nas paredes e no piso das salas de aula, frequentemente, são negligenciadas e, quanto utilizadas, fazem uma grande diferença, tornando-as mais convidativas e menos monótonas, influenciando as decisões sobre o espaço da sala de aula. 
Ainda dentro do campo da educação, pesquisas descrevem como as cores podem auxiliar os distúrbios de aprendizado como dislexia, deficiência de atenção e hiperatividade.

Frank (1996) afirma que cores brilhantes quentes são recomendadas para salas de aula da pré-escola e ensino fundamental, porque elas complementam a natureza extrovertida dos alunos; cores frias são recomendadas para salas de aula de escolas do ensino fundamental e médio por causa de sua capacidade de relaxar e foco na concentração; verde pálido ou luz é uma boa escolha para as bibliotecas, pois essas cores melhoram a tranquilidade e concentração.

\subsubsection{Conforto sonoro}

Em uma sala de aula, a comunicação entre alunos e professores é necessária para o aluno ouvir e entender o que é dito, sem níveis elevados de ruído, que prejudicam o desempenho do aluno e aumentam o desgaste dos professores. Para avaliar as condições de conforto acústico de um ambiente, é necessário verificar a qualidade interna deste e a influência do meio externo. A qualidade interna refere-se à geometria do espaço, à absorção sonora e à potência e localização das fontes sonoras. A influência do meio externo associa-se a fontes de ruído e à qualidade do isolamento das aberturas, e esses ruídos provêm de trânsito, atividades industriais, atividades comerciais e atividades de lazer, muitas vezes da própria escola. Os ruídos internos referem-se a impactos, vozes e reverberação de som. Ambos, ruídos internos e externos, resultam em falta de privacidade e dificuldade de comunicação verbal em sala de aula (KOWALTOWSKI, 2011).

Para Abadié et al. (2009), no caso do estudo do conforto acústico devem-se considerar três aspectos principais: o som reverberante, que mede a persistência do som no local, a absorção dos diferentes materiais e a sua distribuição no ambiente. Paya (1994) afirma que é fundamental estudar a correta propagação do som nos recintos, caso contrário podem originar diversas doenças nervosas, diminuindo qualiquantitativamente o rendimento dos usuários.

Montmollin (1990) afirma que o ruído como uma agressão sonora se torna mais nociva com a repetição, podendo levar a uma situação progressiva de surdez. Pode ser também um obstáculo para as comunicações verbais no trabalho. As normas que regem os índices de tolerância ajudam a resguardar os trabalhadores, mas não têm condições de considerar a variabilidade interindividual e a natureza psicológica que envolve a percepção de ruído. Para Grandjean (1998), o contraste é medido em uma escala na unidade de cibel-dB. Salas de escritório ou similares estão entre níveis e ruído de 50 a 65 dB. Porém, o valor máximo de ruído admitido para uma atividade de 8 horas diárias é de $80 \mathrm{~dB}$. Acima disso, corre-se o risco de lesões auditivas por ruído.

Estímulos sonoros inadequados propiciam dificuldades de aprendizagem (RIBEIRO, 2004) devido à inintegibilidade do som e à dificuldade de comunicação professor/aluno. 
3.1. Elementos e parâmetros técnicos que estruturam a relação entre espaço arquitetônico e ensino-aprendizagem

Nas áreas escolares, os valores recomendáveis, em decibéis (dB), são de 40 db, para as salas de aula, e de 70 db para outras dependências. Em escolas pesquisadas em Feira de Santana, os níveis estavam bem acima dos recomendados; em algumas salas de aula, inclusive com a presença do professor, registram-se até $85 \mathrm{~dB}$, porém todo esse ruído era de origem interna, proveniente dos corredores e das próprias salas (os alunos falavam alto ao mesmo tempo).

Ferreró, González e Hechevarría (1985) afirmam que em quaisquer circunstâncias os ruídos (internos e/ou externos) em excesso, levam a uma série de patologias, tais como excitação, estresse, insônia, úlceras no estômago, fadiga, neuroses, náuseas, surdez precoce etc. Além disso, ainda aumenta a incidência de crianças nervosas e agressivas, aumenta o número de acidentes e diminui o rendimento escolar.

Para Seep et al. (2002), o ruído de salas adjacentes interrompe o processo de aprendizagem, especialmente durante os períodos tranquilos de leitura e de provas. Há cinquenta anos, quando as paredes das escolas eram construídas com tijolos maciços ou blocos de concreto, este não era um problema muito grave. Em décadas recentes, a necessidade de diminuir os custos da construção civil levou ao uso de paredes finas com materiais leves, que oferecem uma redução mínima do ruído. Ainda pior, nas décadas de 1960 e 1970, muitas salas de aula panorâmicas foram construídas sem quaisquer divisórias entre elas. Em algumas escolas, tais espaços foram sendo divididos, mas a redução de ruído entre as salas continuou insuficiente.

Segundo os autores, outro impacto do ruído é a reverberação que interfere com a inteligibilidade da fala. Ecos podem ser controlados usando absorção e/ou difusão.

Os autores, no entanto, acham que pode ser desejável querer reforçar certas reflexões. Isso é especialmente necessário em salas de aula grandes, com tempo de reverberação curto. A energia sonora da voz do professor pode ser absorvida pelo forro acústico antes que atinja os estudantes no fundo da sala. A voz do professor pode ser espalhada para toda a sala, com o uso de uma placa de gesso refletora de som, colocada no teto na parte frontal da sala, ou simplesmente deixando a região central do teto dura e reflexiva. Essas superfícies irão refletir o som para o fundo da sala.

Ruído de fundo elevado proveniente de equipamentos mecânicos, como sistemas de calefação, ventilação e ar-condicionado barulhentos são bastante comuns nas escolas existentes (americanas). Esse é um problema sério para professores e alunos. Os professores devem aumentar suas vozes para manter $+10 \mathrm{~dB}$ de relação sinal/ruído necessária para uma boa inteligibilidade da fala. Isto resulta em vários dias de ausência de muitos professores devido a problemas de estresse vocal, o que onera o contribuinte com recursos que poderiam ser empregados em equipamentos mecânicos menos ruidosos. Simultaneamente, os alunos necessitam se concentrar para escutar, ou então se distraem, deixando de prestar atenção. Ruído mecânico é principalmente o resultado de um mau planejamento, podendo ser difícil 
e caro para eliminar em salas de aula existentes (SEEP et al., 2002).

Ainda de acordo com Seep et al. (2002), isolamento sonoro das paredes externas é também importante, já que muitas atividades ruidosas e potencialmente perturbadoras existem externamente à escola. A maioria das escolas possuem paredes externas construídas de tijolos ou blocos de concreto, que são boas barreiras acústicas, mas com janelas inadequadas que permitem considerável transmissão do som. Para que ocorra a redução do ruído, as janelas devem ser bem lacradas. Janelas com dupla camada de vidro conferem melhor isolação sonora do que janelas com vidro simples (assim como um melhor isolamento térmico e redução no custo de energia). Um outro ponto crítico para vazamento de som são os ventiladores de parede que se comunicam diretamente com a parte externa do prédio. Essas unidades não apenas transmitem ruído do exterior, como geram ruídos próprios que devem ser evitados sempre que possível. Na fase de layout da edificação no terreno, considere as fontes de ruído externas que podem perturbar a aprendizagem, procurando localizar as salas de aula longe de tais fontes.

A portaria do Ministério do Trabalho de 8 de junho de 1978, que define normas regulamentadoras de Segurança e Medicina do Trabalho (NR 15) traz em seu anexo ${ }^{\circ} 1$ os limites de tolerância para ruído contínuo ou intermitente e no anexo $\mathrm{n}^{\mathrm{o}} 2$ os limites de tolerância para ruídos de impacto. A Norma Brasileira NB-95 estabelece os níveis de ruído aceitáveis para diferentes atividades. A NB-101 aprimora a NB-95, fixando níveis de ruído compatíveis com o conforto acústico em ambientes diversos.

Segundo a NBR 10151 (ABNT, 1987), o nível de pressão sonora ambiental, ou ruído ambiental ou de fundo, é o ruído em um denominado local e que não diz respeito ao objeto de apreciação ou medição. É representado em dB.

Souza, Almeida e Bragança (2006) apontam as principais etapas do projeto que devem levar em conta a questão acústica:

- seleção do local, integração e verificação do impacto no entorno urbano;

- implantação do edifício;

- escolha da forma do edifício e sua relação com as edificações adjacentes;

- distribuição dos espaços internos do edifício;

- escolha da forma dos espaços internos;

- escolha das soluções construtivas;

- escolha dos materiais; e

- detalhes construtivos. 
3.1. Elementos e parâmetros técnicos que estruturam a relação entre espaço arquitetônico e ensino-aprendizagem

Segundo Kowaltowski (2011), os resultados das condições acústicas das escolas mostram que há necessidade de maior conscientização por parte dos órgãos responsáveis pelo projeto, construção e implantação das edificações escolares no quesito acústico, que não é considerado nas fases iniciais de projeto. Esse aspecto não resulta apenas das definições dos materiais de acabamento, porque os fatores que determinam as condições acústicas são bem mais complexas e também resultam das definições da forma espacial do edifício e das salas. A percepção da qualidade acústica também é um reflexo das experiências sensoriais dos indivíduos que irão utilizar os espaços, como mostrado nas recentes pesquisas neurológicas que a Medicina desenvolve. Entretanto os fatores de qualidade acústica devem ser definidos em função dos valores dos usuários e do tipo de uso que terá o edifício (DUDEK, 2007). Em países de clima quente como o Brasil, os parâmetros acústicos se chocam com os parâmetros térmicos. Salas com aberturas e ventilação natural sofrem com a falta de inteligibilidade.

A partir do levantamento bibliográfico referido foi possível sintetizar na Tabela 14 os atributos do espaço, vistos pelo conforto ambiental, que interferem nas relações com a aprendizagem.

Tabela 14 - Características do conforto ambiental segundo a visão dos autores

\begin{tabular}{|c|c|c|c|}
\hline Área de Ensino & & Conforto Ambiental & \\
\hline Atributos & Conforto Térmico & Conforto Lumínico & Conforto Sonoro \\
\hline Autores & & & \\
\hline Beltrame e Moura (2009) & $\mathrm{X}$ & $\mathrm{x}$ & $\mathrm{X}$ \\
\hline Shalaway (1998) & $\mathrm{X}$ & $\mathrm{x}$ & $\mathrm{x}$ \\
\hline Sommer (1973) & $\mathrm{X}$ & $\mathrm{x}$ & $\mathrm{X}$ \\
\hline CHPS (2002) & $\mathrm{X}$ & & \\
\hline Mueller (2007) & $\mathrm{X}$ & & \\
\hline $\begin{array}{l}\text { Nogueira, Durante e Nogueira } \\
(2005)\end{array}$ & $\mathrm{X}$ & & \\
\hline Silva et al. (1996) & $\mathrm{X}$ & & \\
\hline Filho et al. (2007) & $\mathrm{X}$ & & \\
\hline Frota e Schiffer (1995) & $\mathrm{x}$ & & \\
\hline Lamberts e Xavier (2008) & $\mathrm{X}$ & & \\
\hline Kowaltowski (2011) & $\mathrm{x}$ & $\mathrm{x}$ & $\mathrm{X}$ \\
\hline Mascaró (1985) & $\mathrm{X}$ & & \\
\hline Ruas (1999) & $\mathrm{x}$ & & \\
\hline Mellati (2004) & $\mathrm{X}$ & $\mathrm{x}$ & $\mathrm{x}$ \\
\hline EFL (1963) & $\mathrm{X}$ & $\mathrm{x}$ & $\mathrm{X}$ \\
\hline Grandjean (1998) & & $\mathrm{x}$ & $\mathrm{x}$ \\
\hline Dudek (2007) & & $\mathrm{x}$ & \\
\hline Oliveira e Ribas (1995) & & $\mathrm{x}$ & \\
\hline
\end{tabular}




\begin{tabular}{|c|c|c|c|}
\hline \multirow{3}{*}{$\begin{array}{l}\text { Área de Ensino } \\
\text { Atributos } \\
\text { Autores }\end{array}$} & \multicolumn{3}{|c|}{ Conforto Ambiental } \\
\hline & \multirow[t]{2}{*}{ Conforto Térmico } & \multirow[t]{2}{*}{ Conforto Lumínico } & \multirow[t]{2}{*}{ Conforto Sonoro } \\
\hline & & & \\
\hline $\begin{array}{l}\text { Castro, Rheingantz e Gonçalves } \\
\text { (2006) }\end{array}$ & & $\mathrm{X}$ & \\
\hline Heidi e Maki (2009) & & $\mathrm{X}$ & \\
\hline Willard et al. (2008) & & $\mathrm{X}$ & \\
\hline Frank (1996) & & $\mathrm{X}$ & \\
\hline Vargas (2009) & & $\mathrm{X}$ & \\
\hline Gonçalves e Vianna (2001) & & $\mathrm{X}$ & \\
\hline Álvares (1995) & & $\mathrm{X}$ & \\
\hline Rio e Pires (2001) & & $\mathrm{X}$ & \\
\hline Labaki e Bueno-Bartholomei (2001) & & $\mathrm{X}$ & \\
\hline Küller e Lindsten (1992) & & $\mathrm{X}$ & \\
\hline Filho (1997) & & $\mathrm{X}$ & \\
\hline Karuse et al. (2005) & & $\mathrm{X}$ & \\
\hline Randon (2007) & & $\mathrm{X}$ & \\
\hline Heschong Mahone Group (1999) & & $\mathrm{X}$ & \\
\hline Iida (2005) & & $\mathrm{X}$ & \\
\hline Ribeiro (2004) & & $\mathrm{X}$ & \\
\hline Albuquerque (1998) & & $\mathrm{X}$ & \\
\hline Bertolotti (2007) & & $\mathrm{X}$ & \\
\hline Pimentel (1992) & & $\mathrm{X}$ & \\
\hline Gropius (1945) & & $\mathrm{X}$ & \\
\hline Montmollin (1990) & & & $\mathrm{X}$ \\
\hline Grandjean (1998) & & & $\mathrm{x}$ \\
\hline Sousa et al. (2007) & & & $\mathrm{x}$ \\
\hline Dudek (2007) & & & $\mathrm{X}$ \\
\hline Abadié et al. (2009) & & & $\mathrm{x}$ \\
\hline Seep et al. (2002) & & & $\mathrm{X}$ \\
\hline Paya (1994) & & & $\mathrm{X}$ \\
\hline Ribeiro (2004) & & & $\mathrm{X}$ \\
\hline $\begin{array}{l}\text { Ferreró, González e Hechevarría } \\
\text { (1985) }\end{array}$ & & & $\mathrm{X}$ \\
\hline
\end{tabular}

Fonte: Elaboração própria (2014/2015). 


\subsubsection{O papel da ergonomia na concepção de espaços de ensino-aprendizagem}

Tavares et al. (2000) afirma que as pesquisas realizadas na área da ergonomia no ambiente escolar visam à contribuição para o ensino-aprendizagem, no sentido de melhorar as condições e a organização do trabalho no ambiente de sala de aula. A sensação de bemestar gerada inicialmente pelo ambiente predispõe positivamente o aluno para as relações afetivas, emocionais e cognitivas. As relações ocorridas nas zonas de desenvolvimento proximal, por exemplo, têm nesses fatores os elementos fundamentais.

Para Leucz et al. (2001):

[...] o estudo do espaço físico da sala de aula consiste em um tópico de fundamental interesse para a prática pedagógica. O ambiente pode tanto construir-se num facilitador de ensino-aprendizagem como pode fornecer obstáculos para ocorrência normal deste processo. Vendo a sala de aula pela ótica da ergonomia, podemos entendê-la então como um ambiente de trabalho, onde o aluno cumpre um tempo pré-estabelecido de permanência e desempenha várias atividades prático-cognitivas. (LEUCZ et al., 2001, p. 23)

Hahn et al. (1999), diz que:

[...] pedagogia e ergonomia, apesar de tradicionalmente constituíremse em campos de investigação extremamente distintos, possuem vários pontos em comum, sendo o "conforto" e a "facilidade" na execução das tarefas, aspectos relevantes de identificação, visando uma adequação do homem aos processos de trabalho. (HAHN et al., 1999, p. 21)

Existem sobreposições entre temas tratados pelo conforto ambiental e pela ergonomia e aqui serão descritos, mas ao final quando da consolidação dos elementos que devem integrar o programa de necessidades do projeto de arquitetura dos espaços de ensino-aprendizagem essas sobreposição serão eliminadas.

\subsubsection{Antropometria}

Dul Jan \& Weerdmeester (2004) afirmam que no estudo da biomecânica são aplicadas leis físicas da mecânica ao corpo humano, possibilitando estimular tensões que possam incidir nos músculos e articulações durante um movimento ou uma postura.

Segundo Iida (2005, p. 97 e p. 98), "Antropometria refere-se às medidas físicas do corpo humano, sendo que até a década de 1940, visavam apenas determinar grandezas médias da população, com pesos e estaturas, sendo que com o tempo passou a determinar as variações e os alcances dos movimentos".

Ainda de acordo com Iida (2005),

as medições antropométricas, sempre que for possível e economicamente justificável, devem ser efetuadas diretamente, através de uma amostra 
significativa de indivíduos que serão usuários ou consumidores de um objeto a ser projetado. Estas medições compreendem as etapas de definição de objetivos e das medidas com a escolha do método de medição, seleção da amostra, as medidas e as respectivas estatísticas. (IIDA, 2005, p. 109)

Franceschi (2013) relata que inicialmente deve-se definir o motivo da utilização das medidas antropométricas, pois a partir dessa definição é decidido o tipo de aplicação antropométrica, estática ou dinâmica com a escolha das variáveis a serem medidas, de acordo com os detalhamentos e precisões com que essas medidas devem ser realizadas. Um exemplo pode ser visto em Iida (2005), em que para o projeto de um posto de trabalho para digitadores são tomadas, no mínimo, seis medidas críticas do operador sentado.

Principais dimensões antropométricas a serem consideradas no projeto de um posto de trabalho para uma pessoa sentada (Figura 8).

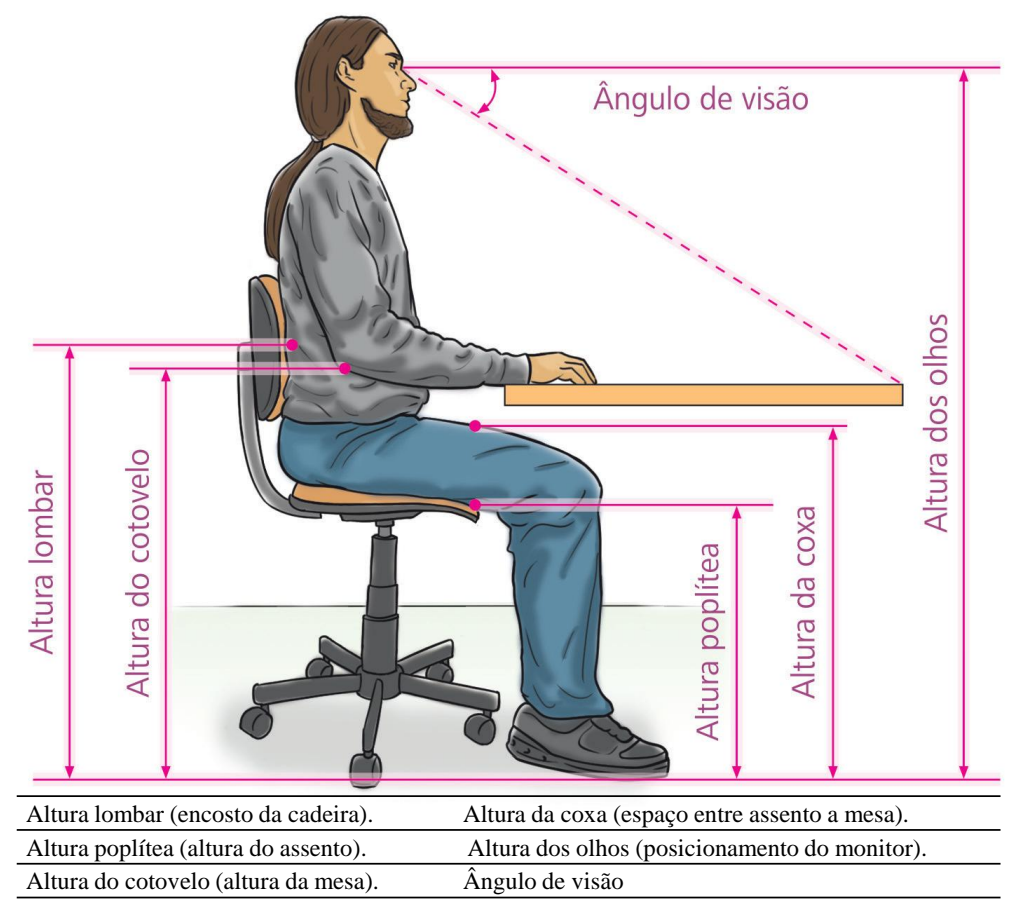

Figura 8 - Posto de trabalho para uma pessoa sentada

Fonte: CTISM (apud Franceschi (2013)).

Consideram, assim, para que os alunos possam realizar suas funções, a instituição de ensino a qual estão vinculados precisa estar equipada com mobiliário "classe", que é a carteira escolar ou cadeira e mesa, adequados ergonomicamente a cada estudante. Segundo Siqueira, Oliveira e Vieira (2008), além do programa de ensino, não menos importante para a formação do aluno é a adequação ergonômica do ambiente, o que envolve determinadas condições de ordem física, como a limpeza, a organização, a conservação, a iluminação, a temperatura, o ruído e o mobiliário escolar. 
A permanência por longos períodos sentado em seu escritório/sala para preparar as aulas, no caso do professor, e assistir às aulas, no caso dos alunos: o uso inadequado do computador na escola (falta de apoio para os alunos, monitor não ao nível da vista, cadeira sem regulagem de altura, reflexo etc.), pode causar problemas de natureza ergonômica (REVISTA PROTEÇÃO, 2006).

Outro problema que acomete professores e alunos está relacionado à má postura em sala de aula é o hábito de escrever no quadro em ângulo superior a 90 graus. Nesse caso, pode-se usar um quadro móvel ou uma plataforma de madeira para elevar o professor. Em vez de escrever no quadro todo o conteúdo da aula, ditar ou fornecer um resumo de apoio como retroprojetor, data show e vídeo também são indicados.

Segundo Ferreira (2000), os mecanismos de regulagem da mesa e da cadeira são compostos de manípulos anatômicos com uma superfície revestida, para evitar possíveis acidentes ou de facilitar o manuseio pelos usuários. Da mesma forma, para essas regulagens podem ser fixadas tarja com indicações de valores referenciais de estatura, para facilitar, ou melhor, orientar no ajuste adequado. O autor considera que no mobiliário tradicional, de altura fixa, algumas crianças são forçadas a se posicionarem nas bordas do assento, na tentativa de evitar que os pés fiquem sem o apoio do chão e, também, diminuir a pressão excessiva na parte posterior da coxa.

Portanto, um mobiliário escolar do tipo regulável é a mais importante adequação ergonômica apresentada até o presente momento, para superar os velhos conceitos de sala de aula. Moro (2005) afirma que as incompatibilidades do mobiliário escolar-usuário sugerem que os projetistas aplicaram pouco do que já é conhecido a respeito da anatomia da criança na posição sentada.

Carvalho (2001) afima que cadeiras inadequadas induzem a posturas erradas, que podem desencadear problemas na coluna lombar e cervical e em membros superiores, além de causar deficiências circulatórias nos membros inferiores. Para este autor, as cadeiras com melhores qualidades ergonômicas permitem a adaptação da cadeira ao aluno e não o inverso. Além disso, promovem alternância postural e, ao mesmo tempo, são capazes de evitar o desconforto da posição sentada por períodos mais longos.

\subsubsection{Adequabilidade do mobiliário ao desempenho das atividades}

Trabalhos conduzidos por Nunes et al. (1985) demonstraram que o design do mobiliário escolar chamou a atenção como sendo uma variável que induziu e manteve vários repertórios de comportamento dos alunos. Da mesma forma, essas pesquisas mostraram uma estreita ligação entre carteiras escolares e problemas médicos, segurança e disciplina na aula. Comportamentos indesejados na sala de aula, ocorrência de barulho repetitivo, como também, comportamento acadêmico apropriado foram associados com essas relações, e, então relacionadas ao tema do design dessa mobília. 
Kowaltowski (2011) considera que além dos espaços de uma instituição educacional, o mobiliário escolar, os equipamentos e o material didático afetam a funcionalidade do ambiente escolar. As dimensões do mobiliário devem relacionar-se com a estrutura e a faixa etária da população de cada estabelecimento de ensino. A disponibilidade do mobiliário escolar com diversos tamanhos acomoda a variação de estaturas e idades de cada série. Recomendam-se móveis ajustáveis e anatomicamente corretos no seu projeto para atender às variações usuais e às necessidades especiais. Atividades específicas, como arte ou experimentos em laboratórios, exigem o formato apropriado de equipamento e mobiliário para a otimização do desempenho.

O critério antropométrico preconiza que um padrão aceitável de mobília poderá ser identificado como aquele que acomoda o maior número possível de indivíduos de uma população. Paradoxalmente, conforme sustentado por Oxford (1969) o equipamento não pode ser dimensionado para o usuário médio, pois este não existe.

Para Siqueira, Oliveira e Vieira (2008) e Sousa et al. (2007), os estudos comparativos entre as medidas antropométricas dos estudantes universitários e as dimensões do mobiliário escolar utilizado nesses ambientes de ensino indicam inadequação entre as dimensões corporais dos alunos e as carteiras utilizadas por eles em sala de aula. Segundo os autores, essa relação usuário-mobiliário mostra-se mais inadequada na altura do assento, visto que todas as carteiras apresentaram essa medida maior que a recomendada, podendo causar prejuízos à circulação sanguínea e à estabilidade corporal, além de favorecer a compressão nervosa, o que pode, com o tempo, ocasionar alterações posturais.

Diante dos resultados encontrados, os autores sugerem a utilização de um tipo de carteira cujas medidas das variáveis estudadas abranjam, pelo menos, $90 \%$ dos usuários, ou então que se adote uma carteira ajustável a fim de atender, de forma ergonômica, o maior número de alunos possível. Outra recomendação é em relação às indústrias, no que diz respeito ao dimensionamento das carteiras, para que sejam respeitados os fatores regionais, sociais, econômicos e físicos dos usuários. O ângulo de inclinação do pescoço em aproximadamente 29 graus obedece ao limite natural do eixo de visão, que vai até 30 graus abaixo da linha horizontal, segundo Bendix (1984). Da mesma forma, essa postura foi facilitada devido, também, aos 5 graus de inclinação da superfície da mesa.

Wilson, Corlett e Manenica (1986) e Mandal (1981), afirmam que as más posturas da coluna vertebral ao sentar são causadoras de dores nas costas, principalmente, segundo Chaffin, Andersson e Martin (1991) nas regiões cervicais, glúteas e lombares. A causa desses problemas, segundo Mandal (1986), são as cadeiras inclinadas para trás, com a superfície da mesa na horizontal, em que, na tentativa de se acomodar, as crianças inclinam-se sobre a superfície da mesa, comprimindo as suas vértebras lombares. A pressão mantida por diversas horas sobre os ossos em formação das crianças ocasionará transformações posturais permanentes, que irão lhes incomodar para o resto de suas vidas (MORO, 2005). 
Para Iida (2005, p. 571), as posturas inadequadas causam dores e degenerações que podem persistir durante toda vida. Cerca de $30 \%$ dos alunos tem dores na coluna e cerca de $36 \%$ dos adultos apresentam deformações ósseas e dores na coluna, que podem originar-se de posturas inadequadas na sala de aula. Cerca de $30 \%$ a $65 \%$ das crianças e adolescentes reclamam de dores nas costas, pescoço e cabeça. A introdução dos computadores tende a agravar esse problema, porque estes são instalados, muitas vezes, em situações improvisadas.

Segundo Abrahão e Pinho (2002), os efeitos da informatização têm consequências diferenciadas. As queixas que se apresentam de forma massiva e homogênea, são aquelas relacionadas aos aspectos que são visíveis. Elas são formuladas, sobretudo com relação ao dispositivo técnico, podendo ser reagrupadas em três categorias:

1. a visão, por exemplo, sensação de ardência nos olhos, diminuição da acuidade visual, ofuscamento, dentre outras;

2. a fadiga geral, dores cervicais, (postura), fadiga mental, por exemplo, dificuldade de compreensão de um texto simples após várias horas de trabalho de correção no vídeo;

3. as transformações nas modalidades de funcionamento mental, por exemplo, os operadores que lidam com a entrada de dados numéricos durante a sua jornada de trabalho decompondo-os mentalmente para melhor memorizá-los encontram dificuldades em reestruturar séries numéricas na sua vida cotidiana. A percepção de um preço fixado em um produto é vista como uma série numérica sem significado.

Com os avanços da tecnologia da informação que concentraram diversas funções em dispositivos únicos, os monitores planos, CPUs menores e o arquivamento digital, a necessidade de espaço reduziu-se e gerou um novo conceito de projetar, no qual se prima pelo aproveitamento de espaço, aproximando mais as pessoas sem perder o conforto e tendo ainda como benefícios maior interação e redução de custo imobiliário.

Segundo Ferreira (2000), a qualidade da estação de trabalho no contexto de Educação a Distância (EaD) joga papel fundamental para reduzir o custo cognitivo e postural do aluno nas suas atividades de aprendizagem, proporcionando bem-estar e melhor desempenho. A Figura 9 ilustra alguns parâmetros importantes para que a estação de trabalho torne-se mais compatível com a atividade do sujeito. 


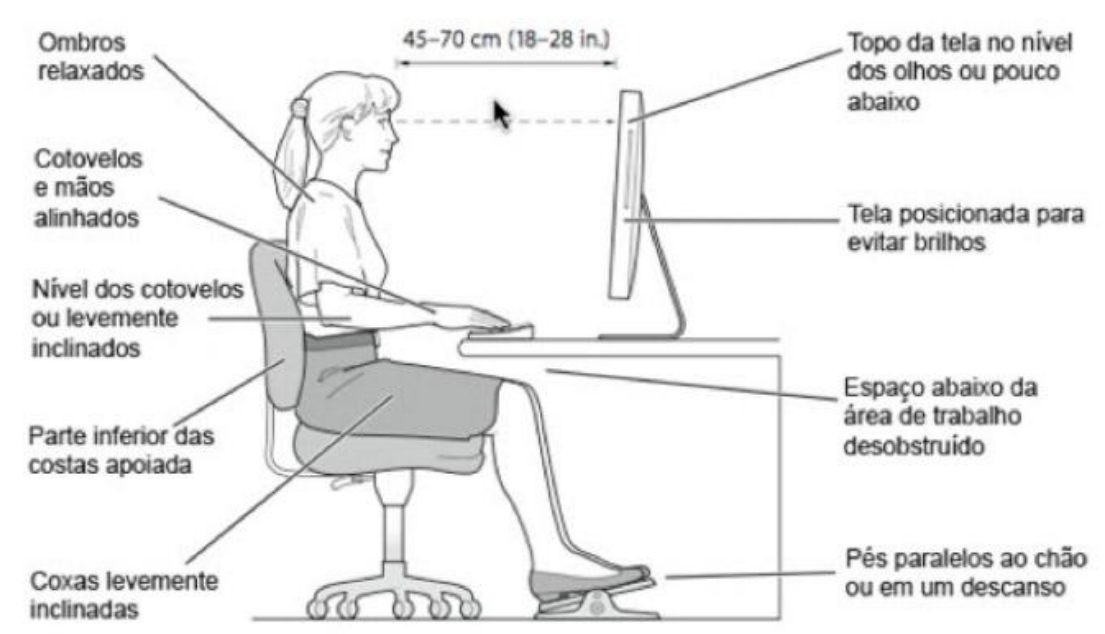

Figura 9 - Pessoa utilizando equipamento em posto de trabalho

Fonte: Marelli (2015).

O autor considera que, do ponto de vista corporal, a compatibilidade da estação de trabalho diminui, atenua e/ou elimina a sobrecarga muscular imposta pela postura sentada. Assim, evita-se a ocorrência de sintomas como formigamento, sensação de peso nas costas, pescoço, pernas, braços e mãos, e previne-se que tais desconfortos sejam considerados como algo natural e, desse modo, evoluam para doenças osteomusculares (por exemplo, tenossinovite). Do ponto de vista cognitivo, a compatibilidade da estação deve facilitar a percepção visual, a atenção e concentração inerentes às exigências das tarefas, reduzindo a ocorrência de sintomas como avermelhamento das pálpebras, visão dupla, irritação e lacrimejamento, que podem ser entendidos como naturais e, assim, transformarem-se em distúrbios oculares mais graves.

Ainda de acordo com Ferreira (2000), além dos aspectos apontados pela figura, outros cuidados são importantes para aumentar a compatibilidade da estação de trabalho do aluno, tornando-a mais confortável. Dentre eles, merecem destaque:

1. Tela do monitor: a inclinação da tela deve evitar a produção de reflexos e ofuscamentos que dificultem a percepção visual e causem mal-estar (vide Figura 9). Uma angulação que permita aos olhos recair naturalmente sobre a parte superior da tela. Algumas medidas podem contribuir para facilitar a interação olho-tela, como: o uso de iluminação difusa vinda do teto, mobiliário fosco, uso de persianas. A distância "olhotela"deve ter como parâmetro o tamanho dos caracteres na tela. A literatura tem recomendado uma distância entre o sujeito-tela e sujeito-documento em torno de 50 $\mathrm{cm}$, mas resultados recentes baseados em preferências individuais e no esforço visual 
(acomodação e convergência) indicam que essas distâncias podem ser variáveis e até mesmo maiores (COURY, 1995). Importante: procure "descansar"a vista, olhando para objetos (quadros, plantas, aquários etc.) e paisagens, situados a mais de $5 \mathrm{~m}$.

2. Posição do teclado: o teclado não deve ser duro e deve situar-se em uma altura que possibilite ao punho ficar levemente dobrado e com liberdade para os movimentos dos dedos. Um suporte para os punhos é muito importante para reduzir o esforço biomecânico da musculatura. O teclado deve ter mobilidade para possibilitar o ajuste de posições e sua cor deve ser fosca para evitar reflexos.

3. Arranjamento da estação de trabalho: os equipamentos e acessórios que compõem a estação devem ser arranjados espacialmente de modo a facilitar a atividade do sujeito, atenuando o esforço postural e melhorando a performance. A superfície da mesa deve ser suficiente para os objetos a serem utilizados no trabalho de aprendizagem e sua cor deve ser neutra, a fim de evitar reflexos e ofuscamentos. O arranjo deve ser um facilitador dos movimentos corporais do sujeito e de sua variabilidade postural.

4. Acessórios da estação: é muito importante que a estação de trabalho disponibilize suportes para documentos (com régua deslizante, ajustável para proporcionar boa postura, visualização e operação para evitar movimentos frequentes do pescoço e fadiga visual), suporte para os pés do usuário (superfície com material antiderrapante, regulagem de inclinação, flexibilizando posições) e suporte para punhos para deixar as mãos em posição neutra e reduzir a sobrecarga muscular.

Ferreira (2000) afirma que, além desses aspectos mais comuns, dependendo do contexto onde ocorre o processo de aprendizagem, é importante também que a estação de trabalho esteja equipada com uma série de suportes (disquetes, fitas, formulários), abafador de ruídos (caso, por exemplo, da utilização de impressoras matriciais) e dispositivos para proteção e passagem da fiação dos equipamentos.

Para Franceschi (2013), diversos estudos e pesquisas envolvendo as mais variadas atividades laborais comprovam que, de acordo com as condições a que essas atividades estão expostas, estas possibilitam o surgimento e/ou agravamento de quadros relacionados a LER/DORT. Nesse sentido, é pertinente conhecer as "Normas Regulamentadoras"do Ministério do Trabalho (1990), em especial a NR - 17, que trata da ergonomia. 
Já em relação aos fatores físicos de risco não organizacionais, destacam-se quatro elementos, conforme a Tabela 15:

Tabela 15 - Fatores físicos de risco não organizacionais

\begin{tabular}{ll}
\hline Fatores & Riscos \\
\hline $\begin{array}{l}\text { Regiões anatômicas submetidas aos } \\
\text { fatores de risco }\end{array}$ & Punho, cotovelo, ombro, mão, pescoço, etc. \\
\hline $\begin{array}{l}\text { Magnitude ou intensidade dos fato- } \\
\text { res de risco }\end{array}$ & $\begin{array}{l}\text { Para carga muculoesquelética, por exemplo, pode ser o peso do objeto } \\
\text { levantado. Para características psicossociais do trabalho, pode ser per- } \\
\text { cepção do aumento da carga de trabalho. }\end{array}$ \\
\hline $\begin{array}{l}\text { Variação de tempo dos fatores de } \\
\text { risco }\end{array}$ & $\begin{array}{l}\text { Duração do ciclo de trabalho, distribuição das pausas, estrutura de } \\
\text { horários, etc. }\end{array}$ \\
\hline $\begin{array}{l}\text { Tempo de exposição aos fatores de } \\
\text { risco }\end{array}$ & $\begin{array}{l}\text { O tempo de latência das lesões e dos distúrbios pode variar de dias a } \\
\text { décadas. }\end{array}$ \\
\hline
\end{tabular}

Fonte: BRASIL (2012).

\subsubsection{Ambiências na ergonomia}

Em uma abordagem ergonômica é necessário conhecer a atividade ou uma atividade semelhante que se desenvolverá no ambiente antes de configurá-lo. No caso de um ambiente de ensino, para as atividades a serem desenvolvidas, sugere-se que sejam estipuladas condições nas quais se possa estabelecer uma sensação de conforto ambiental que propicie a criatividade, motivação, interação, evitando assim ambientes que gerem fadiga e monotonia, que impeçam o processo de aprendizagem.

Falzon (2007) afirma que, em geral, as ambiências são abordadas por seu aspecto negativo e beiram com frequência os limites de intensidade admitidos, com duração de exposições flutuantes, o que torna a análise na ergonomia mais difícil.

Em se tratando da temperatura, Dul Jan \& Weerdmeester (2004) relatam que geralmente não se percebe um clima confortável no ambiente, mas o trabalhador identifica imediatamente quando o clima não está confortável, ou seja, muito quente ou muito frio. Segundo os mesmos autores, a garantia de um clima confortável no ambiente é, assim, um pré-requisito necessário para a manutenção do bem-estar, da capacidade física e psíquica.

Perturbações no conforto térmico são acompanhadas de alterações funcionais que atingem todo o organismo. Segundo Siqueira, Oliveira e Vieira (2008) calor excessivo leva primeiro a um cansaço e sonolência, o que reduz a prontidão de resposta e aumenta a tendência de falhas. Entretanto, no ambiente muito frio, o organismo necessita da produção de calor para evitar o resfriamento do corpo, aumentando, assim, a atividade corporal, o que diminui a atenção; principalmente a concentração; prejudicando o trabalho intelectual do aluno.

No que tange à iluminação, Siqueira, Oliveira e Vieira (2008) consideram a iluminação da sala de aula como outro ponto importante no rendimento do aluno, e deve ser uniformemente distribuída e difusa. A iluminação geral ou suplementar deve ser projetada 
e instalada de forma a evitar ofuscamento, reflexos incômodos, sombras e contrastes excessivos. Uma boa iluminação no ambiente contribui para aumentar a satisfação, melhorar a produtividade e reduzir a fadiga.

Nos ambientes de ensino-aprendizagem, os aspectos de acústica são relevantes. A relação fonte/ruído diz respeito à capacidade do timbre e da potência da voz do professor serem capazes de ultrapassar o ruído existente na sala de aula. E finalmente, a distância professor-aluno que, quanto maior, mais difícil fica para o aluno entender o que o professor está falando Revista Proteção (2006). Na figura 10 verifica-se o reflexo das ondas sonoras em sala de aula.

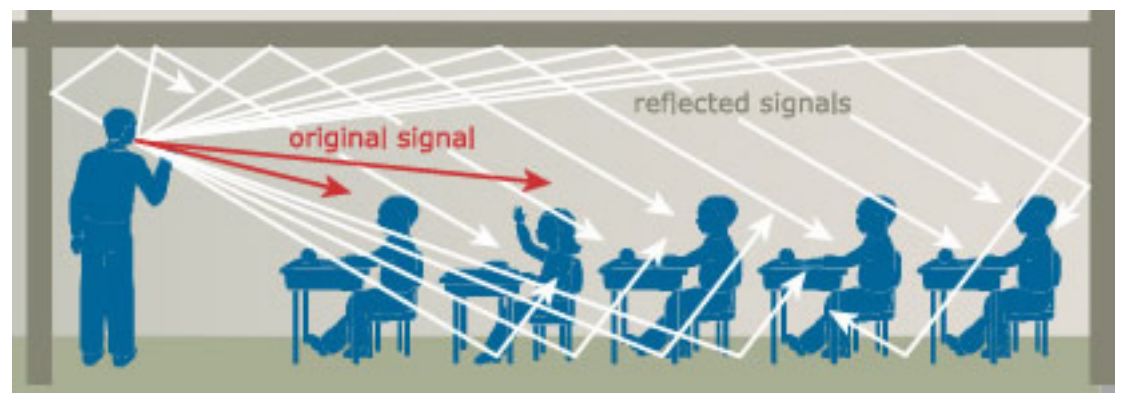

Figura 10 - Reflexo das ondas sonoras

Fonte: Revista Proteção (2006).

À distância professor-aluno de $1 \mathrm{~m}$, a energia ou intensidade da voz mede cerca de 60 dB. Entretanto, cada vez que essa distância é dobrada, o som diminui 6 dB. Assim, para um aluno sentado a $2 \mathrm{~m}$ do Professor, a intensidade do som é de $54 \mathrm{~dB}$ mas, a $4 \mathrm{~m}$, é de apenas $48 \mathrm{~dB}$ (vide figura 11, mas seguindo as linhas horizontais que partem da escala vertical e não a linha vermelha) Revista Proteção (2006).

No esquema a seguir, a linha pontilhada horizontal representa o ruído de fundo (background noise) e a linha vermelha, o nível sonoro da voz do professor. Para que os alunos ouçam com clareza a voz do professor, o som percebido por cada aluno deve estar acima da linha pontilhada; os valores da intensidade sonora, neste caso, são precedidos pelo sinal positivo $(+15 \mathrm{~dB}$, significa que a intensidade da voz do professor está 15 decibéis acima da linha que representa o ruído de fundo). Observe que, no caso do penúltimo e do último aluno, os mais distantes do professor, a linha vermelha está abaixo da pontilhada e o sinal em decibéis é negativo (-3dB), indicando que eles não estão ouvindo bem o que o professor está dizendo, o que seria possível se a linha vermelha estivesse acima da preta-pontilhada (Figura 11). 


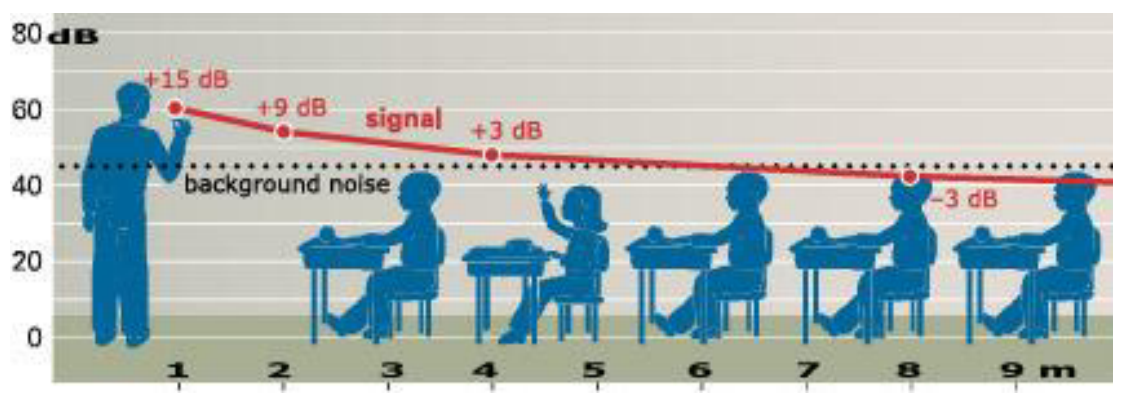

Figura 11 - Intensidade do Som

Fonte: Revista Proteção (2006).

Com relação aos ruídos, Siqueira, Oliveira e Vieira (2008) consideram que, quando são muito intensos ou constantes tendem a produzir aumento da sensação de cansaço e de desgaste. A observação e o cumprimento dos parâmetros relacionados com ruído, temperatura e iluminação são fundamentais para se buscar equilíbrio, conforto e produtividade do estudante.

Ligada ao conforto térmico se encontram as sensações que as cores produzem no ambiente. A cor é um elemento atuante no sistema relacional professor, aluno e ensino, condicionando as pré-disposições de estado de espírito dos educandos e educadores e suas percepções do espaço.

A Tabela 16 sumariza os efeitos ilusórios das cores, que dizem respeito à distância, à temperatura e aos pressupostos efeitos no estado mental.

Tabela 16 - Efeitos psicológicos das cores

\begin{tabular}{llll}
\hline Cor & Efeito distância & Efeito temperatura & Disposição psíquica \\
\hline Azul & Distância & Frio & Tranquilizante \\
\hline Verde & Distância & Frio a quente & Muito tranquilizante \\
\hline Vermelho & Próximo & Quente & Muito irritante e intranquilizante \\
\hline Laranja & Muito próximo & Muito quente & Estimulante \\
\hline Amarelo & Próximo & Muito quente & Estimulante \\
\hline Marrom & Muito próximo Contenção & Neutro & Estimulante \\
\hline Violeta & Muito próximo & Muito quente & $\begin{array}{l}\text { Agressivo,intranquilizante, desesti- } \\
\text { mulante }\end{array}$ \\
\hline
\end{tabular}

Fonte: Kroemer e Grandjean (2005)

Existem algumas cores, segundo Falcão et al. (2008) que são recomendáveis para utilização em ambientes de aprendizagem, como o laranja que ajuda a liberar as emoções reprimidas dos alunos, e o azul, que possui um poder terapêutico (Tabelas 17 e 18) sendo que "[...] a energia bloqueada por sentimentos de inadaptação e frustração pode resultar em explosões de agressividade e raiva. Sob orientação, o laranja tem o poder de canalizar 
3.1. Elementos e parâmetros técnicos que estruturam a relação entre espaço arquitetônico e ensino-aprendizagem

essa energia para alguma atividade criativa e, ao mesmo tempo, de vitalizar a pessoa". (LACY, 2002, p. 46). Esta autora ainda afirma que "[...] o uso certo das cores pode resultar numa relação melhor entre professores e alunos" (LACY, 2002, p. 47).

Lacy (2002, p. 48) afirma que, a introdução das cores certas nas universidades pode melhorar muitíssimo a vida dos estudantes. As cores usadas nas universidades ou faculdades devem estimular a área específica de estudo, seja ela ciências humanas, direito, informática, música, artes etc. Nos lugares em que se estuda muito, são necessários tons amarelos quentes misturados com azul (mais amarelo do que azul). A cor amarela estimula o estudo, traz clareza e desperta novas ideias.

O círculo cromático, composto de 12 cores, auxilia a perceber como as cores se relacionam e ajudam na seleção de cores para tornar um ambiente agradável (ver Figura 12.

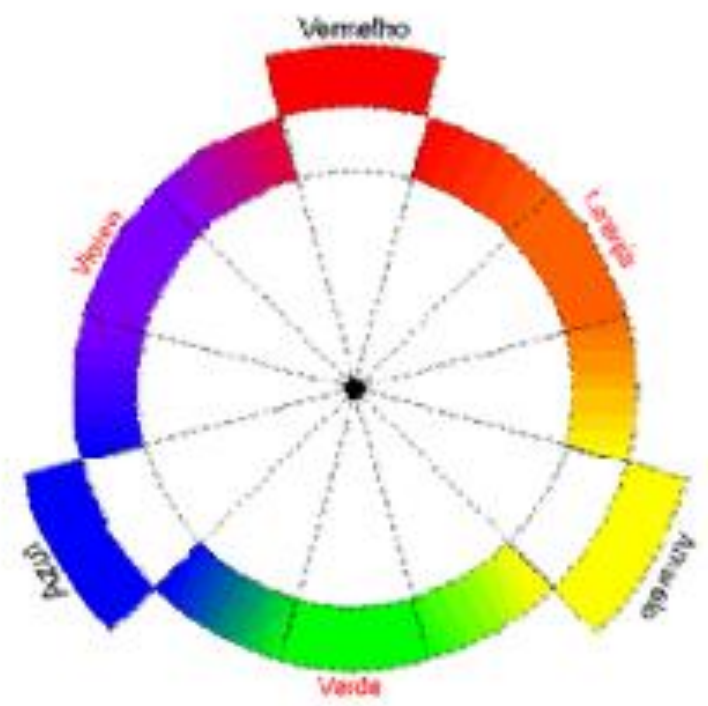

Figura 12 - Círculo Cromático.

Fonte: Lacy (2002).

Tabela 17 - As cores e alguns de seus efeitos terapêuticos

\begin{tabular}{ll}
\hline Cor & Efeito Terapêutico \\
\hline Azul & Acalma e cura a mente, reduz a pressão arterial e aumenta a consciência. \\
\hline Verde & $\begin{array}{l}\text { Dá acesso às emoções profundas, pode começar a liberar traumas passados - leva à paz } \\
\text { e à harmonia. }\end{array}$ \\
\hline Vermelho & Energiza e ativa as emoções, eleva a pressão arterial e afeta o sistema muscular. \\
\hline Rosa & Tranquiliza, relaxa os músculos, reduz a tensão, acalma as emoções. \\
\hline Pêssego & Ativa os impulsos criativos, induz a melhorar os relacionamentos. \\
\hline Amarelo & $\begin{array}{l}\text { Estimula o sistema nervoso, transforma o pessimismo em otimismo, o uso dessa cor } \\
\text { sobrecarrega o sistema nervoso. }\end{array}$ \\
\hline
\end{tabular}




\begin{tabular}{ll}
\hline Cor & Efeito Terapêutico \\
\hline Turquesa & $\begin{array}{l}\text { Relaxa, acalma e tranquiliza sistema nervoso. Ajuda a pessoa a lidar com a vida. Liberta-a } \\
\text { dos sentimentos de inaptidão ou insuficiência. }\end{array}$ \\
\hline Violeta & $\begin{array}{l}\text { Pode ajudar na depressão mental e emocional, limpa o passado, abrindo caminho para o } \\
\text { novo começo. }\end{array}$ \\
\hline Majenta & Eleva a pessoa emocional, mental e espiritualmente. \\
\hline
\end{tabular}

Fonte Lacy (2002).

Tabela 18 - Uma visão geral das reações emocionais e mentais e algumas cores

\begin{tabular}{llll}
\hline Cor & Geral & Reações emocionais & Reações mentais \\
\hline Azul & Frio & Calma e distanciamento & Reflexão e introspecção \\
\hline Verde & Natureza & Calma, quietude, harmonia, esperança e liberdade & Receptividade e crescimento \\
\hline Vermelho & Vivo & Superestimulante e quente & Ativação e perturbação \\
\hline Laranja & Quente & Energizante e excitante & Criatividade e comunicação \\
\hline Amarelo & Luz do sol & Expansividade e ausência de limites & Prontidão e irradiação \\
\hline Violeta & profundo & Devoção e respeito & Meditação e magia \\
\hline Turquesa & Repousante & Relaxamento tranquilidade & Ampliação do espaço e liberação \\
\hline Majenta & Majestoso & Inspiração e elevação & Controle, consciência e espiritual \\
\hline Branco & Claro & Brilho e frieza & Limpeza e pureza \\
\hline Preto & Escuro & Depressão e medo & Desconhecido e vácuo \\
\hline Cinza & Nublado & Infelicidade, sem amor próprio & Negatividade e indecisão \\
\hline
\end{tabular}

Fonte Lacy (2002).

Em relatos de Lacy (2002) sobre os estudos experimentais feitos por Wohlfarth, fica caracterizado que a cor no ambiente educacional exerce influência no comportamento dos alunos. Nessa experiência, realizada por doze meses, foi adotado o uso de duas cores: uma quente (amarelo - estimulante do intelecto) e outra fria (azul - que possui efeito tranquilizante sobre a mente), e a mudança conjunta de cor e iluminação gerou as seguintes melhoras: no comportamento, no desempenho nos testes de Q.I, no humor, e na redução no número de faltas por motivos de saúde.

Num outro experimento com alteração das cores no ambiente de trabalho (administrativo), realizado por Fonseca e Mont'Alvão (2004) foram adotadas como cores predominantes duas cores frias: o verde (textura terracor verde / referência: 860 original) e o azul (marca coral, referência: 7981). O resultado obtido, com relação às cores aplicadas nesse ambiente, indica que "[...] as pessoas não consideram que estas sejam capazes de desviar a atenção do trabalho que se esteja realizando e uma pequena parte se sente motivada pelas mesmas" (FONSECA; MONT'ALVÃO, 2004, p. 74). 
Para os autores essas duas práticas levam à dedução de que onde ocorre atividade cognitiva predominante, é necessário promover o equilíbrio entre estímulo e tranquilidade. Esse equilíbrio parece evidente no primeiro experimento, no qual foram aplicadas cores opostas, quentes e frias (azul e amarelo), que resultaram no bom desempenho e comportamento dos alunos. Entretanto, o segundo experimento demonstrou que a combinação entre duas cores frias reproduziu um ambiente apático, provocado pelo efeito psicofísico muito tranquilizante das cores empregadas.

A partir do levantamento bibliográfico, referido acima foi possível sintetizar na Tabela 19 os atributos do espaço, vistos pela ergonomia, que interferem nas relações com a aprendizagem. 


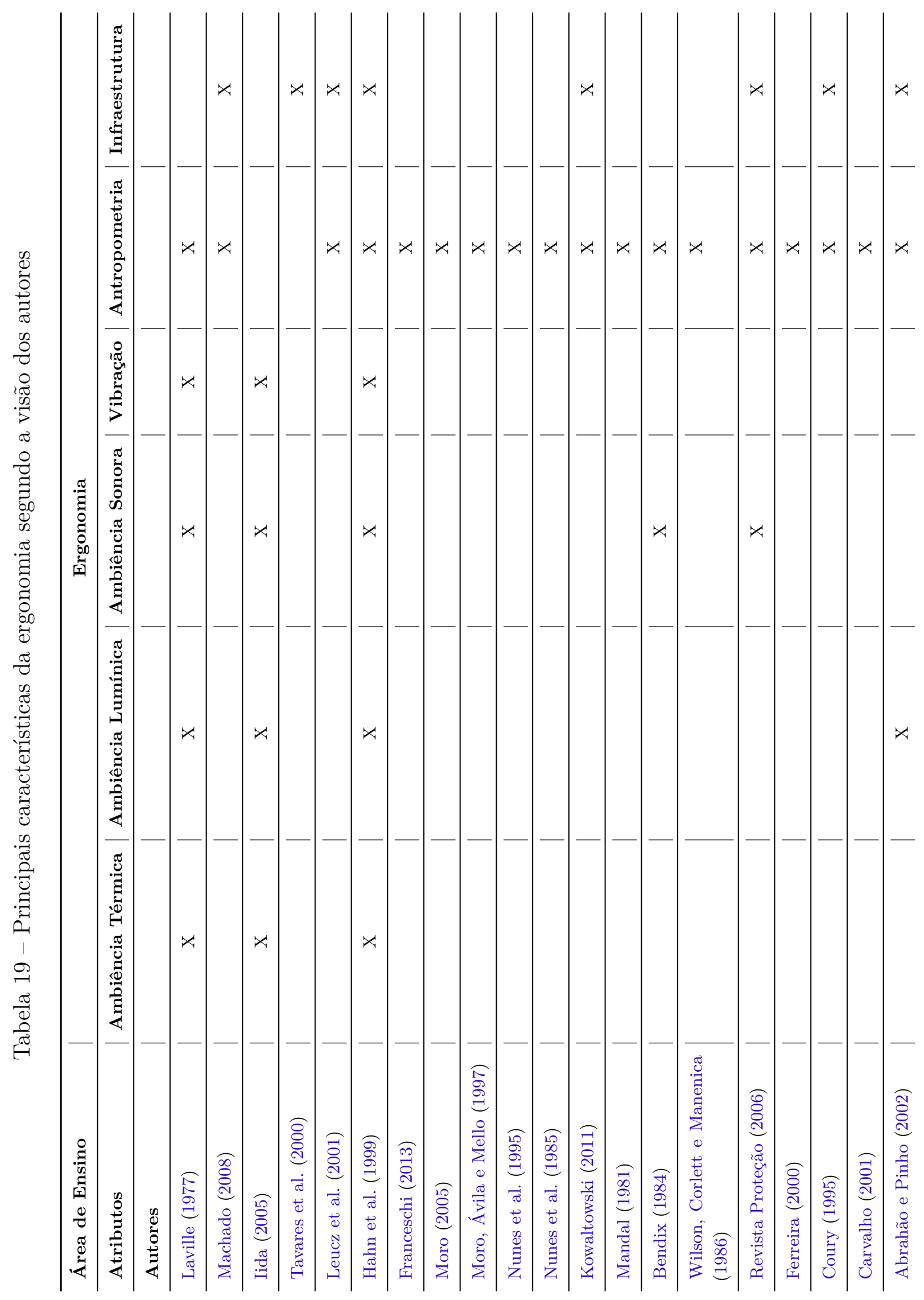




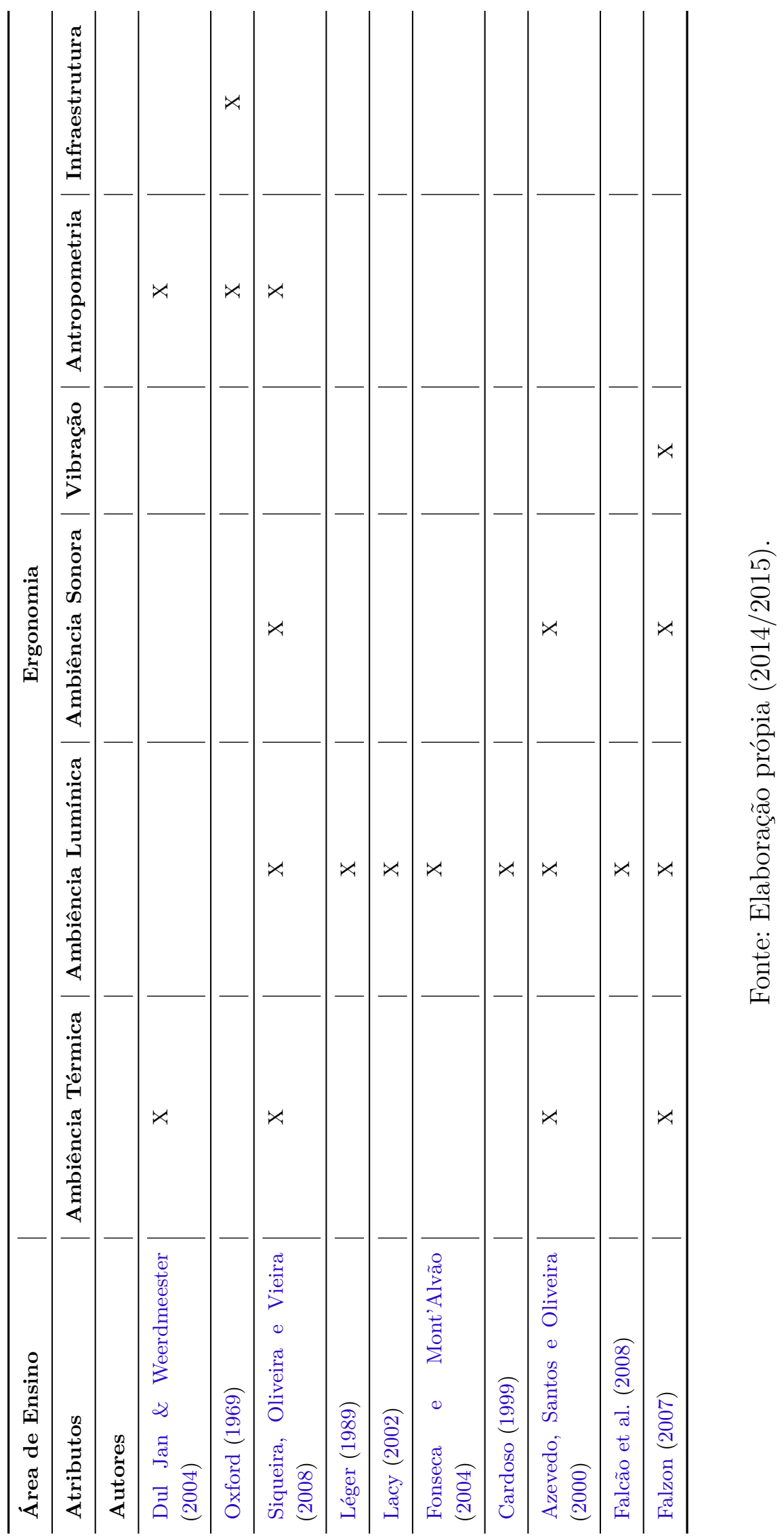




\subsubsection{O papel da psicologia ambiental na concepção de espaços de ensino- aprendizagem}

A psicologia ambiental estuda a transação entre os indivíduos e seus ambientes físicos onde os indivíduos mudam o ambiente e seu comportamento é mudado pelo ambiente. A psicologia ambiental contribui para o entendimento dessa relação de modo a tornar mais humana e melhora do nosso relacionamento com o meio ambiente (GIFFORD, 1997).

As pesquisas da psicologia ambiental têm contribuído para a construção de ambientes mais humanizados e para o restabelecimento do bom relacionamento entre os indivíduos, o meio ambiente natural e o ambiente construído. Seus estudos enfatizam o processo dinâmico e biunívoco da relação entre pessoa e ambiente, na qual indivíduos, por meio de suas ações, modificam o ambiente e ambientes, por intermédio de suas configurações, influenciam o comportamento humano (GUIDALLI et al., 2012).

\subsubsection{Espaço pessoal}

Canter e Stringer (2001) afirmam que a tarefa dos psicólogos ambientais que estudam o aprendizado é identificar condições sob as quais os elementos físicos e não físicos do arranjo da sala se combinam, resultando em uma melhora do aprendizado.

As relações pessoa-meio no espaço do aprendizado, segundo Weinstein (1979), compõem o esquema apresentado na Figura 13.

Weinstein (1979) considera que os efeitos do espaço físico sobre o aprendizado devem ser analisados sob quatro dimensões: o próprio aprendizado, sentimentos com relação ao aprendizado, o comportamento social relacionado ao aprendizado e os aspectos de saúde e estresse do aprendizado. Nestas análises, os psicólogos ambientalistas utilizam-se de premissas referentes ao aprendizado e ao arranjo físico ou design ambiental:

- o arranjo físico não influi diretamente, mas pode tanto facilitar quanto dificultar o aprendizado de forma simbólica e direcionada;

- o arranjo físico produz efeito sobre o aprendizado, mas não é determinístico, mas são regulados pelo contexto social e do programa acadêmico;

- o arranjo físico melhor é aquele coerente com o conteúdo programático do que está sendo aprendido, com os objetivos da classe e com as características dos aprendizes;

- o arranjo físico maximiza o aprendizado se considerado de forma tão cuidadosa quantos outros aspectos da situação do aprendizado, como a habilidade do professor e o currículo do curso. 


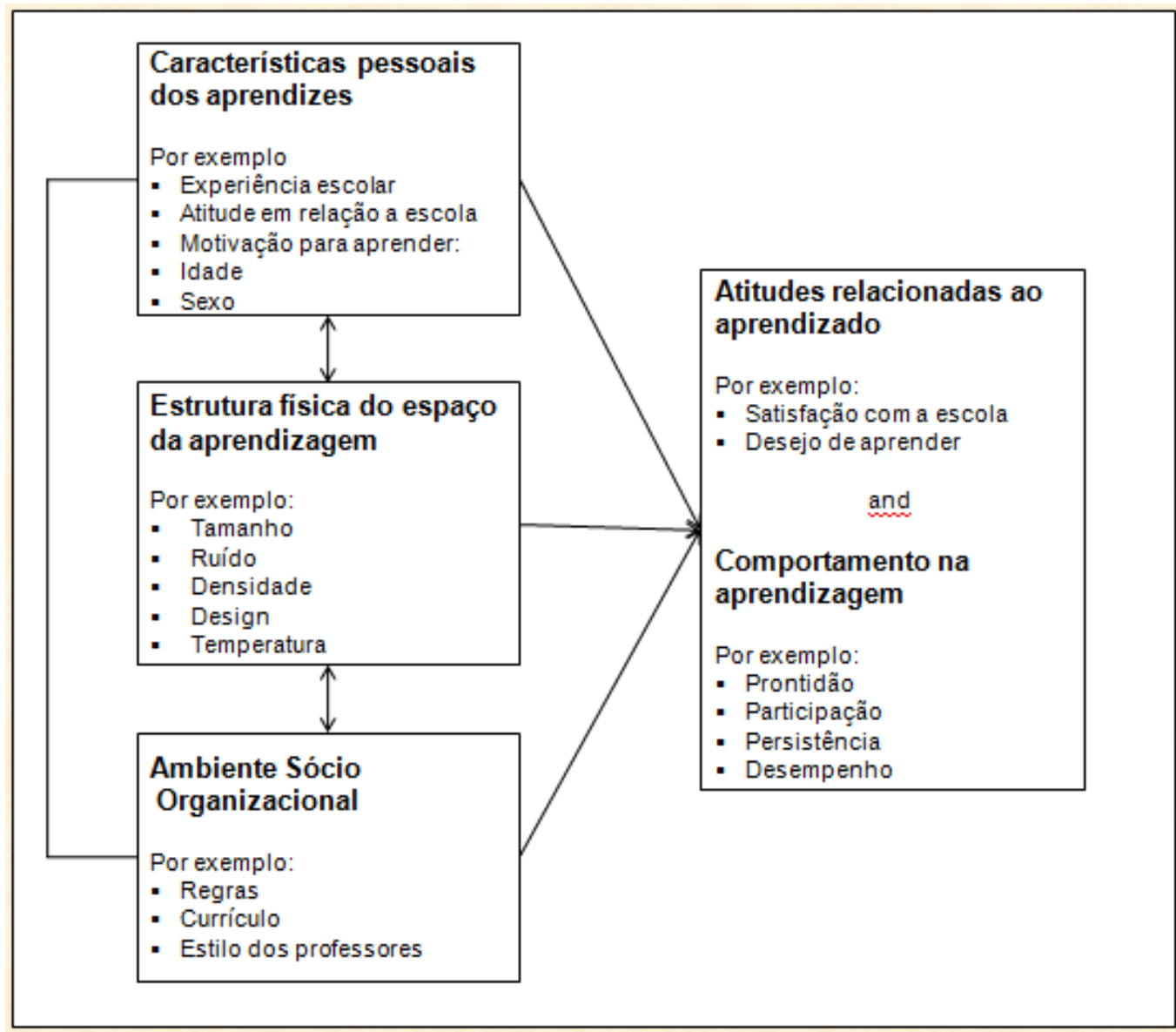

Figura 13 - Relações pessoa-meio no espaço de aprendizado

Fonte: Weinstein (1979).

Nessa função de produzir um ambiente propício para o trabalho em grupo, os autores consideram que a disposição do mobiliário é fator preponderante:

- Disposição em fileiras: os assentos disponibilizados em fileiras impedem que os aprendizes da frente interajam com os que estão atrás. Essa disposição é interessante em aulas expositivas e centradas no professor, cuja face é a única enxergada pela classe.

- Disposição circular: esse arranjo permite que todos os membros interajam livremente uns com os outros e com o professor, que também deverá fazer parte do grupo, mesmo quando os alunos estão realizando tarefas individuais, tais como o uso de equipamentos, como computadores. Esse arranjo permite interação e mobilização. A ausência de um anteparo, como uma mesa ou carteira, deixa os aprendizes expostos e os obriga a ficar atentos e participativos com os demais membros do grupo.

- Disposição em "U": nem sempre a disposição ao redor de uma mesa grande ajuda, porque os membros de um dos cantos podem formar o seu próprio grupo. O professor deve atentar para que as pessoas não se sentem sempre no mesmo lugar. A ausência da 
mesa também permite a mobilidade dos alunos na classe e provoca mais participação nas dinâmicas.

Segundo Imai e Duarte (2009), do mesmo modo que o ambiente construído tem poder de influência na conduta humana, em suas percepções e emoções, modelando sua personalidade, as pessoas possuem instrumentos para modelar o ambiente construído.

Para Matai e Matai (2008), as características pessoais dos estudantes (atitudes em relação ao aprendizado, idade, personalidade, sexo, experiências escolares anteriores) interagem com o layout do espaço de aprendizagem (tamanho, ruído, densidade populacional e disposição do mobiliário) e o ambiente sócio-organizacional (normas, currículos, metodologia de ensino, orientação educacional) produzindo atitudes relacionadas com o aprendizado (satisfação com a escola, insatisfação com a classe, compromisso com o aprendizado) e comportamentos (participação da classe, atenção com os materiais de aprendizagem, questionamento, atitude proativa ou não persistência, criatividade, aprendizagem e desempenho).

O layout dos espaços físicos destinados ao ensino e aprendizado do aprender a conviver e o aprender a ser deverão ser construídos para facilitar o trabalho do professor no desenvolver desses comportamentos sociais.

\subsubsection{Territorialidade e privacidade}

O psicólogo Sommer (2002) trabalha sobre a relação entre ambiente e comportamento que trata de como as pessoas se distribuem, organizam-se nos edifícios e nos ambientes abertos. O trabalho foi baseado nos estudos de zoologistas e ecologistas europeus, especialmente Konrad Lorens, Jakob Von Uexkull e Niko Tinbergen, que estudaram o uso do espaço por animais selvagens em cativeiro. Os estudos sobre o tipo de ambientes de que esses animais necessitavam e sobre os efeitos causados neles pelo ambiente possibilitaram compreender que um espaço inadequado aos animais em cativeiro pode não apenas perturbá-los, como também aumentar a incidência de doenças e dificultar sua reprodução, tornando-os inúteis como animais de zoológico e, muitas vezes, causando sua morte. O trabalho influenciou outros psicólogos, como Albert Mehrabian, Michael Argyle, além de Robert Sommer.

Segundo o autor, os estudos realizados foram sobre o grau de proximidade entre as pessoas, sobre sua organização em espaços grandes e pequenos, sobre a influência da distribuição de mesas e cadeiras na interação que se realiza em diferentes tipos de ambiente. Também houve influência de psiquiatras que estudaram os espaços em diferentes tipos de instituição. Com uma pesquisa básica, esses trabalhos foram utilizados embasando a propriedade de conceitos, tais como espaço pessoal, territorialidade, multidão e privacidade. 
3.1. Elementos e parâmetros técnicos que estruturam a relação entre espaço arquitetônico e ensino-aprendizagem

Sommer (2002) afirma que o estudo mais importante sobre territorialidade é o conceito de espaço defensável (defensible space), de Oscar Newman, utilizado com grande sucesso no processo de humanização da habitação pública nos Estados Unidos, que, à época das pesquisas de Newman, passava por uma grave crise em decorrência da grande escala dos projetos dos conjuntos habitacionais, na qual a criminalidade, a insegurança e o vandalismo dominavam. Como exemplo, o famoso conjunto habitacional de Pruin-Igoe, no qual os prédios abrigavam o mesmo tipo de morador dos dois lados da rua.

Newman descobriu que a incidência de crimes nos edifícios altos era cinco vezes maior que nos edifícios baixos, o que o fez tentar dividir os edifícios maiores e desenvolveu, então, o conceito de espaço defensável, que possui dois aspectos:

- Territorialidade: grau de controle dos moradores sobre os ambientes comuns de seu edifício, mais evidente nos edifícios menores, onde, por conhecerem seus vizinhos, eles podem questionar as pessoas estranhas sobre os motivos de estarem ali em seu edifício:

- Vigilância: a capacidade de poder ver e controlar os frequentadores dos edifícios era muito mais fácil e evidente nos edifícios menores que nos edifícios maiores.

Sommer (2002) tem desenvolvido pesquisas sobre espaço pessoal com objetivo de melhorar os edifícios. Numa delas verificou sua teoria de espaço defensável no campus da universidade Califórnia (Figuras 14 e 15). Como consequência dos resultados obtidos, os grandes e altos projetos habitacionais foram implodidos.

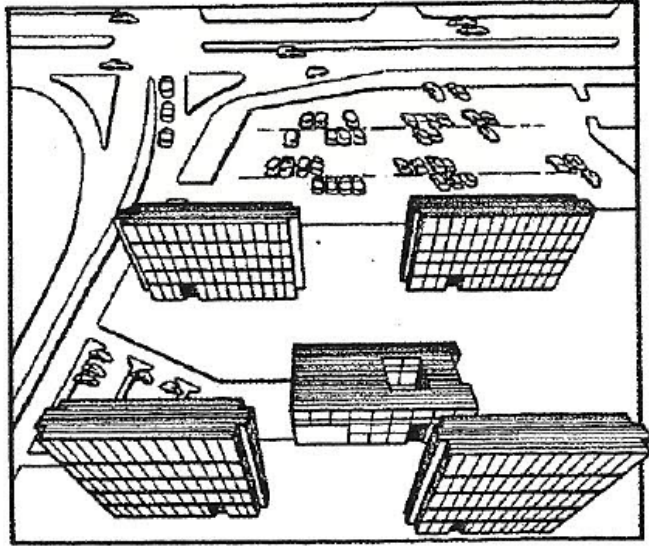

Figura 14 - Alojamento de estudantes em prédios altos, Universidade da Califórnia - Davis

Fonte: Sommer (2002)

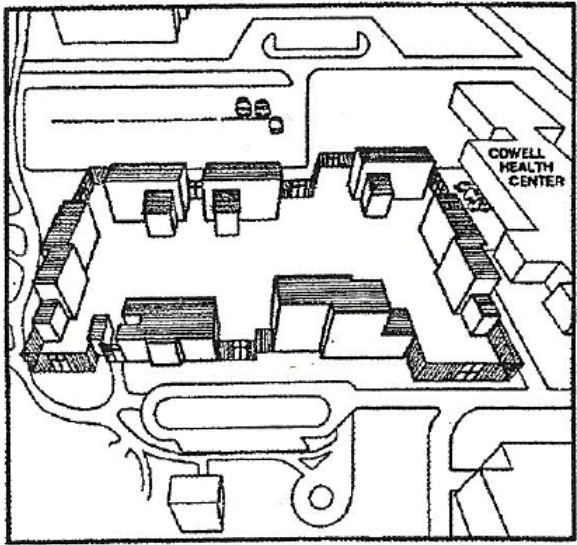

Figura 15 - Alojamento em prédio básico agrupado em clusters, Universidade da Califórnia - Davis

Fonte: Sommer (2002) 


\subsubsection{Humanização}

Mezzomo (2002, p. 14-15) afirma que, a humanização é entendida como valor de resgate do respeito à vida humana e abrange aspectos sociais, éticos, educacionais e psíquicos presentes nos relacionamentos humanos. Considera, também, que a humanização de ambientes consiste na qualificação do espaço construído a fim de promover ao seu usuário conforto físico e psicológico para a realização de suas atividades, por meio de atributos ambientais que provocam a sensação de bem-estar. A ambiência arquitetônica é, portanto, criada por uma diversidade de elementos num espaço, resultando num conjunto que interage na percepção do usuário de forma agradável ou desagradável. Esses elementos nada mais são que os atributos de humanização agregando valor pessoal ao espaço físico.

Para Sommer (1974), existe a necessidade de humanizar o espaço interno, atribuirlhe características pessoais, adequar a proporção com a escala humana, para permitir a manipulação do mobiliário pelos usuários, enfatizando a necessidade de paisagismo, harmonia entre os elementos construtivos, as cores e os materiais. O espaço de sala de aula que oferece conforto para a realização de suas atividades contribui diretamente com a qualidade do aprendizado e com o bem-estar de seus usuários.

\footnotetext{
[...] ambientes que contribuem para aumentar a sensação de alegria, motivação e segurança, geram maior participação das pessoas na resolução de problemas e no trabalho de modo geral. Estes ambientes podem ser considerados humanizados (BINS ELY, 2003, p. 2).
}

O descontentamento do indivíduo com o seu ambiente pode facilitar a emergência de certas doenças, sejam mentais ou físicas, como afirma Moser (1998):

\begin{abstract}
[...] porque a Psicopatologia vê cada vez mais a importância da relação entre saúde e ambiente. Não é por acaso que certos doentes se encontram em certos lugares e não em outros, da mesma forma que algumas doenças se encontram em determinados lugares e não em outros. Pode-se também ver a relação que o indivíduo tem com o ambiente em que vive, em relação ao surgimento de doenças (MOSER, 1998, p. 121-130)
\end{abstract}

Mais uma vez se somam os focos de estudo do conforto ambiental, ergonomia e psicologia ambiental no tema do conforto ambiental. Os aspectos relativos aos níveis de iluminamento e distribuição da luz nos ambientes, que contribuem para a distribuição das pessoas e dos grupos em função de personalidades, tarefa e ambiente, ou seja, interferem nos limites do "espaço pessoal" do indivíduo, são também, amplamente tratados por uma corrente da psicologia ambiental.

De acordo com Sommer (2002), além do aspecto de um bom planejamento físico para a sala de aula, aponta a necessidade de renovação desses espaços, conforme estudos realizados em uma sala de aula do ensino superior americano. Em uma palestra realizada 
3.1. Elementos e parâmetros técnicos que estruturam a relação entre espaço arquitetônico e ensino-aprendizagem

na universidade Federal do Rio de Janeiro (UFRJ), ele descreve um estudo realizado em uma sala de aula do ensino superior americano, onde o grau de satisfação dos estudantes em relação à sala vem sendo avaliado e documentado desde 1969. Nesse espaço, várias alterações já foram realizadas por meio de projetos de estudantes de arquitetura com ajuda dos estudantes de psicologia, que procuraram enfatizar a estética e a atratividade do ambiente, com o objetivo de melhorar a interação entre os alunos. O resultado dessa investigação mostrou a necessidade de reformar o ambiente em intervalos de cinco anos, uma vez que se observou a diminuição da satisfação do usuário após esse período, devido ao desgaste e à desatualização da aparência da sala.

Ornstein, Bruna e Roméro (1995) descrevem um estudo semelhante realizado pelo Building Perfomance Research Unit em edifícios escolares em 1972, que mostrou que a insatisfação dos usuários tende a crescer conforme aumenta a vida útil do edifício. Também foi verificado que o espaço que favorece as mudanças espaciais propostas pelos usuários aumenta o nível de satisfação dos mesmos. Essa observação ressalta o valor de se conceber ambientes dotados de flexibilidade.

A partir do levantamento bibliográfico, referido acima foi possível sintetizar na Tabela 20 atributos do espaço, vistos pela psicologia ambiental, que interferem nas relações com a aprendizagem.

Tabela 20 - Principais características da psicologia ambiental segundo a visão dos autores

\begin{tabular}{|c|c|c|c|}
\hline \multirow{2}{*}{$\begin{array}{l}\text { Área de Ensino } \\
\text { Atributos }\end{array}$} & \multicolumn{3}{|c|}{ Psicologia Ambiental } \\
\hline & \multirow{2}{*}{ Espaço Pessoal } & \multirow[t]{2}{*}{ Territorialidade } & \multirow[t]{2}{*}{ Privacidade } \\
\hline Autores & & & \\
\hline Gifford (1997) & $\mathrm{X}$ & $\mathrm{X}$ & $\mathrm{X}$ \\
\hline Canter e Stringer (2001) & & $\mathrm{X}$ & $\mathrm{X}$ \\
\hline Imai e Duarte (2009) & $\mathrm{X}$ & $\mathrm{X}$ & $\mathrm{X}$ \\
\hline Sommer (2002) & $\mathrm{X}$ & $\mathrm{X}$ & \\
\hline Lee (1977) & $\mathrm{X}$ & & $\mathrm{X}$ \\
\hline (WEINSTEIN, 1979) & $\mathrm{X}$ & $\mathrm{X}$ & $\mathrm{X}$ \\
\hline Matai e Matai (2008) & & & $\mathrm{X}$ \\
\hline Guidalli et al. (2012) & $\mathrm{X}$ & & \\
\hline Mezzomo (2002) & $\mathrm{X}$ & & \\
\hline Boing et al. (2003) & $\mathrm{X}$ & & \\
\hline Sommer (1974) & $\mathrm{X}$ & & \\
\hline Bins Ely (2003) & $\mathrm{X}$ & & \\
\hline Moser (1998) & $\mathrm{X}$ & & \\
\hline Sommer (1973) & $\mathrm{X}$ & $\mathrm{X}$ & \\
\hline Ornstein, Bruna e Roméro (1995) & $\mathrm{X}$ & & \\
\hline
\end{tabular}




\begin{tabular}{l|c|c|c}
\hline \multicolumn{1}{c}{ Área de Ensino } & \multicolumn{3}{c}{ Psicologia Ambiental } \\
\hline Atributos & Espaço Pessoal & Territorialidade & Privacidade \\
\hline Autores & & & \\
\hline Sommer (1969) & $\mathrm{X}$ & $\mathrm{X}$ & $\mathrm{X}$ \\
\hline
\end{tabular}

Fonte: Elaboração própria (2015).

\subsection{Recorrência dos aspectos abordados por diferentes técnicas para programa de necessidades}

A literatura pesquisada permitiu a identificação de estudos que buscaram estabelecer valores que deveriam ser considerados para o desenvolvimento de projetos de arquitetura de qualidade. Esses valores deveriam servir como base ao desenvolvimento do programa de necessidades, indicando as informações necessárias à fase de preparação que antecede o projeto, e também como ferramenta de avaliação ao final do processo, por meio da verificação se os itens estabelecidos foram considerados adequadamente (DELIBERADOR, 2010).

A análise dos diversos modelos e métodos, realizada por autores nacionais e internacionais, citadas no capítulo 2, itens 2.3.1 e 2.3.2, demonstra que os parâmetros imprescindíveis para o programa de necessidades podem ser traduzidos em requisitos funcionais dos projetistas, contemplando os espaços arquitetônicos do edifício. Dos dois métodos referidos, é possível vislumbrar campos disciplinares que mais são recorrentes quando o tema é arquitetura escolar. Os métodos DQI (Design Quality Indicator), de Cabe (2005) e o Método Patters - Parâmetros de Projeto Escolar de Nair e Fielding, citados nas Tabelas 21 e 22, a seguir, contemplam parâmetros considerados para o edifício escolar importantes para o projeto de arquitetura:

i - Princípios para arquitetura escolar segundo Cabe (2005) faz uma análise de dez parâmetros importantes para o programa de necessidades escolar sendo considerados relevantes para o ensino-aprendizado, conforme autores pesquisados na literatura.

Utilizando princípios que correspondem aos de Vitruvius, Cabe (2005) considera critérios importantes para a arquitetura escolar referentes ao edifício, estabelecendo relações entre o espaço escolar e as necessidades das práticas pedagógicas. Ao mesmo tempo os critérios estabelecidos possuem uma relação com as áreas encontradas na literatura escolar.

Na tabela 21, apresenta-se a relação do processo de projetos por DQI (Design Quality Indicator) e os atributos e parâmetros propostos pela pesquisa. 


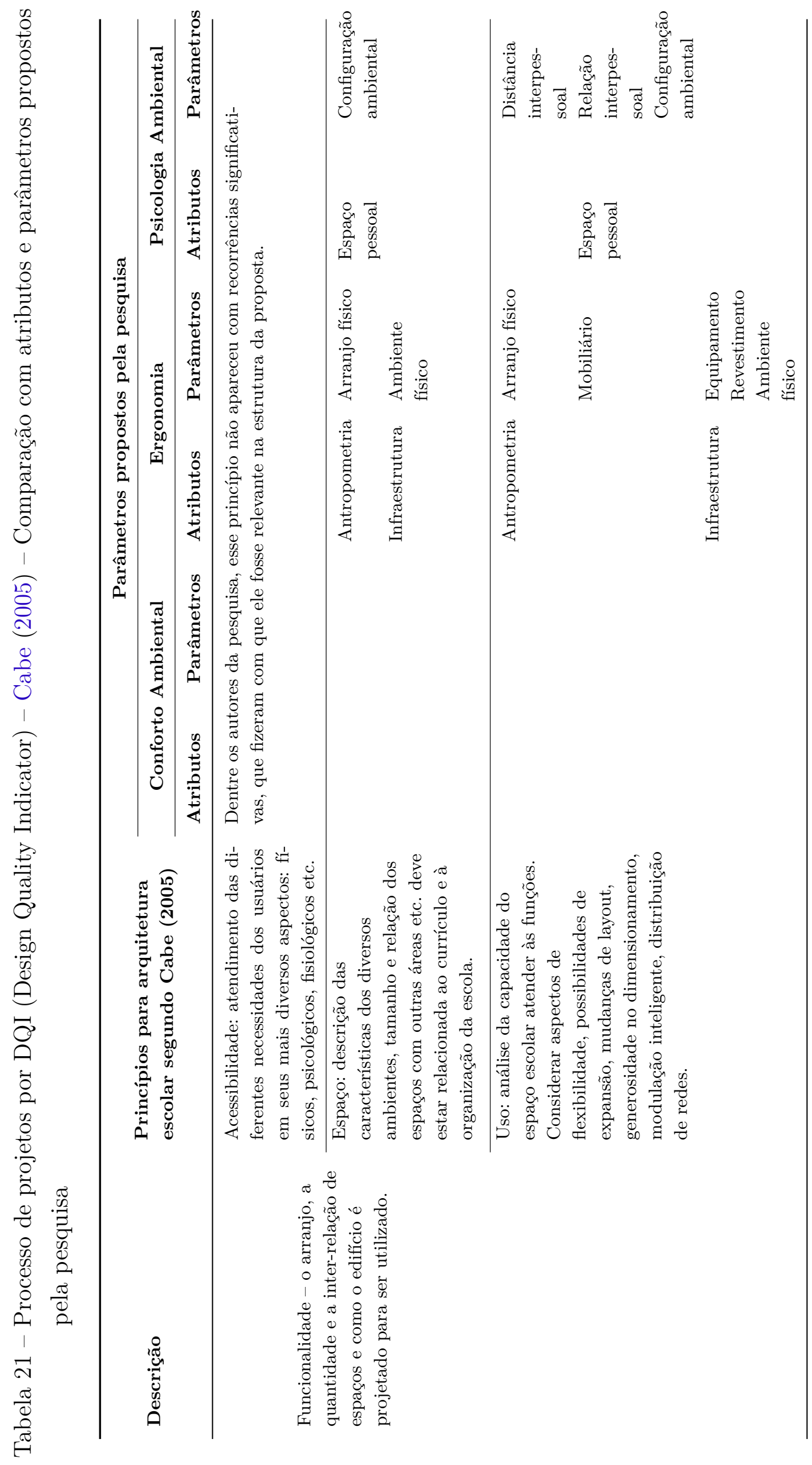




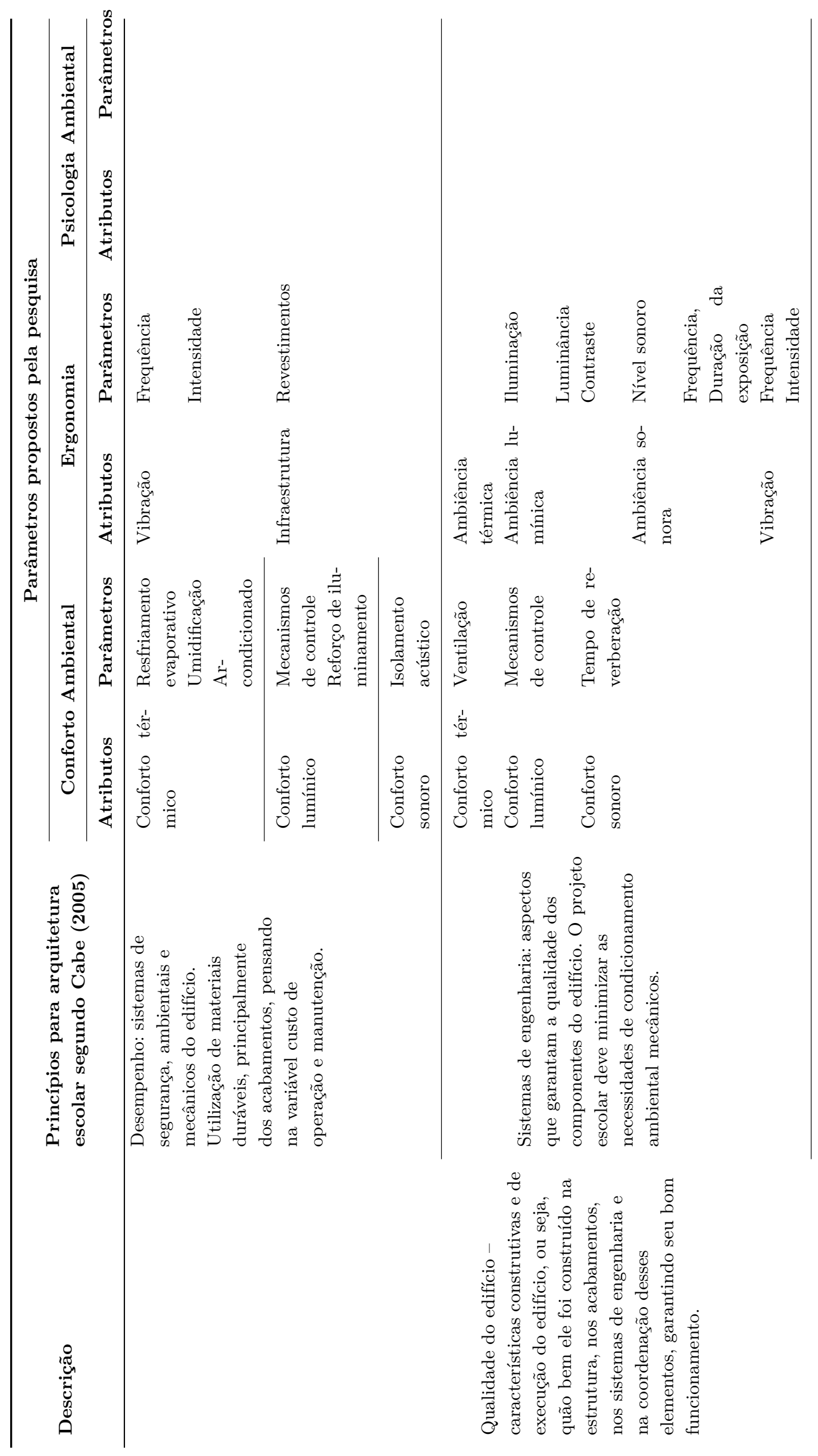




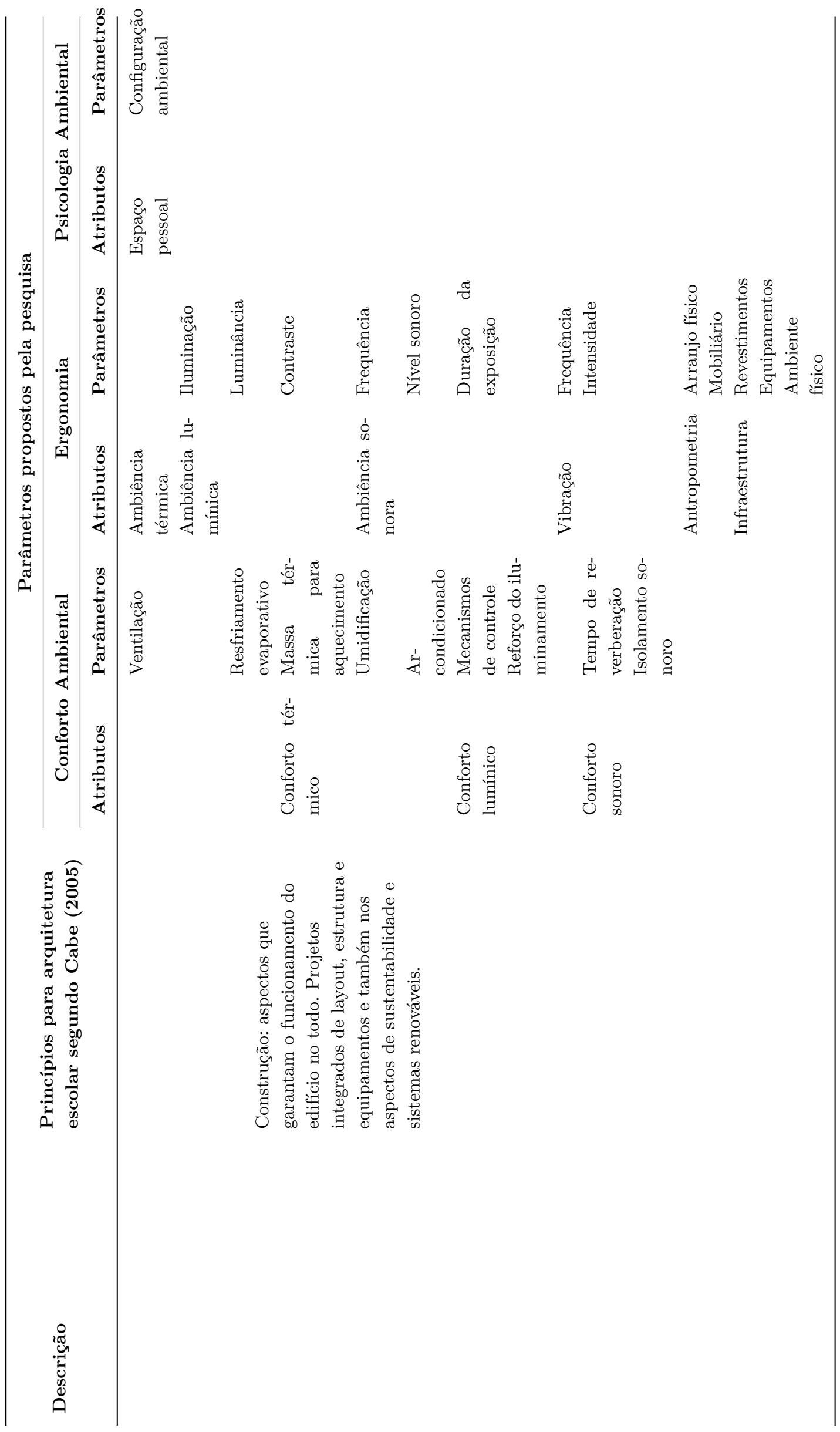




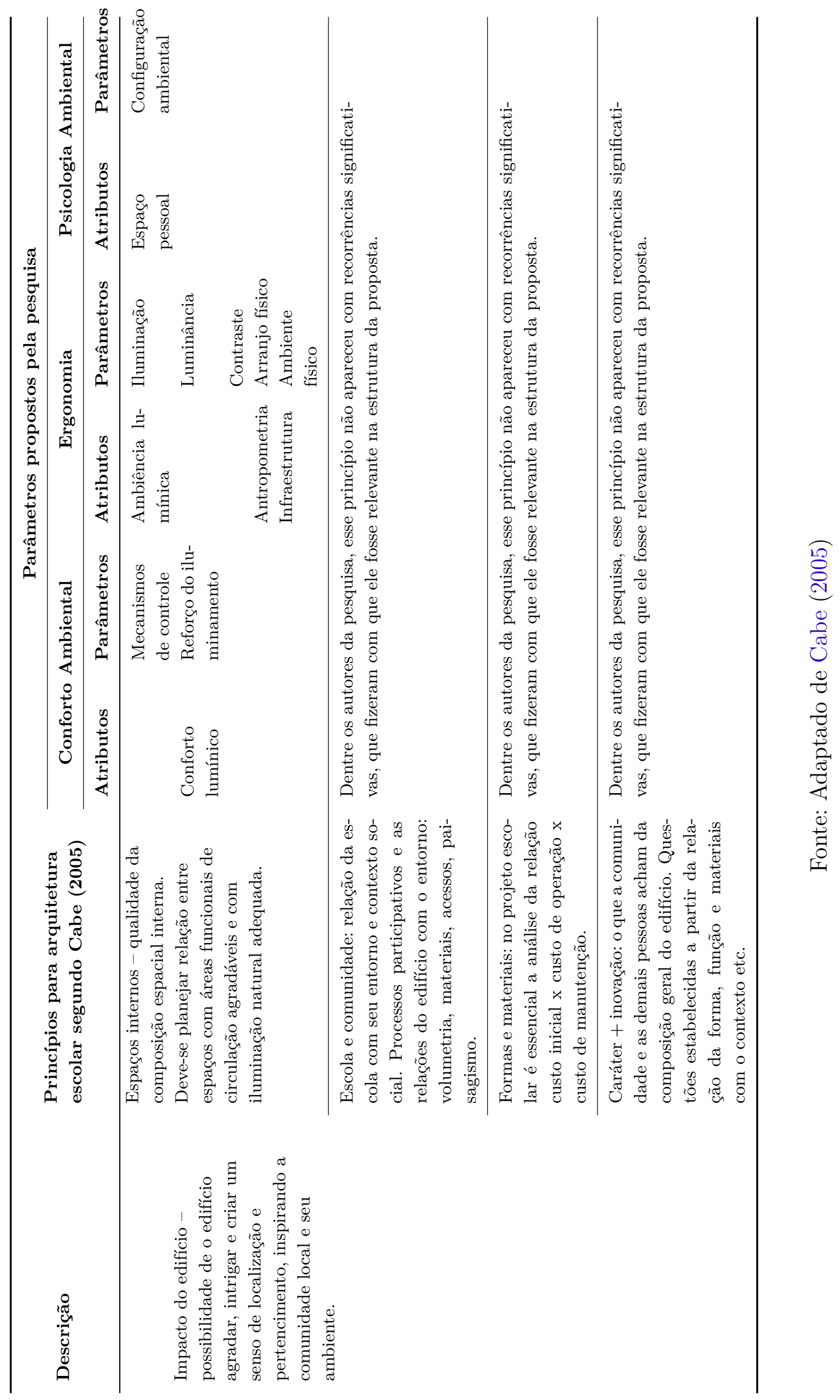


ii - Parâmetros de Projeto para o projeto escolar (Pattters) - considera trinta e dois parâmetros citados por Nair e Fielding (2005) importantes para o programa de necessidades escolar, sendo considerados relevantes para o ensino-aprendizado. (Tabela $22)$.

Esses princípios de projeto, que garantem a boa qualidade dos ambientes escolares, foram desenvolvidos a partir das considerações de Christopher Alexander que, em suas pesquisas, buscou a qualificação de sua arquitetura por meio de métodos que procuraram diminuir seu caráter subjetivo sem deixar de considerar os aspectos de humanização do ambiente construído. Nair e Fielding (2005) explicitam o uso do conceito dessa linguagem para o projeto escolar, mediante um re-enquadramento das discussões entre arquitetura e educação, baseadas em vinte e cinco parâmetros por eles estabelecidos, que deveriam enriquecer a experiência humana no ambiente de ensino (DELIBERADOR, 2010).

Esses parâmetros são pontos iniciais e provocativos para o desenvolvimento de diretrizes próprias a cada situação com que o projeto escolar vai trabalhar. Podem ser considerados como indicadores para a obtenção de uma arquitetura de qualidade.

A aplicação do método dos "patterns" abarca os quatro mais significativos campos da experiência humana: espacial, psicológico, fisiológico e comportamental.

Na tabela 22, apresenta-se a relação entre o método Patterns (Parâmetros de Projeto Escolar) e os atributos e parâmetros propostos na pesquisa. 


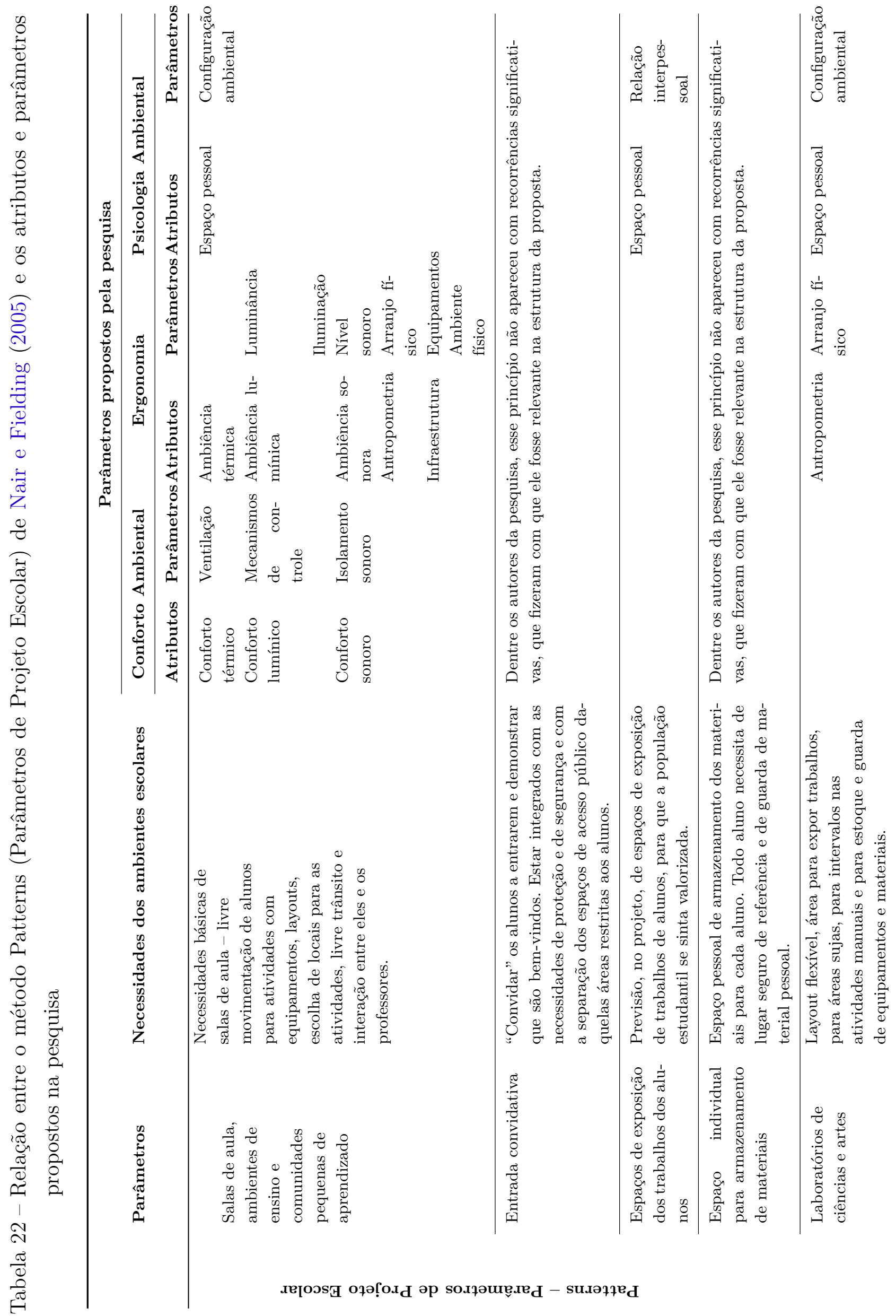




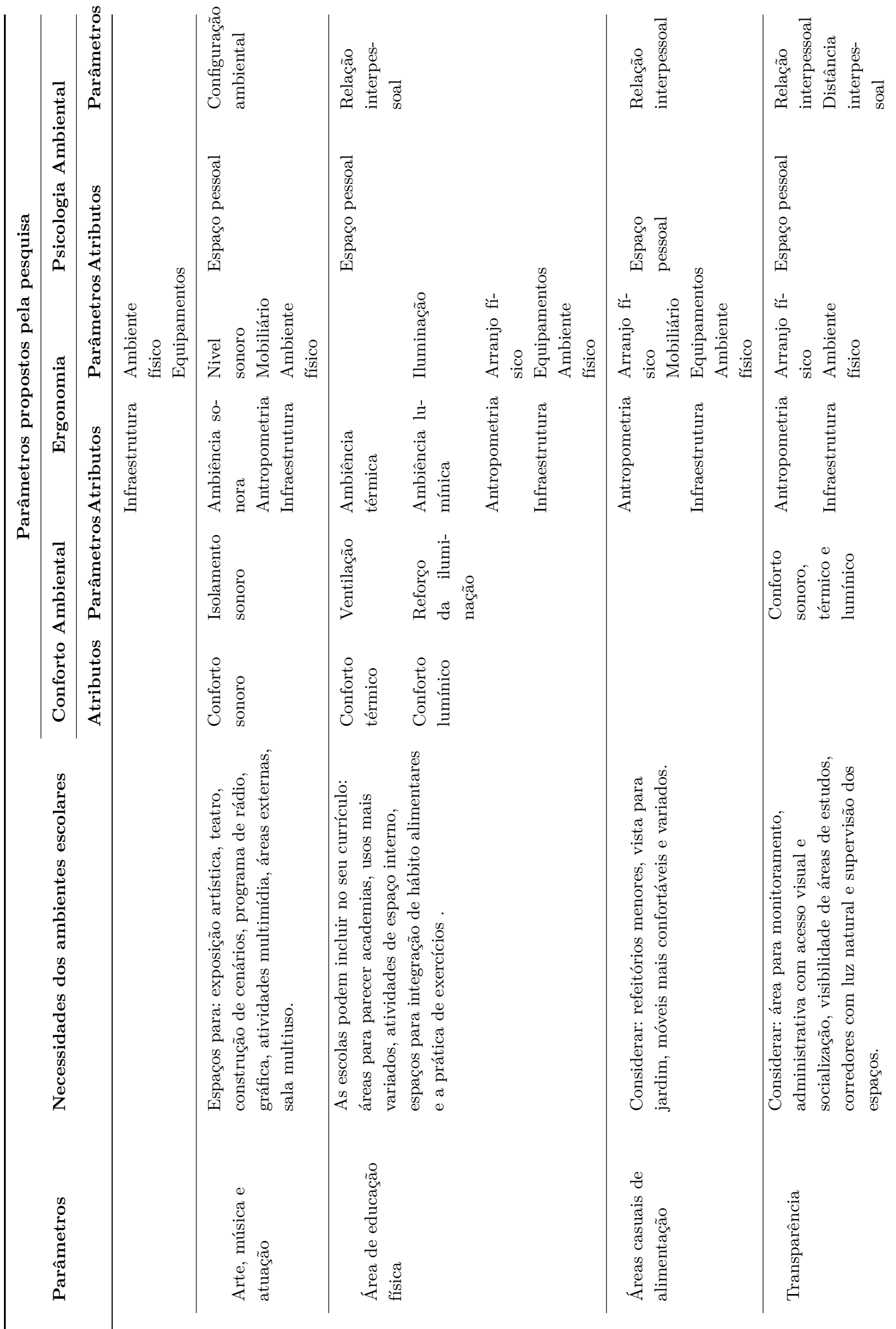




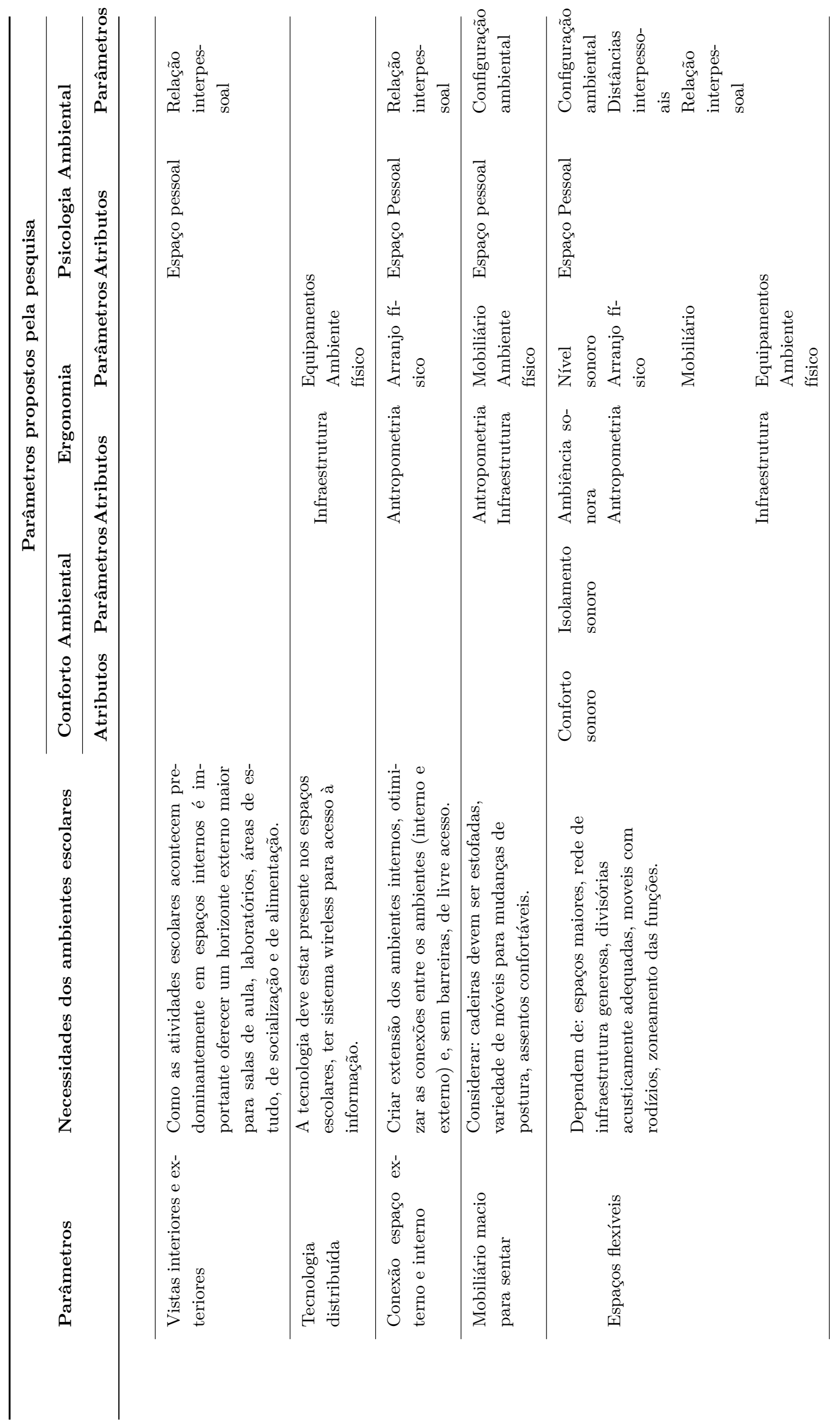




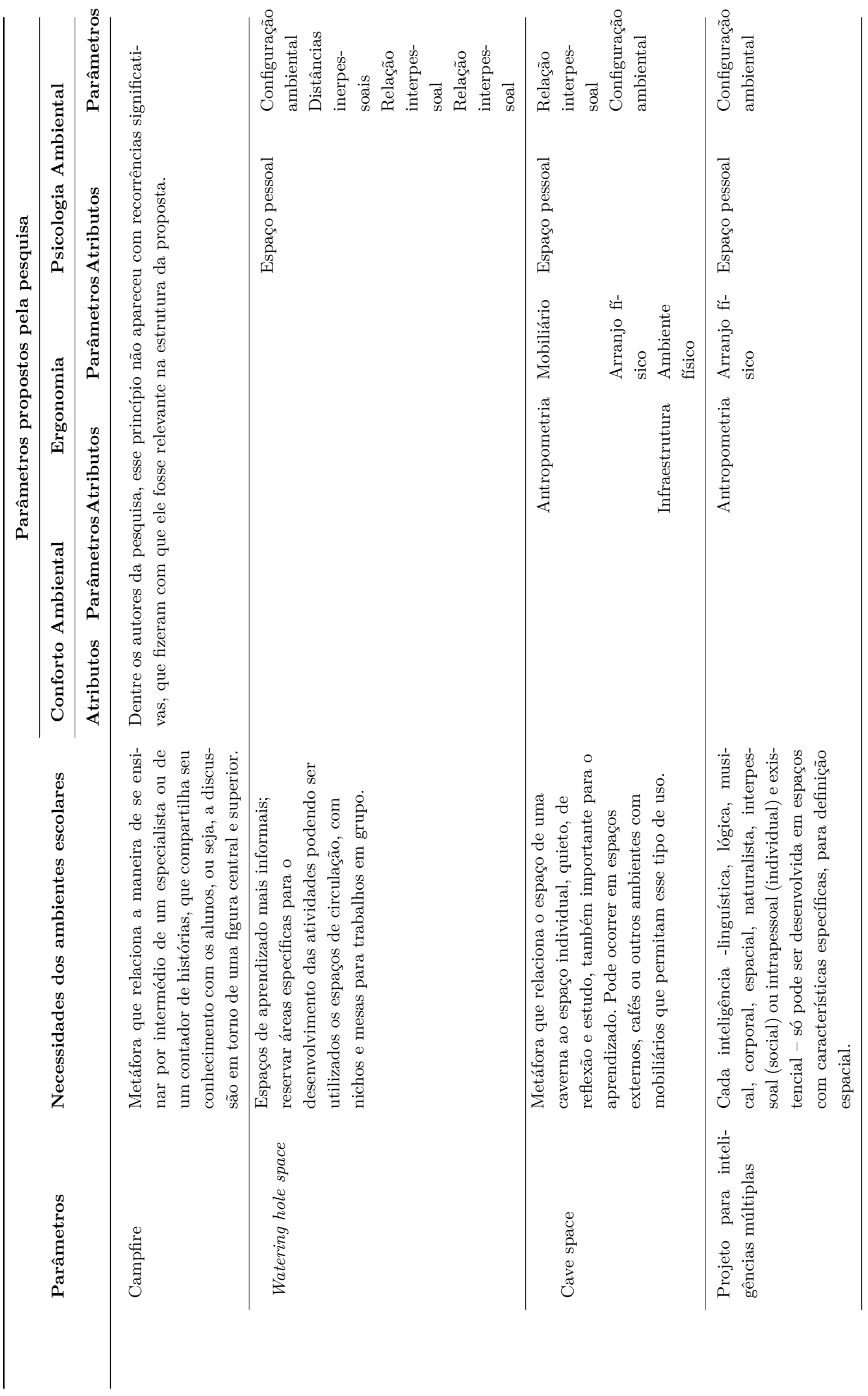




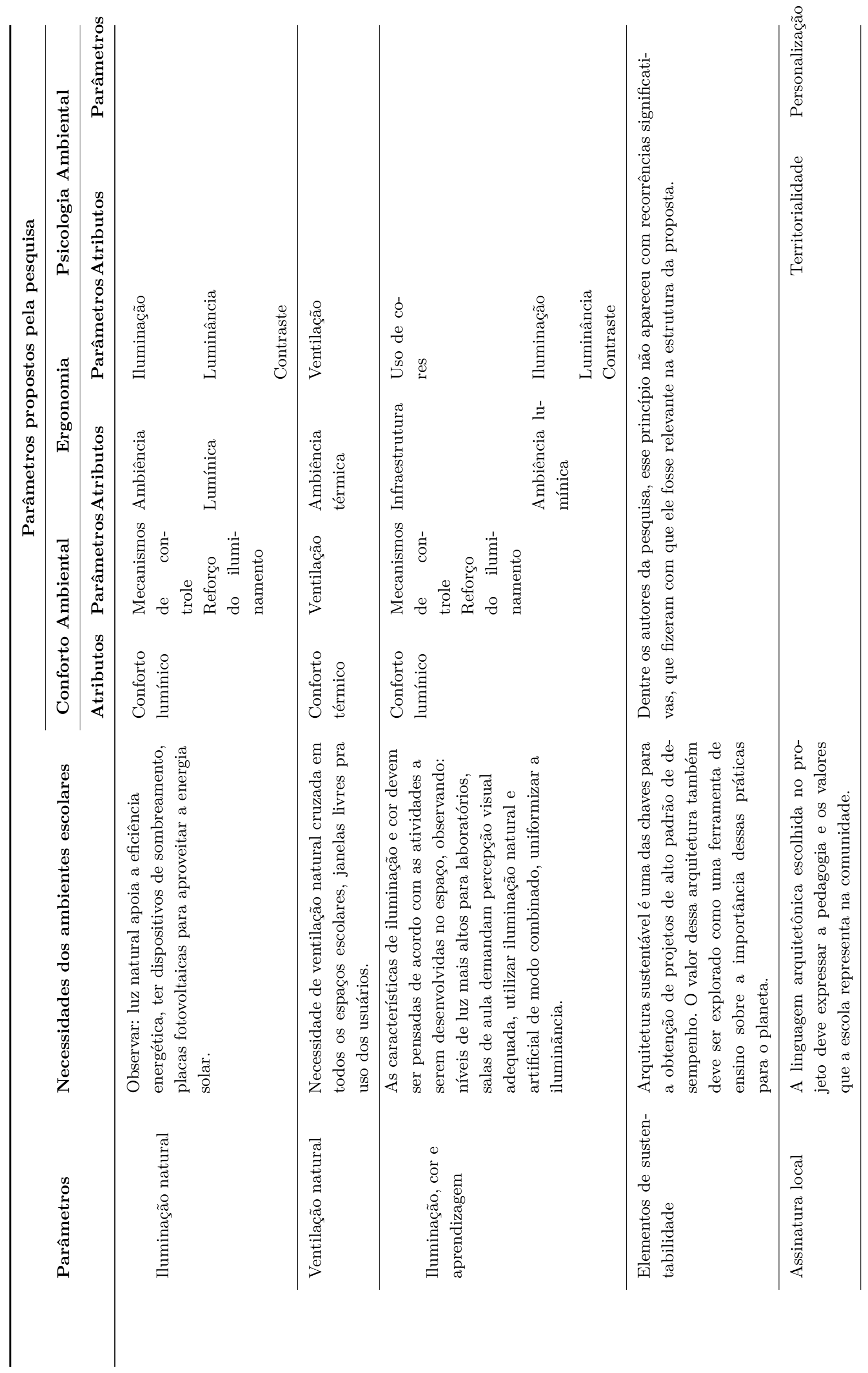




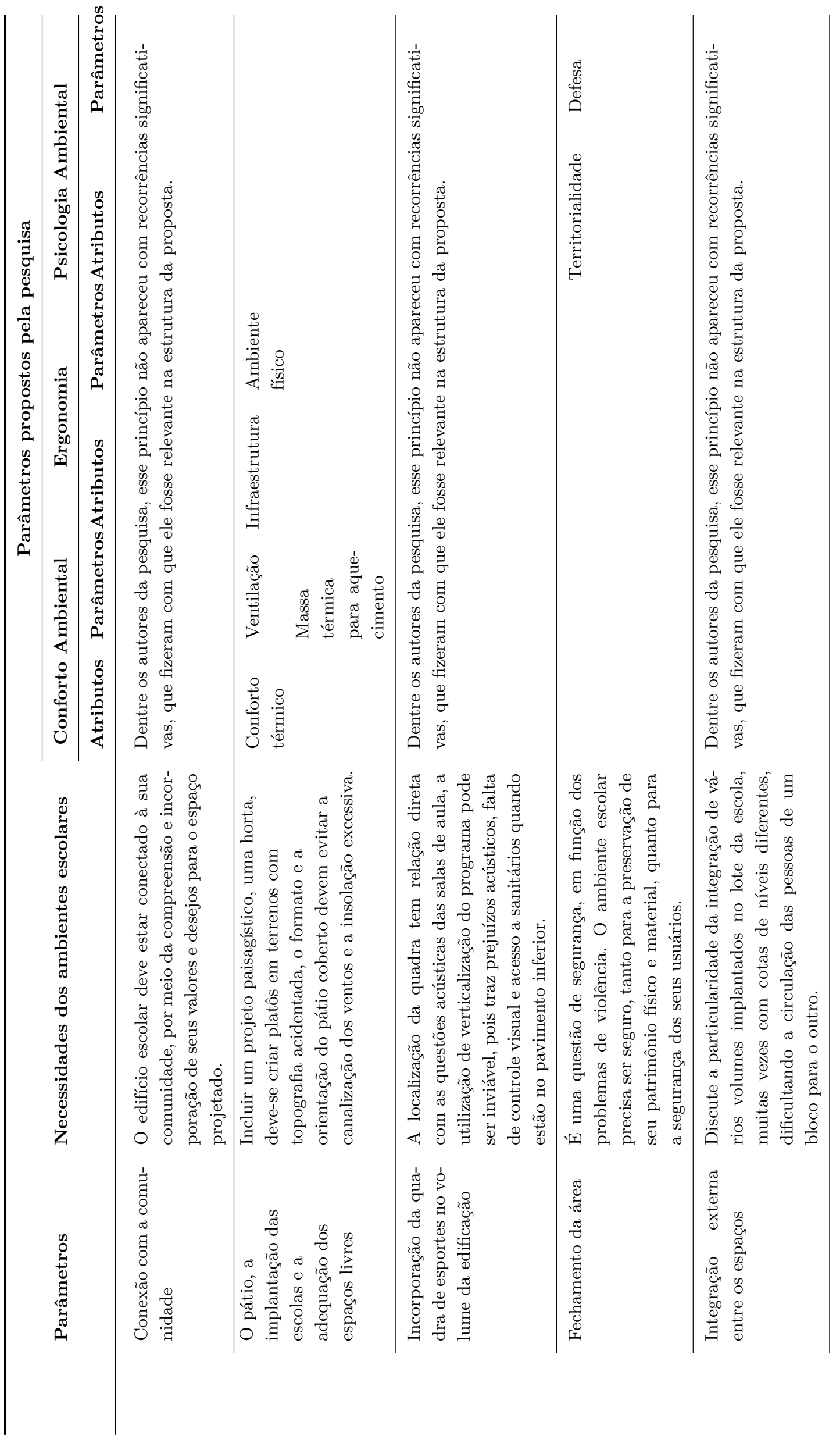




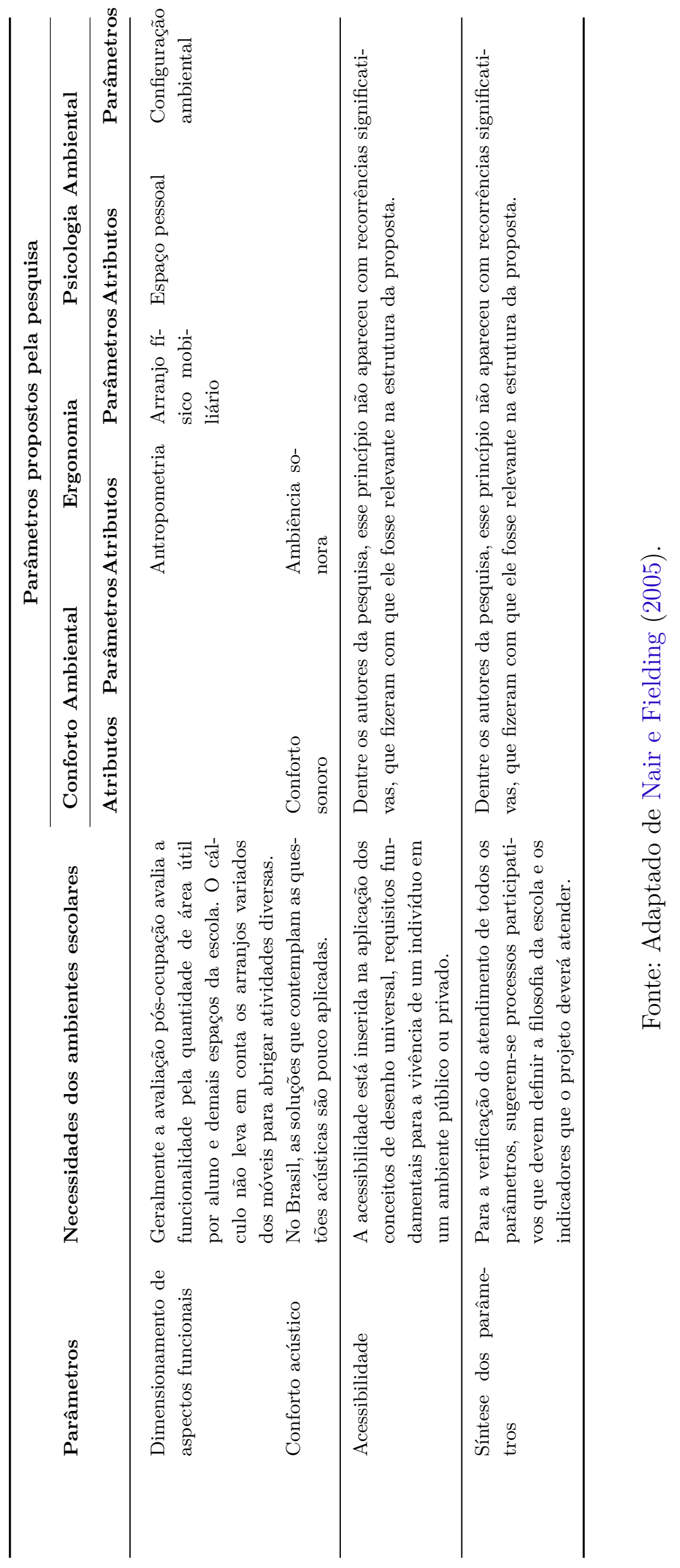




\subsection{Identificação das características espaciais facilitadoras do ensino- aprendizado}

Este item trata da identificação dos atributos espaciais que impactam na qualidade e na relevância do aprendizado por meio das diferentes abordagens estudadas. A síntese foi ordenada pelos campos disciplinares analisados, denominados categorias que estruturaram os atributos espaciais associados à qualidade do espaço construído de modo a se constituir num facilitador do aprendizado.

A síntese dos atributos, constante da Tabela 23, corresponde às relações recorrentes e relevantes identificadas nessa pesquisa para construção da relação espaço/ensino/aprendizagem e que corrobora com a premissa de trabalho da tese.

Tabela 23 - Atributos dos espaços arquitetônicos facilitadores do ensino-aprendizagem

\begin{tabular}{|c|c|c|c|}
\hline $\begin{array}{l}\text { Campo } \\
\text { discipli- } \\
\text { nar }\end{array}$ & Conceito & Atributo & Descritor \\
\hline \multirow{3}{*}{ 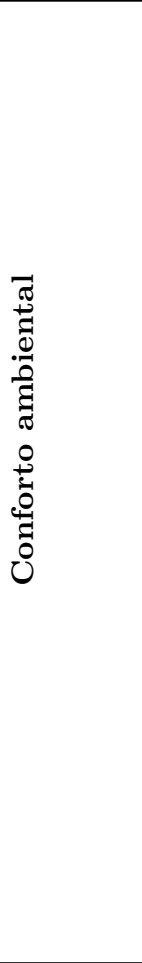 } & \multirow{3}{*}{$\begin{array}{l}\text { Os fatores externos podem } \\
\text { contribuir ou retardar o } \\
\text { processo de } \\
\text { ensino-aprendizagem } \\
\text { dependendo da natureza de } \\
\text { cada elemento: acústica, } \\
\text { temperatura, iluminação e } \\
\text { conforto visual. }\end{array}$} & $\begin{array}{l}\text { Conforto tér- } \\
\text { mico }\end{array}$ & $\begin{array}{l}\text { Consiste no conjunto de condições em que } \\
\text { os mecanismos de autorregulação são míni- } \\
\text { mos, ou ainda na zona delimitada por ca- } \\
\text { racterísticas térmicas em que o maior nú- } \\
\text { mero de pessoas manifestem se sentir bem } \\
\text { (GARCÍA, } 1995, \text { p. 199). }\end{array}$ \\
\hline & & $\begin{array}{l}\text { Conforto } \\
\text { lumínico }\end{array}$ & $\begin{array}{l}\text { Fenômeno físico resultante da exposição de } \\
\text { uma fonte de luz num ambiente que pode } \\
\text { absorver ou refletir a luz, tornando-se vi- } \\
\text { sível. Grau de satisfação visual produzido } \\
\text { pelo ambiente iluminado. Propõe reduzir } \\
\text { ofuscamentos visuais, equilibrar a luminân- } \\
\text { cia e ampliar a reprodução de cores, permi- } \\
\text { tindo que o olho tenha uma perfeita dimen- } \\
\text { são dos espaços do ambiente, volume das } \\
\text { formas, texturas dos materiais e fidelidade } \\
\text { de cores. }\end{array}$ \\
\hline & & $\begin{array}{l}\text { Conforto } \\
\text { sonoro }\end{array}$ & $\begin{array}{l}\text { Ramo da física que estuda o som. O som } \\
\text { é um fenômeno ondulatório causado pelos } \\
\text { mais diversos objetos e se propaga através } \\
\text { dos diferentes estados físicos da matéria. }\end{array}$ \\
\hline \multirow[t]{2}{*}{ 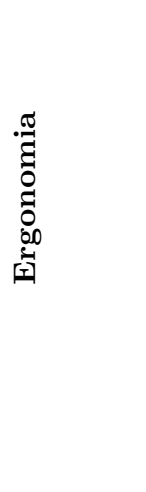 } & \multirow{2}{*}{$\begin{array}{l}\text { Conjunto de conhecimentos } \\
\text { a respeito do desempenho } \\
\text { do homem em atividade, a } \\
\text { fim de aplicá-los à } \\
\text { concepção das tarefas dos } \\
\text { instrumentos, das máquinas } \\
\text { e dos sistemas de produção. }\end{array}$} & $\begin{array}{l}\text { Ambiência } \\
\text { térmica }\end{array}$ & $\begin{array}{l}\text { Trata-se do microclima do posto de tra- } \\
\text { balho. Numa edificação, este pode variar } \\
\text { de uma zona a outra do local, conforme o } \\
\text { processo utilizado, mas também sofrer a in- } \\
\text { fluência do clima exterior de suas vibrações } \\
\text { sazonais. }\end{array}$ \\
\hline & & $\begin{array}{l}\text { Ambiência lu- } \\
\text { mínica }\end{array}$ & $\begin{array}{l}\text { É a quantidade de luz natural ou artificial } \\
\text { no nível da situação de trabalho. Uma ilu- } \\
\text { minação incorreta induz à fadiga, ao des- } \\
\text { conforto, mas não provoca, a priori, ne- } \\
\text { nhuma doença profissional. }\end{array}$ \\
\hline
\end{tabular}




\begin{tabular}{|c|c|c|c|}
\hline $\begin{array}{l}\text { Campo } \\
\text { discipli- } \\
\text { nar }\end{array}$ & Conceito & Atributo & Descritor \\
\hline & & $\begin{array}{l}\text { Ambiência } \\
\text { sonora }\end{array}$ & $\begin{array}{l}\text { Compreende a exposição a ruídos no local } \\
\text { de trabalho. A nocividade do ruído para a } \\
\text { audição está ligada a três parâmetros: o } \\
\text { nível sonoro, a frequência e a duração da } \\
\text { exposição. }\end{array}$ \\
\hline & & Vibração & $\begin{array}{l}\text { É qualquer movimento que o corpo ou } \\
\text { parte dele executa em torno de um ponto } \\
\text { fixo. Esse movimento pode ser regular, do } \\
\text { tipo senoidal ou irregular, quando não se- } \\
\text { gue nenhum padrão determinado. }\end{array}$ \\
\hline & & Antropometria & $\begin{array}{l}\text { Ramo das ciências humanas que se ocupa } \\
\text { do estudo das dimensões e proporções do } \\
\text { corpo humano, forma, forças e capacidade } \\
\text { de trabalho. Sua grande dificuldade reside } \\
\text { na variabilidade das medidas do corpo hu- } \\
\text { mano entre os diferentes indivíduos, de- } \\
\text { vido às diferenças dos gêneros, raças, idade, } \\
\text { clima e de época. }\end{array}$ \\
\hline & & Infraestrutura & $\begin{array}{l}\text { O projeto correto das máquinas, postos de } \\
\text { trabalho e do ambiente influem no desem- } \\
\text { penho do trabalhador. Da mesma forma, } \\
\text { o projeto adequado dos mobiliários, salas } \\
\text { de aula, bibliotecas, laboratórios, e outros } \\
\text { meios de apoio didático, podem influir no } \\
\text { desempenho dos professores e alunos. }\end{array}$ \\
\hline \multirow{3}{*}{ 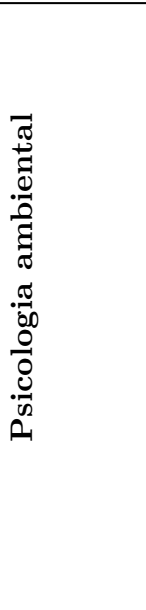 } & \multirow{3}{*}{$\begin{array}{l}\text { Indivíduos, por meio de } \\
\text { suas ações, modificam o } \\
\text { ambiente e ambientes, por } \\
\text { meio de suas configurações, } \\
\text { influenciam o } \\
\text { comportamento humano. }\end{array}$} & $\begin{array}{l}\text { Espaço pes- } \\
\text { soal }\end{array}$ & $\begin{array}{l}\text { Espaço invisível que circunda o indivíduo } \\
\text { e funciona como um regulador das relações } \\
\text { interpessoais. }\end{array}$ \\
\hline & & Territorialidade & $\begin{array}{l}\text { O indivíduo demarca um território, usando } \\
\text { aspectos existentes de seu meio ambiente } \\
\text { ou pela modificação de seu ambiente para } \\
\text { estabelecer marcações ou limites. Essas li- } \\
\text { nhas de demarcação são entendidas e res- } \\
\text { peitadas por outros indivíduos. }\end{array}$ \\
\hline & & Privacidade & $\begin{array}{l}\text { É a gestão do indivíduo sobre as informa- } \\
\text { ções de si mesmo e sobre a sua interação } \\
\text { com as outras pessoas. "É um controle sele- } \\
\text { tivo de acesso a si próprio ou ao seu grupo". }\end{array}$ \\
\hline
\end{tabular}

Fonte: Elaboração própria (2015/2016).

De modo a poder contribuir para a elaboração do programa de necessidades se faz relevante definir para cada atributo os parâmetros que devem ser considerados para que o atributo compareça na configuração espacial do edifício escolar. Nesse sentido, ainda baseado na pesquisa realizada, apresentam-se na Tabela 24 o campo disciplinar, os atributos e parâmetros na estrutura metodológica de elaboração de programas de necessidades. 


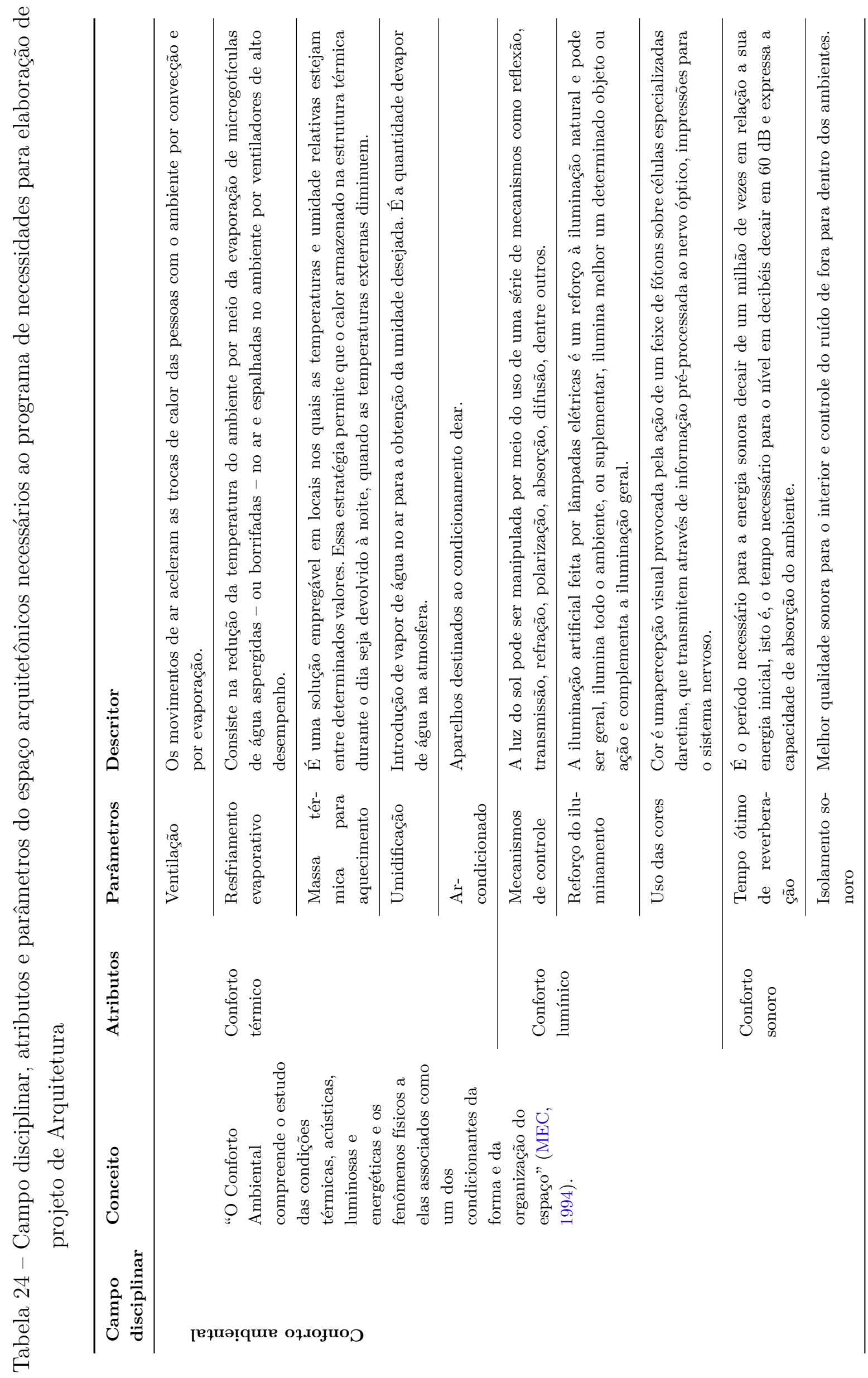




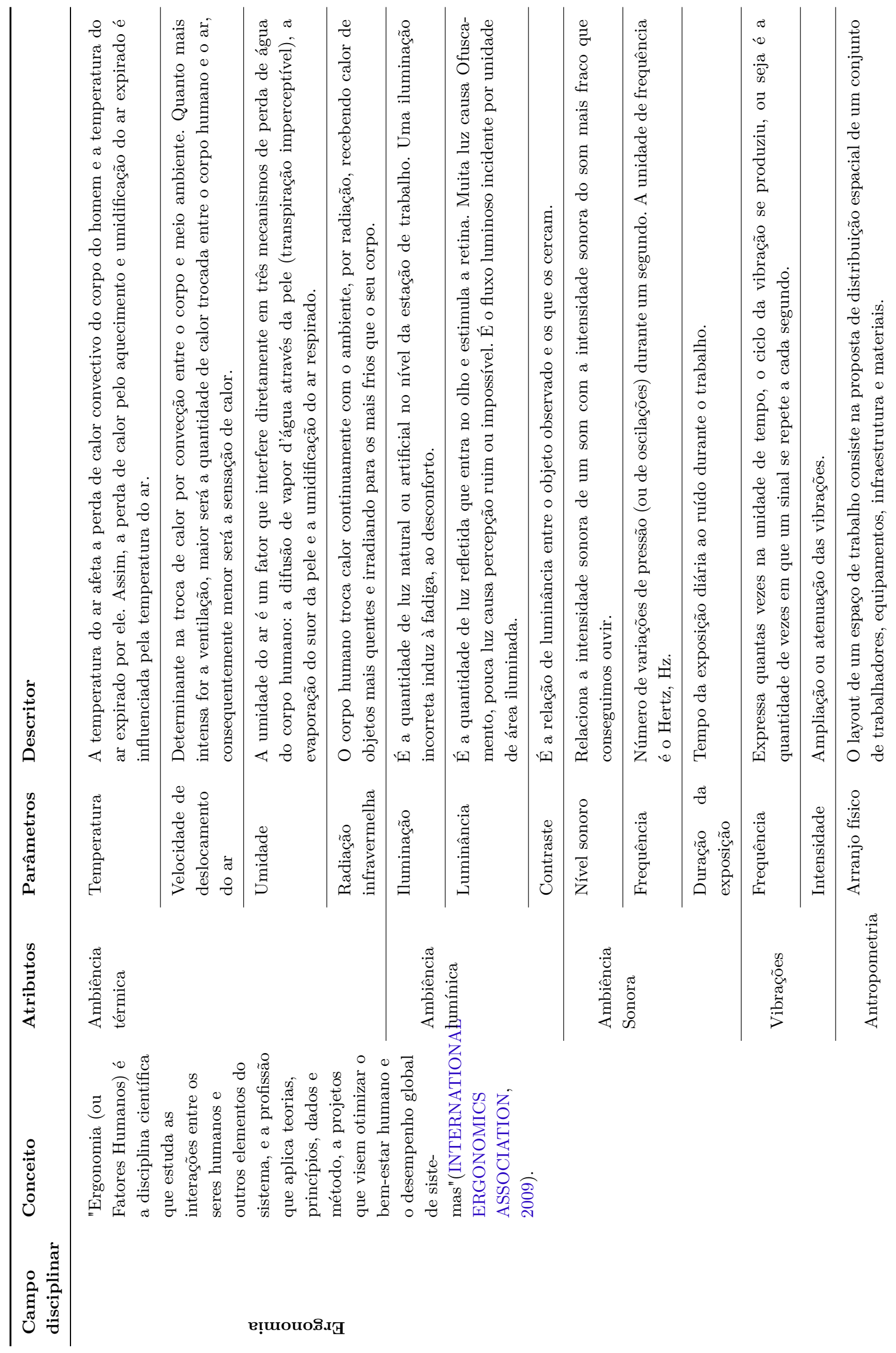




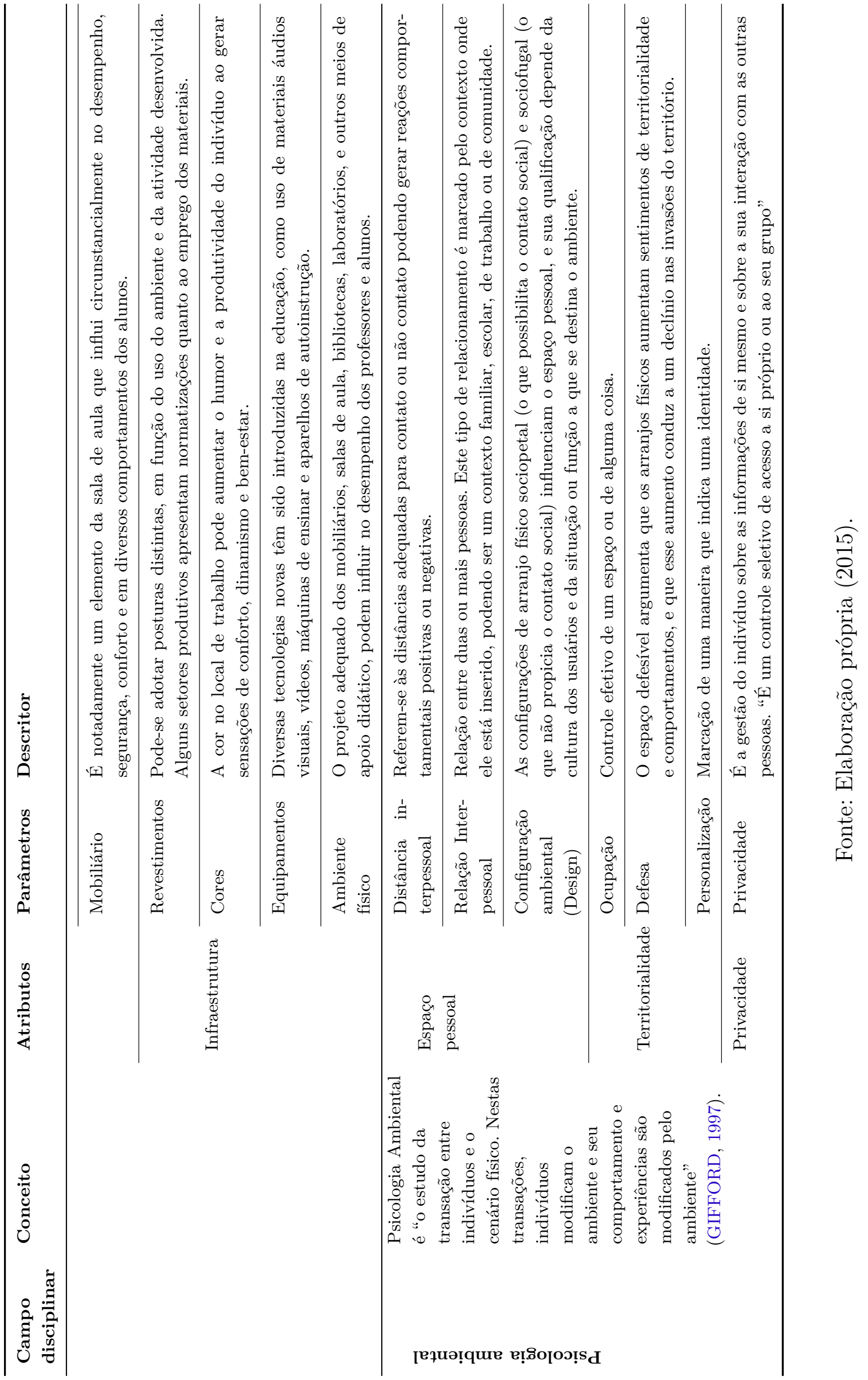





\section{Método de avaliação dos atribu- tos/parâmetros facilitadores do ensino- aprendizagem e bases para o modelo de arquitetura da informação}

O capítulo procede à discussão conceitual da metodologia de Análise Multicritério e sua aplicabilidade para validar quadro de atributos/parâmetros que foi obtido com a pesquisa bibliográfica. É apresentada a estruturação do Modelo Multicritério de Apoio à Decisão (MCDA-C) com enfoque para a identificação do contexto decisório, construção do modelo de avaliação e análise de sensibilidade. Ao final, como parte necessária, a aplicação do método foi elaborado questionário e aplicado aos professores do curso de Arquitetura e Urbanismo da FAU/UnB, grupo de atores do estudo de caso. Apresenta considerações conceituais sobre a construção da Arquitetura da Informação e como esta pode se constituir em um instrumento de apoio ao programa de necessidades arquitetônicas.

\subsection{Escolha do método adequado ao tema da pesquisa}

A revisão bibliográfica sintetizada nos capítulos 1, 2 e 3 contemplou o referencial teórico de suporte à pesquisa, quando foram definidos conceitos para os termos que norteiam a área de educação e arquitetura, seguindo pela discussão dos três campos disciplinares onde a relação entre espaço e ensino-aprendizagem se faz mais evidente, chegando à identificação de quadro de atributos/parâmetros. Para sua aplicabilidade na elaboração de programa de necessidades de projetos de arquitetura de espaços adequando a aprendizagem, faz-se necessário validação e ajuste a tipos específicos de espaços de ensino, o que se constitui num problema de tomada de decisão.

O estudo de metodologias que pudessem apoiar a validação para casos específicos nos remeteu a teorias de apoio a decisão e, por fim, à metodologia de análise muticritério, o que levou à necessidade de construir um Modelo Multicritério de Apoio à Decisão para embasamento ao programa de necessidades para projetos de escolas de arquitetura que será aplicado aos professores da FAU que responderam às perguntas de acordo com seu juízo de valor, ou seja, conforme sua avaliação do espaço arquitetônico das condições que considera ideais para ministrar sua disciplina e que é relevante para o ensino-aprendizagem. 
Capítulo 4. Método de avaliação dos atributos/parâmetros facilitadores do ensino-aprendizagem e bases 170 para o modelo de arquitetura da informação

\subsubsection{Fundamentos teóricos da análise Multicritério}

As origens da Metodologia Multicritério de Apoio à Decisão datam do final da década de 1960, quando a comunidade científica começou a buscar alternativas para a Pesquisa Operacional tradicional para a solução de problemas complexos e mal estruturados Ensslin, Neto e Noronha (2001). De acordo com Quirino (2002), no inicio dos anos 1970, uma nova fase do processo de apoio à decisão começou a tomar forma, quando os estudos se intensificaram em busca de um novo paradigma metodológico para a solução de problemas com esse nível de complexidade.

O reconhecimento da importância das metodologias multicritério culminou com a realização, em outubro de 1972, da I Conferência Mundial sobre a Tomada de Decisões Multicritério, na universidade da Carolina do Sul, evento que é considerado a pedra fundamental dessa metodologia. De acordo com Romero (1993), foi constituído, então, um grupo de estudos sobre tomada de decisão multicritério (Special Interest Group on Multiple Criteria Decision Making), o qual posteriormente se transformou na Sociedade Internacional de Tomada de Decisões Multicritério (International Society on Multiple Criteria Decision Making).

A abordagem tradicional monocritério, considera que as decisões são tomadas sob o ponto de vista de um único decisor, para um conjunto bem definido de alternativas possíveis, comparáveis entre si com base em um único critério e que os problemas possuem uma formalização matemática bem definida (ROY, 1990).

As Metodologias Multicritério de Apoio à Decisão, por sua vez, auxiliam na interação entre atores para a construção de uma estrutura e uma linguagem de comunicação partilhada por todos dando suporte para a avaliação e comparação de opções e o estabelecimento de compromissos entre diferentes organizações e sistemas de valores.

Para Roy (1990), os modelos multicritérios podem auxiliar na tomada de decisão em nível nacional e local, em uma companhia, fábrica ou departamento, ou mesmo dentro de uma família. Nesses contextos, as decisões se relacionam a planos de desenvolvimento, políticas de desenvolvimento regional, estratégias para implementação de serviços de trem de alta velocidade, localizações para indústrias ou empreendimentos etc. Para Bana e Costa (2001), quando as atividades de planejamento e gestão são entendidas como indissociáveis da interação com os agentes envolvidos nos processos de decisão, surge a necessidade de aplicar metodologias de avaliação que tornem possível considerar e confrontar diretamente diferentes objetivos e pontos de vista.

Em uma análise multicritério, o conjunto de critérios representa os diferentes eixos por meio dos quais os vários atores do processo de decisão justificam, transformam e demonstram suas preferências. Dessa forma, as comparações feitas a partir desses critérios são interpretadas como preferências parciais, isto é, preferências restritas aos aspectos 
levados em consideração para a definição do critério. Os pontos de vista sobre os quais são definidos os critérios devem ser entendidos e aceitos por todos os atores, ainda que estes discordem sobre sua importância relativa. Além disso, os critérios devem ser suficientemente familiares para que os atores possam fazer discussões a respeito deles.

Bana e Costa (2001) afirma que, a análise de decisão necessita de aplicação de metodologias e técnicas para ajudar a melhorar as tomadas de decisão em organizações públicas e privadas, na indústria e nos serviços, em contextos que envolvem: incertezas, risco, múltiplos objetivos, avaliação de estratégias e alternativas, alocação de recursos, decisão em grupo, negociação etc. Considera nesses processos as etapas fundamentais: definir o problema, especificar valores, identificar opções, compreender as consequências, estabelecer compensações, clarificar incerteza e analisar tolerância de risco.

De acordo com Quirino (2002), no contexto decisório, a metodologia MCDA apresenta três convicções básicas do processo decisório:

- as características subjetiva e objetiva são inseparáveis e interligadas. A subjetiva relaciona-se ao juízo de valor dos atores, enquanto a objetiva, às ações na tomada de decisão;

- os atores tem uma aprendizagem na participação e começam a entender e a interpretar melhor o seu juízo de valor, por meio dos conhecimentos adquiridos;

- a visão construtivista é a metodologia necessária na construção de um modelo, que espelhe as preferências dos atores tanto no entendimento do problema, como na geração do conhecimento para alcançar os objetivos desejados.

Essas características são essenciais para a validação dos resultados obtidos na pesquisa diante de um contexto de múltiplos decisores e opções de decisão como é o caso de um colegiado de professores de diferentes disciplinas tendo que decidir sobre um conjunto de atributos e parâmetros de qualidade espacial que interfere no ensino e aprendizagem como o que foi definido na pesquisa.

\subsubsection{Processo decisório e a MCDA}

O método tem sido utilizado para subsidiar processos de tomada de decisão, permitindo ao decisor identificar claramente seus objetivos, mensurar-los e visualizar o impacto das alternativas no conjunto dos mesmos. Além disso, o método considera que o processo de tomada de decisão não deve ser feito somente com base em critérios objetivos e quantitativos, destacando a necessidade de se incorporar fatores subjetivos, ainda que estes impliquem dificuldades operacionais para o processo de análise. Dessa forma, o modo 
Capítulo 4. Método de avaliação dos atributos/parâmetros facilitadores do ensino-aprendizagem e bases 172 para o modelo de arquitetura da informação

como o decisor percebe a realidade é condicionante para a forma como é estruturado o problema (SABOYA et al., 2005).

Roy (1990) destaca que um modelo multicritério consiste em um esquema que permite a representação de um determinado fenômeno, auxiliando na investigação e facilitando a comunicação entre os atores. A representação desse fenômeno pode se dar de uma forma mais intuitiva ou de uma forma mais rigorosa, neste caso, baseada exclusivamente em fatos, dados quantitativos e lógica.

Para a estruturação de um processo de decisão, Malczewski (1999) identifica uma série de elementos para sua estruturação:

- objetivo ou conjunto de objetivos que devem ser atingidos;

- decisor ou grupo de decisores envolvidos no processo e suas preferências no que diz respeito aos critérios de avaliação;

- conjunto de critérios de avaliação (elementos e/ou atributos) com base nos quais os decisores irão avaliar as alternativas de ação;

- conjunto de variáveis externas ou fora do controle dos decisores (estados da natureza);

- conjunto de consequências ou resultados associados a cada uma das alternativas.

Para Bouyssou (1989), o sucesso do processo de decisão está na forma como cada critério (ou critérios) é construído, tanto em uma avaliação monocritério, como numa avaliação multicritério. Em uma análise multicritério, o conjunto de critérios representa os diferentes eixos por meio dos quais os vários atores do processo de decisão justificam, transformam e demonstram suas preferências. Dessa forma, as comparações feitas a partir desses critérios são interpretadas como preferências parciais, isto é, preferências restritas aos aspectos levados em consideração para a definição do critério. Os pontos de vista sobre os quais são definidos os critérios devem ser entendidos e aceitos por todos os atores, ainda que estes discordem sobre sua importância relativa. Além disso, os critérios devem ser suficientemente familiares para que os atores possam fazer discussões a respeito deles.

Além da dificuldade em se definir uma família de critérios que represente todos os pontos de vista relevantes para o processo de decisão, há muitas vezes dificuldade em se quantificar a importância relativa dos critérios, uma vez que estes podem ter graus de importância variáveis para diferentes decisores. Dessa forma, é necessário definir a importância relativa de cada critério no processo de decisão, o que é feito, normalmente, atribuindo um determinado peso a cada critério interveniente. A correta atribuição de pesos é importante para que seja mantidas as preferências dos decisores (SILVA et al., 2004). 
Segundo Silva et al. (2004), outra questão reside na comparação dos critérios para a tomada de decisão. Normalmente os valores de diferentes critérios não são comparáveis entre si, o que inviabiliza para sua agregação imediata. Para resolver esse problema é necessário normalizar para uma mesma escala de valores a forma de avaliar os diferentes critérios. Para tal, existem diferentes processos de normalização, os quais podem ser vistos em maior detalhe em (MENDES, 1999).

Uma vez normalizados os scores dos critérios para intervalo fixo, estes podem ser agregados de acordo com a regra de decisão. Nesse sentido, muitos critérios podem ser utilizados para a combinação de critérios. Alguns desses métodos (combinacão linear ponderada, média ponderada ordenada, entre outros) podem ser vistos em Mendes (1999), Malczewski (1999) e Silva et al. (2004).

De acordo com Quirino (2002), a metodologia MCDA consegue fazer a interação do modelo construído com o tomador de decisão (dono do problema) e é capaz de gerar critérios de avaliação condizentes à situação real do problema estudado, segundo o juízo de valor dos avaliadores, e não impostos de forma normativa e dogmática.

Ainda conforme Quirino (2002), a escolha do tema desta pesquisa - modelo MCDA - justifica-se pelo fato de não ser um modelo predeterminado, mas sim, construído, com base na tendência epistemológica de Piaget e sua visão construtivista: "conhecimento como resultado da relação entre o sujeito e o objeto em estudo" (LANDRY, 1995, p. 317). Ainda, segundo Quirino (2002), a metodologia MCDA consiste basicamente em quatro fases distintas, intrinsecamente correlacionadas:

- estruturação do modelo;

- determinação dos pesos, dos níveis dos descritores, dos critérios e subcriterios;

- avaliação dos PVEs e/ou SubPVEs;

- considerações finais.

A fase de estruturação, de acordo com Ensslin, Neto e Noronha (2001), visa ao entendimento do problema e de todo o contexto em que ele está inserido. Para alcançar tal entendimento, uma estrutura, aceita/negociada por todos os decisores é construída. Essa estrutura deverá representar, de forma organizada, os objetivos, seus fatores explicativos e a forma como estes serão alcançados.

Para chegar a tal representação, são necessárias as seguintes subetapas: i) caracterização do contexto e identificação dos atores; ii) identificação dos elementos primários de avaliação (EPA); iii) agrupamento dos EPA por afinidade (áreas de interesse); iv) construção da árvore de pontos de vista (estruturas hierárquicas de objetivos) e mapas de relação meios-fins; e v) construção dos descritores dos objetivos considerados. 
Capítulo 4. Método de avaliação dos atributos/parâmetros facilitadores do ensino-aprendizagem e bases 174 para o modelo de arquitetura da informação

A fase de avaliação visa à construção de um modelo matemático, conforme a percepção dos decisores, no qual as alternativas serão avaliadas. O modelo matemático será resultado da realização das seguintes etapas: i) construção das funções de valor; ii) identificação das taxas de compensação/substituição entre objetivos; iii) identificação do perfil de desempenho; e iv) avaliação global.

A fase de recomendação procura fornecer subsídios aos decisores/organização, por meio de algumas ferramentas, para que estes tenham condições de aperfeiçoar cada alternativa e de analisar qual o conjunto de alternativas que mais contribui para a organização como um todo.

Essa situação se enquadra nos termos da pesquisa que já identificou um conjunto de relações entre o espaço arquitetônico e seus efeitos na aprendizagem de modo genérico sobre os diferentes tipos de ensino e necessita de uma "decisão" sobre o caso especifico do ensino-aprendizagem de arquitetura que, por sua vez, possui no coletivo dos professores e suas disciplinas na FAU/UnB a comunidade de "decisores".

Como referido, a metodologia é uma forma de analisar situações complexas, que são caracterizadas por um conjunto de indicadores distintos, incluindo indicadores financeiros, indicadores físicos, indicadores de insumos, processos, produtos e resultados, e indicadores quantitativos e qualitativos. Nesse sentido, é apresentado a seguir o Modelo Multicritério de Apoio à Decisão, que permite integrar critérios qualitativos e quantitativos, bem como atender às particularidades do processo de definição de parâmetros para a elaboração de programa de necessidades para o campo disciplinar da Arquitetura e Urbanismo, especialmente no que diz respeito à multiplicidade de atores e seus diferentes pontos de vista.

Nos modelos de análise multicritério em que o processo decisório utiliza o paradigma construtivista, levam-se em conta os aspectos subjetivos dos decisores. Cada decisor percebe e interpreta de forma diferente o contexto decisório porque eles têm diferentes valores individuais, objetivos, crenças, relações sociais e de poder. No paradigma construtivista, os modelos buscam descrever de forma mais adequada possível à realidade dos decisores, levando em conta os aspectos subjetivos dos decisores para resolver o problema real. Portanto os modelos, neste paradigma, descrevem um problema que depende das pessoas que estão decidindo (Figura 16). 


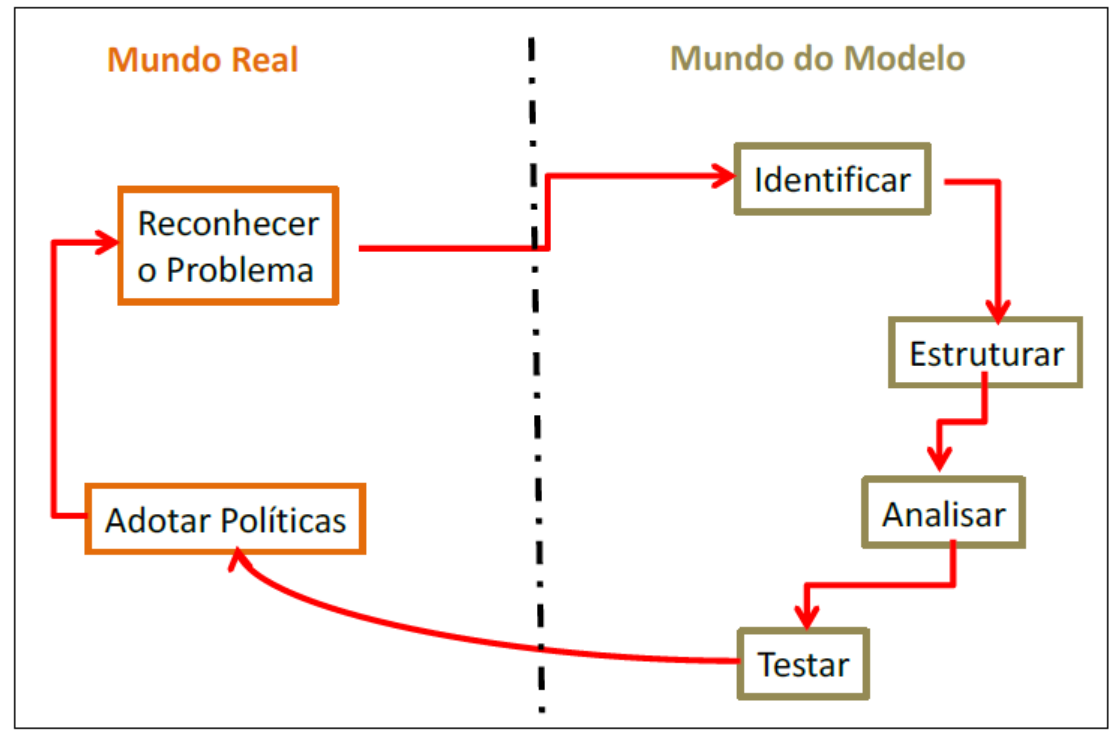

Figura 16 - Ligação entre o Mundo Real e do Modelo

Fonte: adaptado de Keisler e Noonan (2012)

Nesse sentido, segue a modelagem que permitiu integrar critérios qualitativos e quantitativos, bem como atender às particularidades do processo de definição de parâmetros para a elaboração de programa de necessidades para o campo disciplinar da Arquitetura e Urbanismo, especialmente no que diz respeito à multiplicidade de atores e seus diferentes pontos de vista.

\subsection{Estruturação do Modelo MCDA-C}

A construção do Modelo Multicritérios para apoiar a Decisão inicia com a definição dos Pontos de Vista Fundamentais (PVFs - critérios), Pontos de Vista Elementares (PVEs) e Subpontos de Vista Elementares (SubPVEs - subcritérios) que suportam a elaboração do questionário e depois a análise de seus resultados. Foram inicialmente definidos com os dados da pesquisa bibliográfica e posteriormente ajustados com apoio de professores das referidas áreas: Conforto Ambiental, Ergonomia e Psicologia Ambiental na avaliação dos critérios.

O modelo ainda prescinde de um grupo de decisores na nomenclatura da metodologia multicritério que, no caso da pesquisa, foi apoiada por especialistas ${ }^{1}$ nas diferentes áreas que envolvem a decisão (Conforto Ambiental, Ergonomia e Psicologia Ambiental). Esse grupo apoiou a pesquisadora a estratificar o que foi encontrado na literatura e identificando o grau de relevância (ordenamento de cada PVE e SubPVE) por meio de pesos para cada um, conforme seu grau de importância. Por fim, o grupo de pesquisa foram os professores

1 Os especialistas que estruturaram o Modelo Multicritério de Apoio à Decisão - prof. Dr. Otto Ribas, da Faculdade de Arquitetura e Urbanismo; prof. Dr. Hartmut Gunther, do Instituto de Psicologia; e prof. Dr. Francisco Aviani, do Desenho Industrial, todos da Universidade de Brasília. 
Capítulo 4. Método de avaliação dos atributos/parâmetros facilitadores do ensino-aprendizagem e bases 176 para o modelo de arquitetura da informação

das diferentes áreas na Universidade de Brasília para apoiar essa fase da pesquisa, bem como na própria utilização do método de multicritérios.

\subsubsection{Operacionalização da análise multicritério ao estudo de caso}

A construção do modelo de avaliação, com base em Ensslin, Neto e Noronha (2001), com os ajustes que se fizeram necessários, constou das seguintes etapas básicas:

- definição pelos decisores de um rótulo para o problema;

- contexto decisório (Título);

- identificação de todos os atores envolvidos no processo decisório (pesquisa);

- identificação dos elementos de avaliação (critérios);

- construção da árvore de valor;

- construção dos descritores;

- construção das funções de valor;

- determinação das taxas de substituição.

\subsubsection{Definição do rótulo}

Com base em Ensslin, Neto e Noronha (2001), o rótulo tem a função de delimitar o contexto decisório de tal forma a manter o foco nos aspectos mais relevantes na resolução do problema. O rótulo foi definido pelos autores junto ao facilitador como sendo:

Avaliação de critérios ajustados ao ensino-aprendizagem para apoiar a elaboração do programa de necessidades de um projeto de escola de arquitetura em projetos de arquitetura.

\subsubsection{Contexto decisório}

O contexto decisório (ambiente de pesquisa) é o espaço físico da Faculdade de Arquitetura e Urbanismo da Universidade de Brasília, em um recorte do curso de Arquitetura e Urbanismo. No capítulo 5 apresenta-se a caracterização do universo do objeto de pesquisa empírica, a Faculdade de Arquitetura e Urbanismo da UnB.

\subsubsection{Identificação dos atores}

A metodologia MCDA-C apresenta uma nomenclatura própria para identificar os indivíduos ou grupos de indivíduos envolvidos no processo, denominados de atores, 
qualificando-os conforme a influência (direta ou indireta) que exercem sobre o problema. Os atores do processo decisório são assim identificados por categoria:

- Decisor - individuo ou entidade para a qual foi delegada a responsabilidade pela tomada de decisão. O decisor detém o controle sobre os meios necessários para que o processo aconteça e para que as ações posteriores sejam efetivadas.

- Facilitador - responsável por intermediar o processo, auxiliando o decisor a coletar as informações necessárias, e a estruturar o modelo de avaliação. Ao facilitador compete ainda elaborar recomendações para o decisor no final do processo de avaliação.

- Intervenientes - pessoas ou grupos que podem influenciar diretamente nas decisões por meio de seu sistema de valores.

- Agentes Externos - influenciam diretamente o processo decisório, não possuindo contato direto com o decisor. No entanto, são afetados pelas decisões tomadas e podem também pressionar os demais atores e influenciar seu sistema de valores (ROY, 1996; WOLFF et al., 2005; SABOYA et al., 2005; NETO, 2001).

O enquadramento dos atores na pesquisa foi realizado da seguinte forma:

- Decisor: neste caso, os decisores se configuram pelos docentes especialistas nas áreas de Conforto Ambiental, na área de Ergonomia e na área de Psicologia Ambiental, responsáveis por disciplinas ou coordenadores de atividades de aprendizagem.

- Facilitador: pessoa responsável em auxiliar o decisor no processo de construção do modelo de negociação e avaliação, ou seja, a pesquisadora.

- Intervenientes: indivíduos ou instituições que podem influenciar diretamente as decisões por meio de seu sistema de valores. Nesse caso, constituem-se os professores da Faculdade de Arquitetura e Urbanismo da Universidade de Brasília.

\subsubsection{Identificação dos elementos de avaliação}

Os elementos de avaliação constituem a base do processo avaliativo. Segundo Ensslin, Neto e Noronha (2001), o conjunto de passos para a identificação dos elementos são:

- identificação dos Elementos Primários de Avaliação (EPAs);

- construção de Mapas Cognitivos; e

- identificação dos Pontos de Vistas Fundamentais (PVFs). 
Capítulo 4. Método de avaliação dos atributos/parâmetros facilitadores do ensino-aprendizagem e bases 178 para o modelo de arquitetura da informação

1. Identificação dos Elementos Primários de Avaliação (EPAs): os elementos (aspectos) que o decisor e os representantes consideram relevantes dentro do contexto decisório são chamados de elementos primários de avaliação (EPA). Segundo Quirino (2002), os EPAs permitirão o início da construção do Mapa Cognitivo, técnica para identificar os PVFs (critérios) de avaliação. Os Elementos Primários de Avaliação (características) do espaço que favorecem o ensino-aprendizagem foram obtidos por meio da pesquisa bibliográfica em que vários autores consultados os diagnosticaram.

2. Construção do mapa cognitivo: não foi necessária a construção do mapa cognitivo, ou mapa de relações meios e fins, pois as EPAs foram identificadas na pesquisa bibliográfica. O mapa cognitivo nesse caso advém da própria estruturação do conjunto de relações identificadas na pesquisa.

O mapa cognitivo é uma representação gráfica cuja finalidade é representar da melhor maneira possível uma situação (problema) onde os atores desejam que alguma coisa seja diferente de como ela é, não se sentindo, porém, muito seguros de como obtê-la. Em outras palavras, "o mapa cognitivo é uma ferramenta necessária para definir o problema a ser resolvido". Ele possibilita a identificação dos critérios de avaliação (ENSSLIN; NETO; NORONHA, 2001, p. 77).

3. Identificação dos Pontos de Vista Fundamentais (PVFs): segundo Belton, Ackermann e Shepherd (1997) a estrutura de modelo multicritério é de árvore. A estrutura arborescente utiliza a lógica de decomposição, em que um critério mais complexo a ser mensurado é decomposto em subcritérios de mais fácil mensuração. O critério de nível hierárquico superior é definido pelo conjunto de critérios de nível hierárquico inferior que estão ligados a ele na árvore.

Os critérios de nível hierárquico inferior devem ser mutuamente exclusivos e coletivamente necessitam fornecer uma caracterização completa do critério de nível hierárquico superior (KEENEY, 1992). Para o autor, o enquadramento do processo decisório é formado pelo conjunto de ações potenciais (as oportunidades de escolha) associado aos pontos de vista fundamentais dos decisores.

O conjunto de ações potenciais define quais ações são consideradas em uma situação decisória específica. Os Pontos de Vista Fundamentais (PVFs) explicitam os valores que os decisores consideram importantes naquele contexto e, ao mesmo tempo, definem as características dos decisores (BANA E COSTA, 1992).

Os objetivos estratégicos se projetam nos Pontos de Vista Fundamentais a serem considerados em uma determinada situação. Os PVFs delimitam o conjunto de ações potenciais, internamente ao conjunto de todas as ações disponíveis, que são formadas por um subconjuntos de todas as ações disponíveis no contexto decisório. 
O conjunto de candidatos a Pontos de Vista Fundamentais (BANA E COSTA, 1992) constituíram uma família que servirá à construção de uma modelo multicritério das ações potenciais (ENSSLIN; NETO; NORONHA, 2001).

De acordo com Quirino (2002), para que os candidatos a PVF passem a ser uma família de PVF, convém obedecer-se às seguintes propriedades (Tabela 25)

Tabela 25 - Propriedades dos Pontos de Vista Fundamentais (PVFs)

\begin{tabular}{ll}
\hline Propriedade & Conceito \\
\hline Essencial & $\begin{array}{l}\text { O PVF deve levar em conta os aspectos que sejam de fundamental importância aos } \\
\text { decisores, segundo seus sistemas de valores. }\end{array}$ \\
\hline Controlável & O PVF deve representar um aspecto que seja influenciado apenas pelas ações potenciais \\
& em questão. \\
\hline Completo & O conjunto de PVFs deve incluir todos os aspectos considerados como fundamentais pelos \\
& decisores. \\
\hline Mensurável & O PVF permite especificar, com a menor ambiguidade possível, a performance das ações \\
& potenciais, segundo os aspectos considerados fundamentais pelos decisores. \\
\hline Operacional & O PVF possibilita coletar as informações requeridas sobre a performance das ações po- \\
& tenciais, dentro do tempo disponível e com um esforço viável. \\
\hline Isolável & O PVF permite a análise de um aspecto fundamental de forma independente com relação \\
& aos demais aspectos do conjunto. \\
\hline Não redundante & O conjunto de PVFs não deve levar em conta o mesmo aspecto mais de uma vez. \\
\hline Conciso & O número de aspectos considerados pelo conjunto de PVFs deve ser o mínimo necessário \\
& para modelar de forma adequada, segundo a visão dos decisores, o problema. \\
\hline Compreensível & O PVF deve ter seu significado claro para os decisores, permitindo a geração e comuni- \\
cação de ideias.
\end{tabular}

Fonte: Ensslin, Neto e Noronha (2001).

Foi identificado um conjunto de candidatos a PVF no âmbito da pesquisa já realizada e após a constatação de seu atendimento às propriedades acima, estes foram submetidos à validação de cada especialista. Depois de validados, passaram a constituir uma família de PVFs, que será o pilar para a estruturação do modelo multicritério de avaliação que será utilizado no presente estudo.

Foram identificados três Pontos de Vista Fundamentais (PVFs) a partir da bibliografia consultada, que se constituem em campos disciplinares:

- PVF 1 - Conforto Ambiental;

- PVF 2 - Ergonomia;

- PVF 3 - Psicologia Ambiental.

\subsubsection{Estrutura da árvore de valor}

A partir da identificação dos PVFs é possível construir a estrutura arborescente (Figura 17) que permite a melhor visualização, organização e hierarquização dos conceitos 
Capítulo 4. Método de avaliação dos atributos/parâmetros facilitadores do ensino-aprendizagem e bases 180 para o modelo de arquitetura da informação

relevantes para os decisores, formadas pelo objetivo estratégico, pelas áreas de interesse e pelos PVFs. Eventualmente, há a necessidade de se detalhar e explicar melhor um PVF, decompondo-o em dois ou mais Pontos de Vista Elementares (PVEs). Um PVF decompõem os Pontos de Vista Elementares (PVEs), permitindo uma melhor avaliação da performance das ações potenciais no ponto de vista considerado. Com isso, eles permitem uma maior compreensão do que um Ponto de Vista Fundamental pretende levar em conta.

A Figura 17 ilustra um exemplo de árvores de pontos de vista fundamentais ou hierarquia de valores.

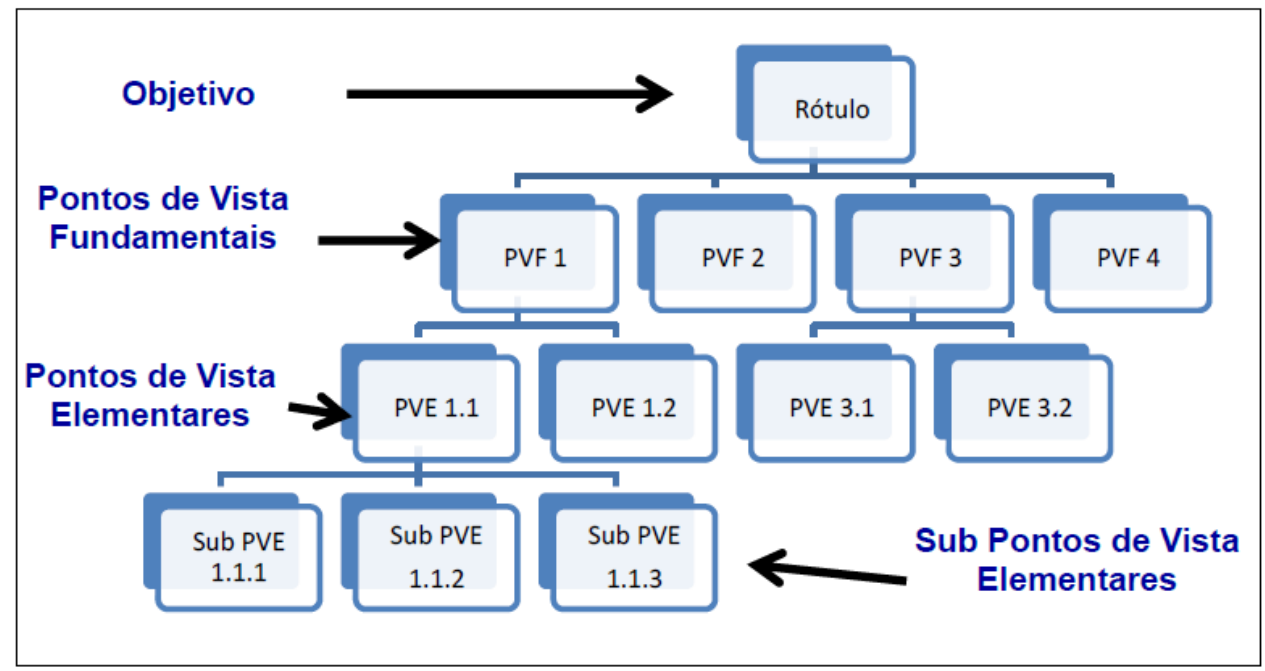

Figura 17 - Construção da Árvore da Família de Pontos de Vista Fundamentais (PVFs) Fonte: Quirino (2015).

Quirino (2002) afirma que os PVFs da árvore de valor de nível hierárquico superior (primeiro nível) são, em geral, complexos de ser mensurados, sendo às vezes necessário decompô-los em subcritérios, denominados de Pontos de Vista Elementares (PVEs), tornando mais fácil a mensuração. O critério de nível hierárquico superior é definido pelo conjunto de critérios de nível hierárquico inferior a ele ligados na árvore (ENSSLIN; NETO; NORONHA, 2001).

De acordo com Ensslin, Neto e Noronha (2001) e Quirino (2002), os critérios de nível hierárquico inferior devem ser mutuamente exclusivos e coletivamente necessitam fornecer uma caracterização exaustiva (completa) do critério de nível hierárquico superior. Devem existir pelo menos dois PVEs conectados ao ponto de vista de nível hierárquico superior $(\mathrm{PVF})$.

O critério PVF i é decomposto em um conjunto de dois ou mais critérios hierarquicamente inferiores PVE i.1 e PVE i.2. Por sua vez, o primeiro (PVE i.1) é subdividido em dois ou mais PVE i.1.1 e PVE i.1.2. Já o segundo (PVE i.2) segue o mesmo raciocínio do primeiro até chegar nos critérios hierarquicamente inferiores da árvore de valor, construída, 
segundo o juízo de valor do decisor, onde i=1,2,3.....n (ENSSLIN; NETO; NORONHA, 2001).

Assim, após essa verificação, e o conjunto final de PVFs, foi feita a representação inicial da arborescência, formada pelo objetivo estratégico, pelas áreas de interesse e por todos os PVFs. As Figuras 18, 19 e 20 mostram a estrutura genérica inicial do modelo multicritério que adota a estrutura de árvore de valor, contemplando os PVF 1 - Conforto Ambiental, PVF 2 - Ergonomia e o PVF 3 - Psicologia Ambiental.

Quirino (2002) observa que, a partir dos terminais dos critérios de avaliação pode-se formular perguntas depois de estratificar cada critério. Teremos uma escala que são as opções que vão transformar em perguntas para o questionário.

A seguir, apresenta-se a estrutura genérica do modelo multicritério para o PVF 1 Conforto Ambiental, contituído dos PVEs e SubPVEs inicialmente definidos pelos autores da literatura abordada pelos decisores, bem como para o PVF 2 - Ergonomia e PVF 3 Psicologia Ambiental.

A Figura 18 mostra a estrutura inicial dos elementos que compõem a arborescência da família do ponto de Vista Fundamental/PVF 1 - Conforto Ambiental.

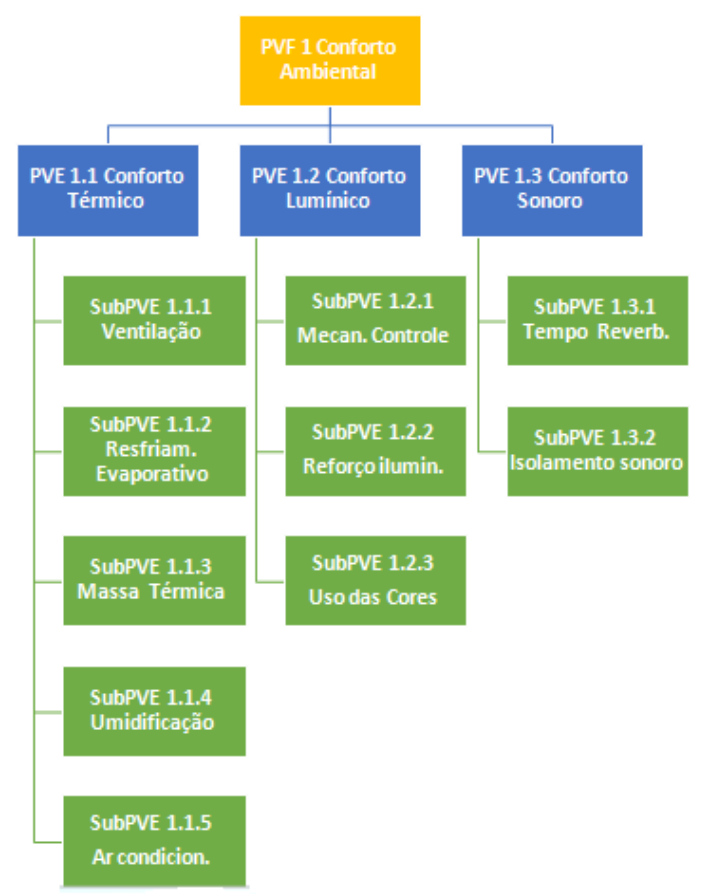

Figura 18 - Elementos que compõem a arborescência da família do PVF 1 - Conforto Ambiental (Estrutura Inicial)

Fonte: Elaboração própria (2015).

A Tabela 26 apresenta o critério (PVF 1) Conforto Ambiental e seus subcritérios (PVEs e SubPVEs). 
Capítulo 4. Método de avaliação dos atributos/parâmetros facilitadores do ensino-aprendizagem e bases 182 para o modelo de arquitetura da informação

Tabela 26 - Estrutura inicial dos PVEs e SubPVEs do PVF 1 - Conforto Ambiental

\begin{tabular}{|c|c|c|}
\hline PVF & PVEs & SubPVEs \\
\hline \multirow{10}{*}{$\begin{array}{l}\text { 1. Conforto } \\
\text { Ambiental }\end{array}$} & \multirow{5}{*}{ 1.1 Conforto térmico } & 1.1.1Ventilação \\
\hline & & 1.1.2 Resfriamento evaporativo \\
\hline & & 1.1.3 Massa térmica para aquecimento \\
\hline & & 1.1.4 Umidificação \\
\hline & & 1.1.5 Ar-condicionado \\
\hline & \multirow{3}{*}{ 1.2 Conforto lumínico } & 1.2.1 Mecanismos de controle \\
\hline & & 1.2.2 Reforço de iluminamento \\
\hline & & 1.2.3 Uso de cores \\
\hline & \multirow{2}{*}{1.3 Conforto sonoro } & 1.3.1 Tempo ótimo de reverberação \\
\hline & & 1.3.2 Isolamento sonoro \\
\hline
\end{tabular}

Fonte: Elaboração própria (2015).

A Figura 19 mostra a estrutura inicial dos elementos que compõem a arborescência da família dos pontos do Vista Fundamental PVF 2 - Ergonomia

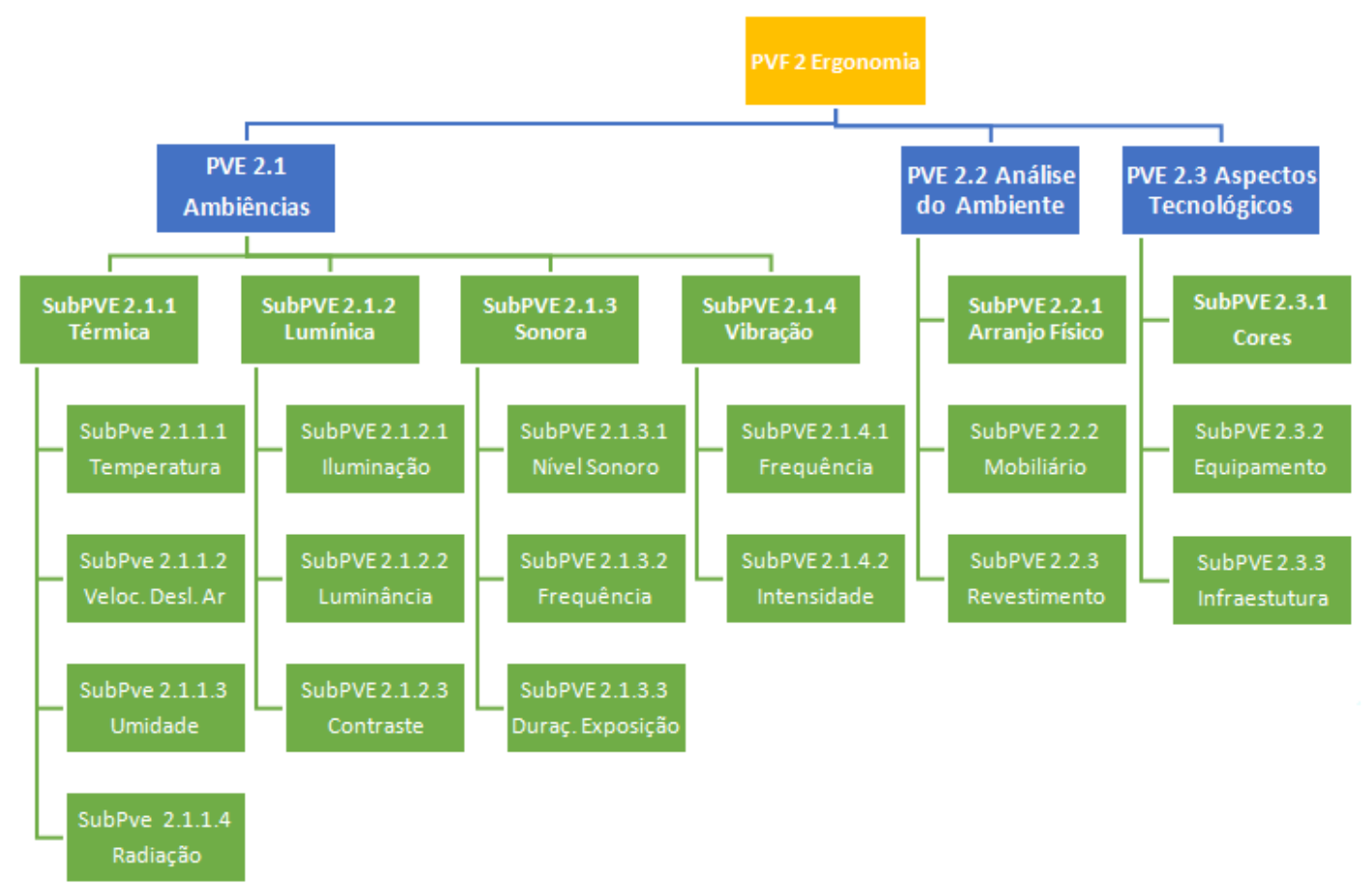

Figura 19 - Elementos que compõem a arborescência da família do PVF 2 - Ergonomia (Estrutura Inicial)

Fonte: Elaboração própria (2015).

A Tabela 27 apresenta o critério (PVF 2) Ergonomia e seus subcritérios (PVEs e SubPVEs). 
Tabela 27 - Estrutura inicial dos PVEs e SubPVEs do PVF 2 - Ergonomia

\begin{tabular}{|c|c|c|}
\hline PVF & PVEs & SubPVEs \\
\hline \multirow{19}{*}{ 2. Ergonomia } & \multirow{5}{*}{ 2.1 Ambiência térmica } & 2.1.1 Temperatura \\
\hline & & $\begin{array}{l}\text { 2.1.2 Velocidade de deslocamento } \\
\text { do } \mathrm{Ar}\end{array}$ \\
\hline & & 2.1.3 Umidade \\
\hline & & 2.1.4 Umidificação \\
\hline & & 2.1.5 Radiação \\
\hline & \multirow{3}{*}{ 2.2 Ambiência lumínica } & 2.2.1 Iluminação \\
\hline & & 2.2.2 Luminância \\
\hline & & 2.2.3 Contraste \\
\hline & \multirow{3}{*}{ 2.3 Ambiência sonora } & 2.3.1 Nível sonoro \\
\hline & & 2.3.2 Frequência \\
\hline & & 2.3.3 Duração da exposição \\
\hline & \multirow{2}{*}{ 2.4 Vibração } & 2.4.1 Frequência \\
\hline & & 2.4.2 Intensidade \\
\hline & \multirow{2}{*}{ 2.5 Antropometria } & 2.5.1 Arranjo físico \\
\hline & & 2.5.2 Mobiliário \\
\hline & \multirow{4}{*}{ 2.6 Infraestrutura } & 2.6.1 Revestimento \\
\hline & & 2.6.2 Cores \\
\hline & & 2.6.3 Equipamento \\
\hline & & 2.6.4 Ambiente Físico \\
\hline
\end{tabular}

Fonte: Elaboração própria (2015). 
Capítulo 4. Método de avaliação dos atributos/parâmetros facilitadores do ensino-aprendizagem e bases 184 para o modelo de arquitetura da informação

A Figura 20 mostra a estrutura inicial dos elementos que compõem a arborescência da família do Ponto de Vista Fundamental PVF 3 - Psicologia Ambiental

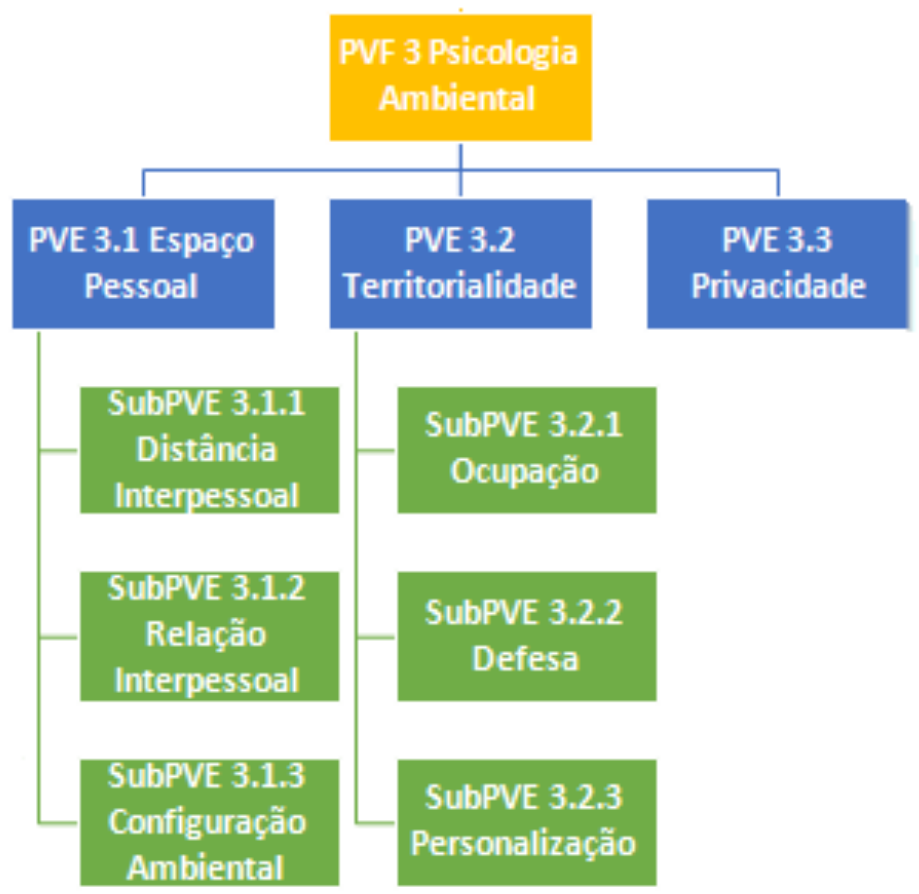

Figura 20 - Elementos que compõem a arborescência da família do PVF 3 - Psicologia Ambiental (Estrutura Inicial)

Fonte: Elaboração própria (2015).

A Tabela 28 apresenta o critério de avaliação do PVF 3 - Psicologia Ambiental e seus subcritérios (PVEs e SubPVEs).

Tabela 28 - Estrutura inicial dos PVEs e SubPVEs do PVF 3 - Psicologia Ambiental

\begin{tabular}{|c|c|c|}
\hline PVF & PVEs & SubPVEs \\
\hline \multirow{7}{*}{$\begin{array}{l}\text { 3. Psicologia } \\
\text { Ambiental }\end{array}$} & \multirow{3}{*}{ 3.1 Espaço pessoal } & 3.1.1 Distância interpessoal \\
\hline & & 3.1.2 Relação interpessoal \\
\hline & & 3.1.3 Configuração ambiental (design) \\
\hline & \multirow{3}{*}{ 3.2 Territorialidade } & 3.2.1 Ocupação \\
\hline & & 3.2.2 Defesa \\
\hline & & 3.2.3 Personalização \\
\hline & 3.3 Privacidade & \\
\hline
\end{tabular}

Fonte: Elaboração própria (2015).

Existem interfaces entre os parâmetros identificados na área de Conforto Ambiental e Ergonomia que podem, a rigor, ser considerados aspecto de conforto que a Ergonomia 
também adota como relevantes para o desempenho de atividades. Para efeito da aplicação da metodologia multicritério, esses parâmetros serão considerados na árvore de conforto de modo a não ocorrerem sobreposição na análise final. Na prática, isso significa que os atributos ambiência térmica, ambiência lumínica e ambiência sonora serão transpostos para o tema do conforto ambiental retirados os parâmetros que já eram considerados por este.

A Figura 21 mostra a estrutura genérica final do modelo multicritério que dota a estrutura de árvore de valor validada pelos especialistas (decisores). 


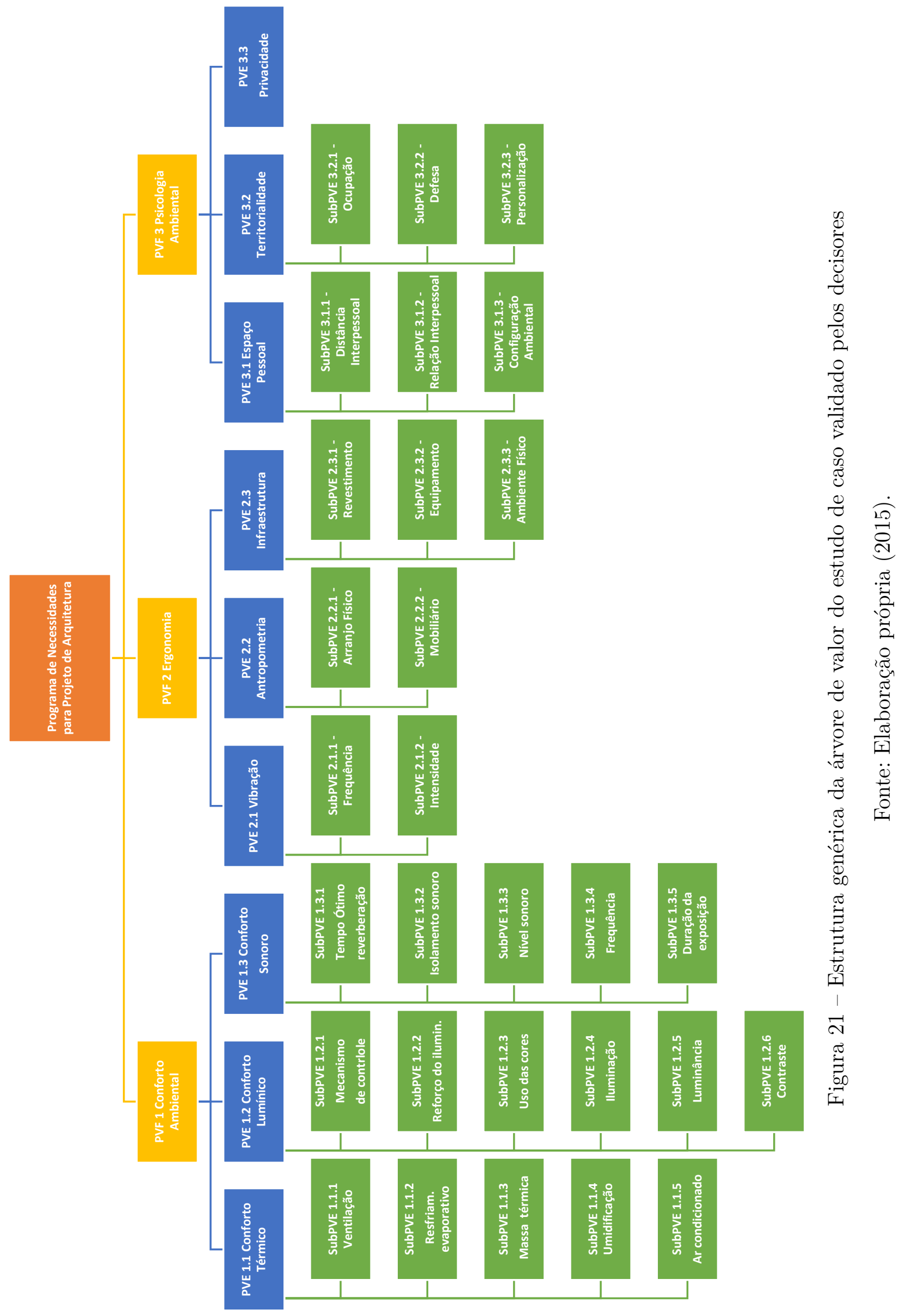


A árvore de valor validada pelos especialistas tem a seguinte estrutura:

a) um objetivo estratégico (vermelho);

b) três critérios ou PVFs (amarelo);

c) nove subcritérios ou PVEs de segundo nível (azul);

d) Trinta subcritérios ou PVEs de terceiro nível (verde).

Na Figura 22 apresenta-se a arborescência da família dos Pontos de Vista Elementares /PVEs do PVF1 - Conforto Ambiental, validada pelos decisores.

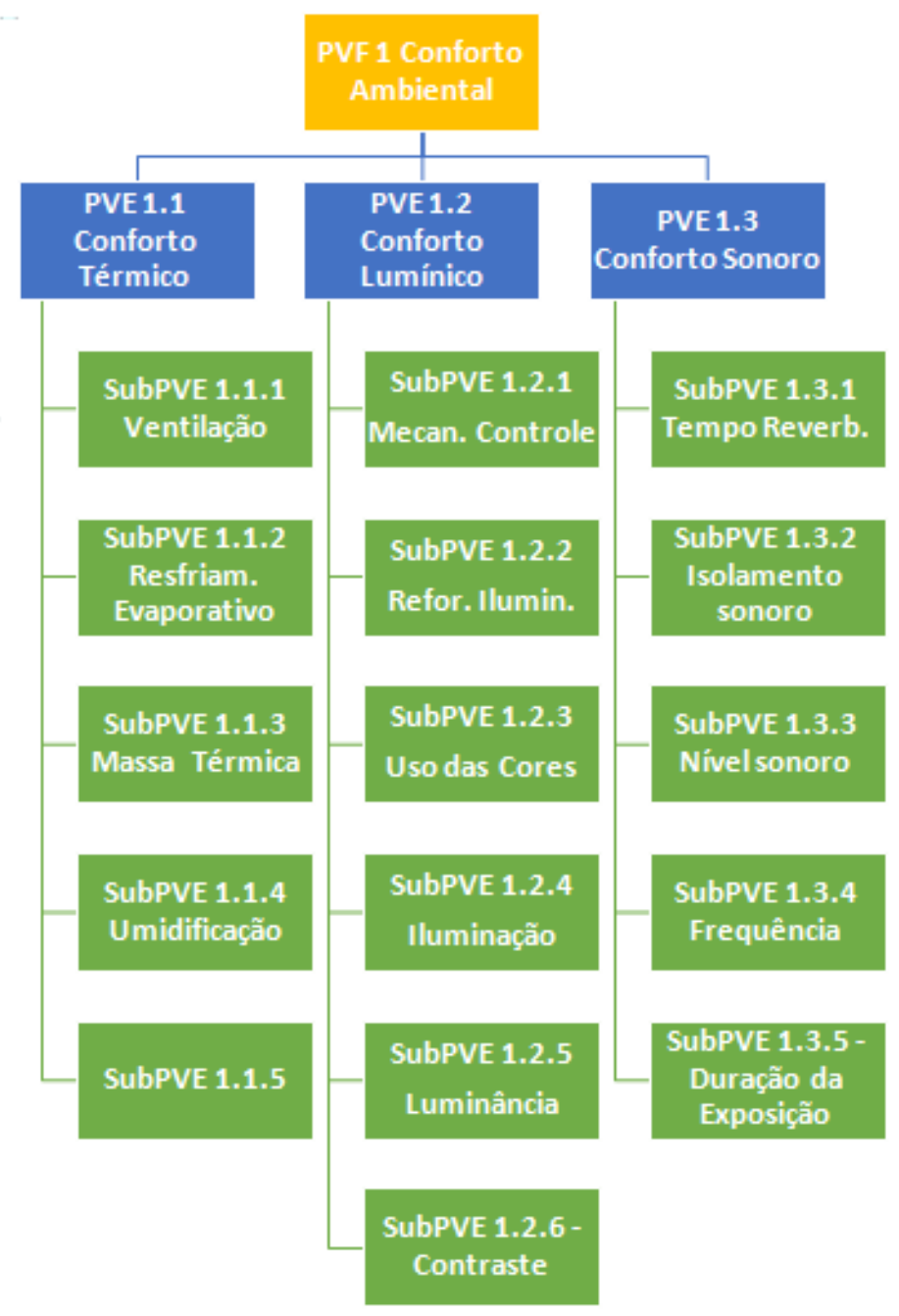

Figura 22 - Elementos que compõem a arborescência da família do PVF 1 - Conforto Ambiental

Fonte: Elaboração própria (2015).

Para a análise dos PVEs e SubPVEs do PVF Conforto Ambiental, foi considerado pelo especialista na área, que o clima a ser contemplado nessa pesquisa é o Clima de Brasília, o Tropical de Altitude, que tem as seguintes características: i) quente no verão - 
Capítulo 4. Método de avaliação dos atributos/parâmetros facilitadores do ensino-aprendizagem e bases 188 para o modelo de arquitetura da informação

(até $\left.32^{\circ} \mathrm{C}\right)$; ii) frio no inverno - (até $\left.10^{\circ} \mathrm{C}\right)$; iii) baixa umidade - $(12 \%$ UR inverno/20\% UR Verão); e iv) ventilação predominante Leste.

A Tabela 29 apresenta o critério de avaliação do PVF 1 - Conforto Ambiental e seus subcritérios (PVEs e SubPVEs).

Tabela 29 - PVEs e SubPVEs do PVF 1 - Conforto Ambiental

\begin{tabular}{|c|c|c|}
\hline PVF & PVEs & SubPVEs \\
\hline \multirow{16}{*}{$\begin{array}{l}\text { 1. Conforto } \\
\text { Ambiental }\end{array}$} & \multirow{5}{*}{ 1.1 Conforto térmico } & 1.1.1Ventilação \\
\hline & & 1.1.2 Resfriamento evaporativo \\
\hline & & $\begin{array}{l}\text { 1.1.3 Massa térmica para aqueci- } \\
\text { mento }\end{array}$ \\
\hline & & 1.1.4 Umidificação \\
\hline & & 1.1.5 Ar-condicionado \\
\hline & \multirow{6}{*}{ 1.2 Conforto lumínico } & 1.2.1 Mecanismos de controle \\
\hline & & 1.2.2 Reforço de iluminamento \\
\hline & & 1.2.3 Uso de cores \\
\hline & & 1.2.4 Iluminação \\
\hline & & 1.2.5 Luminância \\
\hline & & 1.2.6 Contraste \\
\hline & \multirow{5}{*}{ 1.3 Conforto sonoro } & 1.3.1 Tempo ótimo de reverberação \\
\hline & & 1.3.2 Isolamento Sonoro \\
\hline & & 1.3.3 Nível Sonoro \\
\hline & & 1.3.4 Frequência \\
\hline & & 1.3.5 Duração da exposição \\
\hline
\end{tabular}

Fonte: Elaboração própria (2015). 
Na Figura 23 apresenta-se a arborescência da família dos Pontos de Vista Elementares do PVF 2 - Ergonomia validada pelos decisores.

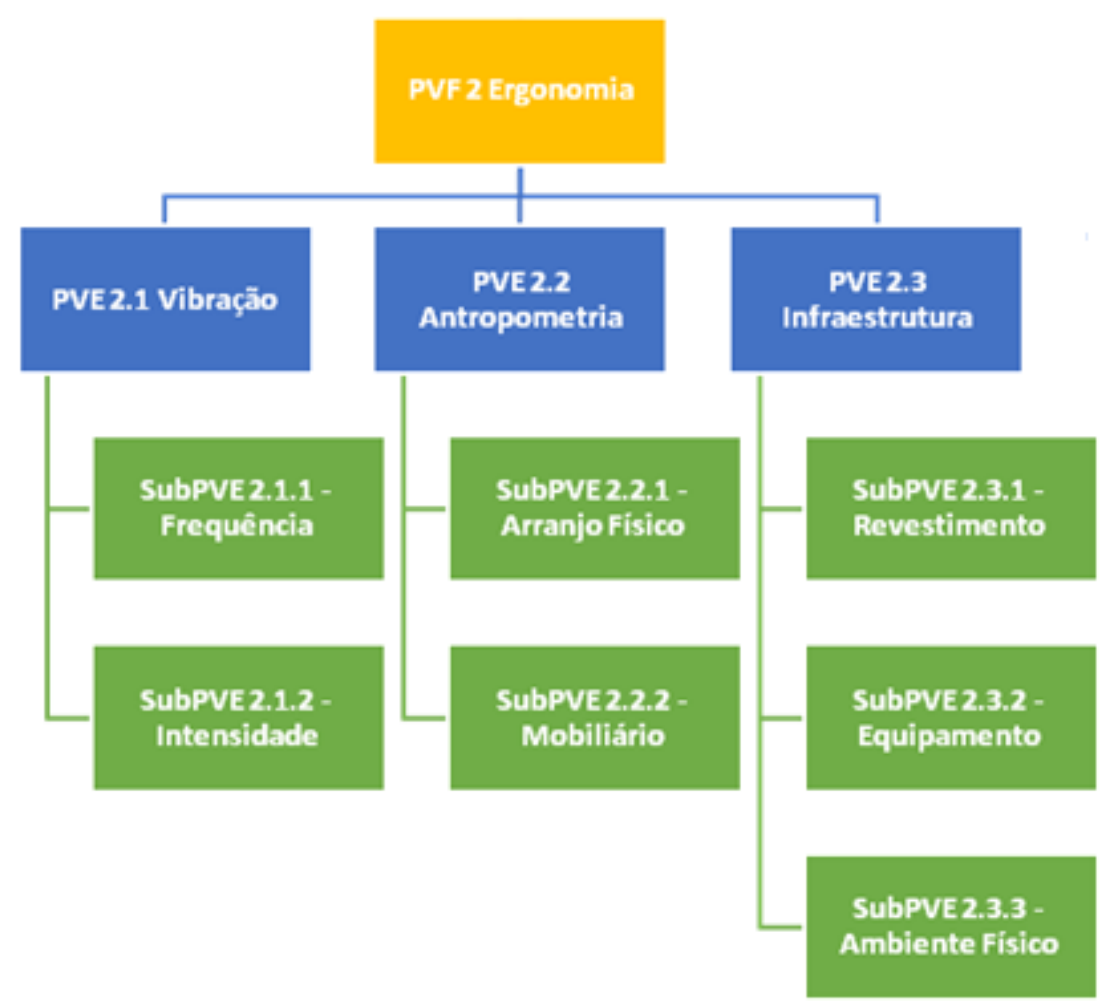

Figura 23 - Elementos que compõem a arborescência da família do PVF 2 - Ergonomia Fonte: Elaboração própria (2015).

A Tabela 30 apresenta o critério de avaliação do PVF 2 - Ergonomia e seus subcritérios (PVEs e SubPVEs).

Tabela 30 - PVEs e SubPVEs do PVF 2 - Ergonomia

\begin{tabular}{lll}
\hline PVF & PVE's & SubPVEs \\
\hline & 2.1 Vibração & $\frac{2.1 .1 \text { Freqüência }}{2.1 .2 \text { Intensidade }}$ \\
\cline { 2 - 3 } & 2.2 Antropometria & $\frac{2.2 .1 . \text { Arranjo físico }}{2.2 .2 \text { Mobiliário }}$ \\
\cline { 2 - 3 } 2. Ergonomia & 2.3 Infraestrutura & 2.3 .1 Revestimento \\
\cline { 2 - 2 } & & 2.3 .2 Equipamento \\
& & 2.3 .3 Ambiente físico \\
\hline
\end{tabular}

Fonte: Elaboração própria (2015).

Na Figura 24 apresenta-se a arborescência da família dos Pontos de Vista Elementares do PVF 3 - Psicologia Ambiental, validada pelos decisores. 


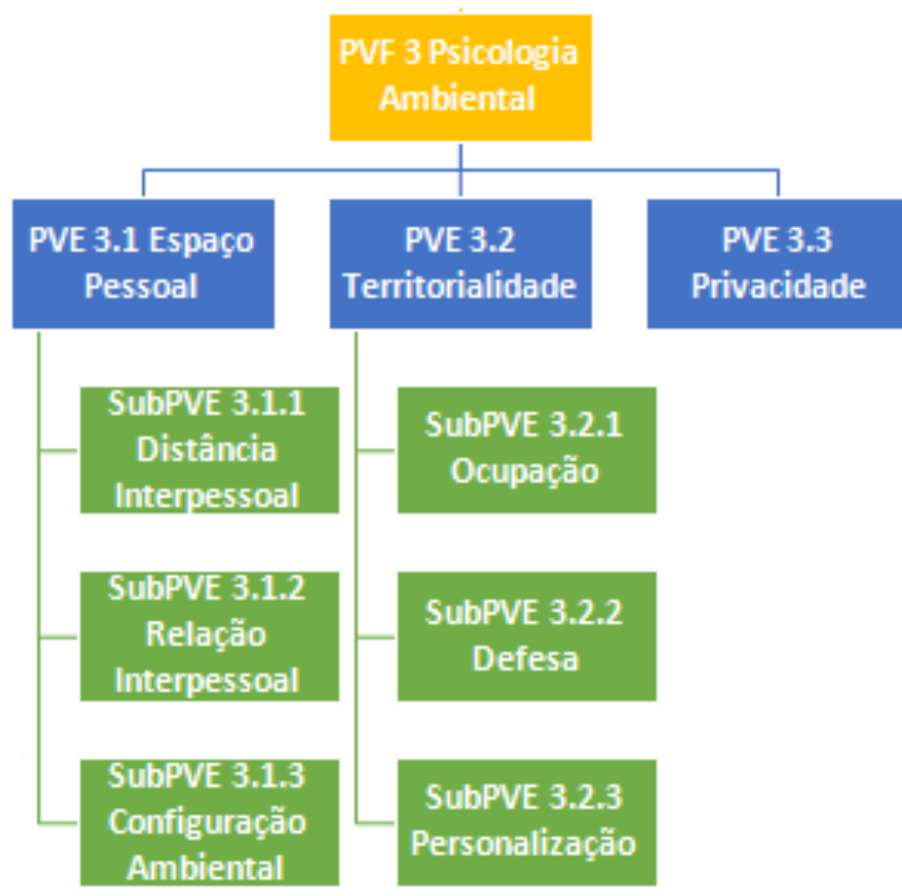

Figura 24 - Elementos que compõem a arborescência da família do PVF 3 - Psicologia Ambiental

Fonte: Elaboração própria (2015).

A Tabela 31 apresenta o critério de avaliação do PVF 3 - Psicologia Ambiental e seus subcritérios ( PVEs e SubPVEs ).

Tabela 31 - PVEs e SubPVEs do PVF 3 - Psicologia Ambiental

\begin{tabular}{|c|c|c|}
\hline PVF & PVEs & SubPVEs \\
\hline \multirow{7}{*}{$\begin{array}{l}\text { 3. Psicologia } \\
\text { Ambiental }\end{array}$} & \multirow{3}{*}{ 3.1 Espaço pessoal } & 3.1.1 Distância interpessoal \\
\hline & & 3.1.2 Relação interpessoal \\
\hline & & 3.1.3 Configuração ambiental (design) \\
\hline & \multirow{3}{*}{ 3.2 Territorialidade } & 3.2.1 Ocupação \\
\hline & & 3.2.2 Defesa \\
\hline & & 3.2.3 Personalização \\
\hline & 3.3 Privacidade & \\
\hline
\end{tabular}

Fonte: Elaboração própria (2015).

No caso da pesquisa tanto os "Eixos de Avaliação" e "Níveis" que compõem a arborescência da família dos Pontos de Vista Fundamentais (PVFs) quanto os "Critérios de Avaliação" são decorrência natural das árvores, que, por sua vez, advêm da forma ordenada e hierarquizada que foi montado o quadro geral das variáveis que estão sendo 
avaliadas pelo método. A título de exemplo apresentamos para o caso de um PVF o que seria esse ordenamento a que o método se refere (Figuras 25, 26 e 27).

Ainda na etapa de construção da árvore de valor temos a definição do nível hierárquico,eixos de avaliação e critérios de avaliação, essenciais à estrutura de avaliação e etapas realizadas com apoio dos especialistas. Essas etapas são descritas as seguir:

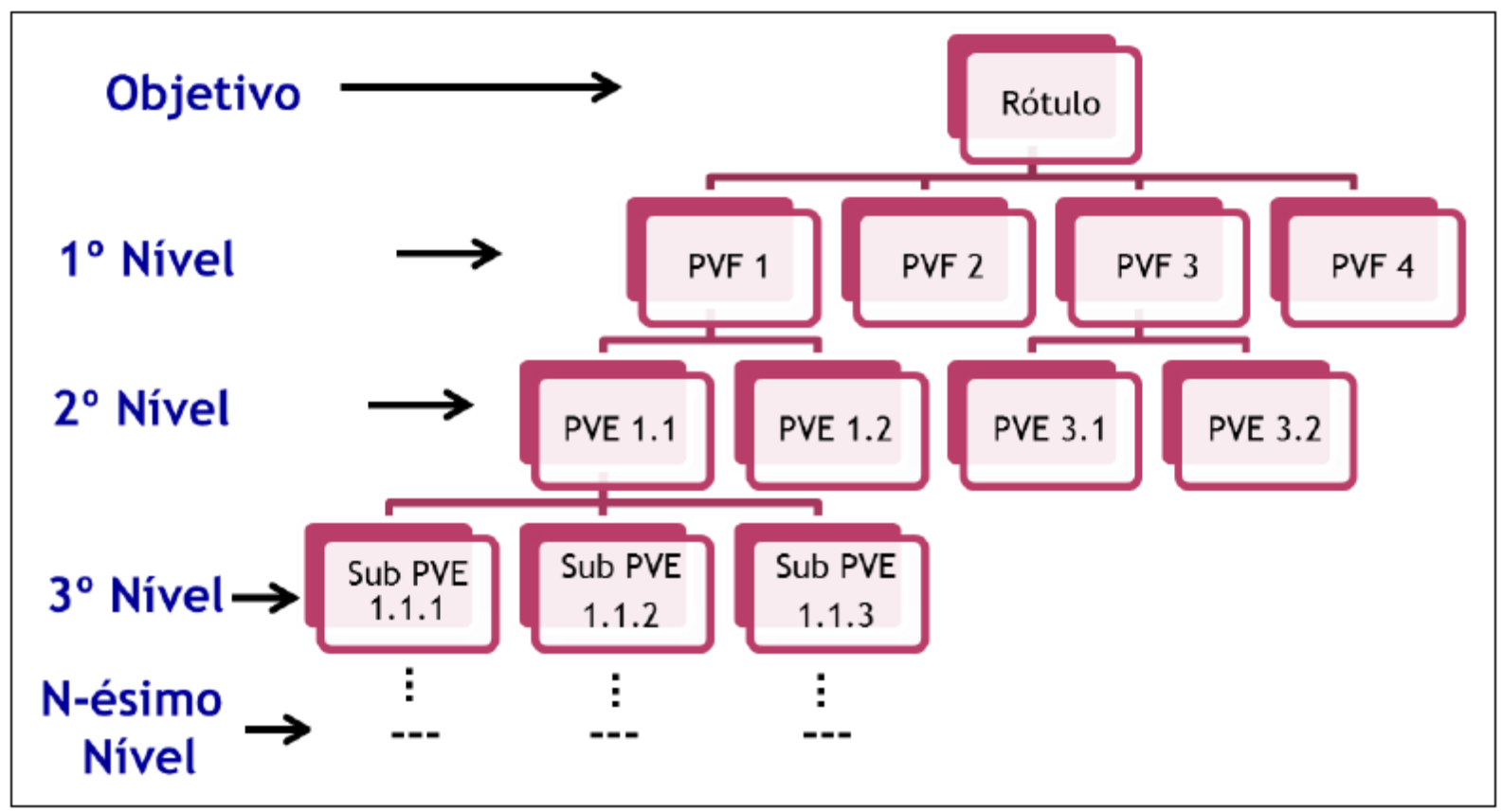

Figura 25 - Níveis que compõem a arborescência da família de Pontos de Vista Fundamentais (PVFs)

Fonte: Quirino (2015).

Os eixos de avaliação decorrem de um ponto de vista (PV) definido pelos decisores que pode ser: i) o PV expressa uma preocupação que pode ser mensurada, mas não diretamente. Nesse caso, é necessário ter um índice composto por um conjunto de descritores, pois diversos são os aspectos que explicam aquele PV, segundo a percepção do decisor; ii) o PV reflete uma preocupação de cunho qualitativo sem um descritor direto para representá-lo. Sua mensuração requer a decomposição do eixo de avaliação em pontos de vista elementares, de mais fácil mensuração.

Muitas vezes existem dificuldades em se quantificar a importância relativa dos critérios, uma vez que estes podem ter graus de importância variáveis para diferentes decisores. Dessa forma, é necessário definir a importância relativa de cada critério no processo de decisão, o que é feito normalmente atribuindo um determinado peso a cada critério interveniente. A correta atribuição dos pesos é importante para que sejam mantidas as preferências dos decisores (SILVA et al., 2004). 
Capítulo 4. Método de avaliação dos atributos/parâmetros facilitadores do ensino-aprendizagem e bases

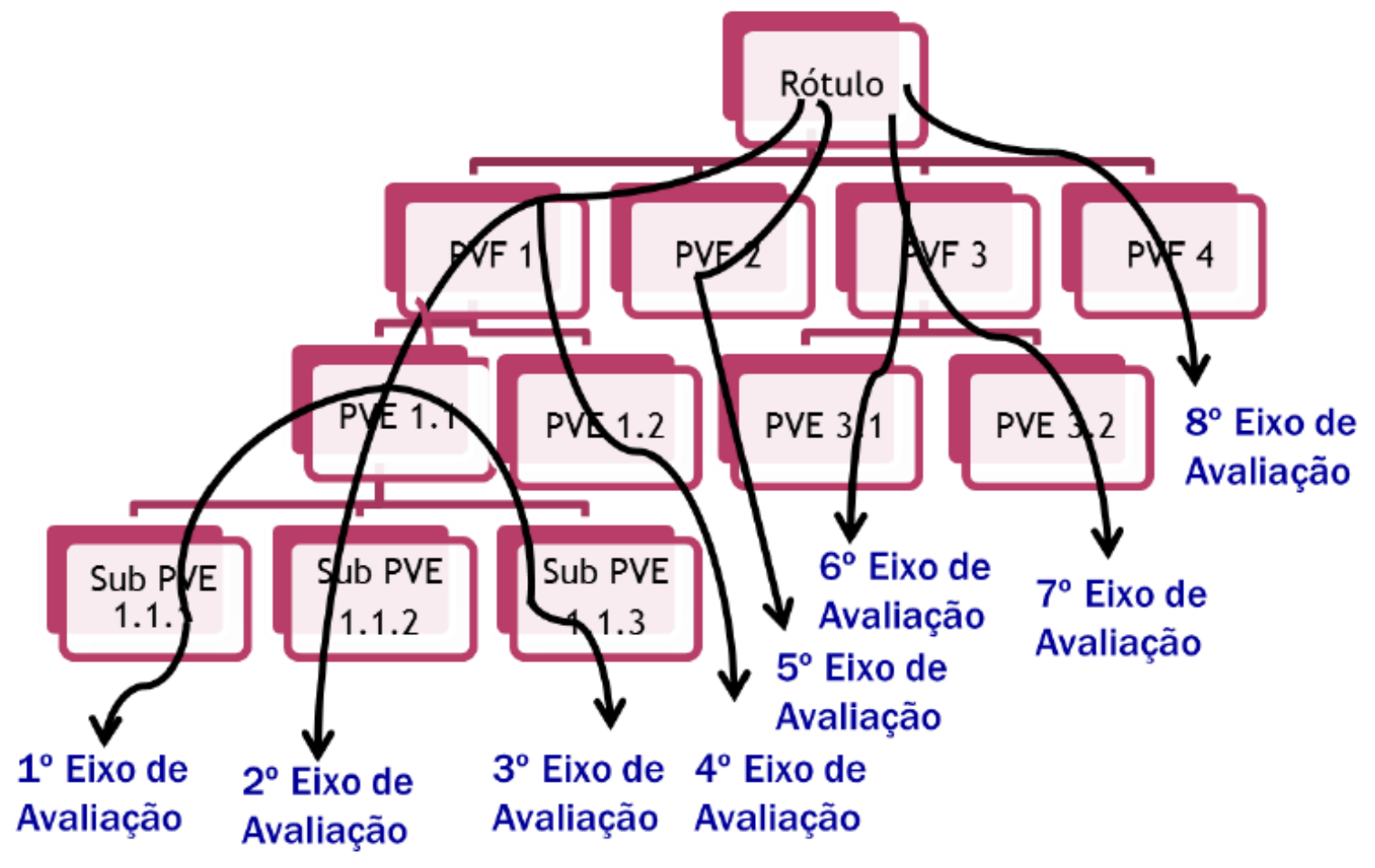

Figura 26 - Eixos de avaliação que compõem a arborescência da família de Pontos de Vista Fundamentais (PVFs)

Fonte: Quirino (2015).

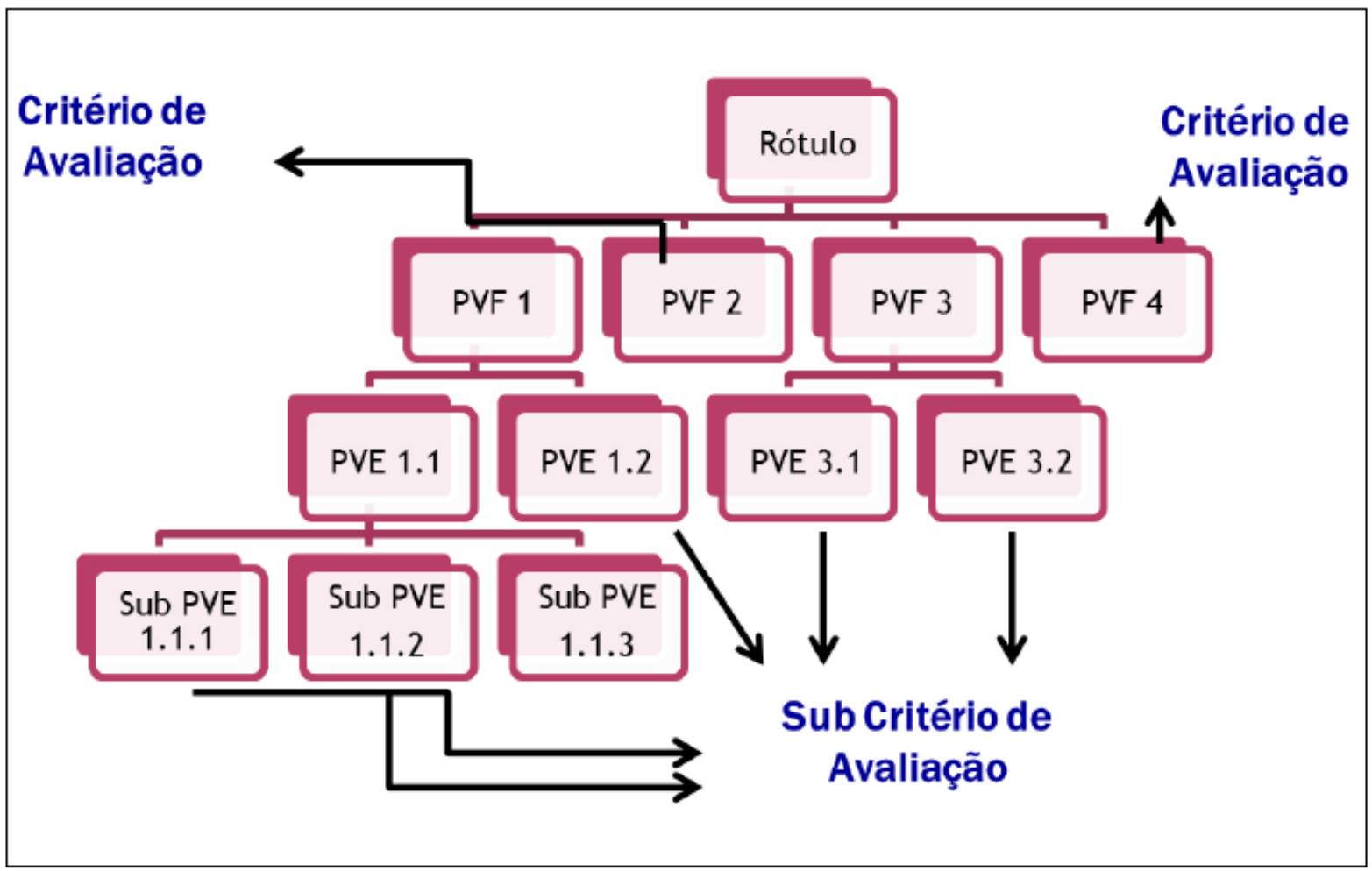

Figura 27 - Critérios de avaliação que compõem a arborescência da família de Pontos de Vista Fundamentais (PVFs) 
Concluídas as etapas relativas à construção da "estrutura física" do modelo multicritério de avaliação, as etapas seguintes dizem respeito à estruturação dos aspectos internos do modelo, de natureza mensurativa das ações que serão avaliadas (ações potenciais), que são os descritores, as funções de valor e as taxas de substituição, constantes nas seções 4.2.7, 4.2 .8 e 4.2 .9 .

\subsubsection{Construção dos descritores}

A etapa de construção da arborescência de PVFs é seguida pela construção de descritores. Os descritores correspondem a níveis de impacto utilizados para descrever as prováveis consequências das ações em termos de cada PVF ou PVE. São, portanto escalas utilizadas para mensurar os objetivos, representando o quanto estes foram alcançados. Por incorporarem julgamentos de valor, os descritores ajudam os atores a esclarecer os objetivos e a gerar subsídios para a criação de novas alternativas (QUIRINO, 2002).

Os descritores, segundo Ensslin, Neto e Noronha (2001), promovem o necessário entendimento do que será mensurado, enquanto a função de valor evidencia as informações relativas às diferenças de atratividade entre os níveis de impacto dos descritores.

Os descritores visam a atingir os seguintes propósitos (QUIRINO, 2002):

- auxiliar na compreensão da ação potencial que está sendo avaliada;

- tornar o ponto de vista inteligível;

- permitir a geração de ações de aperfeiçoamento (quando for o caso);

- possibilitar a construção de escalas de preferências locais;

- permitir a mensuração de desempenho de ações em um critério; e

- auxiliar a construção de um modelo global de avaliação. 
Capítulo 4. Método de avaliação dos atributos/parâmetros facilitadores do ensino-aprendizagem e bases 194 para o modelo de arquitetura da informação

Roy (1993), corroborado por Ensslin, Neto e Noronha (2001), evidencia que não existe, sob a ótica do paradigma construtivista, um descritor ótimo; mas, sim, um descritor adequado, desde que seja considerado uma ferramenta apropriada para a avaliação da ação potencial a que ele se destina. Segundo (QUIRINO, 2002), os descritores podem ser do tipo construídos, qualitativos e discretos, os quais apresentam as seguintes características (Tabela 32):

Tabela 32 - Tipos dos descritores utilizados na presente pesquisa

\begin{tabular}{ll}
\hline Tipo & Características \\
\hline Construídos & Explicam, segundo as percepções dos atores, os \\
& possíveis níveis de impactos que uma ação pode \\
& ter em um PVF de forma exaustiva e concisa, a \\
& partir da decomposição do eixo de avaliação (de- \\
& composição dos PVFs em PVE); \\
\hline Qualitativos & Descrevem os pontos de vistas a partir de expres- \\
& sões semânticas e por representações pictóricas; \\
\hline Discretos & São representados por um número finito de níveis \\
& de impacto, os quais expressam as possíveis con- \\
& sequências das ações que compõem o descritor. \\
\hline
\end{tabular}

Fonte: Quirino (2002).

Para (KEENEY, 1992), três são as propriedades desejáveis aos descritores, todas elas criticamente afetadas pelo problema da ambigüidade, a seguir discriminadas (Tabela 33):

Tabela 33 - Propriedades dos descritores

\begin{tabular}{ll}
\hline Propriedade & Conceito \\
\hline Mensurabilidade & Um descritor é mensurável quando permite quan- \\
& tificar a performance de uma ação de forma clara. \\
\hline Operacionalidade & Um descritor é operacional quando define clara- \\
& mente como e quais dados coletar; permite men- \\
& surar um aspecto de forma independente de qual- \\
& quer outro aspecto considerado; o desempenho de \\
& uma ação potencial em um determinado PVF é \\
& claramente associável a um único nível de impacto; \\
& fornece uma base de discussão adequada para o \\
& julgamento de valores sobre o PVF. \\
\hline Compreensibilidade & Para que seja compreensível, cada descritor deve \\
& permitir a descrição e interpretação da perfor- \\
mance da ação potencial de forma não ambígua.
\end{tabular}

Fonte: Quirino (2002).

Os descritores devem ser ordenados em termos de preferência dos decisores. Aos níveis de impacto devem ainda ser associados valores de referência, correspondentes ao nível neutro (para qual é atribuído o valor zero) e ao nível bom (para qual é atribuído valor cem) que representam, respectivamente, o pior nível admissível e a melhor ação viável. 
A Figura 28 apresenta um fluxograma do roteiro para construir um descritor

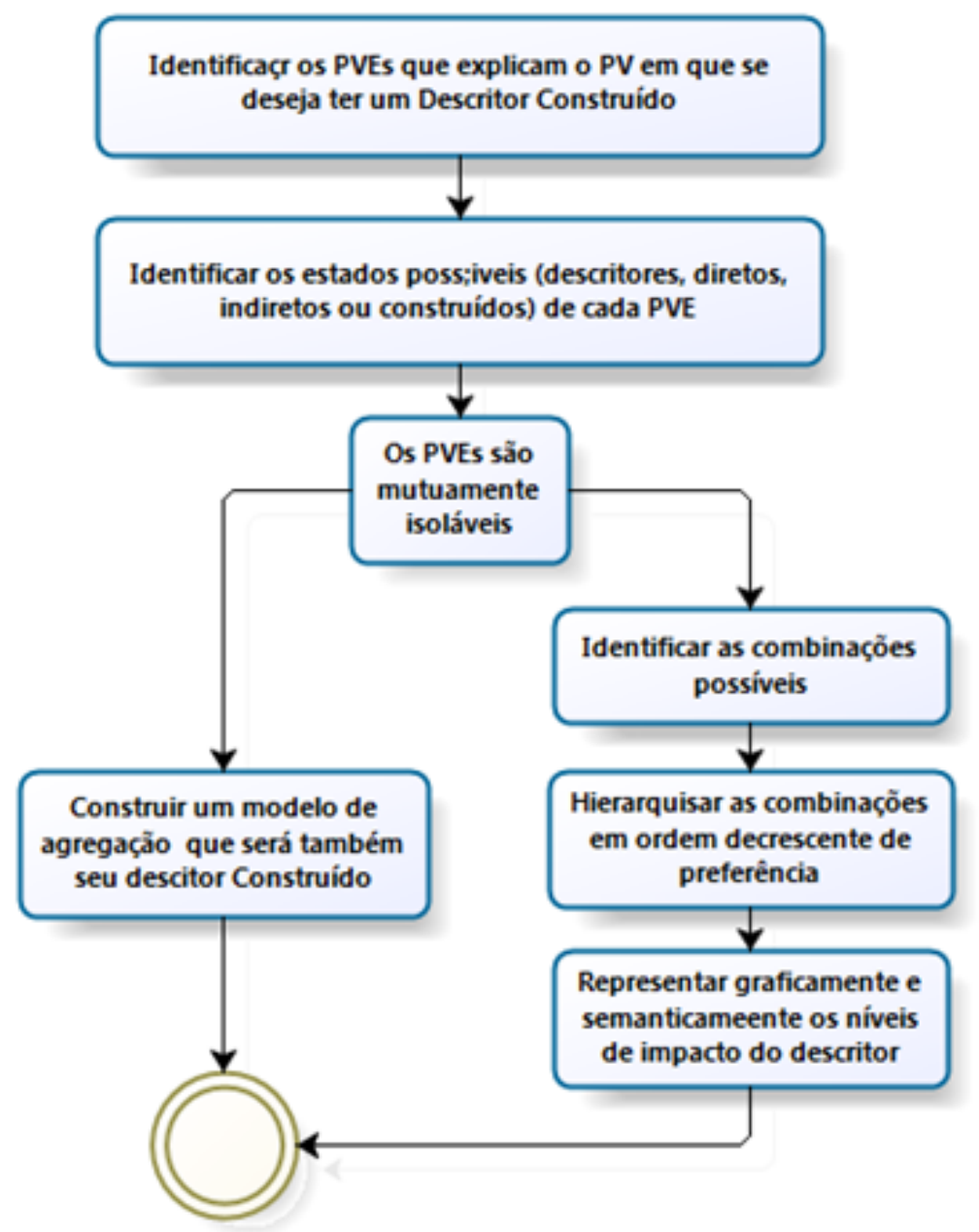

Figura 28 - Fluxograma para gerar um descritor construído

Fonte: adaptado de Ensslin, Neto e Noronha (2001).

Seguindo o roteiro do fluxograma foram construídos os possíveis estados dos PVEs. O especialista definiu para o PVF 1 os PVEs : conforto térmico, conforto lumínico e conforto sonoro e concentrou-se em detalhá-los em SubPVEs (exemplo: vide Tabela 34).

Após a identificação dos estados possíveis dos pontos de vista, verificou-se se havia PVEs não isoláveis e, em seguida, descreveu-se cada estado possível de forma que represente os aspectos mais relevantes de cada ponto de vista. No presente estudo, a cada estado possível do descritor foi associado a um nível de impacto $\mathrm{Nj}$, onde já corresponde à ordem de preferência do decisor, isto é:

- N5 - nível de impacto com maior atratividade (limite superior);

- N4 - nível de impacto com atratividade imediatamente inferior;

- N3 - nível de impacto com atratividade intermediária; 
Capitulo 4. Método de avaliação dos atributos/parâmetros facilitadores do ensino-aprendizagem e bases 196 para o modelo de arquitetura da informação

- N2 - nível de impacto com atratividade imediatamente inferior à intermediária; e

- N1 - nível de impacto com menor nível de atratividade (limite inferior).

Esses níveis de impacto têm uma ordenação decrescente do nível mais atrativo até o nível menos atrativo, como mostra a Figura 29, com 5(cinco) níveis, mas o descritor pode ter mais ou menos de 5 (cinco) níveis.Nessa pesquisa foram utilizados os descritores com cinco níveis de impacto.

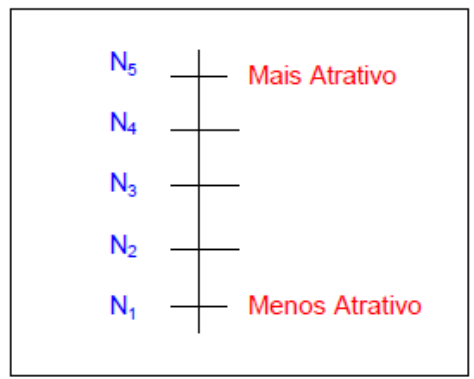

Figura 29 - Estados possíveis de um descritor Fonte: Quirino (2002).

Com base em Bana e Costa e Vansnick (1995), Quirino (2002) afirma que, em cada descritor, definem-se dois níveis de impacto de referência, o Nível Bom e o Nível Neutro. Para o autor o descritor, dotado com níveis Bom e Neutro, fica mais claro, no processo decisório para identificar as ações com nível de excelência (acima do Nível Bom) as ações com de nível de mercado (entre o Bom e o Neutro), as ações com de nível de sobrevivência (abaixo do Neutro), segundo a percepção do decisor (ENSSLIN; NETO; NORONHA, 2001). Esses níveis de impacto que têm um desempenho inferior ao neutro representam, para o decisor, uma situação não satisfatória, mas ainda aceitável, como mostra a Figura 30.

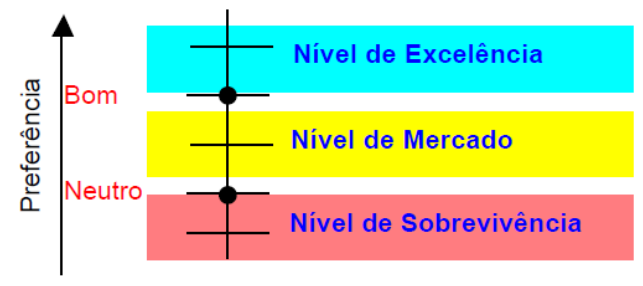

Figura 30 - Descritor com os níveis de impacto Bom e Neutro Fonte: Quirino (2002). 
Na Tabela 34, apresenta-se , para fins de ilustração, o descritor do SubPVE 1.1.1 ventilação, construído a partir do PVE 1.1 - Conforto Térmico, com a indicação dos níveis de impacto em ordem decrescente de preferência dos decisores e dos níveis de referência.

Tabela 34 - Descritor com os níveis Bom e Neutro do SubPVE 1.1.1 - Ventilação

\begin{tabular}{l|l|l}
\hline $\begin{array}{l}\text { Niveis } \\
\text { Impacto }\end{array}$ & $\begin{array}{l}\text { Niveis de re- } \\
\text { ferência }\end{array}$ & Descrição \\
\hline N5 & Bom & $\begin{array}{l}\text { Esse parâmetro merece tratamento diferencial como muito impor- } \\
\text { tante para o projeto de arquitetura por desempenhar papel relevante } \\
\text { para o aprendizado? }\end{array}$ \\
\hline N4 & $\begin{array}{l}\text { Esse parâmetro merece tratamento diferencial como importante para } \\
\text { o projeto de arquitetura por desempenhar papel relevante para o apren- } \\
\text { dizado? }\end{array}$ \\
\hline N3 & $\begin{array}{l}\text { Esse parâmetro merece tratamento diferencial com média importân- } \\
\text { cia para o projeto de arquitetura por desempenhar papel relevante para } \\
\text { o aprendizado? }\end{array}$ \\
\hline N2 & $\begin{array}{l}\text { Esse parâmetro merece tratamento diferencial com pouca importân- } \\
\text { cia para o projeto de arquitetura por desempenhar papel relevante para } \\
\text { o aprendizado? }\end{array}$ \\
\hline N1 & Neutro & $\begin{array}{l}\text { Esse parâmetro merece tratamento diferencial sem importância para } \\
\text { o projeto de arquitetura por desempenhar papel relevante para o apren- } \\
\text { dizado? }\end{array}$ \\
\hline
\end{tabular}

Fonte: Elaboração própria (2015).

Na Tabela 35, apresenta-se, para fins de ilustração, o descritor do SubPVE 1.1.2 - Resfriamento evaporativo, construído a partir do PVE 1.1 - Conforto Térmico, com a indicação dos níveis de impacto em ordem decrescente de preferência dos decisores e dos níveis de referência.

Tabela 35 - Descritor com os níveis Bom e Neutro do SubPVE 1.1.2 - Resfriamento evaporativo

\begin{tabular}{l|l|l}
\hline $\begin{array}{l}\text { Níveis } \\
\text { Impacto }\end{array}$ & $\begin{array}{l}\text { Niveis de re- } \\
\text { ferência }\end{array}$ & Descrição \\
\hline N5 & Bom & $\begin{array}{l}\text { Esse parâmetro merece tratamento diferencial como muito impor- } \\
\text { tante para o projeto de arquitetura por desempenhar papel relevante } \\
\text { para o aprendizado? }\end{array}$ \\
\hline N4 & $\begin{array}{l}\text { Esse parâmetro merece tratamento diferencial como importante para } \\
\text { o projeto de arquitetura por desempenhar papel relevante para o apren- } \\
\text { dizado? }\end{array}$ \\
\hline N3 & $\begin{array}{l}\text { Esse parâmetro merece tratamento diferencial com média importân- } \\
\text { cia para o projeto de arquitetura por desempenhar papel relevante para } \\
\text { o aprendizado? }\end{array}$ \\
\hline N2 & $\begin{array}{l}\text { Esse parâmetro merece tratamento diferencial com pouca importân- } \\
\text { cia para o projeto de arquitetura por desempenhar papel relevante para } \\
\text { o aprendizado? }\end{array}$ \\
\hline N1 & $\begin{array}{l}\text { Esse parâmetro merece tratamento diferencial sem importância para } \\
\text { o projeto de arquitetura por desempenhar papel relevante para o apren- } \\
\text { dizado? }\end{array}$ \\
\hline
\end{tabular}

Fonte: Elaboração própria (2015). 
Capítulo 4. Método de avaliação dos atributos/parâmetros facilitadores do ensino-aprendizagem e bases 198 para o modelo de arquitetura da informação

Nas Tabelas 36, 37 e 38 apresentam-se os descritores do modelo completo, com os respectivos níveis de impacto e níveis de referência, contemplando os critérios (PVFs) Conforto Ambiental, Ergonomia e Psicologia Ambiental. Ressalta-se que os descritores foram construídos preliminarmente pelo facilitador e, após sucessivas aproximações, foram refinados com os especialistas e validados por eles.

Tabela 36 - Descritores com níveis de impacto e de referência do PVF 1 - Conforto Ambiental

\begin{tabular}{|c|c|c|c|c|c|}
\hline $\begin{array}{l}\text { Critérios } \\
\text { (PVFs) }\end{array}$ & $\begin{array}{l}\text { Subcritérios } \\
\text { (PVEs) }\end{array}$ & $\begin{array}{l}\text { Subcritérios } \\
\text { (SubPVEs) }\end{array}$ & NI & NR & Descritores \\
\hline \multirow{30}{*}{ 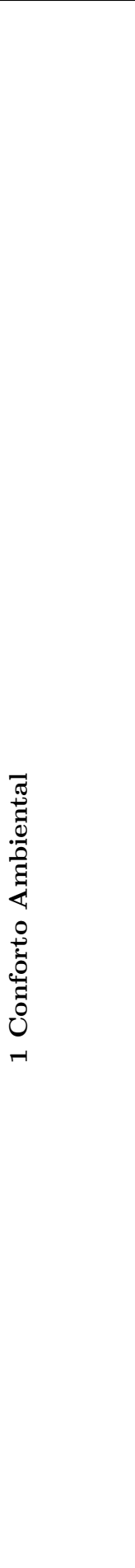 } & \multirow{25}{*}{ 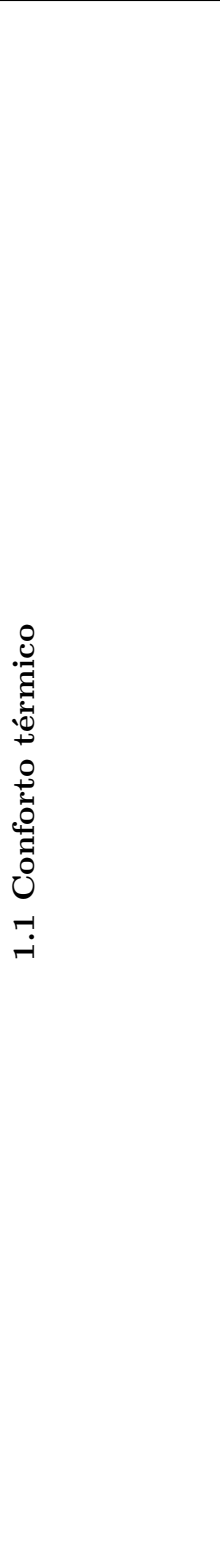 } & 1.1 .1 & N5 & & muito importante \\
\hline & & \multirow[t]{4}{*}{ Ventilação } & N4 & $\mathbf{B}$ & importante \\
\hline & & & N3 & & média importância \\
\hline & & & N2 & $\mathbf{N}$ & pouca importância \\
\hline & & & N1 & & sem importância \\
\hline & & 1.1 .2 & N5 & & muito importante \\
\hline & & \multirow[t]{4}{*}{ Resfriamento evaporativo } & N4 & B & importante \\
\hline & & & N3 & & média importância \\
\hline & & & $\mathrm{N} 2$ & $\mathbf{N}$ & pouca importância \\
\hline & & & N1 & & sem importância \\
\hline & & \multirow{5}{*}{$\begin{array}{l}1.1 .3 \\
\text { Massa térmica para aquecimento }\end{array}$} & N5 & & muito importante \\
\hline & & & N4 & B & importante \\
\hline & & & N3 & & média importância \\
\hline & & & $\mathrm{N} 2$ & $\mathbf{N}$ & pouca importância \\
\hline & & & N1 & & sem importância \\
\hline & & \multirow{5}{*}{$\begin{array}{l}1.1 .4 \\
\text { Umidificação }\end{array}$} & N5 & & muito importante \\
\hline & & & N4 & B & importante para o \\
\hline & & & N3 & & média importância \\
\hline & & & $\mathrm{N} 2$ & $\mathbf{N}$ & pouca importância \\
\hline & & & N1 & & sem importância \\
\hline & & \multirow{5}{*}{$\begin{array}{l}1.1 .5 \\
\text { Ar-condicionado }\end{array}$} & N5 & & muito importante \\
\hline & & & N4 & B & importante \\
\hline & & & N3 & & média importância \\
\hline & & & $\mathrm{N} 2$ & $\mathbf{N}$ & pouca importância \\
\hline & & & N1 & & sem importância \\
\hline & \multirow{5}{*}{ 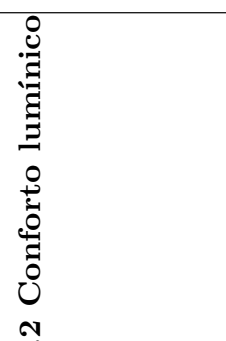 } & \multirow{5}{*}{$\begin{array}{l}1.2 .1 \\
\text { Mecanismos de controle }\end{array}$} & N5 & & muito importante \\
\hline & & & $\mathrm{N} 4$ & B & importante \\
\hline & & & N3 & & média importância \\
\hline & & & $\mathrm{N} 2$ & $\mathbf{N}$ & pouca importância \\
\hline & & & N1 & & sem importância pa \\
\hline
\end{tabular}




\begin{tabular}{|c|c|c|c|c|c|}
\hline $\begin{array}{l}\text { Critérios } \\
\text { (PVFs) }\end{array}$ & $\begin{array}{l}\text { Subcritérios } \\
\text { (PVEs) }\end{array}$ & $\begin{array}{l}\text { Subcritérios } \\
\text { (SubPVEs) }\end{array}$ & NI & NR & Descritores \\
\hline & & 1.2 .2 & N5 & & muito importante \\
\hline & & Reforço de iluminamento & $\mathrm{N} 4$ & B & importante para \\
\hline & & & N3 & & média importância \\
\hline & & & $\mathrm{N} 2$ & $\mathbf{N}$ & pouca importância \\
\hline & & & N1 & & muito importante \\
\hline & & 1.2 .3 & N5 & & importante \\
\hline & & Uso de cores & N4 & B & média importância \\
\hline & & & N3 & & pouca importância \\
\hline & & & $\mathrm{N} 2$ & $\mathbf{N}$ & sem importância \\
\hline & & & N1 & & muito importante \\
\hline & & 1.2 .4 & N5 & & muito importante \\
\hline & & Iluminação & $\mathrm{N} 4$ & B & importante \\
\hline & & & N3 & & média importância \\
\hline & & & $\mathrm{N} 2$ & $\mathbf{N}$ & pouca importância \\
\hline & & & N1 & & sem importância \\
\hline & & 1.2 .5 & N5 & & muito importante \\
\hline & & Luminância & $\mathrm{N} 4$ & B & importante \\
\hline & & & N3 & & média importância \\
\hline & & & N2 & $\mathbf{N}$ & pouca importância para \\
\hline & & & N1 & & sem importância \\
\hline & & & N5 & & muito importante \\
\hline & & & N4 & B & importante \\
\hline & & 1.2.6 Contraste & N3 & & média importância \\
\hline & & & $\mathrm{N} 2$ & $\mathbf{N}$ & pouca importância \\
\hline & & & N1 & & sem importância \\
\hline & \multirow{12}{*}{ 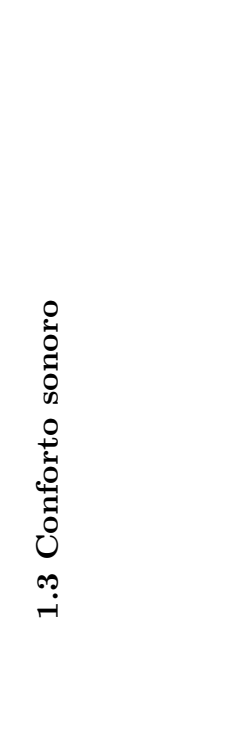 } & 1.3 .1 & N5 & & muito importante \\
\hline & & & N4 & B & importante para \\
\hline & & Tempo de reverberação & N3 & & média importância \\
\hline & & & $\mathrm{N} 2$ & $\mathbf{N}$ & pouca importância \\
\hline & & & N1 & & sem importância \\
\hline & & 1.3 .2 & N5 & & muito importante \\
\hline & & Isolamento sonoro & N4 & B & importante \\
\hline & & & N3 & & média importância \\
\hline & & & $\mathrm{N} 2$ & $\mathbf{N}$ & pouca importância \\
\hline & & & N1 & & sem importância \\
\hline & & 1.3 .3 & N5 & & muito importante \\
\hline & & Nível sonoro & N4 & B & importante \\
\hline
\end{tabular}


Capítulo 4. Método de avaliação dos atributos/parâmetros facilitadores do ensino-aprendizagem e bases para o modelo de arquitetura da informação

\begin{tabular}{|c|c|c|c|c|c|}
\hline $\begin{array}{l}\text { Critérios } \\
\text { (PVFs) }\end{array}$ & $\begin{array}{l}\text { Subcritérios } \\
\text { (PVEs) }\end{array}$ & $\begin{array}{l}\text { Subcritérios } \\
\text { (SubPVEs) }\end{array}$ & NI & NR & Descritores \\
\hline & & & N3 & & média importância \\
\hline & & & $\mathrm{N} 2$ & $\mathbf{N}$ & pouca importância \\
\hline & & & N1 & & sem importância \\
\hline & & 1.3 .4 & N5 & & muito importante \\
\hline & & Frequência & N4 & B & importante \\
\hline & & & N3 & & média importância \\
\hline & & & N2 & $\mathbf{N}$ & pouca importância \\
\hline & & & N1 & & sem importância \\
\hline & & 1.3 .5 & N5 & & muito importante \\
\hline & & Duração da exposição & N4 & B & importante \\
\hline & & & N3 & & média importância \\
\hline & & & N2 & $\mathbf{N}$ & pouca importância \\
\hline & & & N1 & & sem importância \\
\hline
\end{tabular}

Fonte: Elaboração própria (2016).

Tabela 37 - Descritores com níveis de impacto e de referência do PVF 2 - Ergonomia

\begin{tabular}{|c|c|c|c|c|c|}
\hline $\begin{array}{l}\text { Critérios } \\
\text { (PVFs) }\end{array}$ & $\begin{array}{l}\text { Subcritérios } \\
\text { (PVEs) }\end{array}$ & $\begin{array}{l}\text { Subcritérios } \\
\text { (SubPVEs) }\end{array}$ & NI & NR & Descritores \\
\hline \multirow{18}{*}{ 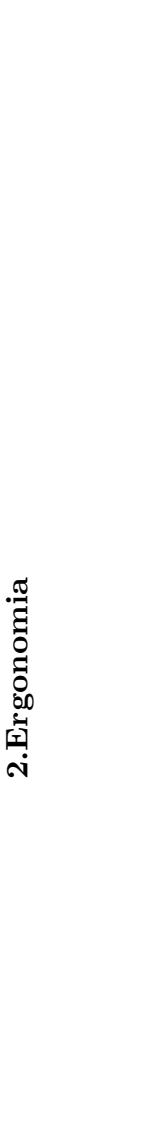 } & \multirow{10}{*}{ 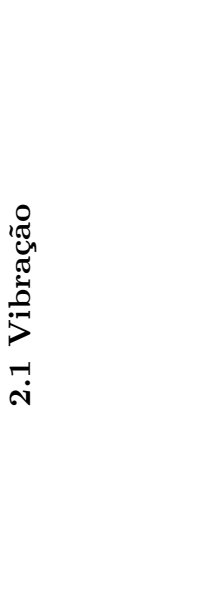 } & \multirow{5}{*}{$\begin{array}{l}\text { Frequência } \\
\mathbf{2 . 1 . 1}\end{array}$} & N5 & & muito importante \\
\hline & & & N4 & B & importante \\
\hline & & & N3 & & média importância \\
\hline & & & N2 & $\mathbf{N}$ & pouca importância \\
\hline & & & N1 & & sem importância \\
\hline & & \multirow{5}{*}{$\begin{array}{l}\text { Intensidade } \\
2.1 .2\end{array}$} & N5 & & muito importante \\
\hline & & & N4 & B & importante \\
\hline & & & N3 & & média importância \\
\hline & & & N2 & $\mathbf{N}$ & pouca importância \\
\hline & & & N1 & & sem importância \\
\hline & \multirow{8}{*}{ 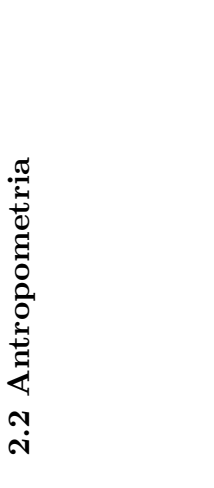 } & \multirow{5}{*}{$\begin{array}{l}\text { Arranjo físico } \\
2.2 .1\end{array}$} & N5 & & muito importante \\
\hline & & & N4 & B & importante \\
\hline & & & N3 & & média importância \\
\hline & & & N2 & $\mathbf{N}$ & pouca importância \\
\hline & & & N1 & & sem importância \\
\hline & & \multirow{3}{*}{$\begin{array}{l}\text { Mobiliário } \\
2.2 .2\end{array}$} & N5 & & muito importante \\
\hline & & & N4 & B & importante? \\
\hline & & & N3 & & média importância \\
\hline
\end{tabular}




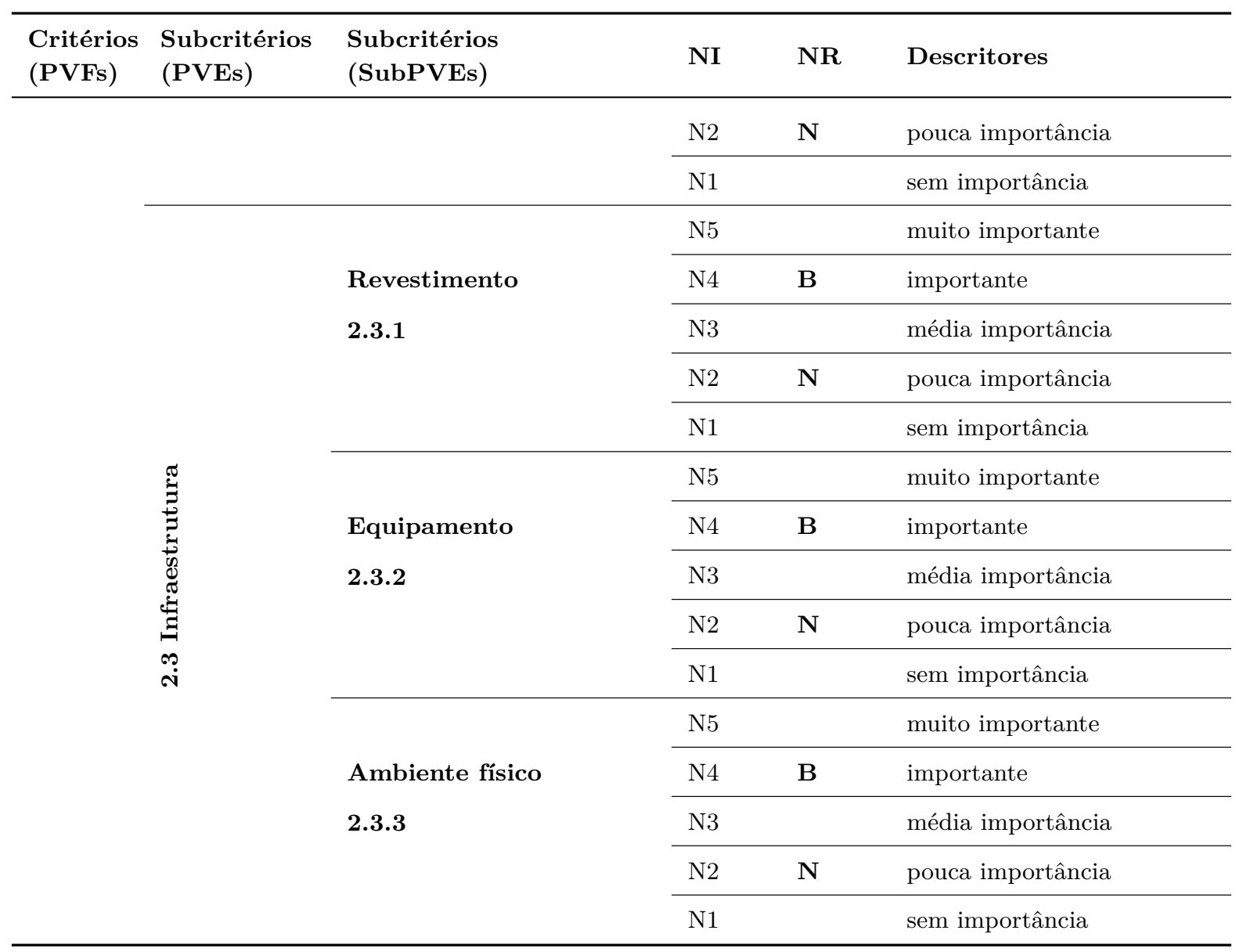

Fonte: Elaboração própria (2016).

Tabela 38 - Descritores com níveis de impacto e de referência do PVF 3 - Psicologia Ambiental

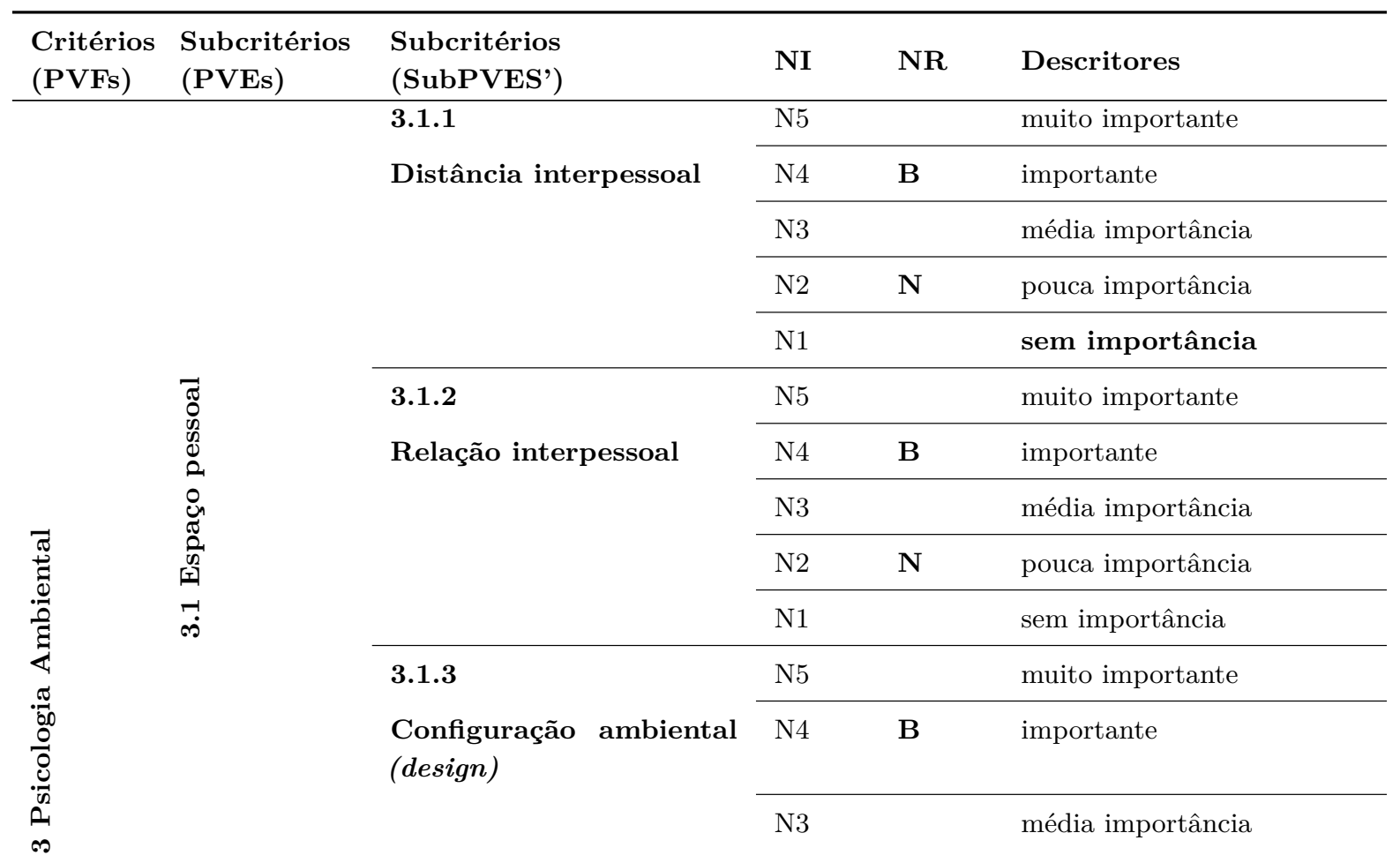


Capítulo 4. Método de avaliação dos atributos/parâmetros facilitadores do ensino-aprendizagem e bases

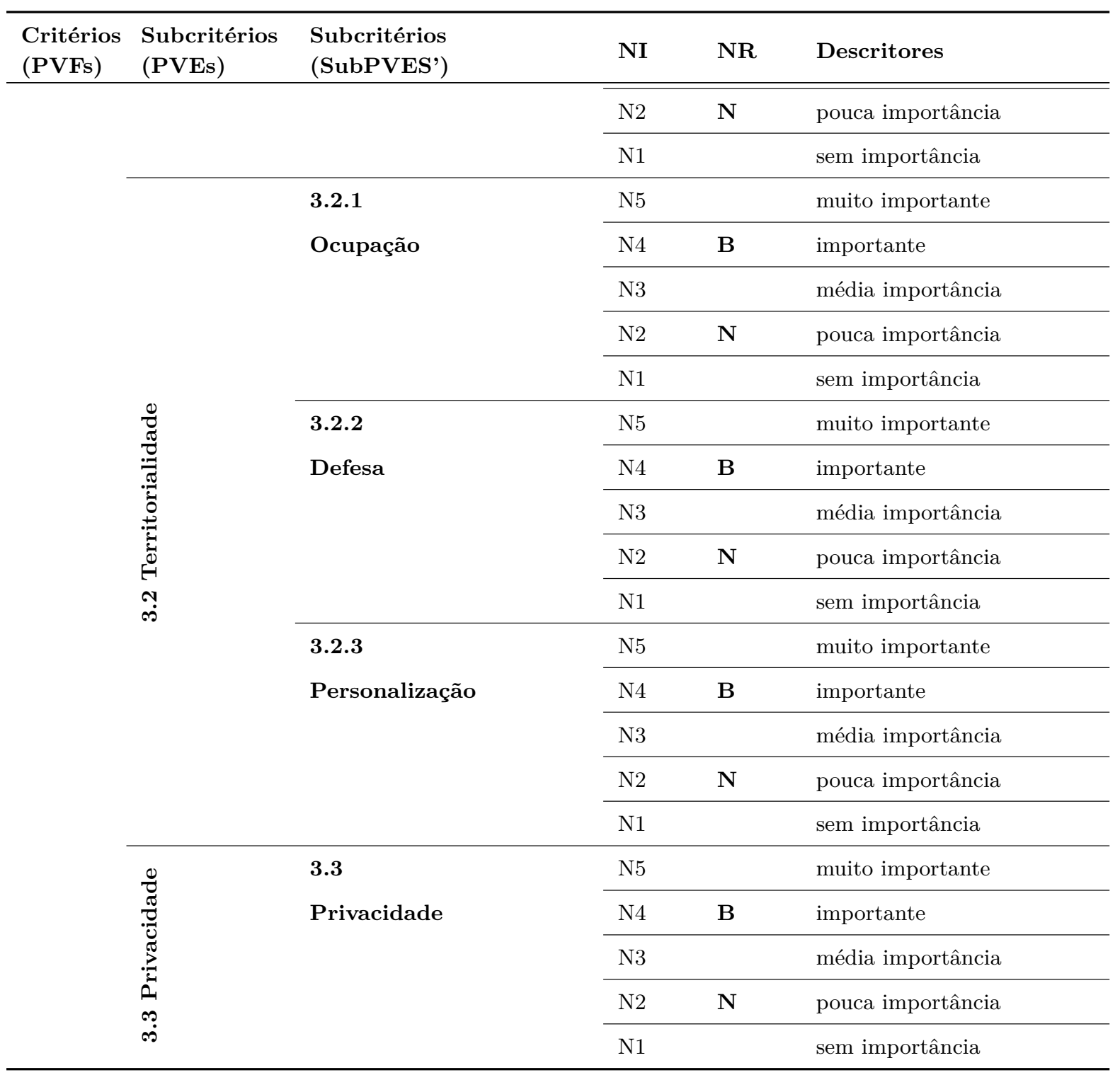

Fonte: Elaboração própria (2016).

De posse dos descritores é possível iniciar a etapa de avaliação do modelo multicritério, com base nos eixos definidos na fase de estruturação. A fase de avaliação compreende as seguintes etapas: i) construção das funções de valor; e ii) construção das taxas de substituição ou compensação.

\subsubsection{Funções de Valor}

As funções de valor (taxas de atratividade locais ou avaliações locais) são representações matemáticas, por meio de gráficos ou escalas numéricas, segundo o julgamento de valor do decisor sobre um determinado critério. De acordo com Ensslin, Neto e Noronha (2001) elas representam, numericamente, o grau de atratividade de cada nível de impacto de um descritor de um ponto de vista fundamental, em relação à escala ancorada em níveis prefixados (Bom e Neutro), de acordo com o sistema de valor do decisor. A Função de 
Valor quantifica os níveis de impacto das ações potenciais por meio das preferências dos decisores (QUIRINO, 2002).

Para Ensslin, Neto e Noronha (2001) existem vários métodos descritos, na literatura, que podem ser utilizados para construir as funções de valor. Neste estudo foi utilizado o método denominado Julgamento Semântico considerado pelo autor como o mais adequado para auxiliar o decisor na articulação de suas preferências, permitindo, assim, avaliar ações potenciais em um determinado ponto de vista.

Nos métodos de julgamento semântico, a função de valor é construída a partir de comparações par a par da diferença de atratividade entre as ações potenciais (BEINAT, 1995), As comparações são feitas, solicitando-se que o decisor expresse qualitativamente, por meio de uma escala ordinal semântica (com palavras), a intensidade de preferência de uma ação sobre a outra (QUIRINO, 2002).

O procedimento adotado consiste em questionar os decisores (nesse caso os especialistas) para que expressem verbalmente a diferença de atratividade entre as duas ações potenciais a e b (a mais atrativa que b), escolhendo uma das categorias semânticas utilizadas pelo software Macbeth, indicadas por Quirino (2002), constantes do Tabela 39.

Tabela 39 - Escala ordinal semântica utilizada pelo Macbeth

\begin{tabular}{ll}
\hline Descrição & Escala \\
\hline Nenhuma diferença de atratividade (indiferença) & Nula \\
\hline Diferença de atratividade muito fraca & Muito fraca \\
\hline Diferença de atratividade fraca & Fraca \\
\hline Diferença de atratividade moderada & Moderada \\
\hline Diferença de atratividade forte & Forte \\
\hline Diferença de atratividade muito forte & Muito forte \\
\hline Diferença de atratividade extrema & Extrema \\
\hline
\end{tabular}

Fonte: Macbeth (2016).

De acordo com Quirino (2002), com base nas categorias semânticas, constrói-se uma matriz, denominada matriz semântica, com as diferenças de atratividade indicadas pelos decisores em relação às ações em análise, a partir da comparação par a par dos níveis de impacto de um mesmo descritor.

Na matriz semântica, deve-se considerar aij um elemento qualquer, onde "i" representa a linha em que o elemento se posiciona na matriz e "j" representa a coluna em que o elemento se posiciona. Para manter a consistência na matriz semântica, torna-se necessário que o decisor cumpra as seguintes propriedades Quirino (2002):

- na linha "i" $\longrightarrow a i j \leq a i j+1 \leq a i j+2 \leq \ldots . \leq a i j+n$; 
Capítulo 4. Método de avaliação dos atributos/parâmetros facilitadores do ensino-aprendizagem e bases 204 para o modelo de arquitetura da informação

- na coluna "j" $\longrightarrow a i j \leq a i+1 j \leq a i+2 j \leq \ldots \leq a i+n j$.

As funções de valor são determinadas pelo Macbeth por programação linear, por isso, torna-se necessário que as propriedades de consistência sejam cumpridas. Caso contrário, pode ocorrer incompatibilidade no sistema de equações lineares que formam a programação linear (tal incompatibilidade é indicada pelo próprio software), demandando ajustes Quirino (2002).

As funções de valor devem satisfazer as condições matemáticas indicadas abaixo, onde A corresponde o conjunto de ações potenciais Ensslin, Neto e Noronha (2001):

- para todo $\mathrm{a}, \mathrm{b} \in \mathrm{A}, \mathrm{v}(\mathrm{a})>\mathrm{v}(\mathrm{b})$ se, e somente se, para o avaliador "a" for mais atrativa que "b" (a P b) ("a" é preferível a "b");

- para todo $\mathrm{a}, \mathrm{b} \in \mathrm{A}, \mathrm{v}(\mathrm{a})=(\mathrm{b})$ se, e somente se, para o avaliador "a" for indiferente $a$ "b"(a I b) ("a"é indiferente a "b");

- para todo a, b, c, d $\in \mathrm{A}, \mathrm{v}(\mathrm{a})-\mathrm{v}(\mathrm{b})>\mathrm{v}(\mathrm{c})-\mathrm{v}(\mathrm{d})$ se, e somente se, para o avaliador a diferença de atratividade entre "a"e "b"for maior que a diferença de atratividade entre "c"e "d".

Na Tabela 40, apresenta-se a função de valor do SubPVE 1.1.1 - Ventilação construída com a utilização do Macbeth.

Tabela 40 - Função de valor do SubPVE 1.1.1 - Ventilação

\begin{tabular}{l|l|l|l}
\hline $\begin{array}{l}\text { Níveis } \\
\text { Impacto }\end{array}$ & $\begin{array}{l}\text { Níveis de re- } \\
\text { ferência }\end{array}$ & Descrição & $\begin{array}{l}\text { Funções } \\
\text { valor }\end{array}$ \\
\hline N5 & Bom & $\begin{array}{l}\text { Muito importante para o projeto de arquitetura por de- } \\
\text { sempenhar papel relevante para o aprendizado }\end{array}$ & 100 \\
\hline N4 & $\begin{array}{l}\text { Importante para o projeto de arquitetura por desempe- } \\
\text { nhar papel relevante para o aprendizado }\end{array}$ & 75 \\
\hline N3 & $\begin{array}{l}\text { Média importância para o projeto de arquitetura por de- } \\
\text { sempenhar papel relevante para o aprendizado }\end{array}$ & 50 \\
\hline N2 & Neutro & $\begin{array}{l}\text { Pouca importância para o projeto de arquitetura por de- } \\
\text { sempenhar papel relevante para o aprendizado }\end{array}$ & 25 \\
\hline N1 & $\begin{array}{l}\text { Sem importância para o projeto de arquitetura por de- } \\
\text { sempenhar papel relevante para o aprendizado }\end{array}$ & 0 \\
\hline
\end{tabular}

Fonte: Elaboração própria (2016).

O decisor (especialista) em conforto definiu que os descritores contemplados para o PVF 1 - Conforto Ambiental teriam 5 níveis de impacto, atribuindo valores registrados no software Macbeth, conforme suas preferências (juízo de valor).

Na Figura 31, mostra-se a tela do Macbeth com a matriz semântica relativa à construção da função de valor do SubPVE 1.1.1 - Ventilação. 


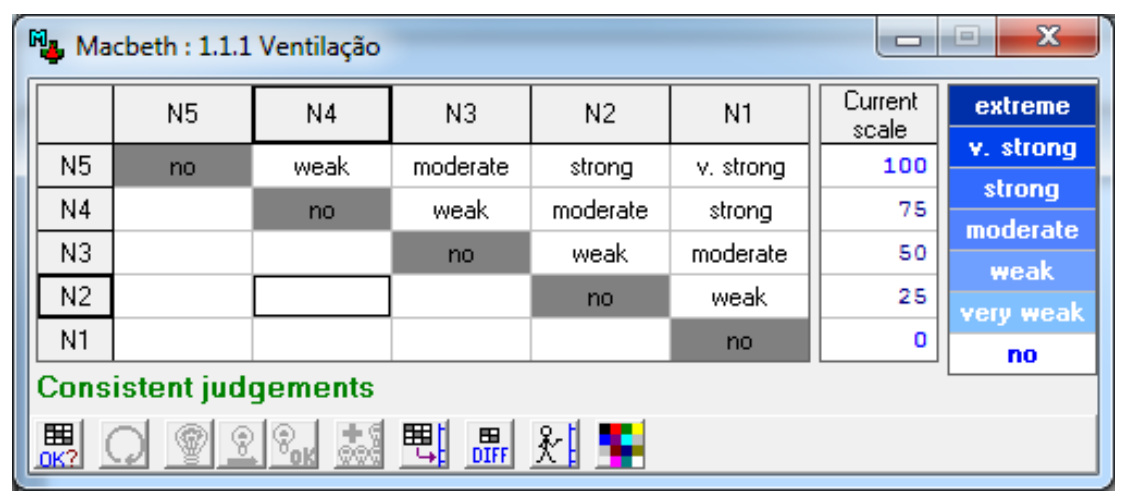

Figura 31 - Função de valor do SubPVE 1.1.1 - Ventilação Fonte: Macbeth (2016).

O decisor (especialista) em ergonomia definiu que os descritores contemplados para o PVF 2 - Ergonomia teriam 5 níveis de impacto, atribuindo valores registrados no software Macbeth, conforme suas preferências (juízo de valor).

Na Figura 32 mostra-se a tela do Macbeth com a matriz semântica relativa à construção da função de valor do SubPVE 2.1.1 - Frequência.

\begin{tabular}{|c|c|c|c|c|c|c|c|}
\hline \multicolumn{6}{|c|}{ Macbeth : 2.1.1 Frequência } & \multicolumn{2}{|c|}{\begin{tabular}{|l|l|l|}
0 & $\square$ & $X$ \\
\end{tabular}} \\
\hline & N5 & N4 & N3 & N2 & N1 & $\begin{array}{l}\text { Current } \\
\text { scale }\end{array}$ & extreme \\
\hline N5 & no & moderate & moderate & moderate & strong & 100 & Y. strong \\
\hline N4 & & no & moderate & moderate & moderate & 75 & strong \\
\hline N3 & & & no & moderate & moderate & 50 & moderate \\
\hline N2 & & & & no & moderate & 25 & weak \\
\hline N1 & & & & & 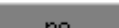 & & yery weak \\
\hline \multirow{2}{*}{\multicolumn{8}{|c|}{ Consistent judgements }} \\
\hline & & & & & & & \\
\hline 围? & & 8 & 罟乩 思 & 연드 & & & \\
\hline
\end{tabular}

Figura 32 - Função de valor do SubPVE 2.1.1 - Frequência

Fonte: Macbeth (2016).

O decisor (especialista) em Psicologia Ambiental definiu que os descritores contemplados para o PVF 3 - Psicologia Ambiental teriam 5 níveis de impacto, atribuindo valores registrados no software Macbeth, conforme suas preferências (juízo de valor).

Na Figura 33 mostra-se a tela do Macbeth com a matriz semântica relativa à construção da função de valor do subPVE 3.1.1 - Frequência 
Capítulo 4. Método de avaliação dos atributos/parâmetros facilitadores do ensino-aprendizagem e bases 206 para o modelo de arquitetura da informação

\begin{tabular}{|c|c|c|c|c|c|c|c|}
\hline \multicolumn{6}{|c|}{ Macbeth : 3.1.1 Dist Interpes } & \multicolumn{2}{|c|}{\begin{tabular}{|l|l|l|}
0 & $\square$ & $x$ \\
\end{tabular}} \\
\hline & N5 & N4 & N3 & N2 & N1 & $\begin{array}{l}\text { Current } \\
\text { scale }\end{array}$ & extreme \\
\hline N5 & no & weak & moderate & strong & v. strong & 100 & Y. strong \\
\hline N4 & & no & weak & moderate & strong & 75 & strong \\
\hline N3 & & & no & weak & moderate & 50 & moderate \\
\hline N2 & & & & no & weak & 25 & weak \\
\hline N1 & & & & & no & & very weak \\
\hline \multicolumn{8}{|c|}{ Consistent judgements } \\
\hline 再? & & & 困酎 & 㩆 & & & \\
\hline
\end{tabular}

Figura 33 - Função de valor do SubPVE 3.1.1 - Distância Interpessoal Fonte: Macbeth (2016).

As demais telas do Macbeth, com as matrizes semânticas relativas à determinação de todas as funções de valor dos descritores de todos os PVEs e SubPVEs, encontram-se no Apêndice C.

Segundo Quirino (2002), a Matrix of judgements (Matriz de Julgamento) significa que o especialista aplicou as propriedades da matriz semântica corretamente. O valor indicado na Figura 33 foi baseado no método da matriz semântica para melhor mensurar os julgamentos do especialista.

Ensslin, Neto e Noronha (2001) ressaltam que, a partir da determinação de uma função de valor associada a um descritor, considera-se que foi construído um critério de avaliação para um dado PVF e subcritérios para os PVEs e SubPVEs.

Após a construção das funções de valores, faz-se necessária a transformação das escalas das funções de valor dos descritores, de modo que o nível Bom fique ancorado na escala 100 e o nível Neutro, na escala 0 (zero). Assim, os descritores com nível acima de Bom ficam com escalas superiores a 100, enquanto os descritores com nível abaixo de Neutro ficam com escalas negativas. Os valores numéricos resultantes dessa transformação são denominados de funções transformadas ou funções de ancoragem (QUIRINO, 2002).

Para a construção das taxas de substituição (seção 4.2.9), faz-se necessário que todos os descritores tenham em comum um intervalo de variação entre o nível de impacto mais preferido (Bom) e menos preferido (Neutro), conforme demonstrado na Figura 34.

Para ser feita a transformação da função de valor para a função de ancoragem, utiliza-se procedimentos matemáticos (transformação linear) a partir do software Macbeth, que determina em conjunto as funções de valores e as funções de ancoragens (QUIRINO, 2002) 


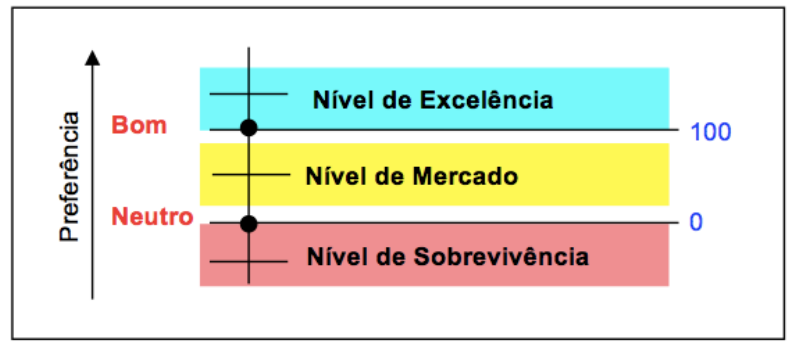

Figura 34 - Demonstração esquemática dos níveis de impacto Bom e Neutro Fonte: Quirino (2002).

\subsubsection{Taxa de substituição (peso)}

\subsubsection{Construção das taxas de substituição ou compensação (pesos)}

As taxas de substituição são utilizadas para determinar a importância relativa dos pontos de vista (PVF, PVE e SubPVE) identificados no modelo multicritério. Dessa forma, definem fatores que revelam a contribuição de um dado ponto de vista no valor global de perfil de uma ação, ou seja, o percentual de participação do objetivo da avaliação. As taxas de substituição são parâmetros que os decisores (especialistas) julgam adequados para agregar, de forma compensatória, desempenhos locais (nos critérios) em uma performance global (ENSSLIN; NETO; NORONHA, 2001).

Como referido, a pesquisa adotou a abordagem construtivista do método e, como tal, não considera a existência de uma taxa de substituição verdadeira, que represente uma realidade preexistente, que corresponda à realidade dos decisores; mas, sim, representa o juízo de valor dos decisores em relação aos pontos de vista de uma determinada situação, em um momento específico (ENSSLIN; NETO; NORONHA, 2001; QUIRINO, 2002).

O cálculo das taxas de substituição é feito a partir de comparações feitas entre os objetivos do modelo, e não mais no nível dos descritores. Os métodos mais difundidos para obtenção das taxas de substituição são: trade-off, swing weights e de comparação par a par, utilizando procedimentos semelhantes aos empregados na obtenção das funções de valor, por meio do software Macbeth.

A determinação das Taxas de Substituição da Árvore de Decisão foi realizada pelo método de pesos balanceados (swing weights) constando de dois passos: i) ordenar os critérios (PVFs, PVEs e SubPVEs) por nível e preferência, segundo o juízo de valor dos especialistas; ii) aplicar a Matriz de Robert (não foi necessário); iii) atribuir ponto para cada critério; e iv) normalizar os valores atribuídos.

\subsubsection{Determinação das taxas de substituição dos critérios e subcritérios}

Método de pesos Balanceados (Swing Weights) 
No caso da presente pesquisa, a ordenação dos critérios e subcritérios foi realizada pelos especialistas responsáveis pelos Pontos de Vista Fundamentais. O especialista em determinada área indica o critério mais atrativo entre os demais e faz-se uma impactacão desse critério no nível Bom 100 pontos e o nível Neutro 0. A seguir, faz-se a comparação dos demais critérios com relação a esse critério mais atrativo. Os resultados dos pontos obtidos pelos critérios são dados em percentuais (valores relativos), e a soma total dos pontos de todos os critérios é igual a 100\%. Com a ordenação dos critérios definidos (Tabela 41) determinaram-se as taxas de substituição.

Apresenta-se, a seguir, o ordenamento dos critérios (PVFs) e dos subcritérios (PVEs e SubPVEs) segundo os juízos de valor dos decisores. 


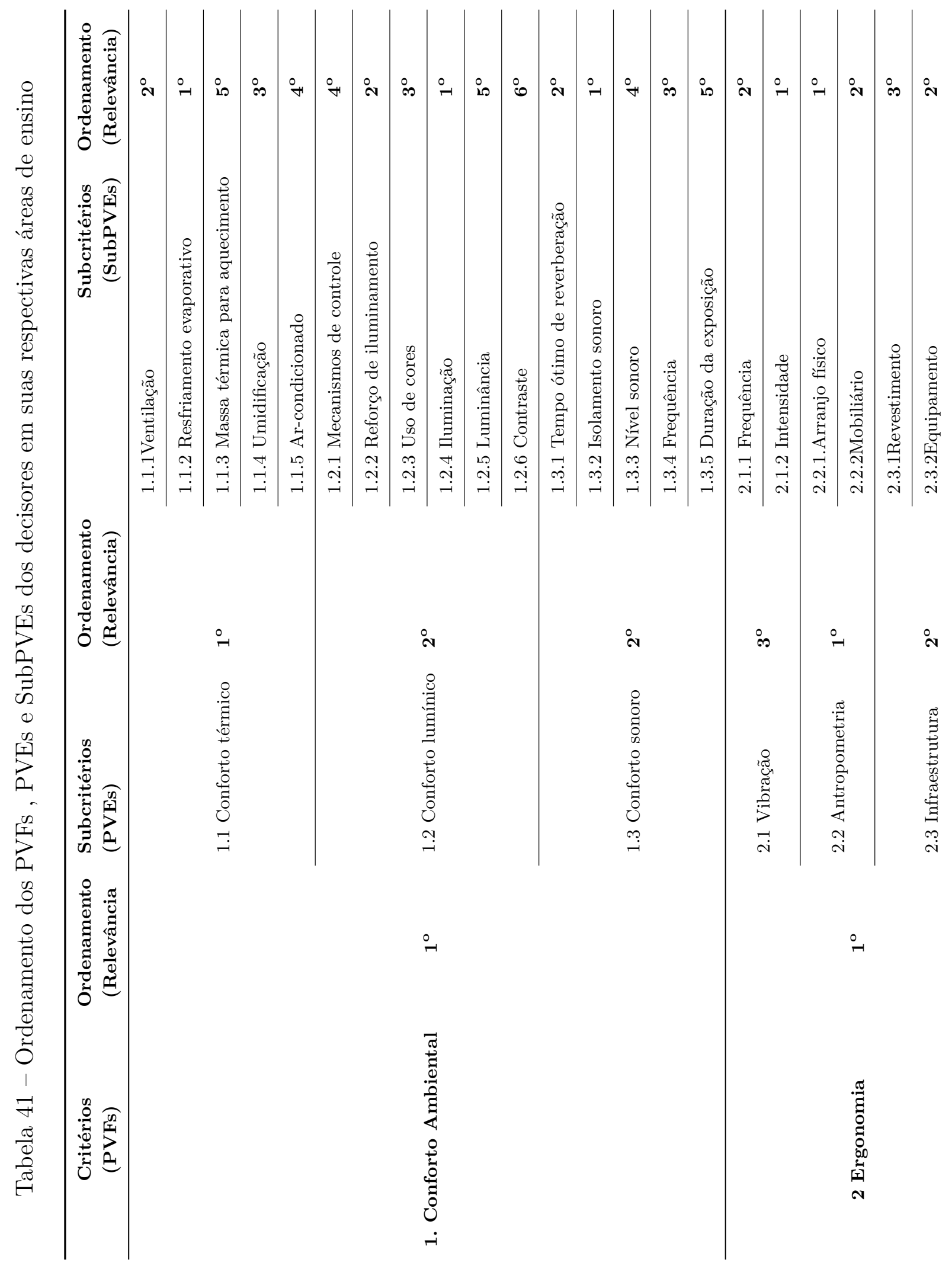




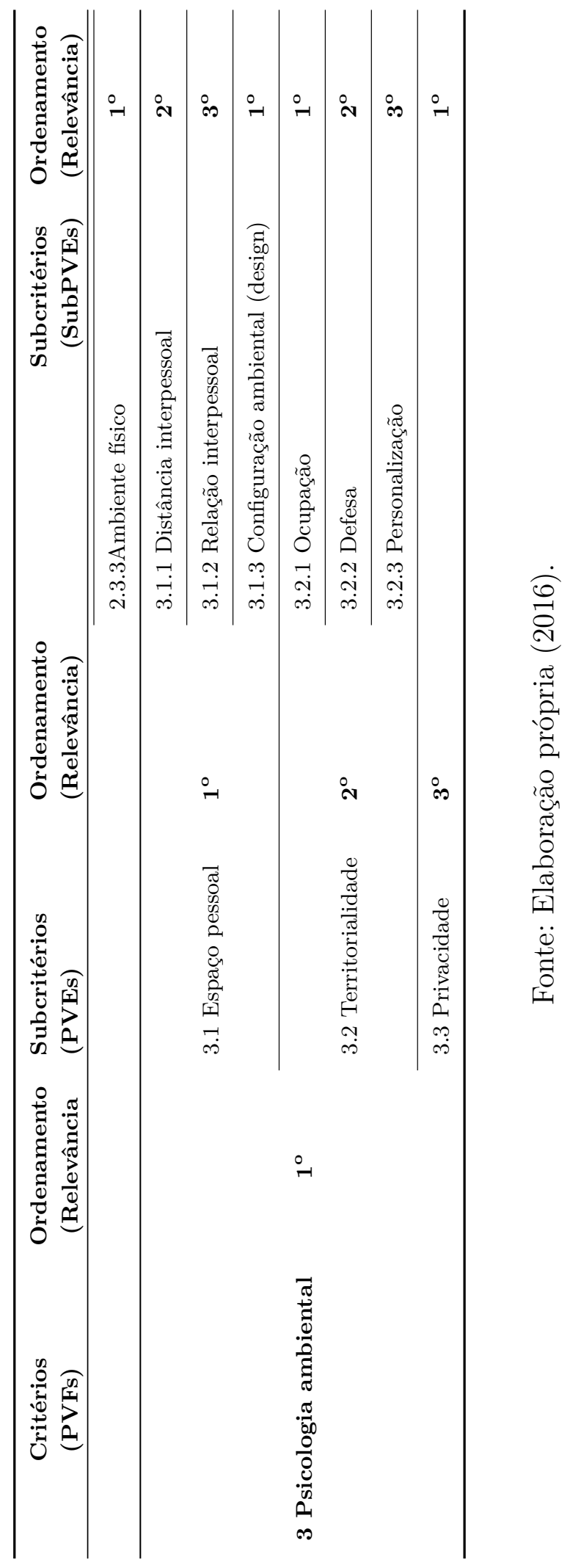


Definida a ordenação dos critérios, o próximo passo foi a definição das taxas de substituição desses critérios, a partir do seguinte encadeamento: o critério mais atrativo, segundo os juízos de valor dos decisores, recebeu a pontuação de 100 e aos demais PVFs foram atribuídos pontos por ordem decrescente, sempre em comparação com o PVF mais atrativo. A pontuação final dos PVFs foram as seguintes:

Determinar-se-á os percentuais de cada critério (PVF) que correspondem às taxas de substituição. Assim, as taxas de substituição dos critérios são (Tabela 42):

Tabela 42 - Cálculo das taxas de substituição dos critérios (PVFs)

\begin{tabular}{ll}
\hline Critérios (PVFs) & Taxas de substituição \\
\hline PVF 1 - Conforto Ambiental & $100 / 300=0,33$ ou $33 \%$ \\
\hline PVF 2 - Ergonomia & $100 / 300=0,33$ ou $33 \%$ \\
\hline PVF 3 - Psicologia Ambiental & $100 / 300=0,33$ ou $33 \%$ \\
\hline
\end{tabular}

Fonte: Elaboração própria (2016).

A seguir apresenta-se a pontuação (pesos) dos criterios (PVFs) (Tabela 43):

Tabela 43 - Pontuação dos PVFs

\begin{tabular}{ll}
\hline Critérios (PVFs') & Pontuação \\
\hline PVF 1 - Conforto Ambiental & 34 pontos \\
\hline PVF 2 - Ergonomia & 33 pontos \\
\hline PVF 3 - Psicologia Ambiental & 33 pontos \\
\hline Total & 100 pontos \\
\hline
\end{tabular}

Fonte: Elaboração própria (2016).

Determinar-se-á os percentuais de cada subcritério (PVE) que correspondem às taxas de substituição. Assim, as taxas de substituição dos subcritérios são (Tabela 44).

Tabela 44 - Cálculo das taxas de substituição dos subcritérios (PVEs)

\begin{tabular}{ll}
\hline Subcritérios (PVEs) & Cálculo das taxas de Substituição \\
\hline 1.1Conforto térmico & $100 / 290=0,34$ ou $34 \%$ \\
1.2 Conforto lumínico & $95 / 290=0.33$ ou $33 \%$ \\
1.3 Conforto sonoro & $95 / 290=0.33$ ou $33 \%$ \\
\hline 1.2.1 Vibração & $80 / 250=0,31$ ou $31 \%$ \\
1.2.Antropometria & $90 / 250=0.35$ ou $35 \%$ \\
1.2.3 Infraestrutura & $85 / 250=0.34$ ou $34 \%$ \\
\hline 1.3.1 Espaço pessoal & $100 / 270=0,37$ ou $37 \%$ \\
1.3.2 Territorialidade & $90 / 270=0.33$ ou $33 \%$ \\
1.3.3 Privacidade & $80 / 270=0,30$ ou $30 \%$ \\
\hline
\end{tabular}

Fonte: Elaboração própria (2016). 
Capítulo 4. Método de avaliação dos atributos/parâmetros facilitadores do ensino-aprendizagem e bases para o modelo de arquitetura da informação

A seguir apresenta- se a pontuação (pesos) dos subcritérios (PVEs) (Tabela 45).

Tabela 45 - Pontuação dos subcritérios (SubPVEs)

\begin{tabular}{ll}
\hline Subcritérios (PVEs) & Pontuação \\
\hline 1.1Conforto térmico & 100 pontos \\
\hline 1.2 Conforto lumínico & 95 pontos \\
\hline 1.3 Conforto sonoro & 95 pontos \\
\hline Total & 290 pontos \\
\hline 2.1 Vibração & 80 pontos \\
\hline 2.2 Antropometria & 90 pontos \\
\hline 2.3 Infraestrutura & 85 pontos \\
\hline Total & 255 pontos \\
\hline 3.1 Espaço pessoal & 100 pontos \\
\hline 3.2 Territorialidade & 90 pontos \\
\hline 3.3 Privacidade & 80 pontos \\
\hline Total & 270 pontos \\
\hline
\end{tabular}

Fonte: Elaboração própria (2016).

Em seguida, foi realizada a determinação do cálculo das referidas taxas de substituição dos SubPVEs e PVEs dos respectivos PVFs, já normalizadas (Tabela 46).

Tabela 46 - Cálculo das taxas de substituição dos SubPVEs

\begin{tabular}{ll}
\hline SubPVEs & Cálculo das taxas de Substituição \\
\hline 1.1.1Ventilação & $90 / 400=0,22$ ou $23 \%$ \\
1.1.2 Resfriamento evaporativo & $100 / 400=0.25$ ou $25 \%$ \\
1.1.3 Massa térmica para aquecimento & $50 / 400=0.12$ ou $12 \%$ \\
1.1.4 Umidificação & $85 / 400=0.21$ ou $21 \%$ \\
1.1.5 Ar-condicionado & $75 / 400=0,19$ ou $19 \%$ \\
\hline 1.2.1 Mecanismos de controle & $75 / 445=0,17$ ou $17 \%$ \\
1.2.2 Reforço de iluminamento & $90 / 445=0.20$ ou $20 \%$ \\
1.2.3 Uso de cores & $80 / 445=0.18$ ou $18 \%$ \\
1.2.4 Iluminação & $100 / 445=0.23$ ou $23 \%$ \\
1.2.5 Luminância & $50 / 445=0,11$ ou $11 \%$ \\
1.2.6 Contraste & $50 / 445=0,11$ ou $11 \%$ \\
\hline 1.3.1 Tempo ótimo de reverberação & $80 / 300=0,27$ ou $27 \%$ \\
1.3.2 Isolamento sonoro & $100 / 300=0.33$ ou $33 \%$ \\
1.3.3 Nível sonoro & $40 / 300=0,13$ ou $13 \%$ \\
1.3.4 Frequência & $60 / 300=0,20$ ou $20 \%$ \\
1.3.5 Duração da exposição & $20 / 300=0.7$ ou $7 \%$ \\
\hline 2.1.1 Freqüência & $100 / 200=0,5$ ou $50 \%$ \\
2.1.2 Intensidade & $100 / 200=0,5$ ou $50 \%$ \\
\hline 2.2.1.Arranjo físico & $30 / 120=0,25$ ou $25 \%$ \\
2.2.2 Mobiliário & $90 / 120=0,75$ ou $75 \%$ \\
\hline 2.3.1Revestimento & $30 / 190=0,16$ ou $16 \%$ \\
2.3.2Equipamento & $80 / 190=0,42$ ou $42 \%$ \\
\hline
\end{tabular}




\begin{tabular}{ll}
\hline SubPVEs & Cálculo das taxas de Substituição \\
\hline 2.3.3Ambiente físico & $80 / 190=0,42$ ou $42 \%$ \\
\hline 3.1.1 Distância interpessoal & $90 / 270=0,33$ ou $33 \%$ \\
3.1.2 Relação interpessoal & $80 / 270=0,30$ ou $30 \%$ \\
3.1.3 Configuração ambiental (design) & $100 / 270=0,37$ ou $37 \%$ \\
\hline 3.2.1 Ocupação & $100 / 270=0,37$ ou $37 \%$ \\
3.2.2 Defesa & $90 / 270=0,33$ ou $33 \%$ \\
3.2.3 Personalização & $80 / 270=0,30$ ou $30 \%$ \\
3.3 Privacidade & $30 \%$ \\
\hline
\end{tabular}

Fonte: Elaboração própria (2016).

A seguir apresenta- se a pontuação (pesos) dos subcritérios (SubPVEs) (Tabela 47).

Tabela 47 - Pontuação dos subcritérios (SubPVEs)

\begin{tabular}{|c|c|}
\hline Subcritérios (SubPVEs) & Pontuação \\
\hline 1.1.1Ventilação & 90 \\
\hline 1.1.2 Resfriamento evaporativo & 100 \\
\hline 1.1.3 Massa térmica para aquecimento & 50 \\
\hline 1.1.4 Umidificação & 85 \\
\hline 1.1.5 Ar-condicionado & 75 \\
\hline 1.2.1 Mecanismos de controle & 75 \\
\hline 1.2.2 Reforço de iluminamento & 90 \\
\hline 1.2.3 Uso de Cores & 80 \\
\hline 1.2.4 Iluminação & 100 \\
\hline 1.2.5 Luminância & 50 \\
\hline 1.2.6 Contraste & 50 \\
\hline 1.3.1 Tempo ótimo de reverberação & 80 \\
\hline 1.3.2 Isolamento sonoro & 100 \\
\hline 1.3.3 Nível sonoro & 40 \\
\hline 1.3.4 Frequência & 60 \\
\hline 1.3.5 Duração da exposição & 20 \\
\hline 2.1.1 Freqüência & 100 \\
\hline 2.1.2 Intensidade & 100 \\
\hline 2.2.1.Arranjo físico & 30 \\
\hline 2.2.2Mobiliário & 90 \\
\hline 2.3.1Revestimento & 30 \\
\hline 2.3.2Equipamento & 80 \\
\hline 2.3.3Ambiente físico & 80 \\
\hline 3.1.1 Distância interpessoal & 90 \\
\hline
\end{tabular}


Capítulo 4. Método de avaliação dos atributos/parâmetros facilitadores do ensino-aprendizagem e bases 214 para o modelo de arquitetura da informação

\begin{tabular}{ll}
\hline Subcritérios (SubPVEs) & Pontuação \\
\hline 3.1.2 Relação interpessoal & 80 \\
\hline 3.1 .3 Configuração ambiental (design) & 100 \\
\hline 3.2 .1 Ocupação & 100 \\
\hline 3.2 .2 Defesa & 90 \\
\hline 3.2 .3 Personalização & 80 \\
\hline 3.3 Privacidade & 100 \\
\hline
\end{tabular}

Elaboração própria (2016).

Determinaram-se, então, as taxas de substituição, que correspondem à participação percentual de cada PVE e SubPVEs dentro do PVF. Essa determinação foi efetuada por estimação, de acordo com os juízos de valor dos decisores. Na tabela 48 ilustram-se os resultados obtidos das Taxas de Substituição dos PVFs Conforto Ambiental, Ergonomia e Psicologia Ambiental. 


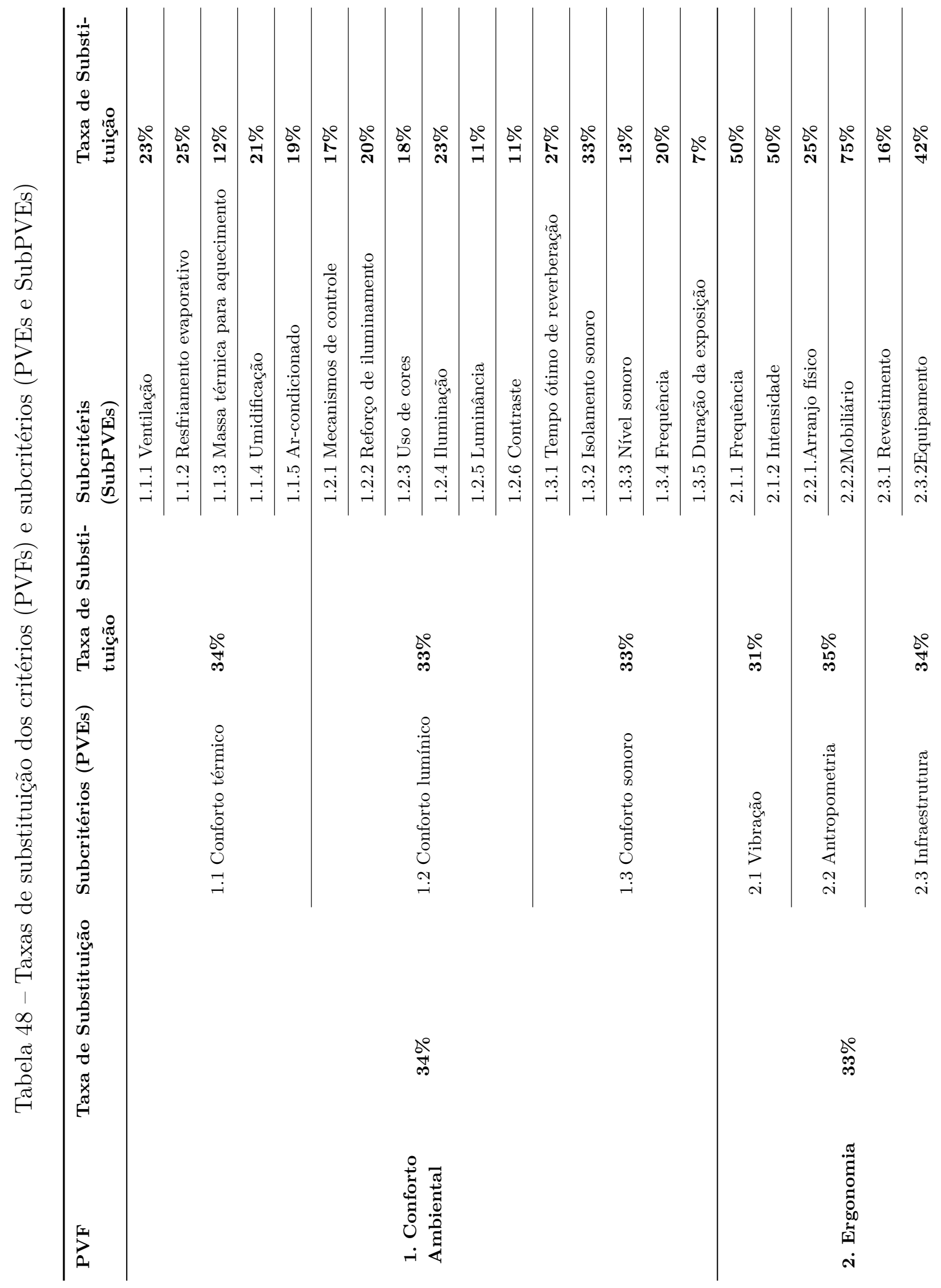




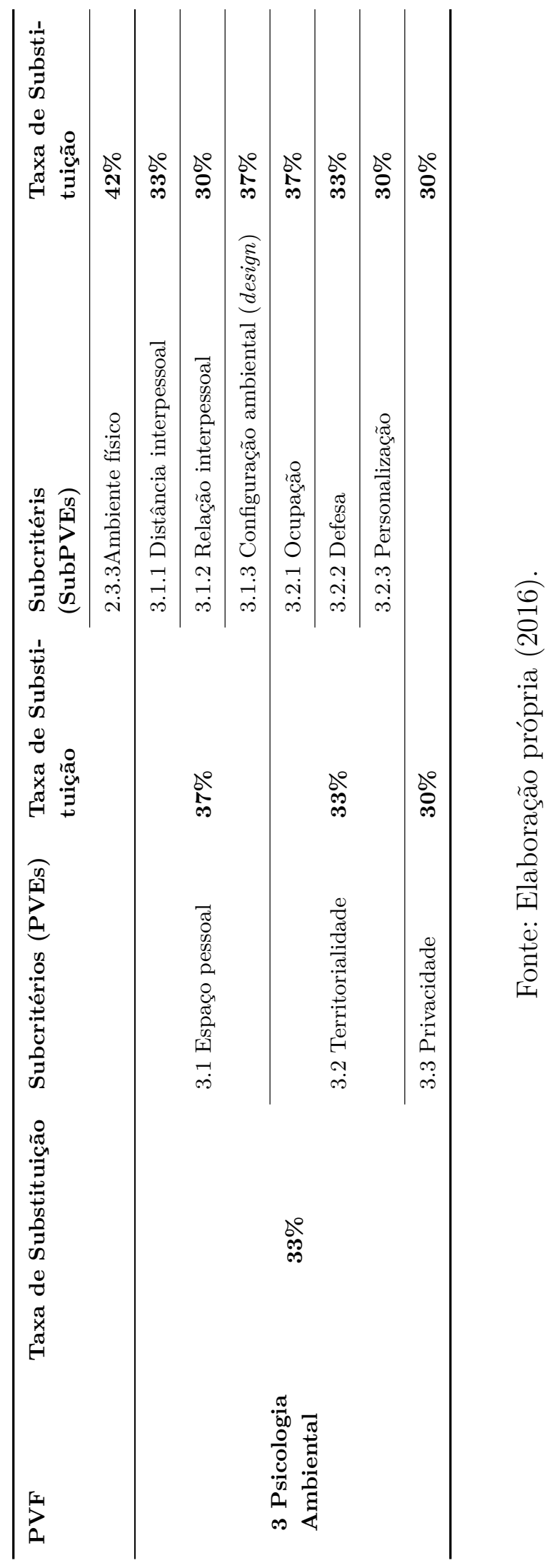


Apresenta-se, a seguir, a estrutura arborescente do modelo multicritério, com a indicação das taxas de substituição (pesos) de todos os critérios e subcritérios (Figura 35).

Estruturado o modelo, foi elaborado o questionário (Apêndice B), o qual foi aplicado aos professores da FAU/UnB, o que se procederá à apresentação e análise dos dados da pesquisa (resultados) a partir de todos os passos referidos anteriormente por meio do programa Hiview e Macbeth no capítulo 5. 

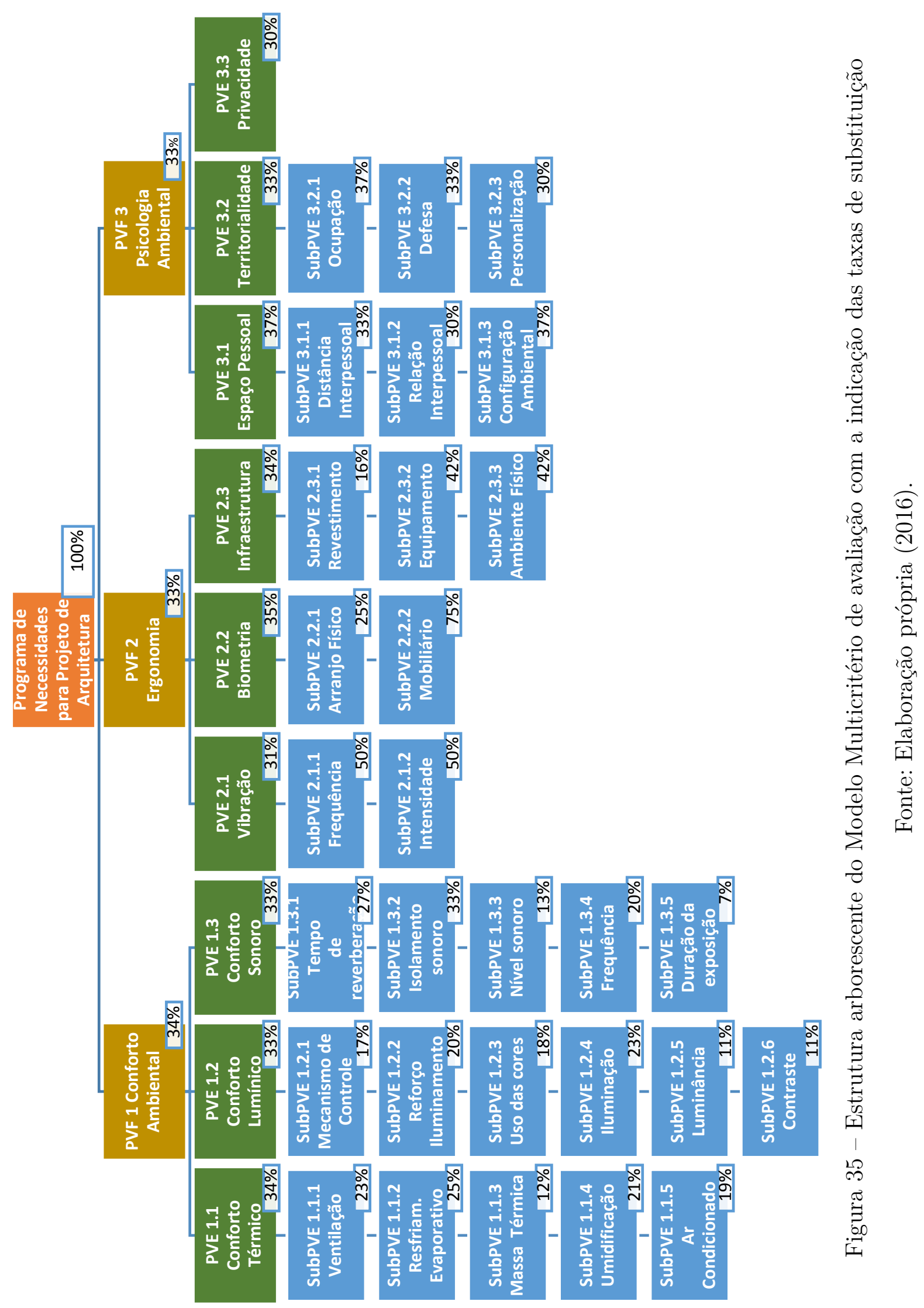
Como complementação da Metodologia Multicritério de Apoio à Decisão (MCDAC), os conteúdos: Perfil de impacto, Avaliação Global e Análise de sensibilidade serão disponibilizadas no capítulo 5.

\subsection{O contexto da Ciência da Informação}

A Ciência da Informação (Science of Information) é mais especificamente o campo da Arquitetura de Informação (AI) que desempenha um papel significativo na análise, crítica e a construção de novos sistemas para o uso adequado de informações nesta nova sociedade (LIMA-MARQUES; CARNIELLI, 2016).

No início dos anos 1990, o biólogo Peter Marijuan, da universidade de Zaragoza, Espanha, e o biofísico Michael Earl Conrad (1941 a 2000), da universidade Estadual de Wayne, Michigan, criaram uma Comunidade de Ciência da Informação. Cientistas de todo o mundo e de diferentes disciplinas foram reunidos para discutir o conceito de informação a partir de uma perspectiva transdisciplinar. Desde então essa Comunidade realizou várias conferências internacionais: 1994, em Madrid; 1996, em Viena; 2005, em Paris; 2010, em Pequim; 2013, em Moscou; e na Cúpula ISIS 2015, em Viena.

Foram feitos esforços no sentido de criar uma organização com foco em desenvolver e promover abordagens transdisciplinares para a informação. Em Paris, um grupo de cientistas reuniu-se em julho de 2005, na $3^{\text {a }}$ Conferência Internacional sobre os Fundamentos da Ciência da Informação (FIS). Na última reunião, os participantes concordaram em estender o trabalho do FIS-Group, criar um instituto e, ainda, montar, coordenar e correlacionar o trabalho teórico atual e o anterior sobre a informação.

Foi nesse contexto que se denominou nova abordagem de Science of Information, para não ser confundido com o termo Information Sciense, que é conhecido como um avanço da Biblioteconomia. O novo campo leva em consideração as recentes e mais amplas perspectivas cobrindo várias disciplinas acadêmicas como campos de interesse.

Em agosto de 2010, durante a $4^{\text {a }}$ Conferência Internacional sobre os Fundamentos da Ciência da Informação (FIS), a primeira conferência científica com o tema "Rumo a uma Nova Ciência da Informação" foi realizada. Um comitê foi criado para preparar a fundação de um Instituto de Ciência da Informação Social (SISI) com a finalidade de avançar estudos globais e colaborativos em Ciência da Informação, Tecnologia da Informação e a Sociedade da Informação. Também a criação de abordagem conceituais e implementá-las em prática para contribuir e enfrentar os desafios da era da informação, e realização de conferências no campo (DOUCETTE et al., 2007).

A ideia de Arquitetura de Informação proposta por M. Lima-Marques segue a mesma abordagem científica. Desde a sua origem, ela foi projetada considerando a crítica 
Capítulo 4. Método de avaliação dos atributos/parâmetros facilitadores do ensino-aprendizagem e bases 220 para o modelo de arquitetura da informação

das atividades desenvolvidas no mercado. Nesse contexto geral, a AI foi utilizada em uma maneira específica e aplicada quase exclusivamente a soluções Web Site (ROSENFELD; MORVILLE, 1998).

\subsubsection{Arquitetura da Informação - aspectos conceituais}

A forma como os seres humanos interagem com o mundo, o que eles pensam, sentem e acreditam, é apoiada por suas percepções sensoriais. O que percebemos e como percebemos o mundo tem uma influência substancial na construção do que somos, de como nos comportamos e de como nos relacionamos com os outros seres humanos. No entanto, a experiência de realidade para nós é algo acessível apenas por meio de mecanismos internos de percepção e pensamento, que produzem uma interpretação pessoal e subjetiva da realidade objetiva. A objetividade desse contexto passa pela organização e comunicação de conjunto de informação mediada pela tecnologia.

Nos últimos anos, o volume da informação tecnológica mediada tem crescido dramaticamente, e parece que esse crescimento está longe de finalizar, aumentando cada vez mais a capacidade tecnológica da sociedade para armazenar, comunicar e para processar a informação.

A AI é uma metodologia de projeto aplicado a qualquer ambiente de informação, entendido como um espaço em um contexto particular, consistindo de fluxo em conteúdo, e servindo a comunidades de usuários para permitir um fluxo eficiente de informações por meio de ambientes de informação projetados (LIMA-MARQUES; MACEDO, 2006).

AI é transdisciplinar e tem várias disciplinas envolvidas na sua implementação. Aplica-se métodos e conceitos que derivam da nova Ciência da Informação e áreas como Filosofia, Matemática, Lógica, Linguística, Ciência da Computação, Ciência Cognitiva, Administração de Empresas, Economia, Ciência da Informação, entre outras. AI é uma composição que envolve processo, prática e conhecimento de domínio. É uma disciplina em que a prática fortalece e promove o seu desenvolvimento (DE SIQUEIRA, 2008).

São objetivos da AI: desenvolver ambientes de informação semanticamente relevantes, em particular, contextos para comunidades de significado; para modelar a informação em ambientes que permitem o seu design, gestão e compartilhamento com usuários; e para promover uma comunicação mais elaborada, colaboração e troca de experiências.

A visão humanista está presente na $\mathrm{AI}$, em que as pessoas são centrais para a criação de soluções cuja tecnologia é somente um suporte necessário. AI deve ser um acordo com os requisitos de informação entre os usuários nos quais há a necessidade de informação em um tempo correto (RANGANATHAN, 1963).

Araujo (2016) define AI como uma disciplina cujo objeto é a configuração da informação, isto é, sua estrutura em fenômeno adequado. De uma perspectiva tecnológica, 
a AI pode ser vista como um conjunto de métodos e técnicas para ambientes de informação desenhados.

A profusão de informações e sua relevância para questões específicas suscitou o desenvolvimento da tecnologia e da Ciência da Informação e, mais especificamente, da AI como uma ferramenta para reduzir a disseminação de informação e torná-la mais adequada para a compreensão humana. Como disciplina, refere-se a um esforço sistemático para identificar padrões e colocar métodos para a configuração do espaço de informação, cuja finalidade é a representação e manipulação da informação; e o estabelecimento de relações ligadas a sua linguística (DE SIQUEIRA, 2008).

Lacerda e Lima-Marques (2014) defendem a proposta de AI como uma disciplina e introduzem uma abordagem metodológica baseada em van Gigch e Pipino (1986). Esse passo importante para a construção de um novo campo anuncia uma tendência internacional em compreender os seus fundamentos. AI deve assimilar elementos de espaço, tempo, estrutura, semântica e contexto; aprofundar a compreensão da natureza da informação e aplicar esses resultados a problemas críticos na sociedade.

Os modelos desenvolvidos para criar a AI a partir de conceitos teóricos e transformado em um sistema de informação: um conjunto de componentes inter-relacionados - hardware, software, procedimentos e bases de dados, entre outros. Esses elementos trabalham juntos para agir no ciclo de vida da informação, caracterizado pelas etapas: coleta, descrição, organização, armazenamento, recuperação, acesso, reembalagem, uso, arquivamento, preservação, prevenção, e destruição. Assim, a tecnologia da informação é a infraestrutura que se materializa cada uma destas perspectivas. A construção de tal sistema requer:

- determinação da configuração da informação em espaços distintos;

- execução dos atos que orientam o desenvolvimento de transformações necessárias;

- desenvolvimento de soluções válidas conforme modelos de AI apropriados para cada finalidade específica.

A AI, a partir da perspectiva das organizações sociais ou da sociedade da informação, (DE SIQUEIRA, 2008), pode ser associada a uma visão de mundo, vista como um conjunto de ações aplicadas a um determinado espaço de informação para transformá-lo no sistema de informação.

Atualmente, o domínio do modelo de informação é vital para a sobrevivência de uma organização. A estrutura econômica geral é montada em padrões de informação. Dominando o ciclo de vida de informação desde a sua origem, os seus padrões de organização, suas representações de modelos apropriados, que permitem a compreensão dos fenômenos e a 
Capítulo 4. Método de avaliação dos atributos/parâmetros facilitadores do ensino-aprendizagem e bases 222 para o modelo de arquitetura da informação

tomada de decisão, tem sido o esforço constante de organizações desde o final do século XX. No entanto, a quantidade de informação revelou-se demasiado grande para a capacidade humana de consumir.

Embora esta sociedade da informação tenha peculiaridades que levam à criação de um novo campo científico, sua característica principal é ainda mantida: pessoas, indivíduos que compartilham experiências uns com os outros, com base na informação. Nesse sentido, os estudos sobre o raciocínio lógico de uma maneira que tenha em conta os aspectos particulares dos indivíduos e das sociedades, como epistêmicos e lógicos sociais, são instrumentos que promovem a compreensão e a descrição de fenômenos de informação no contexto dos agentes humanos. A AI combina lógica e informação para fornecer sistemas que permitem a representação e manipulação de espaços para projetar informações ambientes para apoiar esforços comuns: eles experimentam discursos sobre os fenômeno de informação.

Segundo Lima-Marques e Macedo (2006) compreende-se ambiente de informação, como o espaço que integra contexto, conteúdos e usuários. Os ambientes informacionais são objetos de estudo da Arquitetura da Informação como disciplina, e espaços de atuação desta como prática ou profissão.

Para os autores, uma outra premissa básica considerada como característica da Arquitetura da Informação é que esta existe em qualquer ambiente de informação, independentemente de ter sido concebida por um processo sistemático e racional ou por consequência do acaso. Ou seja, a Arquitetura é uma característica inerente aos espaços de informação, que determina que estes tenham uma forma e uma estrutura, por mais elementares que sejam, estando logicamente organizadas ou não. Partindo desse princípio, se existe um espaço delimitado, que disponibiliza conteúdos de qualquer natureza a uma comunidade de usuários, há uma Arquitetura da Informação embutida. 


\section{Caracterização do Universo de Estudo, De- senvolvimento da Pesquisa de Campo e Análise dos Resultados}

O capítulo apresenta a caracterização do universo do objeto de pesquisa empírica, a Faculdade de Arquitetura e Urbanismo da UnB (FAU/UnB), os procedimentos de aplicação da pesquisa com a Análise Multicritério de Apoio à Decisão, utilizando o programa Hiview3 e Macbeth. Por fim, a comparação de resultados empíricos com os dados secundários para validação e ajuste do quadro de características facilitadoras do ensino-aprendizagem. Apresenta, também, a estruturação de um modelo de arquitetura da informação para organizar as informações obtidas com a pesquisa, facilitando sua disponibilização e utilização na elaboração de programa de necessidades de projetos arquitetônicos de espaços escolares, a partir dos dados obtidos no capitulo 3, validados nesse capitulo.

\subsection{Características do universo de análise: ensino de arquitetura e urbanismo}

O estudo de caso realizado na Faculdade de Arquitetura e Urbanismo da Universidade de Brasília partiu das diretrizes pedagógicas do curso de onde emanam os campos disciplinares que devem ser ministrados para formação do arquiteto e correspondem aos usos pressupondo características próprias aos espaços em apoio à atividade de ensino. A descrição do projeto pedagógico e da grade curricular hoje vigente na FAU/UnB foram estudados para a devida aplicação do questionário decorrente do método.

\subsubsection{A natureza do ensino de Arquitetura e Urbanismo e a FAU/UnB}

Para Almeida (1997), um ensino de arquitetura com pretensão disciplinar é um ensino pragmático. Preocupa-se, essencialmente, com a transmissão de informações, regras de composição do projeto, relativas às suas tipologias específicas e às matérias de apoio técnico. A orientação principal dessa visão de ensino é o exercício profissional. Sua fonte de inspiração são os modelos organizacionais, ou os padrões de projeto, provenientes da prática profissional da arquitetura.

Segundo o autor, as disciplinas universitárias afins da arquitetura, como Artes ou as Ciências Sociais, desempenham um papel secundário ao tronco central, que é a sequência 
de projetos de ateliê. Elas são consideradas, respectivamente, meio de treinamento da capacidade de desenho e fonte de informação para a elaboração de programas.

Com base em Vitruvius (1960), Almeida (1997, p.26) afirma que é, talvez, o primeiro a enfatizar esse ponto de vista. Ele assinala que "o arquiteto deveria ser instrumentado com conhecimento de vários ramos de estudo e tipos de aprendizagem". As principais disciplinas integrantes da elaboração da arquitetura, segundo ele, são: Desenho, História, Filosofia, Música ou Matemática, Medicina, Direito e Astronomia. Ele afirma que o nível de conhecimento dessas disciplinas para o arquiteto não deveria ser nem profundo (conhecimento extensivo) nem superficial. O objetivo de tais disciplinas é tornar o arquiteto ciente dos conhecimentos primários de projeto. Isso pode ser traduzido como informações para o projeto (programa de necessidades) e regras específicas (procedimentos normativos) para sua elaboração.

Vitruvius (1960) destaca três critérios (construção, utilidade e beleza) para a elaboração do projeto arquitetônico. Entre eles, a composição formal do desenho, a aparência visual ou beleza, é uma das mais importantes atividades do arquiteto. Advoga critérios de projeto tais como: o ordenamento e a simetria; a organização dos planos e fachadas; a harmonia (relação entre a altura do edifício com a sua profundidade); a adequação de estilo e dos materiais empregados e a sua implantação no terreno ou sítio. Em Vitruvius, o ideal da beleza formal pode ser traduzido em ordenamento ou ordem, proporção ou relação, e abstração ou razão. Em outras palavras, beleza significa composição derivada de regras racionais de desenho. A forma é o principal veículo de expressão visual da beleza.

No Rio de Janeiro, na década de 1930, durante a reforma do ensino de Arquitetura, Costa (1962) assinalava que a arquitetura é "fundamentalmente, artes plásticas". A intenção plástica desempenha na elaboração do projeto um papel central. Não menos importantes para Lúcio Costa são as disciplinas tecnológicas como, na área da Engenharia Civil, a disciplina de Construção. Lúcio Costa defendia um currículo para o ensino de arquitetura com disciplinas de formação plástica e técnico-científica. Para ele, as artes ocupavam um lugar central entre as disciplinas da formação do arquiteto.

A questão levantada por Lúcio Costa (relacionamento entre a dimensão plástica, técnica e científica do ensino de arquitetura) adquire outra dimensão quando considerada a instituição universidade. Nessa instituição, a antiga dicotomia (entre o ensino de arquitetura na faculdade de belas artes e na politécnica) perde sentido. A diversidade de ramos de ensino da instituição amplia o horizonte do estudante de Arquitetura.

O argumento em prol da exclusividade do ensino de arquitetura fundamenta-se em dois aspectos acadêmicos. Um deles diz respeito à definição ou afirmação da arquitetura como área específica dentro da universidade, e o outro, ao limitado conteúdo e tipo de disciplina oferecida pela universidade à arquitetura. Segundo esse argumento, o estudante 
estará melhor qualificado para exercer suas atribuições profissionais se for preparado principalmente por arquitetos. Em primeiro lugar, a participação de outros profissionais (artistas, acadêmicos etc.) na formação do arquiteto não exclui necessariamente os profissionais de arquitetura. Em segundo lugar, a afirmação de uma área de estudos dentro da universidade não é feita no isolamento. Nesse aspecto, o intercâmbio de experiência e atividades com os setores afins e, principalmente, com os de maior tradição de vida acadêmica, é uma necessidade.

Para Almeida (1997), o segundo ponto de vista do ensino de arquitetura difere do primeiro em um aspecto principal: a inclusão de disciplinas acadêmicas integrantes de outras áreas de ensino universitário na formação do estudante de arquitetura. Trata-se da inserção do estudante na cultura universitária. Do ponto de vista profissional, as disciplinas universitárias, em menor número do que no segundo, desempenham duas funções principais. Elas são a fonte de informação para a elaboração dos programas de necessidades físicas e o complemento (aspectos técnicos) do ensino de arquitetura. Nesse caso, são apenas pré-requisitos obrigatórios do curso de Arquitetura.

O Ateliê ou Composição, nomes comuns dados à disciplina de Projeto Arquitetônico, é o divisor de águas entre esses dois pontos de vista. A elaboração de projeto no ensino de arquitetura pressupõe, entre outros aspectos, o desenvolvimento da capacidade mental e imaginativa do estudante.

Por uma contingência conjuntural (a implantação de novas universidades federais nas capitais estaduais e a reforma do ensino superior brasileiro, durante as décadas de 1960 e 1970, particularmente o estabelecimento do campus universitário), os cursos de arquitetura, na sua grande maioria, estabeleceram-se na universidade. Igualmente, as escolas mais antigas de arquitetura migraram para o campus. O curso de Arquitetura desde então passou a ser considerado uma das áreas de ensino universitário. Assim, as disciplinas integrantes desse curso passaram a ter uma dimensão acadêmica, não somente profissional. A institucionalização do docente arquiteto, em tempo integral, com qualificação acadêmica, reforçou tal quadro.

\subsubsection{Histórico sobre a estrutura do curso da FAU/UnB}

A Universidade de Brasília, com um pouco mais de cinquenta anos de existência, possui como missão "produzir, integrar e divulgar conhecimento, formando cidadãos comprometidos com a ética, com a responsabilidade social e o com desenvolvimento sustentável". Por sua vez, a história Faculdade de Arquitetura e Urbanismo, funcionando desde 1962, confunde-se com a da Universidade como unidade pioneira, pensada e estruturada pelos próprios fundadores da UnB.

O curso de Arquitetura e Urbanismo da UnB entrou em funcionamento em fevereiro 
de 1962, tendo Lúcio Costa e Oscar Niemeyer como seus primeiros coordenadores. Seguia um currículo desenhado por Edgar Albuquerque Graeff, Ítalo Campofiorito e João Filgueiras Lima (Lelé), com o conteúdo estruturado em três "troncos": teoria, composição e tecnologia.

A Faculdade de Arquitetura e Urbanismo elaborou, para o período de 2006 a 2010, o seu Plano de Desenvolvimento Institucional, reafirmando seus compromissos com o ensino público, gratuito e de qualidade e projetando para um futuro próximo uma série de transformações radicais de todas as suas estruturas acadêmicas.

Anteriormente, a FAU/UnB passou por diferentes modelos de ensino que podem ser sintetizados em três principais etapas, que são as seguintes: o ensino original, quando da criação da escola em 1962; o intermediário, resultante da reestruturação de 1969, chamado de projeto cultural; e o atual ensino correspondente à reforma, ou fórum, de 1989.

- O ensino inicial de arquitetura na UnB coincide com a criação do seu curso, em 1962, e com a implantação dessa universidade. Esse currículo produziu uma experiência de ensino que foi bastante significativa. Ela renovou o ensino de arquitetura no Brasil nos aspectos organizacionais.

- O modelo intermediário, iniciado na década de 1970, substitui o modelo ICA-FAU pelo Instituto de Arquitetura, Urbanismo e Artes (IA). Nessa ocasião, a designação FAU, ou Faculdade, desapareceu. A oferta de disciplinas de Artes para os arquitetos foi substancialmente reduzida enquanto a das disciplinas sociais foi ampliada.

Para Almeida (1997), o instituto configurou-se como tal à medida que o ensino de artes na universidade adquiriu status próprio, e o da tecnologia (escola de engenharia) desobrigou-se de ofertar todas as disciplinas de natureza tecnológica ao curso de Arquitetura. Em decorrência disso, o conteúdo das principais disciplinas, que eram oferecidas por outras áreas universitárias para a formação do arquiteto, passou a ser gerenciado (e ministrado) pela própria arquitetura.

Ainda segundo o autor, entre as causas que provocaram o desgaste do modelo de ensino do IA (sob o ponto de vista das relações entre o ensino de arquitetura e o universitário) estão, por exemplo, o distanciamento da universidade da realidade social e um conjunto de medidas organizacionais adotadas pela universidade. São elas: i) eliminação de instâncias organizacionais que possibilitavam o relacionamento das atividades de ensino em nível global, por exemplo, as congregações de carreira e da coordenação do básico geral; ii) ênfase excessiva no ensino disciplinar em detrimento da colaboração mútua entre as áreas de ensino; iii) especialização do corpo docente em disciplinas; e iv) a não implementação de pesquisas no ensino de arquitetura.

O atual modelo de ensino (currículo) da FAU/UnB opõe-se aos dois anteriores quanto à sua inserção na universidade. A principal característica desse modelo é a exclu- 
sividade da formação do arquiteto no âmbito da faculdade. Esse modelo se caracteriza pela composição de um currículo de ensino de arquitetura com disciplinas ministradas e administradas exclusivamente pela faculdade. As dependências de créditos do curso de Arquitetura, em relação aos departamentos afins, são reduzidas ao máximo.

No atual currículo, os demais créditos (relativos às disciplinas tais como as de Artes e de Ciências Sociais) foram reduzidos em quantidade, tipo e importância (transformadas de créditos obrigatórios em optativos). O tradicional ensino das Artes encontra-se embutido nas disciplinas de representação do espaço arquitetônico. Além disso, permanece nesse modelo de ensino de arquitetura, por meio do projeto, o processo indutivo. Neste, a elaboração do projeto é composta de duas etapas principais: programa de necessidades (listagem dos requerimentos e condicionantes funcionais e físicos) e o projeto arquitetônico (peças gráficas e maquete). Esse é o resultado de um tour de force - briga com o traço do arquiteto com a geometria, o programa e o conhecimento técnico dado. Os critérios de escolha da melhor opção de projeto, quanto aos aspectos de layout do edifício, fachadas e volumetria, são atribuídos, entre outros fatores, à intuição e à capacidade do estudante de manipular o repertório de arquitetura existente (ALMEIDA, 1997).

A Faculdade de Arquitetura está organizada em Conselho da FAU, Plenária, que é a instância colegiada consultiva, Colegiados Departamentais, Colegiado de Graduação, Colegiado da Pós-Graduação e Coordenação de Extensão, Secretaria da FAU, Secretaria de Apoio Departamental e Secretaria de Pós-Graduação.

A Faculdade está baseada em três departamentos organizados em áreas de conhecimento cujas atribuições específicas se estabelecem a seguir:

O Departamento de Projeto, Expressão e Representação (PRO), abrange as atividades relativas ao Projeto, Expressão e Representação do objeto arquitetônico em todas as suas escalas. Ao departamento compete o desenvolvimento de pesquisa, extensão e capacitação e formação de alunos para a prática do projeto. Conta com dois professores com graduação, onze professores com mestrado e dezessete professores com doutorado.

O Departamento de Tecnologia (TEC) abrange o conhecimento tecnológico necessário à materialização das ideias de projeto para os espaços arquitetônicos e urbanos, compreendendo os aspectos da Tecnologia da Construção, dos Sistemas Estruturais e do Controle Ambiental e Infraestrutura Urbana. Conta com quatro professores de mestrado e quatorze de doutorado.

Ao Departamento de Teoria e História (THA) compete o desenvolvimento de ensino, pesquisa e extensão para formação dos alunos na prática teórica e historiográfica da Arquitetura em todas as suas escalas. Conta com quatorze professores de doutorado. 


\subsubsection{Discussão sobre a requalificação do espaço físico da FAU/UnB}

O espaço físico da FAU/UnB sofreu, ao longo dos anos, desde sua inauguração em 1962, vários ajustes que mais foram lhe descaracterizando do que atribuindo melhorias qualitativas. Entretanto, nunca foi submetido a uma reforma estruturante que lhe adequasse à demanda que hoje a atividade exige, estando reconhecidamente, por toda comunidade, entendido como num processo de degradação tanto de manutenção quanto de inadequação às suas atividades.

As reformas produzidas desde 1986 foram sempre tópicas e incrementais. A visão da Faculdade com unidade é fundamental para o desenvolvimento de sua função de universidade pública que prima pela qualidade. As discussões ocorridas ao longo dos anos muitas vezes levaram a uma visão conservadora do espaço sem considerar as mudanças tecnológicas e das relações do trabalho de todos, com o espaço e o conforto ambiental.

Em 2014, foi indicada mais uma discussão sobre a reforma do espaço físico da FAU, dessa feita com uma proposta de construção coletiva de um Projeto Institucional, que, de forma equilibrada e complementar, promova o desenvolvimento da graduação e da pós-graduação do campo de conhecimento da Arquitetura e Urbanismo, na universidade.

Foi apresentado um conceito de espaço adequado ao trabalho de todos os docentes, alunos e servidores técnico-administrativos, condição fundamental para o resultado que se espera como projeto de reforma. Esse conceito foi definido como: equilíbrio, unidade e ambiente de trabalho, que são conceitos propostos pela direção da FAU como requisitos do caráter arquitetônico da requalificação a que se pretende chegar. Sua descrição para orientar um zoneamento prévio ao programa de necessidades foi definida na Tabela 62, apresentada no Apêndice A.

As diretrizes gerais e as programáticas, que deveriam condicionar as propostas para elaboração de projeto arquitetônico à FAU, foram definidas nas Tabelas 63 e 64, apresentadas no Apêndice A.

No que diz respeito ao Programa de Necessidades, este foi descrito na forma a seguir, muito próxima do que é feito correntemente, ou seja, um pré-dimensionamento (Tabela 65), e as diretrizes de zoneamento devem ser consideradas nas propostas de reorganização do espaço físico (Tabela 66), apresentadas no Apêndice A.

A descrição das diretrizes definidas no processo coletivo de discussão ocorrida na FAU/UnB podem ser uma referência a mais para validação dos atributos obtidos como resultado da pesquisa e serão utilizados como uma fontes adicional de avaliação. Assim, apontam-se a seguir essas características desejáveis identificada pelo coletivo:

- Os espaços de ensino deverão estar localizados em áreas distantes de poluição sonora e deverão ter condições ambientais (naturais e/ou artificiais) adequadas às atividades de 
ensino-aprendizado. Para as salas de aula, deve-se garantir boa iluminação ambiente e de trabalho, boas condições de ventilação (renovação de ar) e condição acústica adequada.

- Os espaços de pesquisa aplicada e teórica (laboratórios e grupos de pesquisa) -devem ficar localizados em espaço salubre (preferencialmente iluminado e ventilado naturalmente), protegido de ruídos e excessiva circulação.

- Os espaços de pesquisa prática (Laboratório de Modelos Reduzidos e Labcon) - deve ser previsto sistema de iluminação de trabalho nas áreas de estudo tanto para as baias quanto para as mesas. As estações de trabalho e mesas devem ter instalação elétrica com tomadas.

- Os ateliês de projeto devem prever ambientes conjugados com equipamentos de projeção ou transmissão de apresentações (TVs ou projetores), estações de trabalho com computadores e área de trabalho com mobiliário (mesas) com pontos de energia e sistema de iluminação direcionado. Propor divisórias acústicas entre os ateliês. Propor sistema acústico a ser instalado acima dos ateliês para diminuição da reverberação e absorção dos ruídos. Podem ser móbiles ou fixos.

- Salas de professores e laboratórios e grupos de pesquisa: protegidos de ruídos e excessiva circulação, preferencialmente iluminados e ventilados naturalmente.

- Espaços de ocupação eventual (auditórios, biblioteca, depósitos, banheiros, vestiários, copas) poderão estar localizados em áreas com condicionamento artificial.

Após as diversas rodadas de discussão de princípios e concepção de espaços e projetos se avançou para mapas de zoneamento e pré-projeto, que até o momento, ( novembro de 2016), não resultou em continuidade.

Tendo em conta a motivação coletiva com a necessidade de revitalização do seu espaço, mostrou-se um universo de estudo interessante para textuar os parâmetros/variáveis encontrados na pesquisa.

Verifica-se que a ampla discussão ocorrida na FAU/UnB possuiu como foco a definição de necessidades de espaços para as diferentes atividades do curso e o seu dimensionamento com características de fluxo/proximidade e atributos de Conforto Ambiental, não contemplando os aspectos de Ergonomia e Psicologia Ambiental identificados na pesquisa. Essa consideração será retomada nas conclusões, quando se terá os resultados da aplicação dos questionários ao mesmo universo que participou das discussões. 


\subsection{Características do universo de análise: perfil dos professores}

Para efeito de ajustar e validar a pesquisa bibliográfica realizada, foram aplicados questionários aos professores da FAU/UnB sobre os atributos que consideram necessários ao bom desempenho de suas disciplinas e demais espaços de ensino-aprendizagem . Operacionalmente foi aplicado questionário para todas as disciplinas/professores do curso de graduação em Arquitetura e Urbanismo e também aos responsáveis pelos demais espaços constantes da Tabela 49.

A avaliação foi sobre o que foi definido como espaços de ensino-aprendizagem e pode ser verificado seu universo na Tabela 49, onde se apresenta a relação das atividades/funções do espaço da Faculdade de Arquitetura e Urbanismo (FAU) da Universidade de Brasília (UnB), onde foram validados os atributos do espaço arquitetônico que favorecem o ensinoaprendizagem.

Tabela 49 - Atividades/funções do espaço da FAU/UnB

\begin{tabular}{|c|c|}
\hline Tipos/Categorias & Função \\
\hline $\begin{array}{l}\text { Espaços de ensino- } \\
\text { aprendizagem }\end{array}$ & $\begin{array}{l}\text { Ateliê de projeto } \\
\text { Salas de aula } \\
\text { Ateliê de desenho e plásticas } \\
\text { Cediarte } \\
\text { Laboratórios e Núcleo de pesquisa } \\
\text { Laboratórios de Grupos de Pesquisa Prática } \\
\text { Salas de professores } \\
\text { Auditórios }\end{array}$ \\
\hline $\begin{array}{l}\text { Espaços de pesquisa } \\
\text { aplicada e teórica }\end{array}$ & $\begin{array}{l}\text { Área de estudos } \\
\text { Salas de alunos de mestrado e doutorado }\end{array}$ \\
\hline $\begin{array}{l}\text { Espaços de pesquisa prá- } \\
\text { tica }\end{array}$ & Laboratório de Modelos Reduzidos e Labcon \\
\hline Espaços Administrativos & $\begin{array}{l}\text { Secretaria } \\
\text { Direção } \\
\text { Sala de reunião }\end{array}$ \\
\hline Espaços de convivência & $\begin{array}{l}\text { Praça da FAU } \\
\text { Galeria e área de exposição } \\
\text { Centro acadêmico }\end{array}$ \\
\hline Espaços de serviços & $\begin{array}{l}\text { Copa } \\
\text { Sanitários } \\
\text { Vestiários } \\
\text { Almoxarifado } \\
\text { Vestiário } \\
\text { Circulação }\end{array}$ \\
\hline
\end{tabular}

Fonte: FAU/UnB (2013).

Dos sessenta e cinco professores da Faculdade de Arquitetura e Urbanismo da UnB da amostra foi possível entrevistar quarenta e três deles. Os demais ou não aceitaram 
participar da pesquisa, ou não foram localizados, ou não possuíam uma agenda compatível com o calendário de desenvolvimento desta pesquisa.

As 43 respostas ao questionário foram realizadas presencialmente e/ou via e-mail, ou seja, a pesquisadora se apresentou aos professores solicitando que respondessem ao questionário em questão para avaliarem os parâmetros facilitadores do ensino-aprendizagem encontrados na literatura. Na sequência, essas informações foram tabuladas, conforme explicado.

Os 43 professores que contribuíram com a pesquisa registraram os turnos em que são ministradas as aulas (Figura 36):

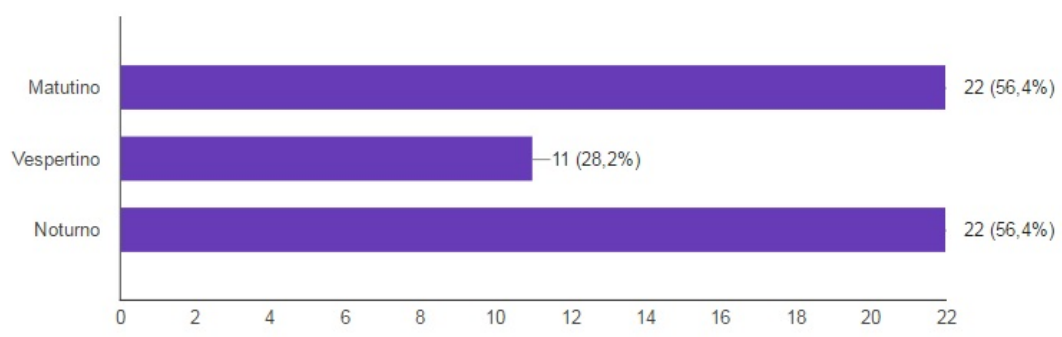

Figura 36 - Turnos das disciplinas ministradas pelos professores da FAU/UnB Fonte: Google Drive (2016).

Em análise, vê-se que a maioria dos professores utiliza espaços para ministrarem suas disciplinas nos turno matutino e noturno com a mesma porcentagem $(56,4 \%)$

A seguir, apresentam-se os departamentos do Curso de Arquitetura e Urbanismo com o número de professores que responderam ao questionário: i) De Projeto, Expressão e Representação - 23 professores; ii) De História da Arquitetura e Urbanismo - 7 professores; iii) De Tecnologia - 13 professores.

A partir dos questionários, foram registrados os aspectos de disciplina prática, teórica ou prática/teórica, conforme as respostas dos professores (Figura 37):

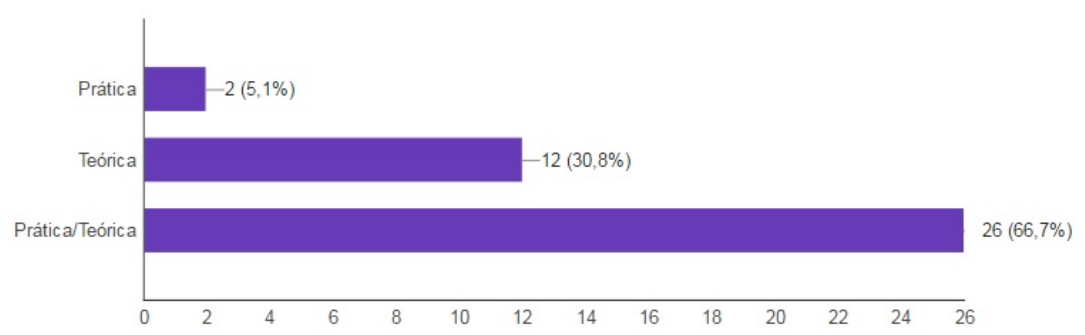

Figura 37 - Tipos de disciplina ministradas pelos professores da FAU/UnB Fonte: Google Drive (2016). 
Em análise, vê-se que a maioria dos professores utiliza espaços para disciplinas que são de caráter prático/teórico (66,7\%). Em seguida, em menor quantidade apresentam-se as disciplinas de caráter teórico em 30,8\%, e em menor percentual, as disciplinas práticas, com $5,1 \%$.

\subsection{Aplicação do modelo Análise Multicritério de Apoio à Decisão (MCDA-C)}

A aplicação dos questionários ocorreu no período de 15 de março de 2016 a 31 de maio de 2016, tendo sido inicialmente enviado questionário por e-mail para todos os professores com uma explicação dos objetivos da pesquisa e posteriormente foram realizadas visitas aos professores para ampliar o universo de respondentes, quando se chegou ao percentual de $65 \%$. A próxima fase constituiu-se em lançar os dados no modelo utilizado o software Hiview3 e se obter os relatórios a serem avaliados e submetidos a uma rodada de discussão com os especialistas.

A primeira fase, definida no capítulo 4, constitui-se na estruturação do Modelo Multicritério de Apoio à Decisão, concluída com a construção das seguintes ferramentas: i) Pontos de Vista Fundamental - PVF; ii) Pontos de Vista Elementares - PVEs; iii) Pontos de Vista Sub-elementares - SubPVEs e iv) Descritores.

A segunda fase que ora se relata contemplou a construção das Funções de Valor (mensurar cada nível de impacto dos descritores) e com as Taxas de Substituição (mensurar os PVEs e SubPVEs) e realizar uma avaliação dos PVFs, PVEs e SubPVEs para a construção de um modelo de apoio a elaboração do programa de necessidades de projetos de arquitetura de espaços de ensino. Nessa fase, temos: i) perfil de impacto das ações potenciais (PVFs, PVEs e SubPVEs); ii) fórmula de Agregação Aditiva (avaliação local e global); iii) Análise de Sensibilidade (verificação da robustez do modelo).

\subsubsection{Avaliação das ações potenciais}

A avaliação (desempenho) local das ações potenciais, denominada de indicador de impacto, representa a pontuação da ação potencial em cada eixo de avaliação (em cada questão do questionário) e permite fazer projeção de cada ação sobre os descritores construídos nos critérios e subcritérios, ou seja, o indicador de impacto associa a uma ação um nível na escala (descritor de um critério e/ou subcritério de acordo com as características da ação (QUIRINO, 2002).

A Tabela 50 mostra como os níveis de impacto determinados pela escala do software Macbeth, associados aos critérios e subcritérios em que cada professor do Curso de Arquitetura e Urbanismo da FAU/UnB forneceu sua pontuação. Apresenta-se uma 
amostra com a avaliação de sete professores que participaram da pesquisa, respondendo o questionário elaborado.

No apêndice D, apresentam-se as telas do software Hiview3 com as pontuações não ponderadas das avaliações dos 43 professores do Curso de Arquitetura e Urbanismo da FAU/UnB que participaram da pesquisa, referentes aos PVEs e SubPVEs dos PVFs. 
Capítulo 5. Caracterização do Universo de Estudo, Desenvolvimento da Pesquisa de Campo e Análise 234

dos Resultados

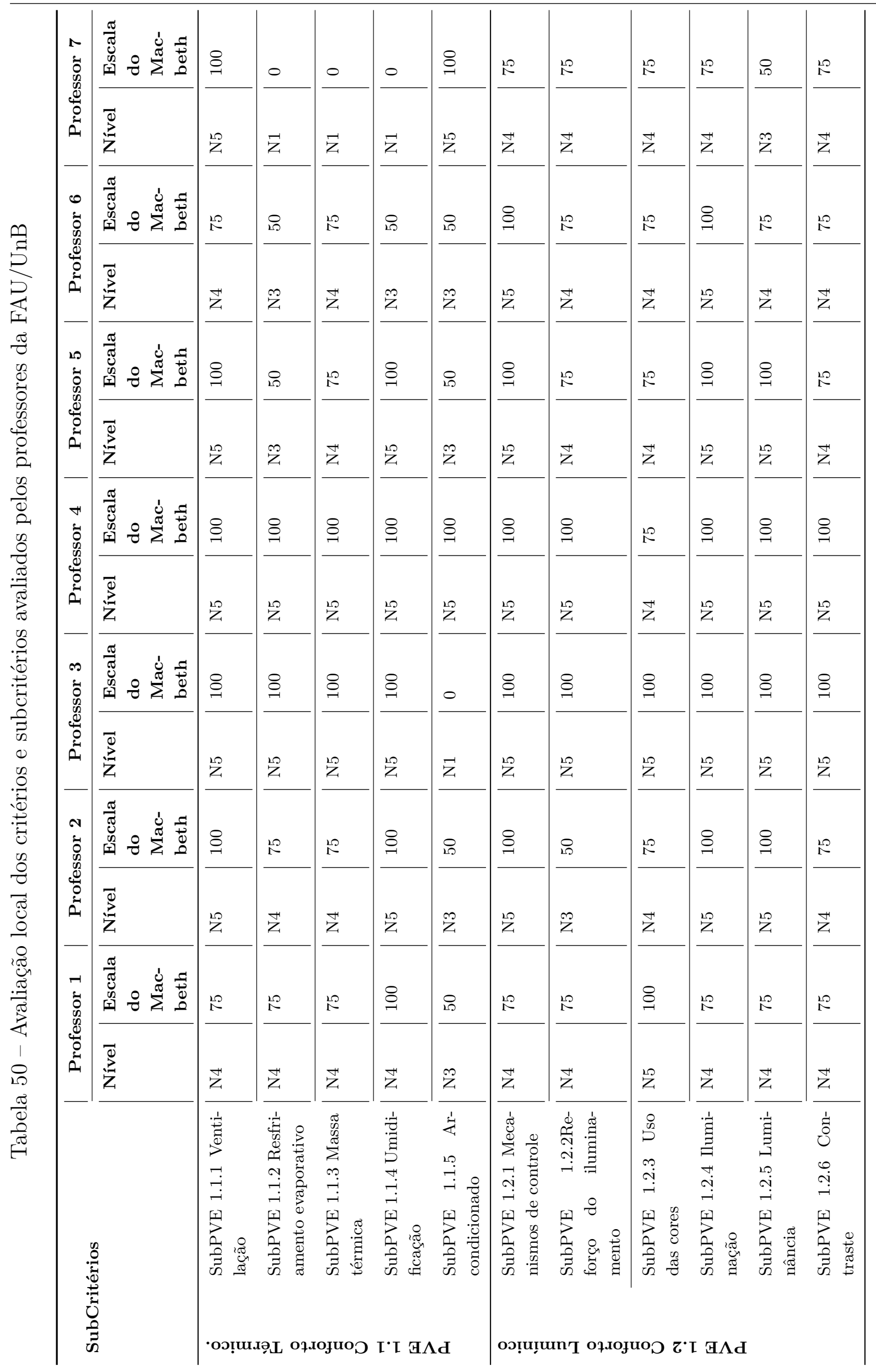




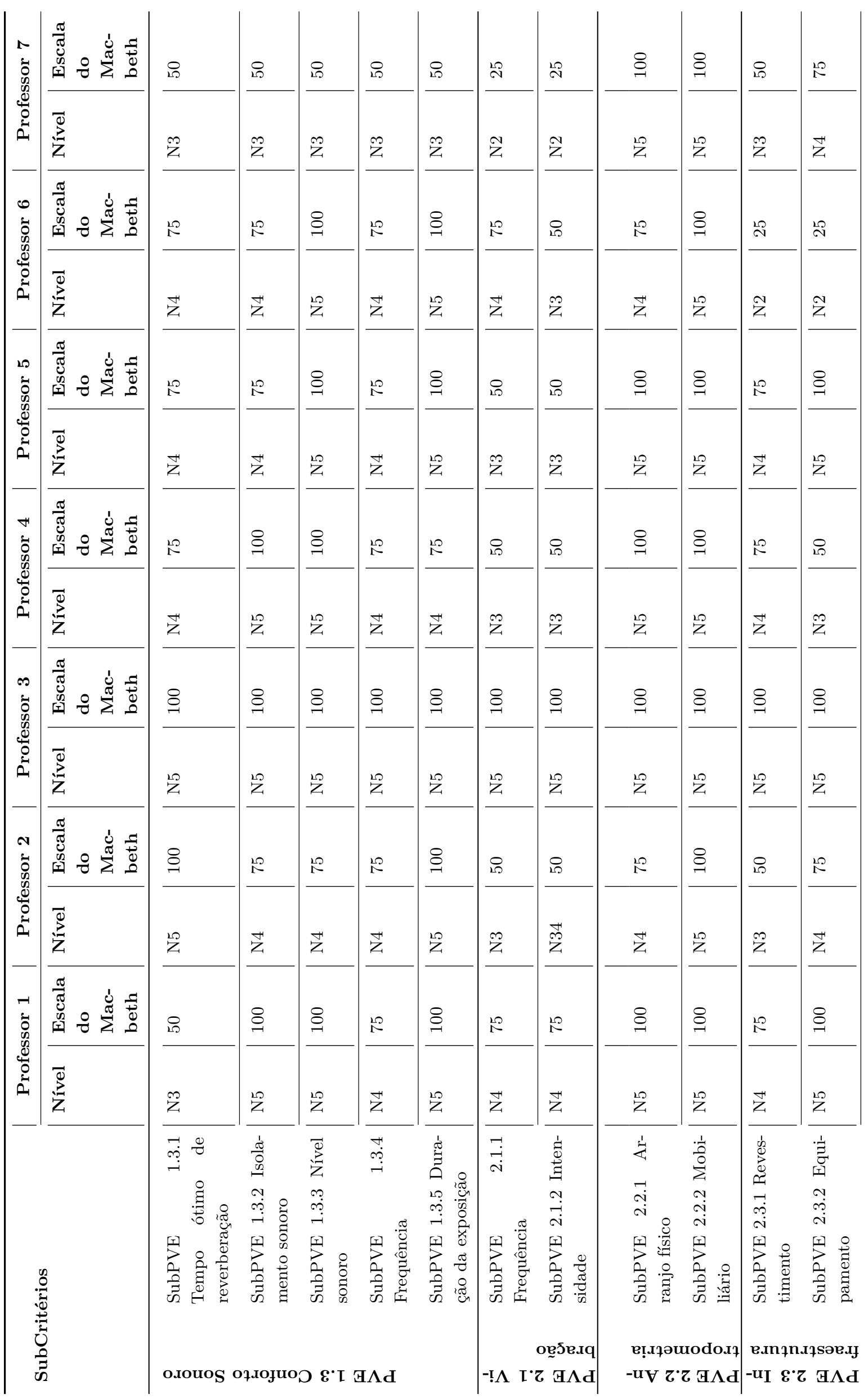


Capítulo 5. Caracterização do Universo de Estudo, Desenvolvimento da Pesquisa de Campo e Análise 236

dos Resultados

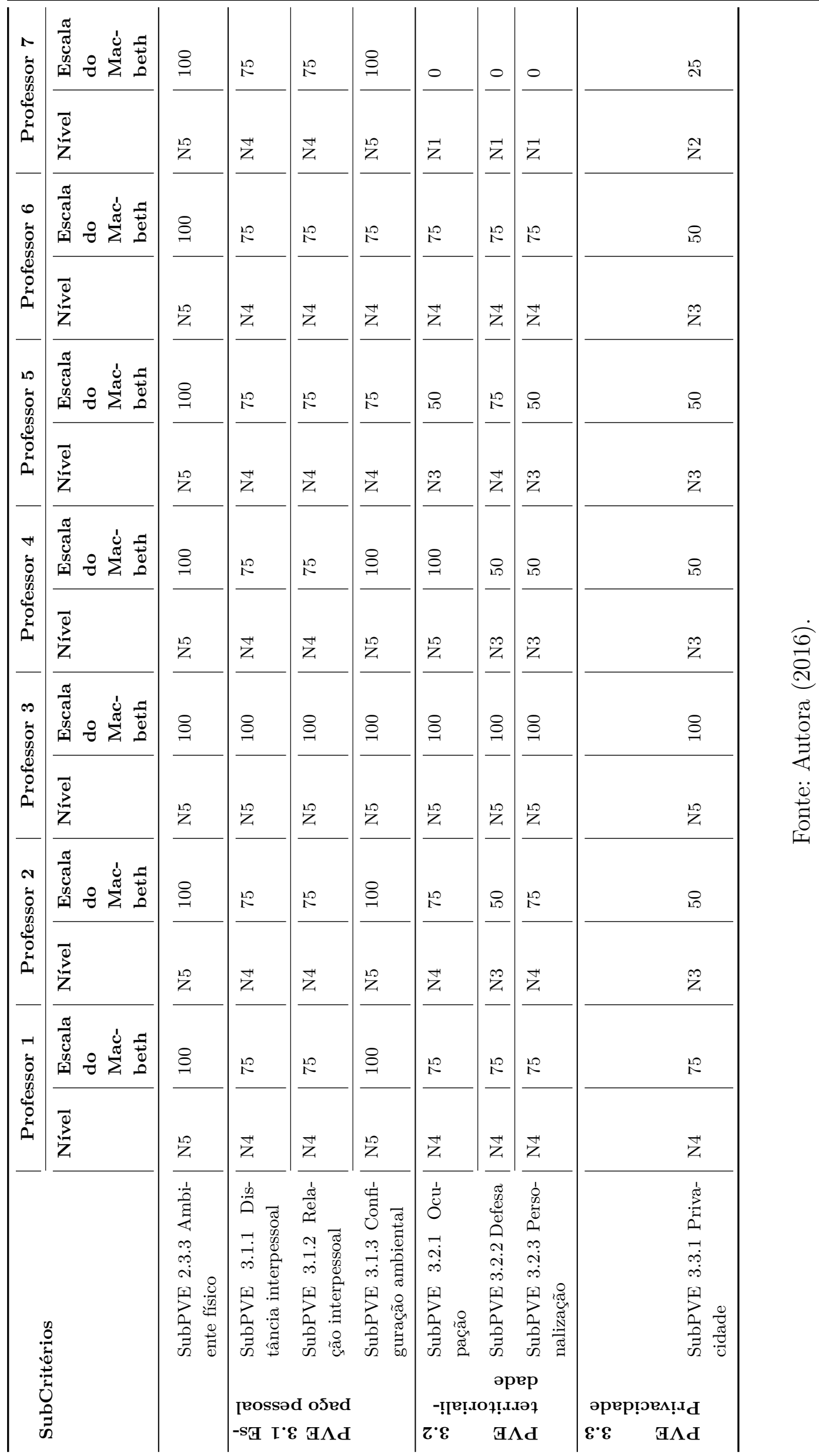




\subsubsection{Perfil de impacto das ações potenciais}

De acordo com Ensslin, Neto e Noronha (2001), para visualizar o determinante das respostas dos professores da FAU/UnB, se construiu um gráfico que ilustra de forma clara cada uma delas. No eixo horizontal, colocou-se o nome dos critérios e subcritérios e no eixo vertical marcou-se o desempenho de cada avaliação, lembrando que o valor 0 representa o nível Neutro e 100 representa o nível Bom.

Utilizaram-se as informações da avaliação (desempenho) local das ações potenciais, em todos os critérios e subcritérios do modelo avaliados pelos professores da FAU/UnB para comparar ações potenciais e determinar seus pontos fortes e fracos. A seguir, mostra-se o perfil de impacto de cada avaliador (professores da FAU/UnB) pelos professores 1, 2, 3, 4 que contribuíram com mais 39 professores do curso de Arquitetura e Urbanismo da FAU/UnB no processo de avaliação dos parâmetros facilitadores do ensino-aprendizagem, totalizando 43 professores.

Na Figura 38, analisa-se graficamente o perfil de impacto do professor avaliador P1 em cada critério e subcritério do Modelo Multicritério de Apoio à Decisão (MCDA-C). O perfil de impacto de todos os professores se encontra no Apêndice E.

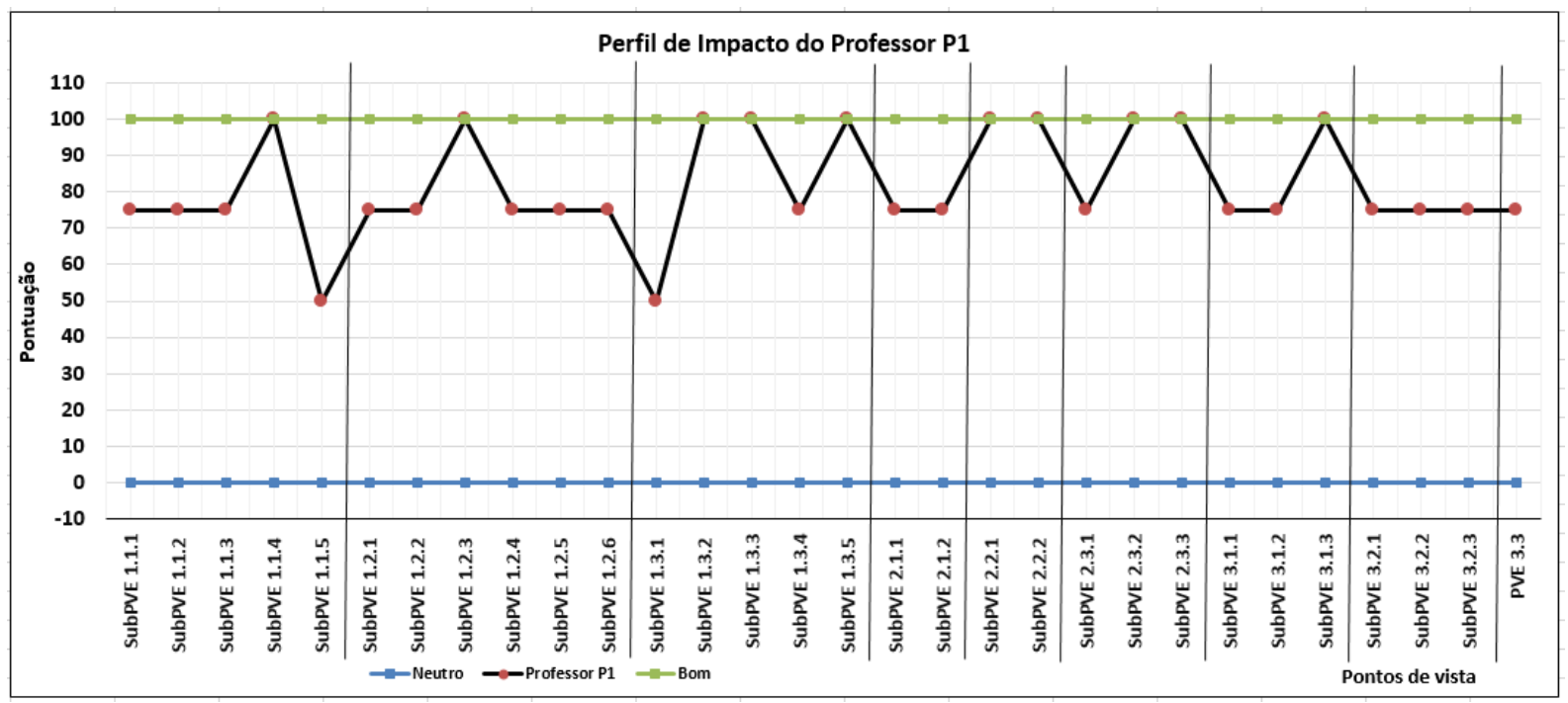

Figura 38 - Perfil de impacto do avaliador professor P1

Fonte: Elaboração própria (2016).

\section{PVF 1 - Conforto Ambiental}

- PVE 1.1 - Conforto térmico - o professor P1 impactou em cinco subcritérios entre os níveis Bom e Neutro (nível de mercado), sendo um subcritério com avaliação 100, três subcritérios com avaliação 75 e um subcritério com avaliação 50 . 
- PVE 1.2 - Conforto Lumínico - o professor P1 impactou em seis subcritérios entre os níveis Bom e Neutro (nível de mercado), sendo um subcritério com avaliação 100, e cinco subcritérios com avaliação 75 .

- PVE 1.2 - Conforto Sonoro - o professor P1 impactou em cinco subcritérios entre os níveis Bom e Neutro (nível de mercado), sendo três subcritérios com avaliação 100, um subcritério com avaliação 75 e um subcrtério com avaliação 50.

\section{PVF 2 - Ergonomia}

- PVE 2.1 - Vibração - o professor P1 impactou em dois subcritérios entre os níveis Bom e Neutro (nível de mercado), sendo os dois com avaliação 50.

- PVE 2.2 - Antropometria - o professor P1 impactou em dois subcritérios entre os níveis Bom e Neutro (nível de mercado), sendo os dois com avaliação 100.

- PVE 2.2 - Infraestrutura - o professor P1 impactou em três subcritérios entre os níveis Bom e Neutro (nível de mercado), sendo dois subcritérios com avaliação 100 e um subcritério com avaliação 75 .

\section{PVF 3 - Psicologia Ambiental}

- PVE 3.1 - Espaço Pessoal - o professor P1 impactou em três subcritérios entre os níveis Bom e Neutro (nível de mercado), sendo um subcritério com avaliação 100 e dois subcritérios com avaliação 75 .

- PVE 3.2 - Territorialidade - o professor P1 impactou em três subcritérios entre os níveis Bom e Neutro (nível de mercado), sendo os três subcritérios com avaliação 75 .

- PVE 3.3 - Privacidade - o professor P1 impactou em um subcritério entre os níveis Bom e Neutro (nível de mercado), sendo o subcritério com avaliação 75.

No geral, o professor P1 apresentou os seguintes resultados: i) impactado entre os níveis Bom e Neutro (nível de mercado) em trinta subcritérios (PVE e SubPVEs); ii) Impactado em dez subcritérios com avaliação 100, dezoito subcritérios com avaliação 75 e dois subcritérios com avaliação 50 .

Na Figura 39, analisa-se graficamente o perfil de impacto do avaliador professor P2 em cada critério e subcritérios. 


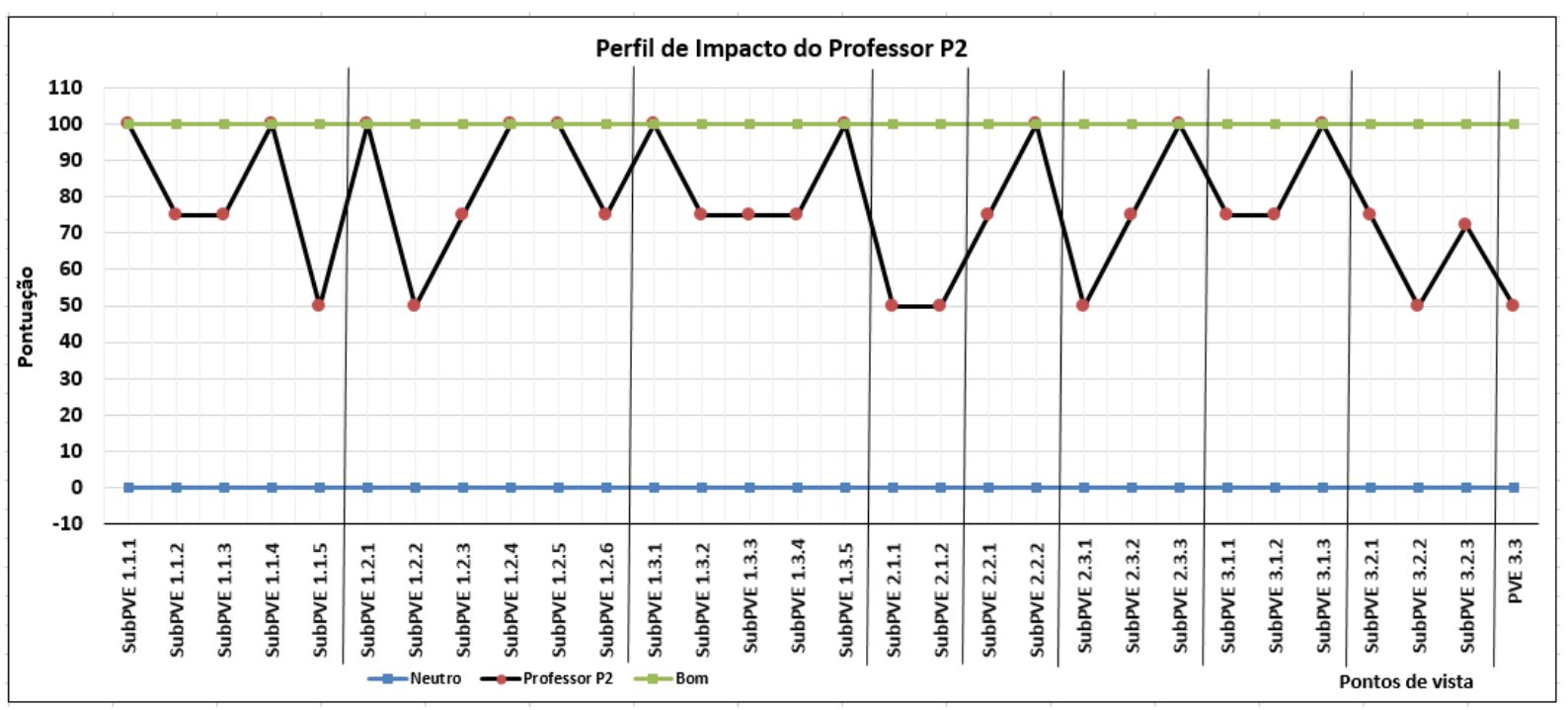

Figura 39 - Perfil de impacto do avaliador professor P2

Fonte: Elaboração própria (2016).

\section{PVF 1 - Conforto Ambiental}

- PVE 1.1 - Conforto térmico - o professor P2 impactou em cinco subcritérios entre os níveis Bom e Neutro (nível de mercado), sendo dois subcritérios com avaliação 100, dois subcritérios com avaliação 75 e um subcritério com avaliação 50.

- PVE 1.2 - Conforto lumínico - o professor P2 impactou em seis subcritérios entre os níveis Bom Neutro (nível de mercado), sendo três subcritérios com avaliação 100, dois subcritérios com avaliação 75 e um subcritério com avaliação 50.

- PVE 1.2 - Conforto sonoro - o professor P2 impactou em cinco subcritérios entre os níveis Bom e Neutro (nível de mercado), sendo dois subcritérios com avaliação 100 e três subcritérios com avaliação 75 .

\section{PVF 2 - Ergonomia}

- PVE 2.1 - Vibração - o professor P2 impactou em dois subcritérios entre os níveis Bom e Neutro (nível de mercado), com avaliação 50.

- PVE 2.2 - Antropometria - o professor P2 impactou em dois subcritérios entre os níveis Bom e Neutro (nível de mercado), sendo um subcritério com avaliação 100 e o outro com avaliação 75 .

- PVE 2.2 - Infraestrutura - o professor P2 impactou em três subcritérios entre os níveis Bom e Neutro (nível de mercado), sendo um subcritério com avaliação 100, um subcritério com avaliação 75 e um subcritério com avaliação 50 . 


\section{PVF 3 - Psicologia Ambiental}

- PVE 3.1 - Espaço Pessoal - o professor P2 impactou em três subcritérios entre os níveis Bom e Neutro (nível de mercado), sendo um subcritério com avaliação 100 e dois subcritérios com avaliação 75 .

- PVE 3.2 - Territorialidade - o professor P2 impactou em três subcritérios entre os níveis Bom e Neutro (nível de mercado), obtendo os dois subcritérios com avaliação 75 e um subcritério com avaliação 50.

- PVE 3.3 - Privacidade - o professor P2 impactou em um subcritério entre os níveis Bom e Neutro (nível de mercado), com avaliação 50.

No geral, o professor P2 apresentou os seguintes resultados: i) impactado entre os níveis Bom e Neutro (nível de mercado) em trinta subcritérios (PVE e SubPVEs); ii) impactado em dez subcritérios com avaliação 100, treze subcritérios com avaliação 75 e sete subcritérios com avaliação 50 .

$\mathrm{Na}$ Figura 40, pode-se visualizar os perfis de impacto dos quatros avaliadores professores da FAU/UnB, para que se possa confrontá-los.

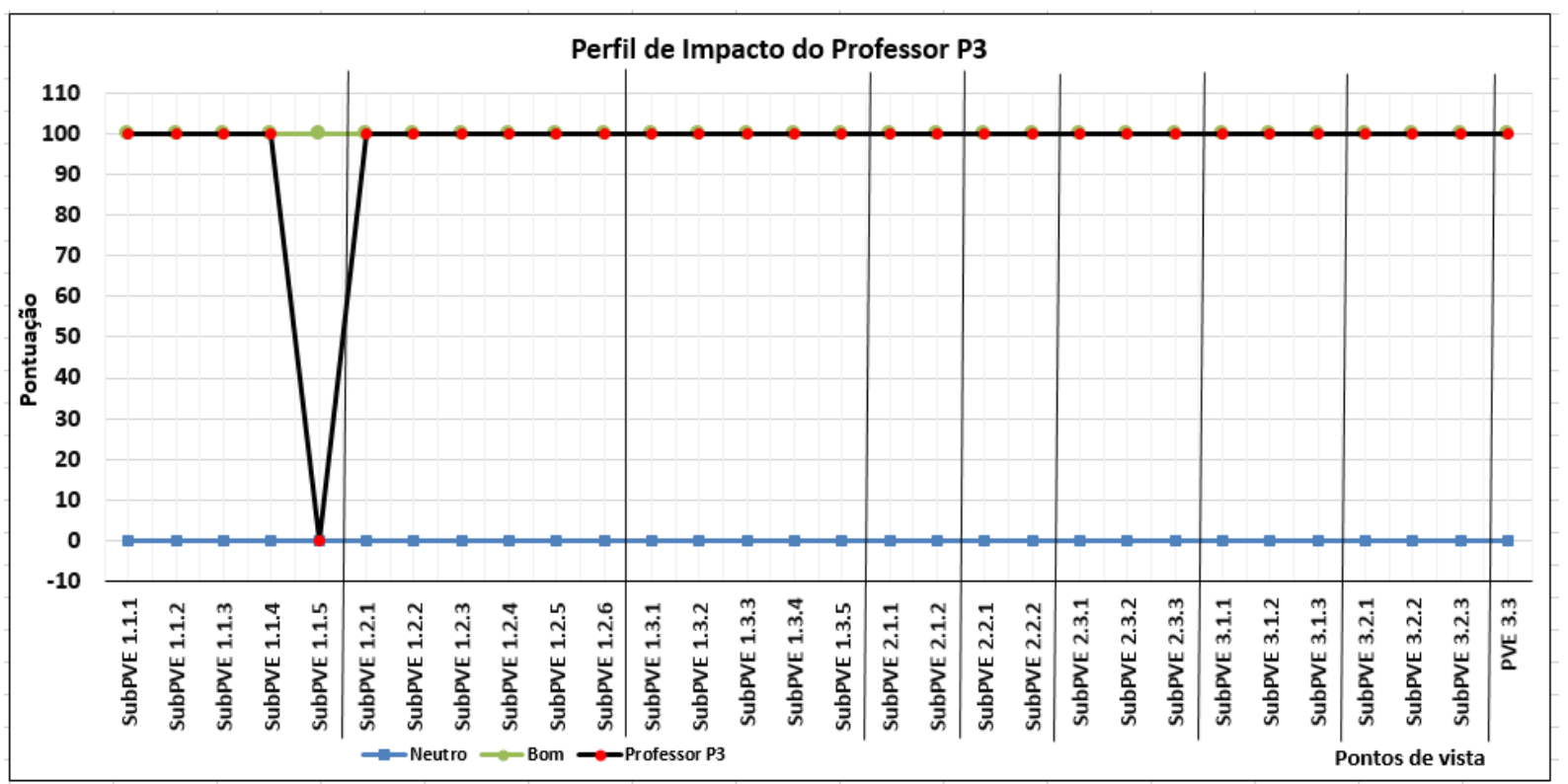

Figura 40 - Perfil de impacto do avaliador professor P3

Fonte: Elaboração própria (2016).

\section{PVF 1 - Conforto Ambiental}

- PVE 1.1 - Conforto térmico - o professor P3 impactou em cinco subcritérios entre os níveis Bom e Neutro (nível de mercado), sendo quatro subcritérios com avaliação 100 e um subcritério com avaliação 0 (zero). 
- PVE 1.2 - Conforto lumínico - o professor P3 impactou em seis subcritérios entre os níveis Bom e Neutro (nível de mercado), sendo todos os subcritérios com avaliação 100 .

- PVE 1.2 - Conforto sonoro - o professor P3 impactou em cinco subcritérios entre os níveis Bom e Neutro (nível de mercado), sendo todos os subcritérios com avaliação 100 .

\section{PVF 2 - Ergonomia}

- PVE 2.1 - Vibração - o professor P3 impactou em dois subcritérios entre os níveis Bom e Neutro (nível de mercado), sendo todos os subcritérios com avaliação 100.

- PVE 2.2 - Antropometria - o professor P3 impactou em dois subcritérios entre os níveis Bom e Neutro (nível de mercado), sendo todos os subcritérios com avaliação 100.

- PVE 2.2 - Infraestrutura - o professor P3 impactou em três subcritérios entre os níveis Bom e Neutro (nível de mercado), sendo todos os subcritérios com avaliação 100.

\section{PVF 3 - Psicologia Ambiental}

- PVE 3.1 - Espaço Pessoal - o professor P3 impactou em três subcritérios entre os níveis Bom e Neutro (nível de mercado), sendo todos os subcritérios com avaliação 100.

- PVE 3.2 - Territorialidade - o professor P3 impactou em três subcritérios entre os níveis Bom e Neutro (nível de mercado), sendo todos os subcritérios com avaliação 100.

- PVE 3.3 - Privacidade - o professor P3 impactou em um subcritérios entre os níveis Bom e Neutro (nível de mercado), sendo todos os subcritérios com avaliação 100.

No geral, o professor P3 apresentou os seguintes resultados: i) Impactado entre os Níveis Neutro e Bom (nível de mercado) em trinta subcritérios (PVE e SubPVEs); ii) Impactado em vinte e nove subcritérios com avaliação 100 e um subcritério com avaliação 0 (zero).

Na Figura 41, analisa-se graficamente o perfil de impacto do professor avaliador P4 em cada critério e subcritério do Modelo Multicritério de Apoio à Decisão (MCDA-C). 


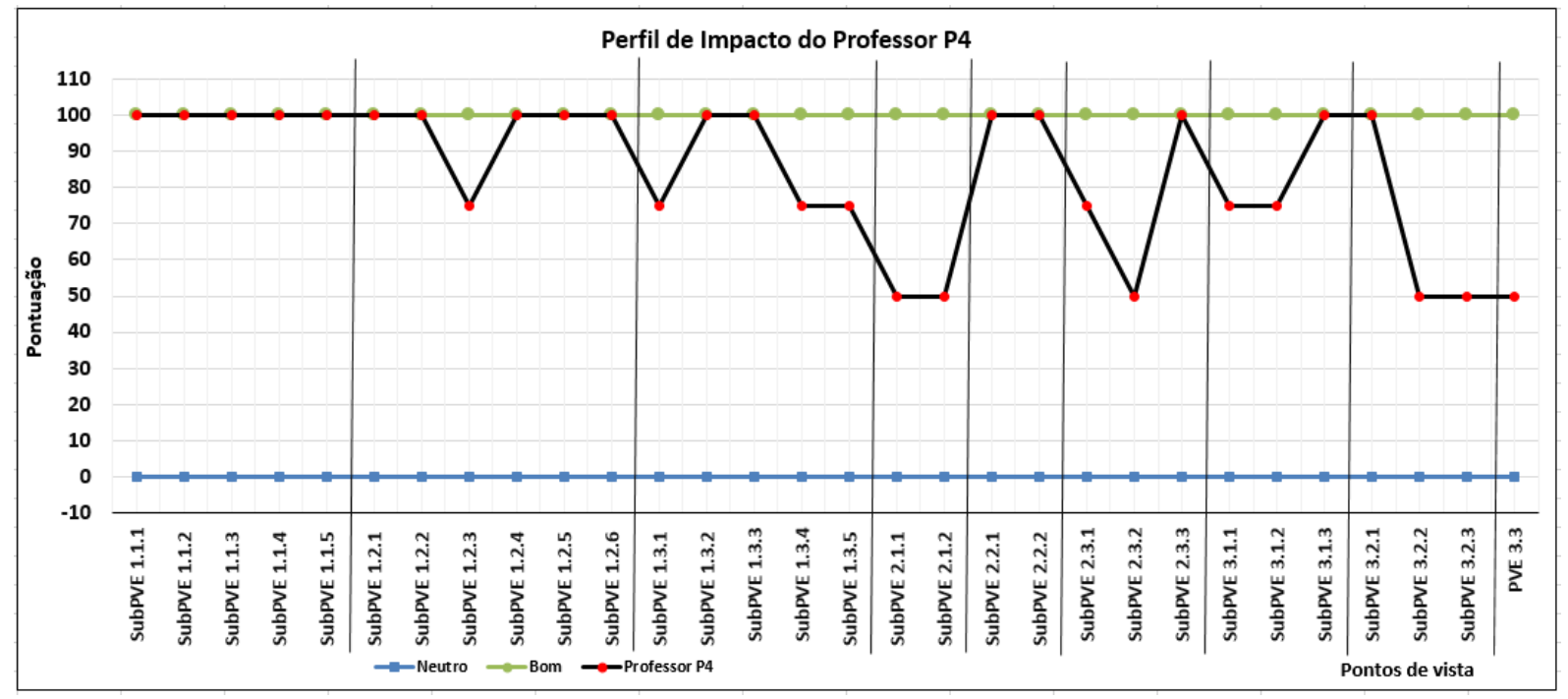

Figura 41 - Perfil de impacto do avaliador professor P4

Fonte: Elaboração própria (2016).

\section{PVF 1 - Conforto Ambiental}

- PVE 1.1 - Conforto Térmico - o professor P4 impactou em cinco subcritérios entre os níveis Bom e Neutro (nível de mercado), sendo os subcritérios com avaliação 100.

- PVE 1.2 - Conforto Lumínico - o professor P4 impactou em seis subcritérios entre os níveis Bom e Neutro (nível de mercado), sendo cinco subcritérios com avaliação 100 e um subcritério com avaliação 75 .

- PVE 1.2 - Conforto Sonoro - o professor P4 impactou em cinco subcritérios entre os níveis Bom e Neutro (nível de mercado), sendo dois subcritérios com avaliação 100 e três subcritérios com avaliação 75 .

PVF 2 - Ergonomia

- PVE 2.1 - Vibração - o professor P4impactou em dois subcritérios entre os níveis Bom e Neutro (nível de mercado), sendo os dois subcritérios com avaliação 50.

- PVE 2.2 - Antropometria - o professor P4 impactou em dois subcritérios entre os níveis Bom e Neutro (nível de mercado), sendo os dois subcritérios com avaliação 100.

- PVE 2.2 - Infraestrutura - o professor P4 impactou em três subcritérios entre os níveis Bom e Neutro (nível de mercado), sendo um subcritério com avaliação 100, um subcritério com avaliação 75 e outro subcritério com avaliação 50. 


\section{PVF 3 - Psicologia Ambiental}

- PVE 3.1 - Espaço Pessoal - o professor P4 impactou em três subcritérios entre os níveis Bom e Neutro (nível de mercado), sendo um subcritério com avaliação 100 e dois subcritérios com avaliação 75 .

- PVE 3.2 - Territorialidade - o professor P4 impactou em três subcritérios entre os níveis Bom e Neutro (nível de mercado), sendo um subcritério com avaliação 100 e dois subcritérios com avaliação 50 .

- PVE 3.3 - Privacidade - o professor P4 impactou em um subcrtitério entre os níveis Bom e Neutro (nível de mercado), com avaliação 50.

No geral, o professor P4 apresentou os seguintes resultados: i) Impactado entre os níveis Neutro e Bom (nível de mercado) em trinta subcritérios (PVE e SubPVEs); ii) Impactado em dezessete subcritérios com avaliação 100, sete subcritérios com avaliação 75 e seis subcritérios com avaliação 50 .

Na Figura 42, analisa-se graficamente o perfil de impacto dos quatro professores avaliador P1, P2, P3 e P4 em cada critério e subcritério do Modelo Multicritério de Apoio à Decisão (MCDA-C) para que se possa confrontá-los.

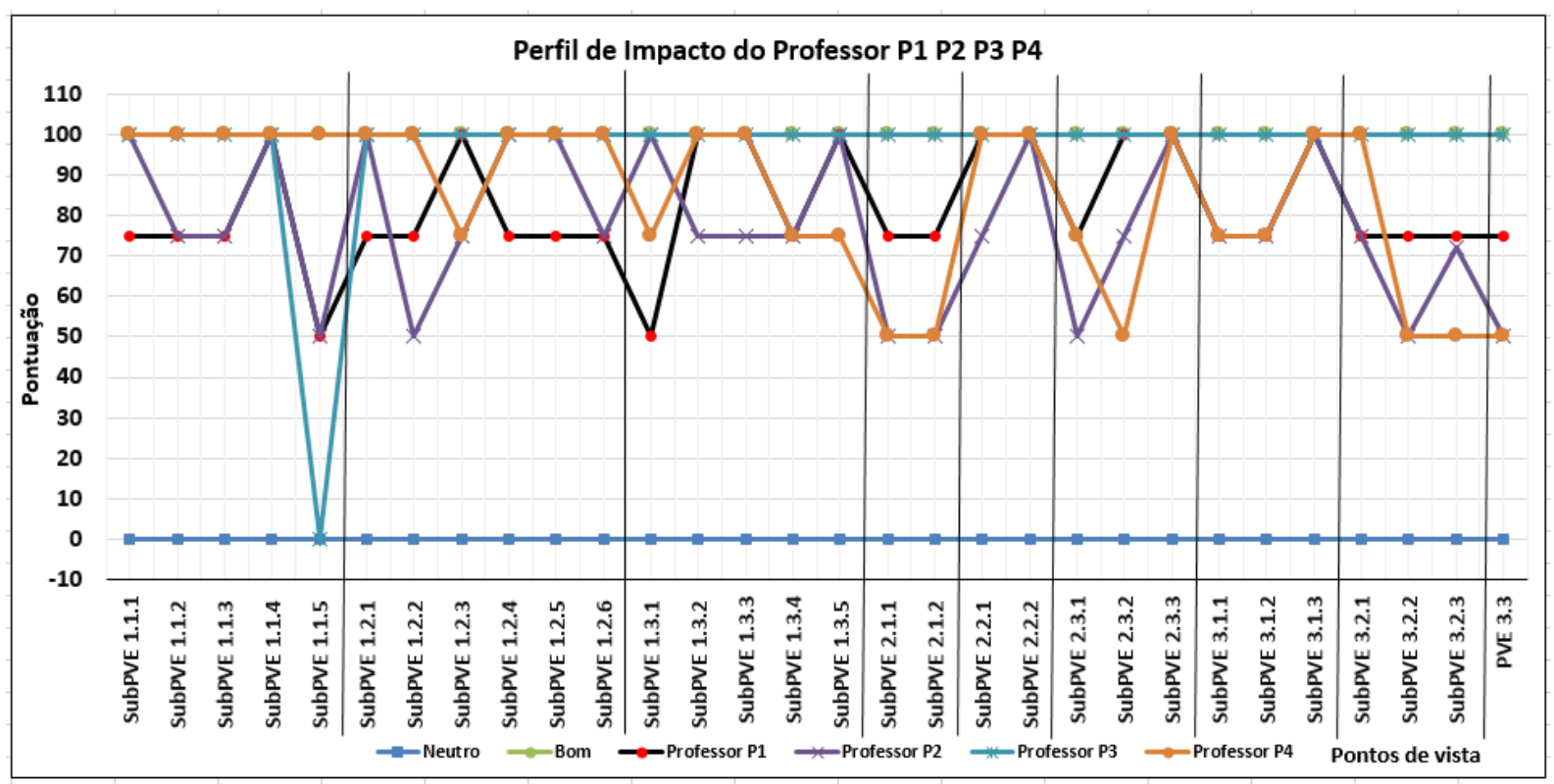

Figura 42 - Perfil de impacto dos avaliadores professores P1, P2, P3 e P4

Fonte: Elaboração própria (2016).

Analisando-se o gráfico da Figura 42, verifica-se a avaliação dos professores da FAU/UnB P1, P2, P3 e P4 nos critérios e subcritérios, obtendo-se os seguintes resultados: 
Impactado entre os níveis Bom e Neutro: i) o avaliador P3 apresentou o maior desempenho; ii) o avaliador P4 apresentou o segundo maior desempenho; e iii) os avaliadores P1 e P2 apresentaram um empate no desempenho.

\subsubsection{Fórmula de Agregação Aditiva Global}

Para determinar a Avaliação Global de um modelo MCDA aplica-se a Fórmula de Agregação Aditiva. De acordo com Ensslin, Neto e Noronha (2001), a Agregação Aditiva é uma fórmula matemática que permite converter os indicadores de impacto de uma ação em uma atratividade global, converter uma pontuação (avaliação) global da ação analisada.

Para os autores, o que se pretende é transformar um modelo que tem múltiplos critérios (avaliar os critérios e subcritérios ao programa de necessidades) num modelo com critério único, que é a pontuação final que uma determinada ação recebe.

Duas informações são necessárias: i) o desempenho local da ação potencial, obtida a partir dos descritores com suas funções de valor; e ii) as taxas de substituição do modelo.

Bana e Costa (2001) apresenta a Fórmula de Agregação Aditiva dada pelas equações a seguir:

$$
\begin{gathered}
V(a)=\omega 1 . v 1(a)+\omega 2 . v 2(a)+\omega 3 . v 3(a)+\ldots \ldots .+\omega n . v n(a) \\
V(a)=\sum_{i=1}^{n} \omega_{i} . v_{i}(a)
\end{gathered}
$$

onde:

a) VG(a) $\longrightarrow$ Valor Global do Desempenho da ação potencial 'a';

b) $\omega_{1}, \omega_{2}, \omega_{3}, \ldots, \omega_{n} \longrightarrow$ Taxa de substituição dos critérios avaliativos (PVF i), $\mathrm{i}=1,2,3, \ldots, \mathrm{n}$;

c) $v_{1}(a), v_{2}(a), v_{3}(a), \ldots, v_{n}(a) \longrightarrow$ Função de valor de cada descritor onde a ação potencial (a) foi impactada no modelo;

d) $\mathrm{n} \longrightarrow$ Número de critérios avaliativos.

As equações 1 e 2 estão submetidas às seguintes restrições:

- $C \omega_{1}=1 \longrightarrow$ O somatório das taxas de substituição (pesos) deve ser igual a 1:

- $0<\omega i<1$, onde $i=1,2, \ldots, n$ A taxa de substituição (peso) é um valor positivo maior que zero(0) e menor do que 1 ;

- a função de valor de uma ação potencial V (a) com impacto no nível Bom é igual a zero em todos os critérios; 
- a função de valor de uma ação potencial V (a) com impacto no nível Neutro Bom é igual a 100 em todos os critérios;

- $\sum_{i}^{n} \omega_{1} \cdot v_{1}(a)=100 \mathrm{O}$ valor global de uma ação potencial V(a) com no nível Neutro em todos os critérios é igual a 100;

- $\sum_{i}^{n} \omega_{1} \cdot v_{1}(a)=0$ O valor global de uma ação potencial $\mathrm{V}(\mathrm{a})$ com impacto no nível Neutro em todos os critérios é igual a 0 ,

Para o caso da pesquisa se adotou-se o cálculo da seguinte forma : cálculo da avaliação global (nota final), definiu-se uma fórmula de agregação aditiva, a partir da seguinte equação:

$\mathrm{VG}=\mathrm{W} 1\{\mathrm{~W} 1.1(\mathrm{~W} 1.1 .1 \mathrm{~V} 1.1 .1(\mathrm{a})+\mathrm{W} 1.1 .2 \mathrm{~V} 1.1 .2(\mathrm{a})+\mathrm{W} 1.1 .3 \mathrm{~V} 1.1 .3$ (a) $+\mathrm{W} 1.1 .4 \mathrm{~V} 1.1 .4(\mathrm{a})+\mathrm{W} 1.1 .5 \mathrm{~V} 1.1 .5(\mathrm{a}))+\mathrm{W} 1.2(\mathrm{~W} 1.2 .1 \mathrm{~V} 1.2 .2(\mathrm{a})+\mathrm{W} 1.2 .2 \mathrm{~V} 1.2 .2$ (a) + W1.2.3V1.2.3 (a) + W1.2.4V1.2.4 (a) + W1.2.5V1.2.5 (a) + W1.2.6V1.2.6 (a)) $\mathrm{W} 1.3$ (W1.3.1V1.3.1 (a) + W1.3.2V1.3.2 (a)) + W1.3.3V1.3.3 (a) + W1.3.4V1.3.4 (a) $+\mathrm{W} 1.3 .5 \mathrm{~V} 1.3 .5(\mathrm{a}))\}+\mathrm{W} 2\{\mathrm{~W} 2.1(\mathrm{~W} 2.1 .1 \mathrm{~V} 2.1 .1(\mathrm{a})+\mathrm{W} 2.1 .2 \mathrm{~V} 2.1 .2(\mathrm{a}))+\mathrm{W} 2.2$ $(\mathrm{W} 2.2 .1 \mathrm{~V} 2.2 .1(\mathrm{a})+\mathrm{W} 2.2 .2 \mathrm{~V} 2.2 .2(\mathrm{a})+\mathrm{W} 2.3(\mathrm{~W} 2.3 .1 \mathrm{~V} 2.3 .1(\mathrm{a}))+(\mathrm{W} 2.3 .2 \mathrm{~V} 2.3 .2(\mathrm{a}))$ $+(\mathrm{W} 2.3 .3 \mathrm{~V} 2.3 .3(\mathrm{a}))\}+\mathrm{W} 3\{\mathrm{~W} 3.1(\mathrm{~W} 3.1 .1 \mathrm{~V} 3.1 .1(\mathrm{a})+\mathrm{W} 3.1 .2 \mathrm{~V} 3.1 .2(\mathrm{a})+\mathrm{W} 3.1 .3$ V3.1.3 (a) + W3.2 ( W3.2.1 V3.2.1(a) + W3.2.2 V3.2.2 (a) + W3.2.3 V3.2.3 (a) ) + W3.3 ( W3.3 V3.3 (a))\}.

Onde:

- VG(a) = Valor global da avaliação dada pelo professor P1;

- $\omega_{i}=$ Taxa de substituição dos critérios i (PVF i) $=1,2,3,4,5$ e 6 (em destaque na cor azul);

- $v_{i}=$ valor impactado de uma ação potencial 'a "no critério i(PVF i) na escala corrigida (Função de ancoragem);

Os subíndices ijkw correspondem aos níveis associados à hierarquia do PVF, isto é:

- $\omega_{i j k w}=$ taxas de substituição correspondente ao subcritério ijkw (PVE jkw);

- $v_{i j k w}(\mathrm{a})=$ Valor impactado de uma função potencial 'a'no critério ijkw (PVE ijkw) na escala corrigida (Função de ancoragem), onde PVF $1=1^{\circ}$ Nível, PVF $2=2^{\circ}$ Nível e PVF $3=3^{\circ}$ Nível

Substituindo-se as taxas de substituição e dos critérios e subcritérios na Equação 3, obtém-se o resultado a seguir: 


$$
\begin{aligned}
& \mathrm{VG}=0,34\{0,34((0,23.75)+(0,25.75)+(0,12.75)+(0,21.100)+(0,19.50)) \\
& +0.33((0,17.75)+(0,20.75)+(0,18.100)+(0,23.75)+(0,11.75)+(0,11.75))+ \\
& 0,33((0,27.50)+(0,33.100)+(0,13.100)(+0,20.75)+(0,7.100))\}+0,33\{(0,31(0,50.75) \\
& +(0,50.75))+0.35((0,25.100)+0,75.100))+0,34((0,16.75)+(0,42.100)+(0,42 . \\
& 100))\}+0,33\{(0,37(0,33.75)+(0,30.75)+(0,37.100))+0,33((0,37.75)+(0,33.75) \\
& +(0,30.75))+0,30(1,00.75)\}=83 .
\end{aligned}
$$

Os valores destacados, em cor azul, correspondem às taxas de substituição dos 3 critérios (PVFs), e os valores internos (dentro das chaves), destacados na cor verde, correspondem às taxas de substituição dos subcritérios (PVEs).

Esse resultado encontra-se na Figura 43, a seguir, editada pelo software Hiview:

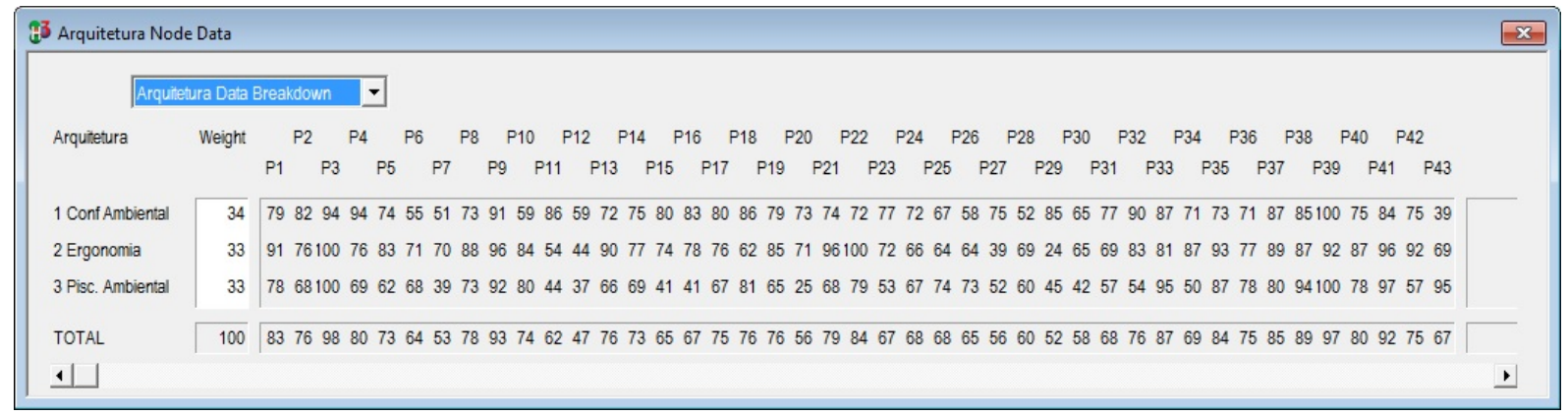

Figura 43 - Valor global da avaliação dada pelo professor P1

Fonte: Hiview3 (2016)

A partir das fórmulas acima utilizadas e dos dados levantados na pesquisa, devidamente tabulados e tratados, foram calculadas as avaliações parciais (notas dos PVFs) e global (nota final) que se constituirão no indicativo das avaliações finais deste trabalho.

\subsubsection{Análise de Sensibilidade}

A Análise de Sensibilidade tem por objetivo verificar se o modelo tem estabilidade forte ou fraca, ou seja, a robustez do modelo é suficiente para imprimir credibilidade ao resultado da avaliação. A Análise de Sensibilidade verifica, também, até que ponto pode alterar as taxas de substituição (pesos) dos PVFs ou dos PVEs sem causar uma grande variação na avaliação das ações potenciais (QUIRINO, 2002).

Ensslin, Neto e Noronha (2001) definem a Análise de Sensibilidade como o exame da robustez das respostas do modelo frente a alterações nos seus parâmetros. Ela permite que se saiba que uma pequena alteração, por exemplo, da taxa de compensação de um critério ou da performance de uma ação, vai causar uma grande variação na avaliação das ações potenciais.

Por ser a Análise de Sensibilidade compulsória em todos os modelos, revela-se 
a importância atribuída a esta fase do processo de avaliação dada pelos pesquisadores, permitindo que o decisor tenha um certo grau de confiança no seu modelo, como também, possa fazer alterações nas taxas de substituição dos critérios, tanto para mais ou para menos ou para menos daqueles encontrados (QUIRINO, 2002).

\subsubsection{Robustez do modelo à variação das taxas de substituição}

Como os critérios são construídos de acordo com as preferências do decisor e depois quantificados (taxas de substituição) para serem entendidos como aproximados, é necessário analisar a robustez do modelo multicritério, pois as taxas de substituição estão dentro de um intervalo de valores representados no modelo por um ponto (valor) (QUIRINO, 2002).

A Análise de Substituição gráfica é feita pelo software Hiview3, a partir de gráficos demonstrando as alterações que possam ocorrer na avaliação global em função das taxas de substituição dos critérios analisados. O eixo vertical (y) é representado pela avaliação global das ações potenciais (dos professores) e o eixo (x), representado pelas taxas de substituição dos critérios do modelo (QUIRINO, 2002).

Em modelos multicritérios de avaliação existem algumas fontes de imprecisão passíveis de ocorrerem e que justificam a realização da análise de sensibilidade para testar a robustez deles, a fim de que, se necessário, sejam feitos ajustes (ENSSLIN; NETO; NORONHA, 2001). As principais fontes de imprecisão são as seguintes:

- devido à complexidade do contexto decisório, às vezes, os decisores definem modelos que, em sua essência, não fornecem bases adequadas para a devida avaliação;

- às vezes, os modelos definidos baseiam-se tão somente no presente, ou em situações passadas, de modo que podem não ser aderentes a situações futuras;

- alguns modelos preocupam-se com medidas exatas e apresentam indecisão quanto ao que se deve medir, de modo a desconsiderar a essência de tais modelos, principalmente o fato de que as representações numéricas devem ser apenas "ordens de magnitude" e não quantidades exatas; e

- sendo a metodologia calcada no paradigma construtivista, segundo o qual as preferências são construídas, e não descobertas, o facilitador desavisado pode influenciar as respostas dos decisores e, com isso, desvirtuar a versão final do modelo.

A Análise de Sensibilidade do modelo de avaliação, com base na variação das taxas de substituição, é processada alterando-se os parâmetros dessas taxas e verificando o impacto que ocorre na avaliação das ações potenciais. De modo que, se o resultado final 
for afetado significativamente a partir de pequenas modificações em tais parâmetros, o modelo não pode ser considerado robusto.

Considerando que as taxas de substituição dos critérios devem ser igual a 1, a alteração de determinada taxa implica, necessariamente, a modificação das demais, ou seja, a alteração efetuada no parâmetro de cada critério desencadeará, por ocasião do teste de sensibilidade, mudanças nos parâmetros dos demais critérios.

Para se calcularem as novas taxas de substituição do modelo como um todo, a partir da modificação no parâmetro de cada critério, Ensslin, Neto e Noronha (2001) sugerem a seguinte fórmula:

$$
\frac{\omega_{n}=\omega_{n} \cdot\left(1-\omega_{i^{\prime}}\right)}{\left(1-\omega_{i^{\prime}}\right)}
$$

Onde:

- $\omega_{i}=$ taxa de substituição (peso) original do critério i;

- $\omega_{i}^{\prime}=$ taxa de substituição (peso) modificada do critério i;

- $\omega_{n}=$ taxa de substituição (peso) original do critério n;

- $\omega_{n}^{\prime}=$ taxa de substituição (peso) modificada do critério n.

A Análise de Sensibilidade do modelo foi devidamente realizada após o tratamento dos dados da pesquisa de campo, a partir de uma variação de 10\% para mais e para menos nas taxas de substituição de cada critério (PVF), cujos resultados são apresentados na seção 5.6.

Com a conclusão da Análise de Sensibilidade termina a fase de avaliação do modelo proposto, ficando a etapa final, as recomendações e as sugestões para aplicação adequada do modelo e, também as sugestões para o desenvolvimento de trabalhos futuros.

Estruturado o modelo, foi elaborado o questionário (Apêndice B), e proceder-se-á à apresentação e análise dos dados da pesquisa (resultados) a partir de todos os passos referidos com os programas Hiwiew3 e Macbeth.

\subsection{Analise dos resultados}

A pesquisa de campo, destinada ao levantamento de dados para aplicação do modelo de avaliação dos critérios e subcritérios facilitadores do ensino-aprendizagem que impactam na elaboração de programa de necessidades para fins de elaboração de projeto de arquitetura escolar foi realizada com os professores do curso de Arquitetura e Urbanismo da 
Faculdade de Arquitetura e Urbanismo da Universidade de Brasília, que se disponibilizaram a responder o questionário elaborado. Para efeito de apresentação dos dados da pesquisa e das respectivas análises, os professores não serão identificados nominalmente. Eles serão codificadas com a numeração de um a quarenta e três, sendo que apresentaremos apenas os dados das avaliações dos professores de 1 a 20, devido ao grande número de dados no geral.

A pesquisa foi realizada de forma presencial e por meio do software Hiview3 com a participação de 43 professores, aplicando o questionário constante do Apêndice B , entre os meses de março e maio do ano de 2016. Foi estruturada em três eixos, caracterizados no Modelo Multicritério de Avaliação desenvolvido para o presente estudo como Pontos de Vista Fundamentais, a saber: i) PVF 1 - Conforto Ambiental; (ii) PVF 2 - Ergonomia; iii) PVF 3 - Psicologia Ambiental.

Em função da complexidade desses eixos estruturantes para serem mensurados, cada um deles foi desmembrado em 9 Pontos de Vista Elementares e 30 Subpontos de Vista Elementares, os quais se constituíram, individualmente, nas "pontas" dos eixos de avaliação, conforme o modelo multicritério desenvolvido (o qual foi descrito no Capítulo 4)

Nas Tabelas 51, 52 e 53 apresentam-se os dados das avaliações (respostas) dos primeiros vinte professores contemplados na pesquisa, como amostra, por meio de questionário, referentes respectivamente aos PVF 1 - Conforto Ambiental, PVF 2 - Ergonomia e PVF 3 - Psicologia Ambiental. Em seguida, cada quesito avaliativo será tratado e analisado pormenorizadamente.

Verificando as respostas, percebe-se que há uma certa similaridade entre elas, com algumas exceções. Isso evidencia um entendimento com certo grau de correlação por parte dos professores da FAU/UnB, guardadas as especificidades de cada espaço arquitetônico em que cada um ministra sua disciplina/aula, que são afetadas em maior ou menor grau pelos diversos itens avaliados. 
Capítulo 5. Caracterização do Universo de Estudo, Desenvolvimento da Pesquisa de Campo e Análise 250

dos Resultados

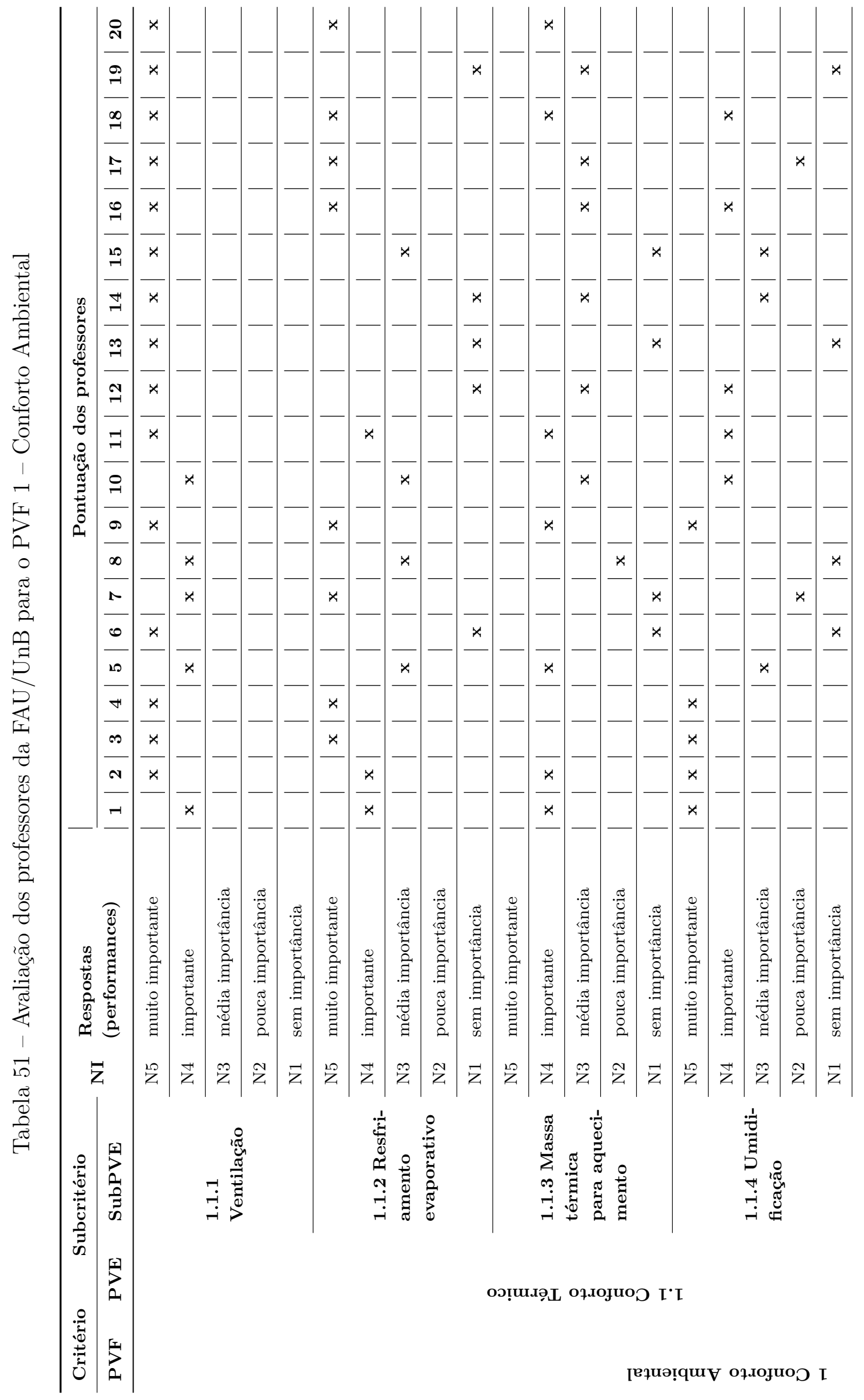




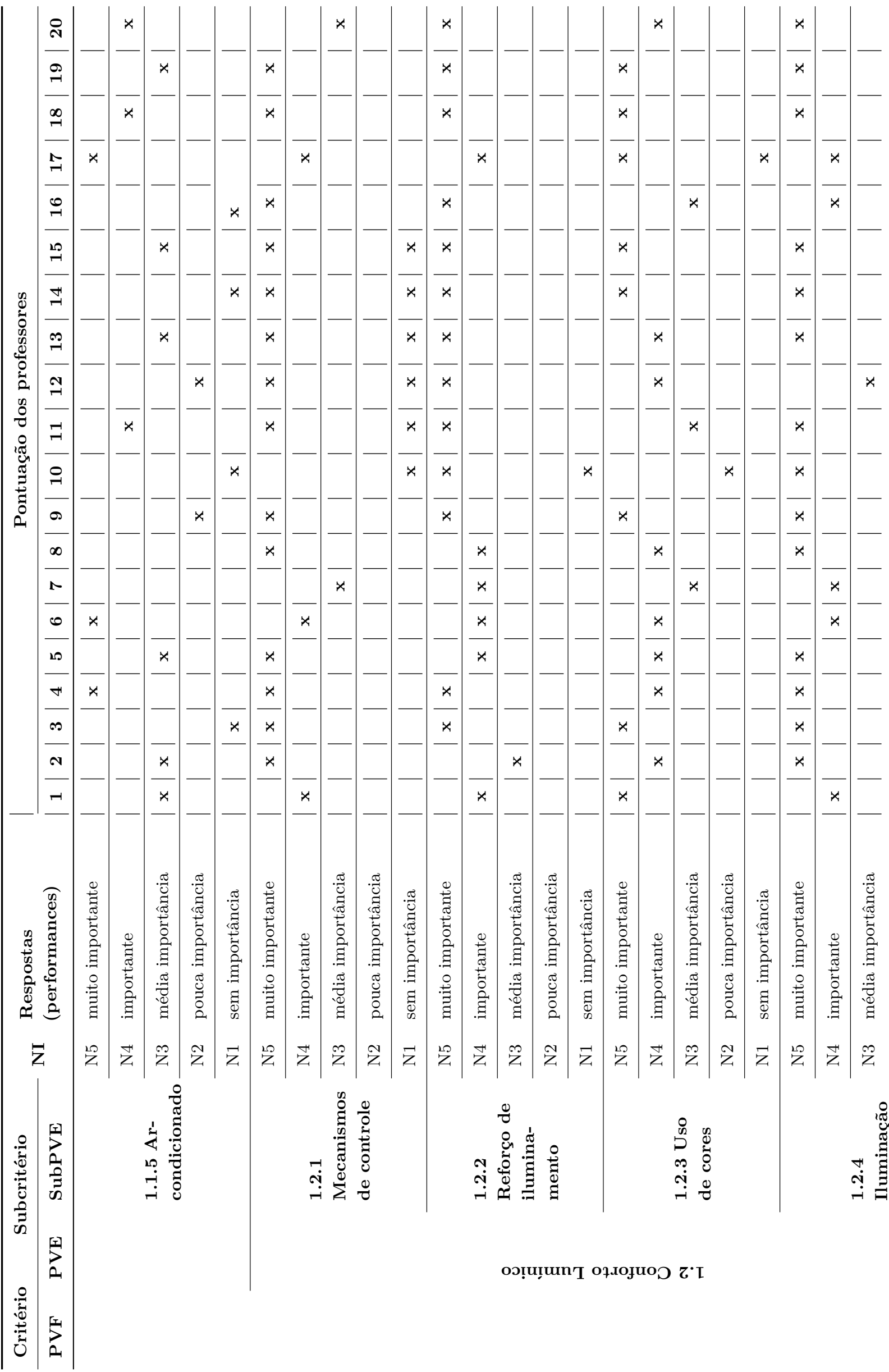


Capítulo 5. Caracterização do Universo de Estudo, Desenvolvimento da Pesquisa de Campo e Análise

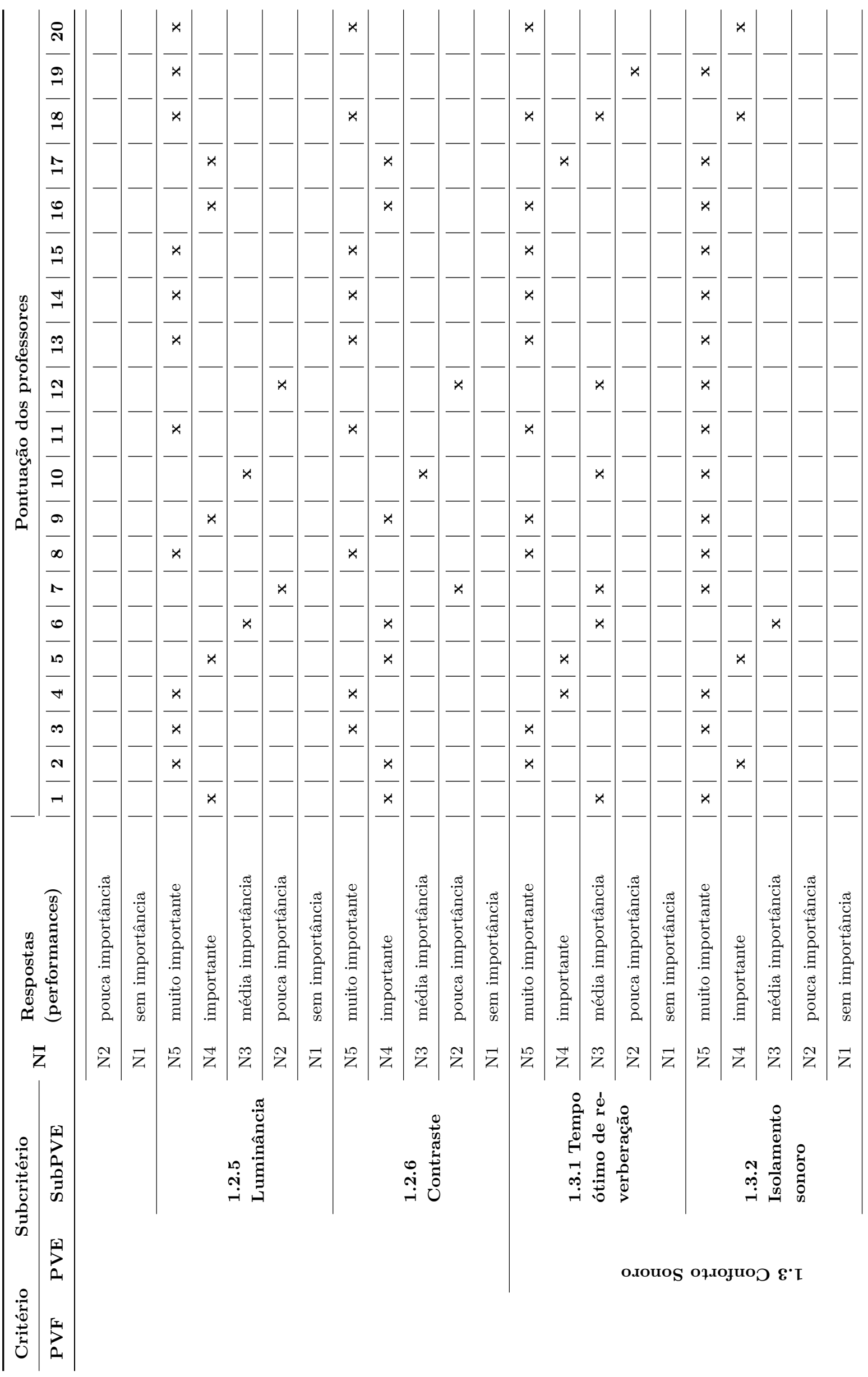




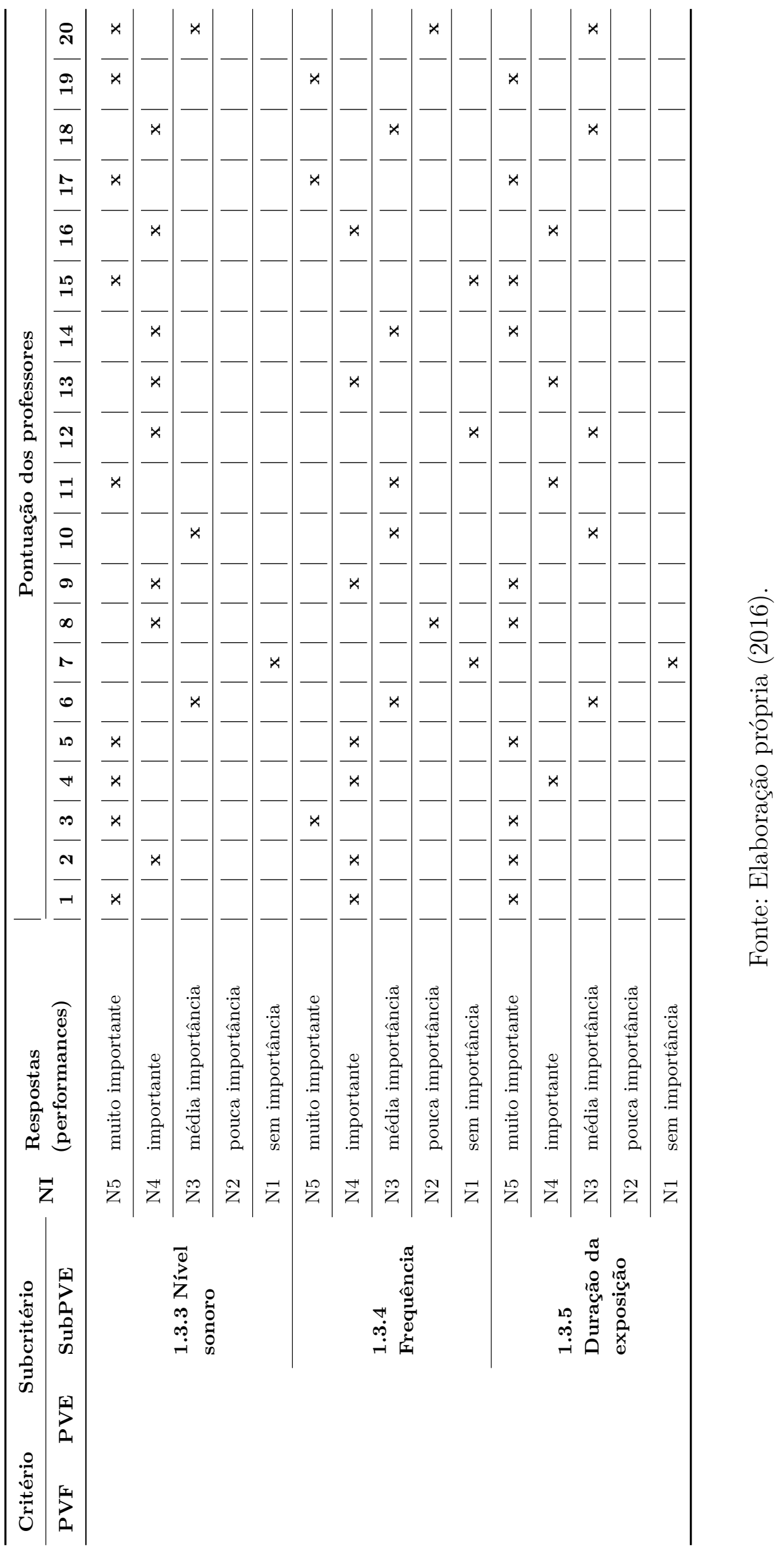


Capítulo 5. Caracterização do Universo de Estudo, Desenvolvimento da Pesquisa de Campo e Análise 254

dos Resultados

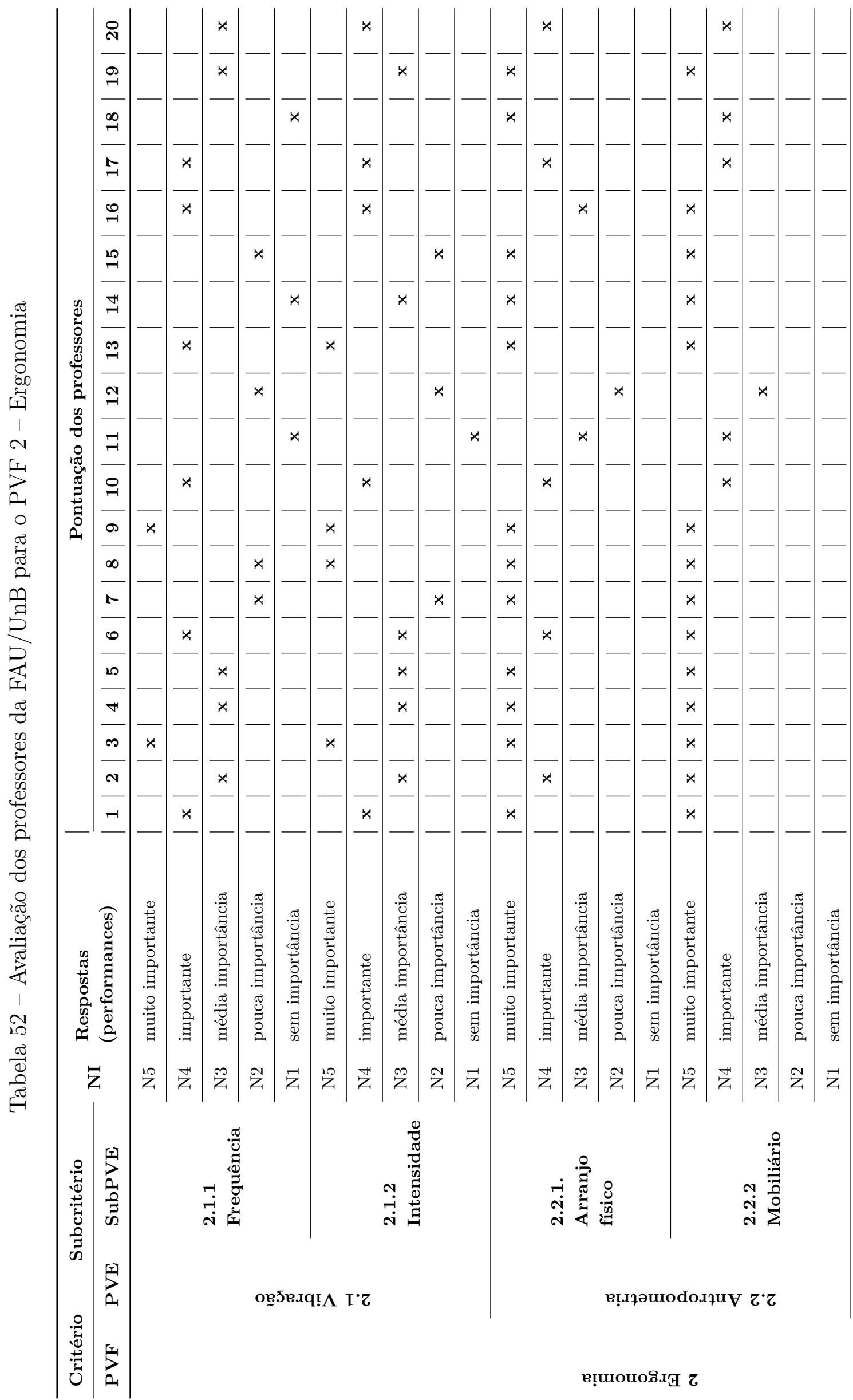




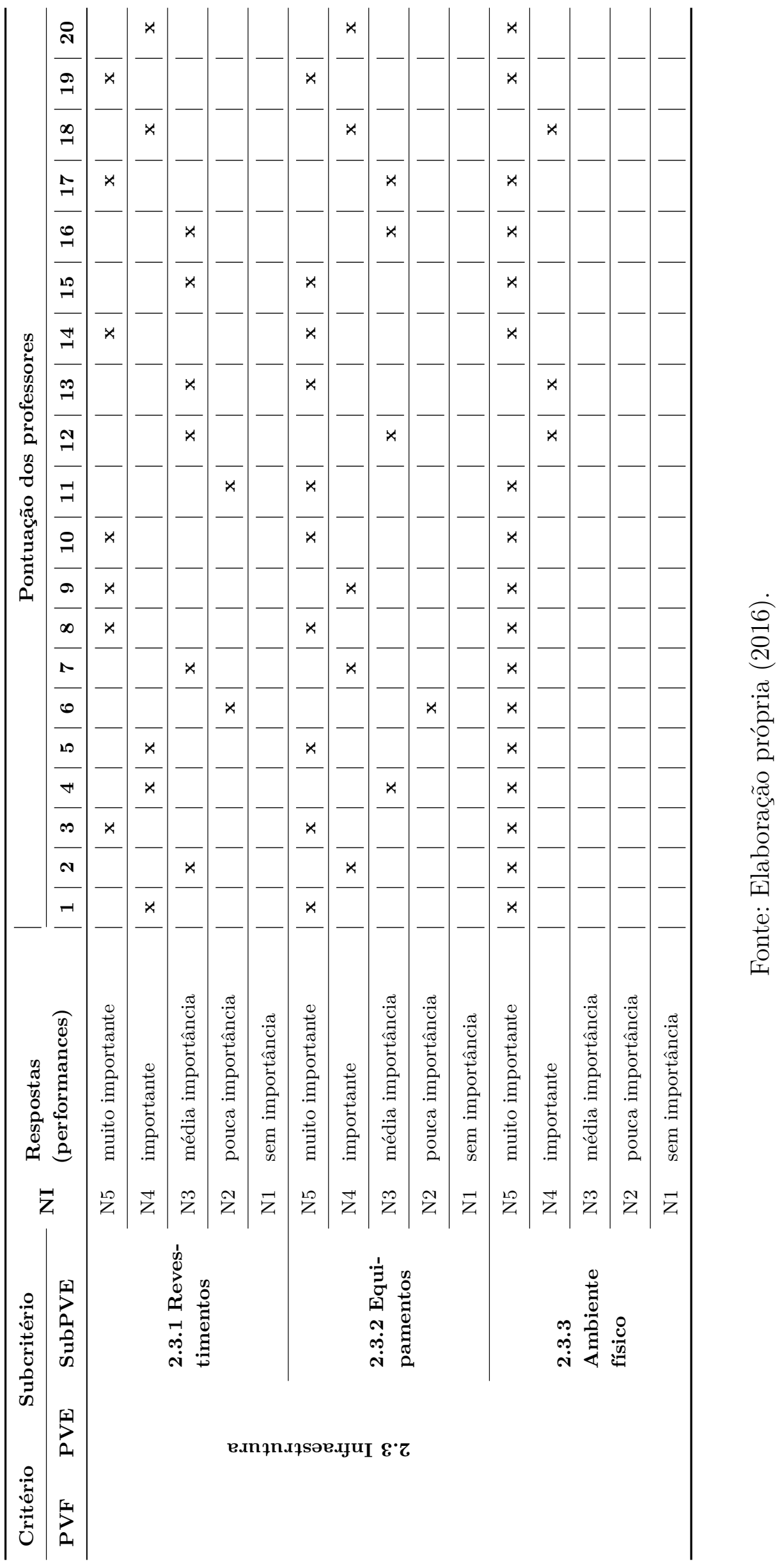


Capítulo 5. Caracterização do Universo de Estudo, Desenvolvimento da Pesquisa de Campo e Análise

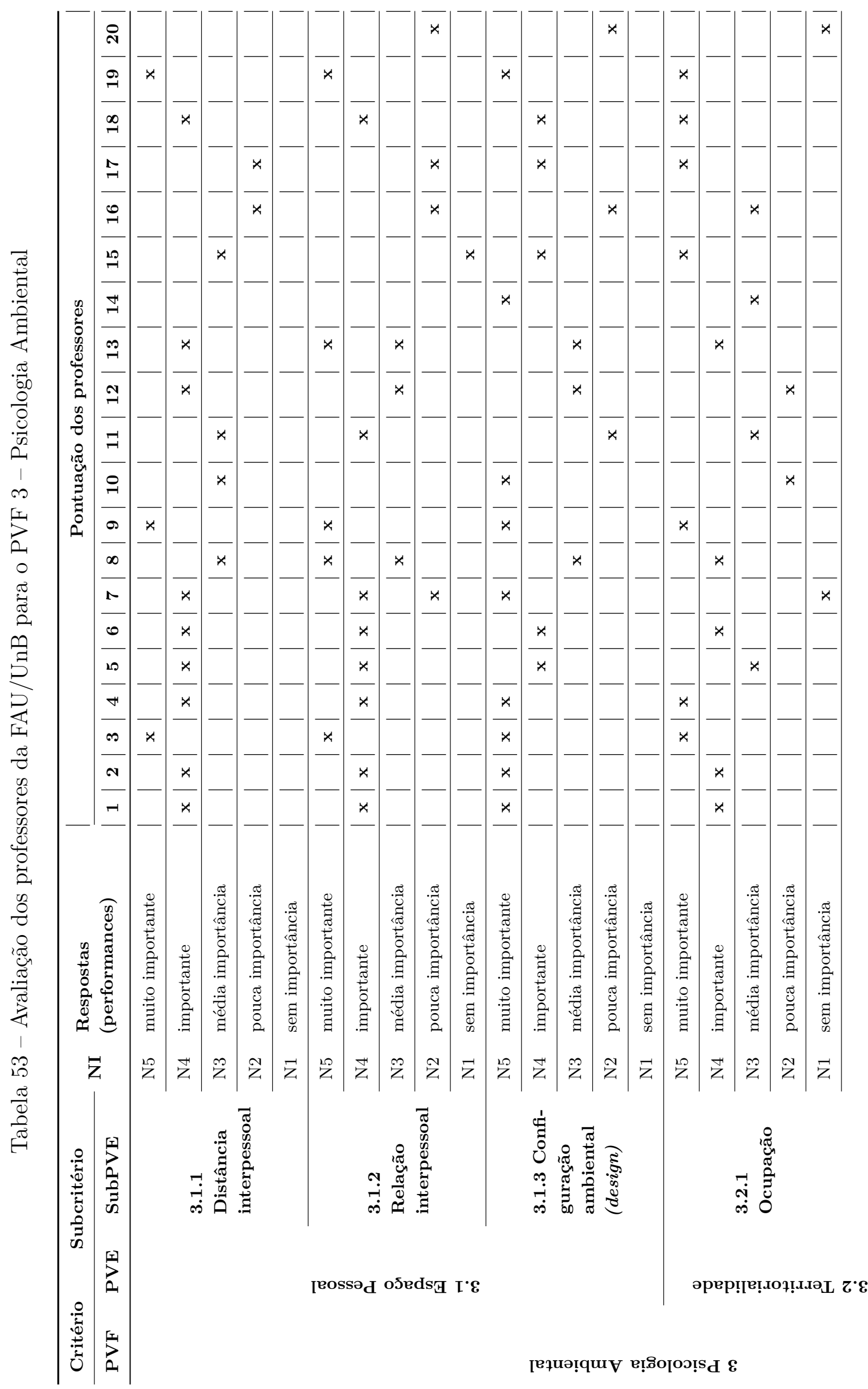




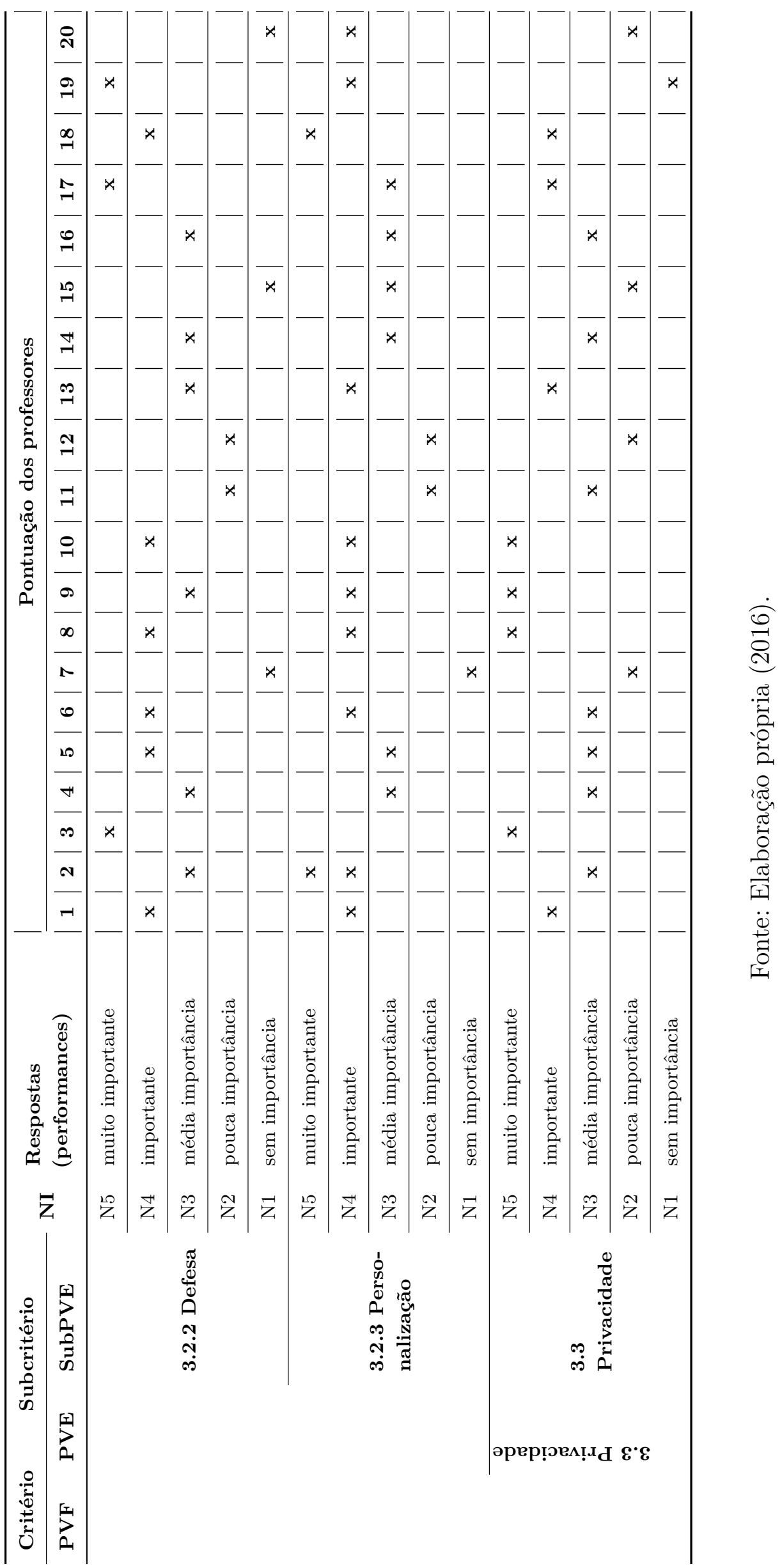




\subsubsection{Análises dos dados}

Os dados apresentados nessa pesquisa foram devidamente processados pelo software Hiview3 e serão apresentados e analisados pelos Pontos de Vista Fundamental PVF 1 - Conforto Ambiental, PVF 2 - Ergonomia e PVF 3 - Psicologia Ambiental. Ao final, será apresentada a avaliação global, refletindo as avaliações dos critérios e subcritérios considerados pelos especialistas como impactantes no ensino-aprendizagem, que contribuem para o programa de necessidades em projetos de arquitetura, a partir dos juízos de valor dos decisores que participaram da construção do modelo multicritério de avaliação.

Os dados relativos às respostas dos diversos professores da área de Arquitetura foram determinados pelo software Hiview3, a partir do modelo desenvolvido no estudo. Foram considerados os pesos definidos para os critérios e subcritérios e as funções de valor atribuídas aos diversos níveis de impacto. A seguir os dados apresentados no estudo serão detalhados, comentados e analisados.

\subsubsection{Conforto Ambiental - PVF 1}

O Conforto Ambiental - PVF 1, compreende o estudo das condições térmicas, acústicas, luminosas e energéticas e os fenômenos físicos a elas associados como um dos condicionantes da forma e da organização do espaço (MEC, 1994).

O bloco a que se refere esse PVF 1 comporta três tipos de PVEs que são: PVE 1.1 - Conforto térmico, PVE 1.2 - Conforto lumínico e PVE 1.3 - Conforto sonoro.

Na Figura 44, apresenta-se a síntese das pontuações globais determinadas pelo Hiview3 a cada uma das avaliações (respostas) dos professores da FAU/UnB para os três PVEs desse ponto de vista fundamental, após o devido tratamento dos dados levantados na pesquisa.

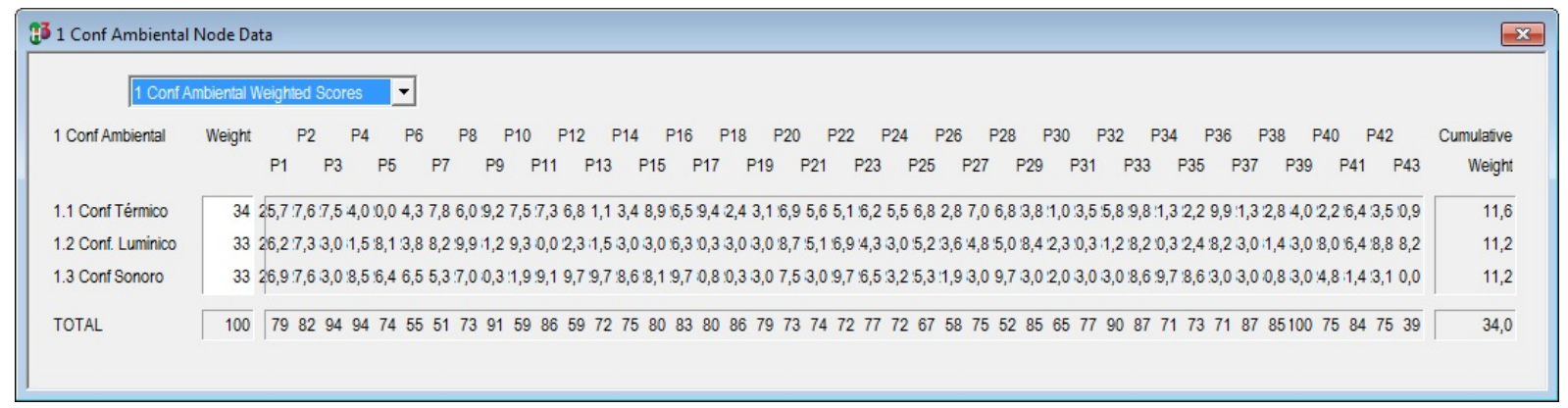

Figura 44 - Pontuações ponderadas das avaliações dos professores da FAU/UnB no PVF 1

Fonte: Hiview3 (2016).

Na coluna da esquerda consta a nomenclatura dos Pontos de Vista Elementares (PVEs) com seus respectivos pesos, totalizando 100\% no PVF 1, Conforto Ambiental. No 
centro da Figura 44, constam as pontuações dos professores do curso de arquitetura da UnB, já tratadas pelo Hiview3, separadas por subcritério (SubPVE), no caso o PVE 1.1 Conforto térmico, o PVE 1.2 - Conforto lumínico e o PVE 1.3 - Conforto sonoro e, na última linha, as pontuações totais atribuídas às respostas, nesse critério (PVF). Na coluna da direita, constam os pesos individualizados de cada subcritério no contexto do modelo de forma geral e a participação do critério no contexto global, $34 \%$ (trinta e quatro por cento).

Considerando a pontuação dos 43 professores, que participaram dessa pesquisa, referente ao PVF 1, foram feitas as seguintes análises: cinco professores pontuaram as avaliações acima de 90 (noventa), correspondendo a um percentual de 5\%; vinte e nove professores pontuaram as avaliações entre 70 e 89, correspondendo a um percentual de $29 \%$; oito professores pontuaram as avaliações entre 40 e 69, correspondendo a um percentual de $8 \%$; um professor pontuou as avaliações abaixo de 39, correspondendo a um percentual de $1 \%$.

No gráfico da Figura 45, explicita-se a contribuição de cada PVE do PVF 1, na composição da pontuação das avaliações dos professores da FAU/UnB.

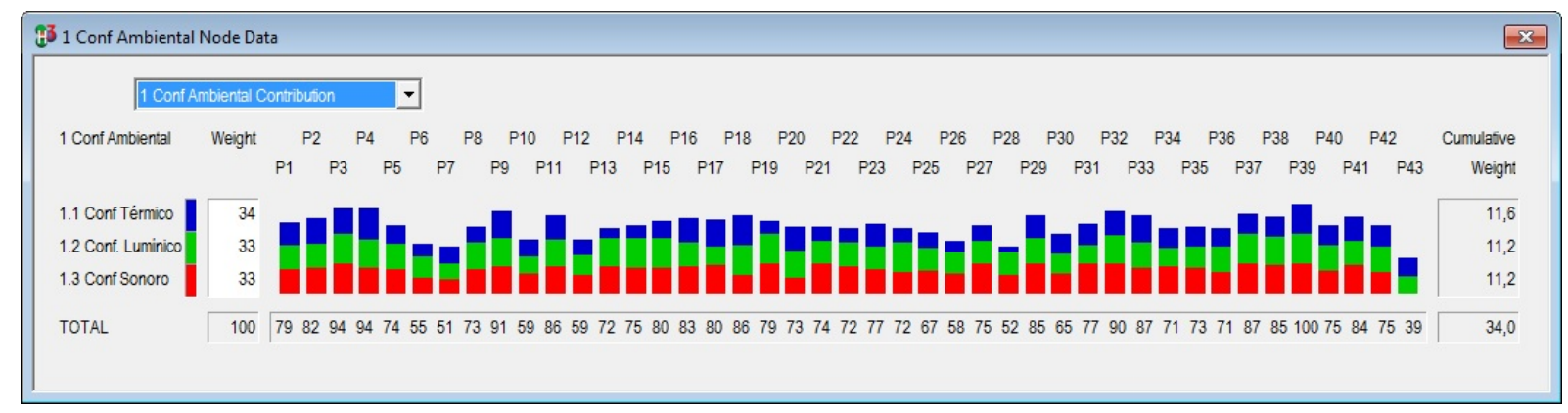

Figura 45 - Contribuição de cada PVE do PVF 1 na pontuação dos professores da $\mathrm{FAU} / \mathrm{UnB}$

Fonte: Hiview3 (2016).

O gráfico da Figura 45 mostra a participação dos PVEs do Conforto Ambiental na composição da pontuação de cada avaliação dos professores, onde se verifica que o PVE 1.2 - Conforto lumínico apresenta uma maior pontuação, seguida do PVE 1.3 - Conforto sonoro e depois o PVE 1.1 - Conforto térmico.

O PVF 1 - Conforto Ambiental apresentou uma avaliação média, alcançando a pontuação 75,25 referente à avaliação dos 43 professores, conforme demonstrado nas Figuras 44 e 45, constituindo-se a segunda melhor avaliação entre os PVFs em análise.

Analisando as pontuações dos professores nota-se que: os PVEs 1.1, 1.2 e 1.3 receberam pontuações parecidas, verificando que os professores do curso de Arquitetura da FAU/UnB pontuaram a menos os parâmetros que contemplam o conforto térmico, especifi- 
camente no SubPVE 1.1.2 - Resfriamento evaporativo, no SubPVE 1.1.4 - Umidificação e no SubPVE 1.1.5 que é a utilização de ar-condicionado, que para alguns professores não é tão importante no espaço arquitetônico onde ministram suas disciplinas. Ao mesmo tempo, a pontuação referente ao Conforto lumínico foi a maior, seguida do Conforto sonoro.

\section{- Conforto Térmico - PVE 1.1}

Existem vários métodos para avaliação do Conforto térmico humano. Neste estudo foi utilizada a Carta Psicométrica. Segundo Oliveira e Ribas (1995), as estratégias para se obter conforto (voltar à zona de conforto térmico humano), as estratégias são: i) SubPVE 1.1.1 - Ventilação - os movimentos de ar aceleram as trocas de calor das pessoas com o ambiente por convecção e por evaporação; ii) SubPVE 1.1.2 - Resfriamento Evaporativo consiste na redução da temperatura do ambiente por meio da evaporação de microgotículas de água aspergidas - ou borrifadas - no ar e espalhadas no ambiente por ventiladores de alto desempenho; iii) SubPVE 1.1.3 - Massa térmica para resfriamento - é uma solução empregável em locais nos quais as temperaturas e umidade relativas estejam entre determinados valores. Essa estratégia permite que o calor armazenado na estrutura térmica durante o dia seja devolvido à noite, quando as temperaturas externas diminuem; iv) SubPVE 1.1.4 - Umidificação - introdução de vapor de água no ar para a obtenção da umidade desejada. É a quantidade de vapor de água na atmosfera; v) SubPVE 1.1.5 Ar-condicionado - aparelhos destinados ao condicionamento de ar.

Na Figura 46, apresenta-se a síntese das pontuações ponderadas atribuídas pelo Hiview3 a cada avaliação dos professores para os cinco SubPVEs do PVE - Conforto térmico, após o devido tratamento dos dados levantados na pesquisa.

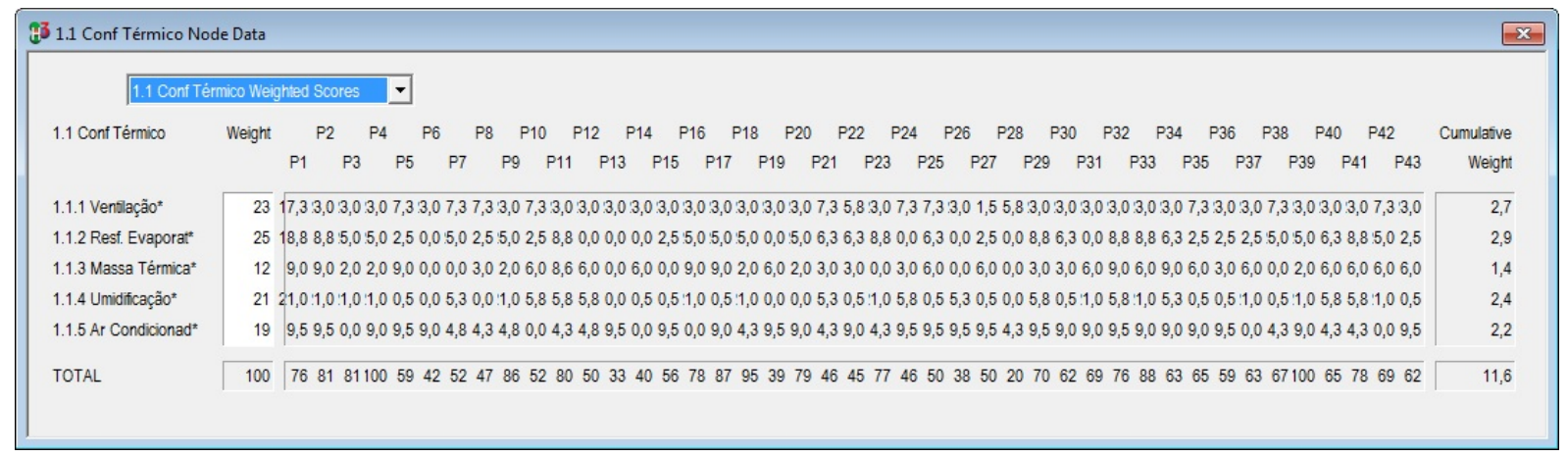

Figura 46 - Pontuações ponderadas dos professores da FAU/UnB no PVE 1.1

Fonte: Hiview3 (2016).

Considerando a pontuação dos 43 professores referente ao PVF 1, foram feitas as seguintes análises: três professores pontuaram as avaliações acima de 90 (noventa), correspondendo a um percentual de $3 \%$; treze professores pontuaram as avaliações entre 
70 e 89, correspondendo a um percentual de 13\%; vinte e três professores pontuaram as avaliações entre 40 e 69, correspondendo a um percentual de $23 \%$; quatro professores pontuaram as avaliações abaixo de 39, correspondendo a um percentual de $4 \%$.

No gráfico da Figura 47, explicita-se a contribuição de cada SubPVE do PVE 1.1, na composição da pontuação das avaliações dos professores da FAU/UnB.

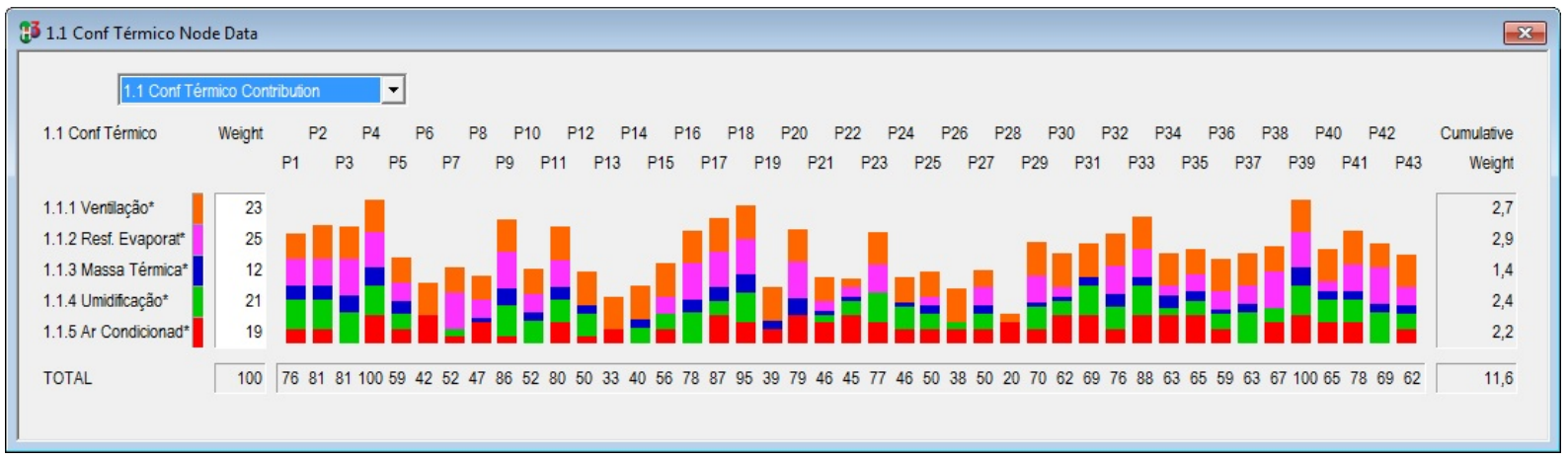

Figura 47 - Contribuição de cada SubPVE do PVE 1.1 na pontuação dos professores da $\mathrm{FAU} / \mathrm{UnB}$

Fonte: Hiview3 (2016).

O gráfico da Figura 47 mostra a participação de cada SubPVE do Conforto térmico na composição da pontuação de cada avaliação dos professores, onde se verifica que o SubPVE 1.1.2 - Resfriamento evaporativo apresenta uma maior pontuação, seguido do SubPVE 1.1.1 - Ventilação, SubPVE 1.1.4 - Umidificação, SubPVE 1.1.5 - Ar-condicionado e, por último, o SubPVE 1.1.3 - Massa térmica.

O PVE 1.1 - Conforto térmico apresentou uma avaliação média, alcançando a pontuação 63,74, referente à avaliação dos 43 professores, conforme demonstrado nas Figuras 46 e 47, constituindo-se a terceira avaliação entre os PVEs em análise do PVF 1.

Analisando as pontuações dos professores nota-se que: o SubPVE que obteve a maior pontuação foi o SubPVE 1.1.1 - Ventilação; a segunda melhor pontuação foi do SubPVE 1.1.4 - Umidificação, seguida do SubPVE 1.1.5 - Ar-condicionado, no mesmo nível de importância para os espaços arquitetônicos em que ministram suas disciplinas. Os subPVEs 1.1.2 - Resfriamento Evaporativo e 1.1.3 - Massa térmica para resfriamento receberam as menores pontuações, respectivamente.

\section{- Conforto Lumínico - PVE 1.2}

Segundo Oliveira e Ribas (1995), para se obter Conforto lumínico (voltar à zona de conforto luminoso humano), as estratégias são: i) SubPVE 1.2.1 - Mecanismos de Controle - a luz do sol pode ser manipulada por meio do uso de uma série de mecanismos como reflexão, transmissão, refração, polarização, absorção, difusão, dentre outros; ii) SubPVE 
1.2.2 - Reforço do iluminamento - a iluminação artificial feita por lâmpadas elétricas é um reforço à iluminação natural e pode ser geral - ilumina todo o ambiente - ou suplementar - ilumina melhor um determinado objeto ou ação e complementa a iluminação geral; iii) SubPVE 1.2.3 - Uso das cores - cor é uma percepção visual provocada pela ação de um feixe de fótons sobre células especializadas da retina, que transmitem por meio de informação pré-processada ao nervo óptico, impressões para o sistema nervoso; iv) SubPVE 1.2.4 - Iluminação - é a quantidade de luz natural ou artificial no nível da estação de trabalho. Uma iluminação incorreta induz à fadiga, ao desconforto; v) SubPVE 1.2.5 Luminância - é a quantidade de luz refletida que entra no olho e estimula a retina. Muita luz causa ofuscamento, pouca luz causa percepção ruim ou impossível. É o fluxo luminoso incidente por unidade de área iluminada; vi) SubPVE 1.2.6 - Contraste - é a relação de luminância entre o objeto observado e os que os cercam.

Na Figura 48, apresenta-se a síntese das pontuações ponderadas atribuídas pelo Hiview3 a cada avaliação dos professores para os cinco SubPVE do PVE 1.2 - Conforto lumínico, após o devido tratamento dos dados levantados na pesquisa.

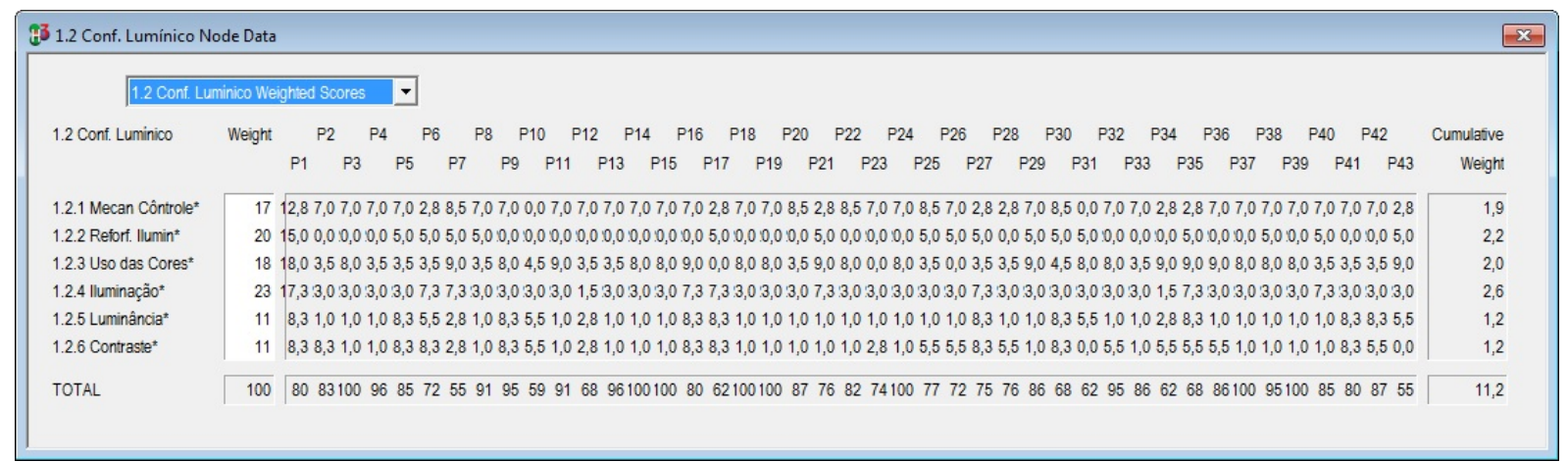

Figura 48 - Pontuações ponderadas dos professores da FAU/UnB no PVE 1.2

Fonte: Hiview3 (2016).

Considerando a pontuação dos 43 professores referente ao PVF 1, foram feitas as seguintes análises: quinze professores pontuaram as avaliações acima de 90 (noventa), correspondendo a um percentual de 15\%; dezenove professores pontuaram as avaliações entre 70 e 89, correspondendo a um percentual de 19\%; nove professores pontuaram as avaliações entre 40 e 69, correspondendo a um percentual de 9\%; não houve pontuação abaixo de 39 .

No gráfico da Figura 49, explicita-se a contribuição de cada SubPVE do PVE 1.2, na composição da pontuação das avaliações dos professores da FAU/UnB. 


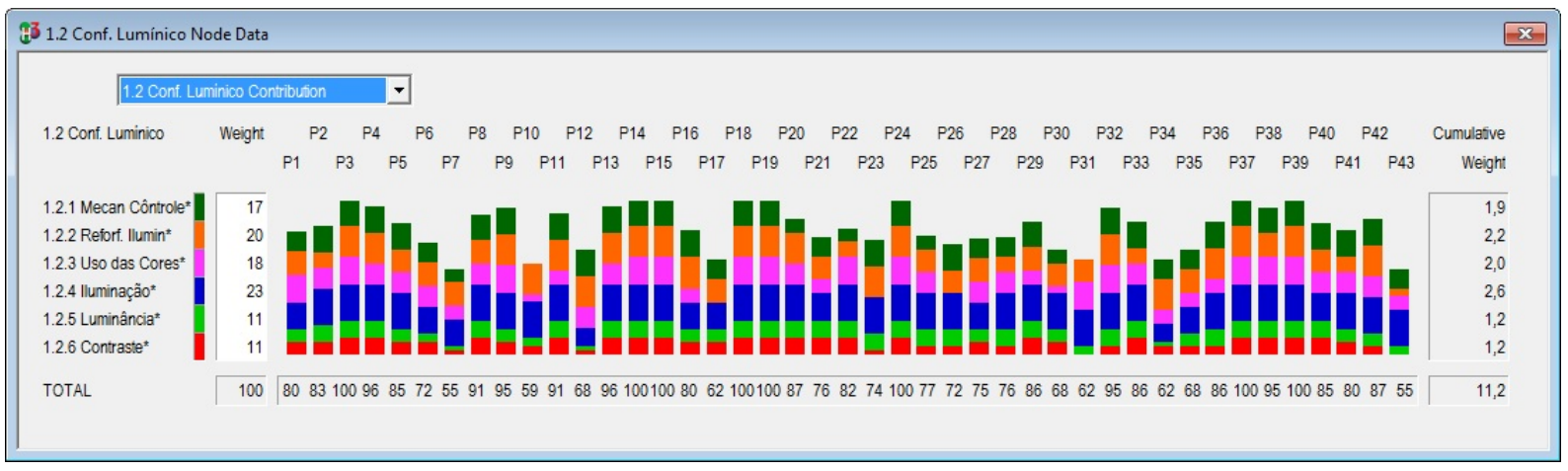

Figura 49 - Contribuição de cada SubPVE do PVE 1.2 na pontuação dos professores da $\mathrm{FAU} / \mathrm{UnB}$

Fonte: Hiview3 (2016).

O gráfico da Figura 49 mostra a participação dos SubPVEs do Conforto lumínico na composição da pontuação de cada avaliação dos professores, onde se verifica que o PVE 1.2.4 - Iluminação apresenta a maior pontuação, seguido do SubPVE 1.2.1 - Mecanismos de Controle e do SubPVE 1.2.5 - Luminância, com a mesma pontuação, seguidos do SubPVE 1.2.2 - Reforço de iluminamento, SubPVE 1.2.6 - Contraste e do SubPVE 1.2.3 - Uso das cores.

O PVE 1.2 - Conforto lumínico apresentou uma avaliação média, alcançando a pontuação 82,48, referente à avaliação dos 43 professores, conforme demonstrado nas Figuras 48 e 49, constituindo-se a primeira avaliação entre os PVEs em análise do PVF 1.

Fica caracterizada, a partir das pontuações dos 43 professores da FAU/UnB a importância do PVE 1.2 - Conforto lumínico para os espaços arquitetônicos de ensinoaprendizagem que contempla os subPVEs desse PVE. Na literatura, os autores expuseram a importância do Conforto lumínico, caracterizado pelos atributos e parâmetros que impactam no ensino-aprendizagem. Analisando as pontuações dos professores nota-se que: o SubPVE que obteve a maior pontuação foi o SubPVE 1.2.4 - Iluminação; a segunda melhor pontuação foi dos SubPVEs 1.1.4 - Mecanismos de controle e SubPVE 1.2.5 - Luminância, seguida do SubPVE 1.2.2 - Reforço do iluminamento, SubPVE 1.2.6 Contraste e, por último, o SubPVE 1.2.3 - Uso das cores.

\section{- Conforto Sonoro - PVE 1.3}

Segundo Oliveira e Ribas (1995) para se obter Conforto sonoro (voltar à zona de conforto sonoro humano), as estratégias são: i) Tempo ótimo de reverberação - para cada ambiente existe um TR considerado ótimo e que varia conforme o volume e o seu uso. A norma NBR 12179 - tratamento acústico em recintos fechados (ABNT, 1992b), apresenta um gráfico com os tempos ótimos de reverberação para diferentes ambientes. ii) isolamento sonoro - melhor qualidade sonora para o interior, e controle do ruído de 
fora para dentro dos ambientes. iii) nível sonoro - relaciona a intensidade sonora de um som com a intensidade sonora do som mais fraco, que conseguimos ouvir. iv) frequência - número de variações de pressão (ou de oscilações) durante um segundo. A unidade de frequência é o Hertz, Hz. v) duração da exposição - tempo da exposição diária ao ruído durante o trabalho.

Na Figura 50, apresenta-se a síntese das pontuações ponderadas atribuídas pelo Hiview3 a cada avaliação dos professores para os cinco SubPVEs do PVE - Conforto sonoro, após o devido tratamento dos dados levantados na pesquisa.

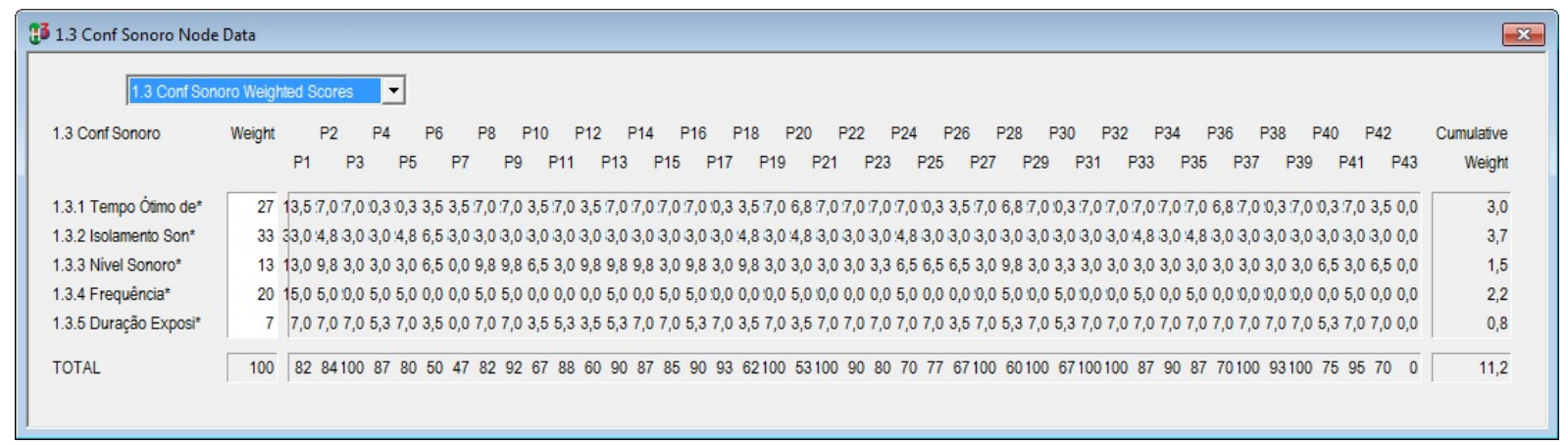

Figura 50 - Pontuações ponderadas dos professores da FAU/UnB no PVE 1.3

Fonte: Hiview3 (2016).

Considerando a pontuação dos 43 professores referente ao PVF 1, foram feitas as seguintes análises: dezessete professores pontuaram as avaliações acima de 90 (noventa), correspondendo a um percentual de 17\%; dezesseis professores pontuaram as avaliações entre 70 e 89, correspondendo a um percentual de 16\%; nove professores pontuaram as avaliações entre 40 e 69 , correspondendo a um percentual de $9 \%$; um professor pontuou as avaliações abaixo de 39, correspondendo a um percentual de $1 \%$.

No gráfico da Figura 51, explicita-se a contribuição de cada SubPVE do PVE 1.3, na composição da pontuação das avaliações dos professores da FAU/UnB.

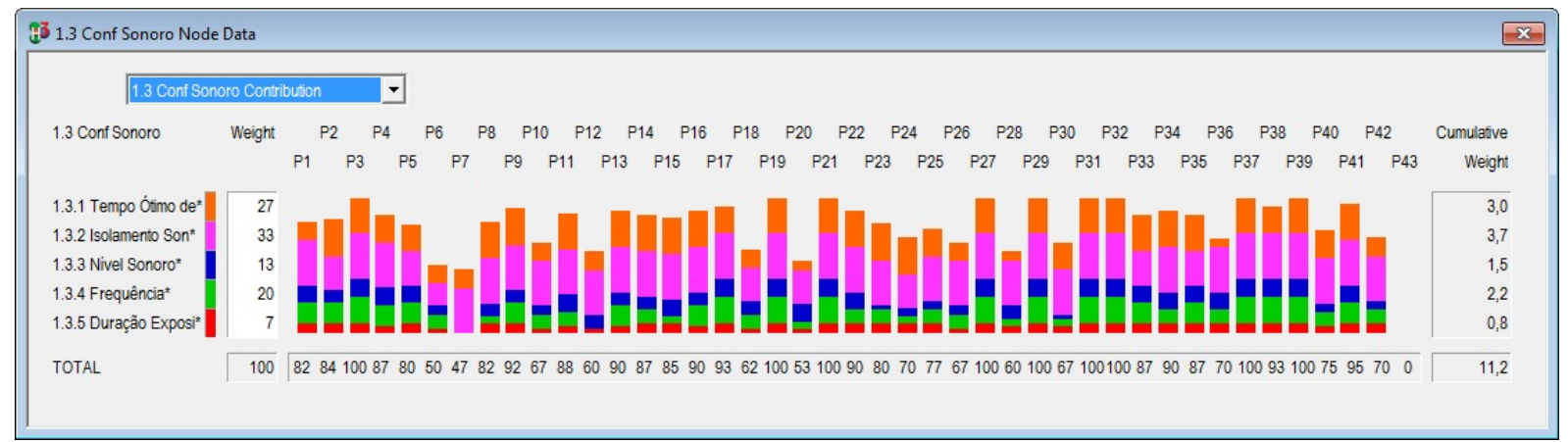

Figura 51 - Contribuição de cada SubPVE do PVE 1.3 na pontuação dos professores da $\mathrm{FAU} / \mathrm{UnB}$ 
O gráfico da Figura 51 mostra a participação dos SubPVEs do Conforto sonoro na composição da pontuação de cada avaliação dos professores, onde se verifica que o SubPVE 1.3.2 - Isolamento sonoro apresenta uma maior pontuação, seguido do SubPVE 1.3.1 - Tempo ótimo de reverberação, SubPVE 1.3.4 - Frequência, SubPVE 1.3.3 - Nível sonoro, e, depois, o SubPVE 1.3.5 - Duração da exposição.

O PVE 1.3 - Conforto sonoro apresentou uma avaliação média, alcançando a pontuação 80,39, referente à avaliação dos 43 professores, conforme demonstrado nas Figuras 50 e 51, constituindo-se a segunda avaliação entre os PVEs em análise do PVF 1.

Fica caracterizada, a partir das pontuações dos 43 professores da FAU/UnB, a importância do PVE 1.3 - Conforto sonoro para os espaços arquitetônicos de ensinoaprendizagem que contemplam os subPVEs desse PVE. Na literatura, o Conforto sonoro foi muito bem conceituado por autores, caracterizado pelos atributos e parâmetros que impactam no ensino-aprendizagem. O SubPVE 1.3.2 - Isolamento sonoro obteve a maior pontuação; a segunda melhor pontuação foi do SubPVE 1.3.5 - Duração da exposição, seguido do SubPVE 1.3.3 - Nível sonoro e do SubPVE 1.3.1, Tempo ótimo de reverberação. A avaliação mais baixa foi do SubPVE 1.3.4 - Frequência.

\subsubsection{Ergonomia - PVF 2}

O bloco a que se refere este PVF comporta três tipos de PVEs que são: Vibração, Antropometria e Infraestrutura. Foi o PVF que obteve uma melhor avaliação no que se refere aos PVFs (vide a pontuação ponderada demonstrada na Figura 52).

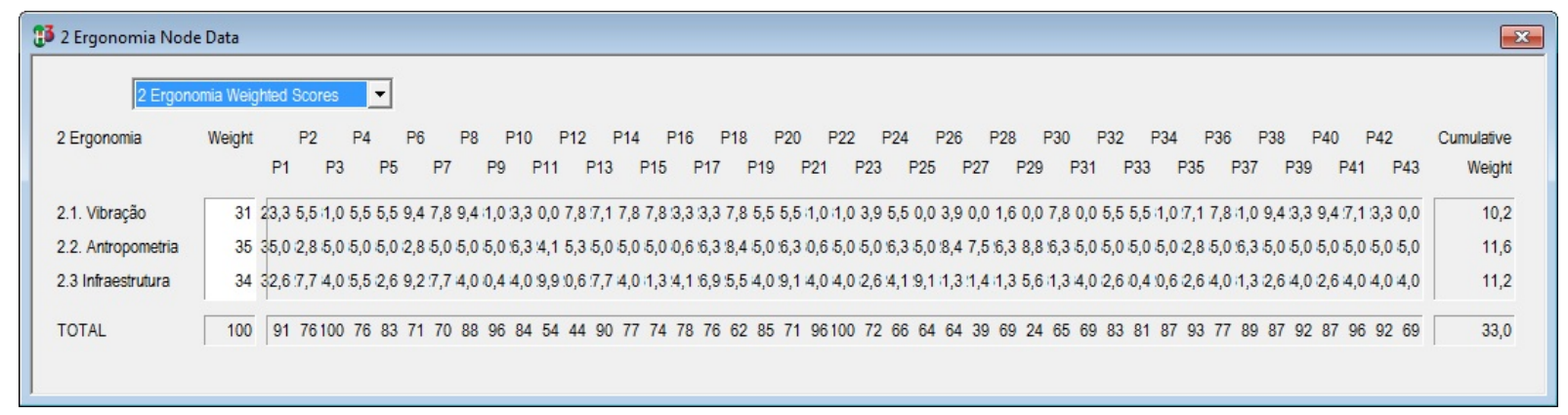

Figura 52 - Pontuações ponderadas dos professores da FAU/UnB no PVF 2

Fonte: Hiview3 (2016).

Na coluna da esquerda consta a nomenclatura dos Pontos de Vista Elementares (PVEs) com seus respectivos pesos, totalizando $100 \%$ no PVF 2 - Ergonomia. No centro da Figura, constam as pontuações dos professores do curso de Arquitetura da UnB, já tratadas pelo Hiview3, separadas por subcritério (SubPVE) e, na última linha, as pontuações totais atribuídas às respostas, nesse critério (PVF). Na coluna da direita, constam os pesos 
individualizados de cada subcritério no contexto do modelo de forma geral e a participação do critério no contexto global, 33\% (trinta e quatro por cento).

Considerando a pontuação dos 43 professores referente ao PVF 2, foram feitas as seguintes análises: dez professores pontuaram as avaliações acima de 90 (noventa), correspondendo a um percentual de 10\%; vinte e um professores pontuaram as avaliações entre 70 e 89, correspondendo a um percentual de $21 \%$; dez professores pontuaram as avaliações entre 40 e 69 , correspondendo a um percentual de $8 \%$; dois professores pontuaram as avaliações abaixo de 39, correspondendo a um percentual de $1 \%$.

No gráfico da Figura 53, explicita-se a contribuição de cada PVE do PVF 2, na composição da pontuação das avaliações dos professores da FAU/UnB.

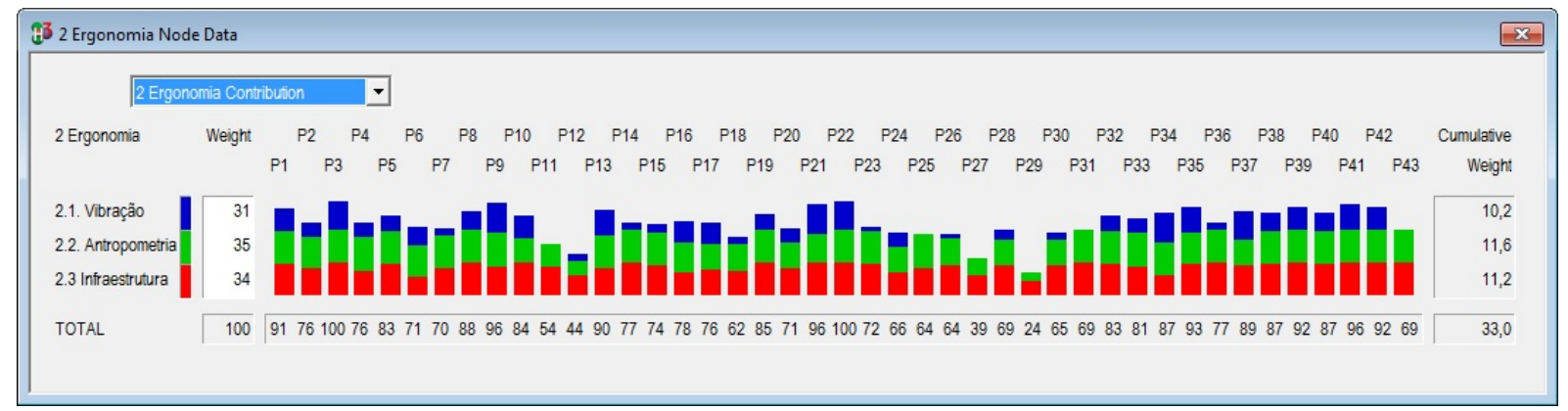

Figura 53 - Contribuição de cada PVE do PVF 2 na pontuação dos professores da $\mathrm{FAU} / \mathrm{UnB}$

Fonte: Hiview3 (2016).

O gráfico da Figura 53 mostra a participação dos PVEs da Ergonomia na composição da pontuação de cada avaliação dos professores, onde se verifica que o PVE 2.2 Antropometria apresenta uma maior pontuação, seguido do PVE 2.3 - Infraestrutura e do PVE 2.1 - Vibração.

O PVF 2 - Ergonomia apresentou uma avaliação média, alcançando a pontuação 76,90, referente à avaliação dos 43 professores, conforme demonstrado nas Figuras 52 e 53, constituindo-se a segunda melhor avaliação entre os PVFs em análise.

Fica caracterizada, a partir das pontuações dos 43 professores da FAU/UnB, a importância do PVF.2 - Ergonomia para os espaços arquitetônicos de ensino-aprendizagem. O PVE 2.3 - Infraestrutura obteve a maior pontuação, sendo a segunda melhor pontuação do PVEs 2.2 - Antropometria. O PVE 2.1 - Vibração obteve a pontuação mais baixa, pelo fato de que são poucas as disciplinas que são ministradas em espaços onde ocorrem vibrações. 


\section{- Vibração - PVE 2.1}

As estratégias utlizadas para expressar a vibração foram: i) frequência - expressa quantas vezes na unidade de tempo, o ciclo da vibração se produziu, ou seja é a quantidade de vezes em que um sinal se repete a cada segundo; ii) Intensidade - ampliação ou atenuação das vibrações. Na Figura 54 apresentam-se as pontuações ponderadas dos SubPVEs do PVE 2.1 - Vibração do PVF 2 Ergonomia, após o tratamento dado pelo Hiview3.

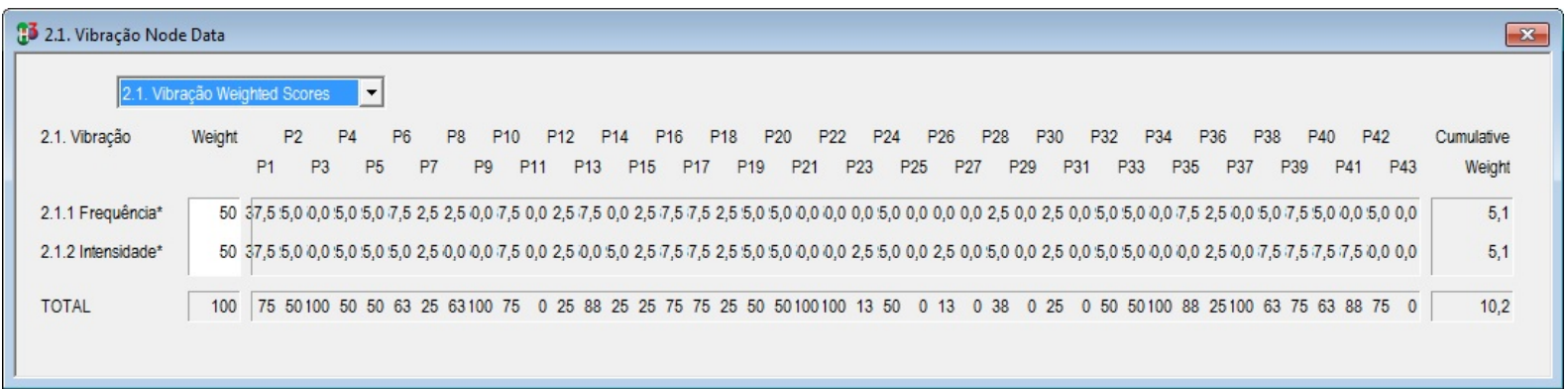

Figura 54 - Pontuações ponderadas dos professores da FAU/UnB no PVE 2.1

Fonte: Hiview3 (2016).

Considerando a pontuação dos 43 professores referente ao PVF 2, foram feitas as seguintes análises: seis professores pontuaram as avaliações acima de 90 (noventa), correspondendo a um percentual de $6 \%$; nove professores pontuaram as avaliações entre 70 e 89, correspondendo a um percentual de $9 \%$; doze professores pontuaram as avaliações entre 40 e 69, correspondendo a um percentual de $12 \%$; dezesseis professores pontuaram as avaliações abaixo de 39, correspondendo a um percentual de $16 \%$.

No gráfico da 55, explicita-se a contribuição de cada SubPVE do PVE 2.1, na composição da pontuação das avaliações dos professores da FAU/UnB.

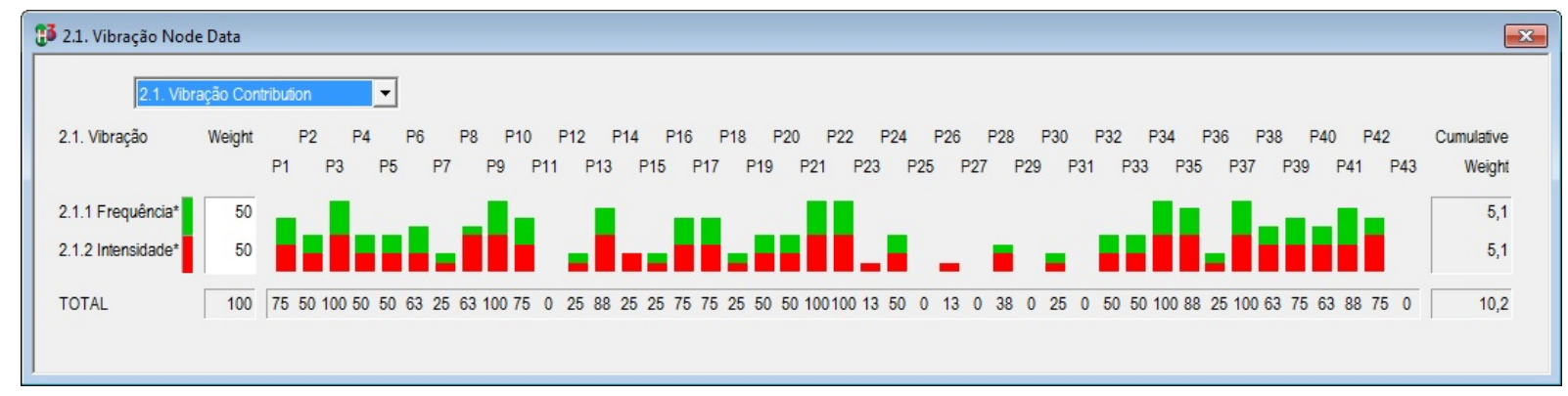

Figura 55 - Contribuição de cada SubPVE do PVE 2.1 na pontuação dos professores da $\mathrm{FAU} / \mathrm{UnB}$

Fonte: Hiview3 (2016).

O gráfico da Figura 55 mostra a participação dos SubPVEs da Vibração na composição da pontuação de cada avaliação dos professores, onde se verifica que os 
SubPVEs 2.1.1 - Frequência e 2.1.2 - Intensidade apresentam a mesma pontuação.

O PVE 2.1 - Vibração apresentou uma avaliação média, alcançando a pontuação 51,28, referente à avaliação dos 43 professores, conforme demonstrado nas Figuras 54 e 55, constituindo-se a terceira melhor avaliação entre os PVEs em análise do PVF 2.

Analisando as pontuações dos professores nota-se que: o SubPVEs 2.1.2 - Frequência obteve a maior pontuação, seguido do SubPVE 2.1.2 - Intensidade. No universo dos 43 professores do curso de Arquitetura da FAU/UnB, receberam as menores pontuações, pois são poucos os espaços onde ocorrem as vibrações nas atividades da FAU/UnB.

\section{- Antropometria - PVE 2.2}

As estratégias utilizadas para expressar a Antroprometria foram : i) Arranjo físico - o layout de um espaço de trabalho consiste na proposta de distribuição espacial de um conjunto de trabalhadores, equipamentos, infraestrutura e materiais; ii) mobiliário - é notadamente um elemento da sala de aula que influi circunstancialmente no desempenho, segurança, conforto e em diversos comportamentos dos alunos. Na Figura 56, apresentam-se as pontuações ponderadas dos dois SubPVEs do PVE 2.2 - Antropometria do PVF 2 Ergonomia, após o tratamento dado pelo Hiview3.

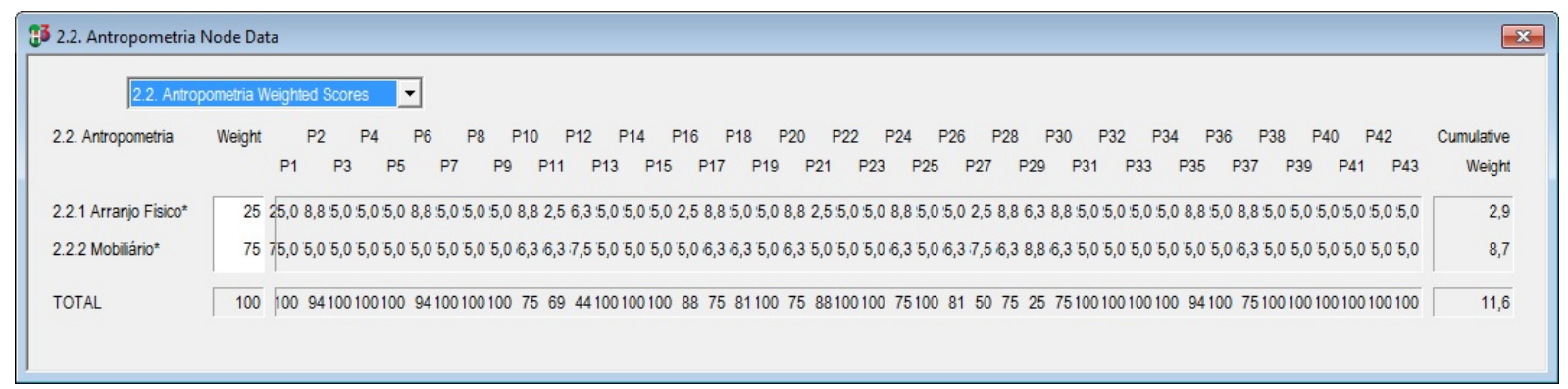

Figura 56 - Pontuações ponderadas dos professores da FAU/UnB no PVE 2.2

Fonte: Hiview 3 (2016).

Considerando a pontuação dos 43 professores referente ao PVE 2, foram feitas as seguintes análises: vinte e oito professores pontuaram as avaliações acima de 90 (noventa), correspondendo a um percentual de $28 \%$; onze professores pontuaram as avaliações entre 70 e 89, correspondendo a um percentual de 11\%; três professores pontuaram as avaliações entre 40 e 69, correspondendo a um percentual de $8 \%$; um professor pontuou a avaliação abaixo de 39 , correspondendo a um percentual de $1 \%$.

No gráfico da Figura 57, explicita-se a contribuição de cada SubPVE do PVE 2.2, na composição da pontuação das avaliações dos professores da FAU/UnB. 


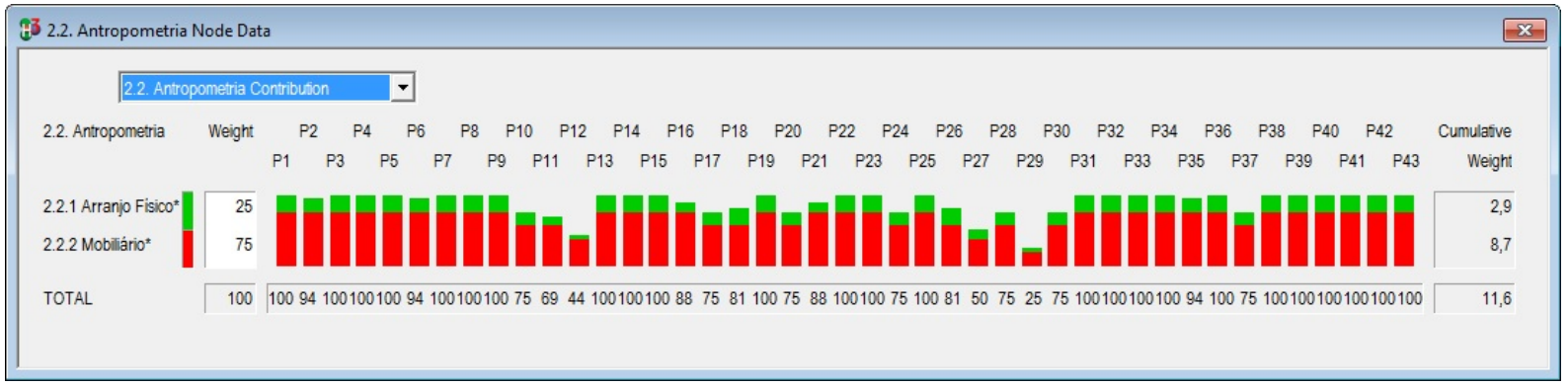

Figura 57 - Contribuição de cada SubPVE do PVE 2.2 na pontuação dos professores da $\mathrm{FAU} / \mathrm{UnB}$

Fonte: Hiview 3 (2016).

O gráfico da Figura 57 mostra a participação dos SubPVEs da Antropometria na composição da pontuação de cada avaliação dos professores, onde se verifica que o SubPVE 2.2.2 - Mobiliário apresenta uma maior pontuação, seguido do SubPVE 2.2.1 - Arranjo físico.

O PVE 2.2 - Antropometria apresentou uma avaliação média, alcançando a pontuação 89,13, referente à avaliação dos 43 professores, conforme demonstrado nas Figuras 56 e 57, constituindo-se a primeira melhor avaliação entre os PVEs em análise do PVF 2.

Na literatura, os autores expuseram a importância da Antropometria, caracterizada pelos SubPVEs que impactam no ensino-aprendizagem. Analisando as pontuações dos professores, nota-se que: o SubPVE que obteve a maior pontuação foi o SubPVE 2.2.2 Mobiliário; a segunda melhor pontuação foi do SubPVE 2.2.1 - Arranjo físico, com uma pequena diferença. Isso mostra a importância do PVE 2.2 no que se refere aos espaços arquitetônicos facilitadores do ensino-aprendizagem, mais especificamente na Ergonomia.

\section{- Infraestrutra - PVE 2.3}

As estratégias utilizadas para expressar a infraestrutura foram: i) SubPVE 2.3.1 - Revestimento - podem-se adotar posturas distintas, em função do uso do ambiente e da atividade desenvolvida. Alguns setores produtivos apresentam normatizações quanto ao emprego dos materiais; ii) SubPVE 2.3.2 - Equipamento - diversas tecnologias novas têm sido introduzidas na educação, como uso de materiais audiovisuais, vídeos, máquinas de ensinar e aparelhos de autoinstrução; iii) SubPVE 2.3.3 - Ambiente físico - o projeto adequado dos mobiliários, salas de aula, bibliotecas, laboratórios e outros meios de apoio didático pode influir no desempenho dos professores e alunos. Na Figura 58, apresentam-se as pontuações ponderadas dos três SubPVEs do PVE 2.3 - Infraestrutura do PVF 2 Ergonomia, após o tratamento dado pelo Hiviews. 


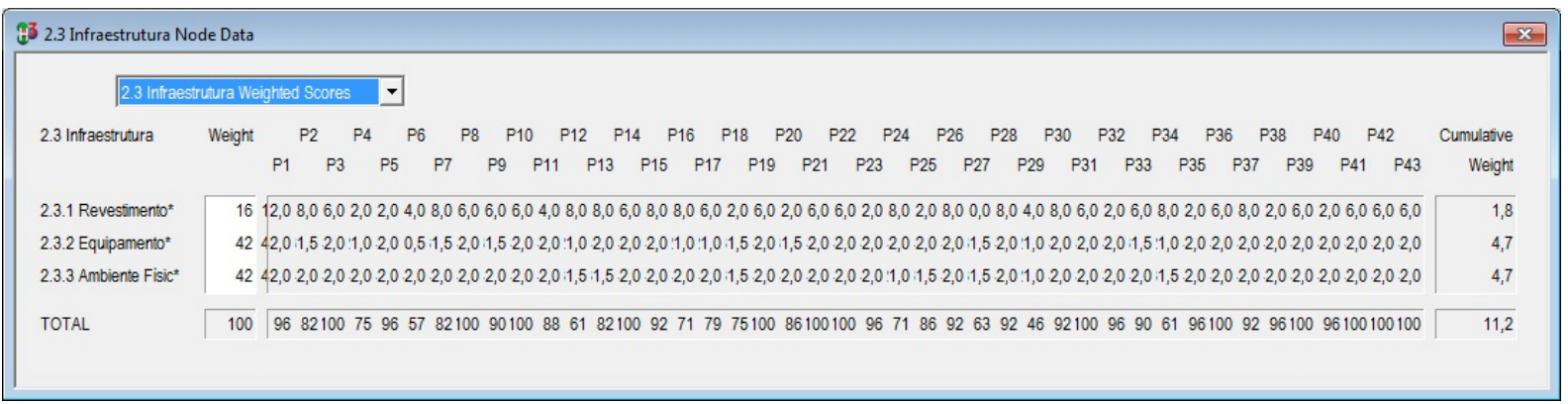

Figura 58 - Pontuações ponderadas dos professores da FAU/UnB no PVE 2.3

Fonte: Hiview 3 (2016).

Considerando a pontuação dos 43 professores referente ao PVE 2.3, foram feitas as seguintes análises: vinte e sete professores pontuaram as avaliações acima de 90 (noventa), correspondendo a um percentual de $27 \%$; onze professores pontuaram as avaliações entre 70 e 89, correspondendo a um percentual de 29\%; cinco professores pontuaram as avaliações entre 40 e 69, correspondendo a um percentual de 5\%; nenhum professor pontuou as avaliações abaixo de 39 .

No gráfico da Figura 59, explicita-se a contribuição de cada SubPVE do PVE 2.3 Infraestrutura, na composição da pontuação das avaliações dos professores da FAU/UnB.

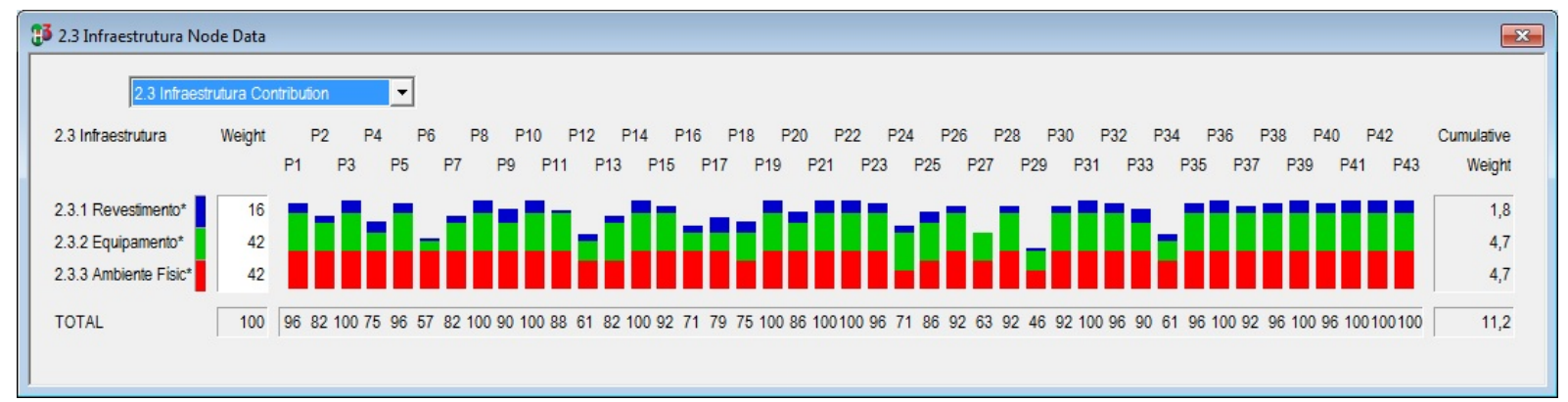

Figura 59 - Contribuição de cada SubPVE do PVE 2.3 na pontuação dos professores da $\mathrm{FAU} / \mathrm{UnB}$

Fonte: Hiview 3 (2016).

O gráfico da Figura 59 mostra a participação dos SubPVEs da Infraestrutura na composição da pontuação de cada avaliação dos professores, onde se verifica que o SubPVE 2.3.2 - Equipamento e o SubPVE 2.3.3 - Ambiente físico apresentam a mesma pontuação.

O PVE 2.3 - Infraestrutura apresentou uma avaliação média, alcançando a pontuação 87,84, referente à avaliação dos 43 professores, conforme demonstrado nas Figuras 58 e 59, constituindo-se a segunda melhor avaliação entre os PVEs em análise do PVF 2.

Na literatura, os autores expuseram a importância do PVE 2.3 - Infraestrutura, caracterizado pelos SubPVEs que impactam no ensino-aprendizagem. Analisando as 
pontuações dos professores nota-se que: o SubPVE que obteve a maior pontuação foi o SubPVE 2.3.3 - Ambiente físico, ficando com a segunda melhor pontuação o SubPVE 2.3.2 - Equipamento. A terceira pontuação foi do SubPVE 2.3.1 - Revestimento.

\subsubsection{Psicologia Ambiental - PVF 3}

O bloco a que se refere esse PVF 3 comporta três tipos de PVEs que são: PVE 3.1 - Espaço pessoal, PVE 3.2 - Territorialidade e PVE 3.3 - Privacidade.

Na Figura 60, apresenta-se a síntese das pontuações ponderadas atribuídas pelo Hiview3 a cada uma das respostas dos professores da FAU/UnB para os três PVEs desse ponto de vista fundamental, após o devido tratamento dos dados levantados na pesquisa.

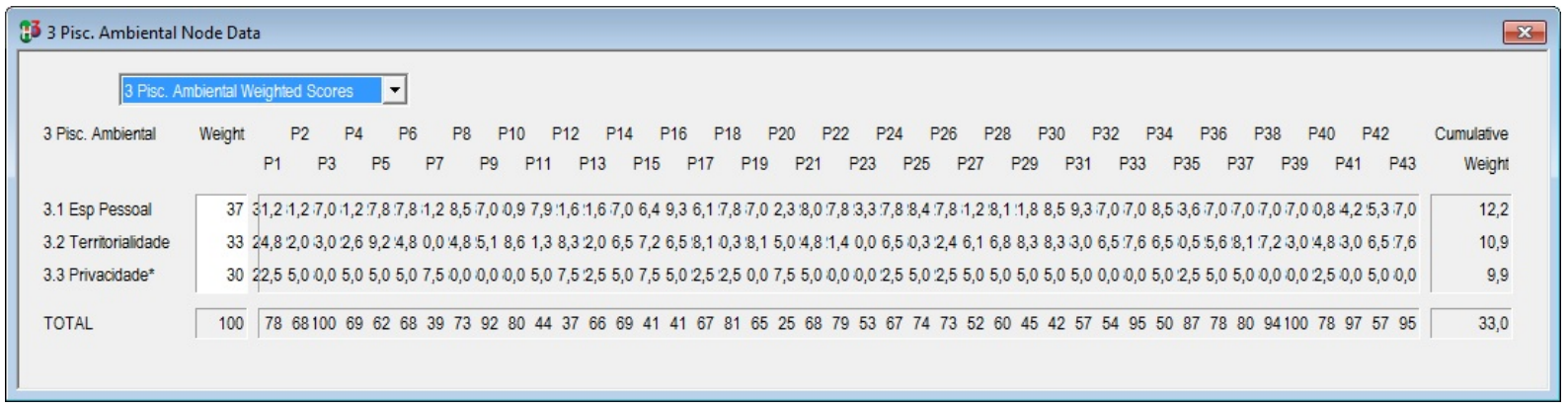

Figura 60 - Pontuações ponderadas dos professores da FAU/UnB no PVF 3

Fonte: Hiview3 (2016).

Na coluna da esquerda consta a nomenclatura dos Pontos de Vista Elementares (PVEs) com seus respectivos pesos, totalizando 100\% no PVF 3, Psicologia Ambiental. No centro da figura, constam as pontuações dos professores do curso de Arquitetura da UnB, já tratadas pelo Hiview3, separadas por Subcritérios (SubPVEs) e, na última linha, as pontuações totais atribuídas às respostas, nesse critério (PVF). Na coluna da direita, constam os pesos individualizados de cada subcritério no contexto do modelo de forma geral e a participação do critério no contexto global, $33 \%$ (trinta e quatro por cento).

Considerando a pontuação dos 43 professores referente ao PVFs 3, foram feitas as seguintes análises: sete professores pontuaram as avaliações acima de 90 (noventa), correspondendo a um percentual de 7\%; onze professores pontuaram as avaliações entre 70 e 89, correspondendo a um percentual de $11 \%$; vinte e dois professores pontuaram as avaliações entre 40 e 69 , correspondendo a um percentual de $22 \%$; três professores pontuaram as avaliações abaixo de 39 , correspondendo a um percentual de $3 \%$.

No gráfico da 61, explicita-se a contribuição de cada PVE do PVF 3, na composição da pontuação das avaliações dos professores da FAU/UnB. 


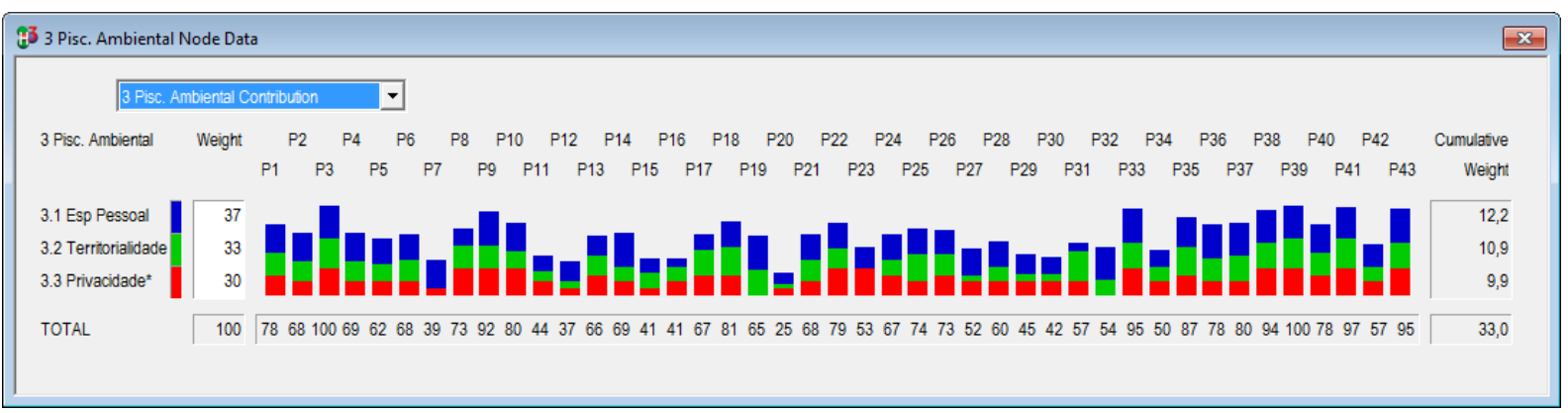

Figura 61 - Contribuição de cada PVE do PVF 3 na pontuação dos professores da FAU/UnB

Fonte: Hiview3 (2016).

O gráfico da Figura 61 mostra a participação dos PVEs da Psicologia Ambiental na composição da pontuação de cada avaliação dos professores, onde se verifica que o PVE 3.1 - Espaço pessoal apresenta uma maior pontuação, seguido do PVE 3.2 - Territorialidade e do PVE 3.3 - Privacidade.

O PVF 3 - Psicologia Ambiental apresentou uma avaliação média/alta, alcançando a pontuação 67,44, referente à avaliação dos 43 professores, conforme demonstrado nas Figuras 60 e 61, constituindo-se a terceira melhor avaliação entre os PVFs em análise do PVF 3.

Na literatura, os autores expuseram a importância da Psicologia Ambiental, caracterizada pelos PVEs que impactam no ensino-aprendizagem. Analisando as pontuações dos professores, nota-se que: o PVE 3.1 - Espaço pessoal obteve a maior pontuação, seguido do PVE 3.2 - Territorialidade. O PVE 3.3 - Privacidade ficou com a terceira pontuação.

\section{- Espaço pessoal - PVE 3.1}

As estratégias utilizadas para expressar espaço pessoal foram: i) SubPVE 3.1.1 Distância interpessoal - refere-se às distâncias adequadas para contato ou não contato podendo gerar reações comportamentais positivas ou negativas; ii) SubPVE 3.1.2 - Relação interpessoal - relação entre duas ou mais pessoas. Esse tipo de relacionamento é marcado pelo contexto onde ele está inserido, podendo ser um contexto familiar, escolar, de trabalho ou de comunidade; iii) SubPVE 3.1.3 - Configuração ambiental (design) - as configurações de arranjo físico sociopetal (o que possibilita o contato social) e sociofugal (o que não propicia o contato social) influenciam o espaço pessoal, e sua qualificação depende da cultura dos usuários e da situação ou função a que se destina o ambiente. Na Figura 62, apresenta-se a síntese das pontuações ponderadas atribuídas pelo Hiview3 a cada avaliação dos professores para os cinco SubPVEs do PVE - Espaço pessoal, após o devido tratamento dos dados levantados na pesquisa. 


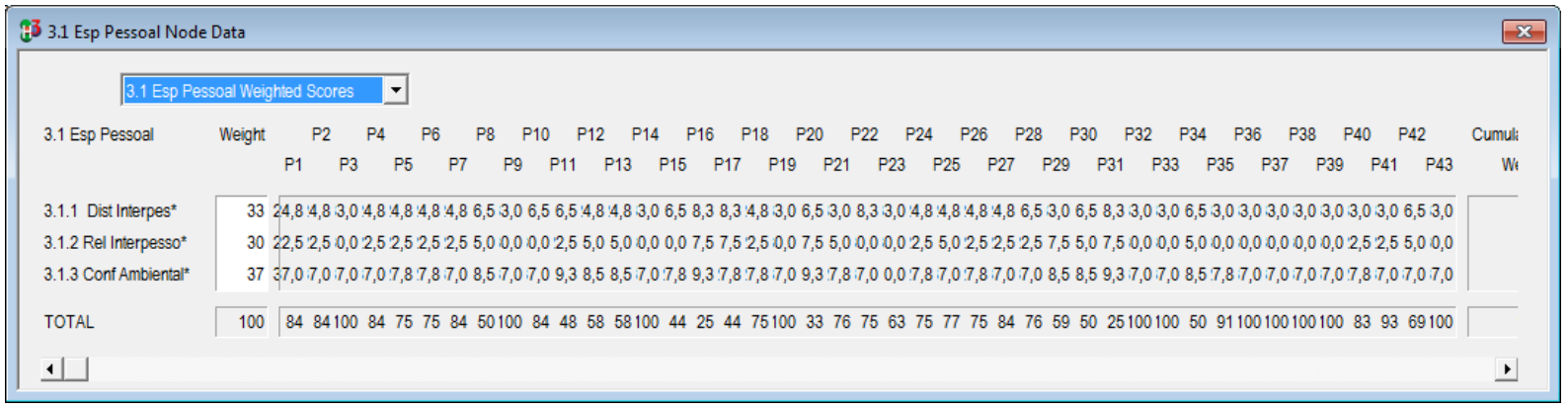

Figura 62 - Pontuações ponderadas dos professores da FAU/UnB no PVE 3.1

Fonte: Hiview3 (2016).

Considerando a pontuação dos 43 professores referente ao PVF 3, foram feitas as seguintes análises: treze professores pontuaram as avaliações acima de 90 (noventa), correspondendo a um percentual de 13\%; dezesseis professores pontuaram as avaliações entre 70 e 89, correspondendo a um percentual de 16\%; onze professores pontuaram as avaliações entre 40 e 69, correspondendo a um percentual de 11\%; três professores pontuaram as avaliações abaixo de 39, correspondendo a um percentual de $3 \%$.

No gráfico da Figura 63, explicita-se a contribuição de cada SubPVE do PVE 3.1, na composição da pontuação das avaliações dos professores da FAU/UnB.

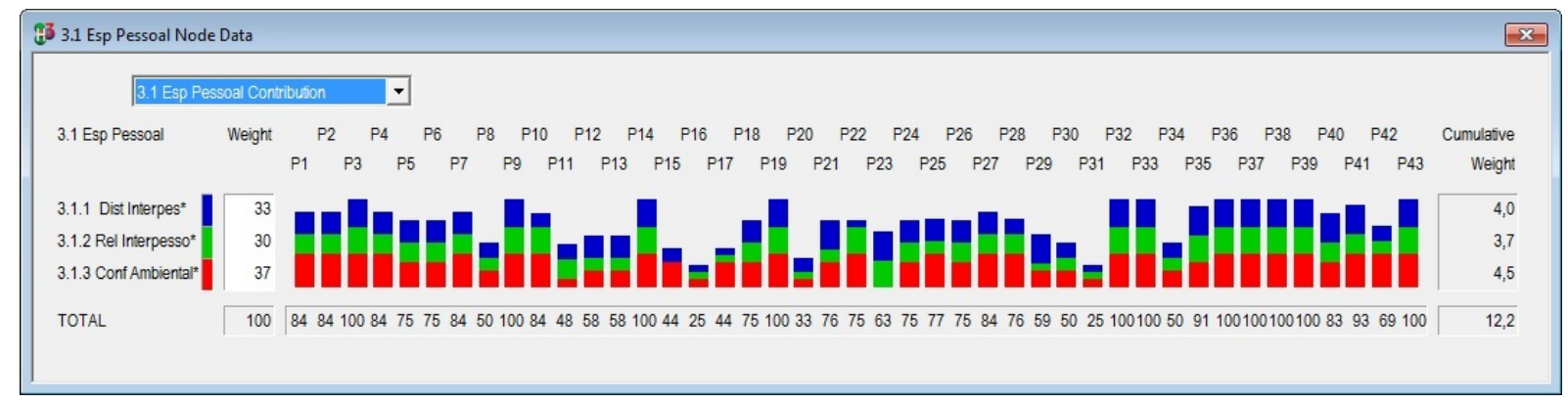

Figura 63 - Contribuição de cada SubPVE do PVE 3.1 na pontuação dos professores da $\mathrm{FAU} / \mathrm{UnB}$

Fonte: Hiview3 (2016).

O gráfico da Figura 63 mostra a participação dos SubPVEs do Espaço pessoal na composição da pontuação de cada avaliação dos professores, onde se verifica que o SubPVE 3.1.3 - Configuração ambiental apresenta uma maior pontuação, seguido do SubPVE 3.1.1 - Distância interpessoal e do SubPVE 3.1.2 - Relação interpessoal.

O PVE 3.1 - Espaço pessoal apresentou uma avaliação média, alcançando a pontuação 75,02, referente à avaliação dos 43 professores, conforme demonstrado nas Figuras 62 e 63, constituindo-se a primeira melhor avaliação entre os PVEs em análise do PVF 3. 
Na literatura, os autores expuseram a importância do PVE 3.1 - Espaço pessoal, caracterizado pelos SubPVEs que impactam no ensino-aprendizagem. Analisando as pontuações dos professores nota-se que: o SubPVE 3.1.3 - Configuração ambiental obteve a maior pontuação, seguido do SubPVE 3.1.1 - Distância interpessoal. O SubPVE 3.1.2 - Relação interpessoal ficou com a terceira pontuação. A avaliação dos professores foi satisfatória para esse PVE, indicando que os SubPVEs são importantes para os espaços arquitetônicos como facilitadores do ensino-aprendizagem.

\section{- Territorialidade - PVE 3.2}

As estratégias utilizadas para expressar territorialidade foram : i) SubPVE 3.2.1 - Ocupação - controle efetivo de um espaço ou de alguma coisa; ii) SubPVE 3.2.2 Defesa - o espaço defesível argumenta que os arranjos físicos aumentam sentimentos de territorialidade e comportamentos, e que esse aumento conduz a um declínio nas invasões do território; iii) SubPVE 3.2.3 Personalização - marcação de uma maneira que indica uma identidade. Na Figura 64, apresenta-se a síntese das pontuações ponderadas atribuídas pelo Hiview3 a cada avaliação dos professores para os três Sub PVEs do PVE 3.2 Territorialidade, após o devido tratamento dos dados levantados na pesquisa.

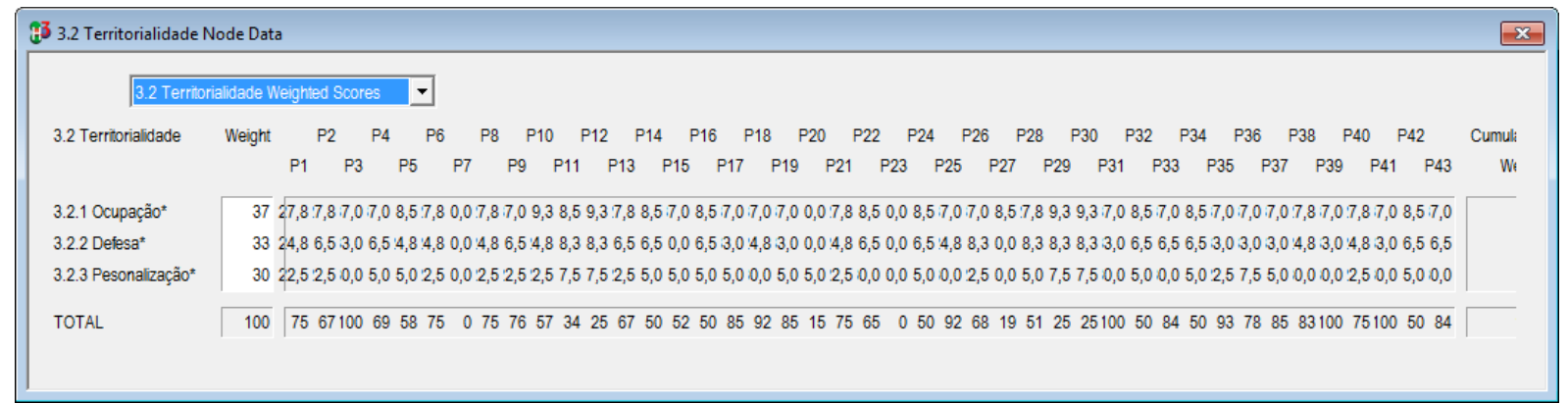

Figura 64 - Pontuações ponderadas dos professores da FAU/UnB no PVE 3.2 Fonte: Hiview3 (2016).

Considerando a pontuação dos 43 professores referente ao PVF 3, foram feitas as seguintes análises: sete professores pontuaram as avaliações acima de 90 (noventa), correspondendo a um percentual de 7\%; treze professores pontuaram as avaliações entre 70 e 89, correspondendo a um percentual de 13\%; quinze professores pontuaram as avaliações entre 40 e 69, correspondendo a um percentual de 15\%; oito professores pontuaram as avaliações abaixo de 39, correspondendo a um percentual de $8 \%$.

No gráfico da Figura 65, explicita-se a contribuição de cada SubPVE do PVE 3.2, na composição da pontuação das avaliações dos professores da FAU/UnB. 


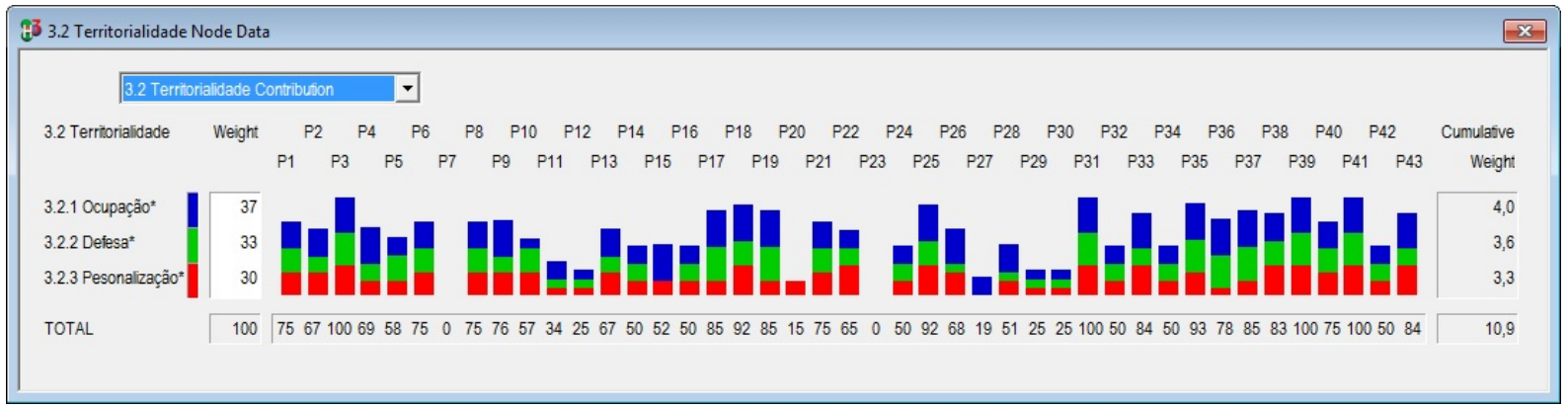

Figura 65 - Contribuição de cada SubPVE do PVE 3.2 na pontuação dos professores da $\mathrm{FAU} / \mathrm{UnB}$

Fonte: Hiview3 (2016).

O gráfico da Figura 65 mostra a participação dos SubPVEs da Territorialidade na composição da pontuação de cada avaliação dos professores, onde se verifica que o SubPVE 3.2.1 - Ocupação apresenta uma maior pontuação, seguido do SubPVE 3.2.2 Defesa e do SubPVE 3.2.3 - Personalização.

O PVE 3.2 - Territorialidade apresentou uma avaliação média, alcançando a pontuação 63,00, referente à avaliação dos 43 professores, conforme demonstrado nas Figuras 64 e 65, constituindo-se a segunda melhor avaliação entre os PVEs em análise do PVF 3.

Na literatura, os autores expuseram a importância do PVE 3.2 - Territorialidade, caracterizado pelos subPVEs que impactam no ensino-aprendizagem. Analisando as pontuações dos professores nota-se que: o SubPVE 3.2.1 - Ocupação obteve a maior pontuação, seguido da segunda pontuação o SubPVE 3.2.2 - Defesa, seguido do SubPVE 3.2.3 Personalização.

\section{- Privacidade - PVE 3.3}

As estratégias utilizadas para expressar privacidade foram: i) PVE 3.3 - Privacidade - é a gestão do indivíduo sobre as informações de si mesmo e sobre a sua interação com as outras pessoas. É um controle seletivo de acesso a si próprio ou ao seu grupo. No gráfico da Figura 61, explicita-se a contribuição do PVE 3.3, na composição da pontuação das avaliações dos professores da FAU/UnB.

Na Figura 60, apresenta-se a síntese das pontuações ponderadas atribuídas pelo Hiview3 a cada avaliação dos professores para o PVE 3.3 - Privacidade que se encontra com os demais PVEs do PVF 3 - Psicologia Ambiental, após o devido tratamento dos dados levantados na pesquisa.

Considerando a pontuação dos 43 professores referente ao PVFs 3, foram feitas as seguintes análises: onze professores pontuaram as avaliações acima de 90 (noventa), 
correspondendo a um percentual de $11 \%$; oito professores pontuaram as avaliações entre 70 e 89, correspondendo a um percentual de 8\%; dezoito professores pontuaram as avaliações entre 40 e 69, correspondendo a um percentual de 18\%; seis professores pontuaram as avaliações abaixo de 39, correspondendo a um percentual de $6 \%$.

O PVE 3.3 - Privacidade apresentou uma avaliação média, alcançando a pontuação 67,44, referente à avaliação dos 43 professores, conforme demonstrado nas Figuras 60 e 61, constituindo-se a terceira melhor avaliação entre os PVEs em análise do PVF 3.

\subsection{Avaliação Global}

As respostas dos professores relativas aos diversos quesitos de avaliação, constantes do questionário que foi aplicado por ocasião da pesquisa de campo, depois de tabulados e tratados pelo software Hiview3, constituíram-se insumos para o cálculo das avaliações quantitativas de cada PVF e, a partir das notas atribuídas, calculou-se a nota relativa à avaliação global.

A avaliação global dos parâmetros facilitadores do ensino-aprendizagem que contribuem para o programa de necessidades para fins de elaboração de projeto de arquitetura definidos na presente pesquisa atingiu 73,16 pontos, numa escala de 0 a 100 . Na Figura 66, as pontuações gerais das diversas avaliações realizadas pelos professores do curso de Arquitetura e urbanismo da FAU/UnB e a avaliação global.

A seguir apresenta-se na Figura 66 a avaliação global de cada professor referentes aos PVFs 1,2 e 3.

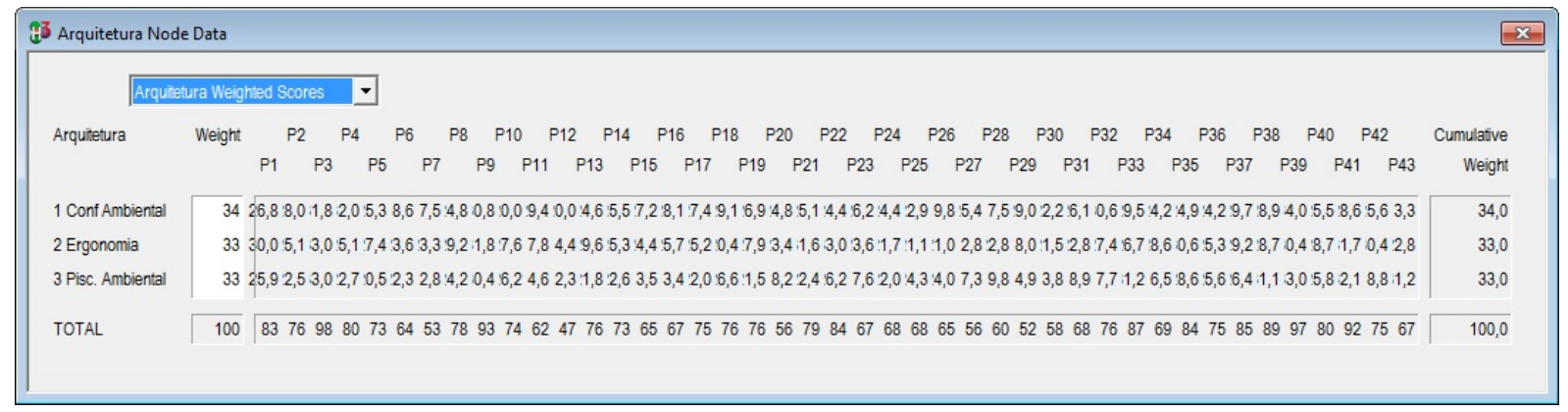

Figura 66 - Pontuação global dos professores da FAU/UnB

Fonte: Hiview3 (2016).

Considerando a pontuação dos 43 professores referente aos PVFs 1, 2 e 3, foram feitas as seguintes análises: quatro professores pontuaram as avaliações acima de noventa, correspondendo a um percentual de 4\%; vinte e um professores pontuaram as avaliações entre 70 e 89 , correspondendo a um percentual de $21 \%$; dezoito professores pontuaram as 
avaliações entre 40 e 69, correspondendo a um percentual de $18 \%$; não foram avaliadas pontuações abaixo de 47.

No gráfico constante da Figura 67, apresenta-se a contribuição de cada PVF na composição da pontuação das respostas dos professores da FAU/UnB e que foram objeto da pesquisa de que trata o presente estudo.

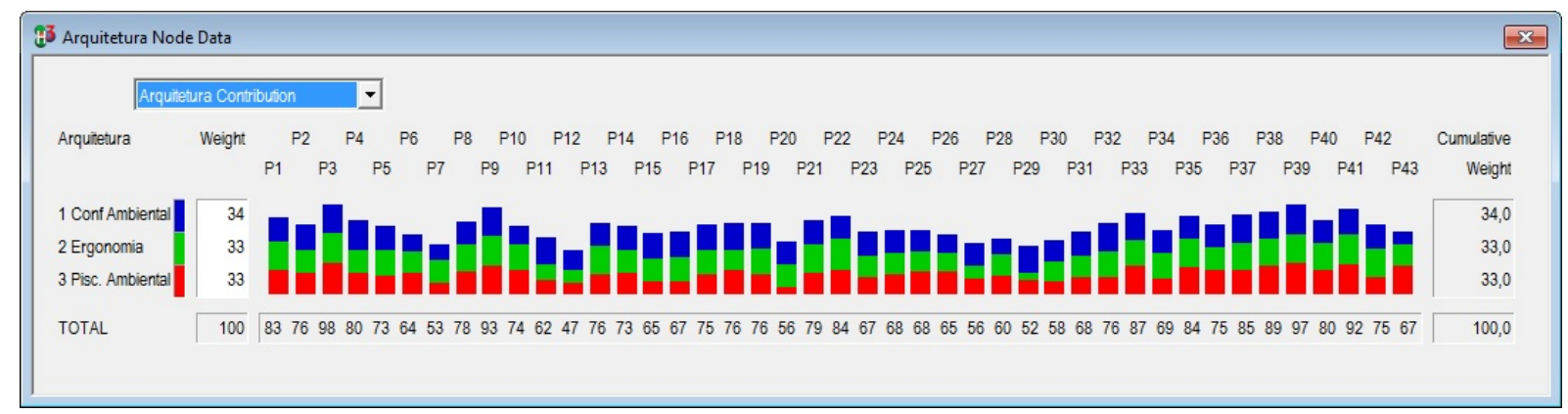

Figura 67 - Contribuição de cada PVF na pontuação dos professores da FAU/UnB

Fonte: Hiview3 (2016).

O gráfico da Figura 67 mostra a participação dos PVFs da pesquisa na composição da pontuação de cada avaliação dos professores, onde se verifica que o PVF 1 - Conforto Ambiental e o PVF 2 - Ergonomia apresentam uma pontuação praticamente igual (empate técnico), ficando o PVF 3 - Psicologia Ambiental na terceira classificação.

A avaliação global dos PVF 1, PVF 2 e PVF 3 foi bastante satisfatória, alcançando a pontuação 73,16, referente à avaliação dos 43 professores, conforme demonstrado nas Figuras 66 e 67, constituindo-se uma boa/ótima avaliação dos PVFs em análise, caracterizando a importância dos critérios para a elaboração de programa de necessidades para projetos arquitetônicos.

A seguir, apresenta-se a Tabela 54 com a avaliação global dos critérios e as avaliações parciais dos subcritérios (PVE e SubPVE). 
Capítulo 5. Caracterização do Universo de Estudo, Desenvolvimento da Pesquisa de Campo e Análise

Tabela 54 - Pontuação global das avaliações dos critérios e subcritérios

\begin{tabular}{|c|c|c|c|c|c|}
\hline \multicolumn{2}{|c|}{ Critério } & \multicolumn{2}{|c|}{ Subcritério } & \multicolumn{2}{|c|}{ Subcritério } \\
\hline PVF & $\begin{array}{l}\text { Pontuação } \\
\text { Global }\end{array}$ & PVE & $\begin{array}{l}\text { Pontuação } \\
\text { Global }\end{array}$ & SubPVE & $\begin{array}{l}\text { Ordem de } \\
\text { pontuação }\end{array}$ \\
\hline \multirow{16}{*}{ 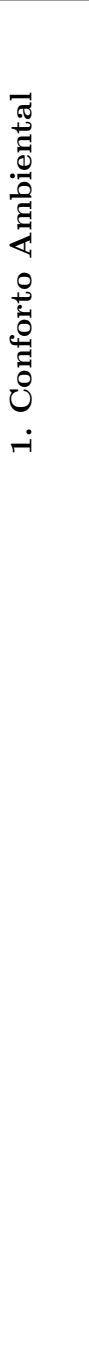 } & \multirow{16}{*}{75,25} & $\begin{array}{l}1.1 \text { Conforto } \\
\text { térmico }\end{array}$ & \multirow{5}{*}{63,74} & 1.1.1Ventilação & $1^{\circ}$ \\
\hline & & & & $\begin{array}{l}\text { 1.1.2 Resfriamento } \\
\text { evaporativo }\end{array}$ & $4^{\mathrm{o}}$ \\
\hline & & & & $\begin{array}{l}\text { 1.1.3 Massa térmica } \\
\text { para aquecimento }\end{array}$ & $5^{\mathrm{o}}$ \\
\hline & & & & 1.1.4 Umidificação & $2^{\circ}$ \\
\hline & & & & $\begin{array}{l}1.1 .5 \quad \text { Ar- } \\
\text { condicionado }\end{array}$ & $3^{\circ}$ \\
\hline & & \multirow{6}{*}{$\begin{array}{l}1.2 \text { Conforto } \\
\text { lumínico }\end{array}$} & \multirow{6}{*}{82,48} & $\begin{array}{l}\text { 1.2.1 Mecanismos de } \\
\text { controle }\end{array}$ & $2^{\circ}$ \\
\hline & & & & $\begin{array}{l}\text { 1.2.2 Reforço de ilu- } \\
\text { minamento }\end{array}$ & $4^{\mathrm{o}}$ \\
\hline & & & & 1.2.3 Uso de cores & $6^{\circ}$ \\
\hline & & & & 1.2.4 Iluminação & $1^{\mathrm{o}}$ \\
\hline & & & & 1.2.5 Luminância & $3^{\circ}$ \\
\hline & & & & 1.2.6 Contraste & $5^{\mathrm{o}}$ \\
\hline & & \multirow{5}{*}{$\begin{array}{l}\text { 1.3 Conforto } \\
\text { sonoro }\end{array}$} & \multirow{5}{*}{80,39} & $\begin{array}{l}\text { 1.3.1 Tempo ótimo de } \\
\text { reverberação }\end{array}$ & $4^{\mathrm{o}}$ \\
\hline & & & & $\begin{array}{l}\text { 1.3.2 Isolamento so- } \\
\text { noro }\end{array}$ & $1^{\mathrm{o}}$ \\
\hline & & & & 1.3.3 Nível sonoro & $3^{\circ}$ \\
\hline & & & & 1.3.4 Frequência & $5^{\circ}$ \\
\hline & & & & $\begin{array}{l}\text { 1.3.5 Duração da ex- } \\
\text { posição }\end{array}$ & $2^{\circ}$ \\
\hline \multirow{7}{*}{ 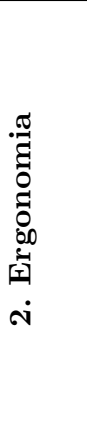 } & \multirow{7}{*}{76,9} & \multirow{2}{*}{2.1 Vibração } & \multirow{2}{*}{51,28} & 2.1.1 Frequência & $2^{\circ}$ \\
\hline & & & & 2.1.2 Intensidade & $1^{\mathrm{o}}$ \\
\hline & & \multirow{2}{*}{$\begin{array}{l}2.2 \\
\text { Antropometria }\end{array}$} & \multirow{2}{*}{89,13} & 2.2.1 Arranjo Físico & $2^{\circ}$ \\
\hline & & & & 2.2.2 Mobiliário & $1^{\mathrm{o}}$ \\
\hline & & \multirow{3}{*}{$\begin{array}{l}2.3 \\
\text { Infraestrutura }\end{array}$} & \multirow{3}{*}{87,84} & 2.3.1 Revestimento & $3^{\circ}$ \\
\hline & & & & 2.3.2 Equipamento & $2^{\circ}$ \\
\hline & & & & 2.3.3 Ambiente físico & $1^{\circ}$ \\
\hline \multirow{5}{*}{ 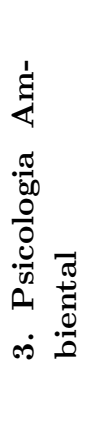 } & \multirow{5}{*}{67,44} & \multirow{3}{*}{$\begin{array}{l}3.1 \text { Espaço } \\
\text { pessoal }\end{array}$} & \multirow{3}{*}{75,02} & $\begin{array}{l}\text { 3.1.1 Distância inter- } \\
\text { pessoal }\end{array}$ & $2^{\circ}$ \\
\hline & & & & $\begin{array}{l}3.1 .2 \text { Relação inter- } \\
\text { pessoal }\end{array}$ & $3^{\circ}$ \\
\hline & & & & $\begin{array}{l}\text { 3.1.3 Configuração } \\
\text { ambiental (design) }\end{array}$ & $1^{\circ}$ \\
\hline & & & & 3.2.1 Ocupação & $1^{\circ}$ \\
\hline & & $\begin{array}{l}3.2 \\
\text { Territorialidade }\end{array}$ & 63,00 & & \\
\hline
\end{tabular}




\begin{tabular}{llllcc}
\hline \multicolumn{2}{c}{ Critério } & \multicolumn{2}{c}{ Subcritério } & \multicolumn{2}{c}{ Subcritério } \\
\hline PVF & $\begin{array}{l}\text { Pontuação } \\
\text { Global }\end{array}$ & PVE & $\begin{array}{l}\text { Pontuação } \\
\text { Global }\end{array}$ & SubPVE & $\begin{array}{l}\text { Ordem de } \\
\text { pontuação }\end{array}$ \\
\hline & & & 3.2 .2 Defesa & $3^{\circ}$ \\
\cline { 3 - 6 } & & & 3.2 .3 Personalização & $2^{\circ}$ \\
\cline { 3 - 6 } & 3.3 Privacidade & 67,44 & & $1^{\circ}$ \\
\hline
\end{tabular}

Fonte: Elaboração própria (2016).

\subsection{Aplicação da Análise de Sensibilidade}

Após o tratamento dos dados da pesquisa de campo e de terem sido computadas as avaliações dos critérios e a avaliação global, procedeu-se a uma análise de sensibilidade do modelo multicritério de avaliação. Os resultados são apresentados a seguir.

Conforme a equação matemática que calcula as novas taxas de substituição do modelo, (Tabela 48 do capítulo 4), apresentam-se na Tabela 55 as taxas de substituição dos critérios PVF 1, PVF 2 e PVF 3 com um aumento do peso em 10\% e também uma diminuição do peso em $10 \%$.

Tabela 55 - Taxas de substituição para análise de sensibilidade

\begin{tabular}{cccc}
\hline Avaliação & PVF 1 & PVF 2 & PVF 3 \\
\hline Avaliação original & $\mathrm{Wi}=34 \%$ & $\mathrm{Wi}=33 \%$ & $\mathrm{Wi}=33 \%$ \\
\hline Avaliação original $+10 \%$ & $\mathrm{Wi}=37,4 \%$ & $\mathrm{Wi}=34,7 \%$ & $\mathrm{Wi}=34,7 \%$ \\
\hline Avaliação original - 10\% & $\mathrm{Wi}=30,6 \%$ & $\mathrm{Wi}=31,3 \%$ & $\mathrm{Wi}=31,3 \%$ \\
\hline
\end{tabular}

Fonte: Elaboração própria (2016).

Segundo Quirino (2002), as retas traçadas na parte superior do gráfico representam a variação da atratividade global (desempenho) das ações potenciais (avaliação dos professores), devido a alterações da taxa de substituição de um critério analisado. Para o autor, é destacada uma reta mais grossa que representa a ação potencial (avaliação do professor) cuja avaliação global é maior naquele valor da taxa de substituição do critério analisado (Figura 66). A reta vertical significa o atual valor da taxa de substituição do critério analisado. Ela também permite analisar a variação feita na taxa de substituição, tanto para a esquerda quanto para a direita do gráfico. Pode se observar, ainda pelas retas se há grandes alterações na ordenação da pontuação global das avaliações dos professores da $\mathrm{FAU} / \mathrm{UnB}$.

Os decisores escolheram critérios para Análise de Sensibilidade e julgaram poder haver alterações nas taxas de substituição com o decorrer de tempo. Para isso, é preciso 
saber se o modelo é robusto nos seguintes critérios:

- PVF 1 - Conforto Ambiental;

- PVF 2 - Ergonomia;

- PVF 3 - Psicologia Ambiental.

A figura 68 mostra a sensibilidade do modelo no critério Conforto Ambiental (PVF $1)$.

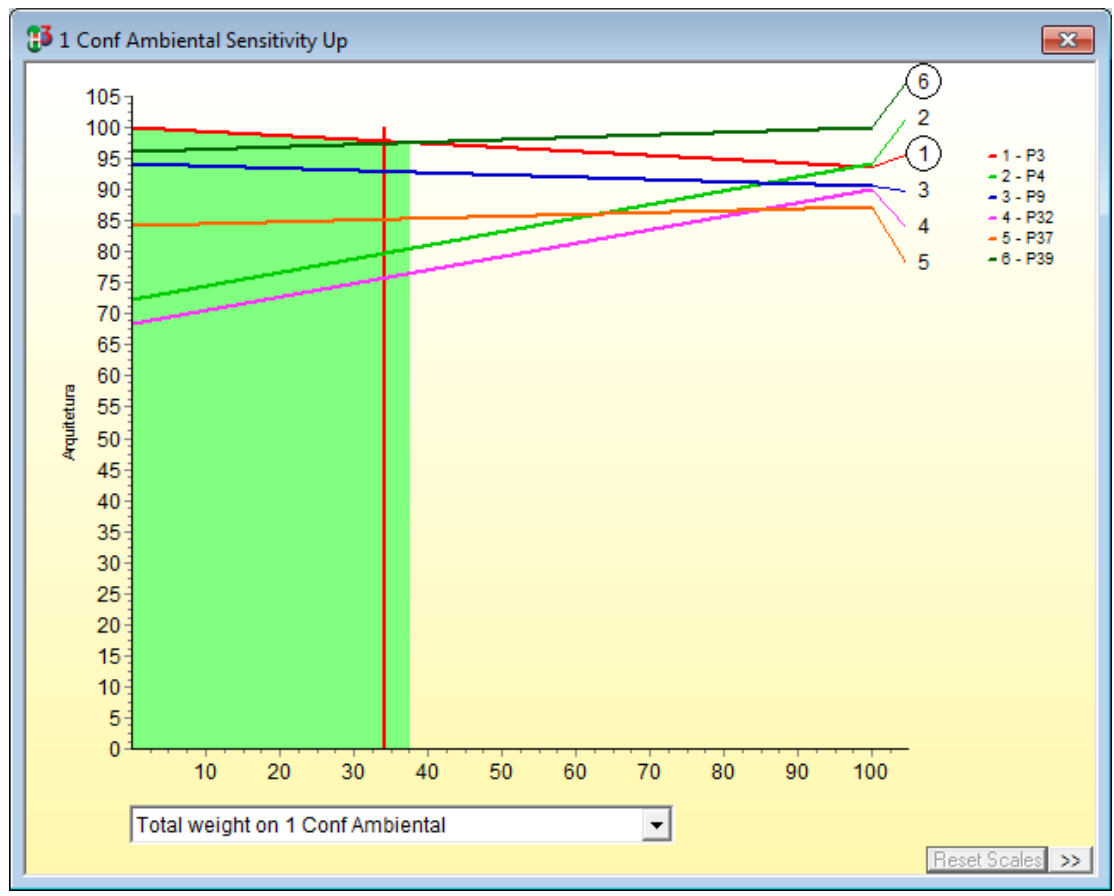

Figura 68 - Análise de sensibilidade do modelo no PVF 1 - Conforto Ambiental

Fonte: Hiview3 (2016).

Analisando-se o gráfico da Figura 68, observa-se que, na situação original, o valor da taxa de substituição em 34\% (linha vertical vermelha) do critério Conforto Ambiental, o professor P39 apresenta melhor avaliação entre os demais com uma avaliação global de 100 pontos (ver Figura 66). À medida que se faz a diminuição do peso $34 \%$ em 10\%, passando para $30,6 \%$, a ordem da classificação dos professores permanece a mesma, conforme o gráfico, onde toda a área verde significa que não há alteração da ordenação dos professores. O mesmo acontece aumentado o peso $34 \%$ em 10\%, passando a 37, 4\%, a ordenação permanece a mesma. Pode-se concluir que, variando-se o valor da taxa de substituição original de $34 \%$ para $-10 \%$ e para $+10 \%$, permanece inalterada a hierarquização da avaliação dos professores, ou seja, o modelo não se mostra sensível. O modelo também se mostra robusto nesse critério, sendo evidente que o professor P39 apresenta um melhor desempenho em todas as situações, seguido pelo professor P3. 
A figura 69 mostra a sensibilidade do modelo no critério Ergonomia (PVF 2).

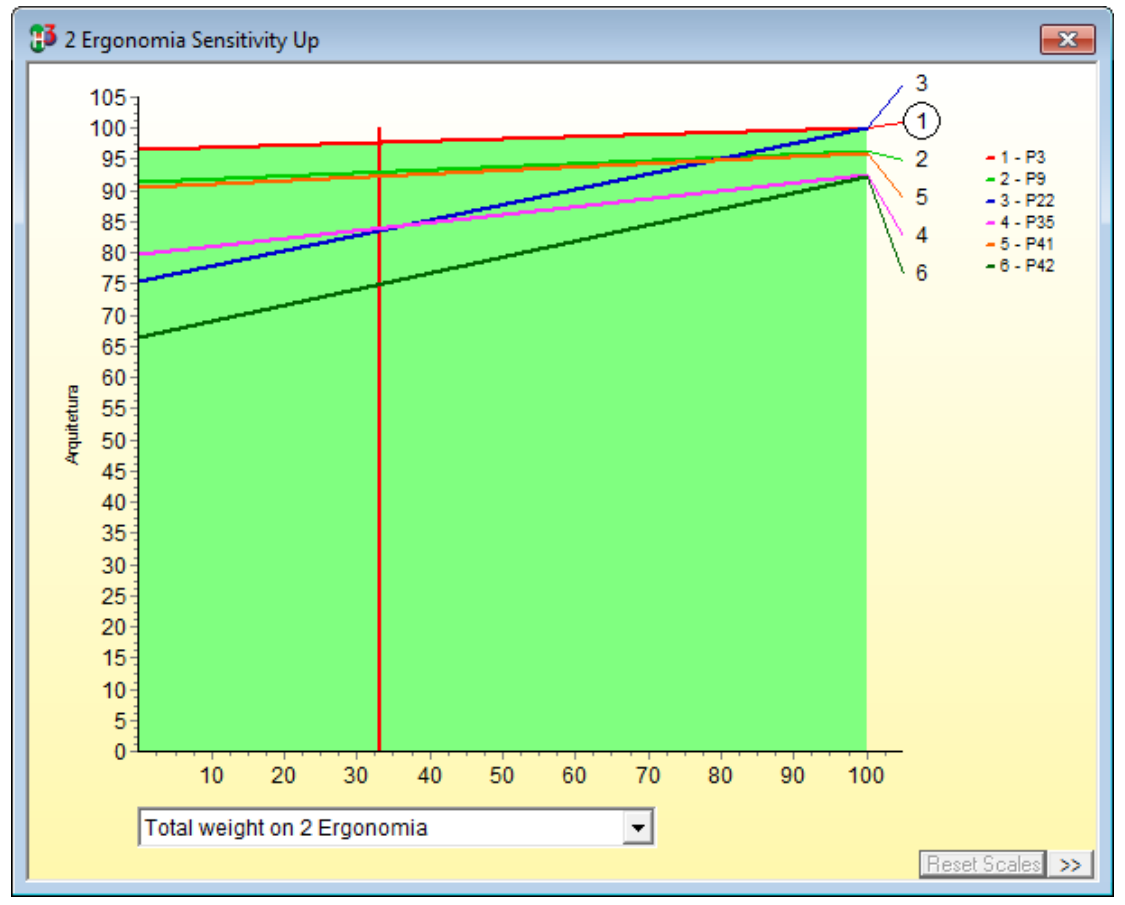

Figura 69 - Análise de sensibilidade do modelo no PVF 2 - Ergonomia Fonte: Hiview3 (2016).

Analisando-se o gráfico da Figura 69, observa-se que, na situação original, o valor da taxa de substituição em $33 \%$ (linha vertical vermelha) do critério Ergonomia, o professor P3 apresenta melhor avaliação juntamente com o professor P22, dentre os demais com uma avaliação global de 100 pontos (ver Figura 66). À medida que se faz a diminuição do peso $33 \%$ em 10\%, passando para 31,3\%, a ordem da classificação dos professores permanece a mesma, conforme o gráfico, onde toda a área verde significa que não há alteração da ordenação da avaliação dos professores. O mesmo acontece aumentado o peso $33 \%$ em $10 \%$, passando a $34,7 \%$, a ordenação permanece a mesma. Pode-se concluir que, variando-se o valor da taxa de substituição original de $33 \%$ para $-10 \%$ e para $+10 \%$, permanece inalterada a hierarquização da avaliação dos professores, ou seja, o modelo não se mostra sensível. O modelo também se mostra robusto nesse critério, sendo evidente que o professor P3 apresenta um melhor desempenho em todas as situações, seguido pelo professor P22.

O gráfico da Figura 70 mostra a sensibilidade do modelo no critério Psicologia Ambiental - PVF 3 


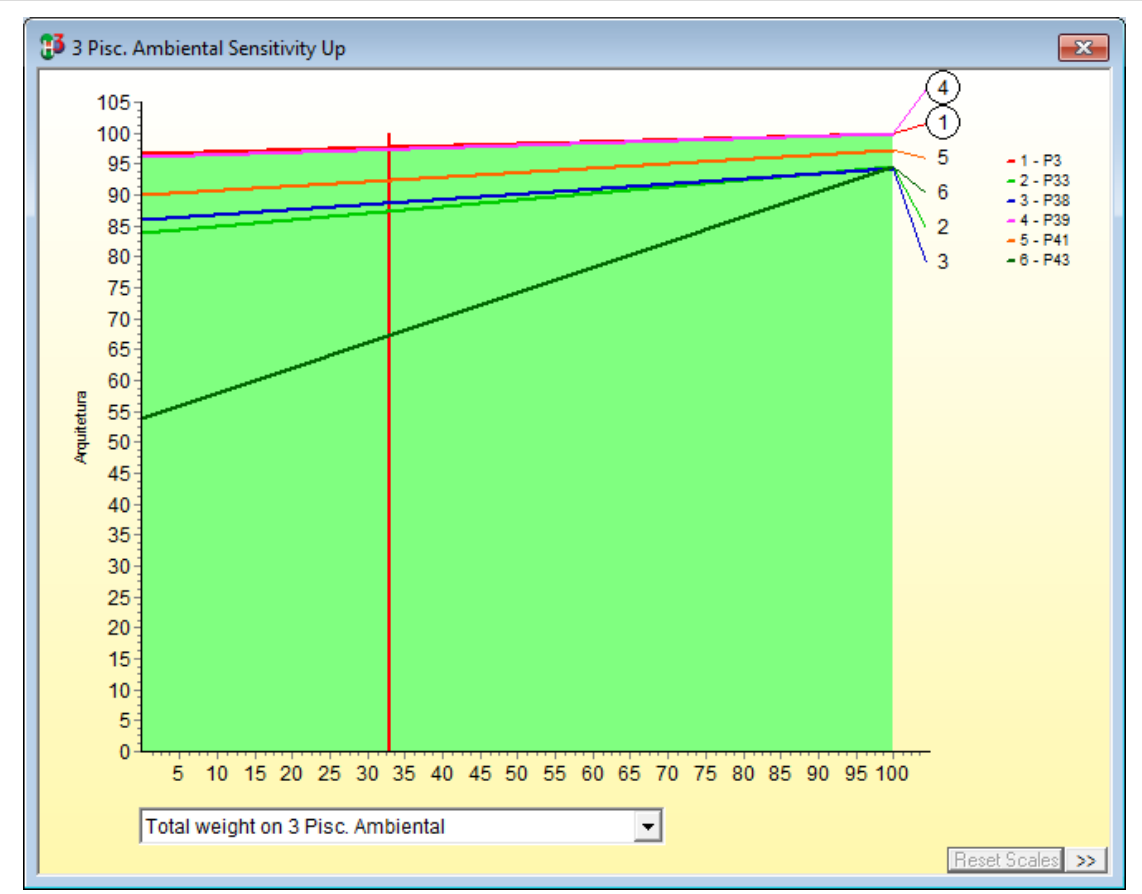

Figura 70 - Análise de sensibilidade do modelo no PVF 3 - Psicologia Ambiental

Fonte: Hiview3 (2016).

Analisando-se o gráfico da Figura 70, observa-se que, na situação original, o valor da taxa de substituição em 33\% (linha vertical vermelha) do critério Psicologia Ambiental, o professor P39 apresenta melhor avaliação juntamente com o professor P3, dentre os demais com uma avaliação global de 100 pontos (ver Figura 66). À medida que se faz a diminuição do peso $33 \%$ em 10\%, passando para 31,3\%, a ordem da classificação dos professores permanece a mesma, conforme o gráfico, onde toda a parte verde significa que não há alteração da ordenação dos professores. O mesmo acontece aumentado o peso $33 \%$ em 10\%, passando a 34,7\%, a ordenação permanece a mesma. Pode-se concluir que, variando-se o valor da taxa de substituição original de $33 \%$ para $-10 \%$ e para $+10 \%$, permanece inalterada a hierarquização da avaliação dos professores, ou seja, o modelo não se mostra sensível. O modelo também se mostra robusto nesse critério, sendo evidente que o professor P39 apresenta um melhor desempenho em todas as situações, seguido pelo professor P3.

Conforme Quirino (2002), pela análise de sensibilidade, feita com os critérios do Conforto Ambiental, Ergonomia e Psicologia Ambiental, conclui-se que:

- Variando-se os valores das taxas de substituição em todos os critérios para $+10 \%$ e para $-10 \%$, permanece inalterada a hierarquização da avaliação dos professores.

- A hierarquização dos critérios só se altera para valores das taxas de substituição acima de $30 \%$ a $40 \%$ aproximadamente. 
- O modelo, segundo Quirino (2002), não se mostrou sensível nos critérios, concluindo que este é robusto nas circunstâncias propostas.

\subsection{Análise do resultado final da MCDA-C}

A utilização do modelo de avaliação com base na Metodologia MCDA para Apoio à decisão dos professores do curso de Arquitetura e Urbanismo da Universidade de Brasília para validar o conjunto de atributos espaciais capazes de facilitar o ensino-aprendizagem foi exitosa. A base nos pressupostos e fundamentos epistemológicos da Multicriteria Decision Aid permitiu a elaboração do modelo ajustado ao caso em análise e elaboração do questionário que contou com o apoio de uma equipe de especialistas nas áreas de Conforto Ambiental, Ergonomia e Psicologia Ambiental. A partir da orientação do paradigma construtivista, construiu-se um modelo capaz de avaliar, quantitativamente, os critérios facilitadores do ensino-aprendizagem, a partir das percepções qualitativas de especialistas, segundo seus juízos de valor (decisores).

Essa conclusão encontra base na análise dos dados obtidos como se verifica abaixo:

- PVFs - os critérios avaliados pelos 43 professores da FAU/UnB corrobora com os autores identificados na literatura, no que diz respeito aos parâmetros facilitadores do ensino-aprendizagem para programa de necessidades, tendo alcançado a nota global 73,16 (setenta e três e dezesseis);

Conforto Ambiental - este PVF 1 foi avaliado com a nota 75,25 (setenta e cinco e vinte e cinco), relativamente em um patamar acima da média. Esta nota representa a importância dos atributos e parâmetros deste PVF citados na literatura por vários autores, corroborando com a avaliação de 43 professores do curso de Arquitetura e Urbanismo da UnB. Reflete uma necessidade imprescindível citada pela maioria dos avaliadores, pois representa uma categoria (campo disciplinar) de grande importância para os espaços arquitetônicos nas edificações escolares do ensino superior.

- Conforto térmico - este PVE recebeu a menor avaliação, com a nota $\mathbf{6 3 , 7 4}$ (sessenta e três e setenta e quatro). Para os professores esse conforto é menos importante para os espaços onde ministram suas discilplinas.

- Conforto lumínico - este PVE recebeu a nota 82,48 (oitenta e dois e quarenta e oito), a maior do PVF 1, indicando que os professores consideram importante para os espaços onde ministram suas disciplinas.

- Conforto sonoro - este PVE recebeu a nota 80,39 (oitenta e trinta e nove), considerada ligeiramente abaixo da nota referente ao conforto lumínico, que representa uma boa avaliação dos professores da FAU/UnB. 
Ergonomia - este PVF 2 foi avaliado com a nota 76,90 (setenta e seis e noventa) ligeiramente superior à nota atribuída ao critério anterior (PVF 1), relativamente em um patamar acima da média, mostrando que o Conforto Ambiental e a Ergonomia estão no mesmo nível, mas com certa priorização da Ergonomia. Esta nota representa a importância dos atributos e parâmetros citados na literatura por vários autores, corroborando com a avaliação de 43 professores do curso de Arquitetura e Urbanismo da UnB. Reflete uma necessidade imprescindível citada pela maioria dos avaliadores, pois representa uma categoria (campo disciplinar) de grande importância para os espaços arquitetônicos nas edificações escolares do ensino superior, adequando as tarefas e atividades ao trabalhador.

- Vibração - este PVE recebeu a menor avaliação do PVF 2, com a nota $\mathbf{5 1 , 2 8}$ (cinquenta e um e vinte e oito). Para os professores, esse atributo é menos importante para os espaços onde ministram suas disciplinas. No caso, somente em um ambiente, o de maquetes utilizam-se de ferramentas com vibração.

- Antropometria - este PVE recebeu a nota 89,13 (oitenta e nove e treze), a maior do PVF 2, indicando que os professores consideram muito importante para os espaços onde ministram suas disciplinas.

- Infraestrutura - este PVE recebeu a nota $\mathbf{8 7 , 8 4}$ (oitenta e sete e oitenta e quatro), considerada a segunda maior do PVF 2, representando uma boa/excelente avaliação dos professores da FAU/UnB.

Psicologia Ambiental - este PVF 3 foi avaliado com a nota 67,44 (sessenta e sete e quarenta e quatro), a mais baixa dos três PVFs. Esta nota representa a importância dos atributos e parâmetros deste PVF citados na literatura por vários autores, corroborando com a avaliação de 43 professores do curso de Arquitetura e Urbanismo da UnB. Reflete uma necessidade imprescindível citada pela maioria dos avaliadores, pois representa uma categoria (campo disciplinar) de grande importância para os espaços arquitetônicos nas edificações escolares do ensino superior, representando o comportamento humano, o ambiente e seus usuários.

- Espaço pessoal - este PVE recebeu a nota 75,02 (setenta e cinco e dois), considerada a maior do PVF 3, representando uma boa avaliação dos professores da FAU/UnB para espaços onde ministram suas disciplinas.

- Territorialidade - este PVE recebeu a menor avaliação, com a nota 63,00 (sessenta e três). Para os professores, esse atributo é considerado menos importante para os espaços onde ministram suas discilplinas. 
- Privacidade - este PVE recebeu a nota 67,44 (setenta e sete e quarenta e quatro), considerada a segunda do PVF 3, representando uma avaliação média pelos professores da FAU/UnB nos espaços onde ministram suas disciplinas.

Os resultados das avaliações realizadas pelos profissionais que atuam na área de Arquitetura e Urbanismo mostram que as necessidades dos espaços arquitetônicos para ministrar suas disciplinas possuem ressonância nos atributos e parâmetros indicados pela pesquisa.

A partir das respostas/avaliações dos 43 professores, pode-se analisar a relevância que cada atributo possui para os diferentes tipos de disciplinas (teórica, teórica/prática e prática), isso para o caso do curso de Arquitetura e Urbanismo da FAU/UnB. Significa que seria possível não só estabelecer os atributos importantes para o espaço de uma Faculdade de Arquitetura, mas para seus diferentes espaços em decorrência da performance esperada na relação ensino-aprendizagem.

A tabela 56 mostra a avaliação dos professores, que participaram da pesquisa referente ao tipo de disciplina e suas características. A análise dos dados foi realizada a partir das pontuações da média das avaliações dos 43 professores da Faculdade de Arquitetura e Urbanismo que participaram da pesquisa.

Tabela 56 - Pontuação da avaliação dos professores da FAU por categoria de disciplina do curso da FAU/UnB

\begin{tabular}{|c|c|c|c|c|c|}
\hline \multirow{2}{*}{ Categorias } & \multirow{2}{*}{ Características } & \multirow{2}{*}{$\begin{array}{l}\text { Número de } \\
\text { respostas }\end{array}$} & \multicolumn{3}{|c|}{$\begin{array}{l}\text { Áreas Disciplinares } \\
\text { Avaliação Média }\end{array}$} \\
\hline & & & $\begin{array}{l}\text { Conforto } \\
\text { Ambien- } \\
\text { tal }\end{array}$ & Ergonomia & $\begin{array}{l}\text { Psicologia } \\
\text { Ambien- } \\
\text { tal }\end{array}$ \\
\hline Prática & $\begin{array}{l}\text { trabalhos em equipe; } \\
\text { maior interação entre alunos; } \\
\text { maior interação com o professor; } \\
\text { menor exigência de concentra- } \\
\text { ção. }\end{array}$ & 1,00 & 79,00 & 85,00 & 65,00 \\
\hline Teórica & $\begin{array}{l}\text { trabalho individual; } \\
\text { menor interação entre alunos; } \\
\text { menor interação com o profes- } \\
\text { sor; } \\
\text { maior exigência de concentra- } \\
\text { ção. }\end{array}$ & 13,00 & 75,30 & 73,07 & 63,76 \\
\hline Pratica/Teórica & $\begin{array}{l}\text { trabalho individual; } \\
\text { menor interação entre alunos; } \\
\text { menor interação com o profes- } \\
\text { sor; } \\
\text { maior exigência de concentra- } \\
\text { ção. }\end{array}$ & 29,00 & 75,10 & 78,34 & 69,17 \\
\hline & Total & 43 & 76,46 & 78,8 & 65,58 \\
\hline
\end{tabular}

Fonte: Elaboração própria (2016).

- Para a disciplina prática foram obtidos os seguintes resultados: 
Na área de Ergonomia, um professor avaliou com nota 85 (oitenta e cinco), indicando a importância dos atributos analisados, que são a Vibração, a Antropometria e a infraestrutra dos espaços onde ministra sua disciplina, reforçando a necessidade de que estes tenham um arranjo físico, mobiliário, revestimentos, equipamentos e ambiente físico que atendam às características da disciplina. Nota-se que essa área disciplinar foi avaliada como a primeira no quesito de disciplina prática por representar a importância dos parâmetros para os espaços de ensino-aprendizagem . Apesar do atributo Vibração ter tido uma avaliação mais baixa, teve a compensação do professor avaliar melhor a Antropometria e a Infraestrutura dos espaços ensino-aprendizagem.

Na área do Conforto Ambiental, o professor avaliou com nota 79 (setenta e nove) indicando a importância dos atributos analisados, que são o Conforto térmico, o Conforto lumínico e o Conforto sonoro dos espaços onde ministra sua disciplina, reforçando a necessidade de que estes tenham os respectivos parâmetros que atendam às características da disciplina. Nota-se que essa área disciplinar foi avaliada como a segunda no quesito de disciplina prática por representar a importância dos parâmetros para os espaços ensinoaprendizagem.

Na área de Psicologia Ambiental, o professor avaliou com nota 65 (sessenta e cinco) indicando a importância dos atributos analisados, que são o Espaço pessoal, a Territorialidade e a Privacidade dos espaços onde ministra sua disciplina, reforçando a necessidade de que estes tenham as distâncias e relações interpessoais entre alunos e professores, contemplando a configuração (design) dos espaços, a ocupação, a defesa e a personalização. Nota-se que essa área disciplinar foi avaliada como a terceira no quesito de disciplina prática por representar a importância dos parâmetros para os espaços ensino-aprendizagem.

- Para as disciplinas teóricas foram obtidos os seguintes resultados:

$\mathrm{Na}$ área de Ergonomia, os professores avaliaram com nota 73,07 (setenta e três e sete) indicando a importância dos atributos analisados, que são a Vibração, a Antropometria e a Infraestrutra dos espaços onde ministra sua disciplina, reforçando a necessidade de que estes tenham um arranjo físico, mobiliário, revestimentos, equipamentos e ambiente físico que atendam às características das disciplinas. Nota-se que esta área disciplinar foi avaliada como a segunda no quesito de disciplina teórica por representar a importância dos parâmetros para os espaços de ensino-aprendizagem .

$\mathrm{Na}$ área do Conforto Ambiental, os professores avaliaram com nota 75,30 (setenta e cinco e trinta) indicando a importância dos atributos analisados, que são o Conforto térmico, o Conforto lumínico e o Conforto sonoro dos espaços onde ministra sua disciplina, reforçando a necessidade de que estes tenham os respectivos parâmetros que atendam às características da disciplina. Nota-se que essa área disciplinar foi avaliada como 
a primeira no quesito de disciplina teórica por representar a importância dos parâmetros para os espaços de ensino-aprendizagem .

Na área de Psicologia Ambiental, os professores avaliaram com nota 62,58 (sessenta e dois e cinquenta e oito) indicando a importância dos atributos analisados, que são o Espaço pessoal, a Territorialidade e a Privacidade dos espaços onde ministra sua disciplina, reforçando a necessidade de que estes tenham as distâncias e relações interpessoais entre alunos e professores, contemplando a configuração (design) dos espaços, a ocupação, defesa e personalização. Nota-se que esta área disciplinar foi avaliada como a terceira no quesito de disciplina teórica por representar a importância dos parâmetros para os espaços de ensino-aprendizagem .

- Para as disciplinas práticas/teóricas foram obtidos os seguintes resultados:

$\mathrm{Na}$ área de Ergonomia, os professores avaliaram com nota 78,34 (setenta e oito e trinta e quatro) indicando a importância dos atributos analisados, que são a Vibração, a Antropometria e a Infraestrutra dos espaços onde ministra sua disciplina, reforçando a necessidade de um arranjo físico, mobiliário, revestimentos, equipamentos e ambiente físico que atendam às características das disciplinas. Nota-se que essa área disciplinar foi avaliada como a primeira avaliação no quesito de disciplina prática/teórica por representar a importância dos parâmetros para os espaços de ensino-aprendizagem . Apesar de o atributo Vibração ter tido uma avaliação mais baixa, teve a compensação dos professores avaliarem melhor a Antropometria e a Infraestrutura dos espaços da FAU/UnB.

Na área do Conforto Ambiental, os professores avaliaram com nota 75,10 (setenta e cinco e dez) indicando a importância dos atributos analisados, que são o Conforto térmico, o Conforto lumínico e o Conforto sonoro dos espaços onde ministra sua disciplina, reforçando a necessidade de que seus parâmetros atendam às características da disciplina. Nota-se que esta área disciplinar foi avaliada como a segunda avaliação no quesito de disciplina prática/teórica por representar a importância dos parâmetros para os espaços de ensino-aprendizagem . Na área de Psicologia Ambiental, os professores avaliaram com nota 69,17 (sessenta e nove e dezessete) indicando a importância dos atributos analisados, que são o espaço pessoal, a territorialidade e a privacidade dos espaços onde ministra sua disciplina, reforçando a necessidade de que seus parâmetros atendam às características de cada disciplina, contemplando as distâncias e relações interpessoais entre alunos e professores, a configuração (design) dos espaços, a ocupação, a defesa e a personalização. Nota-se que esta área disciplinar foi considerada como a terceira avaliação por representar a importância dos parâmetros para os espaços de ensino-aprendizagem .

Pode-se concluir que a avaliação realizada pelos 43 professores da Faculdade de Arquitetura e Urbanismo do curso de Arquitetura e Urbanismo foi positiva, dentro de um patamar médio/alto, corroborando com os critérios definidos nas referencias bibliográficas, 
a partir de vários autores, inclusive internacionais. Os professores consideraram os critérios pontuados importantes para cada espaço em que ministram suas respectivas disciplinas.

\subsection{Modelo de Arquitetura da Informação para edificações escola- res}

No caso de uso apresentado neste estudo o conceito do modelo de AI é: uma estrutura de informação a partir da qual os aspectos pedagógicos do ensino de Arquitetura e Urbanismo expressos pelos professores da Faculdade de Arquitetura e Urbanismo da Universidade de Brasília são representados como fruto de uma pesquisa que procurou validar um conjunto de características especiais contidas na bibliografia sobre a relação entre espaço e aprendizagem e que foram expressas por atributos e parâmetros dos campos disciplinares do Conforto Ambiental, da Psicologia Ambiental e da Ergonomia.

A partir de um referencial teórico e metodológico, propõe-se um modelo de Arquitetura da Informação para edificações escolares que elenca um conjunto de perspectivas, condições, especialidades e informações, representando uma camada de abstração para fundamentar a definição de características, parâmetros e critérios facilitadores do ensinoaprendizagem que contribuem para a elaboração de programa de necessidades.

As perspectivas estão classificadas em: i) Pedagógica; ii) Arquitetônica; iii) Ambiental, iv) Ergonômica e v) Psicológica e foram embasadas a partir da fundamentação teórica estabelecidas nos capítulos 1, 2 e 3 do presente estudo. As principais áreas transversais e explicações adotadas como base para a identificação de premissas, abordagens e resultados que compõem o Modelo de Arquitetura da Informação para projetos escolares foram subdivididos em:

- Perspectiva pedagógica - com enfoque objetivo, está vinculada ao ato de conduzir ao saber ou à sua construção;

- Perspectiva arquitetônica - com enfoque objetivo, visa à construção concebida com o propósito primordial de ordenar e organizar o espaço para determinada finalidade e a determinada intenção;

- Perspectiva ambiental - com enfoque objetivo, estuda as condições térmicas, acústicas, luminosas e energéticas e os fenômenos físicos a elas associados como um dos condicionantes da forma e da organização do espaço;

- Perspectiva ergonômica - com enfoque objetivo, coloca o humano como elemento norteador, estudando a forma como o espaço é utilizado, de maneira a adequá-lo às tarefas e atividades que nele serão desenvolvidas; 
- Perspectiva psicológica - com enfoque objetivo e subjetivo nas relações entre as pessoas e seus ambientes.

\subsubsection{Construção do Modelo de Al em apoio à elaboração de programa de necessidades arquitetônicas de espaços escolares}

A seguir apresentam-se a construção do Modelo de AI com quadros explicativos abordando as premissas, abordagem, base conceitual e resultados para as perspectivas pedagógicas e arquitetônicas, bem como as perspectivas ambiental, ergonômica e psicológica acrescentadas dos critérios, subcritérios, procedimentos técnicos, estratégias e normas técnicas com fechamento da tese, comprovando o que foi estabelecido no inicio da tese, referenciado no procedimento metodológico na seção 1.4.1 e 1.4.2 (capítulo 1). Os conceitos se encontram no Glossário.

Para entendimento do modelo de AI foram utilizadas as seguintes nomenclaturas citadas nas Tabelas 57, 58, 59, 60 e 61: i) perspectiva - área contemplada; ii) premissa - o que determina o assunto, pontos de partida sobre determinado assunto, serve de base para um assunto que levará a uma conclusão, princípio, propósito; iii) abordagem - que foi contemplado no estudo da tese referente a determinada área; iv) referências - "pesquisa bibliográfica"sintética, objetivando construir uma base teórica; v) descrição - detalhamento da abordagem; vi) resultados; vii) critérios; viii) subcritérios; ix) procedimentos técnicos que têm como objetivo a obtenção de um determinado resultado; x) estratégia - ação ou caminho mais adequado a ser executado para alcançar um objetivo ou meta; xi) normas técnicas que estabelecem regras, diretrizes.

Para construção do modelo de Arquitetura da Informação foram ordenados os dados referentes aos campos disciplinares, seus conceitos, atributos e parâmetros que constroem a relação entre as necessidades pedagógicas de ensino-aprendizagem com os espaços arquitetônicos produzidos pela arquitetura.

São estabelecidas as perspectivas, as áreas da Pedagogia e da Arquitetura seguidas dos campos disciplinares que qualificam o espaço, identificadas na pesquisa como: Conforto Ambiental, Ergonomia e Psicologia Ambiental. Assim, para cada campo de conhecimento envolvido na pesquisa, foram estabelecidas referências para sintetizar as informações identificadas/produzidas para apoio à elaboração de programa de necessidades de projetos de arquitetura de ambientes escolares

No modelo de Arquitetura de Informação procurou-se sintetizar as informações mais relevantes sobre as relações entre Pedagogia e Arquitetura. Os conceitos são apresentados em cinco colunas que representam o arcabouço teórico utilizado na pesquisa.

$\mathrm{Na}$ perspectiva pedagógica foram elencados os conceitos: 
- perspectiva, representada por um ícone relacionado ao ensino-aprendizagem, como mera ilustração;

- premissas que norteiam a pesquisa relacionando o processo de ensino-aprendizagem, as práticas pedagógicas e a visão dos pedagogos;

- abordagem que define o conceito de Pedagogia;

- referencial que descreve os conceitos pedagógicos, o currículo escolar e as metodologias de ensino;

- resultados que confirmam a identificação de atributos espaciais relevantes de acordo com a recorrência obtida na visão dos pedagogos sobre a natureza do projeto escolar.

Na perspectiva arquitetônica foram elencados os conceitos:

- perspectiva, representada por um ícone relacionado à arquitetura, como mera ilustração;

- premissas que norteiam a pesquisa caracterizando que o ensino não é aespacial, que o espaço arquitetônico possui especificidades de acordo com o campo disciplinar;

- abordagem que define o conceito de arquitetura;

- hipótese norteadora da pesquisa, que presume que o espaço arquitetônico pode colaborar para um melhor desempenho das funções de ensino-aprendizagem;

- resultados ou contribuição que se apresenta ao tema: atributos e parâmetros que confirmam a premissa de que o espaço arquitetônico pode colaborar para um melhor desempenho das funções de ensino-aprendizagem;

O objetivo é o ordenamento, a organização e a gestão do conjunto de informações relacionadas às necessidades da área da Pedagogia no que tange aos espaços para dar insumos à elaboração de projetos de arquitetura.

Na perspectiva ambiental foram elencados os conceitos:

- perspectiva, representada por um ícone relacionado ao conforto ambiental, como mera ilustração;

- abordagem que define o conceito de conforto ambiental;

- descrição que relaciona os tipos de conforto ambiental e seu impacto no ensinoaprendizagem;

- critérios e subcritérios e seus conceitos utilizados na análise multicritério - (MCDA-C); 
- procedimentos técnicos ou condições essenciais para que os subcritérios possam ser contemplados;

- estratégias bioclimáticas que informam o que pode ser definido para que atenda aos referidos subcritérios, ou seja, como se deve levar em conta os atributos e parâmetros definidos na pesquisa para serem implementados;

- normas técnicas referentes a cada critério e subcritério para que o arquiteto possa considerá-las no levantamento do programa de necessidades para elaboração do projeto arquitetônico.

A partir dos dados obtidos no capítulo 3 e validados no capítulo 5 para o caso da Faculdade de Arquitetura e Urbanismo da UnB, infere-se que o modelo será aplicado em Clima Tropical de Altitude, segundo a classificação de Koppen; ou, Zona Bioclimática 4, segundo a ABNT (2005), com o título "Desempenho térmico de edificações - Parte 3", no qual apresenta-se o Zoneamento bioclimático brasileiro.

Na perspectiva ergonômica foram elencados os conceitos:

- perspectiva, representada por um ícone relacionado ao trabalhador/usuário no que diz respeito à condição do trabalho, como mera ilustração;

- abordagem que define o conceito de ergonomia;

- descrição que relaciona atributos elencados na pesquisa, os critérios e subcritérios estabelecidos pela análise multicritério, com seus conceitos;

- critérios e subcritérios e seus conceitos utilizados na análise multicritério - (MCDA-C) - procedimentos técnicos ou algumas condições essenciais para serem contemplados;

- tem estratégias que informam o que pode ser definido para que atenda aos referidos critérios e subcritérios, ou seja, como deve-se levar em conta os atributos e parâmetros definidos na pesquisa para serem implementados;

- normas técnicas referentes a cada critério e subcritério para que o arquiteto possa considerá-las no levantamento de necessidades para elaboração do projeto arquitetônico.

Na perspectiva psicológica foram elencados os conceitos:

- perspectiva, representada por um ícone relacionado à área da psicologia do ser humano, como mera ilustração;

- abordagem que define o conceito de psicologia ambiental; 
- descrição dos atributos elencados na pesquisa;

- critérios e subcritérios e seus conceitos utilizados na análise multicritério- (MCDA-C)

- procedimentos técnicos ou algumas condições essenciais para serem contemplados;

- estratégias ergonômicas que informam o que pode ser definido para que atenda aos referidos critérios e subcritérios, ou seja, como se deve levar em conta os atributos e parâmetros definidos na pesquisa para serem implementados;

- normas técnicas referentes a cada critério e subcritério para que o arquiteto possa considerá-las no levantamento de necessidades para elaboração do projeto arquitetônico.

A seguir, apresenta-se o modelo de Arquitetura da Informação das perspectivas: Pedagógica (Tabela 57), Arquitetônica (Tabela 58), Ambiental (Tabela 59), Ergonômica (Tabela 60) e Psciológica (Tabela 61). 


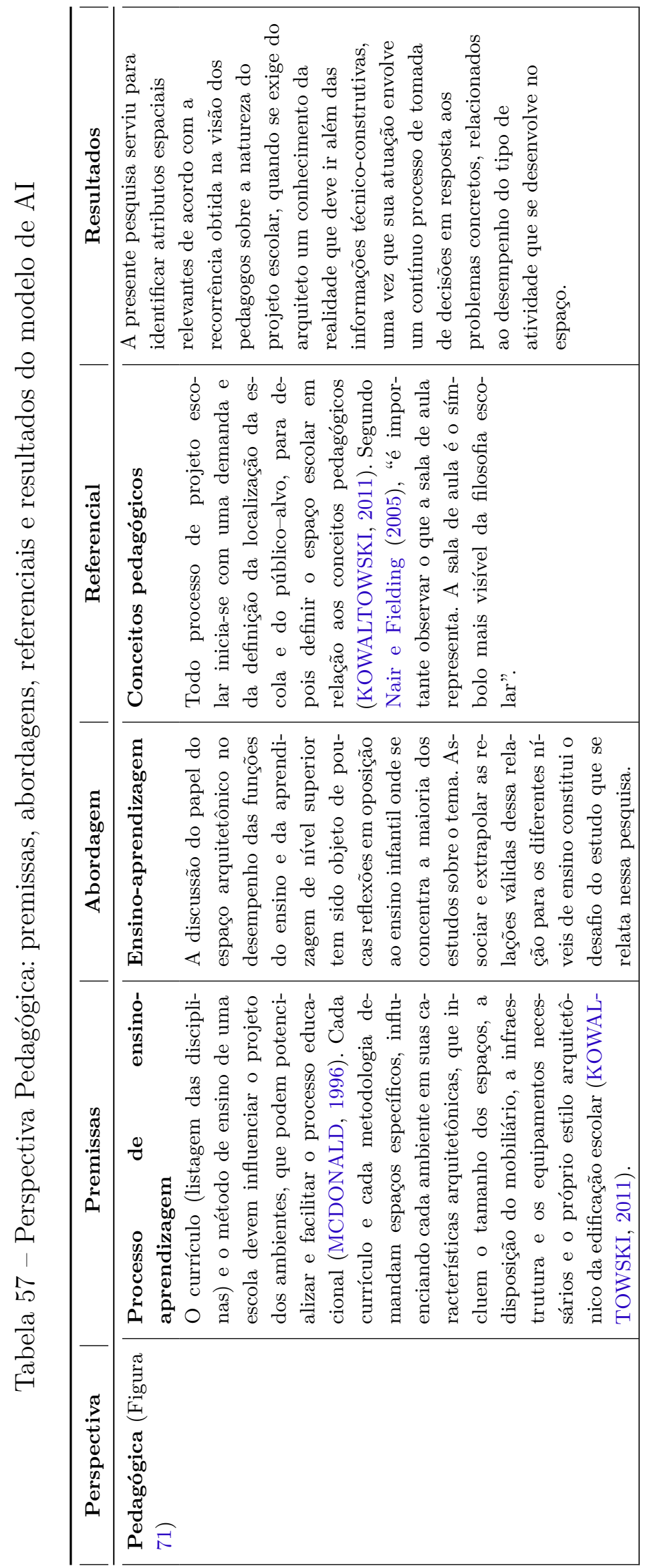




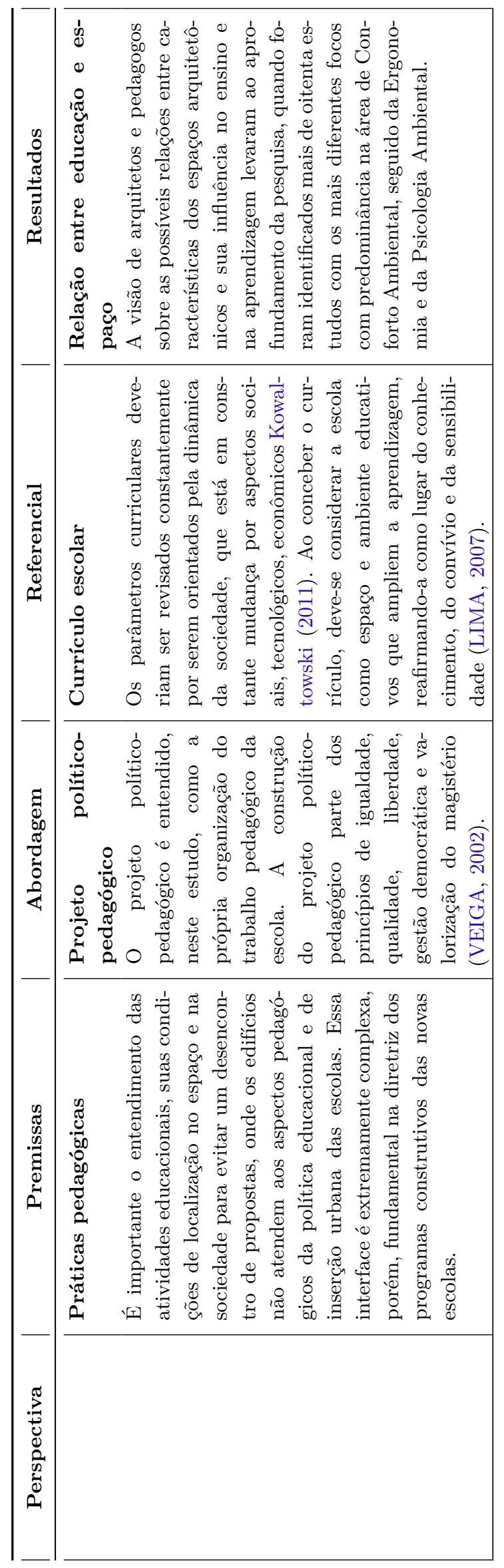




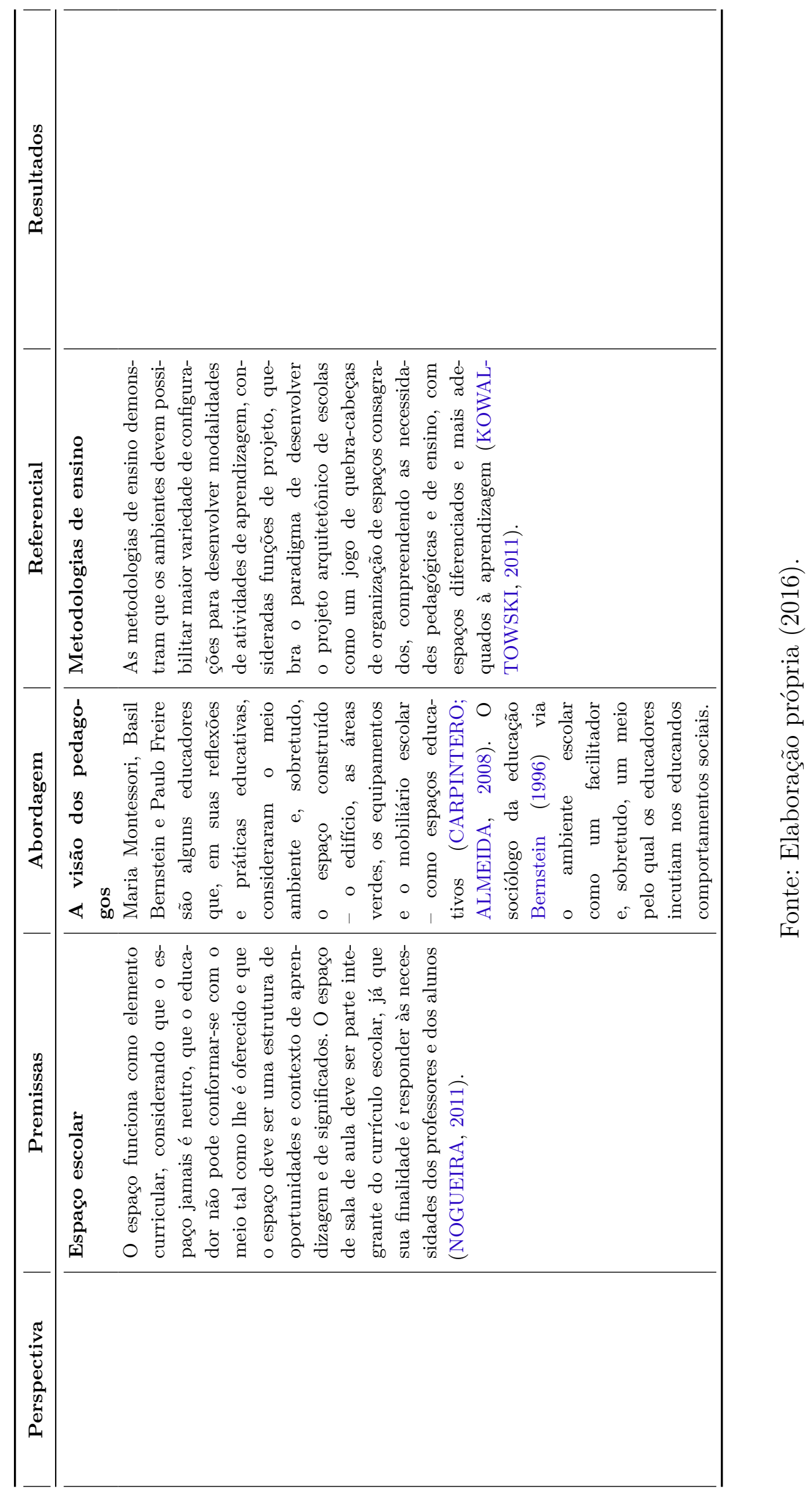




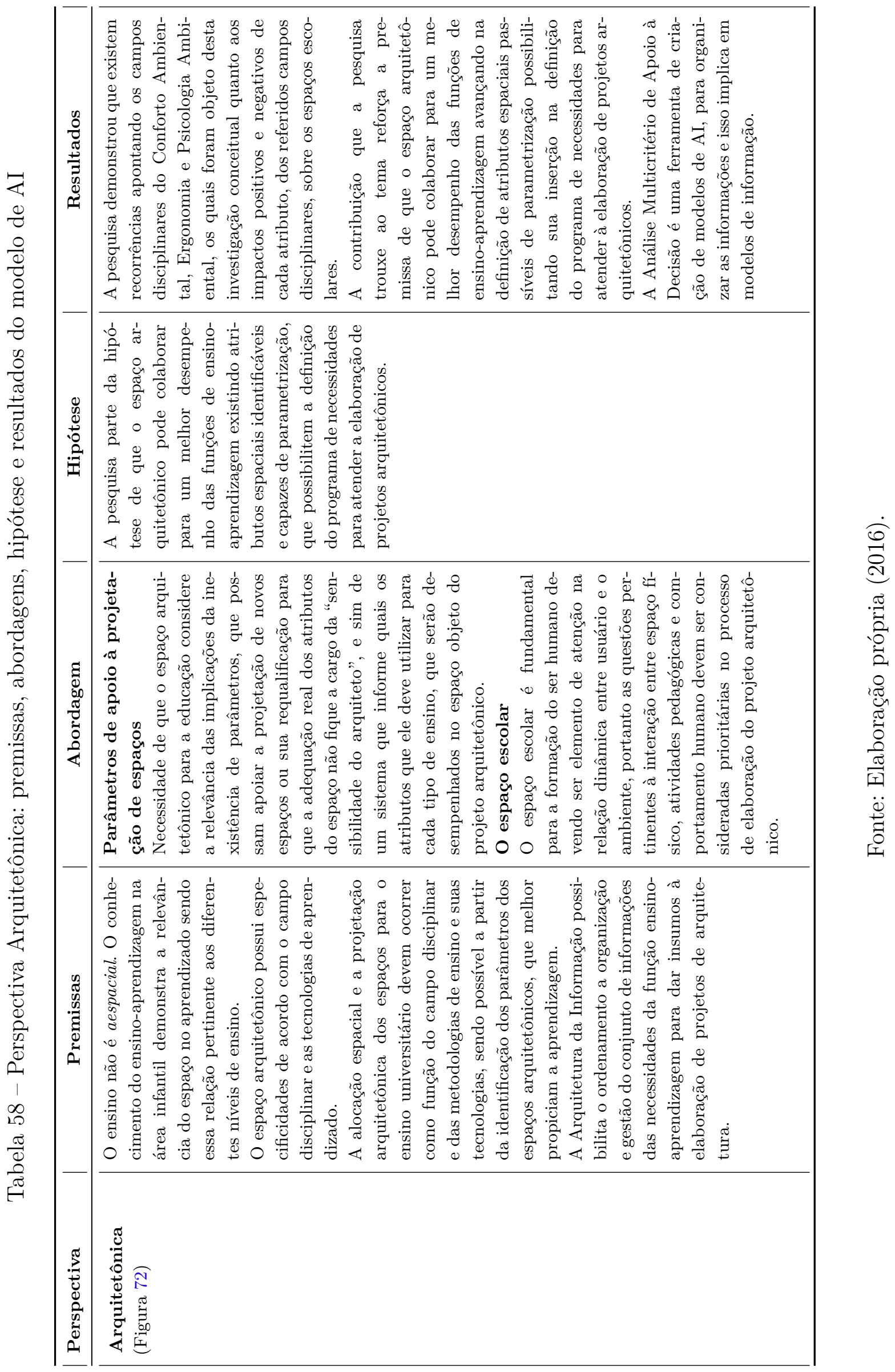




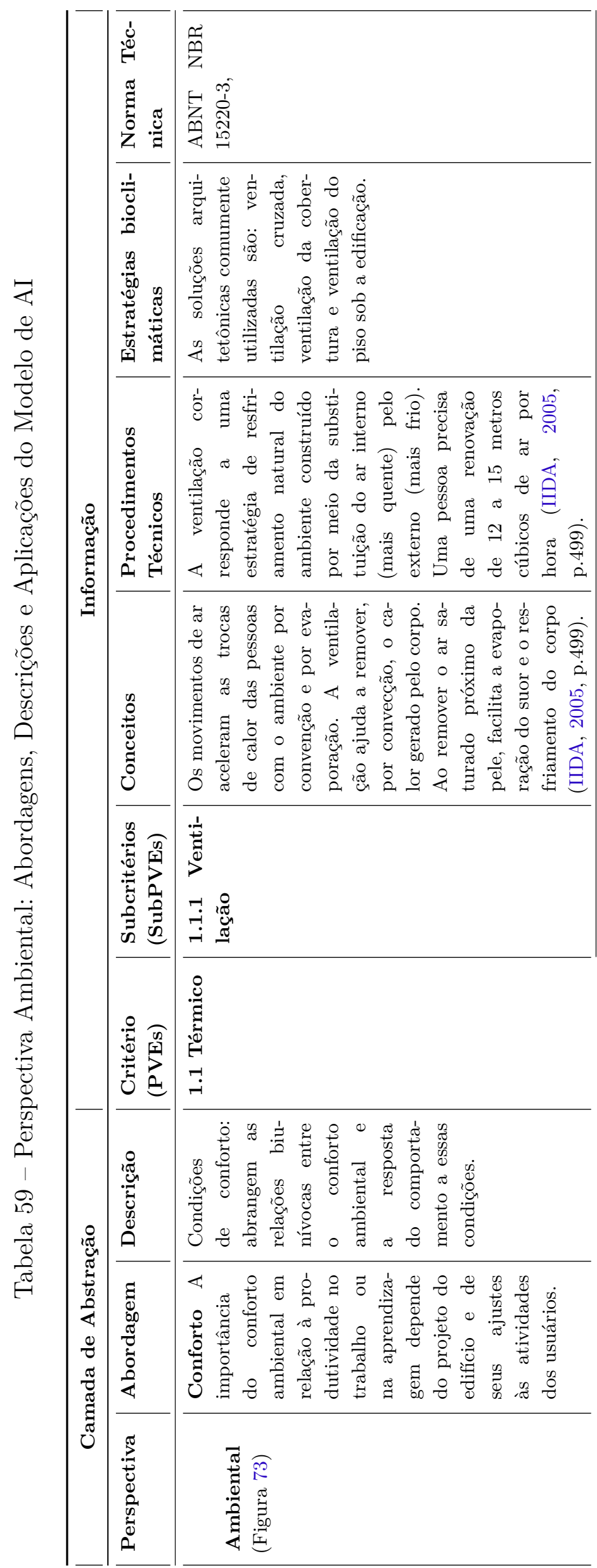


Capítulo 5. Caracterização do Universo de Estudo, Desenvolvimento da Pesquisa de Campo e Análise

\begin{tabular}{|c|c|c|c|}
\hline & 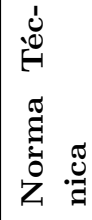 & 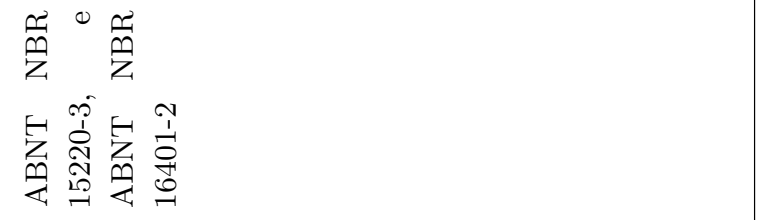 & 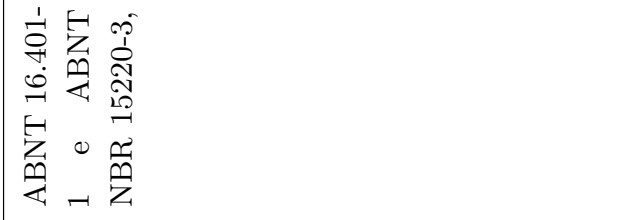 \\
\hline & 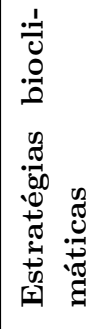 & 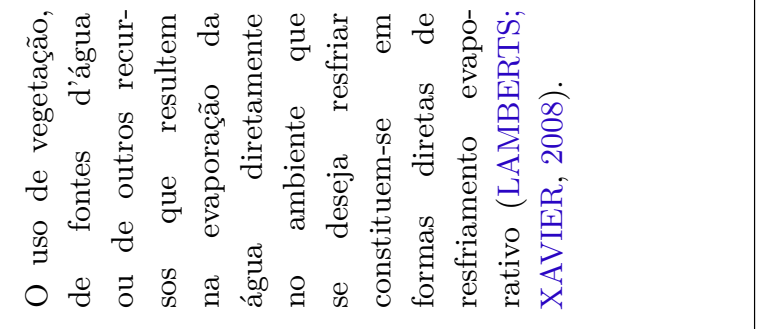 & 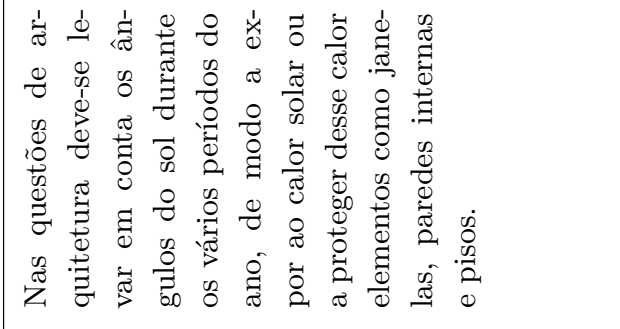 \\
\hline 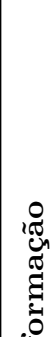 & 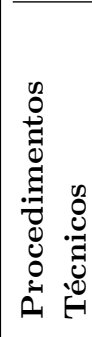 & 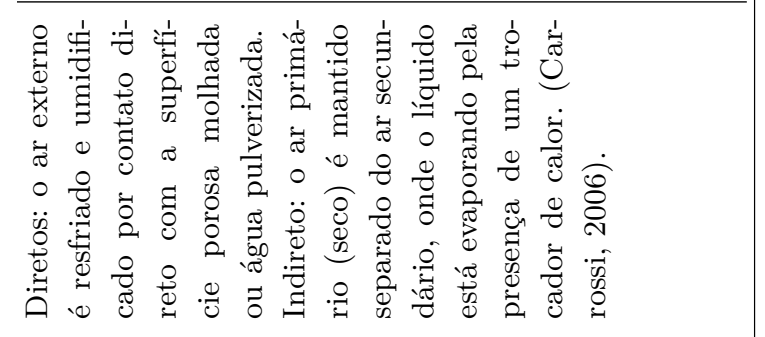 & 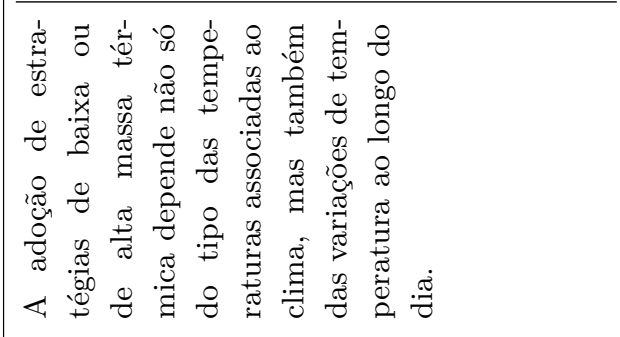 \\
\hline$\xi$ & 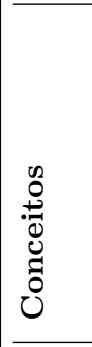 & 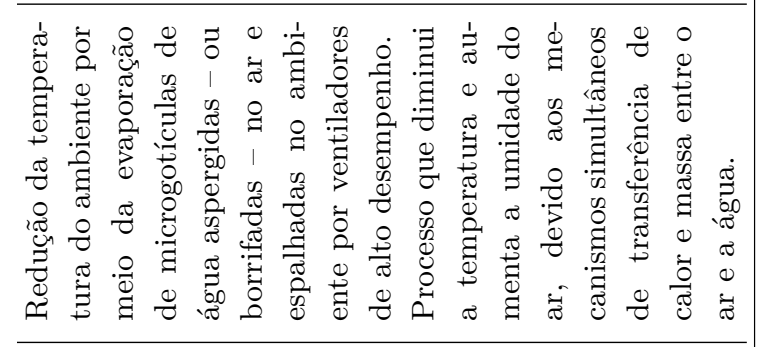 & 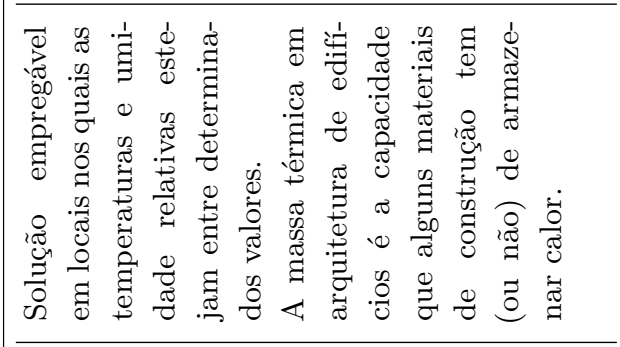 \\
\hline & 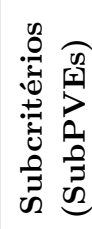 & 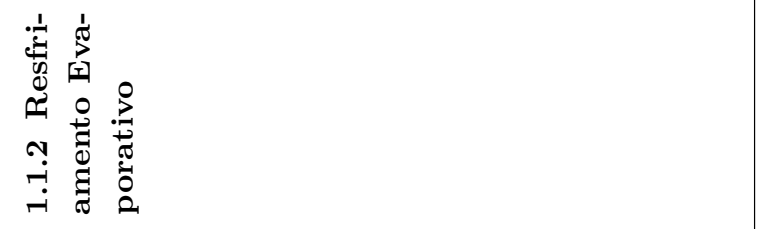 & 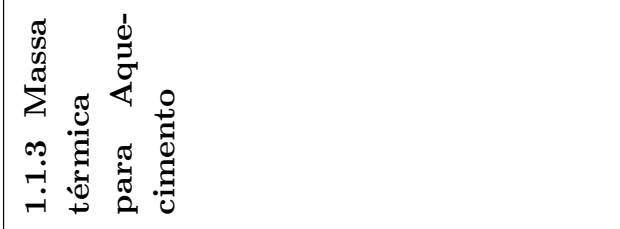 \\
\hline & 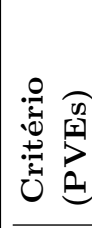 & 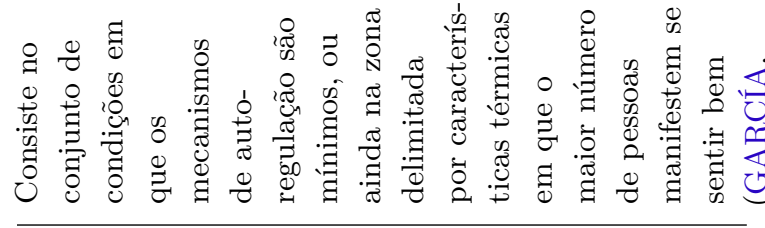 & \\
\hline I & 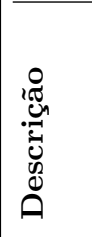 & 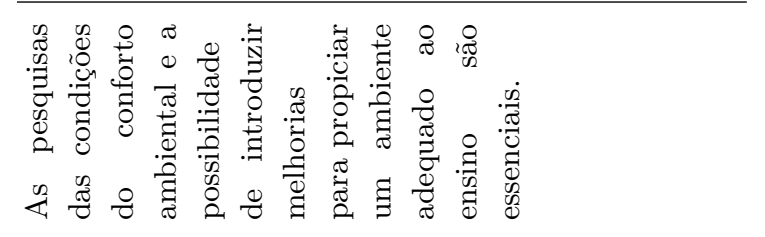 & 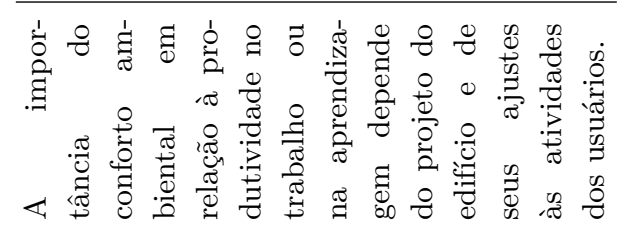 \\
\hline 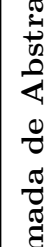 & 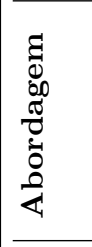 & 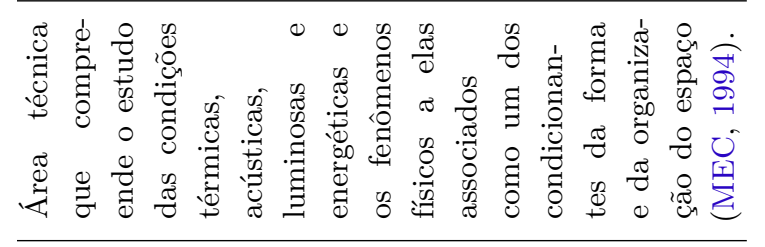 & \\
\hline రూ & 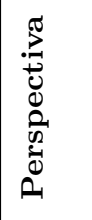 & & \\
\hline
\end{tabular}




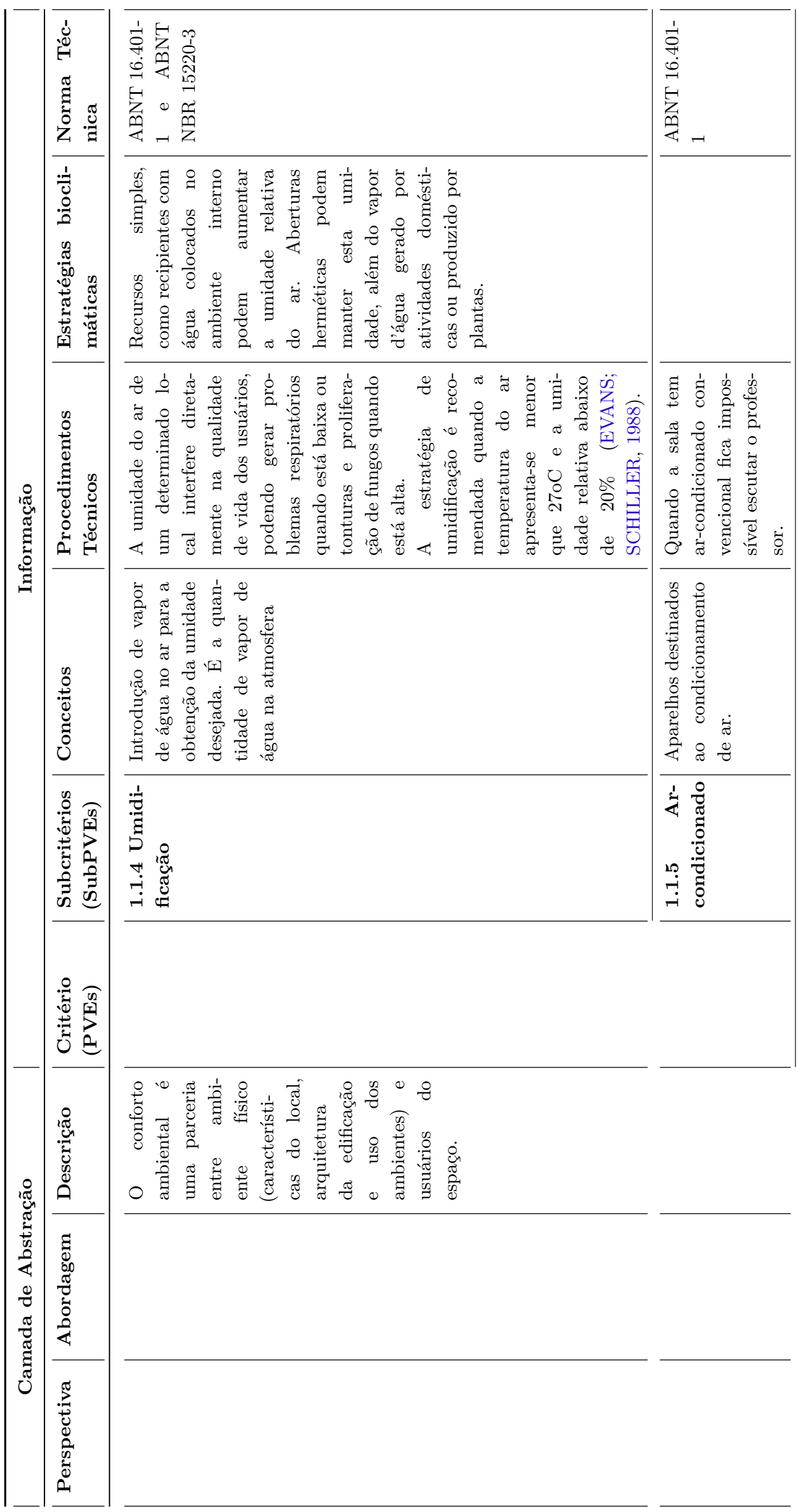


Capítulo 5. Caracterização do Universo de Estudo, Desenvolvimento da Pesquisa de Campo e Análise 300

dos Resultados

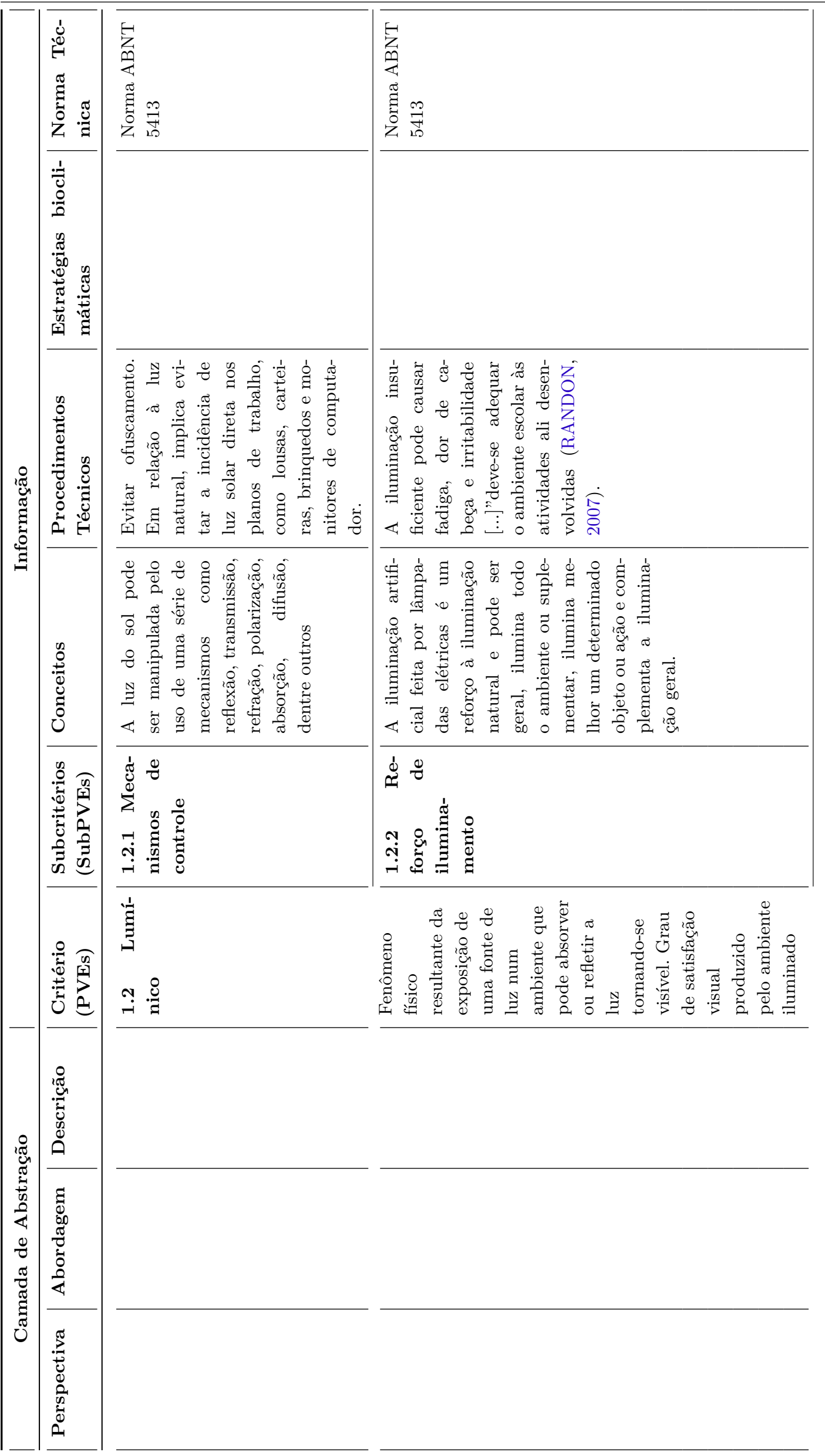




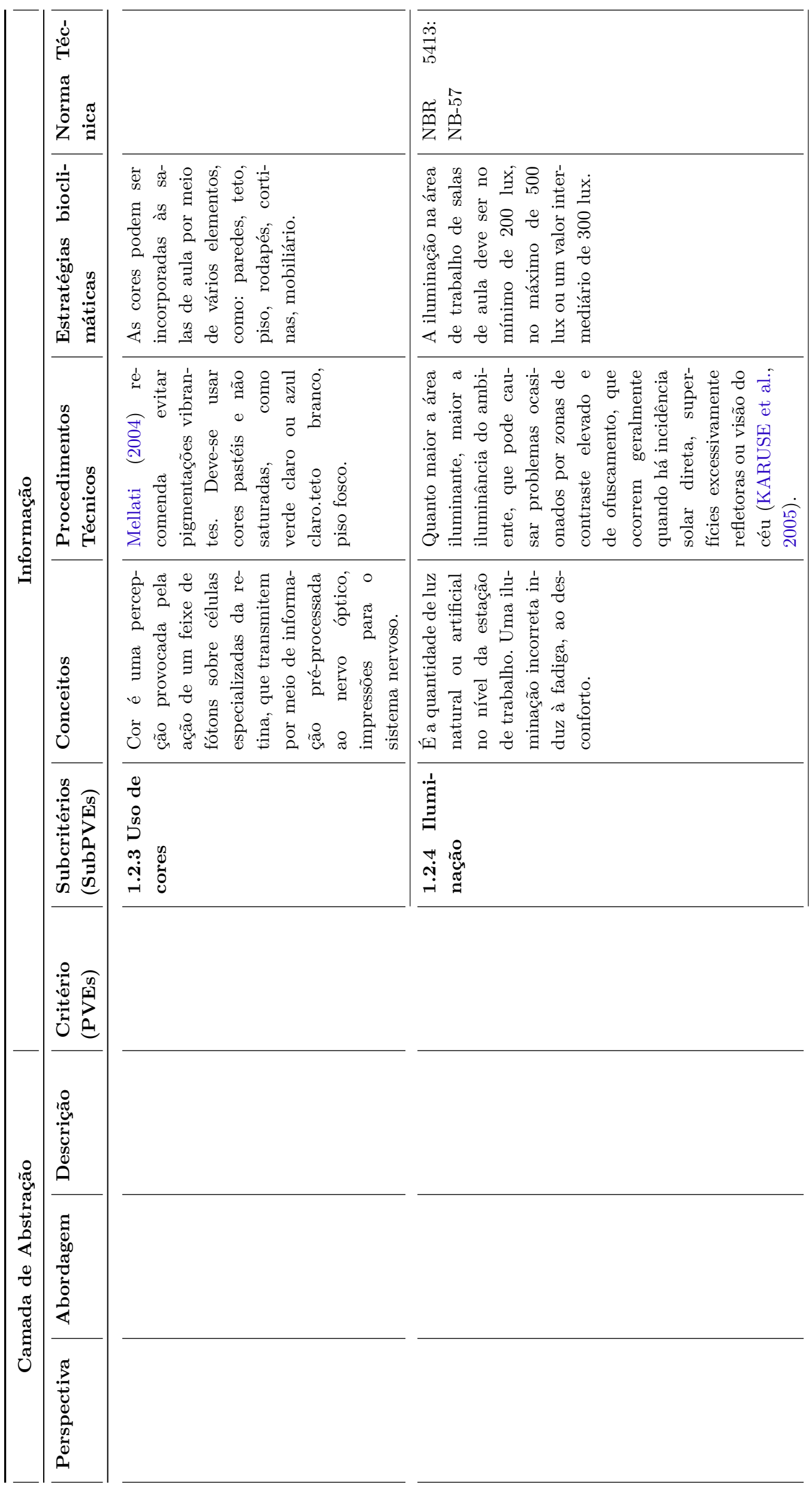


Capítulo 5. Caracterização do Universo de Estudo, Desenvolvimento da Pesquisa de Campo e Análise 302

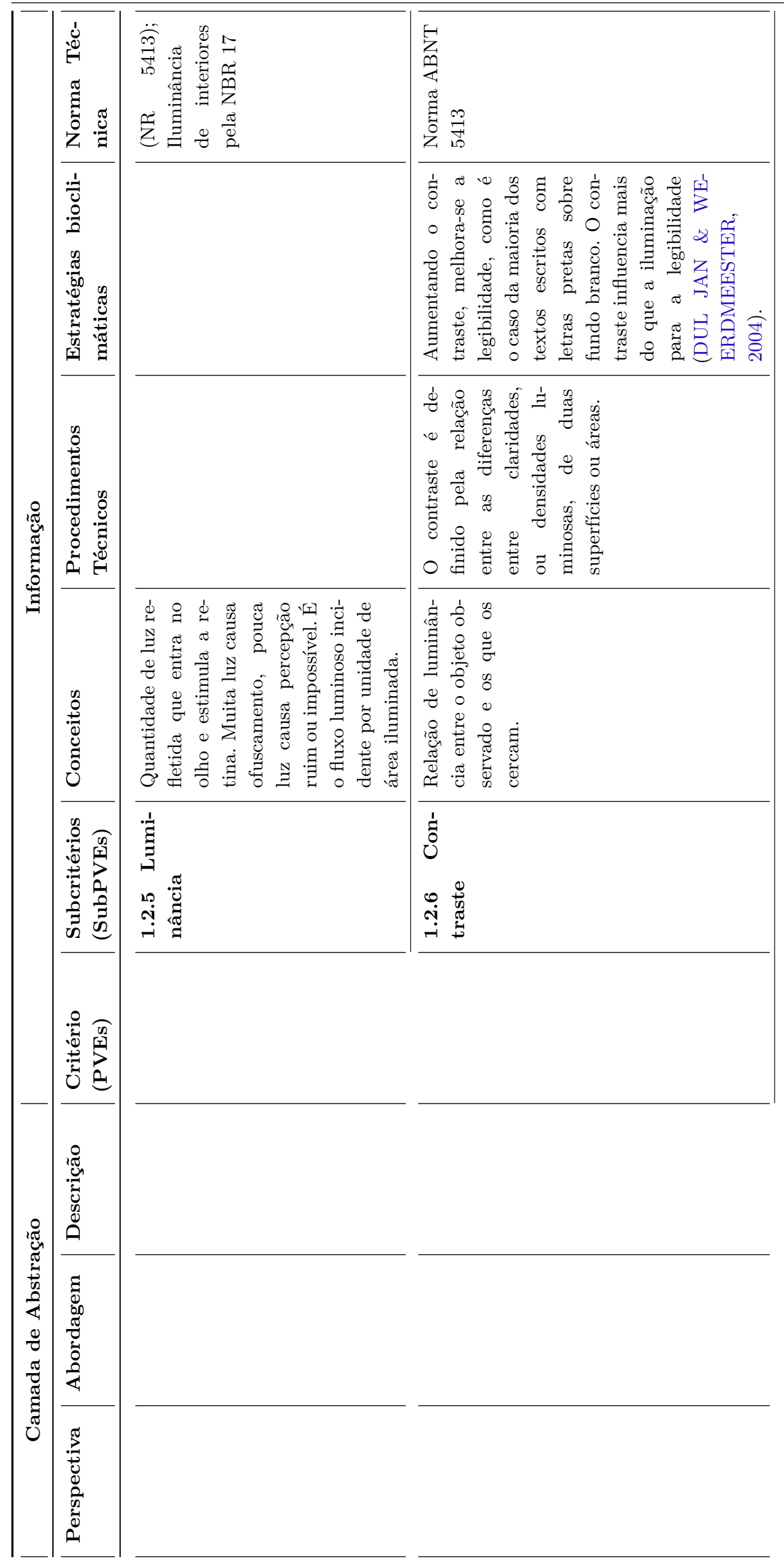




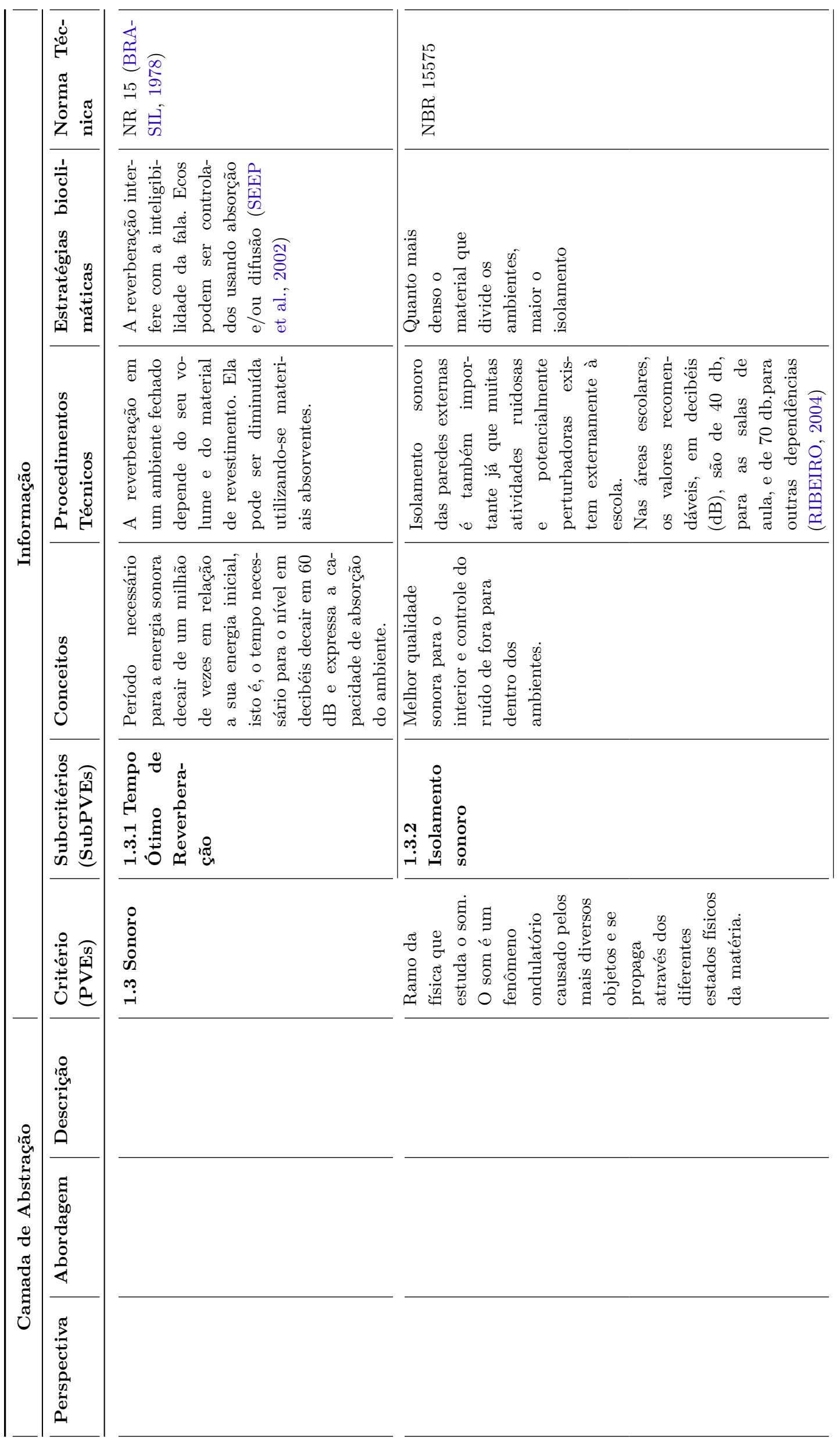


Capítulo 5. Caracterização do Universo de Estudo, Desenvolvimento da Pesquisa de Campo e Análise 304

dos Resultados

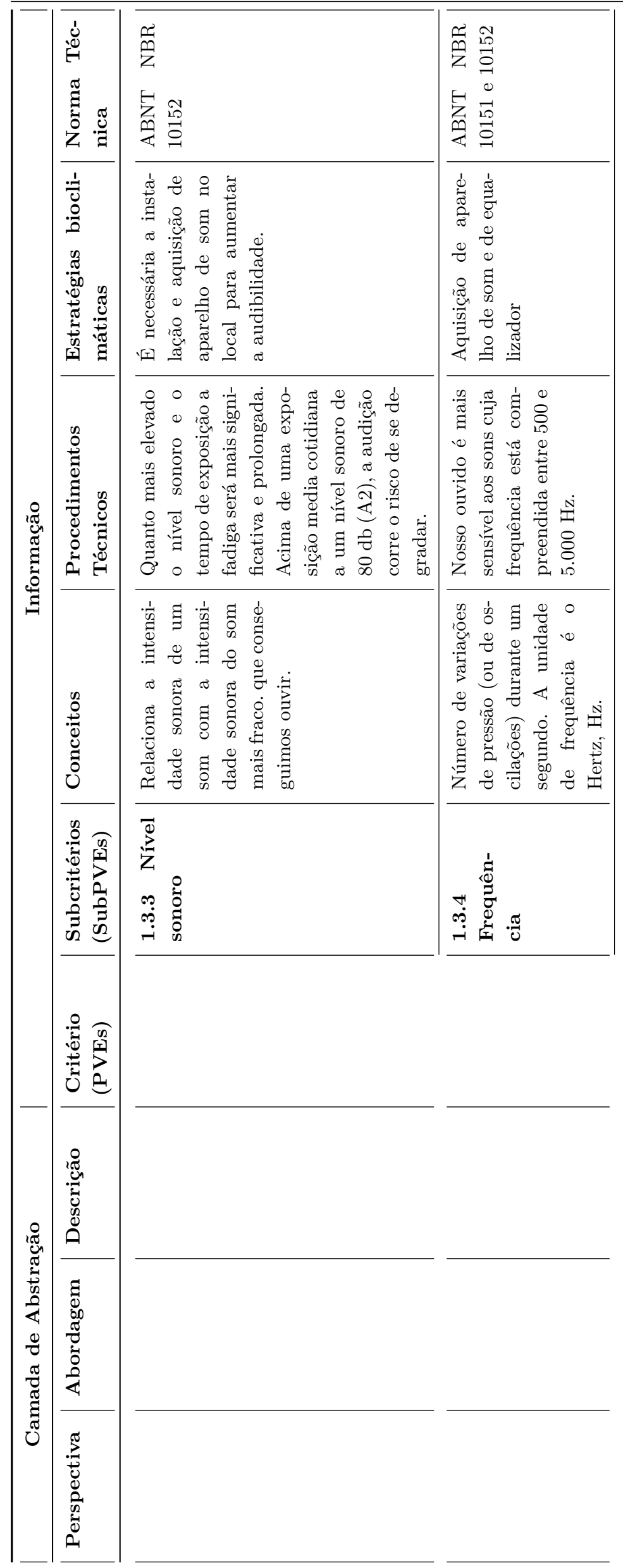




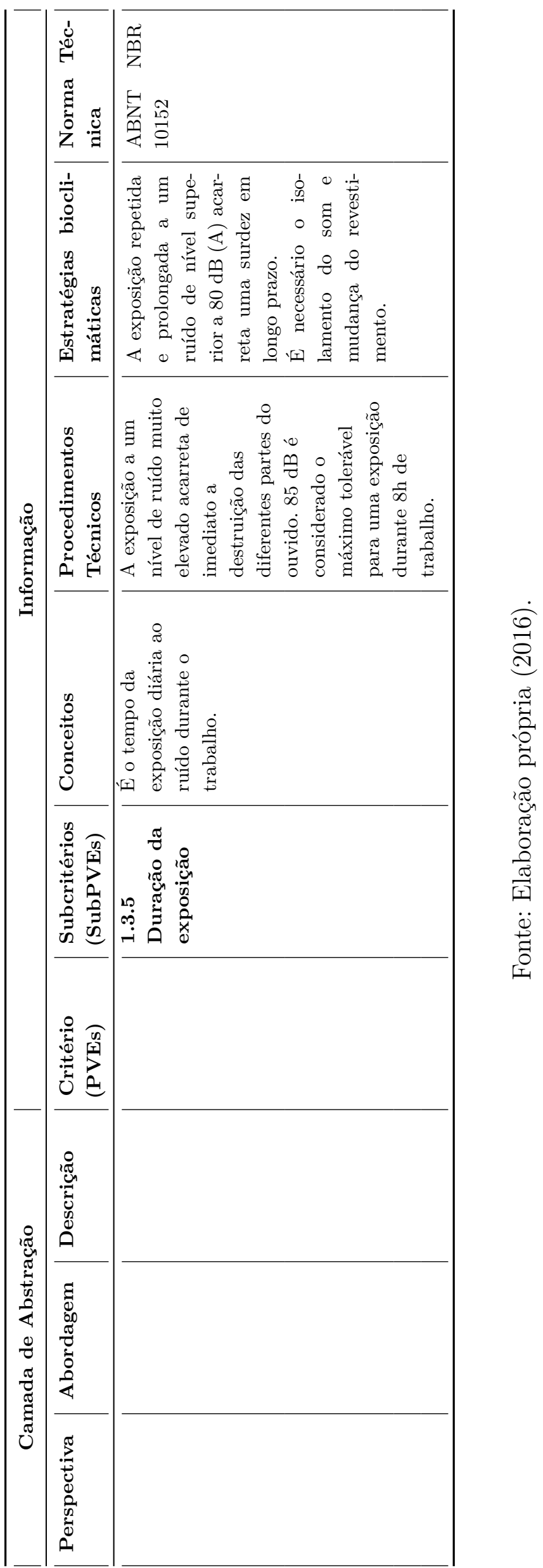




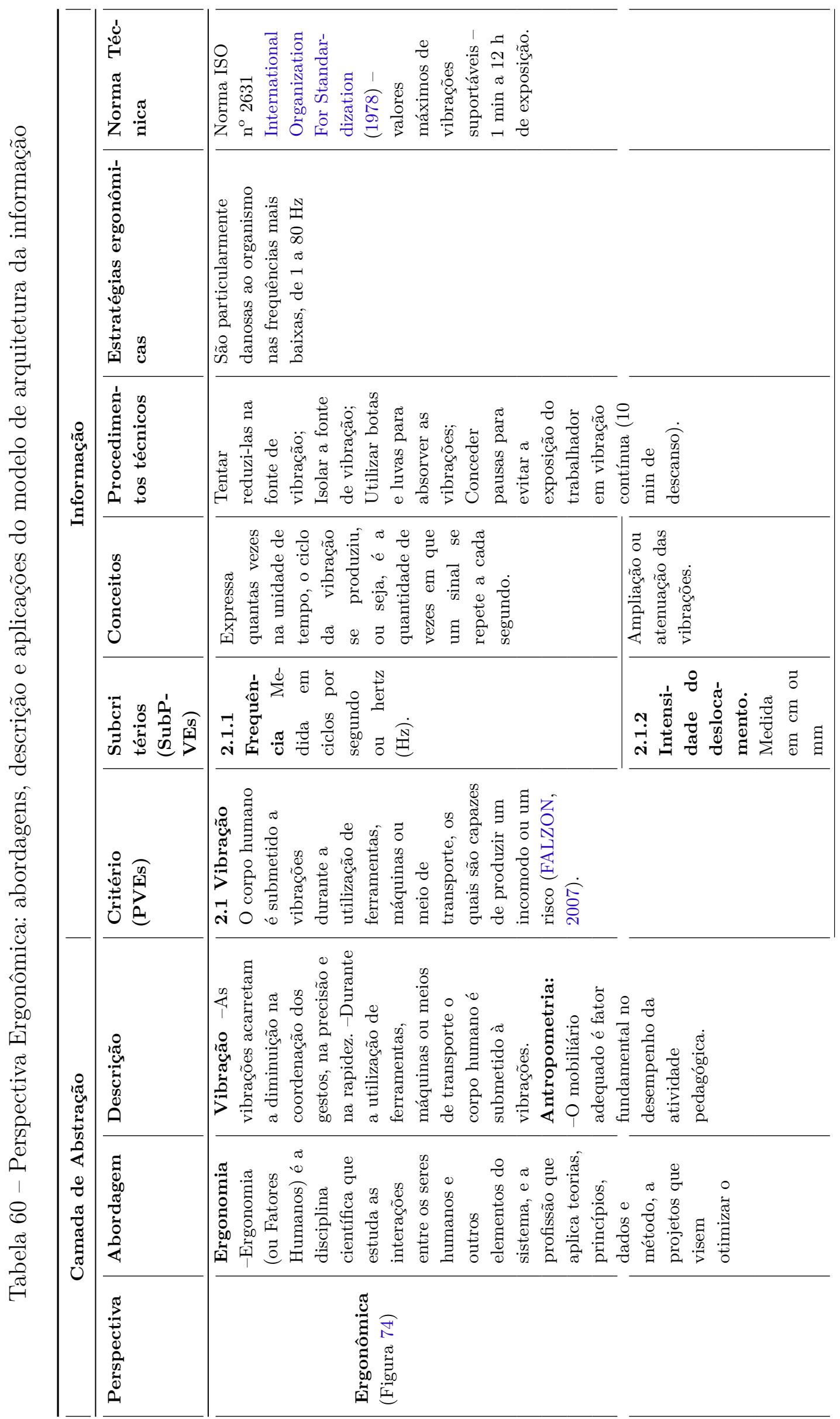




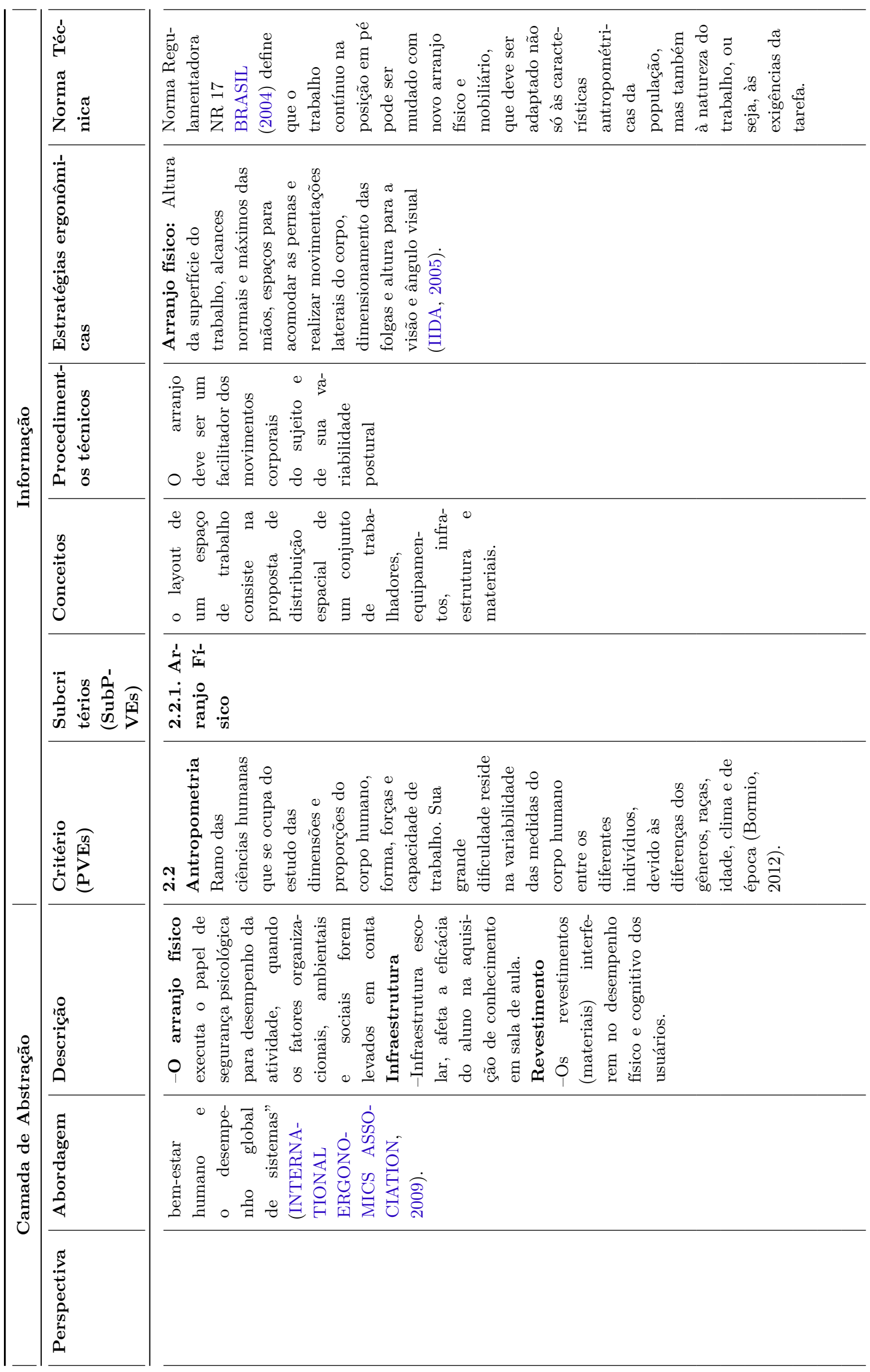




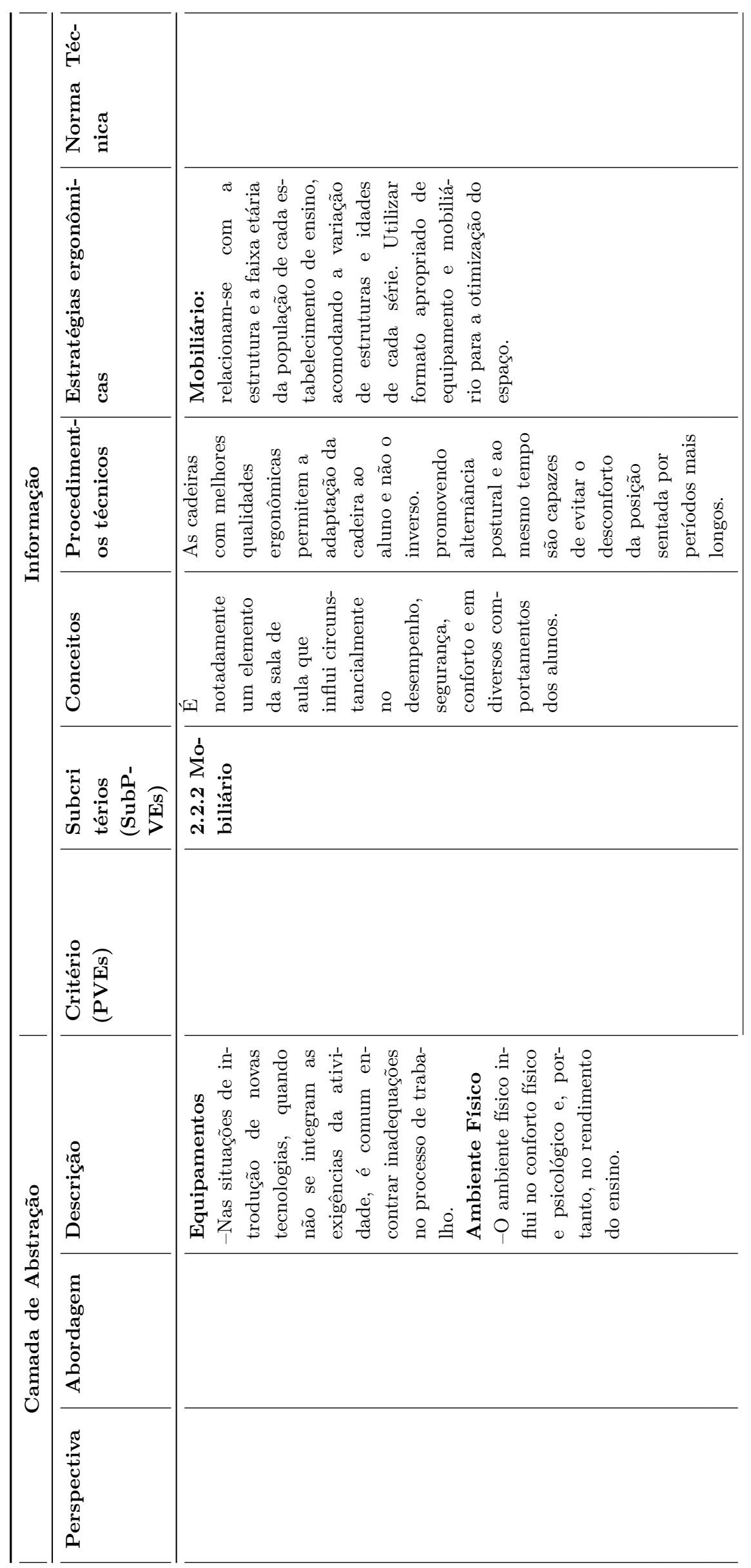




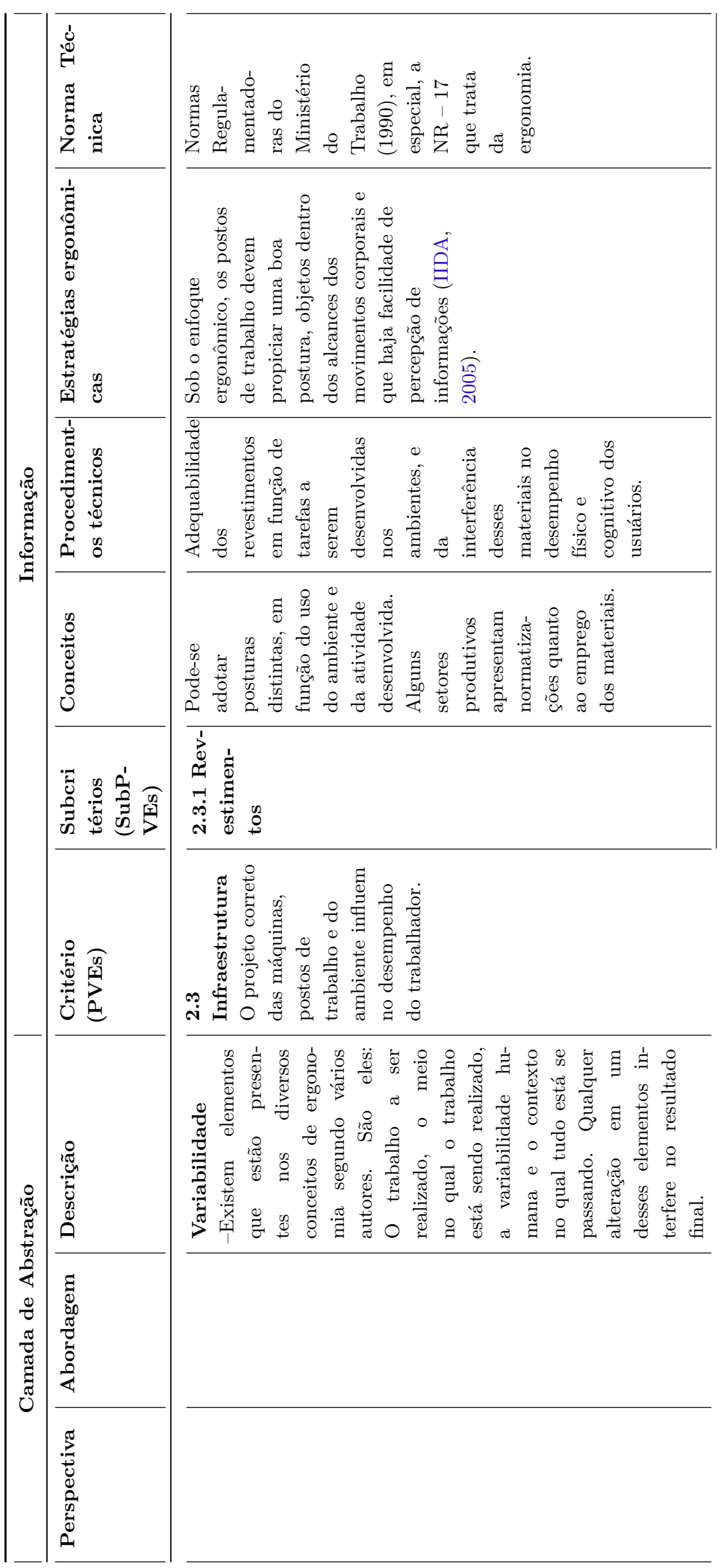




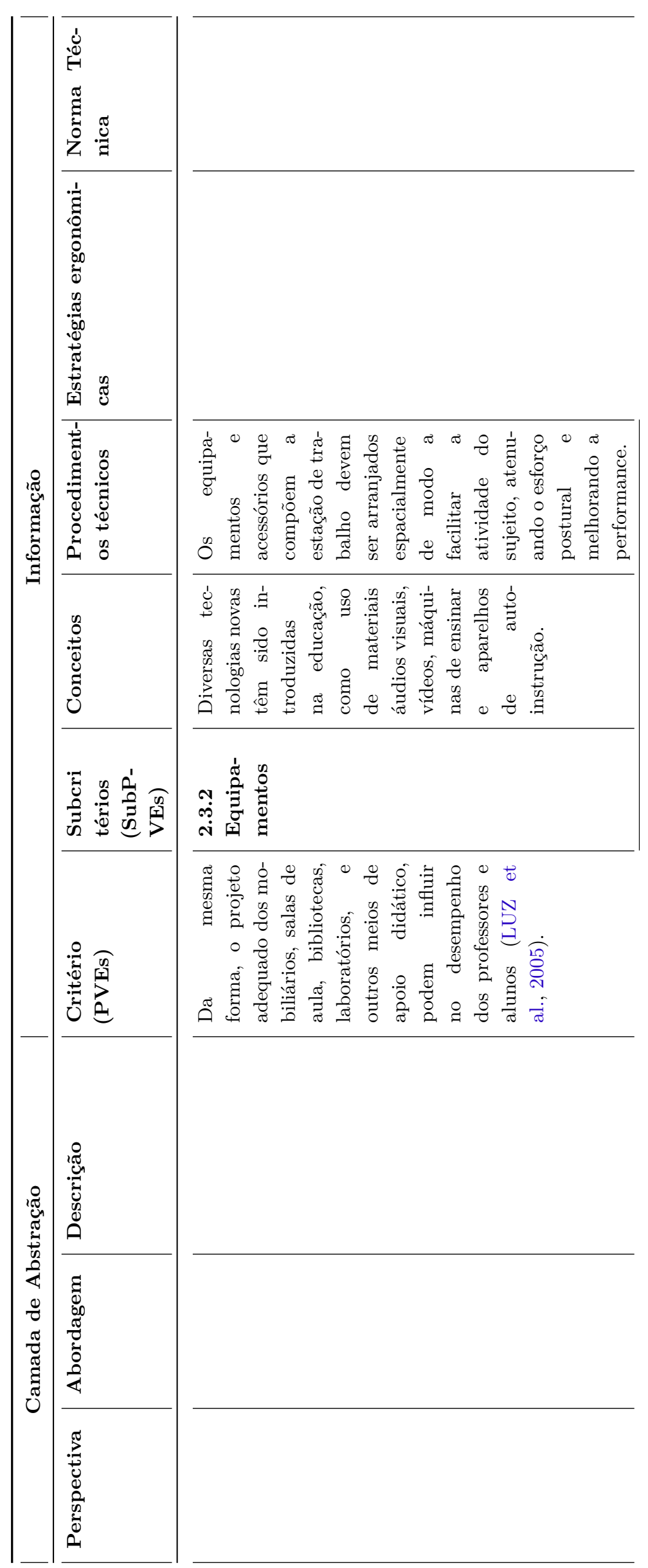




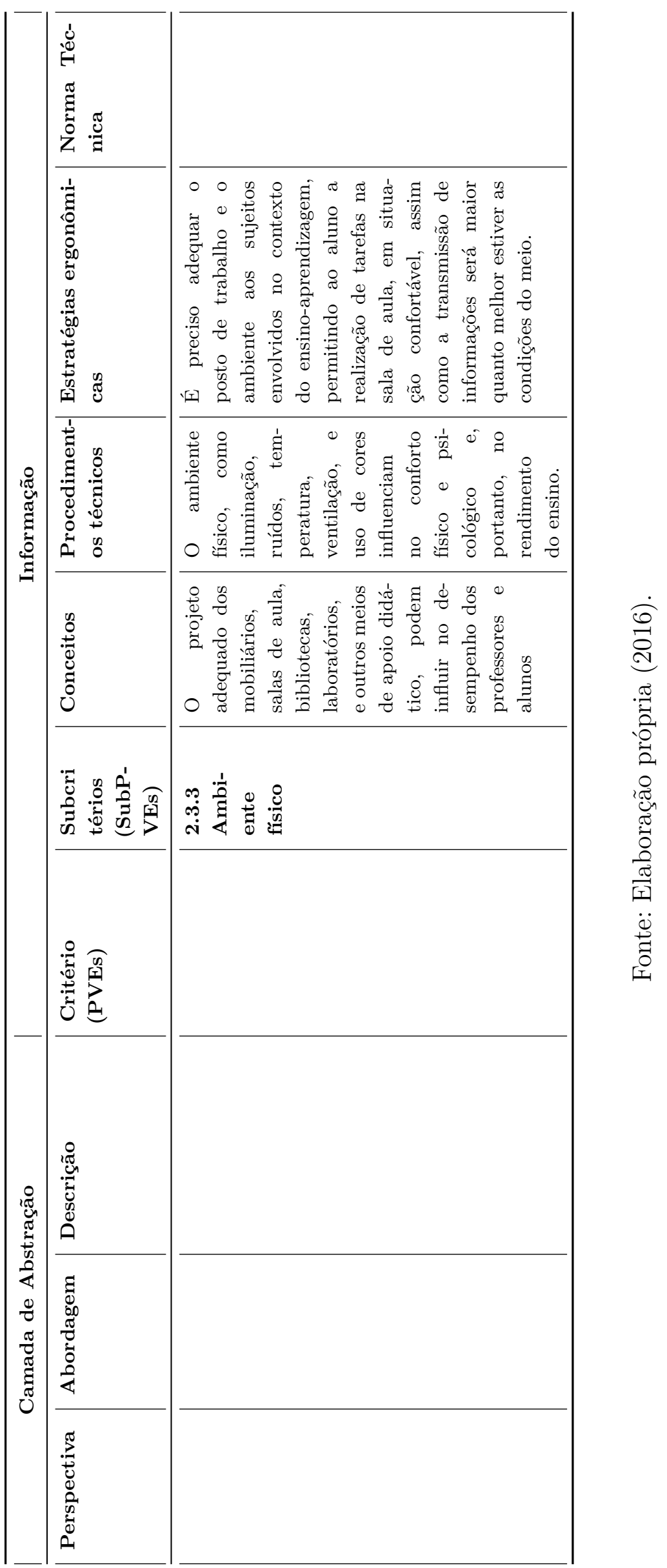


Capítulo 5. Caracterização do Universo de Estudo, Desenvolvimento da Pesquisa de Campo e Análise

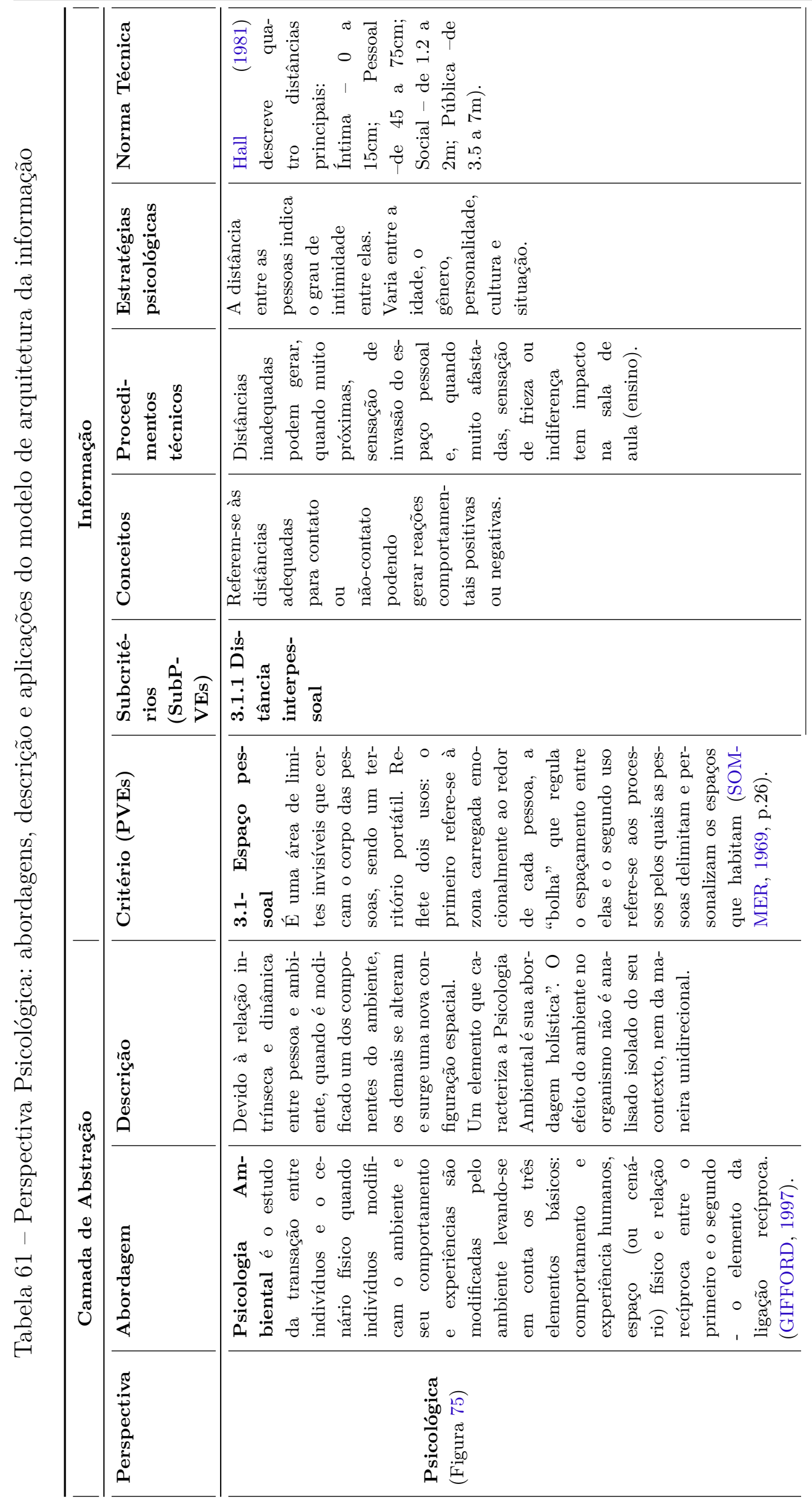




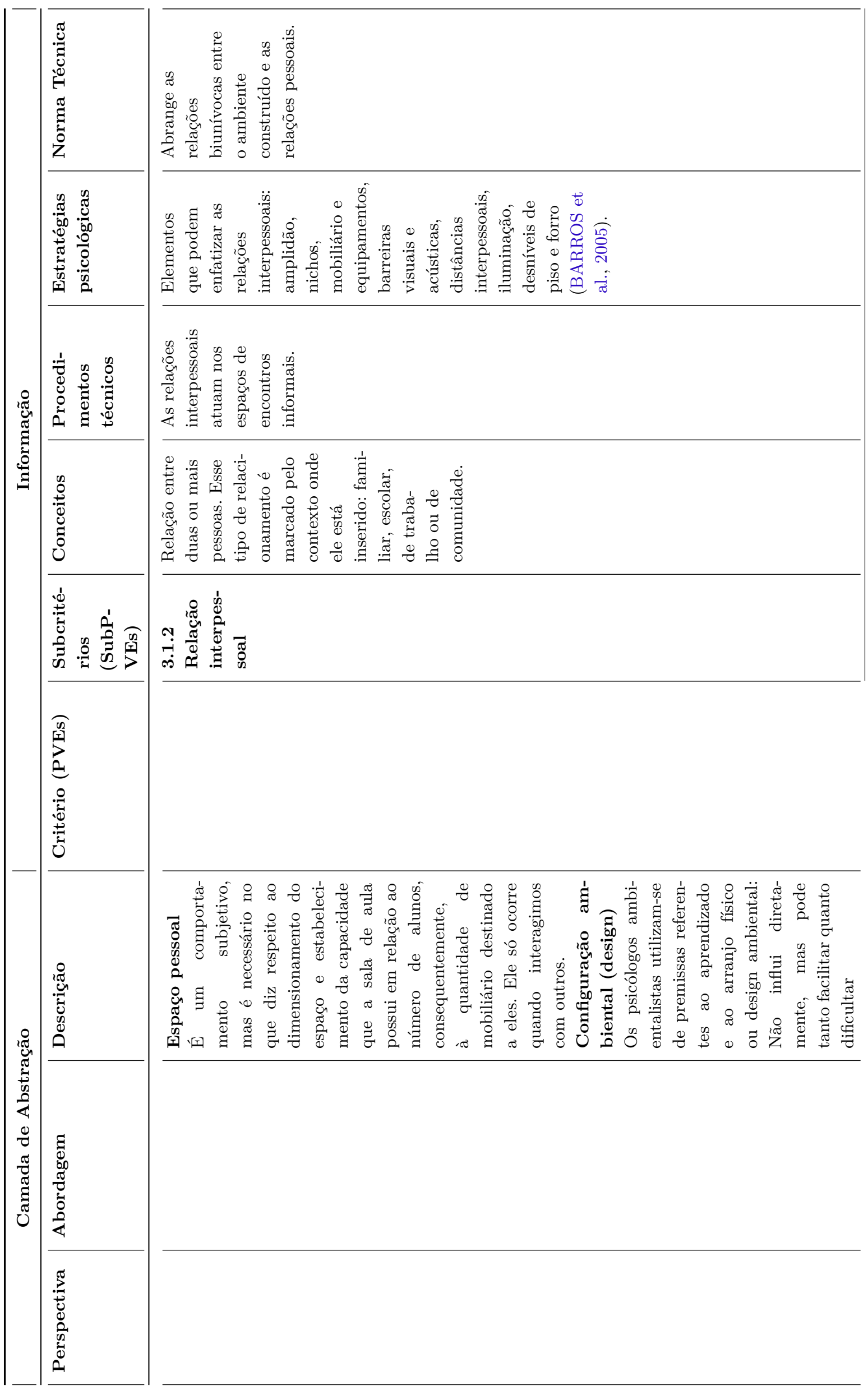


Capítulo 5. Caracterização do Universo de Estudo, Desenvolvimento da Pesquisa de Campo e Análise 314

dos Resultados

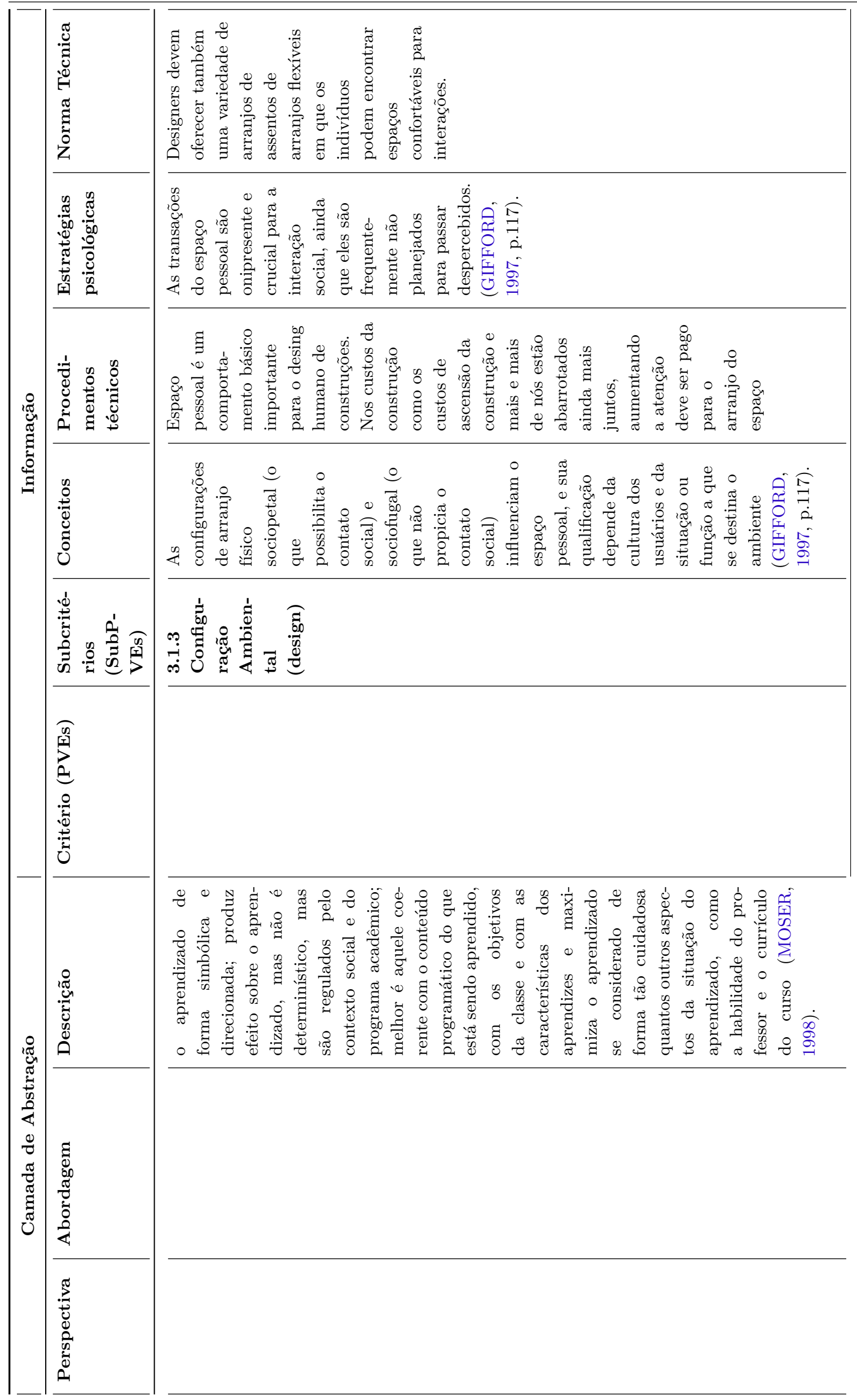




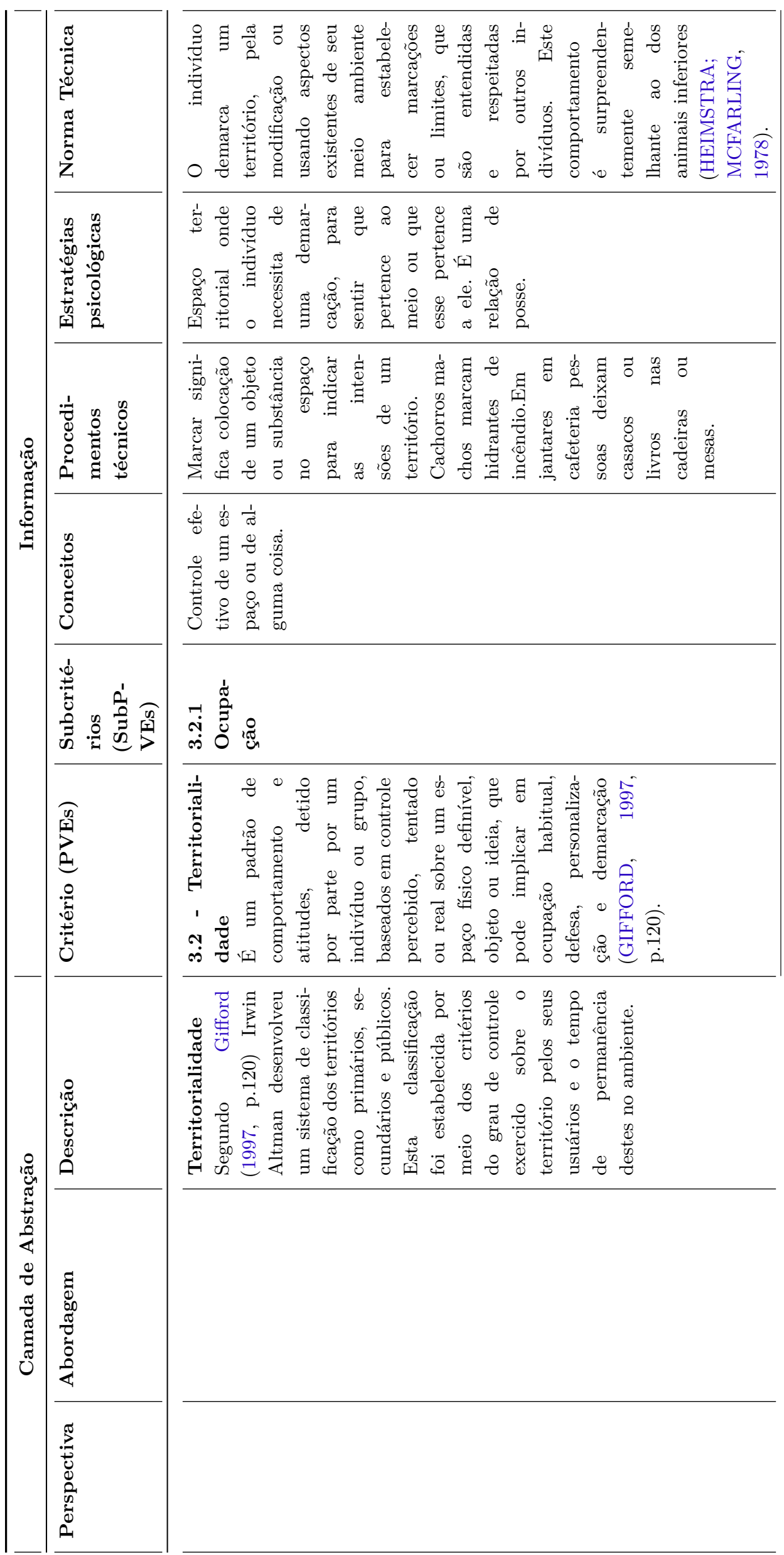


Capítulo 5. Caracterização do Universo de Estudo, Desenvolvimento da Pesquisa de Campo e Análise 316

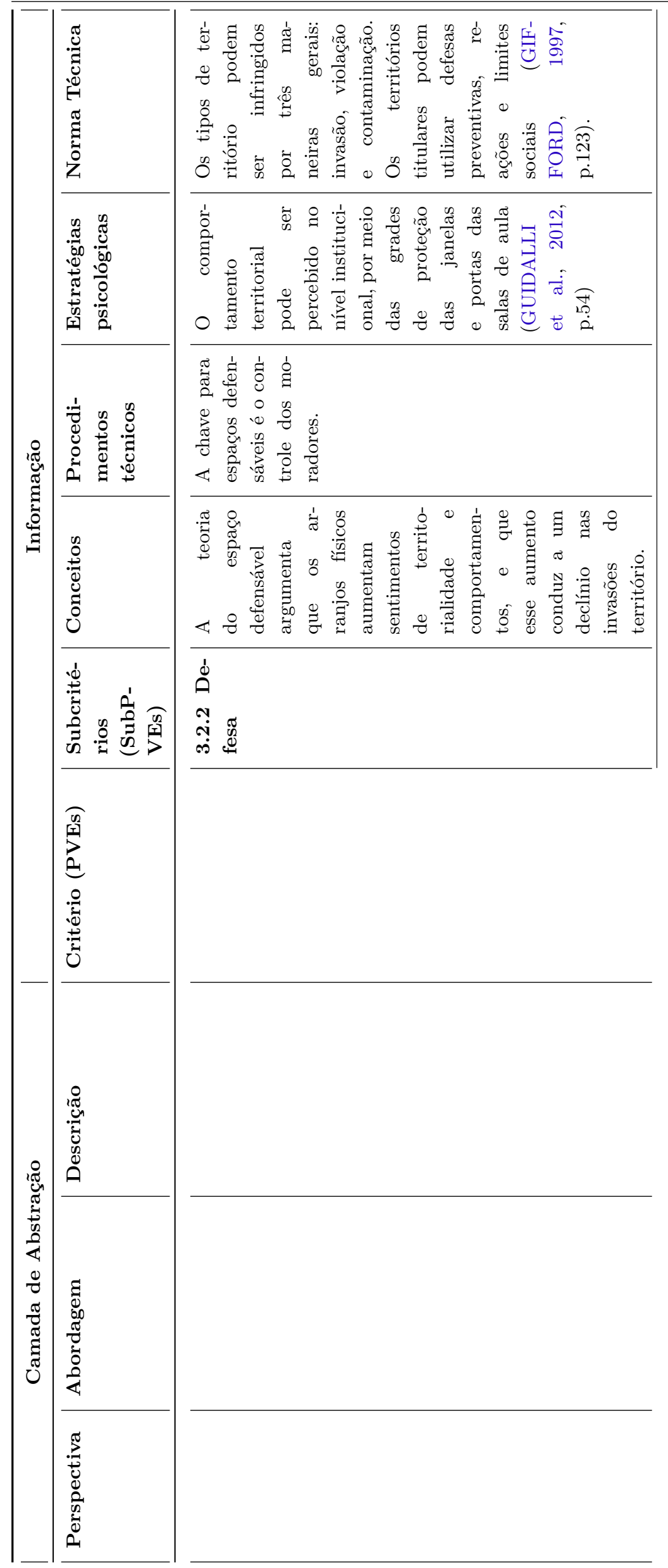




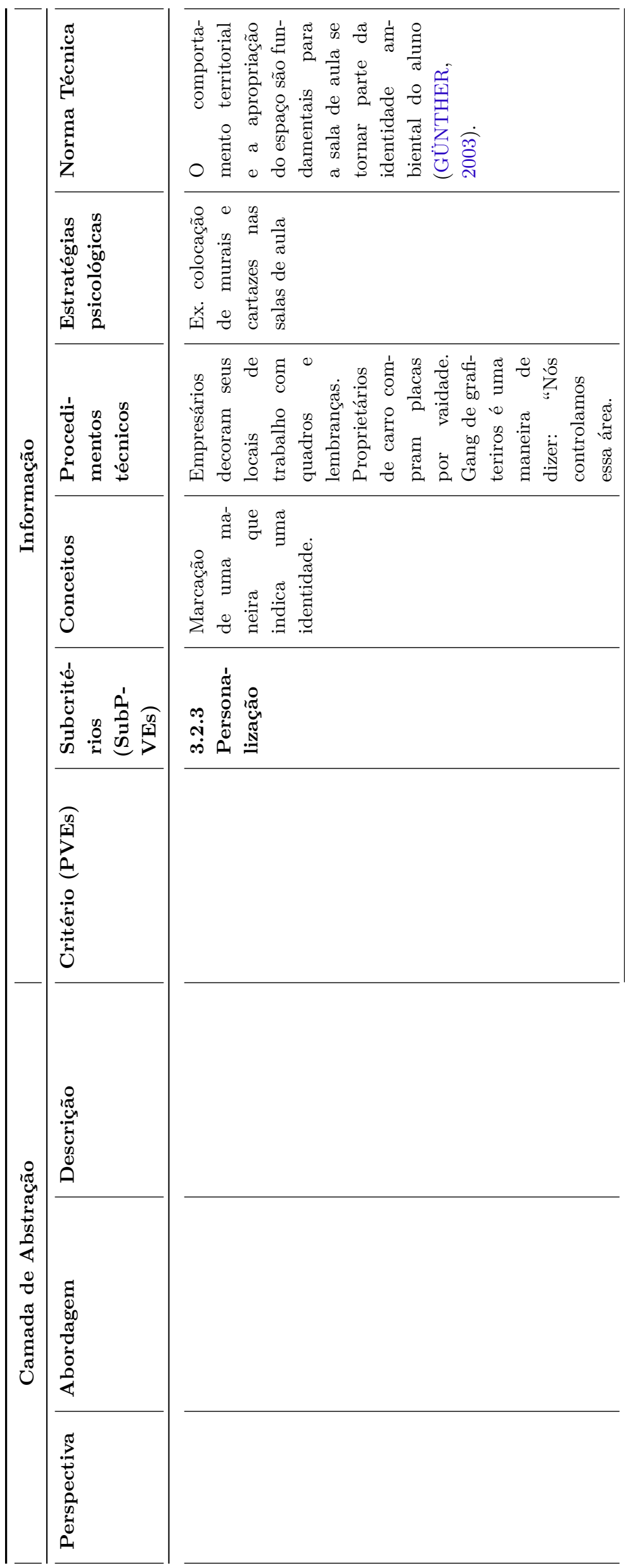




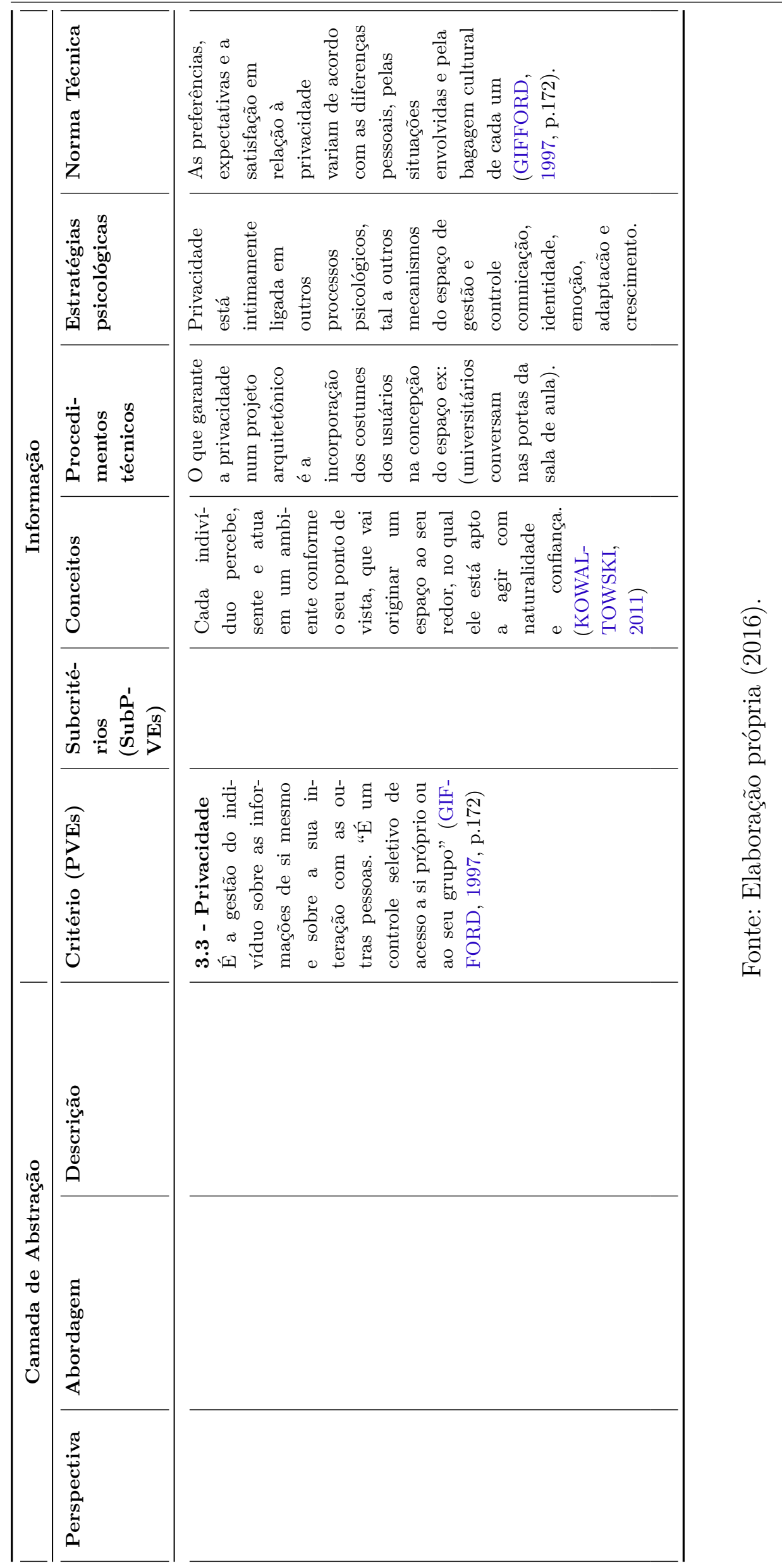




\section{Conclusões e Recomendações}

A partir do referencial teórico e metodológico adotado, apresenta-se os resultados da pesquisa empírica e conclusões sobre as questões motivadoras do estudo, bem como as contribuições e possibilidades de estudos futuros a partir das informações sobre as características do espaço arquitetônico facilitadoras do ensino-aprendizagem.

O problema abordado nesta pesquisa referiu-se à carência de procedimento de análise dos parâmetros a serem considerados na definição de programa de necessidades para a elaboração de projetos de arquitetura com fins educacionais, como a necessidade de que o espaço arquitetônico para a educação considere a relevância das implicações da inexistência de parâmetros, que possam apoiar a projetação de novos espaços ou sua requalificação para que a adequação real dos atributos do espaço não fiquem a cargo da "sensibilidade do arquiteto", e sim de um sistema que informe quais os atributos que ele deve utilizar para cada tipo de ensino, que serão desempenhados no espaço objeto do projeto arquitetônico.

Cabe nessas conclusões fazer referência às questões motivadoras da pesquisa, quais sejam:

- Quais os aspectos do espaço arquitetônico mais influenciam no aprendizado, se é que existem?

As principais questões foram identificadas a partir da análise citada no objetivo 1, do item 6.1, tais como os aspectos referentes ao conforto ambiental, ergonomia e psicologia ambiental.

- O espaço arquitetônico possui relevância no aprendizado de nível superior como o estabelecido nas pesquisas para o ensino infantil ?

Sim, a maioria dos autores, ao longo da pesquisa, confirmam que não foram identificados estudos sobre o aprendizado no nível superior, mas os aspectos acima referidos são gerais para adultos, jovens, crianças, etc. Essa pesquisa conclui que eles são relevantes também para o ensino superior, conforme objetivo 1, citado no item 6.1.

- A Arquitetura da Informação é uma ferramenta que possibilita a organização e o gerenciamento das informações do espaço arquitetônico para apoio à elaboração de projetos arquitetônicos escolares?

Após a identificação dos atributos e parâmetros facilitadores do ensino-aprendizagem, a Arquitetura da Informação se mostrou uma ferramenta de possibilidade de organização da informação, conforme objetivo 4, citado no item 6.1 . 


\subsection{Alcance dos objetivos}

O presente estudo teve por finalidade discutir a relevância do espaço arquitetônico como facilitador do processo de ensino-aprendizagem, identificar as características espaciais que promovem essa qualidade do espaço e definir atributos e parâmetros capazes de apoiar o desenvolvimento de programas de necessidade imprescindíveis na elaboração de projetos arquitetônicos para fins educacionais.

Quanto ao alcance dos objetivos específicos, seguem as considerações:

\section{Proceder à revisão bibliográfica no campo da Pedagogia, Arquitetura} e áreas disciplinares em que se mostrem relevantes suas relações para identificar atributos do espaço arquitetônico que favoreçam o aprendizado (capítulos 2 e 3 ).

Uma das questões motivadoras da pesquisa foi se o espaço arquitetônico possui, de fato, relevância no aprendizado de nível superior como o estabelecido nas pesquisas para o ensino infantil ? E quais os aspectos do espaço que constroem essa relação se ela existe - são os mesmos que para o ensino infantil ?

Nesse sentido, a primeira parte da pesquisa de âmbito teórico responde quando fica demonstrado que existem recorrências quanto à relevância dos campos disciplinares do Conforto Ambiental, Ergonomia e Psicologia Ambiental como aqueles que podem qualificar o espaço com contribuições que facilitam o ensino-aprendizagem. A construção do quadro de relações organiza essas relações e contribuições da pesquisa nos capítulos 2 e 3 (Tabela 24 - Campo disciplinar, atributos e parâmetros do espaço arquitetônicos necessários ao programa de necessidades para elaboração de projeto de Arquitetura).

Como referido ao longo do trabalho, grande parte dos estudos consultados se debruçam sobre o ensino infantil, o que levou a pesquisa a estabelecer um recorte de relevância sobre os aspectos que eram válidos para todos os tipos de públicos com vistas a focar em referências que pudessem ser utilizadas nos espaços universitários, onde certamente o campo do Conforto Ambiental e da Ergonomia se destacaram. Assim, a contribuição no campo acadêmico está em avançar para o estudo no ensino superior, além de ter confirmado o conjunto de atributos e parâmetros que possam orientar a elaboração dos projetos arquitetônicos em sua fase de definição do programa de necessidades, fornecendo insumos à projetação e à requalificação de espaços na universidade. Isso foi feito ao se aplicar a pesquisa empírica na Faculdade de Arquitetura e Urbanismo da Universidade de Brasília e se obter aceitação sobre a relevância dos atributos identificados na pesquisa teórica constante nos capítulos 2 e 3. 
2. Propor um modelo para avaliar as características/parâmetros identificados na referência bibliográfica com base na Metodologia Multicritério de Apoio à Decisão, de acordo com o juízo de valor dos especialistas em Conforto Ambiental, Ergonomia e Psicologia Ambiental (decisores) (capítulo $4)$.

Utilizando a Análise Multicritério de Apoio à Decisão foram avaliadas as características do espaço arquitetônico facilitadoras do ensino-aprendizagem identificadas na pesquisa. Assim, na pesquisa realizada em um universo de 80 autores da literatura especializada, utilizados para levantar os critérios facilitadores do ensino-aprendizagem, foi modelado um questionário aplicado no caso da FAU/UnB, o qual atingiu resultado satisfatório, tomando o universo empírico 43 professores do curso de Arquitetura e Urbanismo da FAU/UnB (65\% de um universo de 65 professores).

A escolha da Metodologia Multicritério de Apoio à Decisão (MCDA-C) para construção do modelo de avaliação mostrou-se adequada por contemplar a validação de um tema complexo que envolveu múltiplos critérios e subcritérios (atributos e parâmetros) do espaço arquitetônico facilitadoras do ensino-aprendizagem para elaboração de programa de necessidades com fins educacionais. A construção do modelo MCDA adaptado ao problema de pesquisa e à formulação do questionário se encontram no capítulo 4.

3. Aplicar o modelo MCDA-C com os professores do curso de Arquitetura e Urbanismo para ajustar parâmetros identificados na referência bibliográfica e validar sua relevância no ensino de arquitetura (capítulo 5).

O tratamento dos dados com apoio dos softwares Hiview3 e Macbeth, suportados pelo modelo de avaliação multicritério, possibilitou avaliar quantitativamente e com exatidão as condições de análise e avaliação dos critérios definidos por autores da literatura e se encontram no capítulo 5 da tese.

Atender à questão colocada de reportar essas informações para o projeto arquitetônico levou à recuperação de conceitos funcionais do espaço arquitetônico, programa arquitetônico que resultou na identificação de modelos e métodos de autores nacionais e internacionais, os quais apresentam parâmetros imprescindíveis para que no programa de necessidades seja possível obter maior objetividade na atividade do arquiteto e, apoiados nesses modelos, adaptaram-se os requisitos funcionais identificados para os espaços arquitetônicos que propiciem facilidade ao ensino-aprendizagem.

4. Propor um modelo de Arquitetura da Informação aplicável a ambientes informacionais de natureza educacional, que seja capaz de ordenar, organizar e gerenciar os parâmetros a serem considerados na definição de 


\section{programa de necessidade para a elaboração de projetos de arquitetura com fins educacionais (capítulo 5).}

Para fins de elaboração do programa de necessidades, foi definido um modelo de arquitetura da informação com principais critérios identificados por diversos autores da literatura e validados pela pesquisa de campo realizada com os professores da Faculdade de Arquitetura e Urbanismo da Universidade de Brasília, constante do capítulo 5 .

A pesquisa avançou, ainda, na definição de melhor desempenho que cada atributo afeto a essas áreas possui, e estabelece uma paraâmetrização, possibilitando sua inserção na definição do programa de necessidades para atender à elaboração de projetos arquitetônicos. Nesse sentido, responde a outra questão motivadora que diz respeito à possibilidade de a arquitetura da informação ser uma ferramenta que possibilita a organização e o gerenciamento das informações do espaço arquitetônico para apoio a elaboração de projetos arquitetônicos escolares que se encontram no capítulo 5 .

Vale destacar que os ajustes devem ser realizados para a realidade de cada contexto de curso na universidade, deve ser realizada por meio de modelo de avaliação multicritério, a partir de uma metodologia que estruture questionários a serem aplicados ao corpo docente e discente, em que são listados atributos e conceitos em discussão para identificar a relevância para contextos de ambientes de ensino diferenciados.

\subsection{Análise do programa de necessidades da FAU/UnB}

Referente à requalificação da Faculdade de Arquitetura e Urbanismo da Universidade de Brasília, mostra-se, pela pesquisa, que os atributos e parâmetros dos campos disciplinares da Ergonomia e da Psicologia Ambiental analisados neste estudo não foram contemplados no programa de necessidades da FAU/UnB de um modo satisfatório, sendo avaliados pelos docentes do curso de Arquitetura e Urbanismo como importantes para o ensino-aprendizagem, impactando na elaboração do programa de necessidades e, consequentemente, no projeto arquitetônico, constante no capítulo 5.

Na Tabela 65 - Diretrizes para Programa de Necessidades da FAU/UnB, apresentada no Apêndice A, verifica-se que foi realizado, na verdade, um pré-dimensionamento dos espaços arquitetônicos da FAU/UnB.

Na Tabela 49 descrevem-se os espaços de ensino-aprendizagem da FAU/UnB com suas atividades/funções, que são analisadas levando em consideração o programa de necessidades descrito na Tabela 65 (Apêndice A). 
Na presente pesquisa, constata-se que os espaços da FAU para ensino-aprendizagem contemplam parâmetros de Conforto Ambiental conforme o programa de necessidades atribuído pelo coletivo. Ao mesmo tempo, não contemplam todos os parâmetros sobre o Conforto Ambiental (térmico, lumínico e sonoro) apresentados nesta pesquisa.

$\mathrm{Na}$ análise dos resultados, ficou evidente que:

\section{- Campo disciplinar Conforto Ambiental}

Para o campo disciplinar do Conforto Ambiental, os atributos e parâmetros a seguir não foram contemplados no programa de necessidades da FAU/UnB:

a) Conforto térmico - Umidificação, Resfriamento evaporativo, Massa térmica e Ar-condicionado, tratados na seção 5.4.1.1 - Conforto Ambiental - Conforto térmico PVE 1.1.

b) Conforto lumínico - Mecanismo de controle, Reforço no iluminamento, Luminância e Contraste, tratados na seção 5.4.1.1 - Conforto Ambiental - Conforto lumínico PVE 1.2.

c) Conforto sonoro - Tempo ótimo de reverberação, Nível sonoro, Frequência, Duração da exposição, tratados na seção 5.4.1.1 - Conforto Ambiental -Conforto sonoro PVE 1.3.

\section{- Campo disciplinar Ergonomia}

Para Patterson (2010), a Ergonomia e a Arquitetura unem-se pelo planejamento e pela investigação das atividades, considerando tanto a visão sistêmica do espaço quanto o processo de concepção arquitetônica desse sistema. Por meio da Ergonomia, é possível entender as atividades humanas e os seus requisitos de desenho. Por meio da arquitetura, é possível oferecer os elementos para que as atividades se realizem.

Segundo Bins Ely (2003), a partir da junção Arquitetura e Ergonomia poder-se-ia criar ambientes atrativos e funcionais, que realmente contribuíssem para o bem-estar dos usuários, durante o desempenho de suas atividades. A melhor estratégia para essa junção seria durante o exercício projetual, momento em que os princípios da Ergonomia seriam incorporados ao projeto de ambientes físicos.

Nessa direção, a autora pondera que toda atividade humana exige um determinado ambiente físico para sua realização. Portanto, se considerarmos tanto a diversidade de atividades quanto a diversidade humana - diferenças nas habilidades, por exemplo podemos entender que as características do ambiente podem dificultar ou facilitar a realização das atividades. Quando um ambiente físico responde às necessidades dos usuários 
tanto em termos funcionais (físico/cognitivos) quanto formais (psicológicos), certamente terá um impacto positivo na realização das atividades.

Villarouco (2002) destaca que, apesar de alguns esforços empreendidos neste segmento, o que se verifica é que, ainda hoje, os estudos de arquitetura e projetos de espaço ressentem-se das abordagens ergonômica e cognitiva, que ficam ausentes no processo de formação de muitos arquitetos.

Fonseca (2004), considera os aspectos psíquicos do indivíduo e que estão relacionados com as atividades a serem realizadas e com a aparência geral do local de trabalho outro aspecto fundamental, que deve ser considerado no planejamento de locais de trabalho e expresso na sua forma arquitetônica. Afirma também que a projetação de locais de trabalho é uma atividade complexa que envolve a síntese de uma gama extensa de dados. É importante relacionar os dados gerais relativos à estrutura, às texturas, aos fluxos e à ordenação espacial com a organização do trabalho.

Abrahão e Pinho (2002) afirmam que, a variabilidade na natureza e na forma como o trabalho se apresenta para o sujeito, associada à sua história pessoal, determina como são ativados os mecanismos psíquicos que possibilitam uma resposta apropriada à situação. Isso não significa, necessariamente, que a subjetividade foi integrada no processo de análise.

Referente ao Conforto Ambiental, as recomendações das normas vigentes devem servir apenas como elementos norteadores e de padrões mínimos a serem obtidos. A definição real deverá advir de um cuidadoso confronto entre aqueles padrões e as necessidades captadas dos usuários, para os quais alguns padrões mínimos podem parecer inadequados.

Para o campo disciplinar da Ergonomia, os atributos e parâmetros a seguir não foram contemplados no programa de necessidades da FAU/UnB:

a) Vibração - Frequência e Intensidade

Para Falzon (2007), toda tarefa se desenvolve num certo contexto de exposição, do operador aos ruídos e vibrações, ao microclima do posto e à iluminação deste.

Este item foi tratado no capítulo 5, na seção 5.4.1.2 Ergonomia - Vibração PVE 2.1 e no capítulo 3.

b) Antropometria - Arranjo físico e Mobiliário.

Os espaços de ensino-aprendizagem citados na Tabela 49 do capítulo 5 não foram contemplados na Ergonomia, que tem referência na análise das atividades. No intuito de adequar o trabalho ao homem, Almeida (1997) sugere que devemos considerar tanto as características dos indivíduos quanto dos fatores que envolvem suas atividades, colocando-as no centro das decisões de projeto. 
Segundo Iida (2005), para garantir o conforto dos alunos, que geralmente permanecem sentados durante longos períodos, é necessário fazer estudo da postura e das dimensões antropométricas, para se projetar adequadamente o "posto" de trabalho escolar. O autor afirma que a projetação do mobiliário e de postos de trabalho deve estar em perfeita consonância com os padrões do usuário, não sendo suficiente a adoção de valores referentes ao homem médio.

Para o autor, a carteira escolar é considerada como um posto de trabalho para as crianças, que passam de $25 \%$ a $30 \%$ do tempo em que estão acordadas na escola. Para Carvalho (2001), as cadeiras com melhores qualidades ergonômicas permitem a adaptação da cadeira ao aluno, e não o inverso, promovendo alternância postural, evitando o desconforto da posição sentada por períodos mais longos.

Este item foi tratado no capítulo 5, na seção 5.4.1.2 Ergonomia - Antropometria PVE 2.2 e no capítulo 3, seção 3.1.2.1.

c) Infraestrutura - Revestimento, Equipamento e Ambiente físico.

Segundo Luz et al. (2005), a ergonomia de ensino é a interação física e psíquica dos alunos em relação à estrutura escolar, equipamentos, materiais, ambiente, metodologia e avaliação, e a falta da infraestrutura escolar afeta a eficácia do aluno na aquisição de conhecimento em sala de aula.

Para Iida (2005), o projeto correto das máquinas, postos de trabalho e do ambiente influem no desempenho do trabalhador. Da mesma forma, o projeto adequado dos mobiliários, salas de aula, bibliotecas, laboratórios e outros meios de apoio didático pode influir no desempenho dos professores e alunos, sendo que a adequação do arranjo físico está diretamente relacionada ao tipo de tarefa realizada.

O ambiente físico, como a iluminação, ruídos, temperatura, ventilação e uso de cores, influi no conforto físico e psicológico e, portanto, no rendimento do ensino.

Abrahão e Pinho (2002) discorrem sobre os efeitos da informatização, mostrando sua importância, relacionando equipamentos e o ambiente físico para compreensão do trabalhador como ator no seu contexto de trabalho.

Para as autoras, a introdução de novas tecnologias impõe maiores exigências de natureza cognitiva ao trabalhador, principalmente em relação aos processos decisórios envolvidos no controle do processo de trabalho e na resolução de problemas dele decorrente, afirmando que o enfoque adotado pela Ergonomia, que tem na análise da atividade em situação real o seu fio condutor, possibilita decompor a atividade de trabalho e recompô-la sob novas bases nos seus 
componentes físicos e cognitivos, levando em conta o princípio da variabilidade que rege toda a concepção ergonômica.

Este item foi tratado no capítulo 5, na seção 5.4.1.2 Ergonomia - Infraestrutura PVE 2.3 e no capítulo 2, seção 2.4.1.1.

\section{- Campo disciplinar da Psicologia Ambiental}

Segundo Elali (1997), a Psicologia Ambiental é um espaço comum entre a Arquitetura e a Psicologia tradicional no que se refere à relação pessoa-ambiente, constituindo-se locus onde a soma entre o conhecimento psicológico e o arquitetônico pode alimentar a produção de um ambiente mais humanizado e ecologicamente coerente.

Para Ornstein (1992), Ornstein (1997) sob a ótica de se enfrentar cada problema de modo isolado, o edifício deixa de ser encarado apenas a partir das suas características físicas (construtivas) e passa a ser avaliado/discutido enquanto espaço "vivencial", sujeito à ocupação, leitura, reinterpretação e/ou modificação pelos usuários, ou seja, ao estudo de aspectos construtivos e funcionais do espaço construído acrescenta-se à análise comportamental e social essencial à sua compreensão.

Para o campo disciplinar da Psicologia Ambiental, os atributos e parâmetros a seguir não foram contemplados no programa de necessidades da FAU/UnB:

a) Espaço pessoal - Distância interpessoal, Relação interpessoal e Configuração ambiental (design).

Gifford (1997) afirma que o espaço pessoal pode ser predito, em parte, quando se conhecem as características pessoais dos indivíduos que influenciam na determinação deste espaço, entretanto depende do arranjo feito entre essas influências para cada situação em particular. As configurações de arranjo físico sociopetal (o que possibilita o contato social) e sociofugal (o que não propicia o contato social) influenciam o espaço pessoal, e sua qualificação depende da cultura dos usuários e da situação ou função a que se destina o ambiente.

Na seção 3.1.3.1, capítulo 3, Weinstein (1979) discorre sobre a importância do arranjo físico, aqui entendido como configuração ambiental (design).

A importância da distância interpessoal para a arquitetura é citada por Barros et al. (2005), em que identificaram alguns elementos que podem enfatizar as relações interpessoais. São elas: amplidão, nichos, mobiliário e equipamentos, barreiras visuais e acústicas, distâncias interpessoais, iluminação, desníveis de piso e forro - os quais, por sua vez, são caracterizados por subelementos como pé-direito, materiais de acabamento, vista exterior.

Este item foi tratado no capítulo 5, na seção 5.4.1.3 Psicologia - Espaço Pessoal PVE 3.1 e no capítulo 3, seção 3.1.3.1. 
b) Territorialidade - Ocupação, Defesa e Personalização

Para Gifford (1997), territorialidade é associada com uma variedade de comportamentos: personalização, marca, agressão, dominio, controle, vencedor, ajudando e inação. Os mais comuns são a personalização e a marca.

O autor considera como fonte de ajuste física do território a teoria do espaço defensável (grau de controle do território e vigilância) e argumenta que os arranjos físicos aumentam sentimentos de territorialidade e comportamentos, e que esse aumento conduz a um declínio nas invasões do território.

Este item foi tratado no capítulo 5, na seção 5.4.1.3 Psicologia - Territorialidade PVE 3.2 e no capítulo 3 (seção 3.1.3.2).

c) Privacidade

O ambiente fisico desempenha um papel fundamental para facilitar o regulamento de privacidade; ele pode tornar a tarefa fácil ou forçar aqueles com poucos recursos arquitetônicos para tornarem-se criativos na busca de privacidade (GIFFORD, 1997).

Este item foi tratado no capítulo 5, na seção 5.4.1.3 Psicologia - Privacidade PVE 3.3 e no capítulo 3, seção 3.1.3.2.

\subsection{Contribuições}

A contribuição da pesquisa nessa área aponta para subsidiar os arquitetos com um modelo de organização da informação para a fase de definição do programa de necessidade, no qual constam dados relativos ao contexto do projeto com indicações de resultados espaciais que se podem alcançar e necessários à atividade de ensino, ou seja, a tradução das informações se dá por meio da definição dos requisitos funcionais.

Apesar do fato de que a subjetividade é parte inerente ao processo de projeto, um procedimento metodológico é importante para aumentar as bases científicas deste projeto. Nessa direção, a pesquisa vem mostrar a necessidade de se utilizar uma metodologia para a elaboração de programa de necessidade que contemple informação de parâmetros facilitadores do ensino-aprendizagem como norteadora para arquitetos e profissionais da área de arquitetura.

A partir das conclusões acima, foi confirmada a hipótese orientadora da pesquisa: a pesquisa parte da hipótese de que o espaço arquitetônico pode colaborar para um melhor desempenho das funções de ensino-aprendizagem, existindo atributos espaciais identificáveis e capazes de parametrização, que possibilitem a definição do programa de necessidades para atender à elaboração de projetos arquitetônicos. 
A pesquisa identificou variáveis e parâmetros gerais, que podem ser aplicados a diversos campos disciplinares (cursos ou faculdades), entretanto a validação ou peso para esses campos demandará a aplicação do método MCDA-C, para que reflita as especificidades exigidas pelo ensino e aprendizagem de cada área.

Em campos disciplinares (cursos ou faculdades) que não disponham de conhecimento sobre os atributos/parâmetros, como é o caso da Faculdade de Arquitetura e Urbanismo onde foi aplicada esta pesquisa, faz-se necessária uma etapa anterior à aplicação do método, qual seja o nivelamento de conceitos.

\subsection{Possibilidades de estudos futuros}

Como estudos futuros relacionados à tese, cabem todos os aprofundamentos acerca do fenômeno da informação no contexto das características do espaço arquitetônico facilitadoras do ensino-aprendizagem na Universidade, dos quais se propõe:

1. É recomendável um teste com arquitetos em fase de elaboração de programas de necessidades a fim de verificar se a propriedade do modelo de Arquitetura da Informação proposto é adequado, uma vez que este não foi validado.

2. Recomenda-se a realização de estudos para a fase de pós-ocupação, ou seja, para projetos já executados, para que possam ser confirmadas as assertivas de atributos e parâmetros aqui definidas.

3. O modelo de avaliação desenvolvido na pesquisa poderá ser utilizado em outras edificações escolares, sendo necessário um ajuste a cada realidade escolar.

4. Produção de artigos científicos sobre cada uma das perspectivas analisadas no modelo de Arquitetura da Informação para Programas de Necessidades - pedagógica, arquitetônica, ambiental, ergonômica e psicológica, destacando: investigação sobre a existência de outros campos disciplinares relevantes para o ensino-aprendizagem, sobre novos atributos e parâmetros espaciais de acordo com a recorrência obtida na visão dos pedagogos sobre a natureza do projeto escolar; como estabelecer um elo nas propostas entre as práticas pedagógicas e o projeto escolar; como integrar o currículo das escolas ao projeto dos ambientes destas; como humanizar os espaços arquitetônicos a partir de outros atributos e parâmetros; e como implementar o modelo de AI em sistemas de informação para auxiliar os usuários em suas atividades.

5. Com a aplicação da Metodologia Multicritério de Apoio à Decisão (MCDA-C), do ponto de vista operacional, é possível desenvolver aplicativo para gerenciar/organizar as informações referentes aos atributos e parâmetros facilitadores do ensino - aprendiazgem. 


\section{Referências}

ABADIÉ, V. D. M. et al. Análise e adequação do conforto térmico, acústico e lumínico de duas salas da unemat - campus renê barbour. 2009. Disponível em: $<$ http://revistamdc.files.wordpress.com/2009/07/victordanielmurilloabadie_cicau.pdf $>$. Acesso em: out. 2013. Citado 2 vezes nas páginas 124 e 128.

ABNT. Nbr 5413: Iluminância de interiores. Rio de Janeiro, 1992. Citado na página 120. ABNT. Nbr 15215-3 - iluminação natural - parte 3 - procedimentos de calculos para a determinação da iluminação natural em ambientes internos. Rio de Janeiro, 2005. Citado na página 120.

ABNT, N. 10151. Avaliação do Ruído em Áreas Habitadas Visando o Conforto da Comunidade, 1987. Citado na página 126.

ABNT, N. Nb 57 - iluminância de interiores. Rio de Janeiro, 1991. Citado 4 vezes nas páginas 99, 117, 119 e 120.

ABNT, N. 5413-iluminância de interiores. Rio de Janeiro, 1992. Citado na página 117.

ABNT, N. Nbr 12179 - tratamento acústico em recintos fechados. Rio de Janeiro, 1992. Citado na página 263.

ABNT, N. Nbr 13531: Elaboração de projetos de edificação - atividades técnicas. Rio de Janeiro, 1995. Citado na página 362.

ABNT, N. Nbr-13532: Elaboração de projetos de edificações - arquitetura. Rio de Janeiro, 1995. Citado na página 93.

ABNT, N. 15220-3: Desempenho térmico de edificações-parte 3: Zoneamento bioclimático brasileiro e diretrizes construtivas para habitações unifamiliares de interesse social. Rio de Janeiro, 2005. Citado na página 291.

ABRAHÃO, J. I.; PINHO, D. L. M. As transformações do trabalho e desafios teórico-metodológicos da Ergonomia. [S.l.]: SciELO Brasil, 2002. Citado 4 vezes nas páginas 133, 142, 324 e 325.

AGUIAR, D. V. d. Espaço, corpo e movimento notas sobre a pesquisa da espacialidade na arquitetura. FAU-PPGAU-UPM/SP, 2009. Citado na página 58.

ALBUQUERQUE, M. E. E. Avaliação ergonômica de ambientes informatizados: um estudo de caso. João Pessoa/PB, 1998. Citado 2 vezes nas páginas 119 e 128.

ALEXANDER, C. Notes on the Synthesis of Form. [S.1.]: Harvard University Press, 1964. v. 5. Citado na página 82 .

ALEXANDER, C. The timeless way of building. [S.l.]: New York: Oxford University Press, 1979. v. 1. Citado na página 65.

ALEXANDER, C.; ISHIKAWA, S.; SILVERSTEIN, M. A pattern language: towns, buildings, construction. [S.1.]: Oxford University Press, 1977. Citado na página 65. 
ALMEIDA, C.; ROCHA, L. O. Em busca de uma aproximação entre arquitetura e educação. Notandum Libro, v. 13, 2009. Citado na página 50.

ALMEIDA, J. G. d. A formação do arquiteto e a universidade. Revista Brasileira de Estudos Pedagógicos, v. 78, n. 188-189-190, p. 22-56, 1997. Citado 7 vezes nas páginas 223, 224, 225, 226, 227, 324 e 354 .

ÁLVARES, A. C. A. Procedimentos para análise e avaliação da iluminação em ambientes escolares. Anais do ENTAC, p. 587-92, 1995. Citado 2 vezes nas páginas 119 e 128.

ARAUJO, L. C. Uma linguagem para formalização de discursos com base em ontologias. Tese (Doutorado) - University of Brasilia, Centre for Research on Architecture of Information, Brasília, Brazil, 2016. Citado na página 220.

AZEVEDO, M. d. F. M. de; SANTOS, M. S. dos; OLIVEIRA, R. de. O uso da cor no ambiente de trabalho: uma ergonomia da percepção. Ensaios de Ergonomia: Revista Virtual de Ergonomia. Florianópolis: UFSC, jun.2000, 2000. Disponível em: $<$ w.eps.ufsc.br/ergon/revista $>$. Acesso em: jul. 2005. Citado na página 143.

BANA E COSTA, C. A. Structuration, construction et exploitation d'un modèle multicritère d'aide à la décision. Portugal: Universidade Técnica de Lisboa, 1992. Citado 2 vezes nas páginas 178 e 179.

BANA E COSTA, C. A. Modelos Multicritério de Apoio à Decisão. [S.1.]: Instituto Superior Técnico, Lisboa, Portugal (In Portuguese), 2001. Citado 4 vezes nas páginas 41, 170,171 e 244.

BANA E COSTA, C. A.; VANSNICK, J. Uma nova abordagem ao problema de construção de uma função de valor cardinal: Macbeth. Investigação operacional, v. 15, p. 15-35, 1995. Citado na página 196.

BARGUIL, P. M. O homem e a conquista dos espaços: o que os alunos e os professores fazem, sentem e aprendem na escola. Fortaleza: Editora LCR, 2006. Citado na página 54.

BARROS, J. A. Uma "disciplina"-entendendo como funcionam os diversos campos de saber a partir de uma reflexão sobre a história. Revista OPSIS, Catalão, v. 11, n. 1, 2011. Citado na página 351.

BARROS, R. R. et al. Conforto e psicologia ambiental: A questão do espaço pessoal no projeto arquitetônico. ENCAC ELACAC 2005, Maceió Alagoas, Brasil - 5 a 7 de outubro, 2005. Citado 2 vezes nas páginas 313 e 326.

BARROSO-KRAUSE, C. Ciência e concepção arquitetônica, reintegrando tecnologia e arquitetura. Artigo IN Arquitetura Pesquisa e Projeto. Programa de Pós-Graduação em Arquitetura. Universidade Federal do Rio de Janeiro. Rio de Janeiro, São Paulo. Proeditores, p. 37-53, 1998. Citado na página 80.

BEINAT, E. Multiattribute value functions for environmental management. [S.1.]: Thesis Publishers Amsterdam, 1995. Citado na página 203.

BELHOT, R. V. A informática no ensino. In: XXIII Congresso Brasileiro de Ensino de Engenharia, Recife-PE, Anais. [S.l.: s.n.], 1995. p. 533-542. Citado na página 365. 
BELTON, V.; ACKERMANN, F.; SHEPHERD, I. Integrated support from problem structuring through to alternative evaluation using cope and v. i. s. a. Journal of Multi-Criteria Decision Analysis, Wiley Online Library, v. 6, n. 3, p. 115-130, 1997. Citado na página 178.

BELTRAME, M. B.; MOURA, G. R. S. Edificações escolares: infraestrutura necessária ao processo de ensino e aprendizagem escolar. Revista eletrônica "Revista Travessias", v. 3, n. 2, 2009. Citado 3 vezes nas páginas 39, 112 e 127.

BENDIX, T. Seated trunk posture at various seat inclinations, seat heights, and table heights. Human Factors: The Journal of the Human Factors and Ergonomics Society, SAGE Publications, v. 26, n. 6, p. 695-703, 1984. Citado 2 vezes nas páginas 132 e 142.

BERNSTEIN, B. A estruturação do discurso pedagógico: classe, códigos e controle. Petrópolis: Vozes, p. 3719-3739, 1996. Citado 2 vezes nas páginas 53 e 295.

BERTOLOTTI, D. Iluminação natural em projetos de escolas: uma proposta de metodologia para melhorar a qualidade da iluminação e conservar energia. Tese (Doutorado) — Universidade de São Paulo, 2007. Citado 2 vezes nas páginas 120 e 128.

BINS ELY, V. H. M. Ergonomia+arquitetura: buscando um melhor desempenho do ambiente físico. In: ERGODESIGN, . (Ed.). Congresso Internacional de Ergonomia e Usabilidade de Interfaces Humano-Tecnologia: Produtos, Programas, Informmações, Ambiente Construído. Rio de Janeiro: LEUI/PUC, 2003. Citado 4 vezes nas páginas 103, 148,149 e 323.

BINS ELY, V. H. M. et al. Contribuição de um método especifico para a analise da relação entre o ambiente arquitetônico e a realização de atividades. ro Congr. Latino Americano, XII Congr. Brasileiro de Ergonomia e I Seminário Brasileiro de Acessibilidade Integral. Recife, 2002. Citado na página 95.

BISELLI, M. Teoria e prática do partido arquitetônico. Revista Arquitextos. ISSN 1809-6298., 2011. Citado 2 vezes nas páginas 360 e 362.

BOING, C. V. Â. et al. Sistemas de circulação vertical e horizontal no deslocamento dos funcionários em edifícios hospitalares. Florianópolis, SC, 2003. Citado na página 149.

BOUYSSOU, D. Modelling inaccurate determination, uncertainty, imprecision using multiple criteria. In: Improving decision making in organisations. [S.l.]: Springer, 1989. p. 78-87. Citado 2 vezes nas páginas 41 e 172.

BRASIL, M. da Saúde. Secretaria de Vigilância em Saúde. Departamento de Vigilância em Saúde Ambiental e Saúde do T. Dor relacionada ao trabalho: lesões por esforços repetitivos (LER): distúrbios osteomusculares relacionados ao trabalho (Dort). [S.l.]: Ministério da Saúde Brasília, 2012. 13 p. Citado na página 136.

BRASIL, M. T. E. Atividade e operações insalubres. nr 15. 1978. Disponível em: $<<$ http://www.mtb.gov.br/legislacao/normas_regulamentadoras/nr_15.pdf $>>$. Acesso em: jul. 2014. Citado na página 303.

BRASIL, M. T. E. Nr 17 - ergonomia. 2004. Citado na página 307.

BRITO CRUZ, J. A. d.; CARVALHO, L. São paulo 450 anos: a escola e a cidade. Sao Paulo. Secretaria Municipal de educação/BEI, 2004. Citado na página 59. 
BUFFA, E.; PINTO, G. de A. Arquitetura e educação: organização do espaço e propostas pedagógicas dos grupos escolares paulistas, 1893-1971. [S.1.]: EdUFSCar, 2002. Citado 4 vezes nas páginas 31, 35, 36 e 49 .

BURNHAM, T. F. Sociedade da informação, sociedade do conhecimento, sociedade da aprendizagem: implicações ético-políticas no limiar do século. Informação \& Informática. Salvador: EDUFBA, p. 283-307, 2000. Citado na página 356.

CABE. Commission for architecture and the built environment. Picturing school design, London, 2005. Citado 8 vezes nas páginas 21, 61, 62, 63, 64, 150, 151 e 154.

CANTER, D.; STRINGER, P. Enviromental interaction, international universities press. Journal of Environmental Psychology, INC, New York, 2001. Citado 2 vezes nas páginas 144 e 149.

CARDOSO, M. L. P. Educação para a nova era. [S.l.]: Grupo Editorial Summus, 1999. Citado na página 143.

CARPintero, A. C.; ALMEIDA, J. G. Teorias do espaço educativo. módulo 10. Universidade de Brasília, p. 106, 2008. Citado 6 vezes nas páginas 52, 54, 56, 59, 295 e 355 .

CARVALHO, F. Mobiliário escolar. 2001. Disponível em: < http://www.tvebrasil.com.br/ salto>. Acesso em: set.2014. Citado 3 vezes nas páginas 131, 142 e 325.

CARvalho, M. I. C. D.; CAlvalCANTE, S.; NóBREGA, L. M. A. ambientes. In: CAVALCANTE SíLVIA; ELALI, G. A. (Ed.). Temas básicos em psicologia ambiental). Petrópolis: Vozes, 2011. Citado na página 101.

CASTRO, I. S.; RHEINGANTZ, P. A.; GONÇALVES, A. M. Cognição e percepção visual: a influência da iluminação artificial sobre uma atividade de trabalho realizada em um ambiente informatizado confinado. In: ABERGO). [s.n.], 2006. Disponível em: $<$ www.fau.ufrj.br/prolugar/artigos.htm $>$. Acesso em: ago. 2014. Citado 2 vezes nas páginas 122 e 128.

CHAFFIN, D. B.; ANDERSSON, G.; MARTIN, B. J. Occupational biomechanics. John Wiley \& Sons, New York, 1991. Citado na página 132.

CHPS. The collaborative for high performance schools. Best Practices Manual 2002:

Criteria. V. III., Califórnia, 2002. Disponível em: <http://.chps.net/manual/index.htm>. Acesso em: mar. 2007. Citado 5 vezes nas páginas 112, 113, 117, 120 e 127.

CHVATAL, K.; KOWALTOWSKI, D.; LABAKI, L. A prática do projeto arquitetônico em campinas, sp e diretrizes para o projeto de edificações adequadas ao clima. Nucleo de Pesquisa em Tecnologia da Arquitetura e Urbanismo. Arquitetura e Urbanismo, Tecnologias para o Seculo, v. 21, 1998. Citado na página 80.

COSTA, L. Considerações sobre a arte contemporânea. [S.l.]: Universidade de São Paulo, Faculdade de Arquitetura e Urbanismo, 1962. Citado na página 224.

COSTA, L. Opção, recomendações e recado; in: Lúcio costa: Registro de uma vivência. São Paulo: Empresa das Artes, p. 382, 1995. Citado na página 57. 
COURY, H. J. C. G. Trabalhando sentado: manual para posturas confortáveis. [S.1.]: EdUFSCar, 1995. Citado 2 vezes nas páginas 135 e 142.

CRANDELl, C. C.; SMALDINO, J. J.; FLEXER, C. Sound-Field FM Amplification: Theory and Practical Applications. [S.l.]: ERIC, 1995. Citado na página 113.

DE SIQUEIRA, A. H. A lógica e a linguagem como fundamentos da Arquitetura da Informação. 143. f. 2008. 2008. Citado 2 vezes nas páginas 220 e 221.

DELIBERADOR, M. S. O processo de projeto de arquitetura escolar no Estado de São Paulo: caracterização e possibilidades de intervenção. Dissertação (Mestrado) Faculdade de Engenharia Civil, Arquitetura e Urbanismo - FEC Universidade Estadual de Campinas - UNICAMP Comissão de Pós-graduação da Faculdade de Engenharia Civil, Arquitetura e Urbanismo da Universidade Estadual de Campinas., 2010. Citado 3 vezes nas páginas 83, 150 e 155 .

DOGAN, F.; ZIMRING, C. M. Interaction of programming and design: the first unitarian congregation of rochester and louis i. kahn. Journal of Architectural Education, Wiley Online Library, v. 56, n. 1, p. 47-56, 2002. Citado na página 82.

DOUCETTE, D. et al. Toward a new science of information. Data Science Journal, CODATA, v. 6, p. S198-S205, 2007. Citado na página 219.

DUDEK, M. Schools and kindergartens: a design manual. [S.l.]: Walter de Gruyter, 2007. Citado 4 vezes nas páginas 117, 119, 127 e 128.

DUL JAN \& WEERDMEESTER, B. Ergonomia prática. Tradução por Itiro Iida. São Paulo: Edgar Blücher, p. 137, 2004. Citado 4 vezes nas páginas 129, 136, 143 e 302.

DULGEROGLU-VUKSEL, Y. Design methods theory and its implications for architectural studies. Research, Education and Practice, v. 33, n. 3, p. 2870-2877, 1999. Citado na página 80.

EARTHMAN, G. I.; LEMASTERS, L. Where children learn: A discussion of how a facility affects learning. ERIC, 1998. Citado na página 113.

EFL. Scsd: the project and the schools. New York, p. 96, 1963. Citado 2 vezes nas páginas 112 e 127.

ELALI, G. A. Psicologia e arquitetura: em busca do locus interdisciplinar. Estudos de psicologia, SciELO Brasil, v. 2, n. 2, p. 349-362, 1997. Citado 3 vezes nas páginas 94, 101 e 326 .

ELALI, G. A. Ambiente na escola: uma discussão sobre a relação escola-natureza em educação infantil. Estud. psicol.(Natal), v. 8, n. 2, p. 309-319, 2003. Citado na página 56.

ELALI, G. A. Uma contribuição da psicologia ambiental à discussão de aspectos comportamentais da avaliação pós-ocupação. Pós. Revista do Programa de Pós-Graduação em Arquitetura e Urbanismo da FAUUSP, n. 20, p. 158-169, 2006. Citado na página 100.

ENSSLIN, L.; NETO, G. M.; NORONHA, S. M. Apoio à decisão: metodologias para estruturação de problemas e avaliação multicritério de alternativas. [S.1.]: Insular, 2001. Citado 23 vezes nas páginas 41, 170, 173, 176, 177, 178, 179, 180, 181, 193, 194, 195, 196, 202, 203, 204, 206, 207, 237, 246, 247, 248 e 350. 
EVANS, G. W.; MAXWELL, L. Chronic noise exposure and reading deficits the mediating effects of language acquisition. Environment and Behavior, Sage Publications, v. 29, n. 5, p. 638-656, 1997. Citado na página 113.

EVANS, J. M.; SCHILLER, S. D. Diseño bioambiental y arquitectura solar. [S.1.]: Secretaría de Extensión Universitaria, Facultad de Arquitectura y Urbanismo, Universidad de Buenos Aires, 1988. Citado na página 299.

FALCÃO, F. d. S. et al. A influência ergonômica da cor no ambiente educacional: uma revisão. Revista Ação Ergonômica, 2008. Disponível em: <http://www.ebah.com.br/content/ ABAAAAgWIAL/a-influencia-ergonomica-cor-no-ambiente-educacional-revisao>. Acesso em: out. 2013. Citado 2 vezes nas páginas 138 e 143.

FALZON, P. Ergonomia. Edgard Blücher, São Paulo, v. 19, p. 640, 2007. Citado 5 vezes nas páginas 136, 143, 306, 324 e 355 .

FDE. Especificação técnica para a elavboração de projetos de unidades escolares. São Paulo, 2003. Citado na página 120.

FERNANDES, C. M. B. Sala de aula universitária - ruptura, memória educativa, territorialidade - desafio da construção pedagógica do conhecimento. Tese (Doutorado), 1999. Citado na página 361.

FERNANDEZ, P. Integração das diretrizes energéticas no processo de concepção arquitetônica. Artigo In Arquitetura Pesquisa e Projeto. Programa de Pós-Graduação em Arquitetura. Universidade Federal do Rio de Janeiro. Rio de Janeiro, p. 25-52, 1998. Citado na página 80.

FERREIRA, M. C. Ambiente de aprendizagem on-line e aprendizagem on-line do ambiente: contribuições da ergonomia na gestão de sistemas educacionais a distância. Ambiente de aprendizagem on-line e aprendizagem on-line do ambiente: contribuições da ergonomia na gestão de sistemas educacionais a distância, Universidade de Brasília, 2000. Citado 5 vezes nas páginas 131, 133, 134, 135 e 142.

FERRERÓ, R.; GONZÁLEZ, P. L. S.; HECHEVARRÍA, O. O. Anatomía y fisiología del desarrollo e higiene escolar. 2. ed. Ciudad de La Habana: Pueblo y Educación, 1985. Citado 2 vezes nas páginas 125 e 128.

FILHO, E. C. et al. Avaliação do conforto ambiental em uma escola municipal de joão pessoa. IX Encontro de extensão/X Econtro de iniciação à docência. João Pessoa-PB, 2007. Citado 2 vezes nas páginas 115 e 127.

FILHO, J. M. Instalações elétricas industriais. LTC, Rio de Janeiro, 1997. Citado 2 vezes nas páginas 118 e 128.

FISHER, J. D.; BELL, P. A.; BAUM, A. Environmental psychology. American Psychologist, Holt, Rinehart and Winston, New York, 1984. Citado na página 100.

FONSECA, J. F. A contribuição da ergonomia ambiental na composição cromática dos ambientes construídos de locais de trabalho de escritório. Pontifícia universaidade Católica do Rio de janeiro. Dissertação de mestrado. Programa de PósGraduação em Design do Departamento de Artes e Design da PUC-RIO, 2004. Citado 3 vezes nas páginas 97, 99 e 324. 
FONSECA, J. F.; MONT'ALVÃO, C. R. A importância dos elementos ambientais na obtenção de locais de trabalho saudáveis e produtivos. In: . [S.1.]: PUC- Rio, 2004. p. 69 74. Citado 2 vezes nas páginas 140 e 143.

FOUCAULT, M. V. Vigiar e punir: nascimento da prisão. Trad. Ligia M. Pondré Vassalo. Petrópolis: Vozes, 1987. Citado na página 63.

FRAGO, A. V. Do espaço escolar e da escola como lugar: propostas e questões. ESCOLANO, Augustín; VIÑAO FRAGO, Antonio. Currículo, espaço e subjetividade: a arquitetura como programa. Tradução de Alfredo José da Veiga-Neto. Rio de Janeiro: DPEGA, p. 59-136, 1998. Citado na página 39.

FRAMPTON, K. Modern Architecture: A Critical History (Fourth Edition). Fourth edition ed. [S.1.]: Thames \& Hudson, 2007. Citado na página 82.

FRANÇA, L. C. M. Caos, espaço, educação. Annablume, v. 21, 1994. Citado na página 56.

FRANCESCHI, A. Ergonomia. Presidência da República Federativa do Brasil Ministério da Educação Secretaria de Educação Profissional e Tecnológica. Colégio Técnico Industrial de Santa Maria/.RS. Rede e-Tec Brasil, 2013. Disponível em: <http://estudio01.proj.ufsm.br/cadernos_seguranca/quinta_etapa/ergonomia.pdf.> Acesso em: out. 2015. Citado 3 vezes nas páginas 130, 135 e 142.

FRANK, H. M. Color, Environment, and Human Response. New York: Hoboken (USA): John Wiley \& Sons Inc, 1996. Citado 2 vezes nas páginas 124 e 128.

FREIRE, M. Dois olhares ao espaço-ação na pré-escola. In: MORAIS, R. (Ed.). Sala de aula: que espaço é esse. 7. ed. Campinas: São Paulo: Papirus, 1994. Citado na página 50.

FROTA, A.; SCHIFFER, S. R. Manual de conforto térmico. São Paulo: Nobel, 1995. Citado 2 vezes nas páginas 115 e 127.

GARCÍA, F. F. Manual de climatologia aplicada: clima, medio ambiente y planificación. [S.l.]: Síntesis, 1995. Citado 3 vezes nas páginas 163, 298 e 352.

GIFFORD, R. Environmental psychology: Principles and practice. University of Victoria, Allyn and Baycon, 1997. Citado 14 vezes nas páginas 100, 102, 106, 144, 149, 167, 312, $314,315,316,318,326,327$ e 363.

GONÇALVES, J. C.; VIANNA, N. S. Iluminação e arquitetura. Geros s/c Ltda. São Paulo, SP, 2001. Citado 2 vezes nas páginas 117 e 128.

GRAÇA, V. A. C. da et al. A integração dos aspectos de conforto ambiental no projeto de escolas: uso da metodologia axiomática e de exemplos simplificados. Campinas, SP, 2008. Citado na página 81.

GRAEFF, E. A. Edifício. Cadernos Brasileiros de Arquitetura, v.7 São Paulo: Projeto, 1979. Citado na página 363.

GRANDJEAN, E. Manual de ergonomia: adaptando o trabalho ao homem. 4. ed. Porto Alegre: Bookman, 1998. Disponível em: <http://www.ebah.com.br/content/ ABAAAgIF0AI/manual-ergonomia-adaptando-trabalho-ao-homem-etienne-grandjean > . Citado 4 vezes nas páginas 122, 124, 127 e 128. 
GROPIUS, W. Nova Arquitetura. 1a edição em português, trad. j grinbusrg e infrid koudela. ed. São Paulo: [s.n.], 1945. Citado 2 vezes nas páginas 122 e 128.

GUIDALLI, C. R. R. et al. Diretrizes para o projeto de salas de aula em universidades visando o bem-estar do usuário. Programa de Pós-graduação em Arquitetura e Urbanismo - PÓSARQ, Universidade Federal de Santa Catarina, 2012. Citado 3 vezes nas páginas 144,149 e 316.

GÜNTHER, H. Mobilidade e affordance como cerne dos estudos pessoa-ambiente. Estudos de Psicologia, SciELO Brasil, v. 8, n. 2, p. 273-280, 2003. Citado 2 vezes nas páginas 100 e 317 .

GÜNTHER, H.; ROZESTRATEN, R. J. Psicologia ambiental: Algumas considerações sobre sua Área de pesquisa e ensino. Instituto de Psicologia. Universidade de Brasília. Laboratório de Psicologia Ambiental. Série: Textos de psicologia Ambiental, v. 10, 2005. Citado na página 100.

HAHN, T. M. et al. Por uma pedagogia ergonômica: mais cidadania no mundo do trabalho. Universidade Federal de Santa Catarina Programa de Pós-Graduação da Engenharia de Produção.Dissertação de Mestrado., Florianópolis, SC, 1999. Citado 2 vezes nas páginas 129 e 142.

HALL, E. T. A. A dimensão oculta. Francisco Alves, Rio de Janeiro, 1981. Citado 2 vezes nas páginas 102 e 312.

HANK, V. L. C. O espaço físico e sua relação no desenvolvimento e aprendizagem da criança. Trabalho de graduação, UNIASSLVI, 2006. Citado na página 54.

HARRISON, S.; DOURISH, P. Re-place-ing space: the roles of place and space in collaborative systems. In: ACM. Proceedings of the 1996 ACM conference on Computer supported cooperative work. [S.l.], 1996. Citado na página 58.

HEIDI, J. S. S.; MAKI, J. A. American school \& university magazine: shaping facilities and business decision. Bookman, kansass, 2009. Disponível em: < http://asumag.com>. Citado 2 vezes nas páginas 123 e 128 .

HEIMSTRA, N. W.; MCFARLING, L. H. Environmental psychology. [S.l.]: Brooks/Cole Pub. Co., 1978. Citado na página 315.

HERSHBERGER, R. Architectural programming and predesign manager. Mc Graw-Hill, New York, 1999. Citado 6 vezes nas páginas 21, 61, 82, 83, 84 e 87.

HESCHONG, L. Thermal delight in architecture. M.I.T., Cambridge, 2002. Citado 2 vezes nas páginas 103 e 113.

HESCHONG MAHONE GROUP. Daylighting in schools: investigation into relationship between daylighting and human performance. CA Board for energy efficiency, Sacramento, 1999. Citado 3 vezes nas páginas 113, 117 e 128.

IESNA. Handbook of the illuminating engineering society of north america. Illuminating Engineering Society of North America, New York, 2000. Disponível em: $<$ http://www.iesna.org.> Acesso em: set. 2015. Citado 2 vezes nas páginas 120 e 121. 
IIDA, I. Ergonomia: projeto e produção. 2a edição revista e ampliada São Paulo: E. [S.1.]: Blücher, 2005. Citado 14 vezes nas páginas 95, 118, 128, 129, 130, 133, 142, 297, 307, 309, $325,353,355$ e 356 .

IMAI, C.; DUARTE, R. B. A construção da percepção no processo projetual arquitrtônico: uma relfexão. In: ENTECA. Universidade Estadual de Maringá, 2009. Disponível em: <http://www.uel.br/nucleos/nepea/?page_id=27.> Citado 2 vezes nas páginas 146 e 149.

INEP/MEC. Pesquisa Nacional: Qualidade na Educação. Brasília: Instituto Nacional de Estudos e Pesquisas Educacionais Anísio Teixeira, 2006. Citado na página 60.

INEP/MEC. Relatório técnico saeb 2003. Sistema Nacional de Avaliação da Educação ação Básica, Brasília, 2006. Citado na página 60.

INTERNATIONAL ERGONOMICS ASSOCIATION. What is ergonomics. IEA Members" and "Study Programs".(nd) Available at http://www. iea. cc/index. php, 2009. Citado 2 vezes nas páginas 166 e 307.

INTERNATIONAL ORGANIZATION FOR STANDARDIZATION. Iso 2631 - guide for the evaluation of human exposure to whole-body vibration. Geneva, p. 15, 1978. Citado na página 306.

INTERNATIONAL ORGANIZATION FOR STANDARDIZATION. Iso 9699 performance standards in building - chesklist for briefing - contents of brief for building desing. Geneva, SW: International Organization for Standardization, 1994. Citado 3 vezes nas páginas 21, 91 e 92 .

INTERNATIONAL ORGANIZATION FOR STANDARDIZATION. Iso 7726, ergonomics of the thermal environment, instruments for measuring physical quantities. Geneva: International Standard Organization, 1998. Citado na página 115.

INTERNATIONAL ORGANIZATION FOR STANDARDIZATION. Iso 7730 ergonomics of the thermal environment. Analytical determination and interpretation of thermal comfort using calculation of the PMV and PPD indices and local thermal comfort criteria, 2005. Citado na página 115.

JUTLA, R. S. An inquary into design. Design methods: theories, research, educations and practice. California, v. 30, n. 1, p. 2304-2308, 1996. Citado na página 80.

KARUSE, C. B. et al. Bioclimatismo no projeto de arquitetura: Dicas de projeto. 2005. Citado 3 vezes nas páginas 119, 128 e 301.

KEENEY, R. L. Value-focused thinking: A path to creative decisionmaking. [S.l.]: Harvard University Press, 1992. Citado 2 vezes nas páginas 178 e 194.

KEISLER, J. M.; NOONAN, P. S. Communicating analytic results: A tutorial for decision consultants. Decision Analysis, INFORMS, v. 9, n. 3, p. 274-292, 2012. Citado na página 175 .

KIATAKE, M. Modelo de suporte ao projeto criativo em arquitetura: uma aplicação da triz-teoria da solução inventiva de problemas. Tese (Doutorado) - Universidade de São Paulo, 2004. Citado na página 81. 
KOWALTOWSKI, D.; LABAKI, L. O projeto arquitetônico e o conforto ambiental: necessidade de uma metodologia. In: VI Encontro Nacional e III Encontro LatinoAmericano sobre conforto no ambiente construído. São Pedro/SP, Brasil. [S.l.: s.n.], 1993. v. 11. Citado na página 80.

KOWALTOWSKI, D. C. Arquitetura escolar: o projeto do ambiente de ensino. [S.l.]: Oficina de textos, 2011. Citado 23 vezes nas páginas 49, 59, 60, 62, 65, 80, 102, 106, 107, 116, 117, 121, 124, 127, 132, 142, 293, 294, 295, 318, 360, 363 e 364.

KOWALTOWSKI, D. C. C. K. et al. Reflexão sobre metodologias de projeto arquitetónico. Ambiente Construído, Porto Alegre, v. 6, n. 2, p. 7-19, 2006. Citado na página 81.

KROEMER, K. H.; GRANDJEAN, E. Manual de ergonomia: adaptando o trabalho ao homem. [S.l.]: Bookman, 2005. Citado na página 138.

KÜLLER, R.; LINDSTEN, C. Health and behavior of children in classrooms with and without windows. Journal of Environmental Psychology, Elsevier, v. 12, n. 4, p. 305-317, 1992. Citado 3 vezes nas páginas 113, 117 e 128.

KUMLIN, R. R. Architectural programming: creative techniques for design professionals. [S.l.]: McGraw-Hill Professional, 1995. Citado na página 82.

LABAKI, L. C.; BUENO-BARTHOLOMEI, C. L. Avaliação do conforto térmico e luminoso de prédios escolares da rede pública, campinas-sp. VI Encontro Nacional e III Encontro Latino-americano sobre Conforto no Ambiente Construído, São Pedro, SP. Anais do ENCAC, 2001. Citado 2 vezes nas páginas 119 e 128.

LACERDA, F.; LIMA-MARQUES, M. Information architecture as a discipline: A methodological approach. In: Reframing Information Architecture. [S.l.]: Human-computer Interaction Series, Springer International Publishing, 2014. p. 1-10. Citado na página 221.

LACY, M. L. Poder das cores no equilíbrio dos ambientes. São Paulo: Editora Pensamento, 2002. Citado 3 vezes nas páginas 139, 140 e 143.

LAKI, R. C.; LIPAI, A. E. Percepção e uso do espaço em arquitetura e urbanismo: um ensaio no ambiente construído. ano 1, n. 1, p. 17-30, Ago 2007. Disponível em: $<$ ftp://ftp.usjt.br/pub/revistaic/pag17_edi01.pdf>. Acesso em: mar. 2013. Citado na página 57.

LAMBERTS, R.; XAVIER, A. A. d. P. Conforto térmico e stress térmico. Florianópolis: Universidade Federal de Santa Catarina/Departamento de Engenharia Civil/Laboratório de Eficiência Energética em Edificações (LABEEE), 2008. Citado 3 vezes nas páginas 115,127 e 298.

LAMPRECHT, B. Richard Neutra, 1892-1970: Survival through Design. 25th anniversary edition. ed. [S.l.]: TASCHEN America Llc, 2009. Citado na página 82.

LANDRY, M. A note on the concept of'problem'. Organization studies, Sage Publications, v. 16, n. 2, p. 315-343, 1995. Citado na página 173.

LANG, J. T. Designing for human behavior: architecture and the behavioral sciences.

Pennsylvania: Dowden, Hutchinson \& Ross, 1974. v. 6. Citado na página 81. 
LANG, J. T. Designing for human behavior: architecture and the behavioral sciences. USA: Dowden, Hutchinson \& Ross, 1987. Citado na página 80.

LAVILLE, A. Ergonomia. EPU, EDUSP, São Paulo, 1977. Citado na página 142.

LEE, T. Psicologia ambiental e meio ambiente. [S.l.]: Rio de Janeiro: Zahar.(Texto original publicado em 1954), 1977. Citado na página 149.

LEFEBVRE, H. The production of space. Oxford/Cambridge, Blackwell Publishers, p. 454, 1991. Citado na página 58.

LÉGER, F. Funções da pintura. [S.l.]: São Paulo: Editora Nobel, 1989. Citado na página 143.

LEUCZ, J. et al. Ambiente de trabalho das salas de aula no ensino básico de curitiba. Florianópolis, SC, 2001. Citado 2 vezes nas páginas 129 e 142.

LIMA, E. S. Indagações sobre o currículo. BEAUCHAMP, Jeanete; PAGEL, Sandra Denise; NASCIMENTO, Auricélia Ribeiro do. Currículo e desenvolvimento humano. Brasília, DF: Ministério da Educação, 2007. Citado na página 294.

LIMA-MARQUES, M.; CARNIELLI, W. Formal aspects of architecture of information. Logical Reasoning and Computation: Essays dedicated to Luis Fariñas del Cerro, p. 33, 2016. Citado na página 219.

LIMA-MARQUES, M.; MACEDO, F. d. Arquitetura da informação: base para a gestão do conhecimento. In: Tarapanoff, K. (ed.) Inteligência, informação e conhecimento. Brasilia: IBICT - Unesco. [S.1.: s.n.], 2006. p. 241-255. Citado 2 vezes nas páginas 220 e 222.

LIMONAD, E. Espaço e tempo na arquitetura e urbanismo: algumas questões de método. Anais: Seminário de História da Cidade e do Urbanismo, v. 7, n. 1, 2012. Citado na página 58.

LOUREIRO, C. Classe, controle, encontro: o espaço escolar. Classe, controle, encontro: o espaço escolar, p. 9, 1999. Citado na página 39.

LOURENÇO, M.; MENEZES, L. Ergonomia e alimentação coletiva: análise das condições de trabalho em uma unidade de alimentação e nutrição. In: Congresso Nacional de Excelência em Gestão. [S.l.: s.n.], 2008. v. 4. Citado na página 95.

LUZ, M. d. L. S. et al. A influência da estrutura e ambientes ergonômicos no desempenho educacional. XII SIMPEP - Bauru, SP, Brasil, 07 a 09 de novembro 2005. Citado 3 vezes nas páginas 95, 310 e 325.

LYNCH, K. A imagem da cidade. São Paulo: Martins Fontes, 1997. Citado na página 58.

MACHADO, R. M. A Utilização de um Ambiente Ergonômico enquanto estratégia facilitadora para Aprendizagem da Disciplina de Matemática Aplicada. Dissertação (Mestrado) - Universidade federal de santa Catarina. Programa de Pós Graduação em Engenhariai de Produção. Florianópolis, 2008. Citado na página 142.

MALCZEWSKI, J. GIS and multicriteria decision analysis. [S.1.]: John Wiley \& Sons, 1999. Citado 3 vezes nas páginas 41, 172 e 173. 
MANDAL, A. The seated man (homo sedens) the seated work position. theory and practice. Applied Ergonomics, Elsevier, v. 12, n. 1, p. 19-26, 1981. Citado 2 vezes nas páginas 132 e 142.

MANDAL, A. Investigation of the lumbar flexion of office workers. AGARD Backache and Back Discomfort 10 p(SEE N 87-13932 05-52), 1986. Citado na página 132.

MARELLI. Ambientes racionais. Revista Ambiente, 2015. Disponível em: <http: //cumincad.scix.net/data/works/att/sigradi2005_517.content.pdf $>$. Citado na página 134.

MASCARÓ, L. R. d. Energia na edificação. Estratégia para minimizar o Consumo, São Paulo: Projeto, 1985. Citado na página 127.

MATAI, P. H. L. dos S.; MATAI, S. Ensino cooperativo: espaço físico. Revista de Ensino de Engenharia, v. 27, n. 1, 2008. Citado 2 vezes nas páginas 146 e 149.

MCDONALD, J. P. Redesigning Schools: Lessons for the 21st Century. The Jossey-Bass Education Series. São Francisco: ERIC, 1996. Citado 3 vezes nas páginas 32, 60 e 293.

MEC. Perfis da área e padrões e qualidade, expansão e verificação periodica dos cursos de arquitetura e urbanismo. 1994. Disponível em: <http://portal.mec.gov.br/sesu/arquivos/ pdf/ar_geral.pdf>. Acesso em: set. 2014. Citado 4 vezes nas páginas 112, 165, 258 e 298.

MEC. Espaços educativos - ensino fundamental: subsídios para elaboração de projetos e adequação de edificações escolares. Cadernos técnicos, Fundescola, Brasília, v. 2, n. 4, 2002. Citado na página 120.

MELLATI, S. P. d. P. C. A arquitetura escolar e a prática pedagógica. 2004. [S.1.]: Dissertação (Mestrado em Educação e Cultura)-Universidade do Estado de Santa Catarina, UDESC, Joinville, 2004. Citado 5 vezes nas páginas 113, 114, 116, 127 e 301.

MELLO, R. B. d. A cultura da crença: uma reflexão sobre o espaço simbólico e o simbolismo na arquitetura religiosa. Tese (Doutorado) - Universidade de São Paulo, 2007. Citado na página 51.

MELO, A. M. C. d. Um modelo de arquitetura da informação para processos de investigação científica. Dissertação (Mestrado em Ciência da Informação) - Universidade de Brasilia, Brasilia, 2010. Citado na página 40.

MENDES, J. Onde viver em Portugal: uma análise da qualidade de vida nas capitais de distrito. Lisboa: Ordem dos Engenheiros - Região Centro, 1999. Citado na página 173.

MEZZOMO, A. A. Humanização hospitalar. Fortaleza: Realce Editora, 2002. Citado 2 vezes nas páginas 148 e 149.

MONTMOLLIN, M. d. A ergonomia. Lisboa: Instituto Piaget, v. 22, 1990. Citado 2 vezes nas páginas 124 e 128.

MONT'ALVãO, C. A ergonomia do ambiente construído no brasil. In: Um novo olhar para o projeto: a ergonomia no ambiente construído. 2ab. ed. Teresópolis: [s.n.], 2011. Citado na página 95. 
MONZÉGLIO, E. Uma avaliação perceptiva de habitats da periferia de são paulo: o pós uso segundo o desenho. Sinopses, 1990. Citado 2 vezes nas páginas 51 e 52.

MOREIRA, A. F. B. Indagações sobre currículo: Currículo, conhecimento e cultura. Brasília: Ministério da Educação, Secretaria de Educação Básica, 2007. Citado na página 353.

MOREIRA, D. d. C.; KOWALTOWSKI, D. C. O programa de necessidades e a importância de apo no processo de projeto. Departamento de Arquitetura e Construção Faculdade de Engenharia Civil, Arquitetura e Urbanismo - UNICAMP, Universidade de Campinas, Brasil, 2009. Disponível em: < http://www.dkowaltowski.net/920.pdf>. Acesso em: jan. 2015. Citado 2 vezes nas páginas 82 e 87.

MORIN, E. O método 5: a humanidade da humanidade, a identidade humana. Porto Alegre: Sulina, v. 312, 2002. Citado na página 51.

MORO, A. R.; ÁVILA, A. O.; MELLO, O. S. A postura do digitador em duas situações experimentais simuladas em um protótipo concebido para estudos ocupacionais na posição sentada. In: Anais do VII Congresso Brasileiro de Biomecânica. [S.l.: s.n.], 1997. p. 103-108. Citado na página 142.

MORO, A. R. P. Ergonomia da sala de aula: constrangimentos posturais impostos pelo mobiliário escolar. Lecturas: Educación física y deportes, Tulio Guterman, n. 85, p. 29, 2005. Citado 3 vezes nas páginas 131, 132 e 142.

MOSER, G. Psicologia ambiental. Universidade René Descartes-Paris V., p. 121-130, 1998. Citado 3 vezes nas páginas 148, 149 e 314.

MOUSSATCHÉ, H. A arquitetura escolar como representação social da escola. Tese (Doutorado) - Faculdade de educação. UFRJ. Rio de Janeiro., 1998. Citado na página 54.

MUELLER, C. M. Espaços de ensino-aprendizagem com qualidade ambiental: o processo metodológico para elaboração de um anteprojeto. 2007. Citado 4 vezes nas páginas 104, 112, 113 e 127.

MURREL, K. F. H. Ergonomics, man in his working environment. Experimental Aging Research, Chapman \& Hall, London, 1969. Citado 2 vezes nas páginas 94 e 95.

NABELEK, A.; NABELEK, L. Room acoustics and speech perception. Handbook of clinical audiology, Williams \& Wilkins Baltimore, MD, 1994. Citado na página 113.

NAIR, P.; FIELDING, R. The language of school design: Design patterns for 21st century schools. Designshare, Inc., 2005. Citado 11 vezes nas páginas 21, 49, 50, 63, 65, 79, 82, $155,156,162$ e 293.

NETO, W. d. A. P. Modelo multicritério de avaliação de desempenho operacional do transporte coletivo por ônibus no município de Fortaleza. Tese (Doutorado) Universidade Federal do Ceará, 2001. Citado na página 177.

NEUFERT, E. Arte de projetar em arquitetura: princípios, normas e prescrições sôbre construção, instalações, distribuição e programa de necessidades, dimensões de edifícios, locais e utensílios,. [S.1.]: Gustavo Gili do Brasil, S.A. São Paulo, 1976. Citado na página 114. 
NOGUEIRA, E. A importância do Espaço como fator de desenvolvimento, Aprendizagem e Bem Estar das crianças e Professoras e como parte integrante da ação Pedagógica. $3^{\text {a }}$ FORMAÇÃO PAIC. Secretaria Municipal de educação. Educação Infantil de Juazeiro do Norte, 2011. Disponível em: <http://www.google.com.br/url?sa=t\& $\mathrm{rct}=\mathrm{j} \& \mathrm{q}=\&$ esrc $=\mathrm{s} \&$ frm $=1 \&$ source $=$ web\&cd $=1 \& v e d=0$ CDAQFjAA\&url $=\mathrm{http} \%$ 3A\%2F\%2Fxa.yimg.com\%2Fkq\%2Fgroups \%2F 27271184\%2F $897245085 \% 2$ Fname\% 2FUNKNOWN_PARAMETER_VALUE\&ei=LC8qUb3sN4eW8gTfzoGgBg\&usg= AFQjCNFESyFqbSZ5kvBUYIYbCsZw08Ze9A\&sig2=g6fVyvNfdtRaB32FQytZtg\& bvm $=$ bv.42768644,d.eWU>. Acesso em: jan. 2013. Citado 3 vezes nas páginas 53, 55 e 295 .

NOGUEIRA, M.; DURANTE, L. C.; NOGUEIRA, J. S. Conforto térmico na escola pública em cuiabá-mt: estudo de caso. Revista eletrônica do mestrado em educação ambiental, v. 14, p. 37-49, 2005. Citado 2 vezes nas páginas 114 e 127.

NUNES, F. et al. Special education teacher's perception of the educational desk: a survey report. International Journal of Instructional Media, v. 12, p. 231-246, 1985. Citado 3 vezes nas páginas 131, 142 e 359.

NUNES, F. et al. Análise experimental do comportamento na posição sentada: ergonomia do mobiliário escolar. RANGÉ, B. Psicoterapia Comportamental e Cognitiva: Pesquisa, Prática, Aplicações e Problemas. Editorial PSY II, Campinas, SP, p. 313-322, 1995. Citado na página 142.

OLIVEIRA, N. C. Evolução e flexibilidade da arquitetura escolar. Arquitetura escolar e política educacional: os programas na atual administração do Estado, Autor São Paulo, p. 11-25, 1998. Citado na página 56.

OLIVEIRA, T. A. D.; RIBAS, O. T. Sistemas de controle das condições ambientais de conforto. CEP, v. 70058, p. 900, 1995. Citado 6 vezes nas páginas 118, 123, 127, 260, 261 e 263.

OLIVEIRA, Z. d. M. R. de. Educação Infantil: fundamentos e métodos. [S.1.]: Cortez Editora, 2002. Citado na página 53.

ORNSTEIN, S. Avaliação pós-ocupação (APO) do ambiente construído. [S.l.]: Studio Nobel, 1992. Citado na página 326.

ORNSTEIN, S.; NETO, J. B. O desempenho dos edifícios da rede estadual de ensino: O caso da grande são paulo [technical evaluation: First results]. São Paulo, Brazil: Editora FAU/USP, 1995. Citado na página 78.

ORNSTEIN, S. W. Postoccupancy evaluation performed in elementary and high schools of greater são paulo, brazil the occupants and the quality of the school environment. Environment and Behavior, Sage Publications, v. 29, n. 2, p. 236-263, 1997. Citado na página 326.

ORNSTEIN, S. W.; BRUNA, G. C.; ROMÉRO, M. de A. Ambiente construído \&G comportamento: a avaliação pós-ocupação e qualidade ambiental. [S.l.]: Nobel, FAUUSP; FUPAM, 1995. Citado na página 149. 
OSTANELLO, A. Action evaluetion and action structuring: Different decision aid situations reviewed through two actual cases. In: Readings in multiple criteria decision aid. [S.1.]: Springer, 1990. p. 36-57. Citado na página 41.

OXFORD, H. Anthropometric data for educational chairs. Ergonomics, Taylor \& Francis, v. 12, n. 2, p. 140-161, 1969. Citado 2 vezes nas páginas 132 e 143.

PAPAlAmBROS, P. Y.; WILDE, D. J. Principles of optimal design: modeling and computation. 2. ed. [S.l.]: Cambridge university press, 2000. Citado na página 80.

PATTERSON, C. B. Ergonomia e arquitetura: interfaces na elaboração de programas arquitetônicos. 2010. Citado na página 323.

PAULY, E. The classroom crucible: What really works, what doesn't, and why. New York: Basic Books, 1992. Citado 2 vezes nas páginas 32 e 60.

PAYA, M. Isolamento térmico e acústico. (edição original: ISBN-84-329-2958-1 CEAC): Plátano Edições técnicas, Barcelona, 1994. Citado 2 vezes nas páginas 124 e 128.

PEÑA, W.; PARSHALL, S. A. Problem seeking: na architectural programming primer. Jonh Wiley \& Sons, n. $4^{\text {a }}$ edição., 2001. Citado 5 vezes nas páginas 11, 82, 83, 87 e 90.

PIAGET, J. A noção de tempo na criança. [S.l.: s.n.], 1973. Citado 3 vezes nas páginas 52,55 e 352.

PIMENTEL, L. Todas as cores do mar. 2a. ed. [S.1.]: Global Editora, 1992. Citado 2 vezes nas páginas 123 e 128.

PINHEIRO, J. Q. Psicologia ambiental brasileira no início do século xxi. sustentável. In: YAMAMOTO OSWALDO HAJIME; GOUVEIA, V. V. (Ed.). Construindo a Psicologia brasileira: desafios da ciência e da prática psicológica. São Paulo: Casa do Psicólogo, 2003. p. 279-313. Citado na página 103.

PLYMPTON, P.; CONWAY, S.; EPSTEIN, K. Daylighting in schools: Improving student performance and health at a price schools can afford. ERIC, 2000. Citado 2 vezes nas páginas 113 e 117.

POL, E. Environmental psychology in europe: From architectural psychology to green psychology. Avebury Aldershot, 1993. Citado na página 100.

QUIRINO, M. Tomadas de decisão com enfoque em análise multicritério. Curso: PPGT, Notas de aula. 2015. Citado 3 vezes nas páginas 180, 191 e 192.

QUIRINO, M. G. Incorporação das relações de subordinação na matriz de ordenaçãoRoberts em MCDA quando os axiomas de assimetria e transitividade negativa são violados. Tese (Doutorado), 2002. Citado 20 vezes nas páginas 170, 171, 173, 178, 179, 180, 181, 193, 194, 196, 203, 204, 206, 207, 232, 246, 247, 279, 282 e 283.

RANDON, C. E. Análise Estatística de Medidas de Iluminância Obtidas In Loco de Por Simulação em Habitações Populares: Estudo de Caso em Cuiabá-MT. Dissertação (Mestrado) — Universidade Federal de Mato Grosso, Instituto de Ciências Exatas e da Terra, Departamento de Física, Programa de Pós-Graduação em Física e Meio Ambiente, 2007. Citado 3 vezes nas páginas 118, 128 e 300. 
RANGANATHAN, S. R. Documentation and its facets: being a symposium of seventy papers by thirty-two authors. Asia Publishing House (Bombay), 1963. Citado na página 220 .

RAPOPORT, A. Human aspects of urban form: towards a man-environment approach to urban form and design. [S.l.]: Elsevier, 2013. Citado 2 vezes nas páginas 51 e 360.

REIS, A. T. da L.; LAY, M. C. D. Avaliação da qualidade de projetos: uma abordagem perceptiva e cognitiva. Ambiente construído: revista da Associação Nacional de Tecnologia do Ambiente Construído. Porto Alegre, RS. Vol. 6, n. 3 (jul./set. 2006), p. 21-34, 2006. Citado na página 52.

REVISTA PROTEÇÃO. A saúde do professor. n. 178, 2006. Disponível em: <http://www.ufrrj.br/institutos/it/de/acidentes/voz1.htm.> Acesso em: mai. 2013. Citado 4 vezes nas páginas 131, 137, 138 e 142.

RIBEIRO, L. G. Ergonomia no ambiente construído-um estudo de caso em aeroportos. Tese (Doutorado) - PUC-Rio, 2004. Citado 5 vezes nas páginas 97, 119, 124, 128 e 303.

RIO, R. P. d.; PIRES, L. Ergonomia: fundamentos da prática ergonômica. [S.1.]: LTr, 2001. Citado 2 vezes nas páginas 117 e 128.

ROCHA, C. M. F. Desconstruções edificantes: Uma análise da ordenação do espaço como elemento do currículo. 2000. Citado na página 53.

ROCHA, I. A. M. O espaço arquitetônico entre o real e o virtual. simulação ou realidade? 2001. Disponível em: <http://cumincad.scix.net/data/works/att/sigradi2005_517.content. pdf $>$. Acesso em: mai. 2013. Citado na página 57.

RODRIGUES, W. C. et al. Metodologia científica. Paracambi: Faetec/ist, v. 40, 2007. Citado na página 358.

ROMERO, C. Teoría de la decisión multicriterio: conceptos, técnicas y aplicaciones. Madrid: Alianza Editorial, 1993. Citado na página 170.

ROSENFELD, L.; MORVILLE, P. Information architecture for the world wide web o'reilly. Sebastopol, CA, 1998. Citado na página 220.

ROSSO, T. Racionalização da construção. São Paulo: FAUUSP, 1980. Citado na página 81.

ROY, B. Decision-aid and decision-making. In: C.A., B. (Ed.). Readins in Multiple Criteria Decision Aid. Berlin: Springer-Verlag, 1990. p. 17-35. Citado 2 vezes nas páginas 170 e 172.

ROY, B. Decision science or decision-aid science? European journal of operational research, Elsevier, v. 66, n. 2, p. 184-203, 1993. Citado 2 vezes nas páginas 41 e 194.

ROY, B. Multiple criteria methodology for decision auditing. [S.l.]: U.S.A, 1996. Citado na página 177.

RUAS, A. C. Conforto térmico nos ambientes de trabalho. São Paulo: Fundacentro, 1999. Citado 2 vezes nas páginas 116 e 127. 
RYD, H. An Attempt to Measure Objectively the Quality of Air. Tese (Doutorado) National Swedish Institute for Building Research, 1967. Citado na página 104.

SABOYA, R. T. d. et al. Sistema de Suporte à Elaboração de planos Diretores. Tese (Doutorado), Florianópolis, SC, 2005. Citado 3 vezes nas páginas 41, 172 e 177.

SANOFF, H. School building assessment methods. ERIC, 2001. Citado 3 vezes nas páginas 55, 60 e 92 .

SANTOS, J. P. et al. Conforto ambiental no centro de tecnologia da universidade federal de santa maria. In: Encontro Nacional do Ambiente Constru;ido. Florianópolis. [S.l.: s.n.], 1998. Citado 2 vezes nas páginas 103 e 352.

SCHNEIDER, M. Do school facilities affect academic outcomes?. ERIC, 2002. Citado na página 113.

SEEP, B. et al. Acústica de salas de aulas. Uma publicação do Comitê Técnico em Acústica Arquitetônica da Sociedade Americana de Acústica. Versão revisada por Bob Coffeen, FASA. Revista de Acústica e Vibrações - no 29, Versão traduzida por Stephanie L.B. Mondl e revisada por Sylvio Bistafa, Márcio H.A. Gomes e Samir N.Y. Gerges, 2002. Citado 4 vezes nas páginas 125, 126, 128 e 303.

SHALAWAY, L. Organização da sala de aula: o ambiente físico. 1998. Disponível em: <http: //www.scholastic.com/teachers/article/classroom-organization-physical-environment>. Acesso em: Dez. 2013. Citado 2 vezes nas páginas 112 e 127.

SILVA, A. N. R. d. et al. Sig: uma plataforma para introdução de técnicas emergentes no planejamento urbano, regional e de transportes. Ed. autores, 2004. Citado 4 vezes nas páginas 41, 172, 173 e 191.

SILVA, L. B. d. et al. Estudos dos sistemas de climatização e iluminação de ambientes com terminais de vídeo, correlacionando suas inadequações com repercussões oculares em trabalhadores - estudo de caso. [S.l.]: Universidade Federal da Paraíba. João Pessoa, 1996. 127 p. Citado 2 vezes nas páginas 114 e 127.

SIQUEIRA, G. R. de; OLIVEIRA, A. B. de; VIEIRA, R. A. G. Inadequação ergonômica e desconforto das salas de aula em instituição de ensino superior do recife-pe-doi: 10.5020/18061230.2008. p19. Revista Brasileira em Promoção da Saúde, v. 21, n. 1, p. 19-28, 2008. Citado 5 vezes nas páginas 130, 132, 136, 138 e 143.

SOARES, M. Contribuições da ergonomia ao design de mobiliários escolares:"cadeira universitária". Estudos em Design, v. 6, n. 1, p. 33-61, 1998. Citado na página 96.

SOMMER, R. Personal space. Prentice-Hall, Englewood Cliffs, 1969. Citado 3 vezes nas páginas 102, 150 e 312.

SOMMER, R. Espaço pessoal: as bases comportamentais de projetos e planejamentos. [S.l.]: EPU-Editora Pedagógica e Universitária Ltda., 1973. Citado 3 vezes nas páginas 112,127 e 149.

SOMMER, R. Tight spaces: Hard architecture and how to humanize it. [S.l.]: Prentice Hall, 1974. v. 322. Citado 2 vezes nas páginas 148 e 149. 
SOMMER, R. O desenvolvimento e a aplicação dos conceitos de espaço pessoal. In: RIO, V. D.; DUARTE, C. R.; (ORGS.), . P. A. R. (Ed.). [S.1.: s.n.], 2002. p. 19-29. Citado 4 vezes nas páginas 146, 147, 148 e 149.

SOPHIE, P. e. O projeto arquitetônico e o conforto ambiental: necessidade de uma metodologia. In: Revista educaçao São Paulo Ano 11. [S.l.: s.n.], 2007. Citado na página 51.

SOUSA, C. O. et al. Relação entre variáveis antropométricas e as dimensões das carteiras utilizadas por estudantes universitários. Fisioterapia e Pesquisa, v. 14, n. 2, p. 27-34, 2007. Citado 2 vezes nas páginas 128 e 132.

SOUZA, L. C. L. de; ALMEIDA, M. G. de; BRAGANçA, L. Bê-a-bá da acústica arquitetônica: ouvindo a arquitetura. [S.l.]: Edufscar, 2006. Citado na página 126.

SOUZA, R. F. D. Templos de civilização: a implantação da escola primária graduada no Estado de São Paulo, 1890-1910. [S.1.]: Unesp, 1998. Citado na página 353.

TAVARES, C. R. G. et al. A ergonomia e suas contribuições para o processo de ensino-aprendizagem: uma análise das salas de aula do cefet/rn. Florianópolis, SC, 2000. Citado 2 vezes nas páginas 129 e 142.

TEIXEIRA, A. pensamento e ação. Rio de Janeiro: Civilização Brasileira, 1960. Citado na página 51.

UNESCO. Tecnologia e aprendizagem.tic's nas escolas. Organização das Nações Unidas para a Educação, Ciência e Cultura, v. 3, n. 3, 2008. Disponível em: $<$ http://unesdoc.unesco.org/images/0015/001585/158529por.pdf>. Acesso em: out. 2013. Citado na página 55.

VAN GIGCH, J. P.; PIPINO, L. L. In search of a paradigm for the discipline of information systems. Future Computing Systems, Maruzen Company Limited, v. 1, n. 1, p. 71-97, 1986. Citado na página 221.

VARGAS, C. R. de A. Os impactos da iluminação: visão, cognição e comportamento. 2009. Citado 4 vezes nas páginas 52, 117, 118 e 128.

VASCONCELOS, C. S. F. et al. Avaliação ergonômica do ambiente construído: Estudo de caso em uma biblioteca universitária. Revista Ação Ergonômica, v. 4, n. 1, 2009. Citado 2 vezes nas páginas 94 e 97.

VEIGA, I. P. A. projeto político-pedagógico da escola: uma construção possível. 14. ed. [S.1.]: Papirus Editora, 2002. Citado 2 vezes nas páginas 56 e 294.

VELÁZQUEZ, F. F. Carga y fatiga mental. In: VELáZQUEZ, F. F. e. a. (Ed.). Manual de Ergonomía. 2. ed. [S.l.]: Madrid, Mapfre, 1997. Citado na página 95.

VIEIRA, A. de M. Arquitetura escolar- a arquitetura no espaço - tempo. Universidade de São Paulo. Universidade Federal de Uberlândia., 2000. Disponível em: <http://www.fae.ufmg.br/portalmineiro/conteudo/externos/2cpehemg/arq-ind-nome/ eixo1/completos/arquitetura-no-espaco.pdf $>$. Acesso em: mar. 2013. Citado na página 55 . 
VILLAROUCO, V. Avaliação ergonômica do projeto arquitetônico. In: XII Congresso Brasileiro de Ergonomia VI Congresso Latino-Americano de Ergonomia Ei SeminÁRio Brasileiro de Acessibilidade Integral. [S.l.: s.n.], 2002. v. 12. Citado 3 vezes nas páginas 97, 98 e 324 .

VILLAROUCO, V. Construindo uma metodologia de avaliação ergonômica do ambiente-avea. In: Anais do $14^{\circ}$ Congresso Brasileiro de Ergonomia. Porto Seguro: ABERGO. [S.l.: s.n.], 2008. v. 13. Citado na página 95.

VILLAROUCO, V.; ANDRETO, L. F. Avaliando desempenho de espaços de trabalho sob o enfoque da ergonomia do ambiente construído. Produção, SciELO Brasil, v. 3, n. 18, p. 523-39, 2008. Citado na página 93.

VILLAROUCO, V. et al. Identificação de parâmetros para concepção de espaços ergonomicamente adequados à habitação social: Anais do $5^{\circ}$. ergodesign. In: Congresso Internacional de Ergonomia e Usabilidade de interfaces humano-tecnologia: Produtos, programa, informação, ambiente construído. [S.l.: s.n.], 2005. Citado na página 98.

VITRUVIUS, M. P. The ten books on architecture. Dover, New York, 1960. Citado 2 vezes nas páginas 61 e 224.

WEINSTEIN, C. S. The physical environment of the school: A review of the research. Review of educational Research, Sage Publications, v. 49, n. 4, p. 577-610, 1979. Citado 4 vezes nas páginas 144, 145, 149 e 326.

WILLARD, D. et al. Color in an optimum learning environment. International center for Leadership in education. pp, 2008. Disponível em: <http://leadered.com>. Citado 2 vezes nas páginas 123 e 128.

WILSON, J.; CORLETT, E. N.; MANENICA, I. The Ergonomics of Working Postures. London: Taylor \& Francis, 1986. Citado 2 vezes nas páginas 132 e 142.

WOLFF, P. R. et al. Construção de um modelo de avaliação de um restaurante no ramo de fast-food: um estudo de caso. Tese (Doutorado), 2005. Citado na página 177.

YANNAS, S. Educacion buildings in europe. In: III Encontro Nacional (Ed.). I Encontro latino-amrericano de conforto no ambiente construído. Gramado(RS): [s.n.], 1995. p. 49-69. Citado na página 106.

ZEVI, B. Saber ver a arquitetura. Trad. Maria Isabel Gaspar e Gaetan Martins de Oliveira. 5. ed. [S.1.]: São Paulo: . Livraria Martins Fontes Editora ltda., 1996. Citado na página 57. 



\section{Glossário}

A

Abordagem

O que foi contemplado no estudo da tese referente a determinada área.

\section{Ambiências Físicas}

É o ambiente de trabalho onde se desenvolvem as tarefas num certo contexto de exposição do operador aos ruídos e vibrações, ao microclima do posto e à iluminação deste.

\section{Ambiente de informação}

O espaço que integra contexto, conteúdos e usuários. Os ambientes informacionais são objetos de estudo da Arquitetura da Informação como disciplina e espaços de atuação desta como prática ou profissão.

\section{Análise de Sensibilidade}

Verifica se o modelo multicritério tem estabilidade forte ou fraca, ou seja, a robustez do modelo é suficiente para imprimir credibilidade ao resultado da avaliação.

\section{Apinhamento (crowding)}

É uma experiêncoa da restrição espacial causada por outras pessoas, enquanto a densidade é uma relação física de pessoas por unidade de área. Densidade percebida é a estimativa de um indivíduo dessa relação.

\section{Ambiente}

Menor fração de um espaço físico, interno à edificação. O termo "Ambiente" designa um espaço físico interno fechado, como salas de aula, laboratórios, salas de reuniões, etc. Refere-se ao conjunto do espaço físico e às relações que se estabelecem nele.

\section{Antropometria}

Ramo das ciências humanas que se ocupa do estudo das dimensões e proporções do corpo humano, forma, forças e capacidade de trabalho. Sua grande dificuldade reside na variabilidade das medidas do corpo humano entre os diferentes indivíduos, devido às diferenças dos gêneros, raças, idade, clima e de época.

\section{Aprendizagem}

É um fenômeno ou um método relacionado com o ato ou efeito de aprender. A aprendizagem estabelece ligações entre certos estímulos e respostas equivalentes, causando um aumento de adaptação de um ser vivo ao seu meio ambiente. 


\section{Arquitetura}

Arte de compor e construir edifícios para qualquer finalidade, tendo em vista o conforto humano, a realidade social e o sentido plástico da época em que se vive. Uma das artes mais antigas. Escritos medievais são ilustrados com Deus segurando compasso e esquadro, uma alusão ao arquiteto do universo.

\section{Arquitetura Escolar}

É a partir do desenvolvimento do projeto de arquitetura que se constitui o espaço físico escolar. O estudo pode partir do programa de necessidades e das carências apresentadas pelos espaços educacionais, com o objetivo de atender às necessidades de ocupação de cada comunidade escolar. A concepção arquitetônica dos prédios escolares, principalmente em países em desenvolvimento, depende da situação socioeconômica e política, mas deve se preocupar com os conceitos educacionais e de conforto, necessários para atingir a qualidade do sistema ensino-aprendizagem

\section{Arquitetura da Informação}

Disciplina cujo objeto é a configuração da informação, isto é, sua estrutura em fenômenos adequados. De uma perspectiva tecnológica, AI pode ser vista como um conjunto de métodos e técnicas para ambientes de informação desenhados.

\section{Árvore de valor}

É uma estrutura arborescente do modelo multicritério que permite a melhor visualização, organização e hierarquização dos conceitos relevantes para os decisores, formadas pelo objetivo estratégico, pelas áreas de interesse e pelos PVFs.

\section{Aspectos}

Ponto de vista ou perspectiva. Designa um determinado tópico de um tema.

\section{Atributos}

Atributo define-se como uma qualidade associada a um elemento já mencionado (ex: A justiça e a ordem são os atributos de toda boa sociedade), ou como uma qualidade restritiva somente a um único elemento (ex: a linguagem é um atributo humano).

\section{Avaliação Global}

A Avaliação Global de um modelo MCDA aplica-se à Fórmula de Agregação Aditiva. De acordo com Ensslin, Neto e Noronha (2001), a agregação aditiva é uma fórmula matemática que permite converter os indicadores de impacto de uma ação em uma atratividade global, converter uma pontuação (avaliação) global da ação analisada.

\section{Área acadêmica}

Relativa ao ensino e promoção de atividades artísticas, literárias, científicas e físicas, 
sobretudo universitárias.

\section{Áreas de conhecimento}

As áreas do conhecimento humano são muitas e, basicamente, estão nelas tudo aquilo que sabemos a respeito de tudo e de todos, contudo esse conhecimento não é uniforme, isto é, algumas pessoas ou grupos de pessoas detêm um conhecimento sobre determinada área, enquanto que outros atentam para outras áreas. Classificar o conhecimento humano em áreas e subáreas passa a ser útil para finalidades práticas, para fins de ensino, pesquisa, entre outros.

\section{C}

\section{Campus}

(campi, no plural) é a palavra latina que deu origem ao termo português campo. Geralmente é sinônimo de polo e refere-se a um local onde uma instituição ou conjunto de instituições, de ensino ou de investigação científica ou tecnológica, tem uma parte ou a totalidade dos seus serviços, nomeadamente salas de aula e laboratórios. Quando se refere a uma estabelecimento de ensino, campus pode ser sinônimo de cidade universitária, principalmente se as dimensões forem consideráveis.

\section{Campo disciplinar}

São campos de conhecimento, incluídos ou não entre os saberes universitários. Um "campo disciplinar" pode ser definido por determinados objetos de interesse, certas singularidades, uma confluência específica de teoria, método e modelos discursivos, relações interdisciplinares, subdivisões intradisciplinares, entre outros aspectos (BARROS, 2011).

\section{Capacidade}

É a quantidade de pessoas que podem desenvolver confortavelmente uma atividade em determinado espaço físico. Essa quantidade é obtida conforme critérios da administração superior da UnB. Para salas de aula, a quantidade máxima de alunos é obtida pela divisão da área total por 1,20 m.

\section{Características do espaço arquitetônico}

O espaço possui:

Tamanho (comprimento, largura, profundidade); Forma, que é seu contorno (formas geométricas como o cubo, o círculo, o prisma, o triângulo...); Cor (resultado da incidência de luz) e textura (principalmente é algo tátil e interfere na maneira como o objeto reflete ou absorve a luz que incide sobre ele); A maneira como são distribuídos e organizados gera sensações e organiza o dia a dia do ser humano. Esses objetos podem ser posicionados de diferentes maneiras, orientações e, de acordo com isso, pode ser inerte ou criar a sensação de que é instável. 


\section{Categoria}

Cada uma das classes em que se dividem as ideias ou os termos e serve para indicar uma classificação ou uma forma de organização.

\section{Cognição}

É o processo de construção de sentido na mente, cumulativo, que se forma por meio da experiência cotidiana, sendo complementar à percepção, quando esta é tratada como exclusivamente sensorial, relacionada à experiência direta com o ambiente (PIAGET, 1973).

\section{Comportamento}

É o conjunto de procedimentos ou reações do indivíduo ao ambiente que o cerca em determinadas circunstâncias, o meio. Pode designar um grupo de atividades ou limitar-se a uma só, o comportamento singular.

\section{Conforto Ambiental}

O Conforto Ambiental é constituído por um conjunto de condições térmicas, acústicas e visuais, propiciando sensação de bem-estar aos usuários de um ambiente, e sua inobservância constitui a principal causa de sintomas diversos e desagradáveis, como: fadiga, desconcentração, desânimo etc. (SANTOS et al., 1998).

\section{Conforto térmico}

Consiste no conjunto de condições em que os mecanismos de autorregulação são mínimos, ou ainda na zona delimitada por características térmicas em que o maior número de pessoas manifestem se sentir bem (GARCÍA, 1995, p. 199).

\section{Conforto sonoro}

Ramo da física que estuda o som. O som é um fenômeno ondulatório causado pelos mais diversos objetos e se propaga através dos diferentes estados físicos da matéria.

\section{Conforto lumínico}

Fenômeno físico resultante da exposição de uma fonte de luz num ambiente que pode absorver ou refletir a luz, tornando-se visível. Grau de satisfação visual produzido pelo ambiente iluminado. Propõe reduzir ofuscamentos visuais, equilibrar a luminância e ampliar a reprodução de cores, permitindo que o olho tenha uma perfeita dimensão dos espaços do ambiente, volume das formas, texturas dos materiais e fidelidade de cores.

\section{Critérios de avaliação}

A partir da determinação de uma função de valor associada a um descritor, considerase que foi construído um critério de avaliação para um dado PVF e subcritérios para os PVEs e SubPVEs. 


\section{Currículo}

Os currículos são uma construção e seleção de conhecimentos e práticas produzidos em contextos concretos e em dinâmicas sociais, políticas e culturais, intelectuais e pedagógicas (MOREIRA, 2007).

\section{Cognição}

É o ato ou processo da aquisição do conhecimento que se dá por meio da percepção, da atenção, associação, memória, raciocínio, juízo, imaginação, pensamento e linguagem.

$\mathrm{D}$

\section{Dados}

Consistem nos atributos que dão significado e unidade às entidades.

\section{Decisor}

Indivíduo ou entidade para a qual foi delegada a responsabilidade pela tomada de decisão. O decisor detém o controle sobre os meios necessários para que o processo aconteça e para que as ações posteriores sejam efetivadas.

\section{Descritor}

São escalas utilizadas para mensurar os objetivos, representando o quanto estes foram alcançados. Por incorporarem julgamentos de valor, os descritores ajudam os atores a esclarecer os objetivos e a gerar subsídios para a criação de novas alternativas.

\section{Dimensionamento do posto de trabalho (ergonomia)}

O posto de trabalho deve ser dimensionado de forma que a maioria de seus usuários tenha uma postura confortável. Deve-se considerar diversos fatores como a postura adequada do corpo, movimentos corporais necessários, alcance dos movimentos, medidas antropométricas, iluminação, ventilação etc (IIDA, 2005, p. 204).

\section{Disciplinas}

É um termo que designa um determinado ramo do conhecimento. No âmbito escolar, designa um conjunto de aulas aos quais os alunos assistem e sobre as quais eles serão examinados, podendo ser aprovados ou não.

$\mathbf{E}$

\section{Edifício escolar}

"O edifício escolar torna-se portador de uma identificação arquitetônica que o diferenciava dos demais edifícios públicos e civis ao mesmo tempo em que o identificava como um espaço próprio - lugar específico para as atividades de ensino e do trabalho docente." (SOUZA, 1998, p.123). 


\section{Edificação}

Obra arquitetônica.

\section{Educação}

A educação é vista como a transmissão de valores e o acúmulo de conhecimento de uma sociedade. Portanto, a história da educação também é a história de uma sociedade e seu desenvolvimento cultural, econômico e político. A origem etimológica da palavra educação - "trazer à luz a ideia", "conduzir para fora", ou seja, dar possibilidade de expressão de conteúdos internos individual e socialmente construídos desmistifica o caráter impositivo e unilateral que se possa dar ao processo educativo.

\section{Einfuhlung}

É a palavra alemã que significa entendimento ou empatia e foi usada por fenomenólogos como Edmund Husserl para explicar uma forma de conhecimento que procura entrar na experiência de outro ser humano e conhecer e sentir o mundo da mesma forma que esse ser humano.

\section{Eixos de Avaliação}

Os eixos de avaliação decorrem de um Ponto de Vista (PV) definido pelos decisores que pode ser: i) o PV expressa uma preocupação que pode ser mensurada, mas não diretamente. Neste caso, é necessário ter um índice composto por um conjunto de descritores, pois diversos são os aspectos que explicam aquele PV, segundo a percepção do decisor; ii) o PV reflete uma preocupação de cunho qualitativo sem um descritor direto para representá-lo.

\section{Elementos}

Coisas; o que compõe o todo; princípios, generalidade.

\section{Ensino de Arquitetura}

Um ensino de arquitetura com pretensão disciplinar é um ensino pragmático. Preocupa-se essencialmente com a transmissão de informações, regras de composição do projeto, relativas às suas tipologias específicas e às matérias de apoio técnico. A orientação principal dessa visão de ensino é o exercício profissional. Sua fonte de inspiração são os modelos organizacionais, ou os padrões de projeto, provenientes da prática profissional da arquitetura (ALMEIDA, 1997).

\section{EPA (Elementos Primários de Avaliação)}

São elementos (aspectos) que o decisor e os representantes consideram relevantes dentro do contexto decisório do modelo MCDA-C.

\section{Ergonomia}


"A Ergonomia (ou fatores Humanos) é uma disciplina científica relacionada ao atendimento das interações entre os seres humanos e outros elementos ou sistemas, e à aplicação de teorias, princípios, dados e métodos a projetos a fim de otimizar o bem-estar humano e o desempenho global do sistema" (FALZON, 2007).

"Ergonomia é o estudo da adaptação do trabalho ao homem." (IIDA, 2005).

\section{Equipamentos}

Equipamentos diversos existentes no campus. Ex. caixa eletrônico, telefone público, bebedouro.

\section{Espacialidade}

O conceito de espacialidade abrange os conceitos de espaço (geometria) e movimento (topologia). Quanto à materialidade - o espaço como matéria espacial - a pesquisa da espacialidade se ocupa das características e propriedades do vazio, o espaço deixado livre entre os objetos, a forma desse vazio, seu modo de arranjo tanto na escala do interior dos edifícios quanto na escala dos interiores urbanos. $\mathrm{O}$ estudo da espacialidade focaliza o fundo em vez da figura. Dessa forma o espaço tem, simultaneamente, uma descrição geométrica e uma descrição topológica. O vazio é naturalmente o domínio espacial do corpo e cenário no qual o movimento do(s) corpo(s) acontece, realizando desse modo o que se conhece, em arquitetura, como atividade ou função, ou ainda, no âmbito do projeto, o programa.

\section{Espaço físico}

Conteúdo limitado e definido por sistemas de coordenadas cartesianas ou geográficas, onde um objeto pode ser localizado. Espaço físico é um termo geral, incluindo áreas internas e externas às edificações, como: salas, corredores, estacionamentos, praças etc.

\section{Espaço}

Espaço [do latim: spatium]. Substantivo masculino. Distância entre dois pontos, ou a área ou o volume entre limites determinados. Lugar mais ou menos bem delimitado, cuja área pode conter alguma coisa (CARPINTERO; ALMEIDA, 2008). Extensão do campo tridimensional que abrange tudo o que nos cerca. É onde as coisas do mundo sensível existem, e no qual nos deslocamos em três dimensões: esquerda e direita, para frente e para trás e para cima e para baixo.

\section{Espaço arquitetônico}

É um espaço físico destinado ao habitar humano.

\section{Espaço arquitetônico para educação}

É um espaço físico destinado ao habitar de educação.

\section{Espaço pessoal}


Refere-se a uma área de limites invisíveis que cercam o corpo das pessoas, sendo um território portátil. Reflete dois usos: o primeiro refere-se à zona carregada emocionalmente ao redor de cada pessoa, a "bolha" que regula o espaçamento entre elas. O segundo uso refere-se aos processos pelos quais as pessoas delimitam e personalizam os espaços que habitam.

\section{Espaço de ensino-aprendizagem}

Espaço de aprendizagem é um "local onde articulam, intencionalmente processos de aprendizagem e de trabalho" (BURNHAM, 2000).

\section{Espaço de trabalho (ergonomia)}

É a configuração física do sistema homem-máquina-ambiente. É uma unidade produtiva envolvendo um homem e o equipamentoque ele utiliza para realizar o trabalho, bem como o ambiente que o circunda (IIDA, 2005, p. 189).

\section{Estratégia}

É o conjunto de objetivos, finalidades, metas, diretrizes fundamentais e os planos para atingir os objetivos.

\section{Estrutura}

Maneira como um edifício ou uma coisa qualquer é construída, organizada e disposta. Maneira como as partes de um todo estão dispostas entre si: estrutura do corpo humano.

\section{Estrutura organizacional}

Organização, disposição e ordem dos elementos essenciais que compõem a organização de uma instituição ou serviço.

\section{Equipamentos}

Aparelho em si, como um todo, usado na execução de uma tarefa ou serviço. É uma ferramenta que o ser humano utiliza para realizar alguma tarefa.

$\mathbf{F}$

\section{Forma}

Estrutura, organização e disposição das partes ou elementos de um corpo ou objeto. Modo pela qual uma determinada coisa em um dado contexto se revela à nossa percepção. São atributos de uma forma: sua configuração, seu tamanho, sua textura, sua cor e sua localização.

\section{Função de valor}

Taxa de atratividade local ou avaliação local, representa, numericamente, o grau de atratividade de cada nível de impacto de um descritor de um ponto de vista fundamental, em relação à escala ancorada em níveis prefixados (Bom e Neutro), de acordo com o 
sistema de valor do decisor

\section{I}

\section{Indicador}

É o parâmetro que medirá a diferença entre a situação desejada e a situação atual. O indicador permite quantificar um processo.

\section{Iluminação geral}

Ação ou efeito de iluminar ou iluminar-se. Irradiação da luz do sol ou da chama. Estado do que é alumiado.

\section{Informação}

Entende-se obtenção ou ganho de conhecimento, por procedimentos logicamente aceitáveis.

\section{Infraestrutura}

Um conjunto de elementos estruturais que enquadram e suportam toda uma estrutura. O termo possui diversas acepções em diferentes campos, mas o mais comum é o referente aos sistemas viários, de esgotos e de fornecimento de energia de uma cidade ou região.

\section{Instalações}

Ação de instalar ou instalar-se; inauguração, começo. Ação de pôr no lugar um aparelho, uma rede elétrica e eletrônica, de telefonia, de drenagem de águas pluviais, mecânicas e de utilidades, gás combustível, vapor, ar comprimido, vácuo e oxigênio e prevenção e combate a incêndio.

L

\section{Layout}

É um desenho que permite visualizar o projeto, destacando a disposição e aspectos principais de seus elementos constituintes. Quando destinado ao cliente, deve simular o produto final com a melhor aproximação possível.

\section{Linguagem arquitetônica}

Conjunto de elementos que dão à composiçao arquitetônica, enquanto expressão artística e manifestação da vontade humana, um certo ordenamento sintático, morfológico e semântico. Os arquitetos não pretendem com sua obra passar "mensagens"concretas, traduzíveis em palavras, pelo domínio da gramática e da sintaxe das formas e do espaço, mas do contrário, transmitir ao usuário da arquitetura uma determinada experiência abstrata. o termo "Linguagem Arquitetônica", diz respeito à uma área de estudos sobre as linguagens aplicadas à arquitetura e também à transmissão da arquitetura como forma 
de conhecimento: a arquitetura entendida como um grande artefato ou espaço construído em diálogo com seu entorno ambiental e também como forma de cultura, que envolve sociedade, técnica e expressão artística, os três pilares nos quais se apoia a arquitetura -

\section{Luminância}

É a quantidade de luz refletida que entra no olho e estimula a retina. Muita luz causa ofuscamento, pouca luz causa percepção ruim ou impossível. É o fluxo luminoso incidente por unidade de área iluminada.

M

\section{Mapas Cognitivos}

São uma representação gráfica cuja finalidade é representar da melhor maneira possível uma situação (problema) em que os atores desejam que alguma coisa seja diferente de como ela é, não se sentindo, porém, muito seguros de como obtê-la. São uma ferramenta necessária para definir o problema a ser resolvido (identificar os critérios de avaliação).

\section{Mapa temático}

Representação gráfica, sobre um mapa básico (topográfico, geográfico ou hidrográfico), de sínteses, de pesquisa e estudos de temas variados, por exemplo, agrícolas, arqueológicos, climáticos, econômicos etc.

\section{Matriz semântica}

É a matriz que contém a resposta do decisor. O decisor não consegue manter uma consistência de todos os seus juízos de valor, principalmente quando há muitos julgamentos a serem analisados para determinar a matriz semântica.

\section{Metodologia científica}

É um conjunto de abordagens, técnicas e processos utilizados pela ciência para formular e resolver problemas de aquisição objetiva do conhecimento, de uma maneira sistemática (RODRIGUES et al., 2007).

\section{Metodologia Multicritério de Apoio à Decisão (MCDA-C)}

Trata-se de uma metodologia voltada para analisar situações complexas, a partir de um conjunto de indicadores quantitativos e qualitativos distintos, incluindo indicadores financeiros, físicos, de insumos, de processos, de produtos e de resultados; que pode ser utilizada tanto para apoio à decisão quanto como um conjunto de técnicas analíticas.

\section{Modelo Multicritério de Apoio à Decisão (MCDA-C)}

É construído para ajudar os decisores (dono do problema) a compreender sua percepção sobre o contexto decisório (território). Cria uma linguagem própria que permite uma comunicação entre vários atores envolvidos no processo decisório, e que, até então, não 
tinham essa intercomunicação, fornecendo uma base adequada para gerar conhecimento, como também para criar alternativas que solucionem o problema do decisor.

\section{Mobiliário escolar}

O mobiliário, em função dos requisitos da tarefa, determina a configuração postural dos usuários e define os esforços, dispêndios e constrangimentos - elementos essenciais para a adoção de comportamentos diversos - estabelecidos numa jornada de trabalho em sala de aula, além de manter vínculo restrito com a absorção do conhecimento (NUNES et al., 1985).

\section{$\mathbf{N}$}

\section{Nível de impacto}

Serve para descrever impactos plausíveis (performance) das ações potenciais associadas a um ponto de vista fundamental. Quando em conjunto, formam um descritror.

\section{Nomenclatura}

Nome de determinado ambiente, edificação ou espaço ao ar livre.

\section{Norma técnica}

Uma norma técnica (ou padrão) é um documento, normalmente produzido por um órgão oficial acreditado para tal, que estabelece regras, diretrizes ou características acerca de um material, produto, processo ou serviço.

\section{$\mathrm{O}$}

\section{Ofuscamento}

É um efeito qualitativo negativo que interfere no conforto visual causado por intensa luz direta que incide sobre os olhos do usuário.

\section{Organograma}

Representação gráfica da estrutura organizacional de uma instituição, que indica os seus componentes e as relações entre eles.

\section{$\mathbf{P}$}

\section{Parâmetros}

São ferramentas de apoio ao programa arquitetônico para abrigarem adequadamente as atividades de ensino propostas.

\section{Parâmetros do conforto térmico}

Modos de transferência de calor, aspectos fisiológicos e outras variáveis.

\section{Paradigmas educacionais}

Constituem um modelo usado na área da educação. O paradigma usado por um 
professor tem grande impacto no aluno, muitas vezes determinando se ele vai aprender ou não aprender o conteúdo que é abordado.

\section{Partido arquitetônico}

É a ideia inicial de um projeto, sua formulação é uma criação autoral e inventiva com base na coerência e na lógica funcional; o partido, sendo uma prefiguração do projeto, faz da projetação um processo que vai do todo em direção à parte (BISELLI, 2011). Partido é uma consequência formal derivada de uma série de condicionantes ou de determinantes; é o resultado físico da intervenção sugerida. Os principais determinantes, ou condicionadores do partido são:

a) técnica construtiva, segundo os recursos locais, tanto humanos quanto materiais, que inclui aquela intenção plástica, às vezes, subordinada aos estilos arquitetônicos;

b) o clima;

c) as condições físicas e topográficas do sítio onde se intervém;

d) o programa das necessidades, segundo os usos, costumes populares ou conveniências do empreendedor;

e) as condições financeiras do empreendedor dentro do quadro econômico da sociedade;

f) a legislação regulamentadora e/ou as normas sociais e/ou as regras da funcionalidade.

\section{Patterns}

São parâmetros escolares que definem a qualidade do edifício, nos níveis micro e macro e que, embora sejam aparentemente independentes, devem funcionar no todo.

\section{Pedagogia}

A palavra Pedagogia tem sua origem na Grécia, a partir de paidós (criança) e de agogôs (condutor). A Pedagogia está vinculada ao ato de conduzir ao saber ou à sua construção (KOWALTOWSKI, 2011).

\section{Percepção}

O conceito de percepção tem sido compreendido e definido, fundamentalmente, de duas maneiras: uma cujo conceito é relacionado à interação entre o espaço e o usuário, exclusivamente, por meio dos sentidos básicos (visão, olfato, audição, tato e paladar); outra, relacionada à interação entre o espaço e o usuário, por meio dos sentidos básicos e de outros fatores tais como memória, personalidade, cultura e tipo de transmissão (RAPOPORT, 2013).

\section{Perfil de Impacto}


A partir das informações da avaliação (desempenho) local das respostas dos professores em todos os critérios e subcritérios do modelo, pode-se utilizar destas informações para comparar as respostas dos professores e determinar seus pontos fortes e fracos.

\section{Perspectivas}

Ë uma palavra de múltiplos significados, podendo estar relacionada com o modo como se analisa determinada situação ou objeto; um ponto de vista sobre uma situação em específico; um modo tridimensional de representação ou tudo aquilo que se consegue ver ao longe.

\section{Planta de arquitetura}

Traçado ou desenho, representando a projeção horizontal de um edifício, cidade etc.

\section{Posto de trabalho}

É a configuração física do sistema homem-máquina-ambiente. É uma unidade produtiva envolvendo um homem e o equipamento que ele utiliza para realizar o trabalho.

\section{Postura (ergonomia)}

É a atitude que a pessoa assume, utilizando a menor quantidade de esforço muscular e ao mesmo tempo protegendo as estruturas de suporte contra traumas. A postura é o aspecto mais influenciado pela cadeira e mobiliário corporativo.

\section{Prática pedagógica}

[... p pática intencional de ensino e aprendizagem não reduzida à questão didática ou às metodologias de estudar e de aprender, mas articulada à educação como prática social e ao conhecimento como produção histórica e social, datada e situada, numa relação dialética entre prática-teoria, conteúdo-forma e perspectivas interdisciplinares (FERNANDES, 1999, p. 159).

\section{Premissa}

O que determina o assunto, pontos de partida sobre determinado assunto, serve de base para um assunto que levará a uma conclusão, princípio, propósito.

\section{Privacidade}

É a gestão do indivíduo sobre as informações de si mesmo e sobre a sua interação com as outras pessoas.

\section{Projetação}

Um aspecto interessante da atividade de projeto é justamente a quantidade de teorias, metodologias, manuais de procedimentos e técnicas as mais diversas da qual foi objeto historicamente. Mais interessante ainda é observar que, embora parte do processo 
de produção do projeto possa estar sujeita a uma sequência de procedimentos, o processo inteiro jamais poderá se enquadrar neste modelo, e, portanto, as metodologias não se sustentam enquanto sistemas universais, embora seja obrigatório conhecê-las, pois a nenhum arquiteto é permitida a ignorância sobre a experiência acumulada que compõe a história da arquitetura. O termo projetação tem sido pouco usado no Brasil, mas é o termo que define a produção do projeto de arquitetura como um processo. Esse processo tem um momento crítico e imponderável que foge a qualquer metodologia, mesmo quando a projetação estava sujeita às regras da composição clássica. Esse momento crítico é o momento que envolve as decisões relativas ao que conhecemos por partido arquitetônico, termo que em outros lugares é também conhecido como estratégia ou conceito (BISELLI, 2011).

\section{Projeto pedagógico}

É a síntese dos princípios, diretrizes e prioridades estabelecidas pela equipe escolar a partir dos objetivos educacionais e da definição dos resultados a serem atingidos, sempre voltados para a melhoria da aprendizagem dos alunos e do desempenho da escola.

\section{Projeto político-pedagógico}

O projeto político-pedagógico é entendido, neste estudo, como a própria organização do trabalho pedagógico da escola. A construção do projeto político-pedagógico parte dos princípios de igualdade, qualidade, liberdade, gestão democrática e valorização do magistério.

\section{Processo}

É o conjunto sequencial e peculiar de ações que objetivam atingir uma meta. É usado para criar, inventar, projetar, transformar, controlar, manter e usar produtos ou sistemas.

\section{Projeto de arquitetura}

"Projeto - criação do espírito, documentada através de representação gráfica ou escrita de modo a permitir sua materialização, podendo referir-se a uma obra ou instalação, a ser realizada através de princípios técnicos e científicos, visando à consecução de um objetivo ou meta e adequando-se aos recursos disponíveis e às alternativas que conduzem à viabilidade de sua execução" (Resolução CAU/BR, 2012).

Conforme ABNT (1995a), de novembro de 1995: “[...] Elaboração de projeto: Determinação e representação prévias do objeto (urbanização, edificação, elemento da edificação, instalação predial, componente construtivo, material para construção) mediante o concurso dos princípios e das técnicas próprias da arquitetura e da engenharia."

\section{Programa de necessidades}

A etapa do programa de necessidades consiste na reunião do material de referência 
necessário ao desenvolvimento do projeto, à organização e apresentação clara de dados, para obter as informações diferenciais das etapas seguintes do projeto (KOWALTOWSKI, 2011).

Determina a realização de um espaço arquitetônico para abrigar e favorecer o exercício de certas atividades humanas. Sob a forma de um edifício ou sob a forma de um espaço urbano, o espaço arquitetônico tem como traço mais importante o fato de constituir um ambiente especialmente condicionado às atividades que abriga (GRAEFF, 1979).

\section{Psicologia Ambiental}

Psicologia Ambiental é o estudo da transação entre indivíduos e o cenário físico quando indivíduos modificam o ambiente e seu comportamento e experiência são modificados pelo ambiente, levando-se em conta os três elementos básicos: comportamento e experiência humanos, espaço (ou cenário) físico e relação recíproca entre o primeiro e o segundo - o elemento da ligação recíproca (GIFFORD, 1997).

\section{Ponto de Vista Elementar (PVE)}

É um critério de nível hierárquico inferior que deve ser mutuamente exclusivo e fornecer uma caracterização exaustiva (completa) do critério de nível hierárquico superior $(\mathrm{PVF})$.

\section{Ponto de Vista Fundamental (PVF)}

É um critério de nível hierárquico superior que expressa os valores do decisor no processo decisório.

\section{$\mathbf{R}$}

\section{Rede de instalação}

Registro dos elementos e das dimensões da rede de eletricidade, telefonia, esgoto, água, drenagem e águas pluviais, prevenção e combate a incêndio etc.

\section{Referências}

"pesquisa bibliográfica"sintética, objetivando construir uma base teórica.

\section{Requalificação}

Na verdade não ocorre o uso ortodoxo da palavra substantiva "requalificação" na língua portuguesa, apenas o verbo "requalificar" (re- + qualificar): tornar a qualificar; qualificar de novo. De qualquer modo, a categoria da Requalificação Urbana tem-se configurado como aquela que atualmente incorpora intervenções urbanas e infraestruturais de maior porte, promovendo transformações urbanas físicas mais pesadas no território.

\section{Revestimento}

Ato ou efeito de revestir. Matéria ou substância (tinta, argamassa, madeira) que 
estendemos sobre a superfície de um corpo, para protegê-lo, orná-lo, dar-lhe melhor aparência.

\section{Robustez do Modelo}

Os critérios são construídos de acordo com as preferências do decisor e depois quantificados pelas taxas de substituição, que estão dentro de um intervalo de valores no modelo por um ponto (valor), daí a necessidade de analizar a robustez do modelo.

\section{Rótulo}

O rótulo tem a função de delimitar o contexto decisório, de tal forma a manter o foco nos aspectos mais relevantes na resolução do problema.

\section{$\mathbf{S}$}

\section{Sistema}

Conjunto estruturado de objetos e atributos com limites definidos, capaz de expressar a própria dinâmica e as relações de inserção com o restante da realidade.

\section{Sistema Informatizado de Gerenciamento do Ambiente Escolar}

Sistema de auxílio eficiente e útil para o gerenciamento de intervenções e o controle sistemático do ambiente educacional em relação ao conforto ambiental, por possibilitar, simultaneamente, a localização de um determinado ambiente pela planta do edifício e a visualização de informações relevantes ao seu desempenho. Isso cria um vínculo dinâmico de vistoria das condições ambientais, facilmente acessado pela comunidade escolar, favorecendo a autonomia no gerenciamento dos espaços construídos. A consciência dos efeitos causados pelas intervenções adotadas aumenta a precisão na tomada de decisões e possibilita uma maior interação entre a população e o ambiente (KOWALTOWSKI, 2011).

\section{Subcritério}

A partir da determinação de uma função de valor associada a um descritor, considerase que foi construído um critério de avaliação para um dado PVF e subcritérios para os PVEs. e SubPVEs.

\section{SubPVE}

É uma decomposição do PVE para ter um esclarecimento melhor, pois o PVE é um critério mais genérico.

\section{$\mathrm{T}$}

\section{Taxas de substituição}

Determinam a importância relativa dos pontos de vista (PVF, PVE e SubPVE) identificados no modelo multicritério. São parâmetros que os decisores (especialistas) julgam adequados para agregar, de forma compensatória, desempenhos locais (nos critérios) em 
uma performance global.

\section{Tecnologia de aprendizado}

No campo da educação, os avanços tecnológicos em hardware e software permitem a introdução de novas técnicas que enriquecem o processo de ensino-aprendizagem (BELHOT, 1995).

\section{Territorialidade}

É um padrão de comportamento e atitudes, detido por parte por um indivíduo ou grupo, baseados em controle percebido, tentado ou real sobre um espaço físico definível, objeto ou ideia, que pode implicar em ocupação habitual, defesa, personalização e demarcação.

W

\section{Walking tour ou walkthrough}

Passeio a pé ou passo a passo.

\section{Wayfinding}

Orientação espacial e ambiental para ajudar na navegação ate um destino. 

Apêndices 



\section{APÊNDICE A - Distribuição dos espaços arquitetônicos da FAU/UnB e suas características}

Este apêndice apresenta a distribuição dos espaços arquitetônicos da FAU/UnB e suas características, diretrizes gerais e programáticas para elaboração de projetos de arquitetura, diretrizes para o programa de necessidades e as diretrizes de zoneamento (Capítulo 5, seção 5.1.3). 


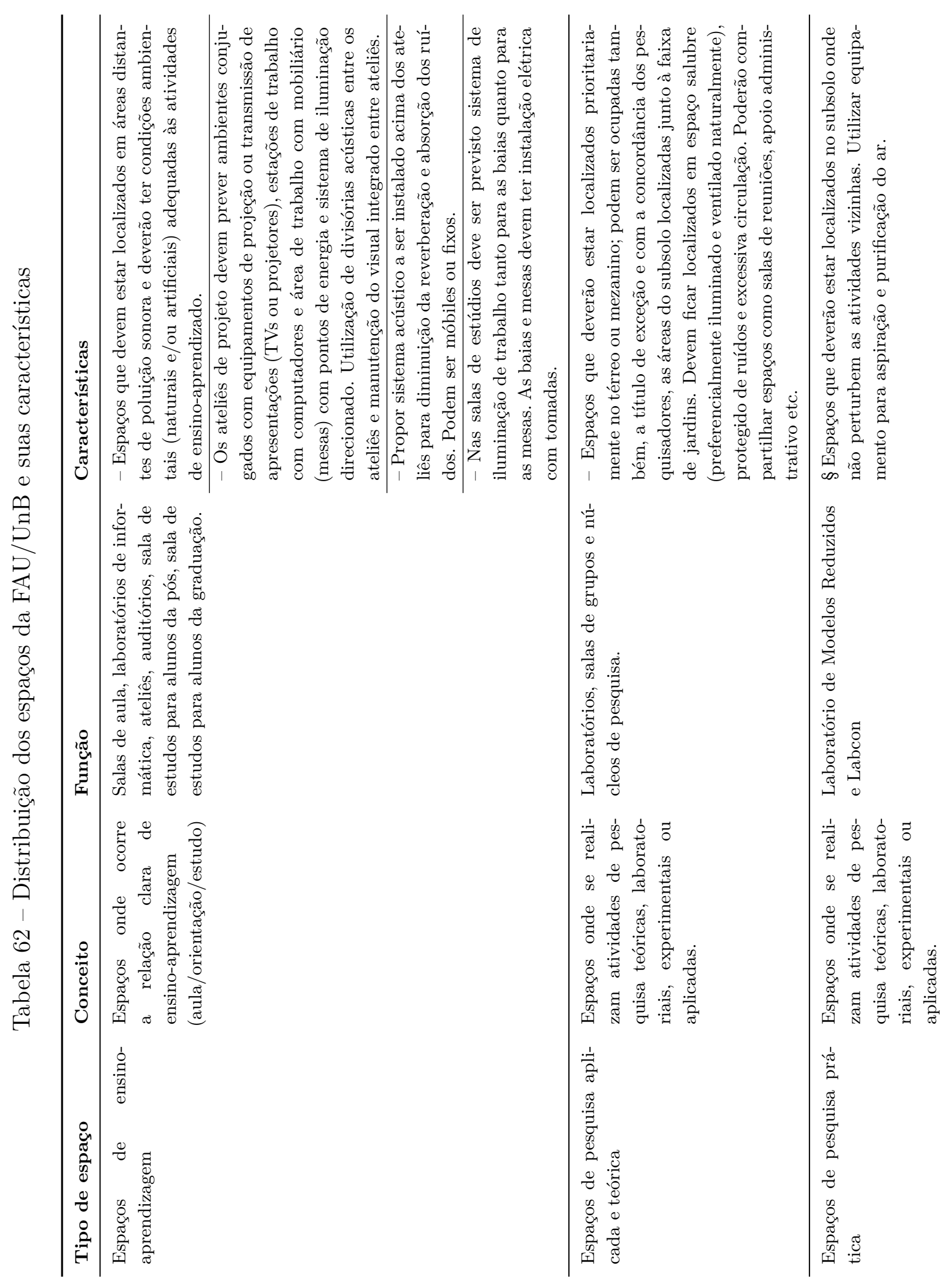




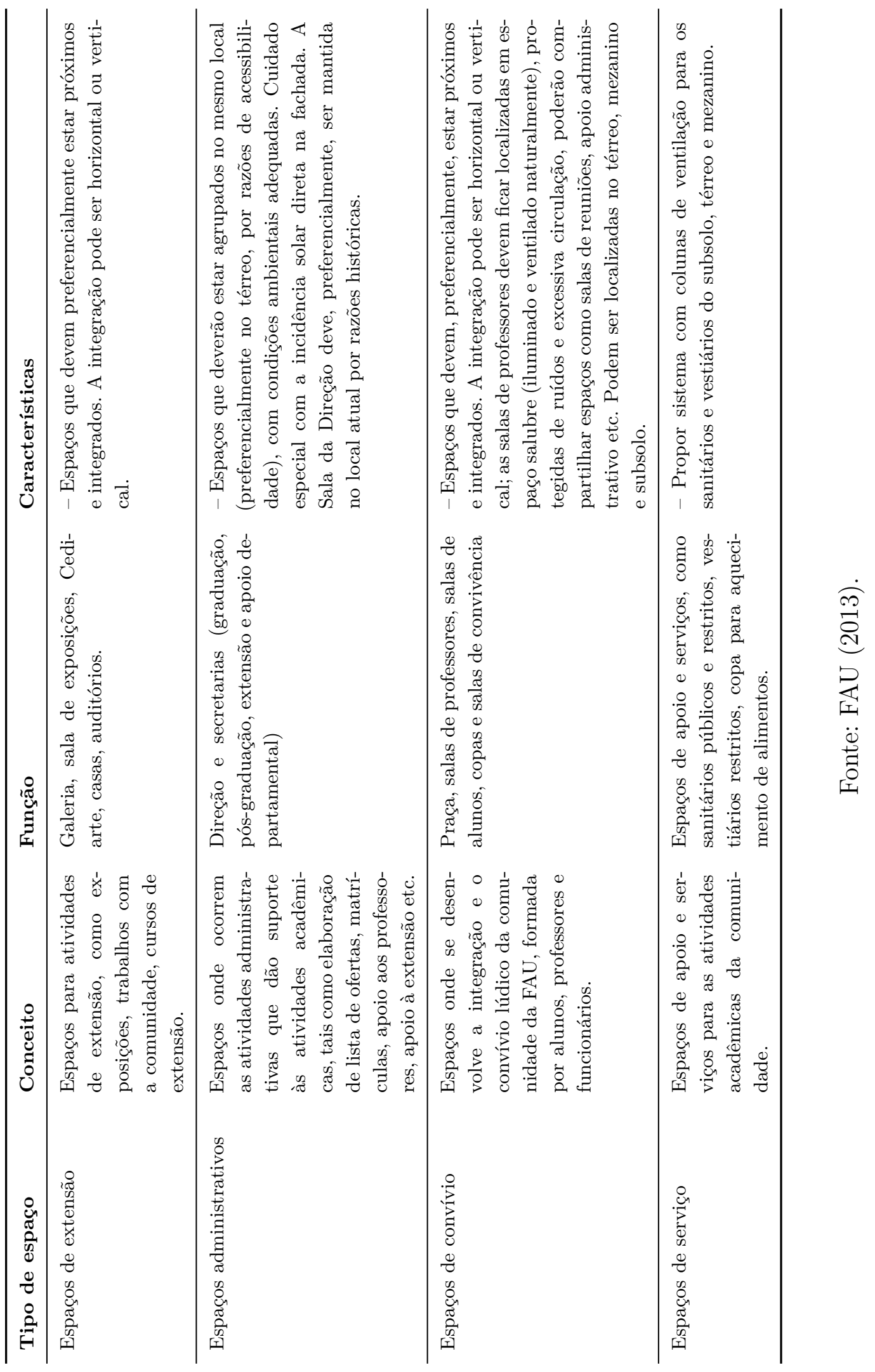


Tabela 63 - Diretrizes gerais para elaboração de alteração do espaço físico da FAU.

\begin{tabular}{l}
\hline Atender ao Projeto Político Pedagógico da FAU; \\
\hline Respeitar as características e premissas de uso e condicionantes ambientais do ICC; \\
\hline Garantir acessibilidade a todos os ambientes da FAU, (térreo, mezanino e subsolo) por escadas, e/ou \\
elevadores e/ou plataformas verticais ou inclinadas; \\
Os avanços no pé-direito duplo (lajes nervuradas apoiadas em vigas metálicas) não serão removidos; \\
\hline Prever no programa de necessidades o compartilhamento de ambientes para atividades semelhantes, como, \\
por exemplo, para as reuniões.
\end{tabular}

Fonte: FAU (2013).

Tabela 64 - Diretrizes programáticas para elaboração do projeto arquitetônico da FAU.

Os espaços de pesquisa aplicada e teórica (laboratórios, núcleos e grupos de pesquisa) deverão compartilhar espaços como salas de reuniões, apoio administrativo, etc.;

Salas de professores deverão compartilhar espaços como salas de reuniões, apoio administrativo, etc.;

Devem ser previstos espaços de convivência para funcionários, professores e alunos;

A Praça da FAU deve ser mantida no programa de necessidades;

Devem ser previstos ateliês específicos para as disciplinas de desenho e plástica com mobiliário adequado;

Devem ser previsto um ateliê de trabalho equipado com baias individuais e por mesas individuais;

A quantidade de salas de professores deverá ser definida a partir de demanda real e pela consideração de que parte dessas salas pode ser atendida nos ambientes de laboratórios, núcleos e grupos de pesquisa;

Deve ser motivado e incentivado que as salas de professores sejam compartilhadas;

O espaço destinado a ateliês e salas de aula deve ter prioridade na alocação dos espaços dentro do ICC.

Fonte: FAU (2013).

Tabela 65 - Diretrizes para Programa de Necessidades da FAU/UnB

\begin{tabular}{ll}
\hline Espaços & Necessidades \\
\hline & 06 (seis) ateliês de projeto. \\
\cline { 2 - 2 } & Cada ateliê deve ser dimensionado para atender de 45 a 50 alunos, sendo \\
garantida a possibilidade de divisão em duas turmas distintas com até 25 \\
alunos cada.
\end{tabular}




\begin{tabular}{ll}
\hline Espaços & Necessidades \\
\hline & Divisórias com modulação e especificações adequadas à exposição de trabalhos, \\
& com sistema de iluminação direcionada e eletrocalha para sistema elétrico de \\
& apoio às mesas (tomadas). Para divisórias altas prever parte superior com \\
material transparente.
\end{tabular}

02 (dois) ateliês específicos (30 alunos cada) com mobiliário adequado às ativi-

Ateliês de Desenho e Plástica dades de desenho (mesas, cavaletes, armários, bancadas com pias, iluminação cenográfica, biombos).

Propor a possibilidade do uso de divisórias móveis e acústicas para a integração dos ateliês.

Posicionar os ateliês em local com iluminação natural direta.

04 (quatro) salas de aula para a graduação dimensionadas para 60 alunos.

06 (seis) salas de aula para a graduação dimensionadas para 30 alunos.

04 (quatro) salas de aula para a pós-graduação dimensionadas para 20 alunos. Posicionar as salas perto da Área Administrativa da Pós.

Salas de Aula

Propor mobiliário com mesas pequenas (com tomada) e cadeiras personalizadas com cores diferentes. Projetor fixo e área de projeção fixa. preferencialmente quadro negro.

Garantir boa iluminação ambiente e de trabalho, boas condições de ventilação (renovação de ar) e condição acústica adequada.

Especificar materiais e cores adequadas aos ambientes de aula e estudo.

Salas de aula para disciplinas apoiadas por computador devem ser dimensionadas e equipadas para atender a turmas de 30 alunos.

Composta pela Direção, Secretaria de Apoio Departamental, Secretaria de Graduação, Secretaria da Pós-Graduação, Secretaria de Apoio à Extensão.

Acessos de funcionários e público pelo corredor do ICC.

Administrativa $\quad$ Integrar os ambientes com divisórias baixas.

Preocupar com a proteção solar da fachada oeste para se garantir conforto ambiental.

O programa de necessidades deve prever o compartilhamento de ambientes para atividades semelhantes, por exemplo, para as reuniões.

Evitar a compartimentação dos espaços e utilizar de mobiliário adequado para a guarda e controle de documentos e materiais de almoxarifado.

Entradas da FAU

Criar a Entrada Principal da FAU com hierarquia superior às demais.

Integrar à Praça da FAU, à Área de Exposições e Eventos da FAU, à Área Administrativa da FAU e à praça interna do ICC. Integração pode ser horizontal ou vertical.

Manter a Galeria e Área de Exposições nos mesmos locais e integrar à Praça

Galeria e Área de Exposições $\frac{\text { da FAU, ou localizar a Área de Exposições e Galeria no subsolo. }}{\text { Propor mobiliário flexível que permita montar exposições de trabalhos com }}$ facilidade e agilidade, bem como sistema de eletrocalhas que permita grande liberdade na organização do espaço.

Dimensionar a Área de Exposições para receber TFG do diurno e noturno. Caso seja posicionada no térreo, a Praça da FAU também pode ser utilizada para esse fim. 


\begin{tabular}{ll}
\hline Espaços & Necessidades \\
\hline & $\begin{array}{l}\text { Valorizar o ambiente da Praça com equipamentos e mobiliário permanente } \\
\text { adequados ao uso. }\end{array}$ \\
\cline { 2 - 2 } & $\begin{array}{l}\text { Integrar à Área de Exposições e Eventos, à Entrada Principal da FAU e à } \\
\text { Praça Externa da FAU. Quando da realização de eventos, a Praça poderia ser } \\
\text { utilizada como foyer do Auditório e da Área de Exposiçoses. }\end{array}$ \\
\hline
\end{tabular}

Criar o CineFAU, um espaço para projeções de filmes e trabalhos relacionados a arte, arquitetura e urbanismo.

Propor sistema de áudio por rede sem fio ou por domos acústicos como parte do CineFAU.

Possibilitar que a Praça seja um complemento do espaço para exposições. Pensar na exposição dos TFGs com diurno e noturno.

Prever vitrines ou nichos para exposições de maquetes, esculturas e outros produzidos pela FAU, amenizando ou evitando a necessidade de pessoal de segurança.

Capacidade para 150 pessoas ou mais.

Palco com mesa para 6 lugares, pano de projeção e apoio dos sistemas de áudio,

Auditório vídeo e iluminação.

O Auditório deve ser posicionado no térreo e estar integrado à Sala de Exposições, Galeria da FAU e Praça da FAU, ou o Auditório deve ser posicionado no subsolo junto da Área de Exposições.

A Praça da FAU ou a Área de Exposições podem ser utilizadas como foyer do Auditório. Se possível, prever pequena copa para apoio ao Auditório e Área de Exposições.

Deve ser motivado e incentivado que as salas de professores sejam compartilhadas.

Sala de Professores

Três ou mais professores num mesmo ambiente, com estações de trabalho individuais e divisórias baixas.

A quantidade de salas de professores deverá ser definida a partir de demanda real e pela consideração de que parte dessas salas pode ser atendida nos ambientes de laboratórios e grupos de pesquisa.

As salas de professores compartilhadas devem ser localizadas preferencialmente no mezanino.

As salas compartilhadas deverão ser dimensionadas para o uso de estações de trabalho individuais. armários individuais com portas. e mesa de reunião pequena.

Cediarte

Propor ambientes, áreas e layout para o Cediarte após a definição do foco/objetivo, se será um centro de documentação ou uma biblioteca setorial.

Definir suas atividades entre somente empréstimo, com consulta e com estudo.

Propor ambiente para as atividades do Centro Acadêmico integrado à Praça da FAU.

Cafau

Assumir a Praça da FAU como o ambiente de reunião e encontro dos alunos e do Centro Acadêmico.

Prever depósito do Cafau no subsolo.

Acesso do Cafau deve acontecer diretamente para a Praça da FAU. 


\begin{tabular}{|c|c|}
\hline Espaços & Necessidades \\
\hline & $\begin{array}{l}\text { Prever no ambiente do Cafau uma área de escritório com estação de trabalho, } \\
\text { uma mesa de reuniões e um ambiente de estar. }\end{array}$ \\
\hline $\begin{array}{l}\text { Laboratórios e Grupos de } \\
\text { Pesquisa Aplicada e Teórica }\end{array}$ & $\begin{array}{l}\text { Definir a área de construção máxima a ser distribuída a esses laboratórios e } \\
\text { centros e dividir proporcionalmente, conforme justificativas de demanda }\end{array}$ \\
\hline \multirow[t]{3}{*}{$\begin{array}{l}\text { Laboratórios e Grupos de } \\
\text { Pesquisa Prática }\end{array}$} & $\begin{array}{l}\text { Devem ser localizados no subsolo em uma de suas das laterais, onde hoje é a } \\
\text { Pós. }\end{array}$ \\
\hline & $\begin{array}{l}\text { Labcon: área para maquinas e equipamentos laboratoriais, bancadas, sala de } \\
\text { técnicos, câmara úmida, porta de serviço direto à rua de serviço. }\end{array}$ \\
\hline & $\begin{array}{l}\text { Laboratório de Modelos Reduzidos: sala de aula para } 50 \text { alunos, área para } \\
\text { máquinas e equipamentos, bancadas com pias, sala de técnicos, vitrines para } \\
\text { guarda e exposição de maquetes, equipamento para aspiração e purificação do } \\
\text { ar, porta de serviço direto à rua de serviço. }\end{array}$ \\
\hline \multirow{2}{*}{$\begin{array}{l}\text { Laboratórios e centros com } \\
\text { alta relação com público ex- } \\
\text { terno }\end{array}$} & $\begin{array}{l}\text { Posicionar esses ambientes preferencialmente no pavimento térreo com acessos } \\
\text { para o corredor do ICC. Favorecer e facilitar o acesso ao público externo. }\end{array}$ \\
\hline & Casas, Lasis e outros que tenham essa demanda. \\
\hline \multirow{4}{*}{ Áreas de Estudos } & $\begin{array}{l}\text { Deve ser prevista uma área de estudos para alunos da graduação, preferenci- } \\
\text { almente no térreo e próximo à entrada secundária. }\end{array}$ \\
\hline & $\begin{array}{l}\text { Deverá ser equipada com baias individuais posicionadas em paredes e divisórias } \\
\text { e por mesas de quatro lugares. }\end{array}$ \\
\hline & $\begin{array}{l}\text { Deve ser previsto sistema de iluminação de trabalho tanto para as baias quanto } \\
\text { para as mesas devendo ter instalação elétrica com tomadas. }\end{array}$ \\
\hline & $\begin{array}{l}\text { Essa área de estudo deverá ter um apoio (copa) para dar maior comodidade } \\
\text { nos horários de refeições. }\end{array}$ \\
\hline \multirow{3}{*}{$\begin{array}{l}\text { Sala de Alunos de Douto- } \\
\text { rado e Mestrado }\end{array}$} & Prever sala de alunos de pós-graduação com dedicação exclusiva. \\
\hline & $\begin{array}{l}\text { Ambiente(s) com estações de trabalho individuais a serem disponibilizadas } \\
\text { para alunos de doutorado (por } 2 \text { anos) e de mestrado (por } 1 \text { ano). copia- } \\
\text { dora/impressora com sistema wireless de impressão e controle de cotas de } \\
\text { impressão, mesa de reunião. }\end{array}$ \\
\hline & Dimensionar conforme oferta de bolsas e/ou demanda da pós. \\
\hline \multirow{4}{*}{$\begin{array}{l}\text { Áreas de Convivência de } \\
\text { Professores e Funcionários }\end{array}$} & $\begin{array}{l}\text { Prever a Área de Convivência privativa para funcionários e professores no } \\
\text { mezanino próxima às salas compartilhadas de professores. }\end{array}$ \\
\hline & $\begin{array}{l}\text { Equipar com televisão, algumas mesas de quatro lugares, copiadora/impressora } \\
\text { com sistema wireless de impressão e controle de cotas de impressão, sofás e } \\
\text { apoio para aquecimento de alimentos (bancada com pia, geladeira, micro-ondas } \\
\text { e máquina de café e chá). }\end{array}$ \\
\hline & Prever local para os escaninhos de professores e funcionários. \\
\hline & $\begin{array}{l}\text { Os sanitários privativos dos funcionários e professores devem ter seus acessos } \\
\text { pela área de convivência }\end{array}$ \\
\hline \multirow{3}{*}{ Sanitários e Vestiários } & $\begin{array}{l}\text { Dobrar a área atual dos dois sanitários do térreo e propor novo layout com } \\
\text { acesso direto ao corredor do ICC. }\end{array}$ \\
\hline & Garantir a proteção visual do interior de todos os sanitários e vestiários. \\
\hline & $\begin{array}{l}\text { Propor dois conjuntos de sanitários privados para professores e funcionários } \\
\text { da FAU no mezanino perto das salas de professores (tranca eletrônica com } \\
\text { controle por senha individual). }\end{array}$ \\
\hline
\end{tabular}




\begin{tabular}{|c|c|}
\hline \multirow[t]{3}{*}{ Espaços } & Necessidades \\
\hline & $\begin{array}{l}\text { Propor um conjunto de vestiários privados para alunos, professores e funcioná- } \\
\text { rios da FAU no subsolo (tranca eletrônica com controle por senha individual). }\end{array}$ \\
\hline & $\begin{array}{l}\text { Propor sistema com colunas de ventilação para os sanitários e vestiários do } \\
\text { subsolo, térreo e mezanino. }\end{array}$ \\
\hline \multirow[t]{2}{*}{ Copas } & $\begin{array}{l}\text { Propor uma pequena copa de uso privado e restrito aos alunos da FAU (micro- } \\
\text { ondas, máquina de café e chá, bancada com pia) próxima à Área de Estudos } \\
\text { dos alunos. }\end{array}$ \\
\hline & $\begin{array}{l}\text { Propor pequena copa (micro-ondas, máquina de café e chá, bancada com pia) } \\
\text { dentro da Área Administrativa e dentro da Sala de Alunos da Pós. }\end{array}$ \\
\hline \multirow{5}{*}{ Armários dos alunos } & Retirar os armários dos alunos que ficam entre os ateliês. \\
\hline & Posicionar os armários nos corredores do mezanino e subsolo. \\
\hline & $\begin{array}{l}\text { Detalhar as vedações onde os armários fiquem apoiados ou detalhar os armários } \\
\text { de maneira a garantir conforto acústico e boa ventilação aos ambientes. }\end{array}$ \\
\hline & $\begin{array}{l}\text { Dimensionar adequadamente os armários para a guarda de material de desenho } \\
\text { tentando otimizar ao máximo a sua área e volume. Largura menor que a atual } \\
\text { (proposta } 30 \mathrm{~cm} \text { ) e profundidade maior que a atual (proposta } 50 \mathrm{~cm} \text { ou } 60 \mathrm{~cm} \text { ). }\end{array}$ \\
\hline & Oferecer um armário para cada aluno da FAU (500 armários duplos). \\
\hline \multirow[t]{3}{*}{ Corredores } & $\begin{array}{l}\text { Posicionar os corredores internos do térreo de maneira a facilitar o controle, a } \\
\text { segurança e a abertura das portas e janelas, bem como o ajuste dos protetores } \\
\text { de fachada da leste. }\end{array}$ \\
\hline & $\begin{array}{l}\text { Corredores internos do térreo que dão acesso aos ateliês com, no mínimo, } 175 \\
\mathrm{~cm} \text { de largura. Corredores internos do mezanino com no mínimo } 140 \mathrm{~cm} \text { de } \\
\text { largura (igual a atual). Corredores internos do subsolo com no mínimo } 200 \mathrm{~cm} \\
\text { (igual a atual). }\end{array}$ \\
\hline & $\begin{array}{l}\text { Seguir as normas de prevenção contra incêndio (saídas de emergência e com- } \\
\text { primento máximo dos corredores). }\end{array}$ \\
\hline \multirow{5}{*}{ Depósitos } & Devem ser posicionados preferencialmente no subsolo.. \\
\hline & $\begin{array}{l}\text { Depósito para móveis e equipamentos enquanto aguardam recolhimento patri- } \\
\text { monial ou em manutenção. Não deve ser grande para não favorecer a perma- } \\
\text { nência prolongada de material a ser recolhido. }\end{array}$ \\
\hline & Depósito do Cafau. \\
\hline & Depósito de apoio à Área de Exposições. \\
\hline & Depósito de material de limpeza. \\
\hline
\end{tabular}

Fonte: FAU/UnB (2013).

Tabela 66 - Diretrizes de Zoneamento da FAU/UnB

\begin{tabular}{ll}
\hline Espaço Físico & Localização \\
\hline Espaços de ensino & deverão estar localizados em áreas distantes de poluição sonora. Podem ser \\
& $\begin{array}{l}\text { localizadas no térreo, mezanino e subsolo. Os ateliês devem ser localizados no } \\
\text { térreo e/ou mezanino; }\end{array}$ \\
\hline
\end{tabular}




\begin{tabular}{|c|c|}
\hline Espaço Físico & Localização \\
\hline $\begin{array}{l}\text { Espaços de pesquisa apli- } \\
\text { cada e teórica (laboratórios, } \\
\text { núcleos e grupos de pes- } \\
\text { quisa) }\end{array}$ & $\begin{array}{l}\text { deverão estar localizados prioritariamente no térreo ou mezanino. Podem ser } \\
\text { ocupadas também, a título de exceção e com a concordância dos pesquisadores, } \\
\text { as áreas do subsolo localizadas junto à faixa de jardins. }\end{array}$ \\
\hline $\begin{array}{l}\text { Espaços de pesquisa prática } \\
\text { (Laboratório de Modelos Re- } \\
\text { duzidos e Labcon) }\end{array}$ & $\begin{array}{l}\text { deverão estar localizados no subsolo onde os ruídos produzidos em suas ativi- } \\
\text { dades não perturbem as atividades vizinhas. }\end{array}$ \\
\hline Salas de Professores & $\begin{array}{l}\text { devem ficar localizadas em espaço salubre, protegido de ruídos e excessiva } \\
\text { circulação. Podem ser localizadas no térreo, mezanino e subsolo. }\end{array}$ \\
\hline Praça da FAU & deve ser integrada à Praça Exterior (fachada leste). \\
\hline Espaços de Administração & $\begin{array}{l}\text { deverão estar próximos (integração horizontal ou vertical). O Apoio Adminis- } \\
\text { trativo da Pós deverá ficar próximo às salas de aula destinadas às disciplinas } \\
\text { da pós e às Salas dos Alunos da Pós. }\end{array}$ \\
\hline O Cediate & deverá estar integrado à Área de Estudos dos alunos da graduação. \\
\hline Entrada principal da FAU & $\begin{array}{l}\text { deverá ser integrada à Praça, à Área de Exposições e Eventos e à Área Admi- } \\
\text { nistrativa FAU. }\end{array}$ \\
\hline $\begin{array}{l}\text { Áreas de exposições e even- } \\
\text { tos, Auditório(s), Sala de Ex- } \\
\text { posições, Galeria da FAU e } \\
\text { Praça da FAU }\end{array}$ & $\begin{array}{l}\text { devem preferencialmente estar próximas e integradas. A integração pode ser } \\
\text { horizontal ou vertical. }\end{array}$ \\
\hline Salas de Professores & $\begin{array}{l}\text { compartilhadas devem ser localizadas preferencialmente no mezanino ou tér- } \\
\text { reo. }\end{array}$ \\
\hline
\end{tabular}

Fonte: FAU/UnB (2013). 



\section{APÊNDICE B - Questionário utilizado na pesquisa}

\section{Objetivo da Pesquisa}

A pesquisa da tese junto ao PPG-FAU tem como objetivo identificar os atributos do espaço arquitetônico que favorecem o aprendizado nas diferentes áreas de ensino, na universidade, de modo a se obter um conjunto de características que possam ser parametrizadas e gerenciadas com vistas a apoiar a definição do programa de necessidades para a elaboração de projetos de arquitetura.

O processo de construção do referencial teórico foi realizado a partir da discussão de conceitos de Pedagogia sobre o aprendizado e a importância do espaço físico nesse processo. Três áreas se destacaram como as mais relevantes para estabelecimento de dados para construção parametrizada da relação espaço arquitetônico - aprendizagem: Conforto Ambiental, Ergonomia e Psicologia Ambiental.

A metodologia Multicritério de Apoio à Decisão - Construtivista (MCDA- C) foi adotada como método de elaboração dos questionários e apoiará em sua tabulação e estabelecimento dos parâmetros.

Os dados obtidos com as respostas do questionário serão utilizados nos resultados da pesquisa mas os dados pessoais dos professores serão mantidos em sigilo.

\section{Dados demográficos-funcionais}

Departamento:

Disciplina: Código

Tipo: Pratica $\square$ Teórica $\square$ Pratica/Teórica

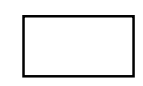

Turma: $\square$

Turno: Matutino

Vespertino

Noturno

Professor :

\section{Questionário}

Uma só questão é objeto da pesquisa: Em sua experiência de ensino, como os parâmetros abaixo contribuem para o aprendizado?

Ela deve ser respondida para cada um dos parâmetros encontrados na pesquisa 
bibliográfica que, segundo cada autor, desempenham papel relevante, mas a questão aqui é a sua relevância para o ensino e aprendizagem de arquitetura e urbanismo. Os parâmetros estão dispostos em tabelas, divididas por atributo. Para cada parâmetro está apresentada uma breve definição, de forma a auxiliar na determinação de sua importância relativa.

Assim, avaliem a importância relativa aos critérios que integram cada uma das categorias prédefinidas numa pontuação variável de níveis 1 a 5, variando de: sem nenhuma importância a muito importante.

\begin{tabular}{l|l|l|l|l|l|l}
\hline Sem importância & 1 & 2 & 3 & 4 & 5 & Muito importante \\
\hline
\end{tabular}

\begin{tabular}{|c|c|c|c|c|c|}
\hline $\begin{array}{c}\text { Em sua experiência de ensino, os parâmetros abaixo merecem tratamento diferencial no projeto de } \\
\text { arquitetura por desempenharem papel relevante para o aprendizado? } \\
\text { PVE: Conforto Térmico }\end{array}$ \\
\hline SubPVE & $\mathbf{4}$ & $\mathbf{2}$ & $\mathbf{3}$ & $\mathbf{4}$ & $\mathbf{5}$ \\
\hline $\begin{array}{c}\text { Ventilação } \\
\text { Movimentos de ar aceleram as trocas de calor das pessoas com o ambiente }\end{array}$ & & & & & \\
\hline $\begin{array}{c}\text { Resfriamento Evaporativo } \\
\text { Redução da temperatura do ambiente por meio da evaporação de } \\
\text { microgotículas de água aspergidas - ou borrifadas - no ar. }\end{array}$ & & & & & \\
\hline $\begin{array}{c}\text { Massa Térmica para Aquecimento } \\
\text { Solução empregável em locais nos quais as temperaturas e umidade relativas } \\
\text { estejam entre determinados valores. }\end{array}$ & & & & & \\
\hline $\begin{array}{c}\text { Umidificação } \\
\text { Introdução de vapor de água no ar para a obtenção da umidade desejada. É a } \\
\text { quantidade de vapor de água na atmosfera }\end{array}$ & & & & & \\
\hline $\begin{array}{c}\text { Ar Condicionado } \\
\text { Aparelhos destinados ao condicionamento de ar. }\end{array}$ & & & & & \\
\hline
\end{tabular}

\begin{tabular}{|c|c|c|c|c|c|}
\hline $\begin{array}{c}\text { Em sua experiência de ensino, os parâmetros abaixo merecem tratamento diferencial no projeto de arquitetura por } \\
\text { desempenharem papel relevante para o aprendizado? } \\
\text { PVE Conforto Lumínico }\end{array}$ \\
\hline SubPVE & $\mathbf{1}$ & $\mathbf{2}$ & $\mathbf{3}$ & $\mathbf{4}$ & $\mathbf{5}$ \\
\hline $\begin{array}{c}\text { Mecanismos de Controle } \\
\text { A luz do sol pode ser manipulada por meio do uso de uma série de } \\
\text { mecanismos como reflexão, transmissão, refração, etc. }\end{array}$ & & & & & \\
\hline $\begin{array}{c}\text { Reforço do Iluminamento } \\
\text { A iluminação artificial feita por lâmpadas elétricas é um reforço à iluminação } \\
\text { natural }\end{array}$ & & & & & \\
\hline $\begin{array}{c}\text { Uso das Cores } \\
\text { Cor no local de trabalho pode aumentar o humor e a produtividade do } \\
\text { indivíduo ao gerar sensações de conforto, dinamismo e bem estar. }\end{array}$ & & & & & \\
\hline $\begin{array}{c}\text { Iluminação } \\
\text { Quantidade de luz natural ou artificial no nível da estação de trabalho. Uma } \\
\text { iluminação incorreta induz à fadiga e ao desconforto. }\end{array}$ & & & & & \\
\hline $\begin{array}{c}\text { Luminância } \\
\text { Quantidade de luz refletida que entra no olho e estimula a retina. Muita luz } \\
\text { causa ofuscamento, pouca luz causa percepção ruim ou impossível. }\end{array}$ & & & & & \\
\hline $\begin{array}{c}\text { Contraste } \\
\text { Relação de luminância entre o objeto observado e os que os cercam. }\end{array}$ & & & & & \\
\hline$\quad$
\end{tabular}




\begin{tabular}{|c|c|c|c|c|c|}
\hline \multicolumn{6}{|c|}{$\begin{array}{l}\text { Em sua experiência de ensino, os parâmetros abaixo merecem tratamento diferencial no projeto de arquitetura por } \\
\text { desempenharem papel relevante para o aprendizado? } \\
\text { PVE: Conforto Sonoro }\end{array}$} \\
\hline \multirow{2}{*}{ SubPVE } & \multicolumn{5}{|c|}{ Nível de importância } \\
\hline & 1 & 2 & 3 & 4 & 5 \\
\hline $\begin{array}{c}\text { Tempo de Reverberação } \\
\text { Período necessário para a energia sonora decair de um milhão de vezes em } \\
\text { relação a sua energia inicial }\end{array}$ & & & & & \\
\hline $\begin{array}{l}\text { Isolamento Sonoro } \\
\text { Melhor qualidade sonora para o interior e controle do ruído de fora para } \\
\text { dentro dos ambientes. }\end{array}$ & & & & & \\
\hline $\begin{array}{c}\text { Nível Sonoro } \\
\begin{array}{c}\text { Relaciona a intensidade sonora de um som com a intensidade sonora do som } \\
\text { mais fraco. que conseguimos ouvir. }\end{array}\end{array}$ & & & & & \\
\hline $\begin{array}{l}\text { Frequência } \\
\begin{array}{l}\text { Número de variações de pressão (ou de oscilações) durante um segundo. A } \\
\text { unidade de frequência é o Hertz, Hz. }\end{array}\end{array}$ & & & & & \\
\hline $\begin{array}{c}\text { Duração da Exposição } \\
\text { Tempo da exposição diária ao ruído durante o trabalho. }\end{array}$ & & & & & \\
\hline
\end{tabular}

\begin{tabular}{|c|c|c|c|c|c|}
\hline \multicolumn{6}{|c|}{$\begin{array}{l}\text { Em sua experiência de ensino, os parâmetros abaixo merecem tratamento diferencial no projeto de arquitetura por } \\
\text { desempenharem papel relevante para o aprendizado? } \\
\text { PVE: Vibracões }\end{array}$} \\
\hline \multirow{2}{*}{ SubPVE } & \multicolumn{5}{|c|}{ Nível de importância } \\
\hline & 1 & 2 & 3 & 4 & 5 \\
\hline \multicolumn{6}{|c|}{$\begin{array}{l}\text { Frequência } \\
\text { Expressa quantas vezes na unidade de tempo, o ciclo da vibração se produziu, } \\
\text { ou seja é a quantidade de vezes em que um sinal se repete a cada segundo. }\end{array}$} \\
\hline $\begin{array}{c}\text { Intensidade } \\
\text { Ampliação ou atenuação das vibrações. }\end{array}$ & & & & & \\
\hline
\end{tabular}

Em sua experiência de ensino, os parâmetros abaixo merecem tratamento diferencial no projeto de arquitetura por desempenharem papel relevante para o aprendizado?

PVE: Antropometria

\begin{tabular}{|c|c|c|c|c|c|}
\hline \multirow{2}{*}{ SubPVE } & \multicolumn{5}{|c|}{ Nível de importância } \\
\hline & 1 & 2 & 3 & 4 & 5 \\
\hline $\begin{array}{c}\text { Arranjo Físico } \\
\text { O layout de um espaço de trabalho consiste na proposta de distribuição } \\
\text { espacial de um conjunto de trabalhadores, equipamentos, infra-estrutura e } \\
\text { materiais. }\end{array}$ & & & & & \\
\hline $\begin{array}{l}\text { Mobiliário } \\
\text { Elemento da sala de aula que influi circunstancialmente no desempenho, na } \\
\text { seguranca, no conforto e em diversos comportamentos dos alunos. }\end{array}$ & & & & & \\
\hline
\end{tabular}




\begin{tabular}{|c|c|c|c|c|c|}
\hline \multicolumn{6}{|c|}{$\begin{array}{c}\text { Em sua experiência de ensino, os parâmetros abaixo merecem tratamento diferencial no projeto de arquitetura por } \\
\text { desempenharem papel relevante para o aprendizado? } \\
\text { PVE: Infraestrutura }\end{array}$} \\
\hline \multirow[t]{2}{*}{${ }^{-1}$} & \multicolumn{5}{|c|}{ Nível de importância } \\
\hline & 1 & 2 & 3 & 4 & 5 \\
\hline $\begin{array}{l}\text { Revestimentos } \\
\text { Pode-se adotar posturas distintas, em função do uso do ambiente e da } \\
\text { atividade desenvolvida. Alguns setores produtivos apresentam normatizações } \\
\text { quanto ao emprego dos materiais. }\end{array}$ & & & & & \\
\hline $\begin{array}{l}\text { Equipamentos } \\
\text { Diversas tecnologias novas têm sido introduzidas na educação, como uso de } \\
\text { materiais áudiovisuais, vídeos, máquinas de ensinar e aparelhos de } \\
\text { autoinstrução. }\end{array}$ & & & & & \\
\hline $\begin{array}{l}\text { Ambiente físico } \\
\text { O projeto adequado dos mobiliários, salas de aula, bibliotecas, laboratórios, e } \\
\text { outros meios de apoio didático, podem influir no desempenho dos professores } \\
\text { e alunos. }\end{array}$ & & & & & \\
\hline
\end{tabular}

\begin{tabular}{|c|c|c|c|c|c|}
\hline \multicolumn{6}{|c|}{$\begin{array}{l}\text { Em sua experiência de ensino, os parâmetros abaixo merecem tratamento diferencial no projeto de arquitetura por } \\
\text { desempenharem papel relevante para o aprendizado? } \\
\text { PVE: Espaço Pessoal }\end{array}$} \\
\hline \multirow{2}{*}{ SubPVE } & \multicolumn{5}{|c|}{ Nível de importância } \\
\hline & 1 & 2 & 3 & 4 & 5 \\
\hline $\begin{array}{l}\text { Distâncias Interpessoais } \\
\text { Distâncias adequadas para contato ou não contato podendo gerar reações } \\
\text { comportamentais positivas ou negativas. }\end{array}$ & & & & & \\
\hline $\begin{array}{l}\text { Relações Interpessoais } \\
\text { Relação entre duas ou mais pessoas. Esse tipo de relacionamento é } \\
\text { marcado pelo contexto onde ele está inserido, podendo ser um contexto } \\
\text { familiar, escolar, de trabalho ou de comunidade. }\end{array}$ & & & & & \\
\hline $\begin{array}{c}\text { Configuração Ambiental (Design) } \\
\text { Configurações de arranjo físico sociopetal (o que possibilita o contato social) } \\
\text { e sociofugal (o que não propicia o contato social). }\end{array}$ & & & & & \\
\hline
\end{tabular}

\begin{tabular}{|c|c|c|c|c|c|}
\hline \multicolumn{6}{|c|}{$\begin{array}{c}\text { Em sua experiência de ensino, os parâmetros abaixo merecem tratamento diferencial no projeto de arquitetura por } \\
\text { desempenharem papel relevante para o aprendizado? } \\
\text { PVE: Territorialidade }\end{array}$} \\
\hline \multirow{2}{*}{ SubPVE } & \multicolumn{5}{|c|}{ Nível de importância } \\
\hline & 1 & 2 & 3 & 4 & 5 \\
\hline \multicolumn{6}{|l|}{$\begin{array}{c}\text { Ocupação } \\
\text { Controle efetivo de um espaço ou de alguma coisa. }\end{array}$} \\
\hline \multicolumn{6}{|l|}{$\begin{array}{l}\text { Defesa } \\
\text { O espaço defesível argumenta que os arranjos físicos aumentam sentimentos } \\
\text { de territorialidade e comportamentos, e que esse aunento conduz a um } \\
\text { declínio nas invasões do território. }\end{array}$} \\
\hline $\begin{array}{c}\text { Personalização } \\
\text { Marcação de uma maneira que indica uma identidade. }\end{array}$ & & & & & \\
\hline
\end{tabular}

\begin{tabular}{|c|c|c|c|c|c|}
\hline \multicolumn{6}{|c|}{$\begin{array}{l}\text { Em sua experiência de ensino, os parâmetros abaixo merecem tratamento diferencial no projeto de arquitetura por } \\
\text { desempenharem papel relevante para o aprendizado? } \\
\text { PVE: Privacidade }\end{array}$} \\
\hline \multirow[t]{2}{*}{ ( } & \multicolumn{5}{|c|}{ Nível de importância } \\
\hline & 1 & 2 & 3 & 4 & 5 \\
\hline $\begin{array}{l}\text { Privacidade } \\
\text { Gestão do indivíduo sobre as informações de si mesmo e sobre a sua } \\
\text { interação com as outras pessoas. "É um controle seletivo de acesso a si } \\
\text { próprio ou ao seu grupo". }\end{array}$ & & & & & \\
\hline
\end{tabular}




\section{APÊNDICE C - Telas do Software Macbeth com as Matrizes Semânticas}

Este apêndice apresenta a função de valor dos PVEs e SubPVEs dos Pontos de Vista Fundamental: PVF 1 - Conforto Ambiental, PVF 2 - Ergonomia e PVF 3 - Psicologia Ambiental construídas por meio do software Macbeth (capítulo 4, seção 4.2.8 ).

\begin{tabular}{|c|c|c|c|c|c|c|c|}
\hline \multicolumn{6}{|c|}{ Mg. Macbeth : 1.1.1 Ventilação } & \multicolumn{2}{|c|}{\begin{tabular}{|l|l|l|}
0 & $\square$ & $x$ \\
\end{tabular}} \\
\hline & N5 & N4 & N3 & N2 & N1 & $\begin{array}{l}\text { Current } \\
\text { scale }\end{array}$ & extreme \\
\hline N5 & no & weak & moderate & strong & v. strong & 100 & v. strong \\
\hline $\mathrm{N} 4$ & & no & weak & moderate & strong & 75 & strong \\
\hline N3 & & & no & weak & moderate & 50 & moderate \\
\hline N2 & & & & & weak & & weak \\
\hline & & & & & & & very weak \\
\hline & & & & & & & no \\
\hline \multicolumn{8}{|c|}{ Consistent judgements } \\
\hline 围 & & 1 & 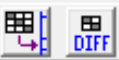 & oft & & & \\
\hline
\end{tabular}

\begin{tabular}{|c|c|c|c|c|c|c|c|}
\hline \multicolumn{6}{|c|}{ Macbeth : 1.1.2 Resf. Evaporat } & \multicolumn{2}{|c|}{\begin{tabular}{|l|l|l|}
0 & $\square$ & $x$ \\
\end{tabular}} \\
\hline & N5 & N4 & N3 & N2 & N1 & $\begin{array}{l}\text { Current } \\
\text { scale }\end{array}$ & extreme \\
\hline N5 & no & moderate & strong & v. strong & extreme & 100 & y. strong \\
\hline $\mathrm{N} 4$ & & no & moderate & strong & v. strong & 75 & strong \\
\hline N3 & & & no & moderate & strong & 50 & moderate \\
\hline N2 & & & & no & moderate & 25 & weak \\
\hline N1 & & & & & no & 0 & \\
\hline \multicolumn{8}{|c|}{ Consistent judgements } \\
\hline 围 & & \pm & 困期 & ㅇt & & & \\
\hline
\end{tabular}

\begin{tabular}{|c|c|c|c|c|c|c|c|}
\hline \multicolumn{6}{|c|}{ 可 Macbeth : 1.1.3 Massa Térmica } & \multicolumn{2}{|c|}{\begin{tabular}{|l|l|l}
0 & $\square$ & $\mathbf{x}$ \\
\end{tabular}} \\
\hline & N5 & N4 & N3 & $\mathrm{N} 2$ & N1 & $\begin{array}{l}\text { Current } \\
\text { scale }\end{array}$ & extreme \\
\hline N5 & no & weak & weak & wea & weak & 100 & Y. strong \\
\hline N4 & & no & weak & wea & weak & 75 & strong \\
\hline N3 & & & no & wea & weak & 50 & moderate \\
\hline N2 & & & & & a & & weak \\
\hline N1 & & & & & & & very weak \\
\hline & & & & & & & no \\
\hline \multicolumn{8}{|c|}{ Consistent judgements } \\
\hline 围? & & and & 田㩆 & 1 & & & \\
\hline
\end{tabular}




\begin{tabular}{|c|c|c|c|c|c|c|c|}
\hline \multicolumn{6}{|c|}{ Macbeth : 1.1.4 Umidificação } & \multicolumn{2}{|c|}{\begin{tabular}{|l|l|l|}
$\square$ & $\square$ & $\mathbf{x}$ \\
\end{tabular}} \\
\hline & N5 & N4 & N3 & N2 & N1 & $\begin{array}{l}\text { Current } \\
\text { scale }\end{array}$ & extreme \\
\hline N5 & no & moderate & strong & v. strong & extreme & 100 & Y. strong \\
\hline N4 & & no & moderate & strong & v. strong & 75 & stiong \\
\hline N3 & & & no & moderate & strong & 50 & $\begin{array}{l}\text { moderate } \\
\text { weak }\end{array}$ \\
\hline $\mathrm{N} 2$ & & & & no & moderate & 25 & yery weak \\
\hline N1 & & & & & no & 0 & no \\
\hline \multicolumn{8}{|c|}{ Consistent judgements } \\
\hline 㙗? & & 80 & 罟乩 思F & 의 & & & \\
\hline
\end{tabular}

\begin{tabular}{|c|c|c|c|c|c|c|c|}
\hline \multicolumn{6}{|c|}{ Macbeth : 1.1.5 Ar Condicionad } & \multicolumn{2}{|c|}{\begin{tabular}{|l|l|l|}
$口$ & $\Xi$ & $\mathbf{X}$ \\
\end{tabular}} \\
\hline & N5 & N4 & N3 & N2 & N1 & $\begin{array}{l}\text { Current } \\
\text { scale }\end{array}$ & extreme \\
\hline N5 & no & very weak & very weak & weak & moderate & 100 & 7. stiving \\
\hline N4 & & no & very weak & very weak & weak & 75 & strong \\
\hline N3 & & & no & veru weak & weru weak & 50 & moderate \\
\hline N2 & & & & \multirow{2}{*}{ no } & Yoru us & \multirow{2}{*}{25} & weak \\
\hline & & & & & & & very weak \\
\hline NI & & & & & no & 0 & no \\
\hline \multicolumn{8}{|c|}{ Consistent judgements } \\
\hline 㖆 & & $80 \mathrm{old}$ & 㖆期 & 影 & & & \\
\hline
\end{tabular}

\begin{tabular}{|c|c|c|c|c|c|c|c|}
\hline \multicolumn{6}{|c|}{ Macbeth : 1.2.1 Mecan Côntrole } & \multicolumn{2}{|c|}{\begin{tabular}{|l|l|l|}
$\square$ & $\square$ & $\mathbf{X}$ \\
\end{tabular}} \\
\hline & N5 & N4 & N3 & N2 & N1 & $\begin{array}{l}\text { Current } \\
\text { scale }\end{array}$ & extreme \\
\hline N5 & no & moderate & strong & $\mathrm{v}$. strong & extreme & 100 & ४. strong \\
\hline N4 & & no & moderate & strong & v. strong & 75 & \multirow{2}{*}{$\begin{array}{c}\text { strong } \\
\text { moderate }\end{array}$} \\
\hline N3 & & & no & moderate & strong & 50 & \\
\hline N2 & & & & no & moderate & 25 & weak \\
\hline & & & & & & & very weak \\
\hline N1 & & & & & no & 0 & no \\
\hline \multicolumn{8}{|c|}{ Consistent judgements } \\
\hline $\begin{array}{l}\text { 㖆 } \\
\text { OK? }\end{array}$ & & $\mathrm{B}_{\mathrm{old}}+\mathrm{f}$ & 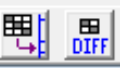 & 애 $=$ & & & \\
\hline
\end{tabular}

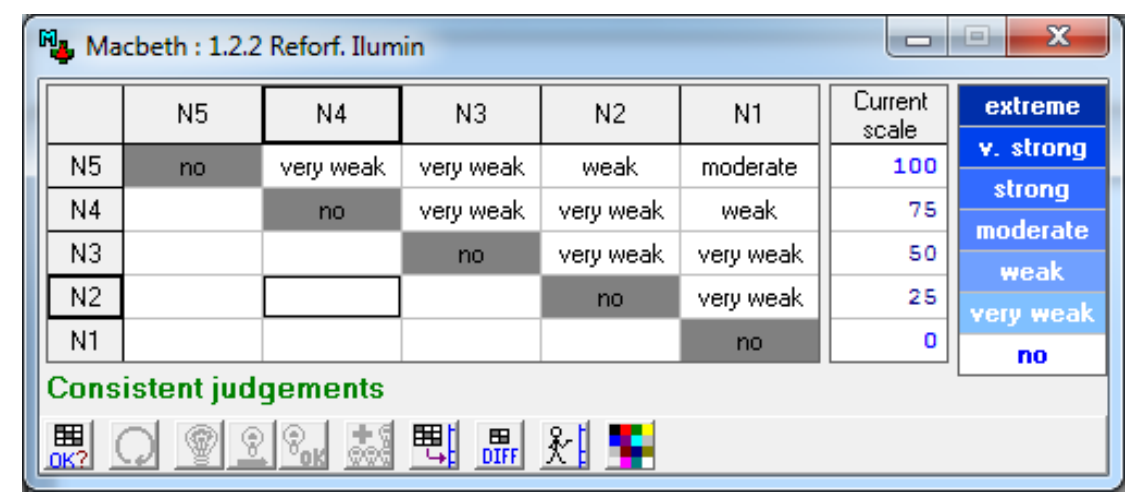




\begin{tabular}{|c|c|c|c|c|c|c|c|}
\hline \multicolumn{6}{|c|}{ Macbeth : 1.2 .3 Uso das Cores } & \multicolumn{2}{|c|}{\begin{tabular}{|l|l|l|}
$\square$ & $\square$ & $x$ \\
\end{tabular}} \\
\hline & N5 & N4 & N3 & N2 & N1 & $\begin{array}{l}\text { Current } \\
\text { scale }\end{array}$ & extreme \\
\hline N5 & no & weak & weak & weak & weak & 100 & v. strong \\
\hline N4 & & no & weak & weak & weak & 75 & strong \\
\hline N3 & & & no & weak & weak & 50 & moderate \\
\hline $\mathrm{N} 2$ & & & & no & weak & 25 & weak \\
\hline N1 & & & & & $n$ & 0 & very weak \\
\hline \multicolumn{8}{|c|}{ Consistent judgements } \\
\hline 稩? & & a & 毗 & 보 & & & \\
\hline
\end{tabular}

\begin{tabular}{|c|c|c|c|c|c|c|c|}
\hline \multicolumn{6}{|c|}{ Mag Macbeth : 1.2.4 Iluminação } & \multicolumn{2}{|c|}{\begin{tabular}{|l|l|l|} 
& $\square$ & $\mathrm{x}$ \\
\end{tabular}} \\
\hline & N5 & N4 & N3 & N2 & N1 & $\begin{array}{l}\text { Current } \\
\text { scale }\end{array}$ & extreme \\
\hline N5 & no & moderate & strong & v. strong & extreme & 100 & Y. strong \\
\hline N4 & & no & moderate & strong & v. strong & 75 & stiong \\
\hline N3 & & & no & moderate & strong & 50 & moderate \\
\hline N2 & & & & no & moderate & 25 & yery weak \\
\hline N1 & & & & & no & 0 & no \\
\hline \multicolumn{8}{|c|}{ Consistent judgements } \\
\hline 围 & & 80 & 罢: & 漹 & & & \\
\hline
\end{tabular}

\begin{tabular}{|c|c|c|c|c|c|c|c|}
\hline \multicolumn{6}{|c|}{ Macbeth : 1.2.5 Luminância } & \multicolumn{2}{|c|}{\begin{tabular}{|l|l|l|}
0 & $\square$ & $x$ \\
\end{tabular}} \\
\hline & N5 & N4 & N3 & N2 & N1 & $\begin{array}{l}\text { Current } \\
\text { scale }\end{array}$ & extreme \\
\hline N5 & no & weak & weak & moderate & moderate & 100 & ४. strong \\
\hline N4 & & no & weak & weak & moderate & 75 & strong \\
\hline N3 & & & no & weak & weak & 50 & moderate \\
\hline $\mathrm{N} 2$ & & & & no & weak & 25 & veru weak \\
\hline N1 & & & & & no & 0 & no \\
\hline \multicolumn{8}{|c|}{ Consistent judgements } \\
\hline 拨? & & & 畏继 & t. & & & \\
\hline
\end{tabular}

\begin{tabular}{|c|c|c|c|c|c|c|c|}
\hline \multicolumn{6}{|c|}{ Macbeth : 1.2 .6 Contraste } & \multicolumn{2}{|c|}{\begin{tabular}{|l|l|l}
0 & $\square$ & $x$ \\
\end{tabular}} \\
\hline & N5 & N4 & N3 & $\mathrm{N} 2$ & N1 & $\begin{array}{l}\text { Current } \\
\text { scale }\end{array}$ & extreme \\
\hline N5 & no & weak & weak & moderate & moderate & 100 & ४. strong \\
\hline N4 & & no & weak & weak & moderate & 75 & strong \\
\hline N3 & & & no & weak & weak & 50 & moderate \\
\hline $\mathrm{N} 2$ & & & & & & & weak \\
\hline & & & & & & & \\
\hline & & & & & . & & no \\
\hline \multicolumn{8}{|c|}{ Consistent judgements } \\
\hline 熏? & & 1 & 田㩆 & oft & & & \\
\hline
\end{tabular}




\begin{tabular}{|c|c|c|c|c|c|c|c|}
\hline \multicolumn{4}{|c|}{ 酸 Macbeth : 1.3.1 Tempo Ótimo de } & 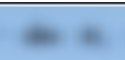 & $=0$ & \multicolumn{2}{|c|}{\begin{tabular}{|l|l|l|}
$口$ & $\Xi$ & $\mathbf{x}$ \\
\end{tabular}} \\
\hline & N5 & N4 & N3 & N2 & N1 & $\begin{array}{l}\text { Current } \\
\text { scale }\end{array}$ & extreme \\
\hline N5 & no & very weak & weak & moderate & strong & 100 & v. strong \\
\hline N4 & & no & very weak & weak & moderate & 75 & strong \\
\hline N3 & & & no & very weak & weak & 50 & $\begin{array}{c}\text { moderate } \\
\text { weak }\end{array}$ \\
\hline $\mathrm{N} 2$ & & & & no & very weak & 25 & yery weak \\
\hline N1 & & & & & no & 0 & no \\
\hline \multicolumn{8}{|c|}{ Consistent judgements } \\
\hline 围? & & $801+8$ & 䕅期 思 & 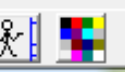 & & & \\
\hline
\end{tabular}

\begin{tabular}{|c|c|c|c|c|c|c|c|}
\hline \multicolumn{6}{|c|}{ Macbeth : 1.3.2 Isolamento Son } & \multicolumn{2}{|c|}{\begin{tabular}{|l|l|l|}
0 & $\square$ & $x$ \\
\end{tabular}} \\
\hline & N5 & N4 & N3 & $\mathrm{N} 2$ & N1 & $\begin{array}{l}\text { Current } \\
\text { scale }\end{array}$ & extreme \\
\hline N5 & no & moderate & strong & v. strong & extreme & 100 & v. strong \\
\hline N4 & & no & moderate & strong & v. strong & 75 & strong \\
\hline N3 & & & no & moderate & strong & 50 & moderate \\
\hline N2 & & & & no & moderate & 25 & weak \\
\hline N1 & & & & & $\infty$ & & very weak \\
\hline \multirow{2}{*}{\multicolumn{8}{|c|}{ Consistent judgements }} \\
\hline & & & & & & & \\
\hline 围? & & + 贯 & 四期 思F & 애은 & & & \\
\hline
\end{tabular}

\begin{tabular}{|c|c|c|c|c|c|c|c|}
\hline \multicolumn{6}{|c|}{ Macbeth : 1.3.3 Nivel Sonoro } & \multicolumn{2}{|c|}{\begin{tabular}{|l|l|l|} 
& $\square$ & $x$ \\
\end{tabular}} \\
\hline & N5 & N4 & N3 & N2 & N1 & $\begin{array}{l}\text { Current } \\
\text { scale }\end{array}$ & extreme \\
\hline N5 & no & very weak & weak & moderate & strong & 100 & Y. strong \\
\hline N4 & & no & very weak & weak & moderate & 75 & strong \\
\hline N3 & & & no & very weak & weak & 50 & moderate \\
\hline $\mathrm{N} 2$ & & & & no & very weak & 25 & yer" weak \\
\hline N1 & & & & & no & 0 & no \\
\hline \multicolumn{8}{|c|}{ Consistent judgements } \\
\hline 围? & & 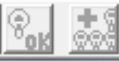 & 㖆虾 思 & 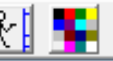 & & & \\
\hline
\end{tabular}

\begin{tabular}{|c|c|c|c|c|c|c|c|}
\hline \multicolumn{6}{|c|}{ Macbeth : 1.3.4 Frequência } & \multicolumn{2}{|c|}{\begin{tabular}{|l|l|l|}
0 & $\square$ & $x$ \\
\end{tabular}} \\
\hline & N5 & N4 & N3 & N2 & N1 & $\begin{array}{l}\text { Current } \\
\text { scale }\end{array}$ & extreme \\
\hline N5 & no & very weak & weak & moderate & strong & 100 & v. strong \\
\hline N4 & & no & very weak & weak & moderate & 75 & strong \\
\hline N3 & & & no & very weak & weak & 50 & weak \\
\hline $\mathrm{N} 2$ & & & & no & very weak & 25 & very weak \\
\hline N1 & & & & & no & 0 & no \\
\hline \multicolumn{8}{|c|}{ Consistent judgements } \\
\hline 围? & & $8_{\mathrm{old}}+$ 영 & 里期 思F & 影 & & & \\
\hline
\end{tabular}




\begin{tabular}{|c|c|c|c|c|c|c|c|}
\hline \multicolumn{6}{|c|}{ Wुg Macbeth : 1.3.5 Duração Exposi } & \multicolumn{2}{|c|}{\begin{tabular}{|l|l|l|}
$\square$ & $\square$ & $x$ \\
\end{tabular}} \\
\hline & N5 & N4 & N3 & N2 & N1 & $\begin{array}{l}\text { Current } \\
\text { scale }\end{array}$ & extreme \\
\hline N5 & no & moderate & strong & v. strong & extreme & 100 & v. strong \\
\hline N4 & & no & moderate & strong & v. strong & 75 & strong \\
\hline N3 & & & no & moderate & strong & 50 & moderate \\
\hline N2 & & & & no & moderate & 25 & weak \\
\hline N1 & & & & & no & 0 & \\
\hline \multicolumn{8}{|c|}{ Consistent judgements } \\
\hline 国 & & \pm & 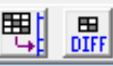 & 影 & & & \\
\hline
\end{tabular}

\begin{tabular}{|c|c|c|c|c|c|c|c|}
\hline \multicolumn{6}{|c|}{ Ty } & \multicolumn{2}{|c|}{\begin{tabular}{|l|l|l|}
$\square$ & $\square$ & $X$ \\
\end{tabular}} \\
\hline & N5 & N4 & N3 & N2 & N1 & $\begin{array}{l}\text { Current } \\
\text { scale }\end{array}$ & extreme \\
\hline N5 & no & moderate & moderate & moderate & strong & 100 & v. strong \\
\hline N4 & & no & moderate & moderate & moderate & 75 & strong \\
\hline N3 & & & no & moderate & moderate & 50 & moderate \\
\hline $\mathrm{N} 2$ & & & & no & moderate & 25 & Yery weak \\
\hline N1 & & & & & no & 0 & no \\
\hline \multicolumn{8}{|c|}{ Consistent judgements } \\
\hline 围? & & 80 & 罷 & K: & & & \\
\hline
\end{tabular}

\begin{tabular}{|c|c|c|c|c|c|c|c|}
\hline \multicolumn{6}{|c|}{ 的, Macbeth : 2.1.2 Itensidade } & \multicolumn{2}{|c|}{\begin{tabular}{|l|l|l|}
0 & $\square$ & $x$ \\
\end{tabular}} \\
\hline & N5 & N4 & N3 & N2 & N1 & $\begin{array}{l}\text { Current } \\
\text { scale }\end{array}$ & extreme \\
\hline N5 & no & moderate & moderate & moderate & strong & 100 & ४. strong \\
\hline N4 & & no & moderate & moderate & moderate & 75 & strong \\
\hline N3 & & & no & moderate & moderate & 50 & moderate \\
\hline $\mathrm{N} 2$ & & & & no & moderate & 25 & чегн meak \\
\hline N1 & & & & & no & 0 & no \\
\hline \multicolumn{8}{|c|}{ Consistent judgements } \\
\hline 国 & & +8 & 喟: 思F & 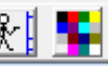 & & & \\
\hline
\end{tabular}

\begin{tabular}{|c|c|c|c|c|c|c|c|}
\hline \multicolumn{6}{|c|}{ Macbeth : 2.2.1 Arranjo Físico } & \multicolumn{2}{|c|}{\begin{tabular}{|l|l|l}
0 & $\square$ & $x$ \\
\end{tabular}} \\
\hline & N5 & N4 & N3 & N2 & N1 & $\begin{array}{c}\text { Current } \\
\text { scale }\end{array}$ & extreme \\
\hline N5 & no & weak & weak & weak & weak & 100 & v. strong \\
\hline N4 & & no & weak & weak & weak & 75 & strong \\
\hline N3 & & & no & weak & weak & 50 & moderate \\
\hline $\mathrm{N} 2$ & & & & no & weak & 25 & yery weak \\
\hline N1 & & & & & no & 0 & no \\
\hline \multicolumn{8}{|c|}{ Consistent judgements } \\
\hline 围? & & 8 & 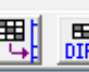 & th & & & \\
\hline
\end{tabular}




\begin{tabular}{|c|c|c|c|c|c|c|c|}
\hline \multicolumn{6}{|c|}{ Macbeth : 2.2.2 Mobiliário } & \multicolumn{2}{|c|}{\begin{tabular}{|l|l|l|}
0 & $\square$ & $X$ \\
\end{tabular}} \\
\hline & N5 & N4 & N3 & N2 & N1 & $\begin{array}{l}\text { Current } \\
\text { scale }\end{array}$ & extreme \\
\hline N5 & no & moderate & moderate & moderate & strong & 100 & v. strong \\
\hline $\mathrm{N} 4$ & & no & moderate & moderate & moderate & 75 & strong \\
\hline N3 & & & no & moderate & moderate & 50 & moderate \\
\hline N2 & & & & no & moderate & 25 & weak \\
\hline N1 & & & & & no & 0 & no \\
\hline \multicolumn{8}{|c|}{ Consistent judgements } \\
\hline 雷? & & $\$ 9$ & 里期 思 & 影目 & & & \\
\hline
\end{tabular}

\begin{tabular}{|c|c|c|c|c|c|c|c|}
\hline \multicolumn{6}{|c|}{ Macbeth : 2.3.1 Revestimentos } & \multicolumn{2}{|c|}{\begin{tabular}{|l|l|l|}
$\square$ & $\square$ & $x$ \\
\end{tabular}} \\
\hline & N5 & N4 & N3 & N2 & N1 & $\begin{array}{l}\text { Current } \\
\text { scale }\end{array}$ & extreme \\
\hline N5 & no & strong & strong & strong & strong & 100 & Y. strong \\
\hline N4 & & no & strong & strong & strong & 75 & strong \\
\hline N3 & & & no & strong & strong & 50 & moderate \\
\hline $\mathrm{N} 2$ & & & & no & strong & 25 & Heak \\
\hline N1 & & & & & no & 0 & \\
\hline \multicolumn{8}{|c|}{ Consistent judgements } \\
\hline 国 & & 列 & 田 思 & $t 5$ & & & \\
\hline
\end{tabular}

\begin{tabular}{|c|c|c|c|c|c|c|c|}
\hline \multicolumn{6}{|c|}{ Macbeth : 2.3.2 Equipamentos } & \multicolumn{2}{|c|}{\begin{tabular}{|l|l|l|} 
& $\square$ & $x$ \\
\end{tabular}} \\
\hline & N5 & N4 & N3 & N2 & N1 & $\begin{array}{l}\text { Current } \\
\text { scale }\end{array}$ & extreme \\
\hline N5 & no & weak & weak & moderate & strong & 100 & Y. strong \\
\hline N4 & & no & weal & weak & moderate & 75 & strong \\
\hline N3 & & & no & weak & weak & 50 & moderate \\
\hline $\mathrm{N} 2$ & & & & no & weak & 25 & mean \\
\hline N1 & & & & & no & 0 & no \\
\hline \multicolumn{8}{|c|}{ Consistent judgements } \\
\hline 畺? & & & & & & & \\
\hline
\end{tabular}

\begin{tabular}{|c|c|c|c|c|c|c|c|}
\hline \multicolumn{6}{|c|}{ Macbeth : 2.3.3 Ambiente Físic } & \multicolumn{2}{|c|}{\begin{tabular}{|l|l|l|}
$\square$ & $\square$ & $x$ \\
\end{tabular}} \\
\hline & N5 & N4 & N3 & N2 & N1 & $\begin{array}{l}\text { Current } \\
\text { scale }\end{array}$ & extreme \\
\hline N5 & no & strong & strong & strong & strong & 100 & v. strong \\
\hline N4 & & no & strong & strong & strong & 75 & strong \\
\hline N3 & & & no & strong & strong & 50 & moderate \\
\hline N2 & & & & no & strong & 25 & weak \\
\hline N1 & & & & & $n$ & 0 & very weak \\
\hline \multirow{2}{*}{\multicolumn{8}{|c|}{ Consistent judgements }} \\
\hline & & & & & & & \\
\hline 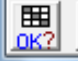 & & & 毗 & 5 & & & \\
\hline
\end{tabular}




\begin{tabular}{|c|c|c|c|c|c|c|c|}
\hline \multicolumn{6}{|c|}{ Macbeth : 3.1.1 Dist Interpes } & \multicolumn{2}{|c|}{\begin{tabular}{|l|l|l|}
0 & $\square$ & $x$ \\
\end{tabular}} \\
\hline & N5 & N4 & N3 & N2 & N1 & $\begin{array}{l}\text { Current } \\
\text { scale }\end{array}$ & extreme \\
\hline N5 & no & weak & moderate & strong & $\mathrm{v}$. strong & 100 & v. strong \\
\hline N4 & & no & weak & moderate & strong & 75 & strong \\
\hline N3 & & & no & weak & moderate & 50 & weak \\
\hline $\mathrm{N} 2$ & & & & no & weak & 25 & very weak \\
\hline N1 & & & & & no & 0 & no \\
\hline \multicolumn{8}{|c|}{ Consistent judgements } \\
\hline 围? & & & 䕅淂 毘 & 影址 & & & \\
\hline
\end{tabular}

\begin{tabular}{|c|c|c|c|c|c|c|c|}
\hline \multicolumn{6}{|c|}{ Macbeth : 3.1.2 Rel Interpesso } & \multicolumn{2}{|c|}{\begin{tabular}{|l|l|l|}
0 & $\square$ & $x$ \\
\end{tabular}} \\
\hline & N5 & N4 & N3 & N2 & N1 & $\begin{array}{l}\text { Current } \\
\text { scale }\end{array}$ & extreme \\
\hline N5 & no & weak & moderate & strong & $v$. strong & 100 & v. strong \\
\hline N4 & & no & weak & moderate & strong & 75 & strong \\
\hline N3 & & & no & weak & moderate & 50 & moderate \\
\hline $\mathrm{N} 2$ & & & & no & weak & 25 & yery weak \\
\hline N1 & & & & & no & 0 & no \\
\hline \multicolumn{8}{|c|}{ Consistent judgements } \\
\hline 围? & & 81 & 㖆期 思F & K: & & & \\
\hline
\end{tabular}

\begin{tabular}{|c|c|c|c|c|c|c|c|}
\hline \multicolumn{6}{|c|}{ Macbeth : 3.1.3 Conf Ambiental } & \multicolumn{2}{|c|}{\begin{tabular}{|l|l|l} 
& $\square$ & $\mathrm{X}$ \\
\end{tabular}} \\
\hline & N5 & N4 & N3 & N2 & N1 & $\begin{array}{l}\text { Current } \\
\text { scale }\end{array}$ & extreme \\
\hline N5 & no & very weak & weak & moderate & strong & 100 & Y. strong \\
\hline $\mathrm{N} 4$ & & no & very weak & weak & moderate & 75 & strong \\
\hline N3 & & & no & very weak & weak & 50 & moderate \\
\hline N2 & & & & no & very weak & 25 & чегн weak \\
\hline N1 & & & & & no & 0 & no \\
\hline \multicolumn{8}{|c|}{ Consistent judgements } \\
\hline 目 & & 80 & 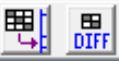 & 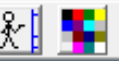 & & & \\
\hline
\end{tabular}

\begin{tabular}{|c|c|c|c|c|c|c|c|}
\hline \multicolumn{6}{|c|}{ Wyacbeth : 3.2.1 Ocupação } & \multicolumn{2}{|c|}{\begin{tabular}{|l|l|l|}
0 & $\square$ & $x$ \\
\end{tabular}} \\
\hline & N5 & N4 & N3 & $\mathrm{N} 2$ & N1 & $\begin{array}{l}\text { Current } \\
\text { scale }\end{array}$ & extreme \\
\hline N5 & no & very weak & weak & moderate & strong & 100 & y. strong \\
\hline N4 & & no & very weak & weak & moderate & 75 & strong \\
\hline N3 & & & no & very weak & weak & 5 & moderate \\
\hline N2 & & & & no & very weak & & weak \\
\hline N1 & & & & & & & very weak \\
\hline \multirow{2}{*}{\multicolumn{8}{|c|}{ Consistent judgements }} \\
\hline & & & & & & & \\
\hline 震? & & 8 & 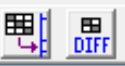 & 애도 & & & \\
\hline
\end{tabular}




\begin{tabular}{|c|c|c|c|c|c|c|c|}
\hline \multicolumn{6}{|c|}{ Macbeth : 3.2.2 Defesa } & \multicolumn{2}{|c|}{\begin{tabular}{|l|l|l|}
0 & $\square$ & $\mathrm{X}$ \\
\end{tabular}} \\
\hline & N5 & N4 & N3 & N2 & N1 & $\begin{array}{l}\text { Current } \\
\text { scale }\end{array}$ & extreme \\
\hline N5 & no & weak & moderate & strong & v. strong & 100 & v. strong \\
\hline N4 & & no & weak & moderate & strong & 75 & strong \\
\hline N3 & & & no & weak & moderate & 50 & moderate \\
\hline N2 & & & & no & weak & 25 & weak \\
\hline N1 & & & & & no & 0 & \\
\hline \multicolumn{8}{|c|}{ Consistent judgements } \\
\hline 围? & & & 㖆胡 思 & 애은 & & & \\
\hline
\end{tabular}

\begin{tabular}{|c|c|c|c|c|c|c|c|}
\hline \multicolumn{6}{|c|}{ Macbeth : 3.2.3 Pesonalização } & \multicolumn{2}{|c|}{\begin{tabular}{|l|l|l|}
0 & $\square$ & $x$ \\
\end{tabular}} \\
\hline & N5 & $\mathrm{N} 4$ & N3 & N2 & N1 & Current & extreme \\
\hline N5 & no & very weak & weak & moderate & strong & 100 & Y. strong \\
\hline N4 & & no & very weak & weak & moderate & 75 & strong \\
\hline N3 & & & no & very weak & weak & 50 & moderate \\
\hline N2 & & & & no & very weak & 25 & weak \\
\hline N1 & & & & & no & 0 & \\
\hline \multicolumn{8}{|c|}{ Consistent judgements } \\
\hline 围 & & 80 & 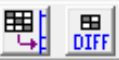 & t & & & \\
\hline
\end{tabular}

\begin{tabular}{|c|c|c|c|c|c|c|c|}
\hline \multicolumn{6}{|c|}{ Macbeth : 3.3 Privacidade } & \multicolumn{2}{|c|}{\begin{tabular}{|l|l|l|}
0 & $\square$ & $\mathrm{X}$ \\
\end{tabular}} \\
\hline & N5 & N4 & N3 & N2 & N1 & $\begin{array}{l}\text { Current } \\
\text { scale }\end{array}$ & extreme \\
\hline N5 & no & weal & moderate & strong & v. strong & 100 & Y. strong \\
\hline $\mathrm{N}_{4}$ & & no & weak & moderate & strong & 75 & strong \\
\hline N3 & & & no & weak & moderate & 50 & moderate \\
\hline $\mathrm{N} 2$ & & & & no & weak & 25 & yeru weak \\
\hline N1 & & & & & no & 0 & no \\
\hline \multicolumn{8}{|c|}{ Consistent judgements } \\
\hline 䍕? & & & 四期 思F & 㩆 & & & \\
\hline
\end{tabular}




\section{APÊNDICE D - Telas do software Hiview3 com as pontuações não ponderadas}

Este apêndice apresenta as telas das pontuações ponderadas atribuídas pelo Hiview3 a cada avaliação dos 43 professores do curso de Arquitetura e Urbanismo da FAU/UnB para os PVFs, PVEs e SubPVEs, após o devido tratamento dos dados levantados na pesquisa (capitulo 5, seção 5.3.1).

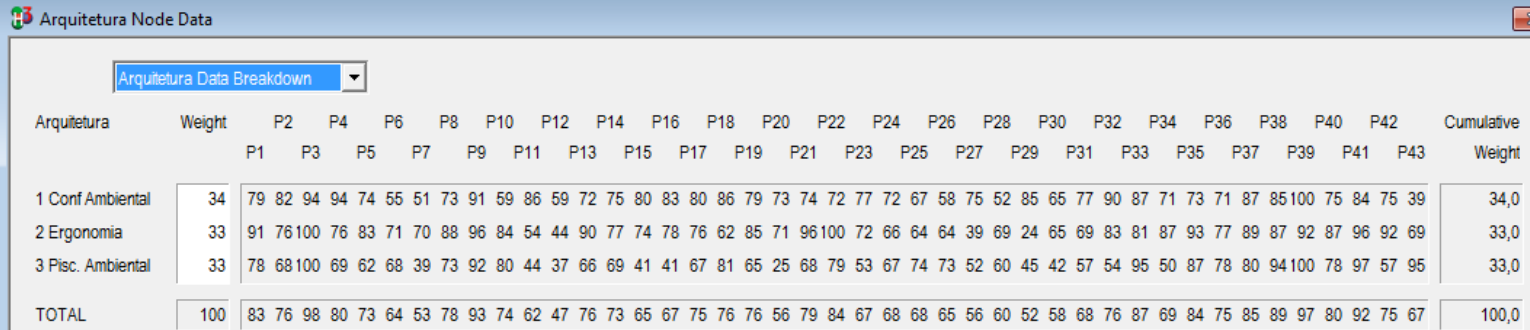

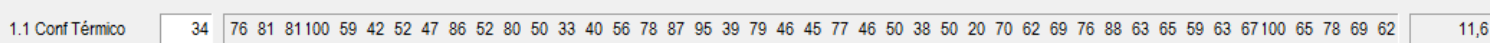

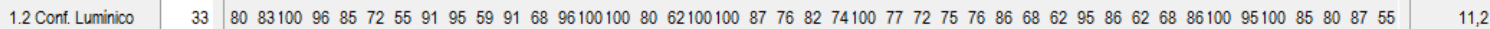

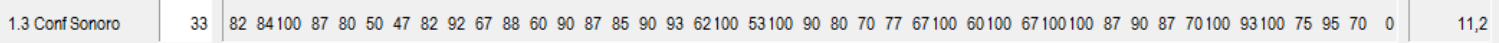

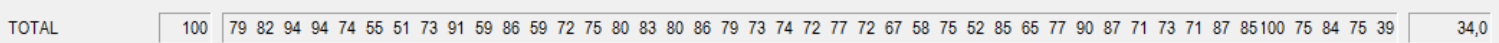

1.1 Conf Térmico Data Breakdown .

$\begin{array}{lllllllllllllllllllllllll}1.1 \text { conf Térmico } & \text { Weight } & \text { P2 } & \text { P4 } & \text { P6 } & \text { P8 } & \text { P10 } & \text { P12 } & \text { P14 } & \text { P16 } & \text { P18 } & \text { P20 } & \text { P22 } & \text { P24 } & \text { P26 } & \text { P28 } & \text { P30 } & \text { P32 } & \text { P34 } & \text { P36 } & \text { P38 } & \text { P40 } & \text { P42 } & \text { Cumulafve }\end{array}$ $\begin{array}{llllllllllllllllllllllll}P 1 & P 3 & P 5 & P 7 & P 9 & P 11 & P 13 & P 15 & P 17 & P 19 & P 21 & P 23 & P 25 & P 27 & P 29 & P 31 & P 33 & P 35 & P 37 & P 39 & P 41 & P 43 & \text { Weight }\end{array}$

1.1.1 Ventlação*

1.1.2 Rest. Evaporat

1.1.3 Massa Térmica*

1.1.4 Umidficação*

7510010010075100757510075100100100100100100100100100100752510075751005025100100100100100100751001007510010010075100

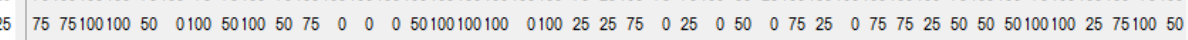

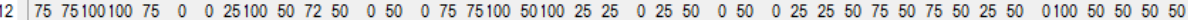
$2110010010010050 \quad 025 \quad 0100757575 \quad 0 \quad 505010050100 \quad 0 \quad 0 \quad 2550100755025 \quad 50 \quad 0 \quad 75 \quad 501007510025 \quad 505010050100757510050$

1.1.5 Ar Condicionad* $195050 \quad 010050100257525 \quad 0752550 \quad 050 \quad 0100755010075100755050505075501001005010010010050 \quad 0751007575 \quad 0 \quad 50$ 


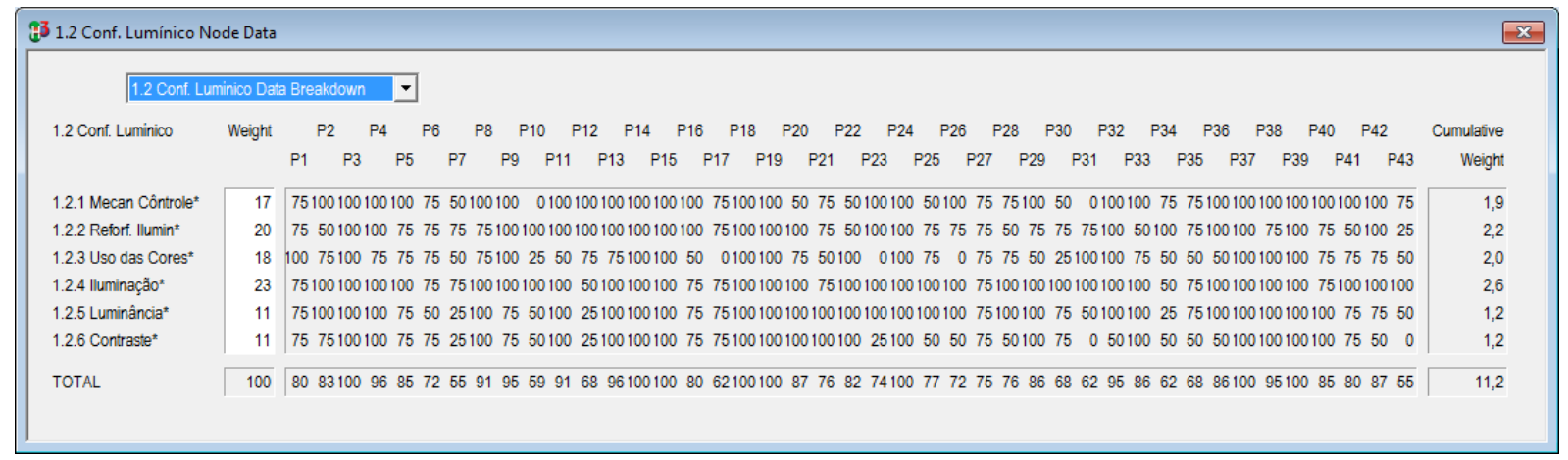

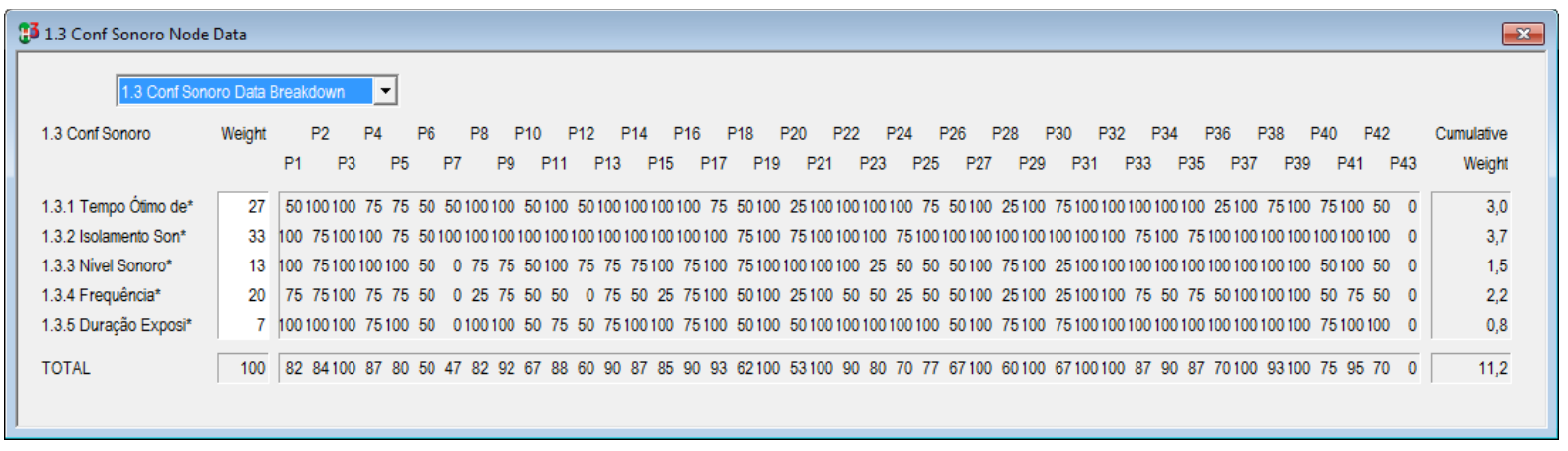

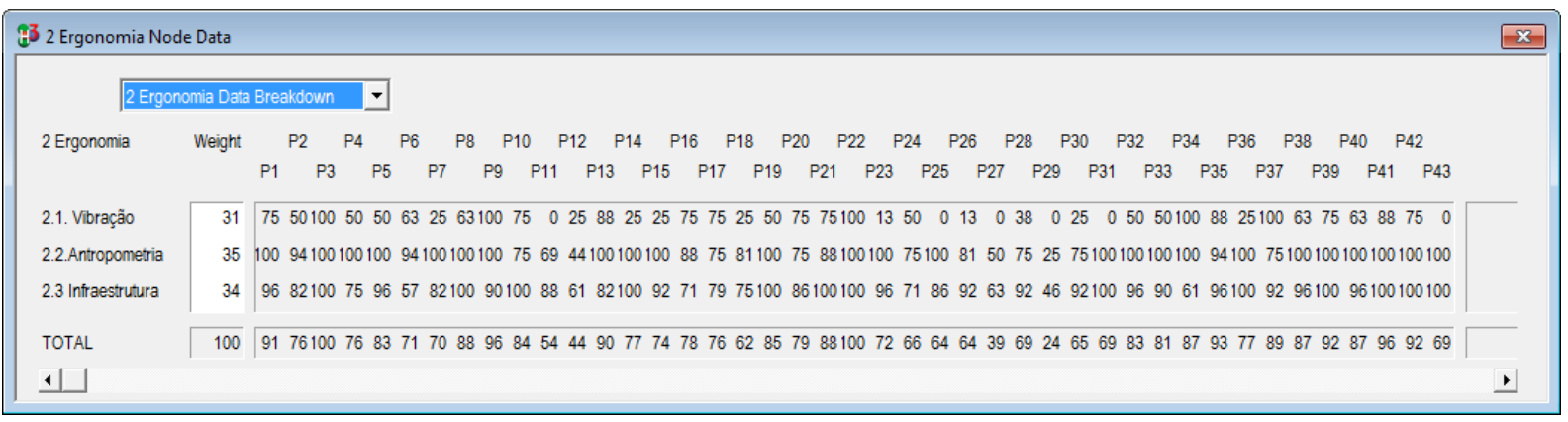

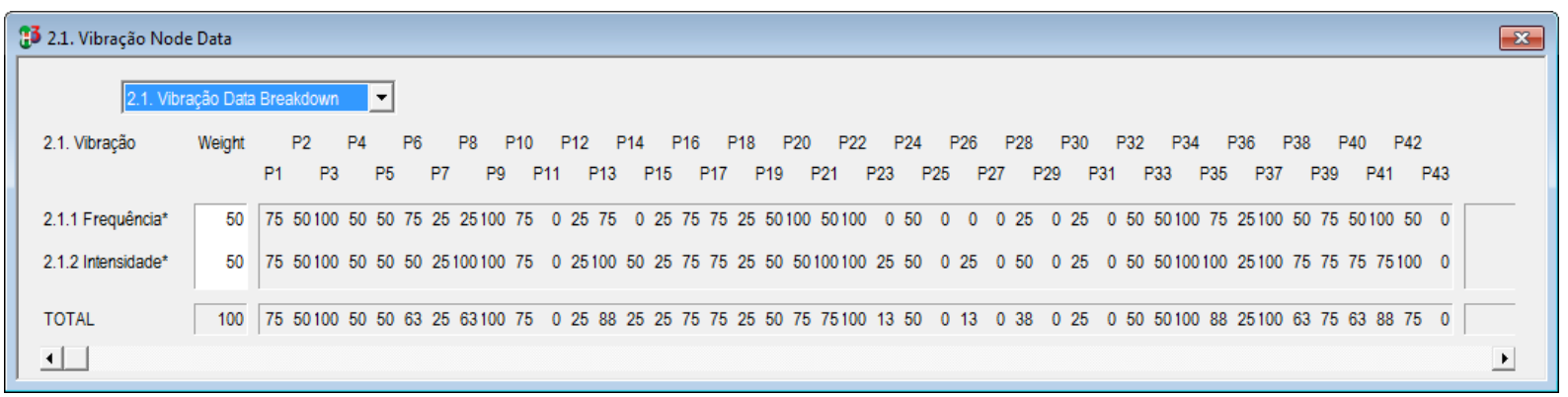

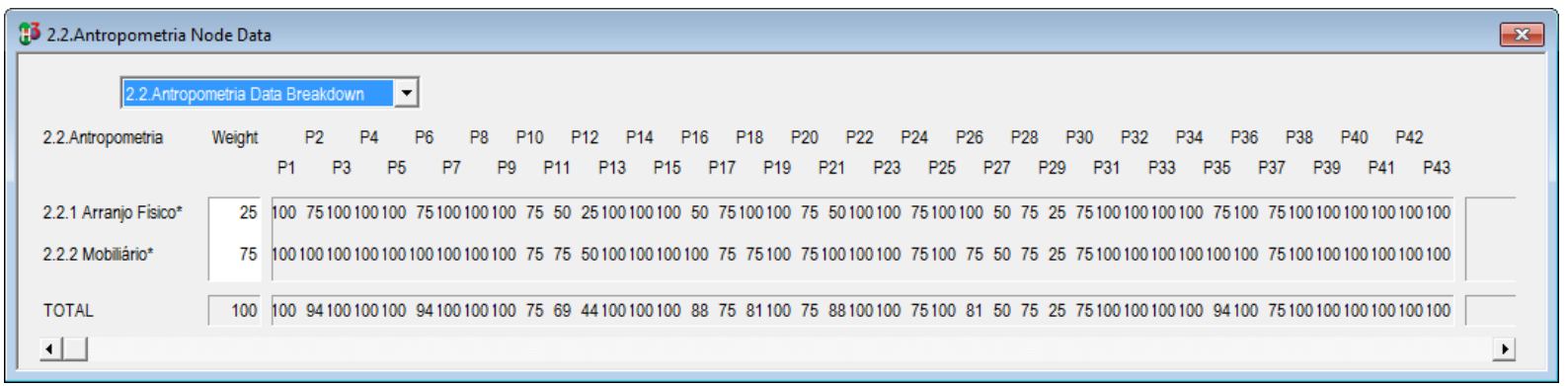



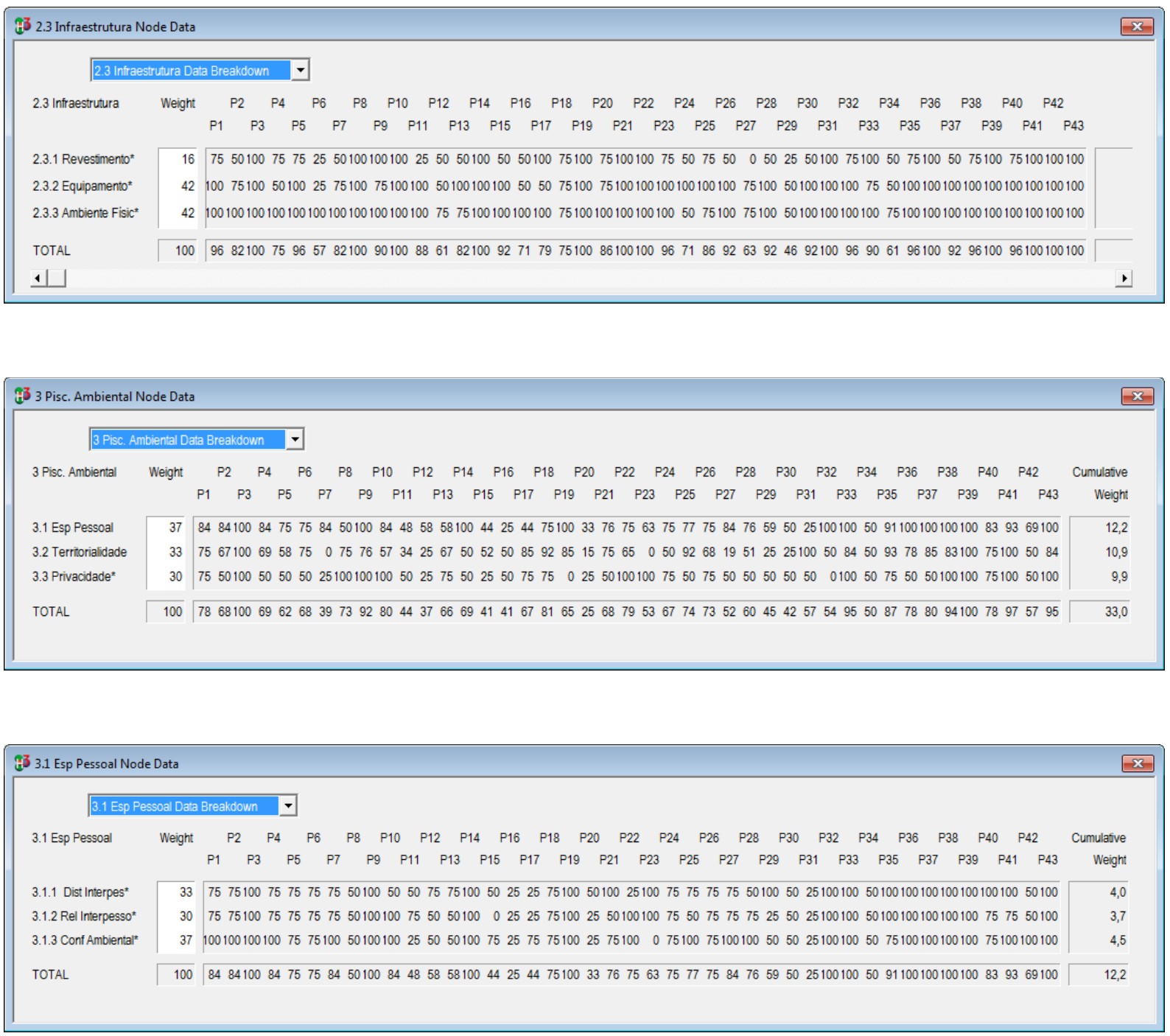

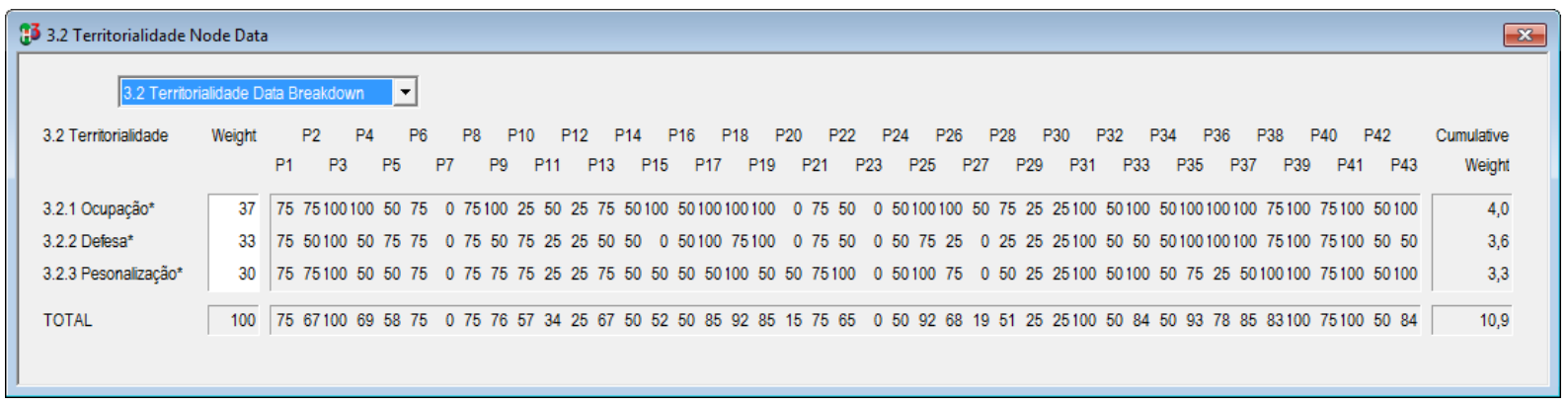





\section{APÊNDICE E - Telas do Software Macbeth com os Perfis de Impacto das ações potenciais}

Este apêndice apresenta os gráficos referentes ao Perfil de Impacto das ações potenciais dos 43 professores do curso de Arquitetura e Urbanismo da Faculdade de Arquitetura e Urbanismo/FAU da UnB no processo de avaliação dos parâmetros facilitadores do ensino-aprendizagem (capítulo 5, seção 5.3.1.1).
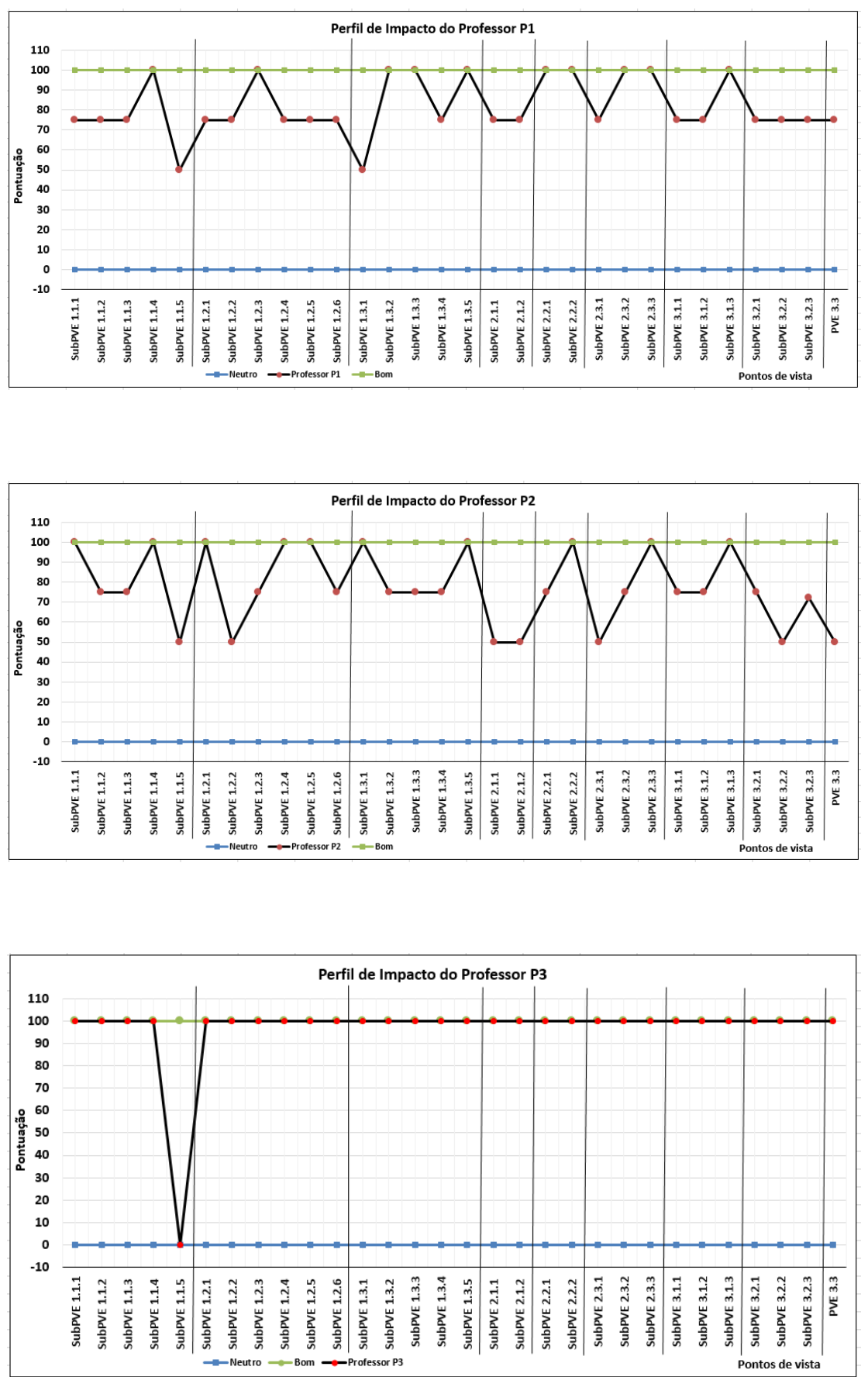

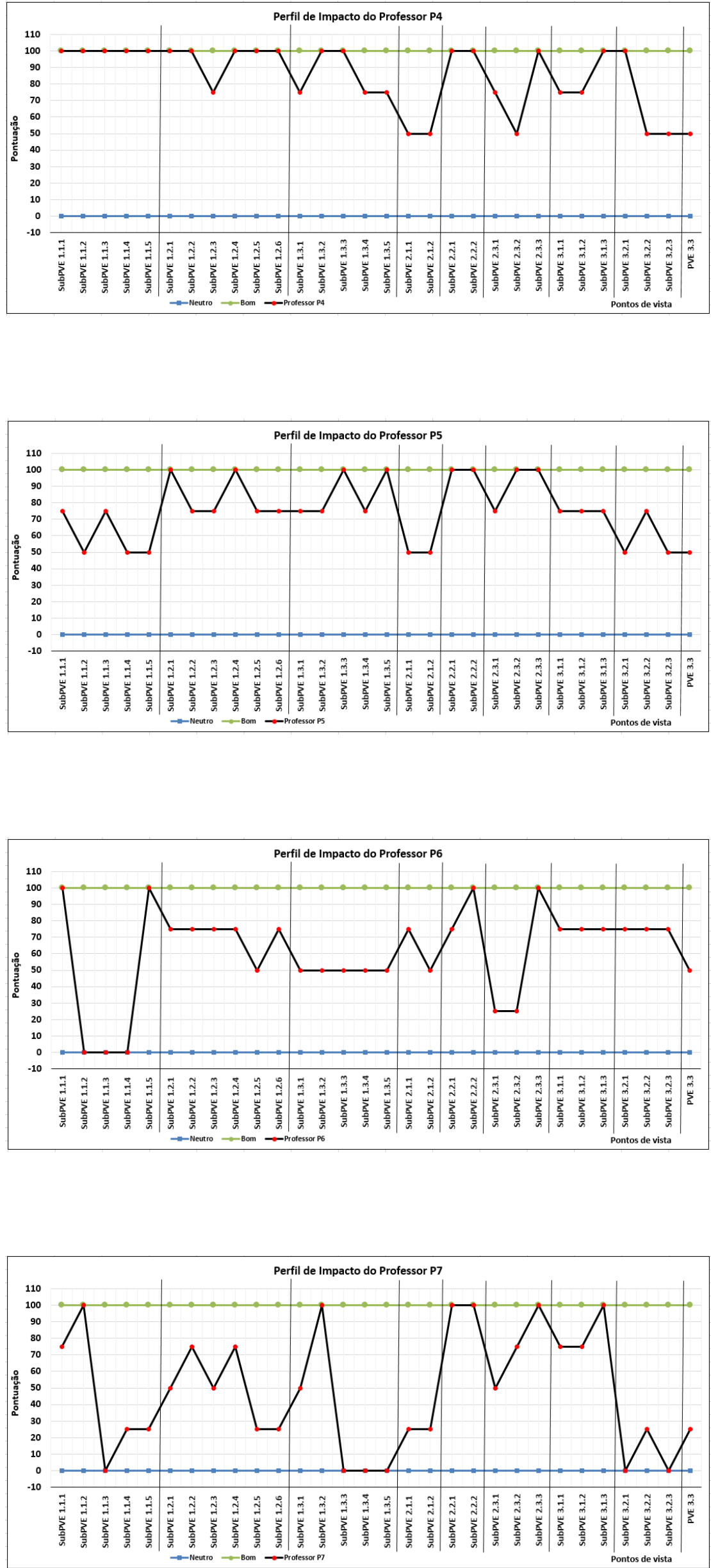

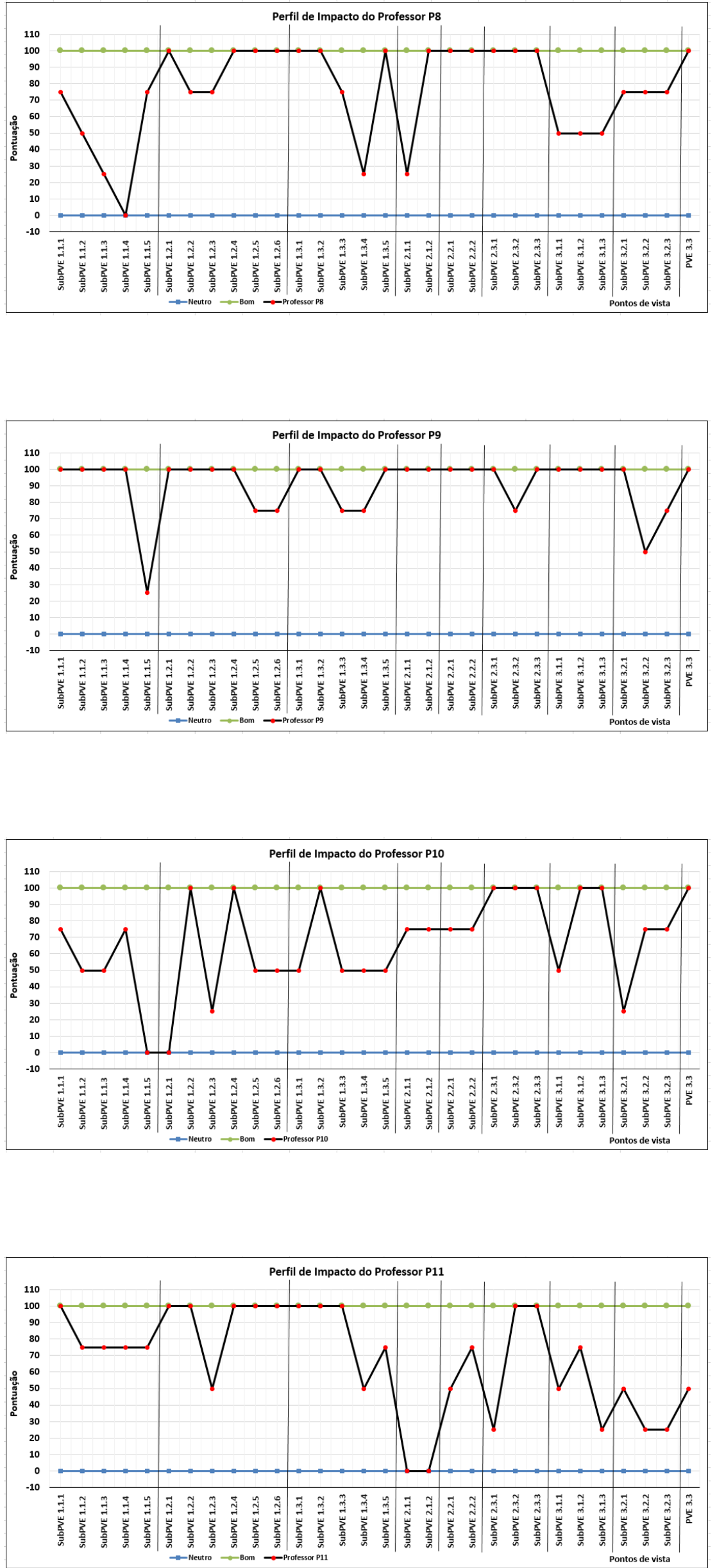

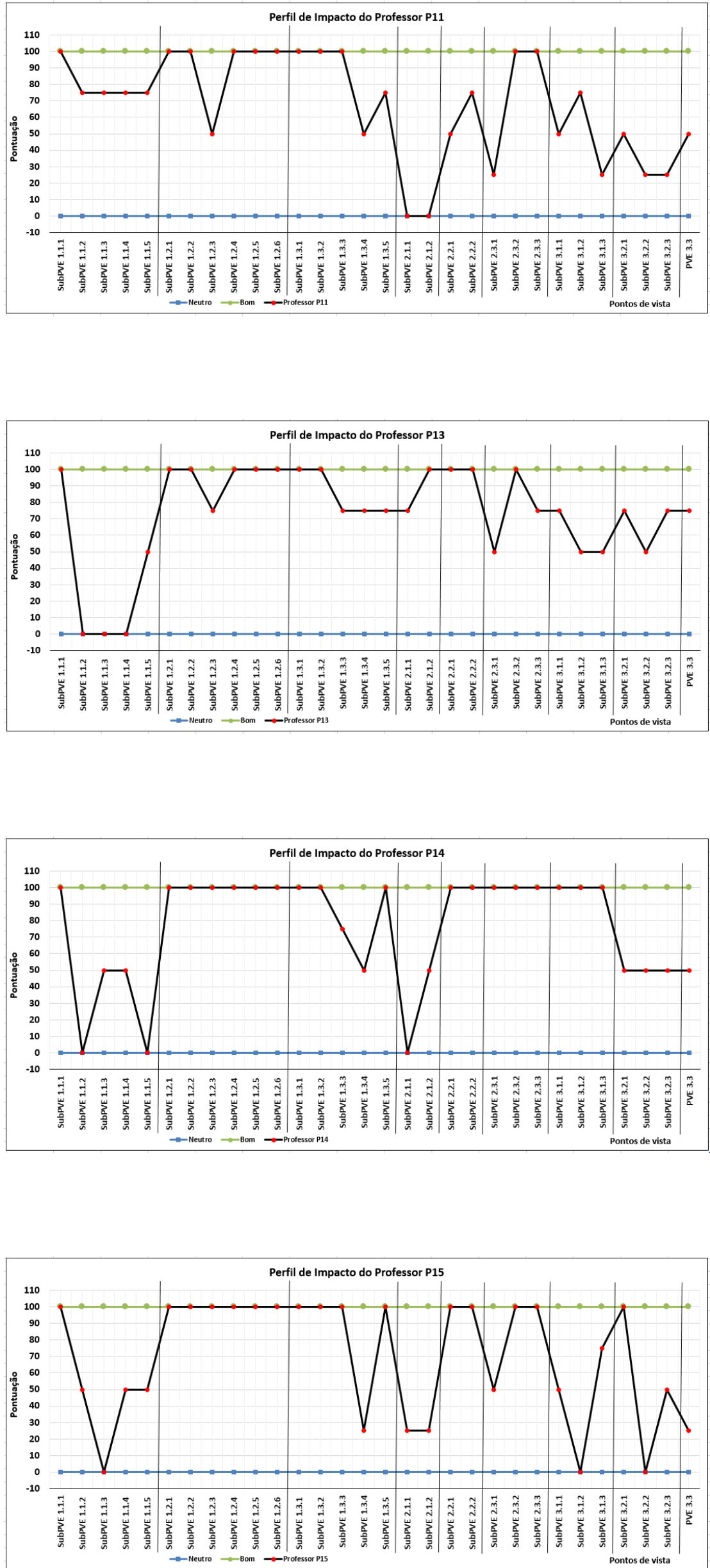

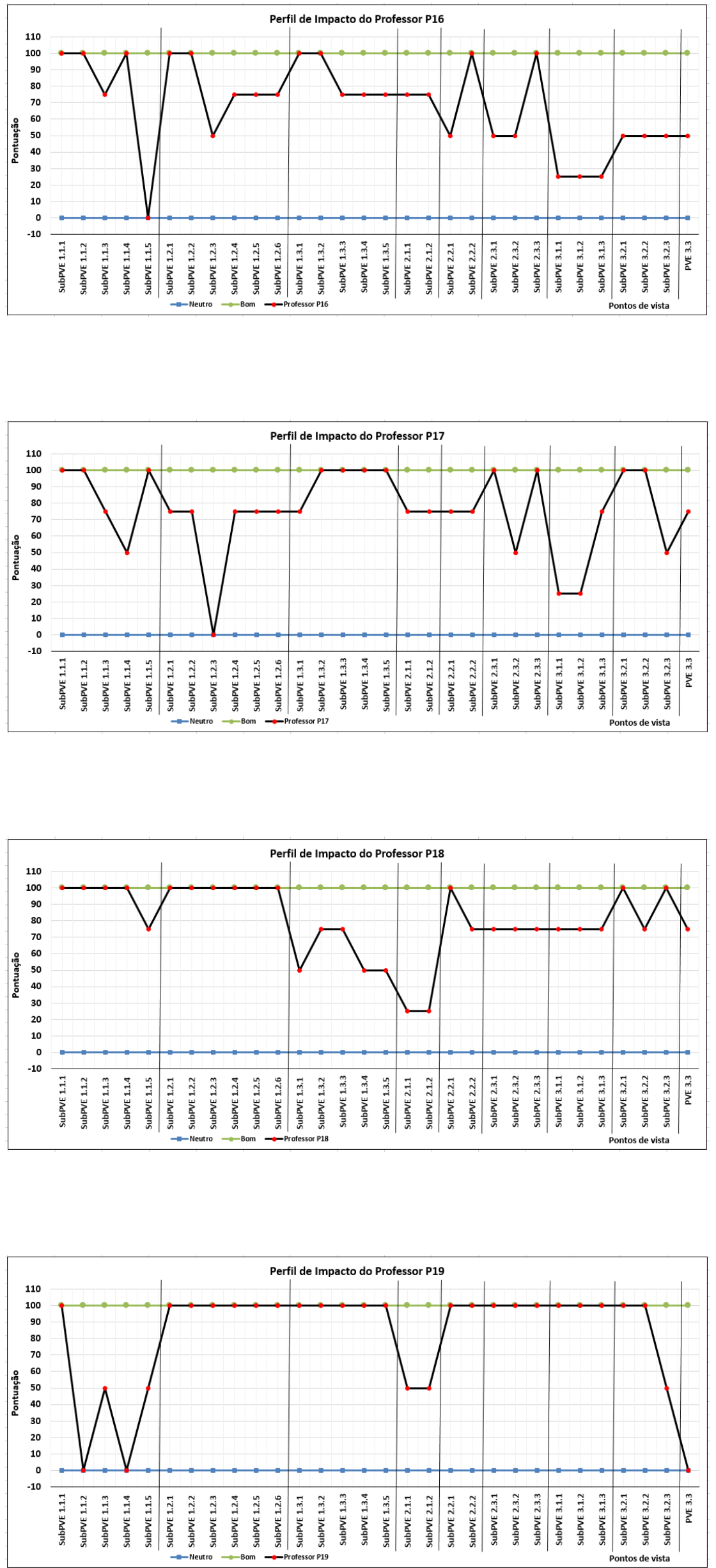

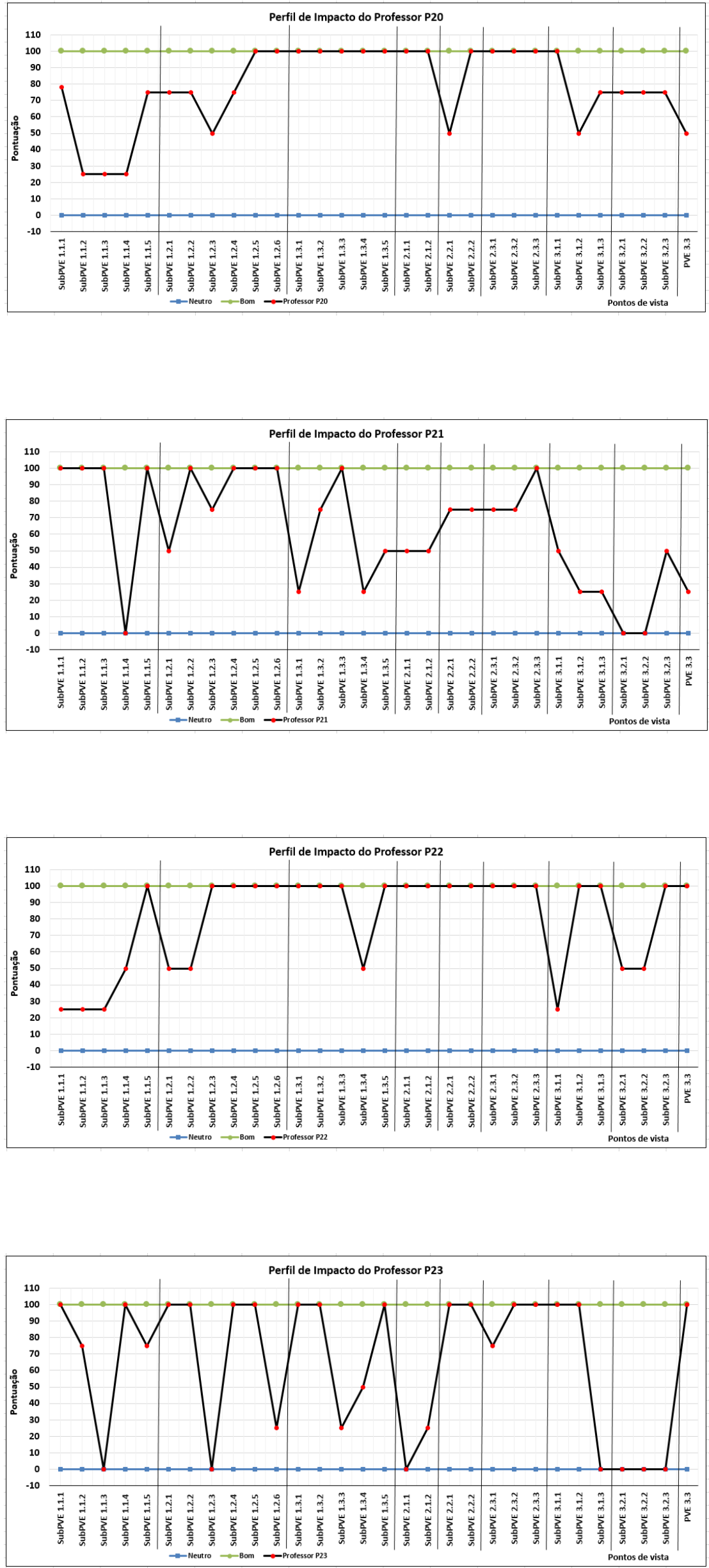

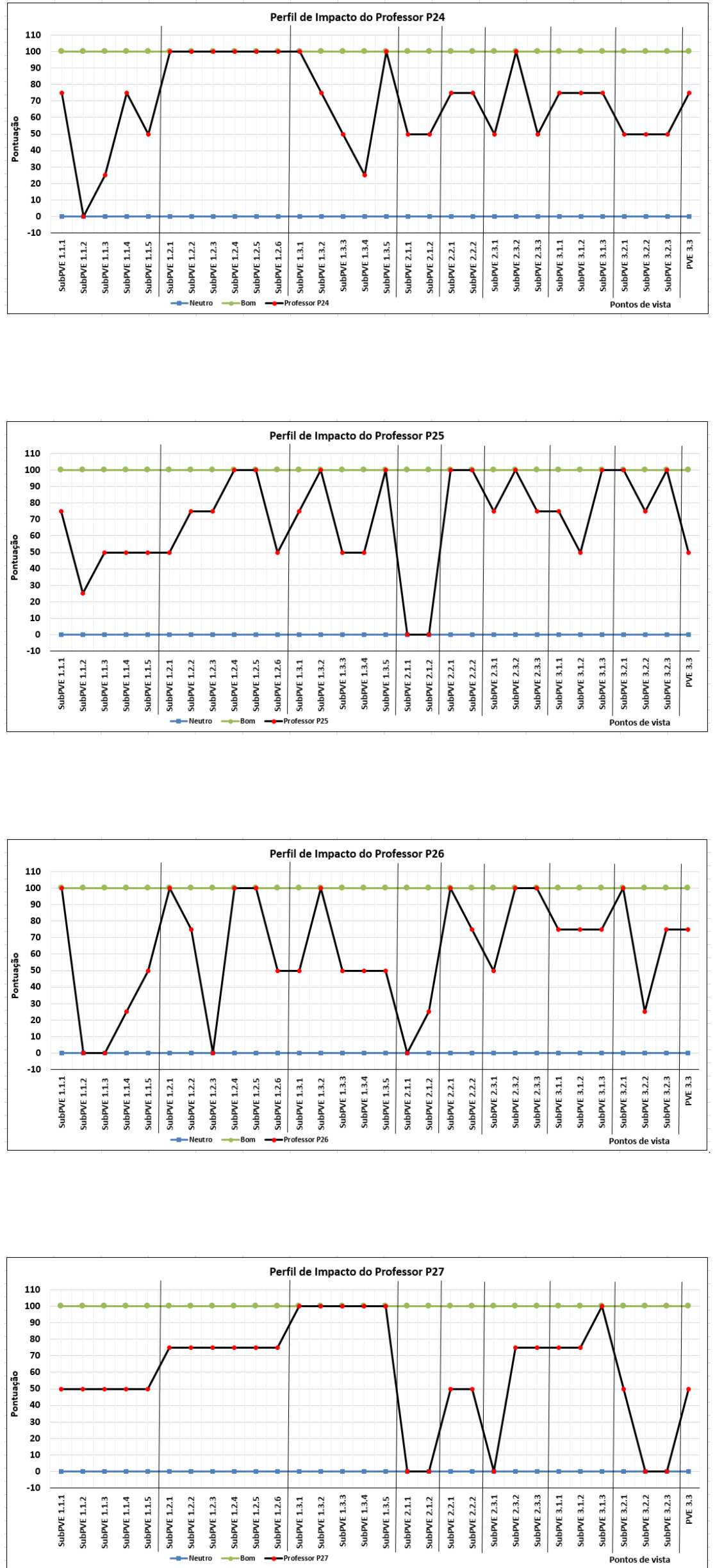

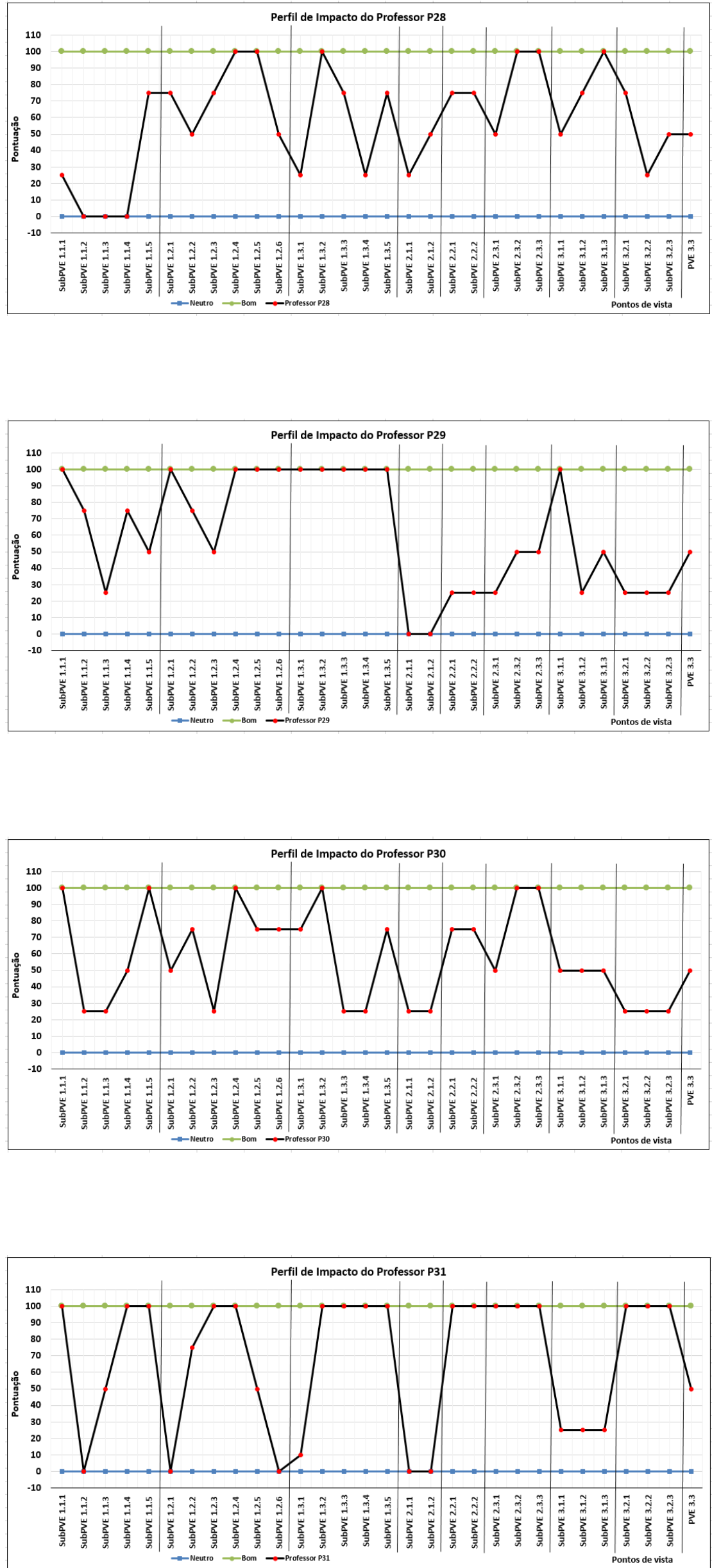

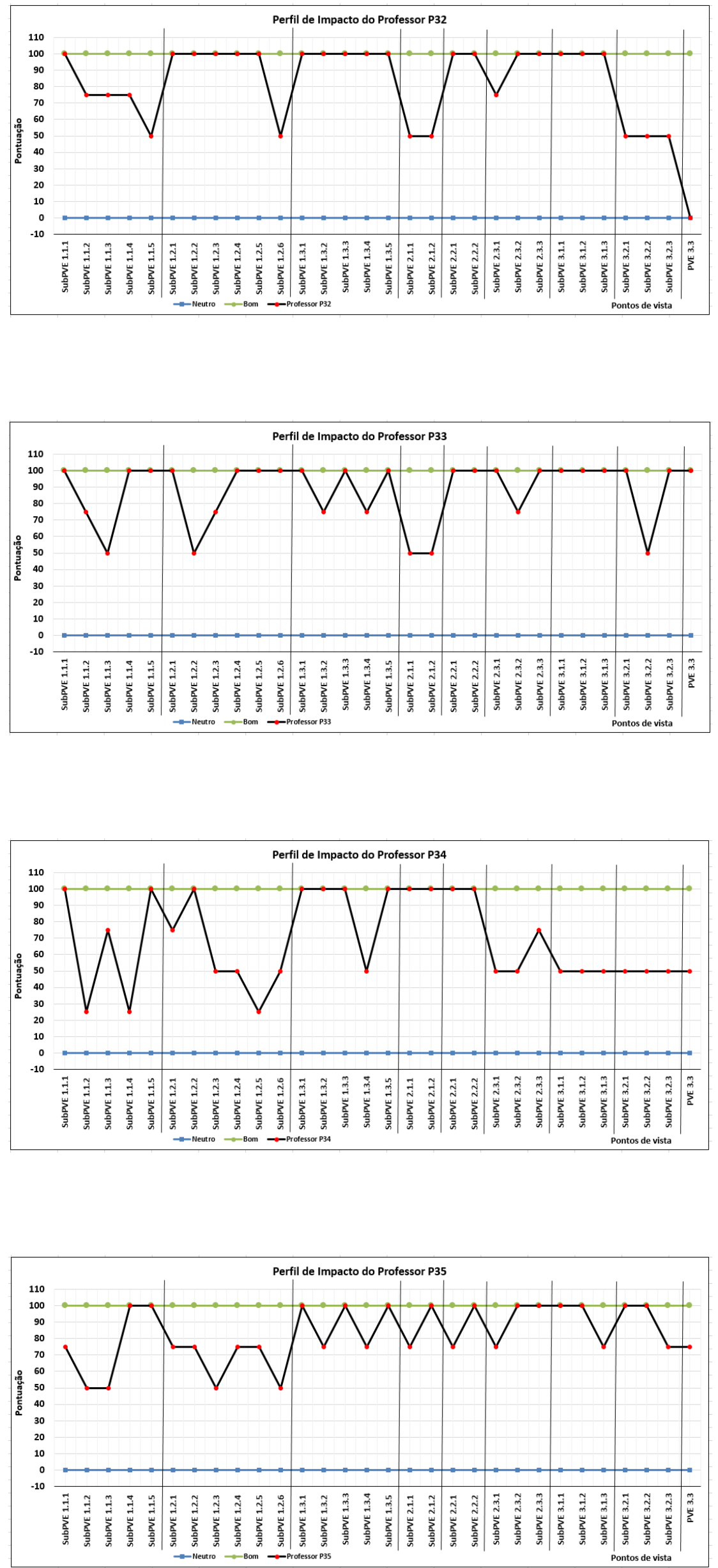

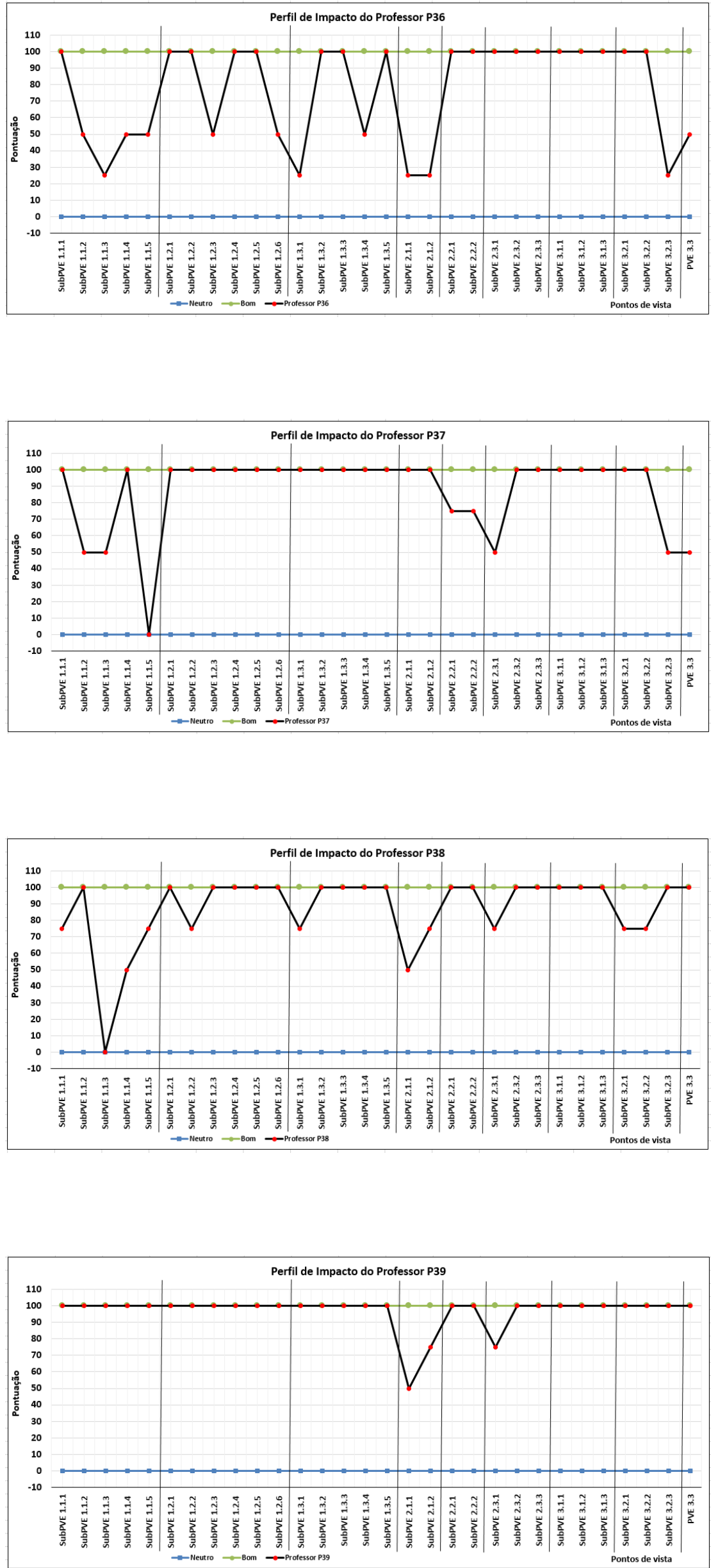

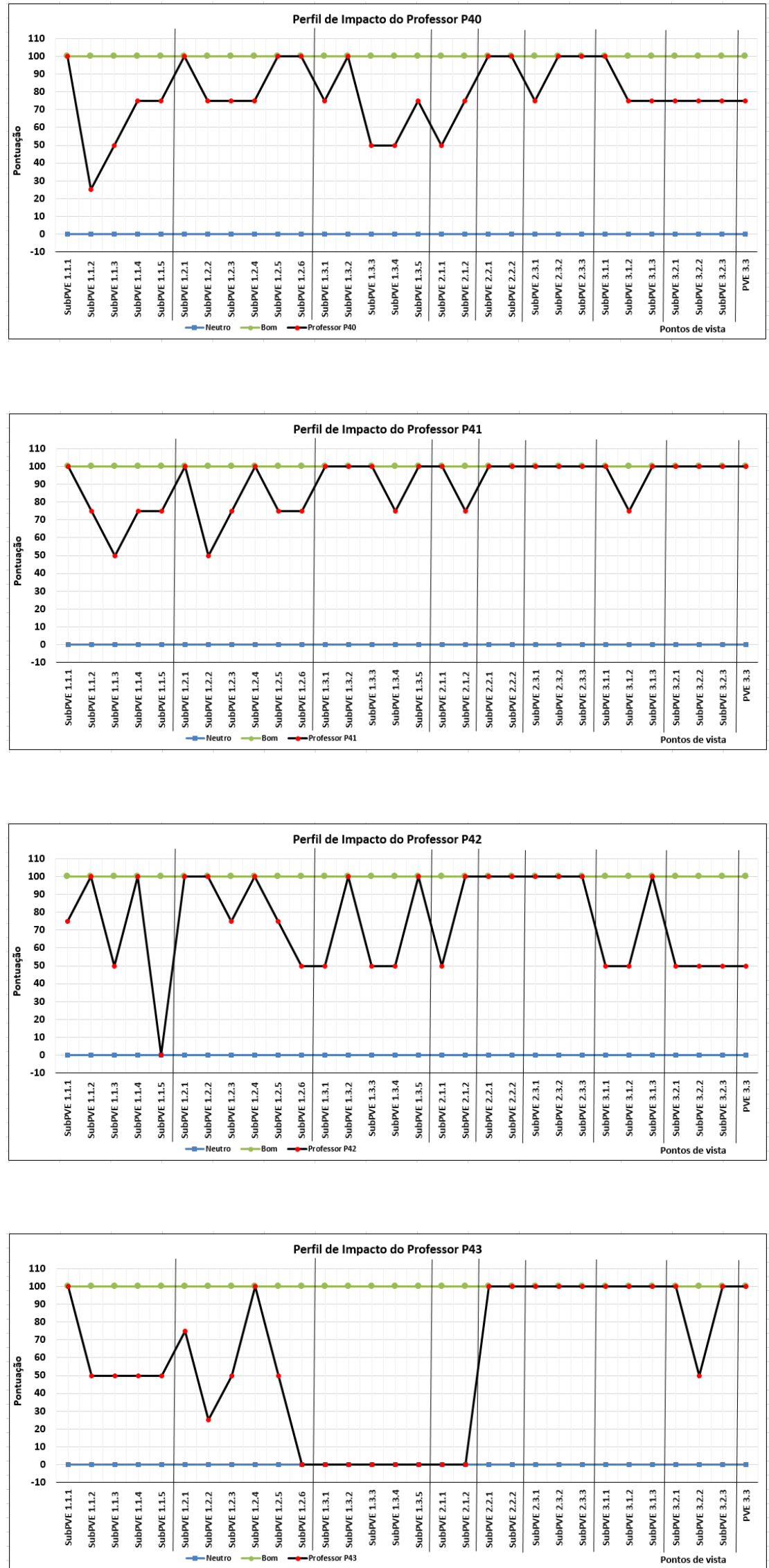



\section{APÊNDICE F - Ícones das perspectivas do Modelo de Arquitetura da Informação - Al}

Este apêndice apresenta representações estéticas das perspectivas do Modelo de Arquitetura da Informação - AI classificadas em Pedagógica, Arquitetônica, Ambiental, Ergonômica e Psciológica (capítulo 5).

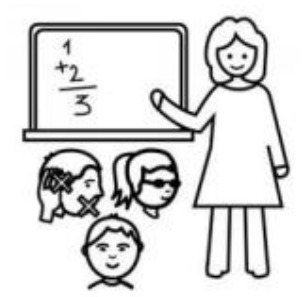

Figura 71 - Perspectiva pedagógica

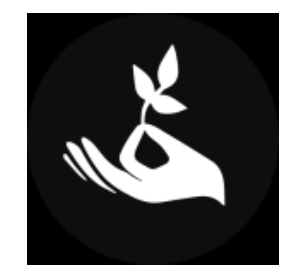

Figura 73 - Perspectiva ambiental

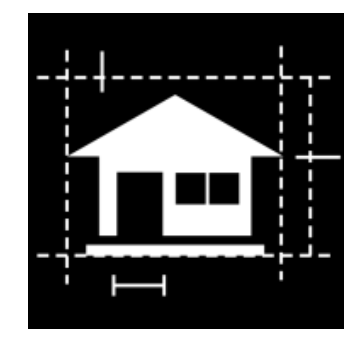

Figura 72 - Perspectiva arquitetônica

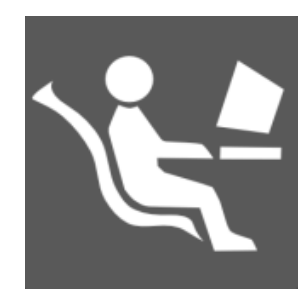

Figura 74 - Perspectiva ergonômica

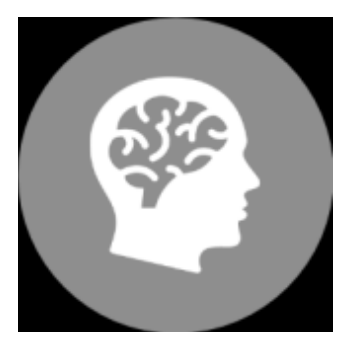

Figura 75 - Perspectiva psciológica 



\section{Índice}

Árvore de valor, 176, 179-181, 185

Análise

de sensibilidade, 246, 247, 279-282

ergonômica, 97

Multicritério de Apoio à Decisão, 169, 170, 172, 176, 223, 232, 292

Arquitetura

da informação, 169, 220, 222, 288, 319, 328

e educação, 39, 50, 51, 155

escolar, 55, 61, 63, 82, 92, 150

Atividade, 31, 107, 129, 132

Atributo

ambientais, 52, 148

de conforto ambiental, 229

de humanização, 148

do espaço arquitetônico, 36, 38, 230, 320

espaciais, 31, 32, 35-37, 40, 44, 111, 127, 141, 149, 163, 283, 290, 296, 319,327

Avaliação

do projeto, 98

global, 244-246

local, 232

pos-ocupação, 81

Campo disciplinar, 36

da arquitetura e urbanismo, 41, 174, 175

da ergonomia, 40, 296, 320, 322, 324

da psicologia ambiental, 40, 296, 320, 322,326

do conforto ambiental, 40, 288, 296, 320,323

Características arquitetônicas, 32, 60

campo disciplinar, 149

das diciplinas do curso da FAU, 286, 287

do ambiente, 323

do campo disciplinar, 36

do espaço arquitetônico, 111, 319, 321, 328

espaciais, 35, 288, 320

espaciais facilitadoras do ensino-aprendizagem,

163

físico-espaciais, 52, 61, 101, 326

Conforto

acústico, 63, 81, 94, 97, 103, 113, 124, 126

ambiental, 50, 56, 60, 80, 83, 93, 94, 103, 104, 106, 107, 112, 117, 122, 129, 136, 148, 175, 177, 179, 181, $228,283,284$

lumínico, 94, 97, 103, 117

térmico, 60, 63, 81, 94, 97, 114-116, 136,138

termico, 97

visual, 63, 81, 99, 119, 121

Critério

de avalição, 173

de avaliação, 172, 178, 190

Currículo, 32

Descritor, 173, 176, 191, 193-198

Disciplina, 223-227, 230-232

prática, 285, 286

prática/teórica, 287

teórica, 286, 287

Edifício, 35-37, 40, 63, 64, 76, 79, 83-87, 91, 92, 101, 104-106, 112, 126, 127, 
146, 147, 150, 151, 224, 227, 294, 295,326

educativo, 119

escolar, 31, 35, 49-51, 67, 76, 86, 107, 149, 150, 164

Educação, 36, 37, 50, 52-55, 60, 80, 83, 96, 112, 114, 124, 133, 169, 269, 319

Ensino

universitário, 38, 225, 296

aprendizagem, 35-38, 41, 44, 49, 55, 59, 60, 96, 111, 112, 114, 129, 137, 169, 174, 176, 178, 223, 230, 288290, 319-323, 327, 328

infantil, 31, 37, 293, 319, 320

Ergonomia, 93-95, 97, 111, 129, 135, 141, 175, 189, 229, 265, 266, 282, 283, 286, 319, 320

Espaço, 35-37

de ensino-aprendizagem, 35, 44, 104, 129, 230, 286, 287, 322, 324

arquitetônico, 31, 36, 37, 40, 41, 44, 49, 93, 169, 174, 227, 249, 260, 290, 293, 296, 319-322, 327

arquitetônicos escolares, 35

de ensino, 59, 82, 93

defensável, 147, 327

escolar, 35, 223

físico, 37

Espacialização

do projeto de arquitetura, 59

Função de valor, 203-206

Informação, 80, 81, 103, 133, 219-225

Juizo de valor, 169, 171

Método

DQI, 61, 62, 150

patterns, 65, 150, 155
Metodologia

de ensino, 31, 36, 38, 49, 82, 146, 290, 295, 296

de projeto, $81,92,220$

ergonômica, 94, 97

Multicritério de Apoio à Decisão (MCDA), 38, 45, 169-171, 173, 175, 176, 185, 219, 283, 321, 328

Modelo

de Arquitetura da informação, 288, 289, 292

Multicritério de Apoio à Decisão, 169, 174,175

Nível de impacto, 195, 196

Parâmetro, 65, 150

de projeto, $82,150,155$

escolares, 65

facilitadores do ensino-aprendizagem, 169, 231, 237, 276, 319

técnico, 111

Pedagogia, 38-40, 44, 54, 56, 59, 83, 129, 289, 290, 320

Perfil de impacto, 237, 238, 241, 243

Perspectivas, 288-293, 297, 306, 312

Práticas pedagógicas, 49, 55

Programa de necessidades, 31, 32, 36

de edificações escolares, 93

escolar, 150, 155, 289

Projeto

arquitetônico, 31, 35, 37, 39, 40, 49, $51,58,81,93,224,225$

político-pedagogico, 55, 56

Psicologia ambiental, 93, 94, 100, 111, 148, 175, 189, 190, 271, 272, 284, 319

Qualidade

do ambiente construído, 52, 117

do edifício, 61, 64, 65, 152

do espaço, 49, 163, 320 
do espaço arquitetônico, 40, 111

do espaço da escola, 52

do espaço físico, 60

do projeto, 79,80

dos ambientes escolares, 155

Relevância

do aprendizado, 37, 163

do espaço arquitetônico, 320

do espaço no aprendizado, 37, 296

dos campos disciplinares, 320

no aprendizado, 319, 320

no ensino de arquitetura, 38, 321

Robutez do modelo, 246, 247

Taxa de substituição, 207

Universidade, 36, 40, 41, 54, 139, 147, 149, 170, 175-177, 219, 223-226, 228, 230, 249, 283, 288, 320, 322, 328 